\title{
Análise Numérica de Seções Transversais e de Elementos Estruturais de Aço e Mistos de Aço e Concreto em Situação de Incêndio
}

Dissertação apresentada ao Departamento de Engenharia de Estruturas da EESC-USP como parte dos requisitos necessários à obtenção do título de Mestre em Engenharia de Estruturas.

Área de Concentração: Estruturas Metálicas Orientador: Prof. Dr. Jorge Munaiar Neto 
A meus pais, Israel e Maria Anésia, e tia Lena, por acreditarem em mim e pelo apoio incondicional. 


\section{AGRADECIMENTOS}

Primeiramente à Deus.

Ao CNPq e à FAPESP, pela bolsa concedida para realização dessa pesquisa.

Ao professor Jorge Munaiar Neto, pela confiança, apoio e orientação desde a iniciação científica.

Ao professor Valdir Pignatta e Silva, pela colaboração no desenvolvimento deste trabalho. Aos professores Maximiliano Malite e José Jairo de Sales, pela atenção dispensada nas mais diversas dúvidas. Ao professor Carlito Calil Junior pela contribuição no exame de qualificação.

À todos os funcionários do Departamento de Engenharia de Estruturas que contribuíram direta ou indiretamente para o desenvolvimento do trabalho.

A colega Tatianne Iamin Kotinda, pela amizade, atenção e ajuda na realização das análises acopladas com o ANSYS.

A todos amigos do Departamento de Engenharia de Estruturas, pelo companheirismo e momentos de descontração. Em especial aos amigos Saulo, André, Edmar, Denis, Gláucia, Iara, Karenina, Lívia, Filipe, Luiz Vieira, Gustavo Siqueira, Rodrigo “Slow” e Marlos Mangini, grande companheiro no café das “Seções Corujão”.

Ao grande amigo eng. Marcos Rodrigues, pelos sempre sábios conselhos e lições de engenharia.

Aos amigos de Rio Crespo e Ariquemes, em Rondônia, por não se esquecerem de mim apesar da distância.

De todo coração aos meus pais, Israel e Maria Anésia, a tia Lena e meus irmãos, Robson e Leandro, pela torcida constante pelo meu sucesso profissional. 


\title{
RESUMO
}

\author{
REGOBELLO, R. Análise numérica de seções transversais e de elementos \\ estruturais de aço e mistos de aço e concreto em situação de incêndio. 254 p. \\ Dissertação (Mestrado) - Escola de Engenharia de São Carlos, Universidade de São \\ Paulo, São Carlos, 2007.
}

O presente trabalho teve como objetivo principal estudar, em caráter essencialmente numérico via ANSYS v9.0, a elevação de temperatura em seções transversais de elementos estruturais de aço e mistos de aço e concreto, com vistas a uma avaliação das equações propostas pelo método simplificado de cálculo da NBR 14323:1999, em especial, para situações em que não ocorra aquecimento uniforme por todos os lados do elemento. São apresentados modelos numéricos de seções transversais de elementos estruturais de aço, mistos de aço e concreto e, em caráter complementar, de madeira, em situação de incêndio, para avaliar a evolução dos níveis de temperatura ao longo do tempo. São também construídos e analisados modelos numéricos com vistas à análise do efeito da elevação de temperatura no comportamento mecânico em vigas de aço de um edifício de interesse. A determinação dos níveis de temperatura em seções transversais de elementos estruturais, obtidas com base nas prescrições normativas da NBR 14323:1999, conduzem a resultados satisfatórios, porém, com temperaturas próximas as temperaturas máximas obtidas numericamente. Para os casos usuais não contemplados pela NBR 14323:1999 fica evidente a necessidade do emprego de modelo avançado de cálculo ou de estudos com vistas ao desenvolvimento de ferramentas analíticas para emprego em tais situações. Com relação à análise do efeito da elevação de temperatura no comportamento mecânico, os fatores de redução de resistência para as vigas em situação de incêndio obtidos via ANSYS resultaram inferiores àqueles obtidos via TCD v5.0, com base na análise da seção transversal e procedimentos normativos.

Palavras-chave: Incêndio, Estruturas de aço, Estruturas Mistas, Análise Térmica, Análise Numérica. 


\section{ABSTRACT}

REGOBELLO, R. Numerical analysis of steel and composite steel-concrete cross sections and structural elements in fire situation. 254 p. Dissertation (Master) Escola de Engenharia de São Carlos, Universidade de São Paulo, São Carlos, 2007.

This research presents a study, within the context of numerical analysis with ANSYS v9.0, in which the main goal has been driven to obtain the rise of temperature in steel and composite steel-concrete structural elements cross sections with the purpose of evaluating the temperature determination by normative equations proposed in Brazilian standard NBR 14323:1999, considering the simple calculation model, specially in situations with not uniform exposition of the elements cross sections to the fire. Numerical models of steel, composite steel-concrete and wooden structural elements cross sections in fire situation are presented to evaluate the levels of temperature throughout the time. Numerical models to analyze the effect of the rise of temperature in the mechanical behavior of steel beams of a building of interest are also presented. The temperature levels obtained for structural elements by prescriptions of NBR 14323:199 lead to satisfactory results but with temperatures near to the maximum temperatures obtained numerically. For the usual cases not contemplated by the NBR 14323:1999, is evident the necessity of employing advanced calculation models or studies for the development of analytical methods for such situations. With respect to the analysis of temperature rising effects in the mechanical behavior, the reduction factors for the resistance in fire situation, obtained by ANSYS, resulted smaller than those ones obtained by TCD v5.0, with base on the analysis of elements cross sections and normative procedures.

Keywords: Structures in Fire, Steel Structures, Composite Structures, Thermal Analisys, Numerical Analysis. 


\section{LISTA DE SÍMBOLOS}

TRRF Tempo requerido de resistência ao fogo

$\mathbf{u}$

A

u/A

$\mathbf{T}$

$\theta$

$\varphi$

$\varphi_{\mathrm{c}}$

$\varphi_{\mathrm{r}}$

$\lambda$

t

Q

$\alpha$

$\alpha_{c}$

$\alpha_{r}$

$\chi$

$\psi$

$\tau$

$\mathbf{E}_{\mathbf{b}}$

E

$\sigma$

$\varepsilon$

$\varepsilon_{\text {res }}$

$\Phi$

$\rho$

C

$\theta_{\mathrm{g}}$

$\theta_{0}$

$\theta_{\mathrm{a}}$
Perímetro; Perímetro exposto ao fogo

Área da seção transversal de aço

Fator de massividade

Temperatura em Kelvin

Temperatura em graus Celsius

Fluxo de calor

Fluxo de calor devido à convecção

Fluxo de calor devido à radiação

Condutividade térmica

Tempo

Energia calorífica

Coeficiente total de transferência de calor (convecção + radiação)

Coeficiente de transferência de calor devido à convecção

Coeficiente de transferência de calor devido à radiação

Absortância

Refletividade

Transmitância

Radiação térmica emitida por uma superfície de corpo negro

Radiação térmica emitida por uma superfície de corpo cinzento

Constante de Stefan-Boltzmann

Emissividade

Emissividade resultante

Fator de configuração

Massa específica

Calor específico

Temperatura dos gases do ambiente $\left({ }^{\circ} \mathrm{C}\right)$

Temperatura dos gases no instante $\mathrm{t}=0$

Temperatura do elemento de aço $\left({ }^{\circ} \mathrm{C}\right)$ 
$\Delta \boldsymbol{l}_{\mathbf{a}} / \boldsymbol{l} \mathbf{a} \quad$ Alongamento relativo do aço

calor específico do aço

$\lambda_{\mathbf{a}} \quad$ Condutividade térmica do aço

$\theta_{\mathbf{c}} \quad$ Temperatura do concreto $\left({ }^{\circ} \mathrm{C}\right)$

$\Delta \ell_{\mathrm{cn}} / \ell_{\mathrm{cn}} \quad$ Alongamento relativo do concreto de densidade normal

$\Delta \ell_{\mathrm{cb}} / \ell_{\mathrm{cb}} \quad$ Alongamento relativo do concreto de baixa densidade

con Calor específico do concreto de densidade normal

$\mathbf{c}_{\mathbf{c b}} \quad$ Calor específico do concreto de baixa densidade

$\lambda_{\text {cn }} \quad$ Condutividade térmica do concreto de densidade normal

$\lambda_{\mathbf{c b}} \quad$ Condutividade térmica do concreto de baixa densidade

$\theta_{\mathrm{cr}} \quad$ Temperatura crítica

SFRM Spray-Applied Fire-Resistive Materials

Bi Número de Biot

V Volume do elemento de aço

$\rho_{\mathbf{a}} \quad$ Massa específica do aço

$\mathrm{T}_{\mathbf{g}} \quad$ Temperatura dos gases do ambiente (K)

$\mathrm{T}_{\mathbf{a}} \quad$ Temperatura do elemento de aço (K)

$\Delta \mathbf{t} \quad$ Intervalo de tempo

$\Delta \mathrm{T}_{\mathrm{a}} \quad$ Variação de temperatura do elemento de aço no intervalo $\Delta \mathrm{t}(\mathrm{K})$

$\Delta \theta_{\mathrm{a}, \mathrm{t}} \quad$ Variação de temperatura do elemento de aço no intervalo $\Delta \mathrm{t}\left({ }^{\circ} \mathrm{C}\right)$

$\boldsymbol{\varepsilon}_{\mathbf{f}} \quad$ Emissividade do compartimento ou das chamas

$\boldsymbol{\varepsilon}_{\mathbf{m}} \quad$ Emissividade do material

$\mathbf{k}_{\text {sh }} \quad$ Fator de correção para o efeito de sombra

[u / A $]_{\mathbf{b}} \quad$ Fator de massividade calculado como se o perfil tivesse proteção tipo caixa, usado no cálculo do $\mathrm{k}_{\mathrm{sh}}$

$\mathbf{A}_{\mathbf{m}} \quad$ Área do material de proteção contra fogo

$\lambda_{\mathbf{m}} \quad$ Condutividade térmica do material de proteção contra fogo

C Calor específico do material de proteção contra fogo

$\rho_{\mathbf{m}} \quad$ Massa específica do material de proteção contra fogo

$\mathbf{t}_{\mathbf{m}} \quad$ Espessura do material de proteção contra fogo

$\Delta \mathrm{T}_{\mathrm{g}} \quad$ Variação da temperatura dos gases no intervalo $\Delta \mathrm{t}(\mathrm{K})$

$\theta_{\mathrm{a}, \mathrm{t}} \quad$ Temperatura do elemento de aço no tempo $\mathrm{t}\left({ }^{\circ} \mathrm{C}\right)$ 


\begin{tabular}{|c|c|}
\hline $\mathbf{u}_{\mathbf{m}} / \mathbf{A}$ & Fator de massividade de elemento de aço com proteção contra fogo \\
\hline$\ell$ & Comprimento de um elemento estrutural \\
\hline $\mathbf{H}$ & Entalpia \\
\hline d & Altura de perfil I \\
\hline $\mathbf{b}_{\mathbf{f}}$ & Largura de mesa de perfil I \\
\hline $\mathbf{b}_{\mathbf{f i}}$ & Largura de mesa inferior de perfil I \\
\hline $\mathbf{b}_{\mathrm{fs}}$ & Largura de mesa superior de perfil I \\
\hline $\mathbf{t}_{\mathbf{f}}$ & Espessura de mesa de perfil I \\
\hline $\mathbf{t}_{\mathbf{f i}}$ & Espessura de mesa inferior de perfil I \\
\hline $\mathbf{t}_{\mathrm{fs}}$ & Espessura de mesa superior de perfil I \\
\hline $\mathbf{t}_{\mathbf{w}}$ & Espessura de alma de perfil I \\
\hline $\mathbf{h}_{\mathbf{w}}$ & Altura de alma de perfil I \\
\hline b & Largura ou largura efetiva de laje de concreto \\
\hline $\mathbf{t}_{\mathbf{c}}$ & Espessura de laje de concreto \\
\hline $\mathbf{h}_{\text {alv }}$ & Altura de alvenaria \\
\hline $\mathbf{t}_{\mathrm{alv}}$ & Espessura de alvenaria \\
\hline $\mathbf{f}_{\mathbf{y}}$ & Tensão de escoamento do aço \\
\hline $\mathbf{E}_{\theta}$ & Módulo de elasticidade tangente inicial do aço à temperatura elevada \\
\hline $\mathbf{k}_{\mathbf{E}, \theta}$ & $\begin{array}{l}\text { Fator de redução do módulo de elasticidade do aço em temperatura } \\
\text { elevada relativo à temperatura ambiente }\end{array}$ \\
\hline $\mathbf{f}_{\mathbf{y}, \theta}$ & Limite de escoamento do aço em temperatura elevada \\
\hline $\mathbf{k}_{\mathbf{y}, \theta}$ & $\begin{array}{l}\text { Fator de redução do limite de escoamento do aço em temperatura elevada } \\
\text { relativo à temperatura ambiente }\end{array}$ \\
\hline$\rho_{\text {alv }}$ & Massa específica da alvenaria \\
\hline Calv & Calor específico da alvenaria \\
\hline$\lambda_{\text {alv }}$ & Condutividade térmica da alvenaria \\
\hline
\end{tabular}





\section{SUMÁRIO}

CAPÍTULO 1 - INTRODUÇÃO ….................................................................1

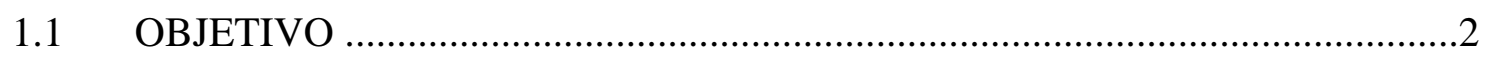

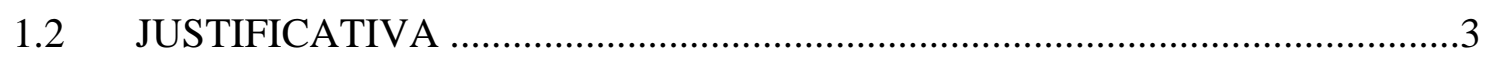

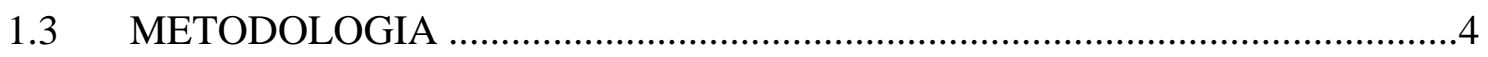

1.4 APRESENTAÇÃO DO TRABALHO.............................................................

\section{CAPÍTULO 2 - O INCÊNDIO E AS AÇÕES TÉRMICAS NAS ESTRUTURAS..7}

2.1 ESTRUTURAS EM SITUAÇÃO DE INCÊNDIO - BREVE HISTÓRICO ........7

2.1.1 Breve histórico no contexto mundial .................................................................

2.1.2 Breve histórico no Brasil ...............................................................................

2.1.3 Normas brasileiras para estruturas de aço em situação de incêndio .....................10

2.2 DETERMINAÇÃO DAS AÇÕES TÉRMICAS - INTRODUÇÃO ....................12

2.3 MECANISMOS DE TRANSFERÊNCIA DE CALOR ……………………......12

2.3.1 Transferência de calor por CONDUÇÃO ...........................................................13

2.3.2 Transferência de calor por CONVECÇÃO ……………………………………..14

2.3.3 Transferência de calor por RADIAÇÃO ...........................................................16

2.3.4 Considerações sobre a radiação térmica em situação de incêndio.........................19

2.4 EQUAÇÃO DIFERENCIAL DE EQUILÍBRIO DO FENÔMENO FÍSICO ....21

2.5 AÇÕES TÉRMICAS EM ESTRUTURAS EM SITUAÇÃO DE INCÊNDIO .23

2.5.1 Curva temperatura-tempo de um incêndio ............................................................23

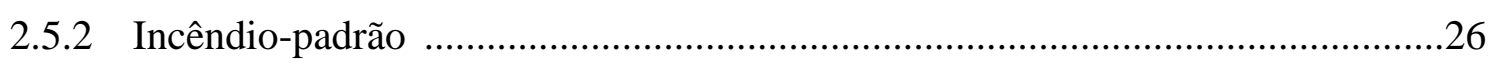

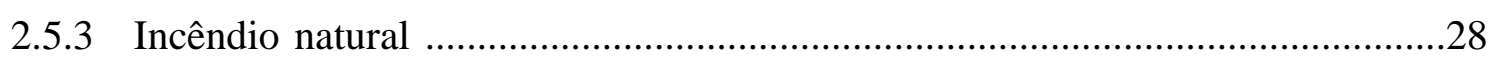

\section{CAPÍTULO 3 - PROPRIEDADES TÉRMICAS DOS MATERIAIS DE}

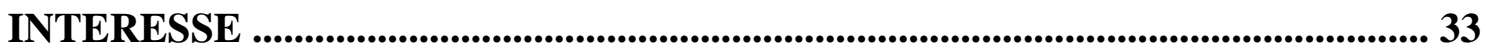

3.1 PROPRIEDADES TÉRMICAS DOS AÇOS ESTRUTURAIS ………………...33

3.1.1 Alongamento relativo .................................................................................34

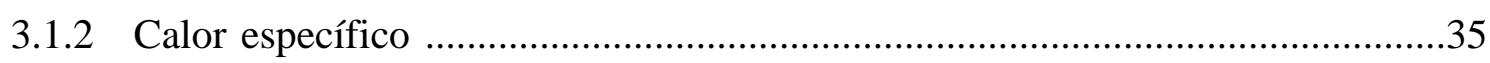

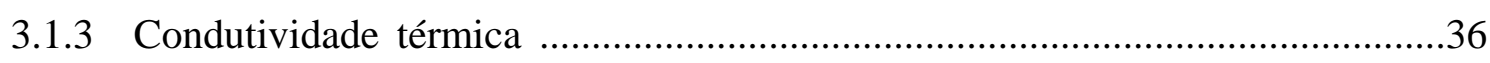

3.2 PROPRIEDADES TÉRMICAS DO CONCRETO ............................................. 
3.2.1 Alongamento relativo …………………………......................................38

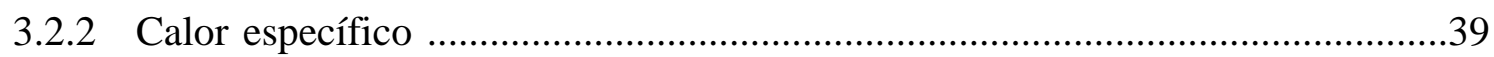

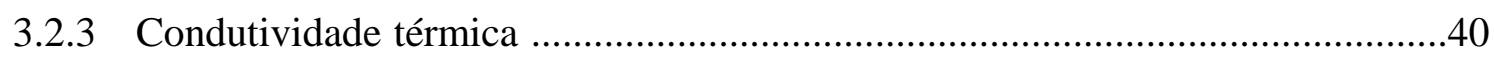

3.3 MATERIAIS DE PROTEÇÃO CONTRA FOGO ………………………........42

3.3.1 Classificação dos materiais de proteção contra fogo ...........................................43

3.3.2 Materiais projetados .........................................................................................45

3.3.3 Placas rígidas ............................................................................................53

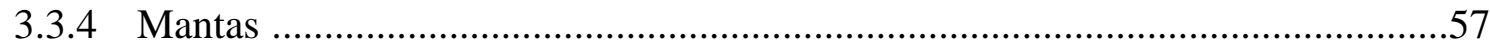

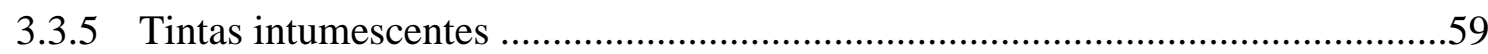

3.4 CUSTO DOS MATERIAIS DE PROTEÇÃO CONTRA FOGO.........................61

\section{CAPÍTULO 4 - ELEVAÇÃO DA TEMPERATURA EM ELEMENTOS}

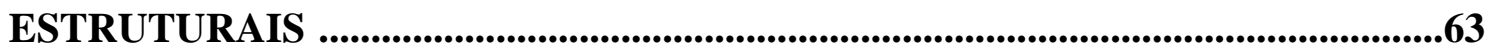

4.1 MODELOS SIMPLIFICADOS DE CÁLCULO ..............................................64

4.1.1 Hipótese de temperatura homogênea na seção .....................................................64

4.1.2 Temperatura em elementos não-revestidos.............................................................65

4.1.3 Temperatura em elementos com revestimento contra fogo ………………….......69

4.1.4 Fator de massividade .................................................................................

4.1.5 Determinação da elevação da temperatura em vigas mistas de aço e

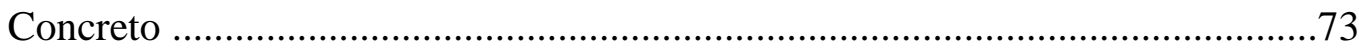

4.2 MODELOS AVANÇADOS DE CÁLCULO ………………………………......75

4.3 ANÁLISE DE FENÔMENOS TÉRMICOS.......................................................76

4.4 ANÁLISE TÉRMICA TRANSIENTE ………………………………….......76

4.5 ANÁLISE TÉRMICA VIA MODELAGEM NUMÉRICA ……….......................77

4.5.1 Análise de Problemas de Condução de Calor ...................................................... 77

4.5.2 Análise de Problemas de Conveç̧ão ...................................................................78

4.5.3 Análise de Problemas de Radiação …………………………………………......78

4.5.4 Fenômenos Térmicos ………………………………………………………....79

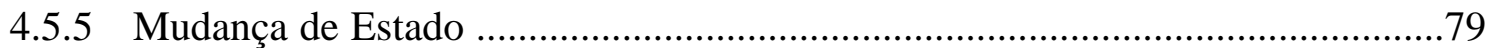

4.5.6 Tipos de Análises Térmicas Consideradas pelo Ansys ........................................80

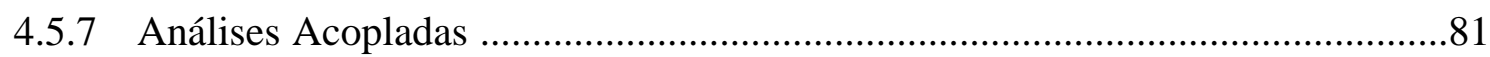

4.6 ELEMENTOS FINITOS PARA ANÁLISE TÉRMICA BIDIMENSIONAL ...81

4.7 APLICAÇÃO DA AÇÃO TÉRMICA ……………………………………....82 


\section{CAPÍTULO 5 - VALIDAÇÃO DA ESTRATÉGIA NUMÉRICA PARA OS}

MODELOS CONSTRUÍDOS.................................................................................85

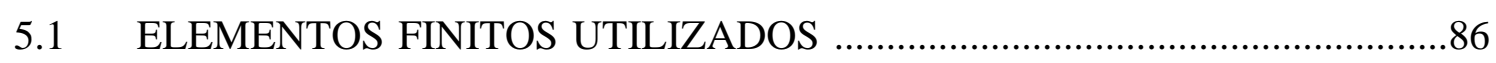

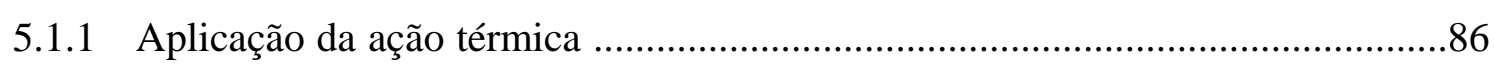

5.2 VALIDAÇÃO DA ESTRATÉGIA NUMÉRICA ............................................87

5.2.1 MODELO 1 - Viga de aço sem revestimento contra fogo ................................88

5.2.2 MODELO 2 - Viga de aço com revestimento contra fogo ................................91

5.2.3 MODELO 3 - Viga mista de aço e concreto ..................................................93

5.2.4 MODELO 4 - Viga de madeira Eucalyptus citriodora ......................................96

CAPÍTULO 6 - ESTUDO DE CASOS E RESULTADOS OBTIDOS......................101

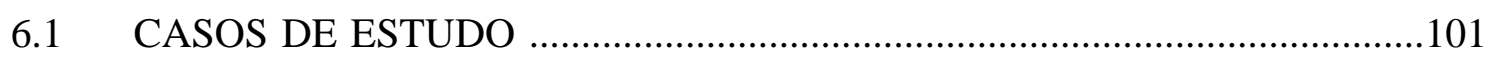

6.1.1 Considerações sobre as condições de contorno e malha de elementos

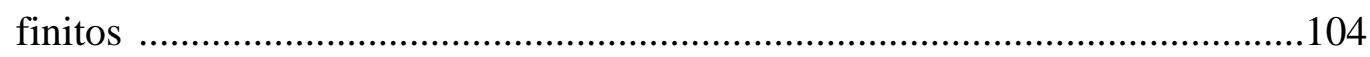

6.1.2 CASO 1 - Seção aberta e exposta ao incêndio por três lados ...........................105

6.1.3 CASO 2 - Chapa exposta ao incêndio por três lados ........................................110

6.1.4 CASO 3 - Mesa de seção I exposta ao incêndio por três lados .........................114

6.1.5 CASO 4 - Seção I com reforço em caixão exposta ao incêndio por todos os lados.

6.1.6 CASO 5 - Seção I com proteção tipo caixa, de espessura uniforme, exposta ao incêndio por todos os lados

6.1.7 CASO 6 - Seção I com proteção tipo caixa, de espessura uniforme exposta ao incêndio por três lados

6.1.8 CASO 7 - Viga I em contato com laje de concreto e alvenaria, exposta ao incêndio pelos dois lados da parede de alvenaria...

6.1.9 CASO 8 - Pilar com mesas em contato com paredes de alvenaria, exposta ao incêndio pelos dois lados da parede de alvenaria

6.1.10 CASO 9 - Viga I em contato com laje de concreto e alvenaria, exposta ao incêndio em apenas um lado da parede de alvenaria

6.1.11 CASO 10 - Pilar com mesas em contato com paredes de alvenaria, exposta ao incêndio em apenas um lado da parede de alvenaria

6.1.12 CASO 11 - Pilar com alma em contato com paredes de alvenaria, exposta ao incêndio em apenas um lado da parede de alvenaria 


\section{CAPÍTULO 7 - EFEITOS DA ELEVAÇÃO DE TEPERATURA NA RESPOSTA}

ESTRUTURAL .159

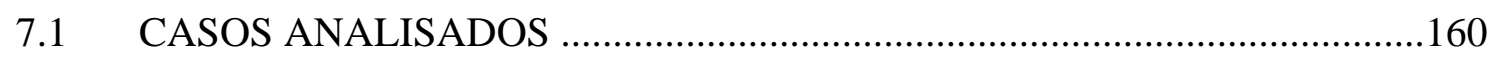

7.2 CONSIDERAÇÕES REFERENTES À GEOMETRIA DAS VIGAS ..............160

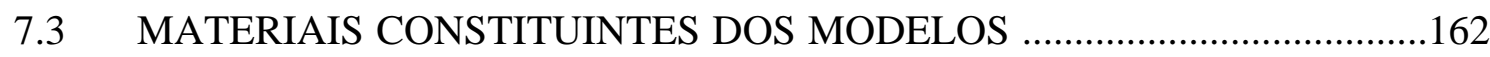

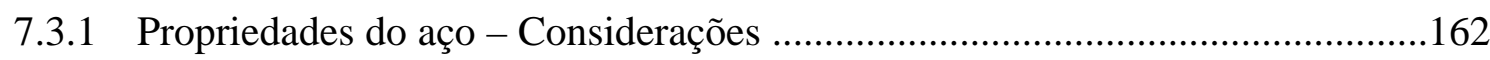

7.3.2 Propriedades do concreto - Considerações ...................................................164

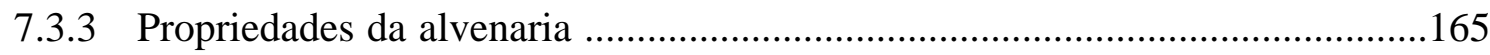

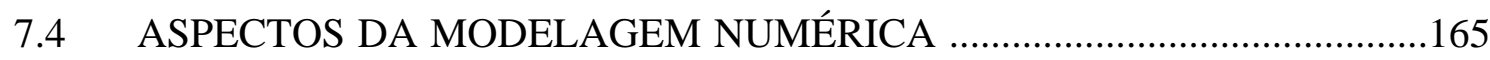

7.4.1 Considerações com relação à ANÁLISE TÉRMICA ......................................165

7.4.2 Considerações com relação à ANÁLISE ESTRUTURAL ...............................166

7.5 ANÁLISE ESTRUTURAL EM TEMPERATURA AMBIENTE ....................168

7.6 ANÁLISE ESTRUTURAL EM SITUAÇÃO DE INCÊNDIO .......................170

7.6.1 CASO: U5-V-EIST, Viga de aço isolada com fogo por todos os lados ...........171

7.6.2 CASO: U5-VL-EIT, Viga de aço com laje de concreto e sem alvenaria, com fogo por todos os lados da viga

7.6.3 CASO: U5-VLA9-EIT, Viga de aço com laje de concreto e alvenaria $(9 \mathrm{~cm}$ de espessura), com fogo por ambos os lados expostos da viga

7.6.4 CASO: U5-VLA9-EIP, Viga de aço com laje de concreto e alvenaria $(9 \mathrm{~cm}$ de espessura), com fogo em apenas um dos lados expostos da viga .178

7.6.5 CASO: U5-VLA14-EIT, Viga de aço com laje de concreto e alvenaria (14 cm de espessura), com fogo por ambos os lados expostos da viga .181

7.6.6 CASO: U5-VLA14-EIP, Viga de aço com laje de concreto e alvenaria (14 cm de espessura), com fogo em apenas um dos lados expostos da viga.

7.6.7 CASO: U5-VLBA14-EII, Viga de aço, de borda, com laje de concreto e alvenaria (14 cm de espessura), com fogo apenas no lado interno expostos da viga .186

\section{CAPÍTULO 8 - CONCLUSÕES E SUGESTÕES PARA TRABALHOS}

FUTUROS. 
ANEXO A - Fator de Massividade para Algumas Seções Transversais de Elementos Estruturais

ANEXO B - Solução Numérica da Equação Diferencial de Equilíbrio do Fenômeno Físico - Fundamentação Teórica. .203

ANEXO C - Campos de Temperatura Complementares Obtidos para os Casos de

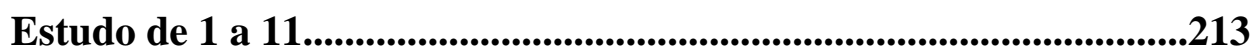





\section{INTRODUÇÃO}

O incêndio sempre constituiu um risco considerável à propriedade e à segurança humana. Quando ocorre de forma descontrolada pode ocasionar conseqüências devastadoras.

Conforme mencionado em SILVA (2001), no passado acreditava-se que o incêndio era obra do acaso e a vítima uma infortunada. Hoje, sabe-se que o incêndio é uma ação que pode ser evitada, e as vítimas, quer por morte ou por perda do patrimônio, surgem por conseqüência de ignorância ou ato criminoso.

Em WANG (2002) afirma-se que até recentemente, as medidas de combate a incêndios em edificações têm seguido procedimentos que evoluíram durante vários anos em resposta a desastres ocorridos anteriormente. Com relação às exigências de resistência ao fogo de elementos estruturais de aço e mistos em situação de incêndio, a maioria dos regulamentos e códigos normativos do mundo todo ainda tem por base ensaios de elementos isolados em fornos.

Atualmente é reconhecido o fato de que as prescrições normativas conduzem, em geral, a projetos anti-econômicos e inflexíveis. Por esta razão, no contexto internacional, a regulamentação de segurança contra incêndio em edificações tem evoluído no sentido de se libertar progressivamente das exigências de caráter prescritivo, passando a basear-se mais no desempenho dos elementos construtivos expostos a situações de incêndios reais.

Em VILA REAL (2003), são citados aspectos que permitem identificar a diferença entre a abordagem prescritiva e aquela baseada no desempenho, com relação ao comportamento de uma estrutura de interesse em situação de incêndio. Na última referência, cita-se que em uma abordagem prescritiva limita-se, por exemplo, a temperatura do aço um valor denominado "temperatura crítica”, isto é, a temperatura de colapso do elemento quando exposto às curvas “temperatura-tempo” normalizadas. 
Esta abordagem tem por base o pressuposto de que, para temperaturas superiores àquela denominada "temperatura crítica”, uma dada estrutura, metálica por exemplo, não é segura. Com este procedimento, a avaliação da temperatura do aço é objetivo último e, neste caso, de principal interesse. Não são levadas em conta circunstâncias particulares às quais a estrutura é sujeita ao incêndio, tais como: o tipo de incêndio, as conseqüências da exposição ao fogo, condições de carregamento ou mesmo a interação entre os vários elementos estruturais.

Por outro lado, em uma abordagem baseada no desempenho, todos os fatores são ponderados e a temperatura do aço é apenas uma das muitas variáveis envolvidas. Nesta abordagem, apesar de consistir de um procedimento mais custoso, é possível obter uma resposta da estrutura, quando submetida a elevadas temperaturas, mais representativa quando comparada às reais situações de incêndio.

Os avanços ocorridos no contexto mundial com relação ao entendimento do desempenho de estruturas em altas temperaturas e as maiores exigências quanto à segurança em situação de incêndio por parte do Corpo de Bombeiros nos grandes centros têm estimulado, no Brasil, estudos relacionados ao tema "segurança contra incêndio” com destaque ao desempenho de estruturas em situações de incêndio.

\subsection{OBJETIVO}

Este trabalho teve como objetivo principal estudar, em caráter essencialmente numérico, a elevação de temperatura em seções transversais de elementos estruturais de aço e mistos de aço e concreto, com vistas a uma avaliação das equações propostas pelo método simplificado de cálculo, para a determinação da temperatura, prescritas pela NBR 14323:1999.

É importante ainda destacar que para elementos de aço e mistos de aço e concreto, a obtenção da elevação de temperatura, obtida por meio das equações prescritas pela norma brasileira NBR 14323:1999, depende diretamente de um parâmetro denominado fator de massividade da seção, o qual é obtido pela relação entre o perímetro exposto ao fogo (u) e a área total da seção (A).

Na figura 1.1 são apresentadas equações para a determinação do fator de massividade, extraídas da NBR 14323:1999, para algumas seções transversais. 


\section{$\frac{\mathrm{u}}{\mathrm{A}}=\frac{\text { perímetro }}{\text { área da seção transversal }} \quad \frac{\mathrm{u}}{\mathrm{A}}=\frac{\text { perímetro exposto ao incêndio }}{\text { área da seção transversal }}$}
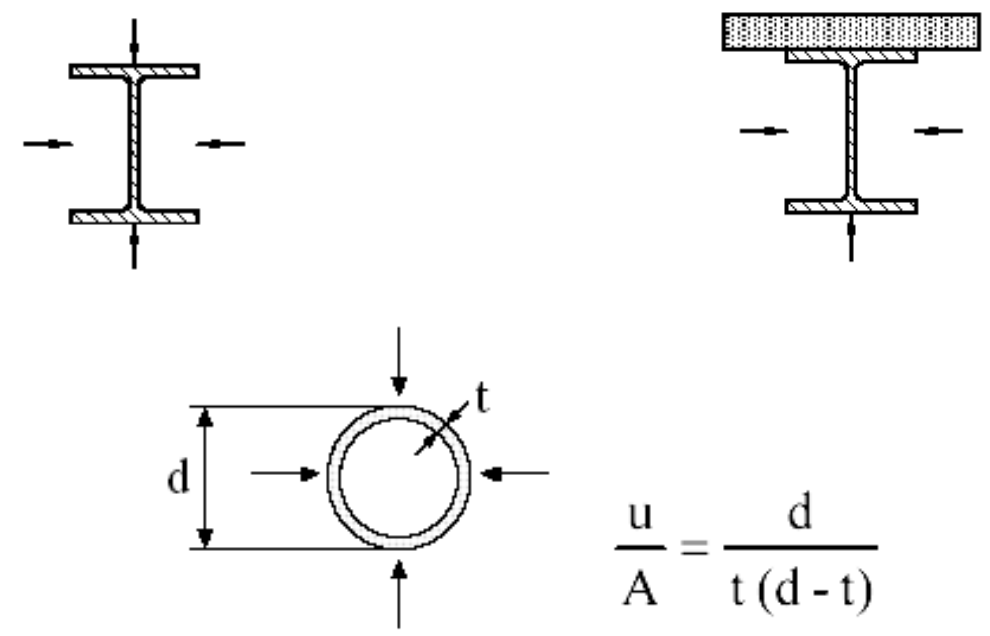

Figura 1.1 - Fatores de massividade para seções sem revestimento térmico.

Fonte: NBR 14323:1999.

Por fim, serão apresentados alguns casos de vigas de aço em situação de incêndio, em que se considera não apenas a ação térmica no elemento de interesse, mas também o carregamento estático a ser suportado pelo elemento em condições de serviço. Em outras palavras, considera-se o acoplamento termo-estrutural.

Em caráter complementar, será também apresentada uma simulação numérica direcionada à obtenção da elevação de temperatura em peças constituídas de madeira, no caso, da espécie Eucalipto Citriodora, cujos resultados serão comparados com outros resultados experimentais. É importante ressaltar que apesar de a madeira não constituir objeto principal de interesse do presente trabalho, tal simulação auxiliará na calibração da estratégia numérica aqui proposta, bem como permitem constatar a potencialidade dos modelos construídos.

\subsection{JUSTIFICATIVA}

Atualmente, na engenharia civil, é de grande interesse a análise de edifícios em situação de incêndio para que se possa garantir a segurança do edifício quanto ao colapso prematuro. 
A importância de estudos direcionados a análise da variação da temperatura ao longo do tempo (análise transiente) em seções transversais de aço e mistas de aço e concreto está relacionada ao fato de o fator de massividade $(\mathrm{u} / \mathrm{A})$, definido no item anterior, ser de fundamental importância na determinação da temperatura máxima atingida pelos elementos estruturais de aço por meio de modelos simplificados de cálculo como os prescritos pela NBR 14323:1999.

Esses modelos foram desenvolvidos para situações que contemplem casos em que ocorra aquecimento uniforme por todos os lados (ou faces) da seção, conforme representados nos casos (a) e (c) da figura 1.1.

Porém, para situações em que não ocorra aquecimento uniforme por todos os lados, caso (b), por exemplo, ou ainda a consideração de seção com revestimento contra fogo, o fator de massividade consiste de uma simplificação normativa (artifício) para determinação da temperatura no elemento de interesse, com vistas ao dimensionamento. Isso pode, eventualmente, conduzir a valores de temperatura máxima na seção que não estejam em concordância com aqueles que de fato venham a ocorrer na prática e que estejam contra a segurança.

\subsection{METODOLOGIA}

Foram realizadas análises térmicas em seções transversais por meio da utilização do ANSYS ${ }^{\circledR}$ v9.0, o qual disponibiliza ao pesquisador ferramentas necessárias para a obtenção dos resultados de interesse para análises térmicas.

O programa permite considerar os três modos primários de transferência de calor: condução, convecção e radiação. A análise aqui de interesse será do tipo análise térmica transiente, que permite determinar a distribuição de temperatura e outras grandezas térmicas com variação num período de tempo.

Os resultados obtidos por meio das simulações numéricas aqui elaboradas são validados confrontando-se com resultados apresentados por outras referências bibliográficas, frutos de trabalhos publicados por diversos pesquisadores, como por exemplo, aqueles apresentados em LEWIS (2000), em SILVA (2002) e em RIBEIRO (2004), para análises térmicas transientes, conforme ilustrados nas figuras 1.2 e 1.3. 

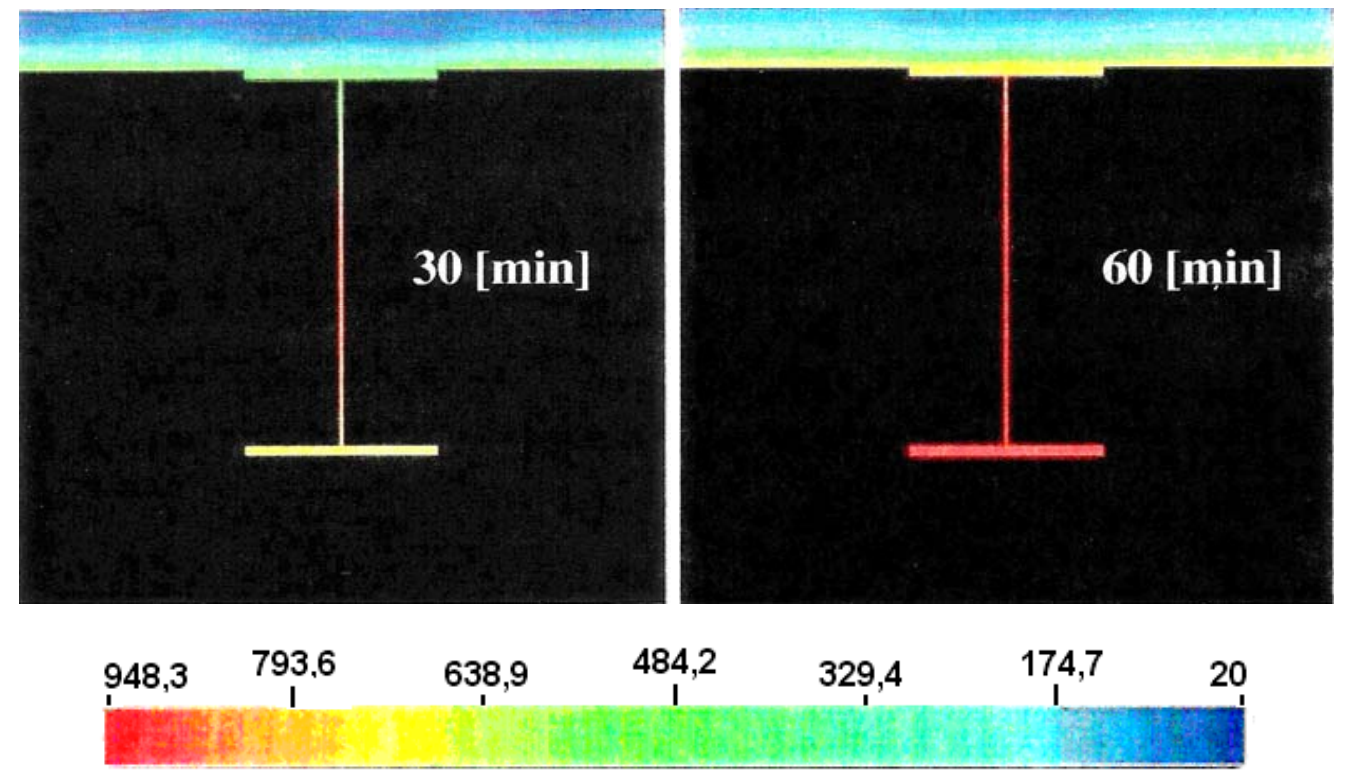

Figura 1.2 - Variação da temperatura em viga mista de aço e concreto.

Fonte: SILVA (2002).
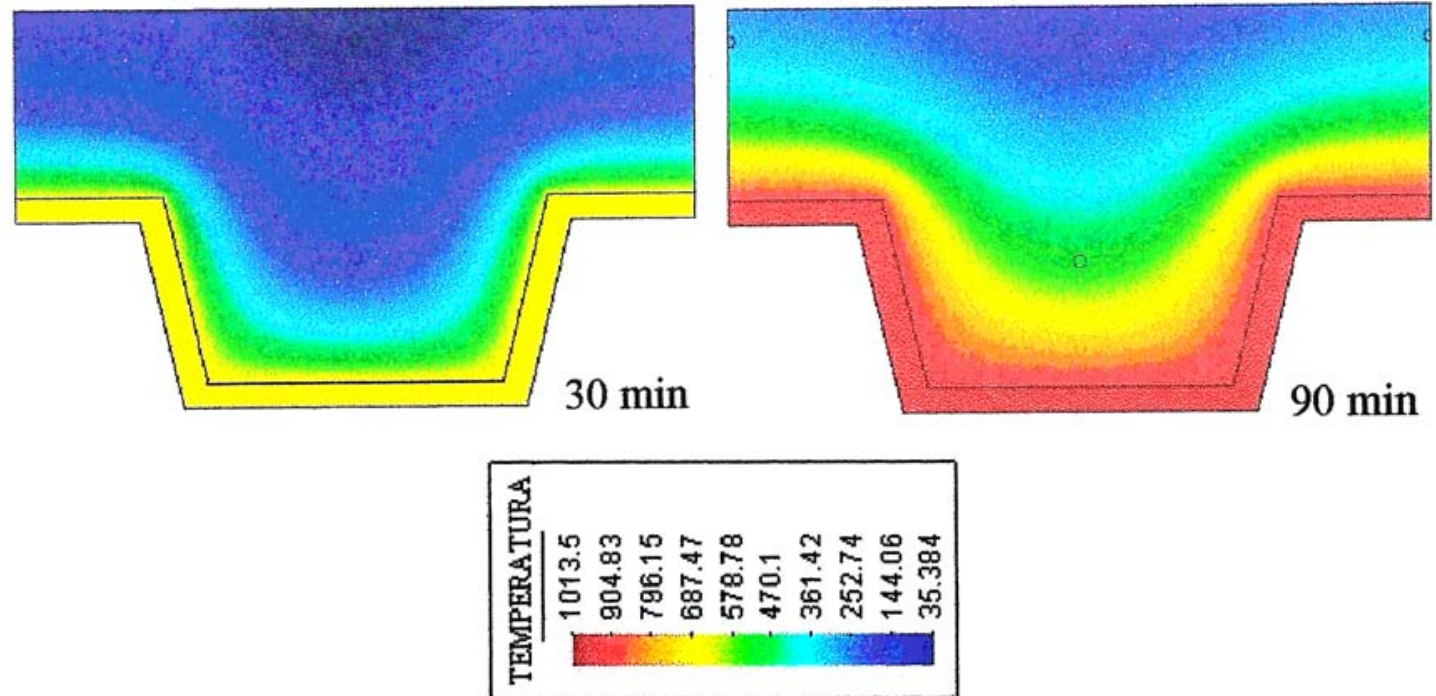

Figura 1.3 - Variação da temperatura em laje mista de aço e concreto.

Fonte: RIBEIRO (2004).

A escolha pela simulação numérica para análise transiente do gradiente térmico em seções transversais faz-se pelo fato de essa permitir análises mais detalhadas e precisas referentes à variação da temperatura na seção transversal ao longo do tempo, sem a necessidade da utilização de modelos matemáticos descritos por equacionamentos custosos. 


\subsection{APRESENTAÇÃO DO TRABALHO}

Ao longo deste capítulo foi apresentada a proposta do presente trabalho, incluindo objetivos, descrição e justificativa.

No capítulo 2 é apresentado um breve histórico sobre estruturas em situação de incêndio, bem como os principais mecanismos de transferência de calor, a equação diferencial de equilíbrio do fenômeno físico e os fundamentos sobre ações térmicas em estruturas em situação de incêndio. No capítulo 3 são apresentadas as propriedades térmicas referentes aos materiais aço e concreto, de interesse direto para o desenvolvimento do presente trabalho. São também apresentados diversos tipos e materiais de proteção contra o fogo.

No capítulo 4 são apresentados os meios de obtenção da elevação de temperatura em elementos estruturais, seja por meio de procedimento simplificado de cálculo ou por meio de métodos avançados de cálculo (simulações numéricas, por exemplo), de acordo com a NBR 14323:1999. São também apresentados aspectos referentes às simulações numéricas desenvolvidas, tais como a abordagem de um problema de transferência de calor, os tipos de elementos utilizados, condições de contorno, etc.

A validação do procedimento numérico é feita no capítulo 5 comparando-se resultados obtidos com casos disponíveis na bibliografia. Nesta etapa, são apresentadas as simulações complementares direcionadas a elementos de madeira.

Em seguida, no capítulo 6, parte-se para a proposta do trabalho propriamente dita, ou seja, avaliar a elevação de temperatura obtida para as situações em que não ocorra aquecimento uniforme por todos os lados. Para tal fim apresentam-se os resultados de 11 casos de interesse estudados.

No capítulo 7 apresenta-se uma estratégia de modelagem para análise acoplada termo-estrutural de elementos de aço, utilizando-se o programa ANSYS ${ }^{\circledR}$ v9.0, bem como um procedimento para a obtenção de um fator de redução para a resistência de um elemento estrutural em função do tempo de exposição ao incêndio.

Finalmente, no capítulo 8 , são apresentadas as conclusões do trabalho, bem como sugestões para trabalhos futuros. 


\section{O INCÊNDIO E AS AÇÕES TÉRMICAS NAS ESTRUTURAS}

\subsection{ESTRUTURAS EM SITUAÇÃO DE INCÊNDIO - BREVE HISTÓRICO}

\subsubsection{Breve histórico no contexto mundial}

Em KIRCHHOF (2004) cita-se que as primeiras exigências de proteção contra incêndio surgiram por volta de 1666, com a ocorrência de um grande incêndio situado na cidade de Londres. Porém, este tema só começou a ser realmente estudado em meados do século 19 e início do século 20.

Conforme mencionado em CLARET (2000) e KIRCHHOF (2004), o estabelecimento das primeiras normas para testes de resistência ao fogo deve-se a ASTM - American Society for Testing and Materials que, em 1911, estabeleceu a norma "Standard tests for fireproof constructions". Em 1932, a British Standard Institution (BSI) publicou a norma BS 476, intitulada "Fire tests on buildings materials and structures", a qual, com as devidas revisões e ampliações, ainda hoje é bastante utilizada e têm por base ensaios de elementos isolados em fornos.

Até os dias atuais, às exigências de resistência ao fogo de elementos estruturais de aço e mistos em situação de incêndio, da maioria dos regulamentos e códigos normativos, ainda tem por base ensaios de elementos isolados em fornos. Tais exigências conduzem a projetos anti-econômicos que, por muitas vezes, inviabilizam a construção em aço.

No intuito de se obter procedimentos mais racionais e econômicos de dimensionamento de estruturas de aço em situação de incêndio, na década de 90 houve uma significativa conjugação de esforços da indústria da construção metálica e do meio científico. 
Como resultado imediato foram realizados ensaios, em escala real, em edifícios construídos de madeira, de concreto e misto de aço e concreto submetido a elevadas temperaturas, realizados entre os anos de 1995 e 1997, no "Cardington Laboratory of the Building Research Establishment", no Reino Unido.

A figura 2.1 ilustra o Laboratório Cardington e uma das edificações ensaiadas, no caso, o edifício misto de aço e concreto com oito pavimentos. A figura 2.2 ilustra a vista geral e a configuração deformada dos elementos estruturais do edifício da figura 2.1, depois de ocorrido o incêndio.
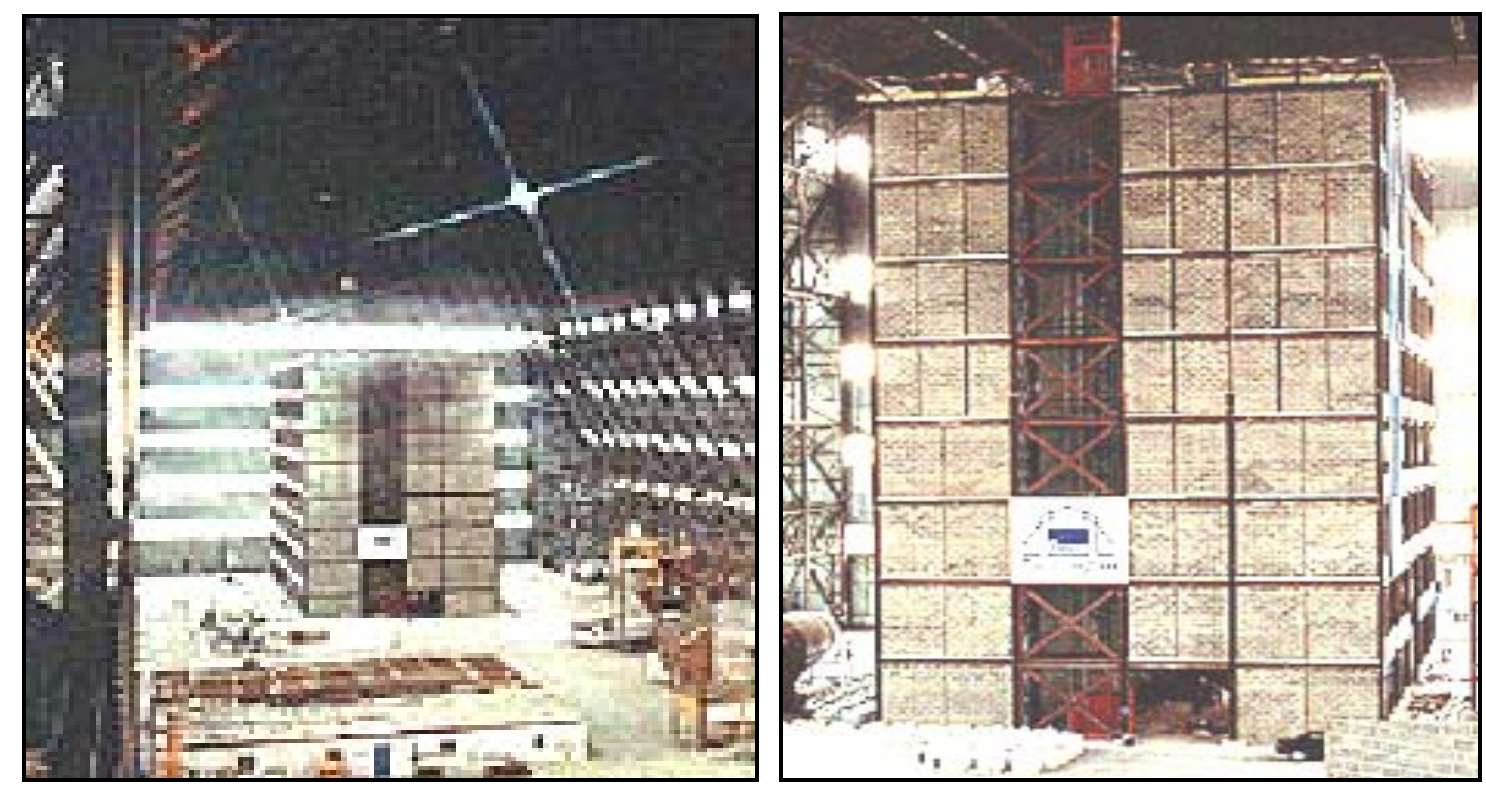

Figura 2.1 - Laboratório Cardington, Inglaterra: Estrutura de 8 (oito) pavimentos em escala real. Fonte: http://fire.nist.gov/bfrlpubs/fire02/art081.html
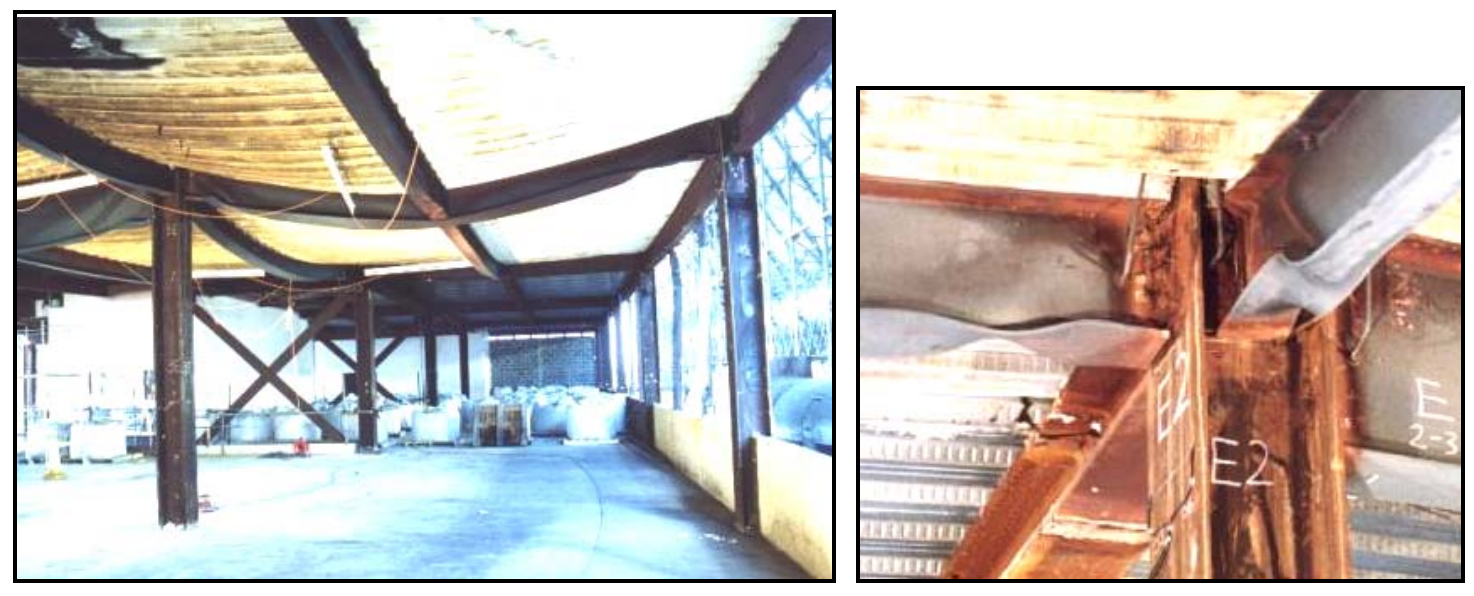

Figura 2.2 - Vista geral de um dos pavimentos e configuração deformada dos elementos estruturais após o incêndio. Fonte: SCI (2000). 
Em KIRCHHOF (2004) cita-se que a BHP, um dos maiores fabricantes de aço da Austrália vem, ao longo dos anos, pesquisando soluções em segurança contra de incêndio para as construções em aço. Testes de resistência ao fogo em escala real tem sido executados no Laboratório de Melbourne, na Austrália. A figura 2.3 ilustra um dos testes de resistência ao fogo executado em escala real.
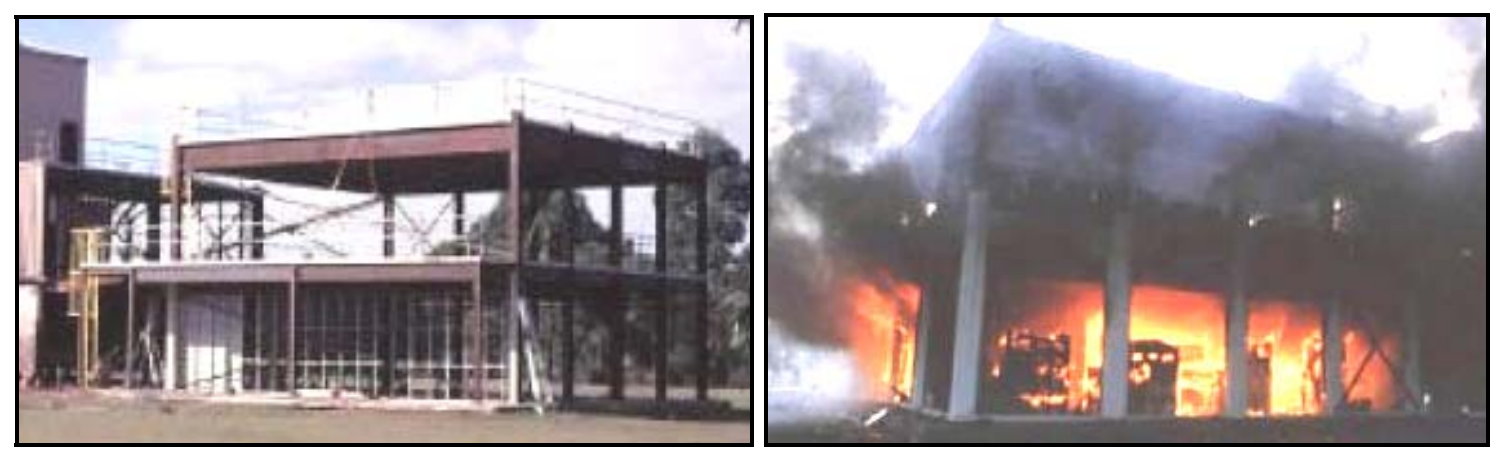

Figura 2.3 - Teste de resistência ao fogo executado pela BHP na Austrália.

Fonte: http://members.fortunecity.com/911/fire/SCI.htm

Os resultados dos ensaios em escala real, principalmente os resultados de Cardington, têm sido utilizados, ainda nos dias de hoje, extensivamente pela comunidade científica internacional para estudos que servirão de base ao desenvolvimento da nova geração de normas e regulamentos de segurança contra incêndio em edifícios, com base no desempenho da edificação como um todo.

\subsubsection{Breve histórico no Brasil}

Até a década de 70 as corporações de bombeiros conviviam com o drama da possibilidade de incêndio no seu cotidiano, porém, sem a ferramenta principal, ou seja, o regulamento compulsório de segurança contra incêndio. Historicamente, são as tragédias (ou situações adversas) que impulsionam a sociedade na busca por soluções para diferentes tipos de problemas ou ameaças.

No caso de incêndio, por exemplo, foram ocorrências como aquelas registradas no Edifício Andraus (1972) com 16 mortes, no Edifício Joelma, em 1974, com mais de 180 vítimas na cidade de São Paulo, e da Caixa Econômica do Rio de Janeiro (1974), que acabou por motivar (ou mesmo obrigar) as autoridades municipais a sancionarem, em tempo recorde, um Decreto sobre a proteção contra incêndio em edificações. (Fonte: 
http://www.lmc.ep.usp.br/people/valdir/homegsi/hist $\% \mathrm{C} 3 \% \mathrm{~B} 3$ rico.html acessado em 08/01/2007).

Foi então que, a partir dessa década, surgiu a maioria dos regulamentos existentes no Brasil. Basicamente consistem da adaptação de legislação estrangeira realizada por meio de Instituto de Resseguros, cujo objetivo principal era a contratação de seguros, FERREIRA, CORREIA e AZEVEDO (2006).

Em 1980 foi publicada a "NBR 5672 - Exigências particulares das obras de concreto armado e protendido em relação à resistência ao fogo", cancelada em 2001 por apresentar valores de cobrimentos e dimensões mínimas, que inviabilizavam economicamente a execução das obras de concreto.

Foi aprovado em 1993 o decreto 38069 no Estado de São Paulo, que estabelecia especificações para proteção contra incêndio. Em 1994, o Corpo de Bombeiros publicou a Instrução Técnica IT-CB-0233/94, que determinava o tempo de resistência ao fogo para vários tipos de estruturas de aço.

\subsubsection{Normas brasileiras para estruturas de aço em situação de incêndio}

Preocupados com a segurança em situação de incêndio, bem como com as rigorosas exigências da Instrução Técnica IT-CB-0233/94, no ano de 1995 representantes dos meios universitário e técnico formaram um Grupo de Trabalho objetivando elaborar textos-base normativos sobre o assunto em questão, conforme descrito em KIRCHHOF (2004).

A elaboração dos textos-base teve a participação do Corpo de Bombeiros/SP, dos fabricantes de estruturas metálicas e de materiais de revestimento contra fogo, de representantes das siderúrgicas, de representante do IPT, etc, os quais deram origem à norma sobre incêndio, NBR 14323, aprovada e publicada em 1999 com o titulo "Dimensionamento de estruturas de aço de edifícios em situação de incêndio".

A NBR 14323:1999 trata do dimensionamento de estruturas de aço em situação de incêndio, e apresenta a variação das propriedades do aço com a temperatura, a elevação da temperatura do aço, bem como fixa condições exigíveis para o dimensionamento de perfis, laminados, perfis soldados não-híbridos, elementos estruturais mistos de aço e concreto (vigas mistas, pilares mistos e lajes de concreto com forma de aço incorporada) e ligações executadas com parafusos ou soldas. 
Após a publicação da NBR 14323:1999, percebeu-se a necessidade da criação de uma norma para determinação da ação térmica nos elementos construtivos dos edifícios. Para tanto, foi publicada em 2000 a NBR 14432:2000, intitulada "Exigências de resistência ao fogo de elementos construtivos das edificações", em que são apresentados critérios para determinação do TRRF - tempo requerido de resistência ao fogo. O TRRF é um tempo fictício, definido por consenso da sociedade e estabelecido em normas ou códigos. Ele padroniza a ação térmica a ser utilizada no dimensionamento das estruturas em incêndio, quando submetidas ao modelo de incêndio-padrão.

Cabe ressaltar aqui a recente publicação da NBR 15200:2004 "Projeto de estruturas de concreto em situação de incêndio" como mais um avanço nacional na área de segurança contra incêndio. Além disso, vale lembrar também que a NBR 14323:1999 e a NBR 14432:2000 se encontram, na presente data, em processo de revisão, com o intuito de atualizar os procedimentos normativos, face aos novos conhecimentos obtidos na área.

Como forma de se adequar às novas normas técnicas que tratam de estruturas em situação de incêndio, principalmente devido à recente publicação da NBR 15200:2004, o Corpo de Bombeiros do Estado de São Paulo publicou em 2004 a Instrução Técnica ${ }^{\circ}$ 08/04 - Segurança Estrutural nas Edificações Resistência ao fogo dos elementos de construção. Esta Instrução Técnica estabelece as condições a serem atendidas pelos elementos estruturais e de compartimentação que integram as edificações, quanto aos Tempos Requeridos de Resistência ao Fogo (TRRF).

Portanto, de acordo com os aspectos citados ao longo deste item, nota-se o interesse imediato e a necessidade da continuidade de desenvolvimento de pesquisas voltadas para as estruturas em situação de incêndio, em caráter experimental e numérico, tanto no contexto mundial como no Brasil.

Porém, a obtenção da elevação da temperatura nos elementos estruturais (independentemente do material de interesse), necessária quando de análise em temperaturas elevadas, depende dos níveis de temperatura do ambiente em chamas. Em outras palavras, trata-se de analisar a transferência de carga térmica dos gases, seja por convecção ou radiação, para os elementos estruturais.

Para proporcionar ao leitor um melhor entendimento do fenômeno de transferência de calor dos gases para a estrutura, no item que segue serão abordados os mecanismos de interesse que permitem considerar as ações térmicas nos elementos 
estruturais. Ressalta-se, no entanto, que esta abordagem será realizada de maneira sucinta (simplificada), pois um estudo aprofundado sobre o mesmo tema não é objeto de interesse do presente trabalho.

\subsection{DETERMINAÇÃO DAS AÇÕES TÉRMICAS - INTRODUÇÃO}

Para a determinação da elevação de temperatura em elementos estruturais em situação de incêndio é necessário primeiramente determinar a quantidade de calor que chega a esses elementos. Para a correta determinação das ações térmicas nos elementos, ou em uma dada estrutura de interesse, é necessário conhecer os mecanismos pelo qual o calor é gerado num ambiente qualquer e, conseqüentemente, o modo como é propagado dentro do mesmo.

Diante disso, os itens que se seguem têm por objetivo apresentar conceitos fundamentais de transferência de calor que regem as ações térmicas em situação de incêndio.

Cabe aqui informar ao leitor que nas deduções e equacionamentos deste capítulo utilizar-se-á a temperatura (T) com unidade em K (Kelvin), por ser a unidade de temperatura mais comumente utilizada em textos sobre fundamentos de transferência de calor. No entanto, quando forem estabelecidos equacionamentos com o intuito de se obter a grandeza de algum parâmetro físico, a temperatura $\theta$ será adotada, convenientemente, em ${ }^{\circ} \mathrm{C}$ (graus Celsius).

\subsection{MECANISMOS DE TRANSFERÊNCIA DE CALOR}

Para um entendimento adequado dos mecanismos de transferência de calor é preciso que se tenha bem claro a definição de duas grandezas básicas: Temperatura $\boldsymbol{e}$ Calor.

Temperatura é a medida da quantidade de energia contida nas moléculas de uma dada substância. Permite determinar o quanto quente ou fria está uma substância, bem como pode ser usada para prever a direção da transferência de calor.

Calor é a energia em trânsito num dado sistema Para que haja transferência de calor num sistema é necessário que haja diferença de temperaturas. Estabelecida uma 
diferença de temperaturas num sistema, o calor que flui da região de maior temperatura para a de menor temperatura é resultante de um gradiente de temperaturas.

Nos estudos de transferência de calor, é usual considerar três modos distintos de transferência de calor: condução, convecção e radiação. Na realidade, a distribuição de temperatura em um meio é controlada pelos efeitos combinados desses três modos de transferência de calor. Entretanto, numa análise "simplificada", pode-se considerar a condução separadamente sempre que a transferência de calor por convecção e radiação possa ser desprezada e vice-versa.

Por exemplo, pode ser citado, para a primeira situação, o caso da transferência de calor de um soldador para o metal que está sendo soldado. Neste caso, praticamente todo o calor se propaga por condução, e a consideração de convecção ou radiação pode ser eventualmente desprezada. Assim, a decisão de qual o mecanismo de transferência de calor que deve ser levado em conta ficará a cargo do bom senso de quem efetuará a análise.

\subsubsection{Transferência de calor por CONDUÇÃO}

A transferência de calor por condução é o processo pelo qual a energia calorífica se transmite, num corpo qualquer, das moléculas com maior energia cinética (maior temperatura) às moléculas com menor energia cinética (menor temperatura), sem que haja transferência de massa. A lei física que governa esse fenômeno é denominada Lei de Fourier, estabelecida em 1822.

Segundo LIENHARD IV e LIENHARD V (2005), a lei de Fourier afirma que "o fluxo de calor, $\varphi\left(\mathrm{W} / \mathrm{m}^{2}\right)$, resultante da condução térmica é proporcional à magnitude do gradiente de temperatura e oposto a este em sinal", conforme equação 2.1 .

$$
\varphi=-\lambda \frac{d T}{d x}
$$

Na última equação $\frac{\mathrm{dT}}{\mathrm{dx}}$ é o gradiente de temperatura na direção do fluxo de calor $(\mathrm{K} / \mathrm{m})$ e $\lambda$ a condutividade térmica do material $(\mathrm{W} / \mathrm{mK})$. O fluxo de calor é uma grandeza vetorial. A equação (2.1) é a forma unidirecional da lei de Fourier. Em campo tridimensional, a condução passa a ser representada pela equação (2.2). 


$$
\vec{\varphi}=-\lambda \nabla \mathrm{T}
$$

Na equação (2.2) $\nabla$ é o operador gradiente, ou seja, $\nabla=\left\{\begin{array}{lll}\partial x & \partial y & \partial z\end{array}\right\}^{T}$. A condutividade térmica $(\lambda)$ é a propriedade que exprime a maior ou menor capacidade de condução de calor de um dado material. Os valores numéricos de $\lambda$ podem variar dependendo da constituição química, do estado físico e da temperatura dos materiais.

\subsubsection{Transferência de calor por CONVECÇÃO}

A convecção é o mecanismo de transferência de calor entre um sólido e um fluido em movimento nas adjacências deste sólido, desde que exista uma diferença de temperatura entre eles. De acordo com LIENHARD IV e LIENHARD V (2005), em 1701, Isaac Newton já considerava o processo de convecção e sugeriu que o "resfriamento" de um corpo, como aquele ilustrado na figura 2.4, fosse descrito pela equação (2.3).

$$
\frac{\mathrm{dT} \text { corpo }}{\mathrm{dt}} \cong \mathrm{T}_{\text {corpo }}-\mathrm{T}_{\infty}
$$

Na equação (2.3) $T_{\text {corpo }}$ é a temperatura do corpo e $T_{\infty}$ é a temperatura do fluído em movimento nas adjacências do corpo, ambas com unidade em K (Kelvin).

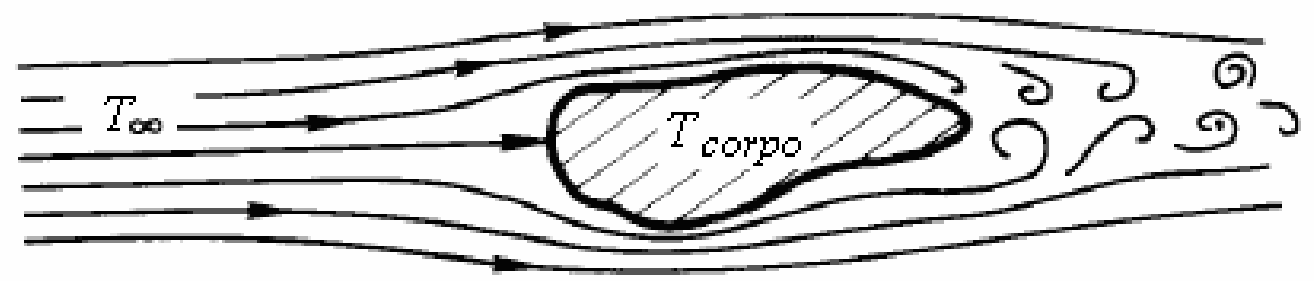

Figura 2.4 - Resfriamento convectivo de um corpo aquecido.

A equação (2.3) sugere que o calor está sendo transferido do corpo aquecido para o fluido. Se for assumida a hipótese de que temperatura do corpo é mantida constante, como que se houvesse geração de calor interno, $\frac{\mathrm{dT}_{\text {corpo }}}{\mathrm{dt}}$ pode ser interpretado como taxa de transferência de calor $(\mathrm{Q})$ entre o corpo e o fluido. 
A equação (2.3) pode ser reescrita, em termos de fluxo de calor, $\varphi=\mathrm{Q} / \mathrm{A}$, onde A é área em $\mathrm{m}^{2}$ da superfície do corpo em contato com o fluido, resultando

$$
\varphi_{\mathrm{c}}=\alpha_{\mathrm{c}}\left(\mathrm{T}_{\text {corpo }}-\mathrm{T}_{\infty}\right)
$$

A equação 2.4 é denominada lei de Newton do resfriamento, na qual $\alpha_{\mathrm{c}}$ é o coeficiente de transferência de calor por convecção em $\mathrm{W} / \mathrm{m}^{2} \mathrm{~K}$. O coeficiente $\alpha_{\mathrm{c}}$ da equação (2.4) é geralmente tomado como um valor médio e a lei de Newton é uma visão simplificada do processo, pois o mecanismo de transferência de calor por convecção é complexo e depende de numerosos fatores, além da já mencionada diferença de temperatura. Dentre estes fatores, pode-se citar:

- velocidade de deslocamento do fluido;

- densidade, viscosidade, calor específico e condutividade térmica do fluido;

- natureza, forma, rugosidade, dimensões e orientação do corpo.

A temperatura de um sólido em contato com um fluido pode induzir movimento nesse fluido resultando em convecção. Ao aquecer-se água em uma chaleira as moléculas da água em contato direto com o fundo da chaleira vão paulatinamente sendo aquecidas tornando-se mais leves e, por conseqüência, tendem a subir na massa líquida.

Nesse intervalo, as moléculas de água das camadas superiores (mais densas) vão tomando o lugar das moléculas mais aquecidas resultando num movimento convectivo. Isso é o que se costuma denominar de "convecção natural", e ocorre unicamente devido às forças resultantes da diferença de temperatura entre camadas do mesmo fluido.

A emissão de ar sobre um sólido por meio do uso de máquinas como foles e bombas é também um exemplo de convecção, porém, neste caso, conhecido como "convecção forçada".

Em um incêndio, na medida em que o ar é aquecido, as moléculas de ar da região aquecida se tornam menos densas e tendem a subir. Ao subirem, podem ser se chocar com elementos estruturais (vigas e as lajes, por exemplo). Neste caso, com o choque das moléculas de ar aquecido em movimento com a superfície dos elementos 
estruturais, ocorre a transferência de calor por convecção. Porém, com sentido (sinal) contrário àquele estabelecido por meio da equação (2.4).

\subsubsection{Transferência de calor por RADIAÇÃO}

A transferência de calor por radiação consiste no fato de que todos os corpos emitem constantemente energia por meio de ondas eletromagnéticas. A radiação é o principal mecanismo nos processos de transferência de calor que ocorrem em elevadas temperaturas, inclusive para situações em que se tenha a ocorrência de vácuo.

No processo de radiação, o calor flui por meio de ondas eletromagnéticas de um corpo sob alta temperatura para outro sob baixa temperatura. O fluxo de calor radiativo entre estes corpos depende, sobretudo, da temperatura dos corpos e da natureza de suas superfícies.

Em WANG (2002) afirma-se que quando a energia térmica radiante trafega num meio qualquer e incide num objeto, este objeto pode absorver, refletir ou transmitir a radiação térmica incidente. Diante disso, empregam-se os termos absortância $(\chi)$, refletividade $(\psi)$ e transmitância $(\tau)$ como fatores que permitem representar as frações de radiação que um corpo absorve, reflete e transmite, respectivamente, conforme descreve a equação (2.5).

$$
\chi+\psi+\tau=1
$$

\section{- Radiação de corpo negro - Ponto de Partida}

Os três fatores anteriormente mencionados e integrantes da equação (2.5) são funções da temperatura, do comprimento de onda e de propriedades da superfície. Um caso extremo é aquele em que toda a radiação térmica, proveniente de uma fonte de calor qualquer e incidente na superfície de um dado corpo de interesse, é absorvida pelo mesmo, isto é, $\chi=1$. Este corpo, considerado ideal, denomina-se corpo negro.

Outra propriedade importante do corpo negro consiste no fato de o mesmo ser também um perfeito emissor. Isto significa que nenhum outro corpo pode emitir mais radiação térmica (por unidade de área) que um corpo negro com uma dada temperatura. A quantidade total de radiação térmica $\left(\mathrm{E}_{\mathrm{b}}\right)$ emitida por uma superfície de corpo negro é 
função somente de sua temperatura, e dada pela lei de Stefan-Boltzmann, na forma da equação (2.6).

$$
\mathrm{E}_{\mathrm{b}}=\sigma \mathrm{T}^{4}
$$

$\mathrm{Na}$ equação (2.6), $\mathrm{E}_{\mathrm{b}}$ é dado em $\mathrm{W} / \mathrm{m}^{2}$, $\sigma$ é a constante de Stefan-Boltzmann , cujo valor utilizado é igual a $5,67 \times 10^{-8} \mathrm{~W} / \mathrm{m}^{2} \mathrm{~K}^{4}$, e T a temperatura em Kelvin.

\section{- Radiação de corpo cinzento}

É intuitivo perceber que o "corpo negro" é uma situação extrema de absorção ou emissão de calor. Portanto, na prática, nenhum material real emite e absorve radiação de acordo com as leis do corpo negro, conforme apresentado no item anterior. Em geral, é necessário definir um termo adicional para quantificar a energia emitida pela superfície de um corpo qualquer. Esse termo é denominado emissividade, e representado pelo parâmetro $\varepsilon$.

Esse termo é definido como taxa da energia total emitida por uma superfície real dividida por aquela emitida por uma superfície de corpo negro, ambas submetidas a uma mesma temperatura. Portanto, a emissividade pode variar entre zero e 1. A energia radiante total emitida por uma superfície real, em W/m², é dada pela equação (2.7).

$$
\mathrm{E}=\varepsilon \sigma \mathrm{T}^{4}
$$

Em geral, a emissividade de uma superfície depende do comprimento de onda da energia radiante, da temperatura da superfície e do ângulo de radiação. Entretanto, por simplificação, se a emissividade for admitida não dependente desses fatores, a superfície radiante é chamada superfície de corpo cinzento. A radiação de corpo cinzento é a adotada nos cálculos de engenharia de segurança contra incêndio.

\section{- Fator de configuração}

As equações (2.6) e (2.7) quantificam a energia total emitida por uma superfície de corpo negro e por uma superfície de corpo cinzento, respectivamente. 
Geralmente, a quantidade de energia radiante emitida por uma dada superfície (emissora), que é interceptada por uma outra superfície (receptora), resulta bem menor que aquela emitida, ou seja, parte daquela energia emitida é perdida ao longo do seu caminho. Para representar a fração de energia radiante que deixa uma superfície emissora e que efetivamente é interceptada por outra superfície, emprega-se um parâmetro denominado fator de configuração $\left(\Phi_{\mathrm{jk}}\right)$.

Conforme mencionado em WANG (2002) este parâmetro possui esta denominação por depender somente da configuração espacial entre as superfícies $\mathrm{dA}_{\mathrm{j}} \mathrm{e}$ $\mathrm{dA}_{\mathrm{k}}$, conforme esquematiza a figura 2.5 .

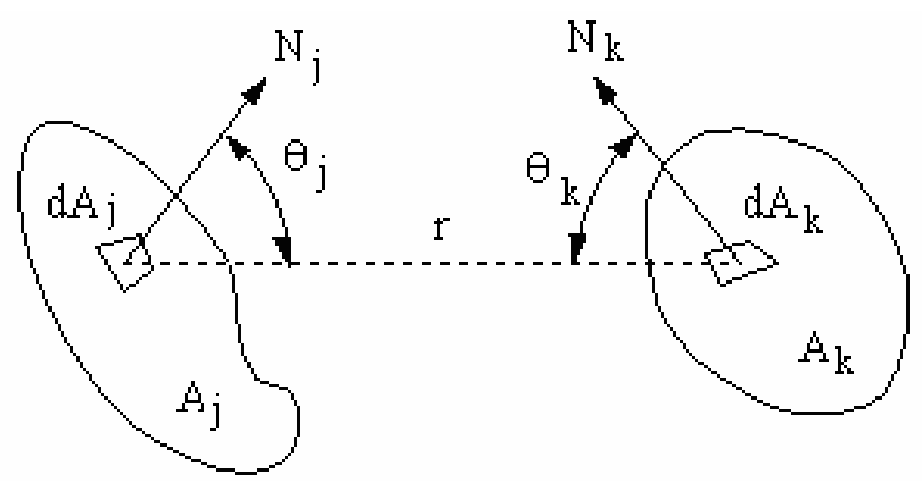

Figura 2.5 - Variáveis necessárias para o cálculo do Fator de Visada.

Adaptado de ANSYS (2004).

O cálculo do fator de visada para o esquema da figura 2.5, de acordo com o exposto em LIENHARD IV e LIENHARD V (2005), é dado pela equação (2.8).

$$
\Phi_{j k}=\frac{1}{A_{j}} \int_{A_{j}} \int_{A_{k}} \frac{\cos \theta_{j} \cos \theta_{k}}{\pi r^{2}} \mathrm{dA}_{k} \mathrm{dA}_{j}
$$

$\mathrm{Na}$ última equação, $\mathrm{A}_{\mathrm{j}}$ e $\mathrm{A}_{\mathrm{k}}$ representam as áreas das superfícies $\mathrm{j}$ e $\mathrm{k}$, respectivamente; $\mathrm{r}$ é o comprimento da reta entre o centro superfícies das superfícies diferenciais $\mathrm{dA}_{\mathrm{j}}$ e $\mathrm{dA}_{\mathrm{k}} ; \mathrm{N}_{\mathrm{j}}$ e $\mathrm{N}_{\mathrm{k}}$ são vetores normais às superfícies $\mathrm{dA}_{\mathrm{j}} \mathrm{e} \mathrm{dA}_{\mathrm{k}}$, respectivamente; $\theta_{\mathrm{j}}$ é ângulo entre $\mathrm{N}_{\mathrm{j}}$ e a linha que une as superfícies $\mathrm{dA}_{\mathrm{j}}$ e $\mathrm{dA}_{\mathrm{k}} ; \theta_{\mathrm{k}}$ é o ângulo entre $\mathrm{N}_{\mathrm{k}}$ e a linha que une as superfícies $\mathrm{dA}_{\mathrm{j}}$ e $\mathrm{dA}_{\mathrm{k}}$.

Com a consideração do fator de visada, tem-se que a radiação térmica (por unidade de área) emitida por uma superfície $\mathrm{dA}_{\mathrm{j}}$ e que incide numa superfície $\mathrm{dA}_{\mathrm{k}}$, pode 
ser dada pela equação 2.9, para o caso de radiação entre duas superfícies de corpo negro, e pela equação 2.10 , para o caso de duas superfícies de corpo cinzento.

$$
\begin{aligned}
& \varphi_{j k}=\Phi_{j k} E_{b_{j}}=\Phi_{j k} \sigma T_{j}^{4} \\
& \varphi_{j k}=\Phi_{j k} E_{j}=\Phi_{j k} \varepsilon_{j} \sigma T_{j}^{4}
\end{aligned}
$$

\subsubsection{Considerações sobre a radiação térmica em situação de incêndio}

Com a introdução dos parâmetros emissividade, refletividade e fator de visada, a forma para se estabelecer a troca de calor entre duas superfícies passa a ser bastante complexa, e a escolha por equações analíticas para representar esse fenômeno só podem ser obtidas (deduzidas) para casos bastante simples.

Um destes casos consiste de duas placas infinitas e paralelas, ambas com área A, cuja distância que as separa é suficientemente pequena, se comparada ao tamanho das placas, de modo a permitir considerar as perturbações devido à radiação nos cantos da placa como desprezíveis. A figura 2.6 esquematiza a situação em questão.

Esse caso pode ser empregado para representar uma situação de incêndio ao redor de um elemento construtivo. Nas aplicações em segurança contra incêndio é assumido, por simplificação, que os gases da combustão e os elementos estruturais estejam em contato direto, de modo que este fenômeno pode ser tratado como o caso de duas superfícies (placas) infinitas.

Radiação absorvida: $\varepsilon_{1} \varepsilon_{2} \sigma T_{1}^{4} \quad \psi_{1} \psi_{2} \varepsilon_{1} \varepsilon_{2} \sigma T_{1}^{4} \ldots . \quad$ Superficie 2

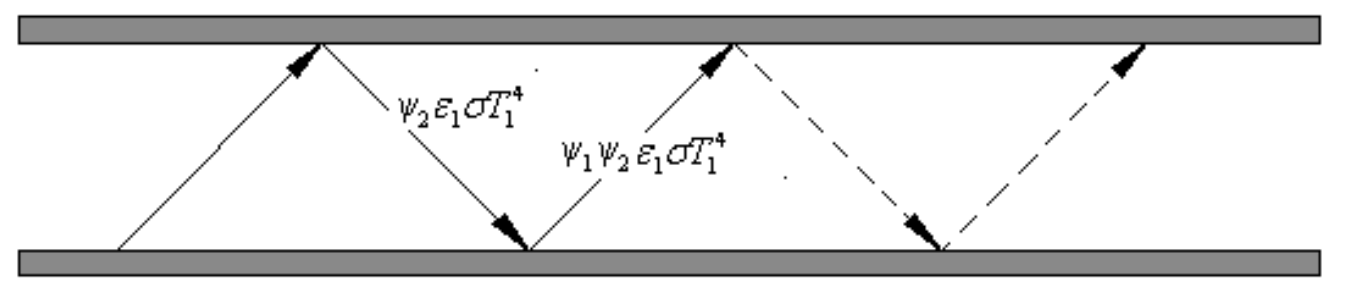

Total emitido: $\varepsilon_{1} \sigma T_{1}^{4} \quad$ absorvido: $\varepsilon_{1} \psi_{2} \varepsilon_{1} \sigma_{1}^{4}$

Superficie 1

Figura 2.6 - Troca de calor radiante entre duas superfícies de corpo cinzento infinitas. Adaptado de WANG (2002). 
A solução analítica desse caso pode ser obtida com base na figura 2.6, lembrando que com a hipótese de superfícies paralelas e infinitas, têm-se para as superfícies 1 e 2 da figura 2.6, por definição, fator de visada $\Phi_{12}=\Phi_{21}=1$.

Considerando-se inicialmente apenas a radiação emitida pela superfície 1 e incidente na superfície 2 (ou seja, desconsidera-se a radiação emitida pela superfície 2 e que incide na superfície 1), o fluxo de radiação $(\mathrm{Q} / \mathrm{A})$ total incidente na superfície 2 é dado pela seguinte série:

$$
\varphi_{1-2}=\varepsilon_{1} \varepsilon_{2} \sigma \mathrm{T}_{1}^{4}\left\{1+\psi_{1} \psi_{2}+\left(\psi_{1} \psi_{2}\right)^{2}+\ldots\right\}
$$

Similarmente, fluxo de radiação incidente na superfície 1 , em resposta à radiação emitida pela superfície 2 resulta:

$$
\varphi_{2-1}=\varepsilon_{1} \varepsilon_{2} \sigma \mathrm{T}_{2}^{4}\left\{1+\psi_{1} \psi_{2}+\left(\psi_{1} \psi_{2}\right)^{2}+\ldots\right\}
$$

O fluxo de calor resultante entre as duas superfícies é, portanto:

$$
\varphi_{\mathrm{r}}=\varphi_{1-2}-\varphi_{2-1}=\varepsilon_{1} \varepsilon_{2} \sigma\left(\mathrm{T}_{1}^{4}-\mathrm{T}_{2}^{4}\right)\left\{1+\psi_{1} \psi_{2}+\left(\psi_{1} \psi_{2}\right)^{2}+\ldots\right\}
$$

Desde que $\psi_{1} \psi_{2}<1$, a série entre chaves na equação (2.13) é convergente, e seu somatório é dado por $1 /\left(1-\psi_{1} \rho_{2}\right)$. O fluxo de energia radiante é, então, dado (2.14).

$$
\varphi_{\mathrm{r}}=\frac{\varepsilon_{1} \varepsilon_{2}}{1-\psi_{1} \psi_{2}} \sigma\left(\mathrm{T}_{1}^{4}-\mathrm{T}_{2}^{4}\right)
$$

Assumindo-se como desprezível a transmitância $(\tau)$, resulta, da equação (2.5), que $\psi=1-\chi$. A lei de Kirchhoff afirma que "a emissividade de uma superficie é igual a sua absortância”. Assim têm-se $\psi=1-\varepsilon$ e, após algumas manipulações matemáticas, a equação (2.14) pode ser reescrita conforme (2.15).

$$
\varphi_{\mathrm{r}}=\varepsilon_{\mathrm{res}} \sigma\left(\mathrm{T}_{1}^{4}-\mathrm{T}_{2}^{4}\right)
$$


Em (2.15) $\varepsilon_{\mathrm{r}}$ é a emissividade resultante dada por:

$$
\varepsilon_{\mathrm{res}}=\frac{1}{1 / \varepsilon_{1}+1 / \varepsilon_{2}-1}=\frac{\varepsilon_{1} \varepsilon_{2}}{\varepsilon_{1}+\varepsilon_{2}-\varepsilon_{1} \varepsilon_{2}}
$$

Em analogia a transferência de calor por convecção e sua definição pela equação (2.4) (ver item 2.1.2), pode-se ainda designar $\alpha_{\mathrm{r}}$ como sendo o coeficiente de transferência de calor devido à radiação, conforme equação (2.17).

$$
\alpha_{\mathrm{r}}=\varepsilon_{\mathrm{res}} \sigma\left(\mathrm{T}_{2}^{2}+\mathrm{T}_{1}^{2}\right)\left(\mathrm{T}_{2}+\mathrm{T}_{1}\right)
$$

A equação (2.15) pode ser reescrita de forma linearizada, analogamente ao caso da convecção, como:

$$
\varphi_{\mathrm{r}}=\alpha_{\mathrm{r}}\left(\mathrm{T}_{1}-\mathrm{T}_{2}\right)
$$

\subsection{EQUAÇÃO DIFERENCIAL DE EQUILÍBRIO DO FENÔMENO FÍSICO}

A primeira lei da termodinâmica considera, por hipótese, que a energia térmica é conservativa (sem perda de calor por dissipação), e pode ser aplicada a um volume de controle qualquer, por exemplo, àquele esquematizado na figura 2.7, com o objetivo de se estabelecer o balanço de energia deste volume de controle.

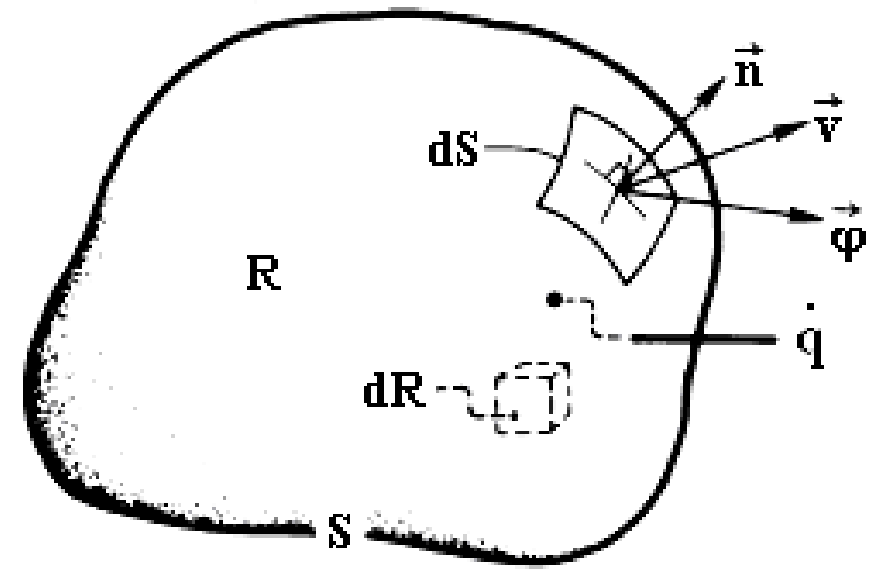

Figura 2.7 - Volume de controle num campo de fluxo de calor e fluido.

Extraído de LIENHARD IV e LIENHARD V (2005). 
O equilíbrio de energia térmica, obtida para um volume de controle, como aquele esquematizado na figura 2.7, é dado por meio da equação (2.19). O procedimento para a obtenção da equação (2.19), bem como as hipóteses adotada para tal fim, de acordo com o exposto em LIENHARD IV e LIENHARD V (2005), estão devidamente apresentados no anexo B.

$$
\rho \mathrm{c}(\underbrace{\frac{\partial \mathrm{T}}{\partial \mathrm{t}}}_{\substack{\text { energia } \\
\text { armazenada }}}+\underbrace{\overrightarrow{\mathrm{v}} \cdot \nabla \mathrm{T}}_{\begin{array}{c}
\text { entalpia } \\
\text { convectiva }
\end{array}})=\underbrace{\lambda \nabla^{2} \mathrm{~T}}_{\text {condução }}+\underset{\begin{array}{c}
\text { geração } \\
\text { de calor }
\end{array}}{\dot{\mathrm{q}}}
$$

Para se obter soluções específicas para a equação (2.19) faz-se necessário estabelecer condições de contorno relacionadas ao fenômeno de interesse. Num problema geral de transferência de calor, há três tipos de condição de contorno:

Condição 1 - Temperaturas especificadas na superfície de contorno: $\mathrm{T}=\left.\mathrm{T}_{0}\right|_{\mathrm{no} \text { contorno }}$.

Condição 2 - Fluxo de calor especificado: $-\left.\lambda_{\overrightarrow{\mathrm{n}}} \frac{\partial \mathrm{T}}{\partial \overrightarrow{\mathrm{n}}}\right|_{\text {no contorno }}=\varphi_{0}$, em que $\overrightarrow{\mathrm{n}}$ é a direção normal à superfície de contorno na qual o fluxo de calor é $\varphi_{0}$.

Condição 3 - Fluxo de calor devido a um fluido no contorno: $-\left.\lambda_{\overrightarrow{\mathrm{n}}} \frac{\partial \mathrm{T}}{\partial \overrightarrow{\mathrm{n}}}\right|_{\text {no contorno }}=\alpha \Delta \mathrm{T}$.

Para o caso de um elemento construtivo em Situação de Incêndio, a condição de contorno é, geralmente, descrita pela Condição 3. Nesta condição, $\alpha$ é o coeficiente total de transferência de calor e $\Delta \mathrm{T}$ é a diferença de temperatura entre o fluido e a superfície do contorno.

O coeficiente total de transferência de calor consiste de duas partes: uma relativa à transferência de calor devido à convecção $\left(\alpha_{c}\right)$ e outra relativa à transferência de calor devido à radiação $\left(\alpha_{\mathrm{r}}\right)$, ou seja, $\alpha=\alpha_{\mathrm{c}}+\alpha_{\mathrm{r}}$.

Portanto, os efeitos da radiação no contorno são considerados de forma semelhante aos efeitos da convecção e o coeficiente $\alpha_{\mathrm{r}}$ pode ser obtido como o emprego da equação (2.17). 


\subsection{AÇÕES TÉRMICAS EM ESTRUTURAS EM SITUAÇÃO DE INCÊNDIO}

A necessidade de um entendimento adequado dos mecanismos te transferência de calor dos gases para elementos estruturais imersos em um ambiente em chamas e, portanto, em situação de incêndio, se deve ao fato de o aumento da temperatura nesses mesmos elementos, em conseqüência da ação térmica, provocar reduções na resistência e na rigidez do material de interesse, bem como o aparecimento de esforços solicitantes adicionais para as estruturas hiperestáticas, conforme descrito em SILVA (2002).

A ação térmica numa estrutura de interesse é a ação descrita por meio do fluxo de calor $\varphi$, o qual consiste de uma parcela devido à radiação $\left(\varphi_{\mathrm{r}}\right)$ e outra parcela devido à convecção $\left(\varphi_{c}\right)$, em conformidade com os fundamentos apresentados nos itens anteriores. Tal ação é provocada pela diferença de temperatura entre os gases quentes do ambiente em chamas e os componentes (elementos) da estrutura.

A principal característica da ação térmica que atua em uma dada estrutura, a qual aparece em resposta às temperaturas elevadas, é a curva que fornece a temperatura dos gases em função do tempo de incêndio. A partir dessa curva, é possível determinar a máxima temperatura atingida pelas peças estruturais e sua correspondente resistência em altas temperaturas. A determinação dessa curva será discutida a seguir.

\subsubsection{Curva temperatura-tempo de um incêndio}

Para que possa ocorrer um incêndio torna-se necessária a existência simultânea de três fatores: uma fonte de calor, o combustível (papel, madeira e similares, por exemplo) e o comburente (oxigênio). O início do incêndio ocorre quando a mistura combustível/oxigênio está suficientemente quente para que ocorra a combustão.

Na figura 2.8, está representada a curva temperatura-tempo típica de um modelo de incêndio real. Na mesma figura, podem ser observadas, ou mesmo estabelecidas para fins de modelagem do fenômeno, três fases sucessivas e de interesse. São as seguintes:

- Ignição - Fase durante a qual as temperaturas permanecem baixas, não tendo nenhuma influência no comportamento estrutural das edificações. Embora não incluída nas curvas "temperatura-tempo" regulamentares é, do ponto de vista da segurança à vida humana a mais crítica, pois durante sua ocorrência são produzidos gases tóxicos; 
- Aquecimento - Esta fase tem seu inicio no instante em que o fogo se espalha por efeito principalmente da radiação ou contato direto, resultando no incêndio generalizado de todo o compartimento, fenômeno conhecido como "flashover". A partir deste instante as temperaturas sobem rapidamente, até todo material combustível começar a extinguir-se;

- Resfriamento - Nesta fase, ocorre uma diminuição progressiva da temperatura dos gases, pela falta de carga combustível ou oxigênio, ou mesmo pela intervenção de uma brigada de incêndio.

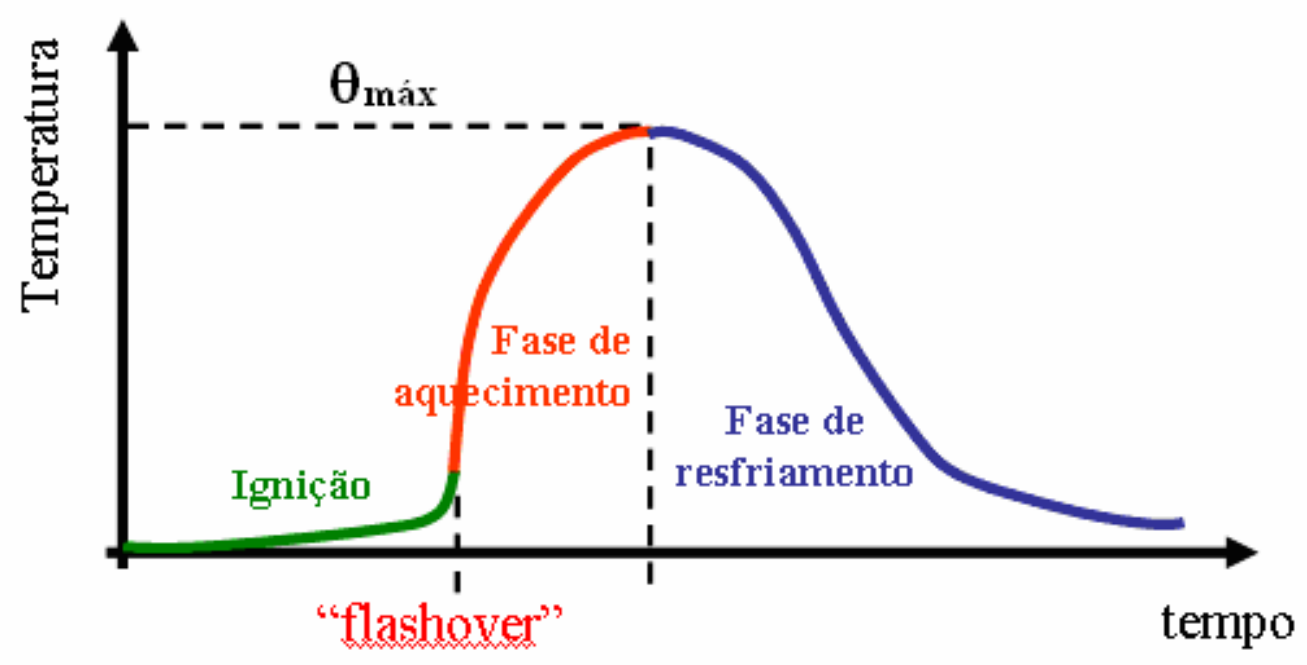

Figura 2.8 - Curva temperatura-tempo típica de um incêndio real.

No caso de edificações em que haja medidas de proteção contra incêndio (detectores de calor e fumaça, chuveiros automáticos, brigada de incêndio, etc.), para extinguir o fogo na fase de ignição não é necessária verificação da estruturas em incêndio, conforme descrito em SILVA (2001).

Se as medidas de proteção contra incêndio não forem suficientes para extinguir o incêndio durante a fase anterior à inflamação generalizada, e houver necessidade de verificação da segurança da estrutura em situação de incêndio, deve-se considerar o efeito da ação térmica nos elementos da estrutura. Para tal fim, pode-se simplificar, para fins de dimensionamento, o modelo (curva) de incêndio real, utilizando-se curvas “temperatura-tempo" como aquela esquematizada na figura 2.9.

Esse modelo de incêndio é conhecido como incêndio natural (item 2.5.2). A curva "temperatura-tempo" nesse tipo de modelo, de acordo com SILVA (2001), tem 
por base ensaios (ou modelos matemáticos aferidos por meio de ensaios) que simulam situações reais de incêndios. Para a utilização adequada deste tipo de modelo de incêndio, devem ser levados em consideração: a variação da quantidade de material combustivel (carga de incêndio), o grau de ventilação do compartimento, entre outros aspectos.

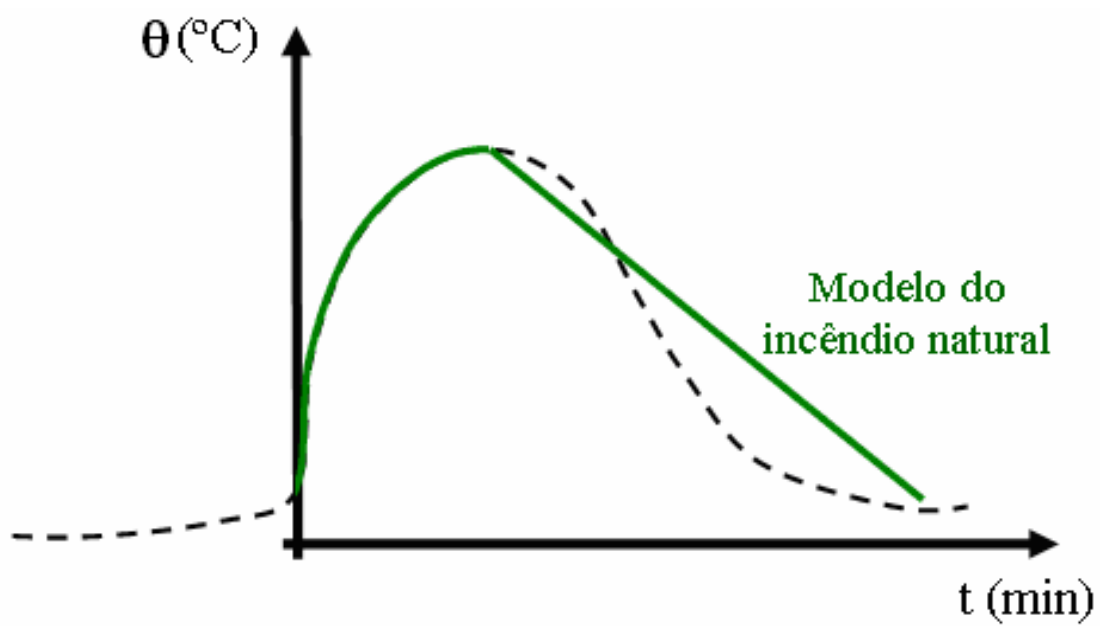

Figura 2.9 - Modelo do incêndio natural.

Tendo em vista que a curva temperatura-tempo do incêndio natural se altera para cada situação estudada (carga de incêndio, grau de ventilação, etc.), conforme será descrito no item 2.5.2, convencionou-se adotar uma curva padronizada como modelo para análise experimental de estruturas e de materiais de revestimento térmico em fornos de institutos de pesquisa. Esse modelo é conhecido como modelo de incêndiopadrão, e está esquematizado na figura 2.10.

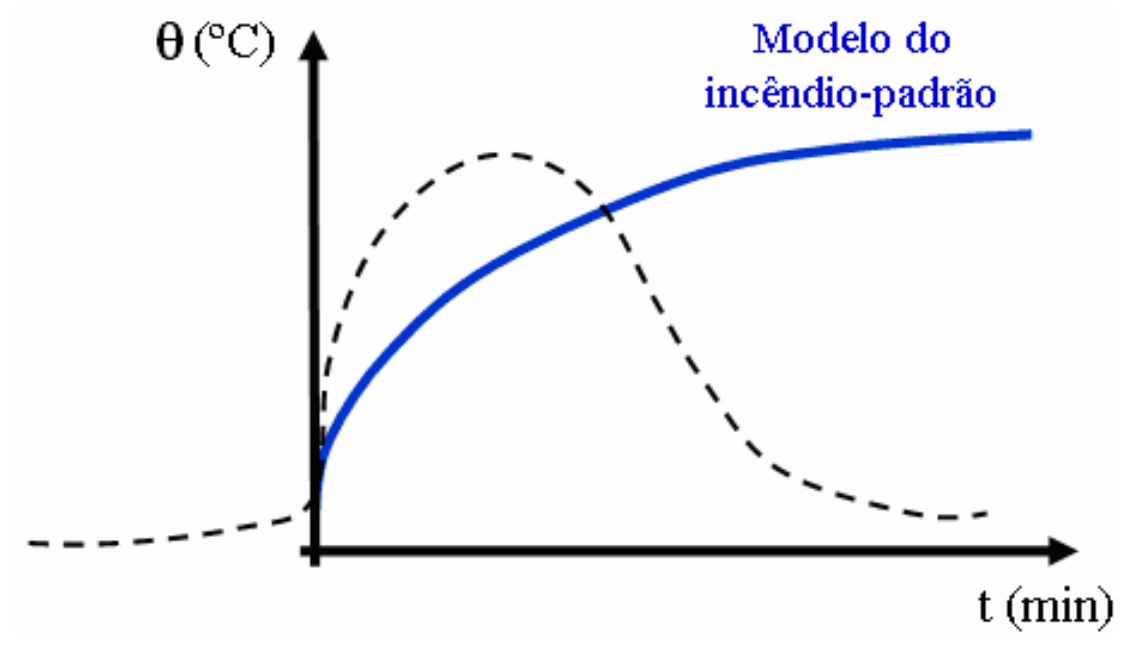

Figura 2.10 - Modelo do incêndio-padrão. 


\subsubsection{Incêndio-padrão}

Denomina-se incêndio-padrão o modelo de incêndio para o qual se admite a temperatura dos gases do ambiente em chamas em concordância com as curvas padronizadas para ensaio. As curvas padronizadas mais citadas na bibliografia consultada são: ISO 834, ASTM E 119 e as curvas do EUROCODE 1 (2002).

\section{- Curvas temperatura-tempo conforme ISO 834 e ASTM E 119}

A International Organization for Standardization, por meio da norma ISO 834 "Fire- resistance tests - Elements of building construction", recomenda a equação (2.20) para a curva do modelo do incêndio-padrão:

$$
\theta_{\mathrm{g}}=\theta_{0}+345 \log (8 \mathrm{t}+1)
$$

$\mathrm{Na}$ equação 2.20, $\theta_{\mathrm{g}}$ é a temperatura dos gases no ambiente em chamas $\left(\mathrm{em}{ }^{\circ} \mathrm{C}\right)$, $\theta_{0}$ é a temperatura dos gases no instante $\mathrm{t}=0$ (geralmente adotada igual a $20^{\circ} \mathrm{C}$ ) e $\mathrm{to}$ tempo (em minutos). O incêndio-padrão é adotado pela NBR 14432:2000 - Exigências de resistência ao fogo de elementos construtivos de edificações e também pela NBR 5628:1980 - Componentes construtivos estruturais - Determinação da resistência ao fogo - Método de Ensaio.

A American Society Testing and Materials, por meio da ASTM E 119 (2000) Standard test methods for fire tests of building construction and materials, apresenta uma relação "temperatura x tempo" para o modelo de incêndio-padrão por meio de valores tabelados, os quais permitem estabelecer a equação (2.21).

$$
\theta_{\mathrm{g}}=\theta_{0}+750\left[1-\mathrm{e}^{-3.79533 \sqrt{\mathrm{t}}}\right]+170.41 \sqrt{\mathrm{t}}
$$

Na equação $2.21, \theta_{\mathrm{g}}$ é a temperatura dos gases no ambiente em chamas $\left(\mathrm{em}{ }^{\circ} \mathrm{C}\right)$, $\theta_{0}$ é a temperatura dos gases no instante $\mathrm{t}=0$ (geralmente $20^{\circ} \mathrm{C}$ ) e $\mathrm{t}$ é o tempo (em horas). Esta relação "temperatura x tempo" curva foi adotada, em 1918, pela ASTM, segundo SILVA (2001), tendo por fundamento a proposta do UL - Underwriters Laboratory de Chicago, que a utilizava para a fase de aquecimento dos ensaios de 
pilares que estavam sendo realizados à época. Supõe-se que os dados tenham sido obtidos em incêndios reais. A figura 2.11 apresenta as curvas padronizadas pela ISO 834 e pela ASTM E 119.

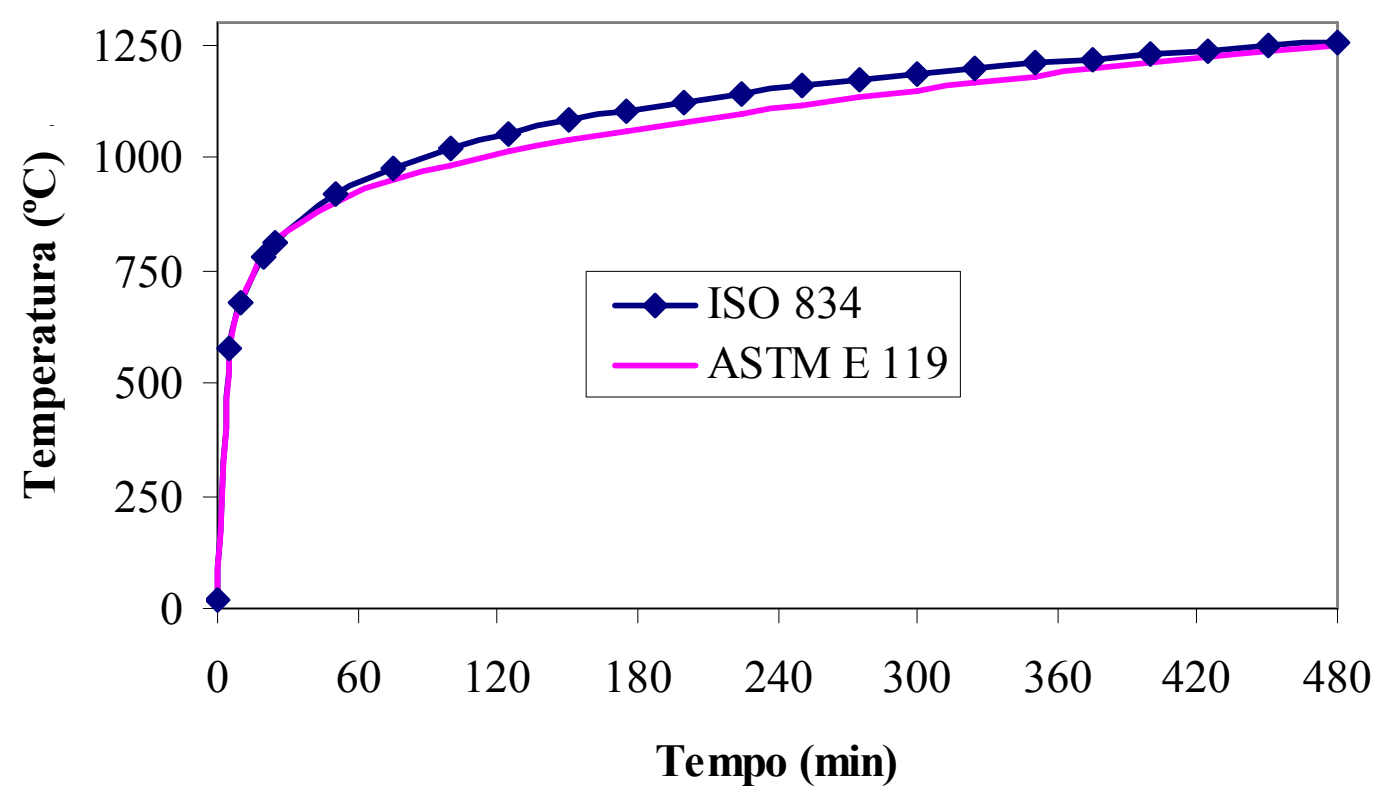

Figura 2.11 - Curvas temperatura-tempo padronizadas.

\section{- Curvas temperatura-tempo conforme o EUROCODE}

O EUROCODE 1 (2002) prescreve em seu texto, para fins de dimensionamento três curvas (equações) do tipo "temperatura-tempo" que permitem obter a temperatura dos gases de um dado ambiente em chamas. São as seguintes:

a-) Curva de incêndio padrão, ISO 834, conforme equação (2.20).

b-) Curva de incêndio para elementos exteriores (t em minutos):

$$
\theta_{\mathrm{g}}=660\left(1-0,687 \mathrm{e}^{-0,32 \mathrm{t}}-0,313 \mathrm{e}^{-3,8 \mathrm{t}}\right)+20
$$

c-) Curva de incêndio de hidrocarbonetos (t em minutos):

$$
\theta_{\mathrm{g}}=1080\left(1-0,325 \mathrm{e}^{-0,167 \mathrm{t}}-0,675 \mathrm{e}^{-2,5 \mathrm{t}}\right)+20
$$


Essas curvas são denominadas curvas nominais, pelo fato de serem estabelecidas por meio de equacionamento simples, bem como resultarem independentes das dimensões ou do tipo dos edifícios. A figura 2.12 apresenta a evolução destas três curvas que, analogamente àquelas apresentadas no item anterior, também não possuem fase de ignição e nem de extinção ou resfriamento.

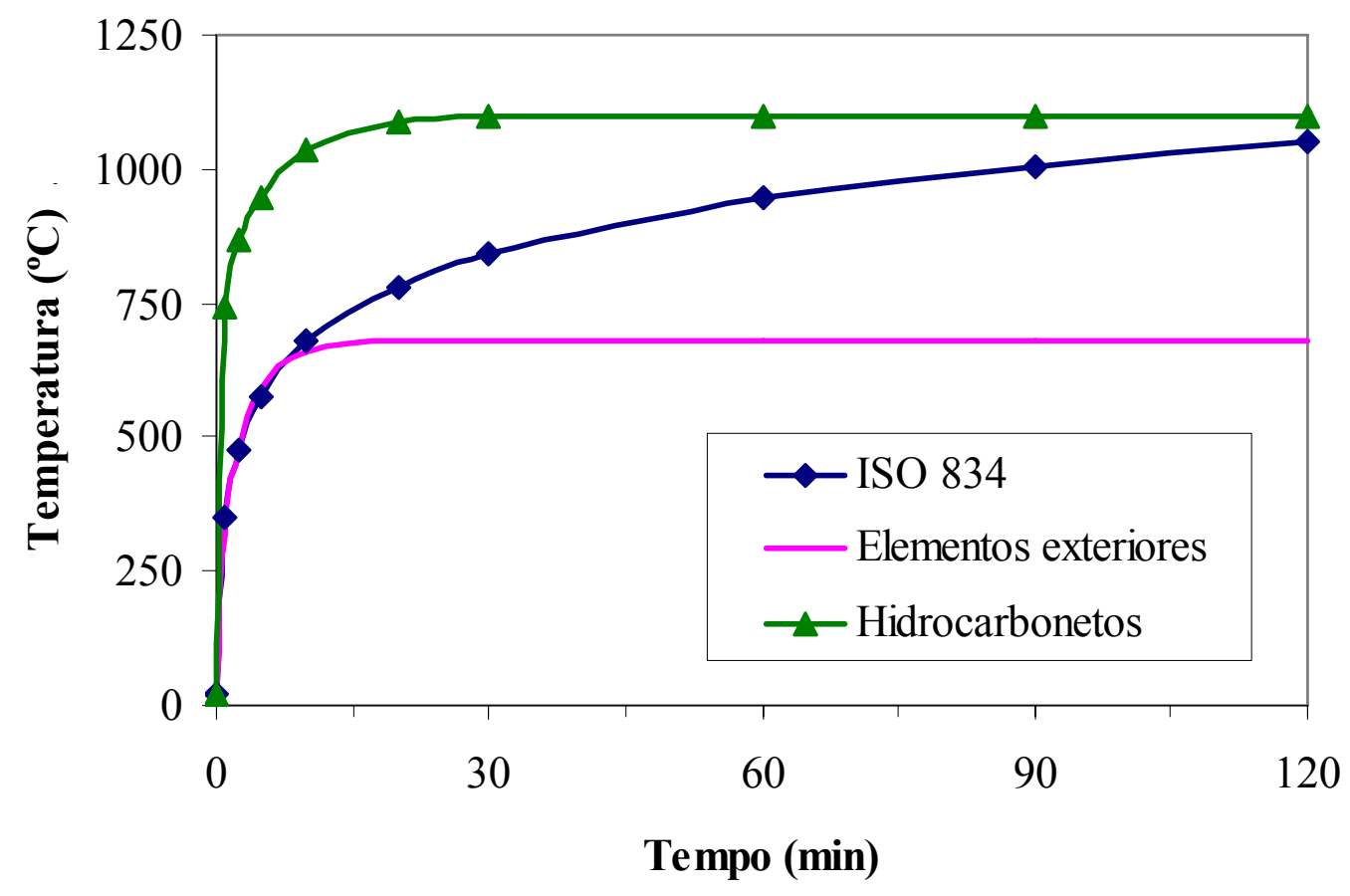

Figura 2.12 - Curvas nominais definidas no EUROCODE 1 (2002).

\subsubsection{Incêndio natural}

Denomina-se incêndio natural o modelo de incêndio para o qual se admite que a temperatura dos gases respeite as curvas "temperatura-tempo" construídas a partir de ensaios (ou modelos matemáticos aferidos a ensaios) de incêndios que simulam a real situação de um compartimento em chamas.

Os ensaios são realizados em compartimentos com aberturas (janelas), nas quais o incêndio ocorre sem possibilidade de se propagar para fora dele, em decorrência das características de isolamento térmico, de estanqueidade e de resistência dos elementos de vedação. Esse modelo de incêndio também é conhecido como incêndio natural compartimentado.

Os resultados desses ensaios demonstram que as curvas "temperatura-tempo" de um incêndio natural compartimentado dependem dos seguintes parâmetros: Carga de 
incêndio, Grau de ventilação e Características térmicas do material componente da vedação.

A principal característica dessas curvas, e que as distinguem da curva de incêndio-padrão, é a de possuírem um ramo ascendente (fase de aquecimento) e um ramo descendente (fase de resfriamento), representado por meio de uma reta, por simplificação. Portanto, essas curvas admitem (racionalmente) que os gases do ambiente em incêndio não têm sua temperatura sempre crescente com o tempo, situação essa mais coerente com o que de fato ocorre em um incêndio.

\section{- Curvas parametrizadas do EUROCODE}

Apresenta-se aqui, de forma sucinta, a obtenção de curvas parametrizadas, de acordo com o EUROCODE 1 (2002) Part 1-2, conforme esquematizadas na figura 2.13.

Tendo em vista o enfoque sucinto que será atribuído às informações constantes no presente item, destaca-se que para informações complementares e maiores esclarecimentos com relação à obtenção de parâmetros não explícitos no texto que segue, fica como sugestão para o leitor consultar as informações constantes no EUROCODE 1 (2002) Part 1-2 e em VILA REAL (2003).

De acordo com o EUROCODE 1 (2002) Part 1-2, as relações temperaturatempo, dadas pela equação (2.24), são válidas para compartimentos de incêndio com, no máximo, $500 \mathrm{~m}^{2}$ de área em planta, sem aberturas no teto e com pé-direito máximo igual a 4 metros, bem como partindo do pressuposto que a carga de incêndio do compartimento é totalmente consumida.

As curvas parametrizadas têm uma fase de aquecimento seguida de uma fase de resfriamento. A fase de aquecimento é dada pela equação (2.24).

$$
\theta_{\mathrm{g}}=20+1325\left(1-0,324 \mathrm{e}^{-0,2 \mathrm{t}^{*}}-0,204 \mathrm{e}^{-1,7 \mathrm{t}^{*}}-0,472 \mathrm{e}^{-19 \mathrm{t}^{*}}\right)
$$

Na equação 2.24, valem:

$\theta_{\mathrm{g}}-$ temperatura no compartimento de incêndio $\left({ }^{\circ} \mathrm{C}\right)$

$\mathrm{t}^{*}=\mathrm{t} \cdot \Gamma$, tempo fictício $(\mathrm{em} \mathrm{h})$ 
$\Gamma=[\mathrm{O} / \mathrm{b}]^{2} /(0,04 / 1160)^{2}$

$\mathrm{b}=\sqrt{\rho \mathrm{c} \lambda}$, fator $b\left(\mathrm{em} \mathrm{J} / \mathrm{m}^{2} \mathrm{~s}^{1 / 2} \mathrm{~K}\right)$ com os limites: $100 \leq \mathrm{b} \leq 2200$

Nas equações $2.25,2.26$ e 2.27, $\mathrm{t}$ é o tempo (em horas), $\rho$ é a massa específica do material de vedação do compartimento $\left(\mathrm{em} \mathrm{kg} / \mathrm{m}^{3}\right)$, c é o calor específico do material de vedação do compartimento (em $\mathrm{J} / \mathrm{kgK}$ ) e $\lambda$ a condutividade térmica do material de vedação do compartimento (em $\mathrm{W} / \mathrm{mK})$. Ainda, com relação à equação 2.26 , vale:

$\mathrm{O}=\mathrm{A}_{\mathrm{v}} \sqrt{\mathrm{h}_{\mathrm{eq}}} / \mathrm{A}_{\mathrm{t}}$, grau de ventilação ou fator de abertura $\left(\mathrm{em} \mathrm{m}^{1 / 2}\right)$ com os limites: $0,02 \leq \mathrm{O} \leq 0,20$

$\mathrm{A}_{\mathrm{v}}$ - área total das aberturas verticais em todas as paredes do compartimento (em $\mathrm{m}^{2}$ )

$\mathrm{h}_{\mathrm{eq}}$ - média ponderada da altura das aberturas das aberturas verticais em todas as paredes (em m)

$A_{t}$ - área total da superfície envolvente (paredes, teto e pavimento, incluindo aberturas) $\left(\mathrm{em} \mathrm{\textrm {m } ^ { 2 } )}\right.$

A fase de aquecimento da curva descrita pela equação (2.24) ocorre até um tempo $t_{\max }$ determinado por:

$$
\mathrm{t}_{\max }=\max \left[\left(0,2.10^{-3} \cdot \mathrm{q}_{\mathrm{t}, \mathrm{d}} / \mathrm{O}\right) ; \mathrm{t}_{\lim }\right] \quad(\mathrm{em} \mathrm{h})
$$

$\mathrm{Na}$ última equação, $\mathrm{q}_{\mathrm{t}, \mathrm{d}}$ é o valor de cálculo da carga de incêndio específica referido à área $A_{t}$ da superfície de vedação, enquanto $t_{\text {lim }}$ é tempo limite da fase de aquecimento em função da velocidade de propagação do incêndio.

Com relação à fase de resfriamento deste modelo de incêndio, a taxa de resfriamento pode ser obtida de acordo com o seguinte:

$$
\frac{\mathrm{d} \theta_{\mathrm{g}}}{\mathrm{dt}}=\left\{\begin{array}{ccc}
-625 & \text { se } & \mathrm{t}_{\text {max }}^{*} \leq 0,5 \\
-250\left(3-\mathrm{t}_{\text {max }}^{*}\right) & \text { se } & 0,5<\mathrm{t}_{\max }^{*}<2 \\
-250 & \text { se } & \mathrm{t}_{\max }^{*} \geq 2
\end{array}\right.
$$


Para a equação (2.30), $\mathrm{t}_{\max }^{*}$ é determinado por meio da equação (2.31):

$$
\mathrm{t}_{\max }^{*}=\left(0,2 \cdot 10^{-3} \cdot \mathrm{q}_{\mathrm{t}, \mathrm{d}} / \mathrm{O}\right) \cdot \Gamma
$$

\section{- Exemplos de Curvas parametrizadas}

Os exemplos de curvas de incêndio parametrizadas apresentadas na figura 2.13 estão em concordância com aqueles apresentados no documento ECCS (2001), cujos parâmetros empregados são $\mathrm{q}_{\mathrm{t}, \mathrm{d}}=180 \mathrm{MJ} / \mathrm{m}^{2}, \mathrm{~b}=1160 \mathrm{~J} / \mathrm{m}^{2} \mathrm{~s}^{1 / 2} \mathrm{~K}, \mathrm{t}_{\text {lim }}=20 \mathrm{~min} \mathrm{e}$, por fim, a fator de abertura, $\mathrm{O}$, variando de $0,02 \mathrm{~m}^{1 / 2}$ até $0,2 \mathrm{~m}^{1 / 2}$.

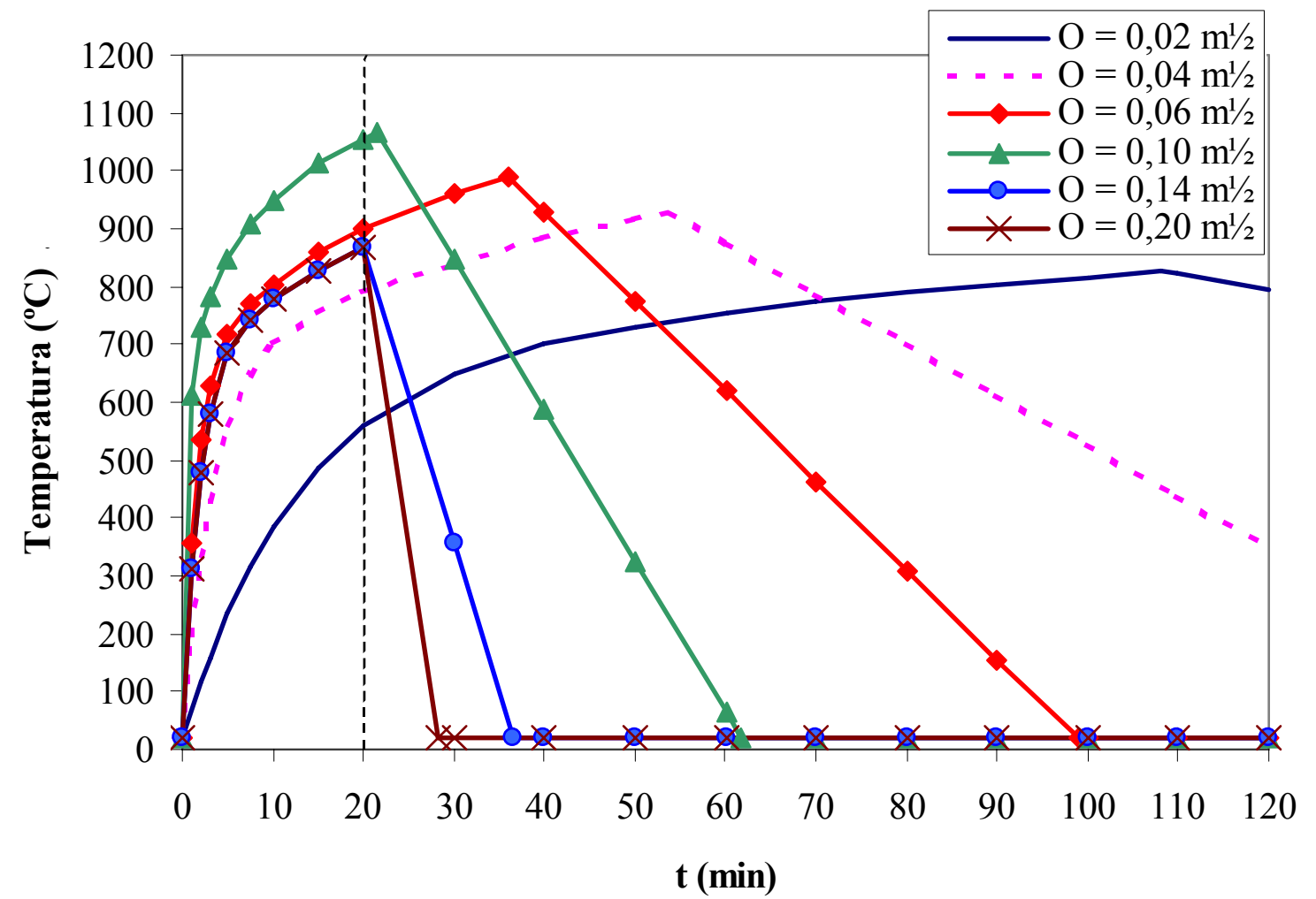

Figura 2.13 - Exemplos de incêndios parametrizados.

A figura 2.13 mostra que para incêndio controlado pela ventilação (instante correspondente à temperatura máxima dado por $\left.0,2 \times 10^{-3} \cdot \mathrm{q}_{\mathrm{t}, \mathrm{d}} / \mathrm{O}\right)$ o aumento do grau de ventilação, $\mathrm{O}$, conduz a incêndios mais curtos e mais severos, situação que permanecerá até que o incêndio passa a ser controlado pela carga de incêndio, ou seja, temperatura máxima correspondente ao tempo $\mathrm{t}=\mathrm{t}_{\text {lim }}$, que neste caso corresponde a $20 \mathrm{~min}$. 
Com relação a este último caso, a influência do fator de abertura é notada apenas na velocidade de resfriamento do incêndio. Vale salientar que, no caso em que $\Gamma=1$, ou seja, para qualquer $\mathrm{q}_{\mathrm{t}, \mathrm{d}}, \mathrm{O}=0,04 \mathrm{~m}^{1 / 2}$ e $\mathrm{b}=1160 \mathrm{~J} / \mathrm{m}^{2} \mathrm{~s}^{1 / 2} \mathrm{~K}$, a curva de temperaturatempo dada pela equação (2.24) praticamente se ajusta à curva ISO 834 na fase de aquecimento, conforme figura 2.14 .

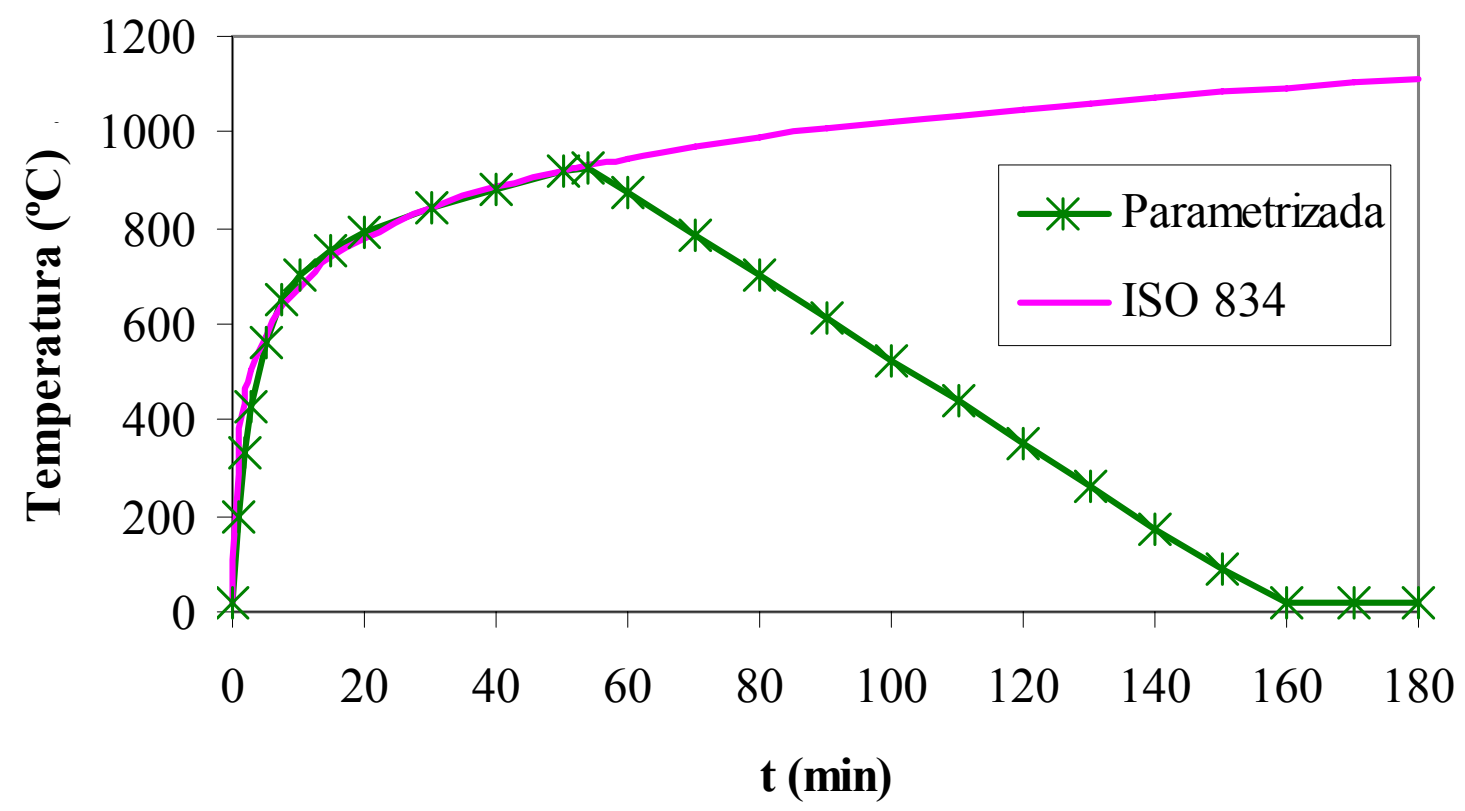

Figura 2.14 - Curva ISO 834 e curva parametrizada (correspondente à $\Gamma=1$ ). 


\section{PROPRIEDADES TÉRMICAS DOS MATERIAIS DE INTERESSE}

A ocorrência da elevação de temperatura em elementos estruturais metálicos ou de concreto, ou mesmo em elementos estruturais de outros tipos de materiais, em decorrência de situação de incêndio, por exemplo, implica na necessidade de se conhecer as propriedades térmicas destes materiais.

Quando ocorre um aumento excessivo de temperatura num elemento estrutural uma das soluções mais freqüentes é envolvê-lo com um material de proteção, o qual é empregado com maior freqüência em elementos metálicos. A maior ou menor eficiência desse revestimento está diretamente relacionada às suas propriedades térmicas como, por exemplo, a baixa condutividade.

Dentro deste contexto, o presente capítulo apresenta as propriedades térmicas dos aços estruturais e do concreto (normal e de baixa densidade), bem como dos materiais de proteção contra fogo freqüentemente empregado nas estruturas correntes da engenharia civil, tendo em vista que no decorrer deste trabalho serão apresentados modelos numéricos que consideram a existência de materiais de proteção.

\subsection{PROPRIEDADES TÉRMICAS DOS AÇOS ESTRUTURAIS}

Segundo o projeto de revisão da NBR 14323:1999, as propriedades térmicas apresentadas nas próximas subseções aplicam-se, em princípio, em temperatura elevada, aos aços de uso estrutural prescritos pela NBR 8800:1986 e NBR 14762:2001.

A NBR 14323:1999 prescreve ainda que caso algum aço estrutural possua propriedades diferentes daquelas presentes na norma, ou fique com propriedades diferentes em virtude de trabalhos realizados para formação ou revestimento de perfis ou composição da estrutura, os valores destas propriedades deverão ser utilizados. Tais valores, todavia, devem ser obtidos em norma ou especificação estrangeira, ou em 
ensaios realizados em laboratório nacional ou laboratório estrangeiro. Os ensaios devem estar de acordo com norma brasileira específica ou de acordo com norma ou especificação estrangeira. As propriedades térmicas dos materiais apresentadas pela NBR 14323:1999 têm por base o EUROCODE 3 Part 1-2.

\subsubsection{Alongamento relativo}

$\mathrm{O}$ alongamento relativo do aço $\Delta \ell_{\mathrm{a}} / \ell_{\mathrm{a}}$ prescrito na NBR 14323:1999 e na Parte 1-2 do EUROCODE 3 (2005), é dado por:

$$
\Delta \ell_{\mathrm{a}} / \ell_{\mathrm{a}}= \begin{cases}1,2 \cdot 10^{-5} \theta_{\mathrm{a}}+0,4 \cdot 10^{-8} \theta_{\mathrm{a}}^{2}-2,416 \cdot 10^{-4} & 20{ }^{\circ} \mathrm{C} \leq \theta_{\mathrm{a}}<750{ }^{\circ} \mathrm{C} \\ 1,1 \cdot 10^{-2} & 750{ }^{\circ} \mathrm{C} \leq \theta_{\mathrm{a}}<860^{\circ} \mathrm{C} \\ 2 \cdot 10-5 \theta_{\mathrm{a}}-6,2 \cdot 10^{-3} & 860{ }^{\circ} \mathrm{C}<\theta_{\mathrm{a}}<1200^{\circ} \mathrm{C}\end{cases}
$$

$\mathrm{Na}$ equação $3.1, \ell_{\mathrm{a}}$ é o comprimento a $20^{\circ} \mathrm{C}, \Delta \ell_{\mathrm{a}}$ é a expansão térmica provocada pela temperatura e $\theta_{\mathrm{a}}$ é a temperatura do aço em ${ }^{\circ} \mathrm{C}$. A variação do alongamento relativo com a temperatura pode ser visto na figura 3.1.

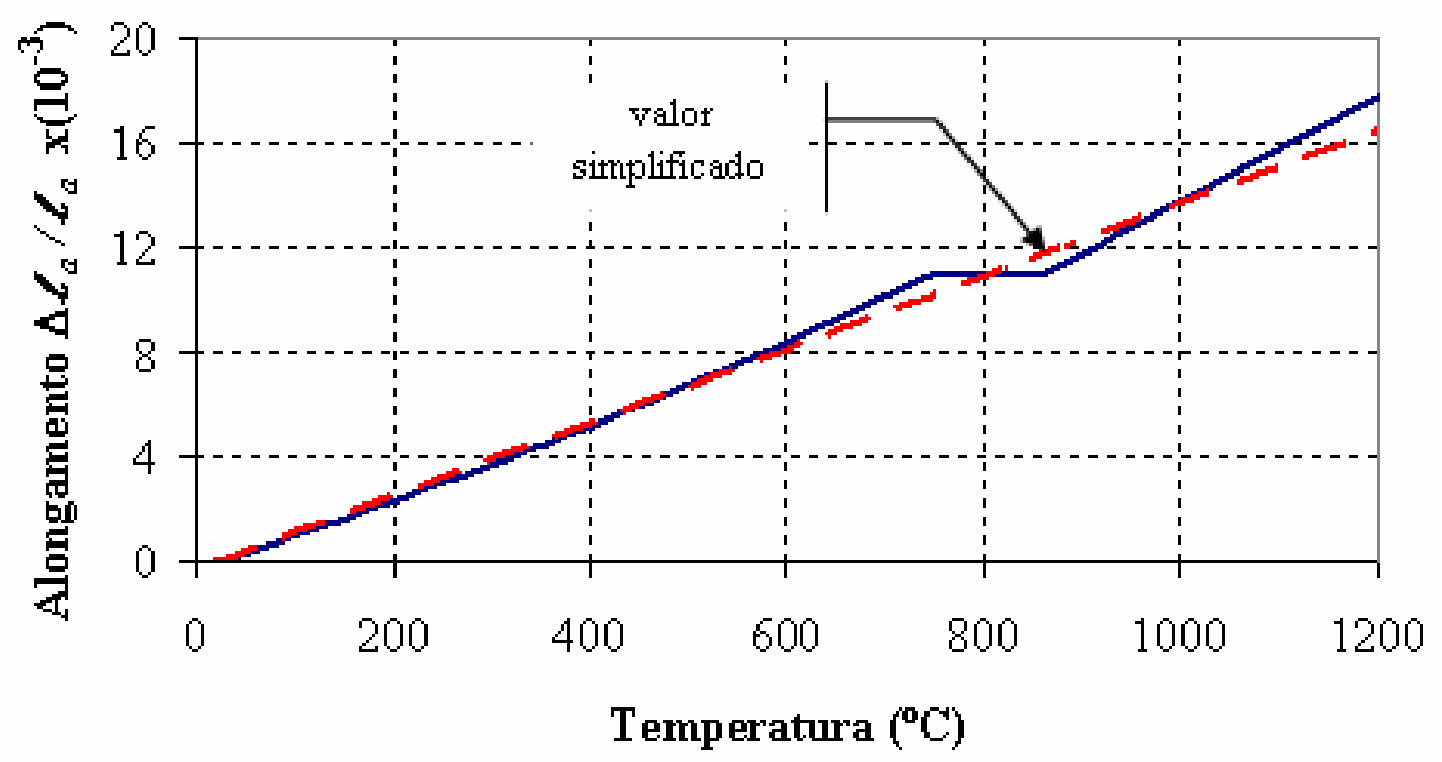

Figura 3.1 - Alongamento relativo do aço com a temperatura. 
A NBR 14323:1999 especifica que, caso se empregue o método simplificado de cálculo (ver capítulo 4), a variação do alongamento relativo do aço com a temperatura pode ser considerada constante (linha tracejada, figura 3.1). Neste caso, pode se adotado o alongamento relativo simplificado, figura 3.1, descrito pela relação (3.2).

$$
\frac{\Delta \ell_{\mathrm{a}}}{\ell_{\mathrm{a}}}=1,4 \cdot 10^{-6}\left(\theta_{a}-20\right)
$$

Esta consideração simplificada fez parte do EUROCODE 3 (1995). No entanto, o EUROCODE 3 (2005) não se refere a esta possibilidade. Já no Projeto de Revisão da NBR14323:1999 este valor também é mencionado como valor simplificado, mas não restringe sua aplicação apenas ao método simplificado de cálculo.

\subsubsection{Calor específico}

O calor específico do aço, em Joule por quilograma e por grau Celsius $\left(\mathrm{J} / \mathrm{kg}^{\circ} \mathrm{C}\right)$, pode ser determinado, segundo a NBR 14323:1999 e o EUROCODE 3 (2005), bem como considerando $\theta_{\mathrm{a}}$ como a temperatura do aço $\left(\mathrm{em}^{\circ} \mathrm{C}\right)$, da seguinte forma:

$$
\mathrm{c}_{\mathrm{a}}= \begin{cases}1,2 \cdot 10^{-5} \theta_{\mathrm{a}}+0,4 \cdot 10^{-8} \theta_{\mathrm{a}}^{2}-2,416 \cdot 10^{-4} & 20{ }^{\circ} \mathrm{C} \leq \theta_{\mathrm{a}}<600{ }^{\circ} \mathrm{C} \\ 666+\frac{13002}{738-\theta_{\mathrm{a}}} & 600{ }^{\circ} \mathrm{C} \leq \theta_{\mathrm{a}}<735^{\circ} \mathrm{C} \\ 545+\frac{17820}{\theta_{\mathrm{a}}-731} & 735 \leq \theta_{\mathrm{a}}<900{ }^{\circ} \mathrm{C} \\ 650 & 900 \leq \theta_{\mathrm{a}} \leq 1200\end{cases}
$$

Segundo a NBR 14323:1999, caso se empregue o método de cálculo simplificado, a ser descrito no próximo capítulo, o valor do calor específico do aço pode se considerado igual a $c_{a}=600 \mathrm{~J} / \mathrm{kg}^{\circ} \mathrm{C}$. O Projeto de Revisão da NBR 14323:1999 também assume este valor como simplificado, e não restringe sua aplicação apenas ao método simplificado de cálculo. 
Por sua vez, o EUROCODE 3 (2005) não se refere a esta possibilidade. Segundo VILA REAL (2003), para a gama de temperaturas usuais nos projetos, o erro cometido no cálculo é diminuto. A apresentação do calor específico, em forma gráfica, pode ser identificada na figura 3.2.

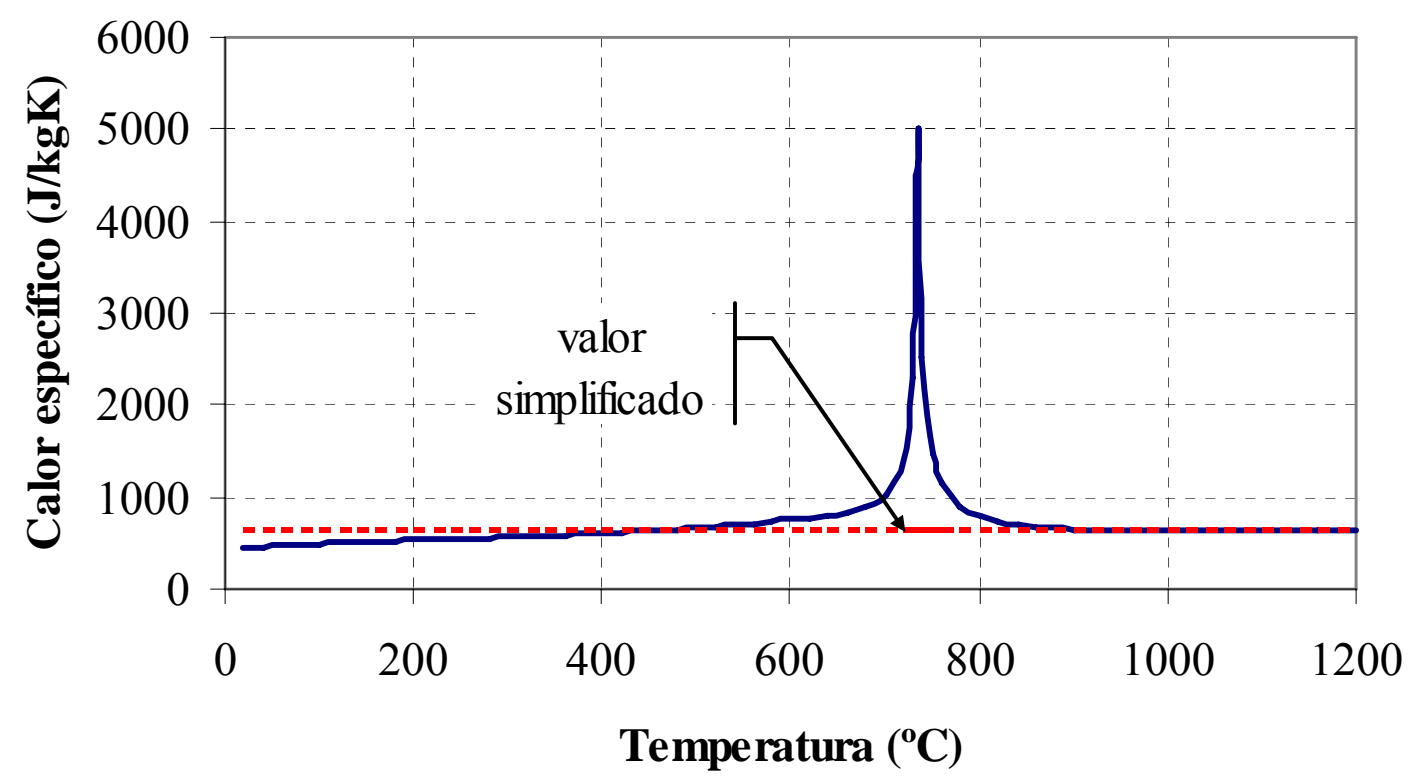

Figura 3.2 - Calor específico do aço em função da temperatura.

\subsubsection{Condutividade térmica}

A condutividade térmica do aço, em Watt por metro e por grau Celsius $\left(\mathrm{W} / \mathrm{m}^{\circ} \mathrm{C}\right)$, segundo a NBR 14323:1999 e o EUROCODE 3 (2005), pode ser determinada, considerando $\theta_{\mathrm{a}}$ como a temperatura do aço $\left(\mathrm{em}^{\circ} \mathrm{C}\right)$, pelo seguinte procedimento:

$$
\lambda_{\mathrm{a}}= \begin{cases}54-3,33 \cdot 10^{-2} \theta_{\mathrm{a}} & 20{ }^{\circ} \mathrm{C} \leq \theta_{\mathrm{a}}<800{ }^{\circ} \mathrm{C} \\ 27,3 & 800^{\circ} \mathrm{C} \leq \theta_{\mathrm{a}}<1200^{\circ} \mathrm{C}\end{cases}
$$

Nos modelos de cálculo simplificado, segundo a NBR 14323:1999, o valor da condutividade térmica pode ser considerado independente da temperatura do aço. $\mathrm{O}$ valor a ser tomado, neste caso, é igual a $\lambda_{\mathrm{a}}=\mathbf{4 5} \mathrm{W} / \mathrm{m}^{\circ} \mathrm{C}$, também especificado pelo 
EUROCODE 3 (1995). No EUROCODE 3 (2005) não há referência a esta possibilidade. O projeto de revisão da NBR 14323:1999 também assume este valor como simplificado. A figura 3.3 ilustra a variação da condutividade térmica com a temperatura.

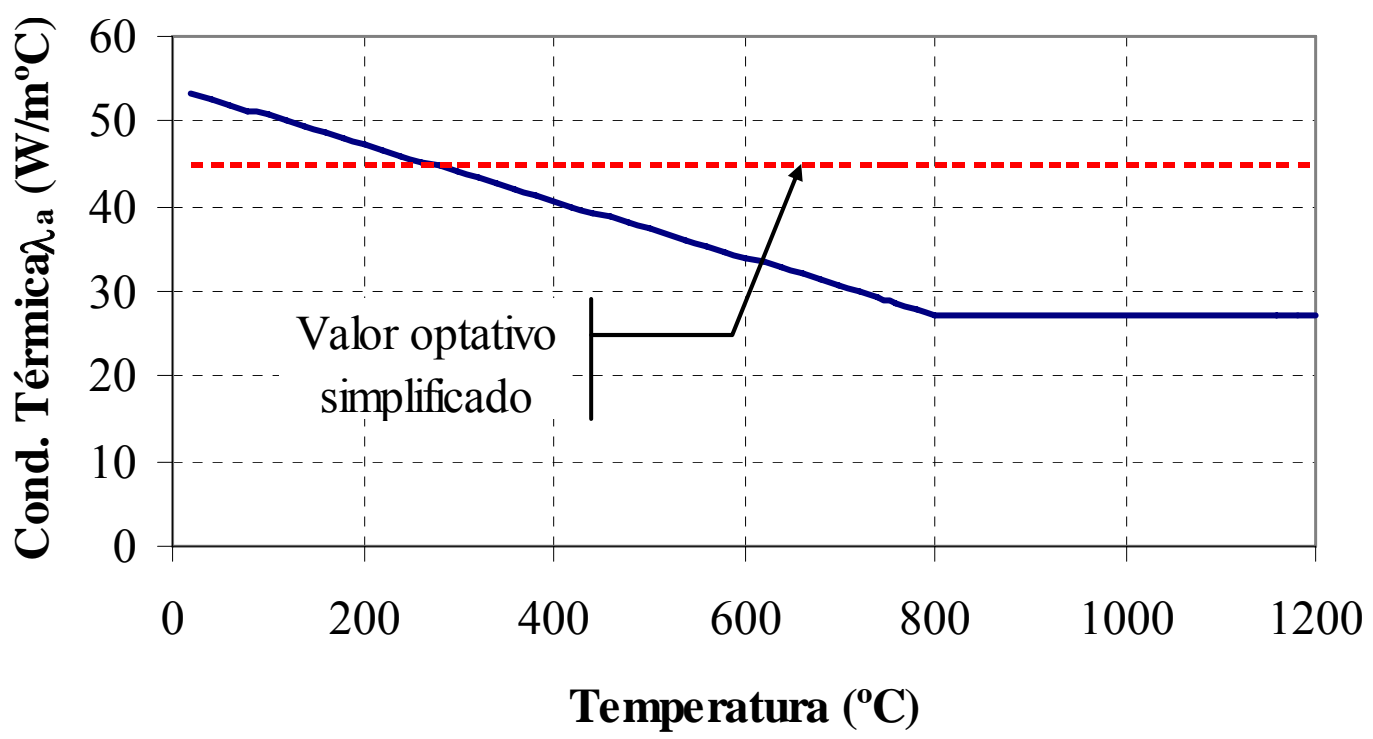

Figura 3.3 - Condutividade térmica do aço em função da temperatura.

\subsection{PROPRIEDADES TÉRMICAS DO CONCRETO}

Segundo o projeto de revisão da NBR 14323:1999, as propriedades térmicas a serem apresentadas se aplicam, em princípio, para temperatura elevada, àqueles concretos normalmente usados na construção, para fins estruturais. Ressalta-se que os concretos de densidade normal são aqueles previstos pela NBR 6118 (2003), e os de baixa densidade por norma ou especificação estrangeira.

O projeto de revisão da NBR 14323:1999 afirma que caso o concreto em questão possua propriedades diferentes daquelas presentes na norma, os valores destas propriedades deverão ser utilizados. No entanto, esses valores devem ser obtidos em ensaios realizados em laboratório nacional ou laboratório estrangeiro, de acordo com norma brasileira específica ou de acordo com norma ou especificação estrangeira.

As propriedades térmicas dos concretos apresentadas pelo projeto de revisão da NBR 14323:1999 têm por base o EUROCODE 4 Part 1-2. No Brasil, a norma que trata do dimensionamento das estruturas de concreto em situação é a NBR 15200:2004. 
Apesar de recente, esta norma não menciona nada sobre as propriedades térmicas a serem levadas em conta na no cálculo da elevação e distribuição de temperaturas na seção transversal dos elementos de concreto.

\subsubsection{Alongamento relativo}

\section{- Concreto de densidade normal}

O alongamento relativo do concreto, considerando esse mesmo material com densidade normal, pode ser determinado, conforme esquematiza a figura 3.4, pelo seguinte procedimento:

$\Delta \ell_{\mathrm{cn}} / \ell_{\mathrm{cn}}= \begin{cases}9 \cdot 10^{-6} \theta_{\mathrm{c}}+2,3 \cdot 10^{-11} \theta_{\mathrm{c}}^{3}-1,8 \cdot 10^{-4} & 20{ }^{\circ} \mathrm{C} \leq \theta_{\mathrm{a}}<700{ }^{\circ} \mathrm{C} \\ 1,1 \cdot 10^{-2} & 700{ }^{\circ} \mathrm{C} \leq \theta_{\mathrm{a}} \leq 1200^{\circ} \mathrm{C}\end{cases}$

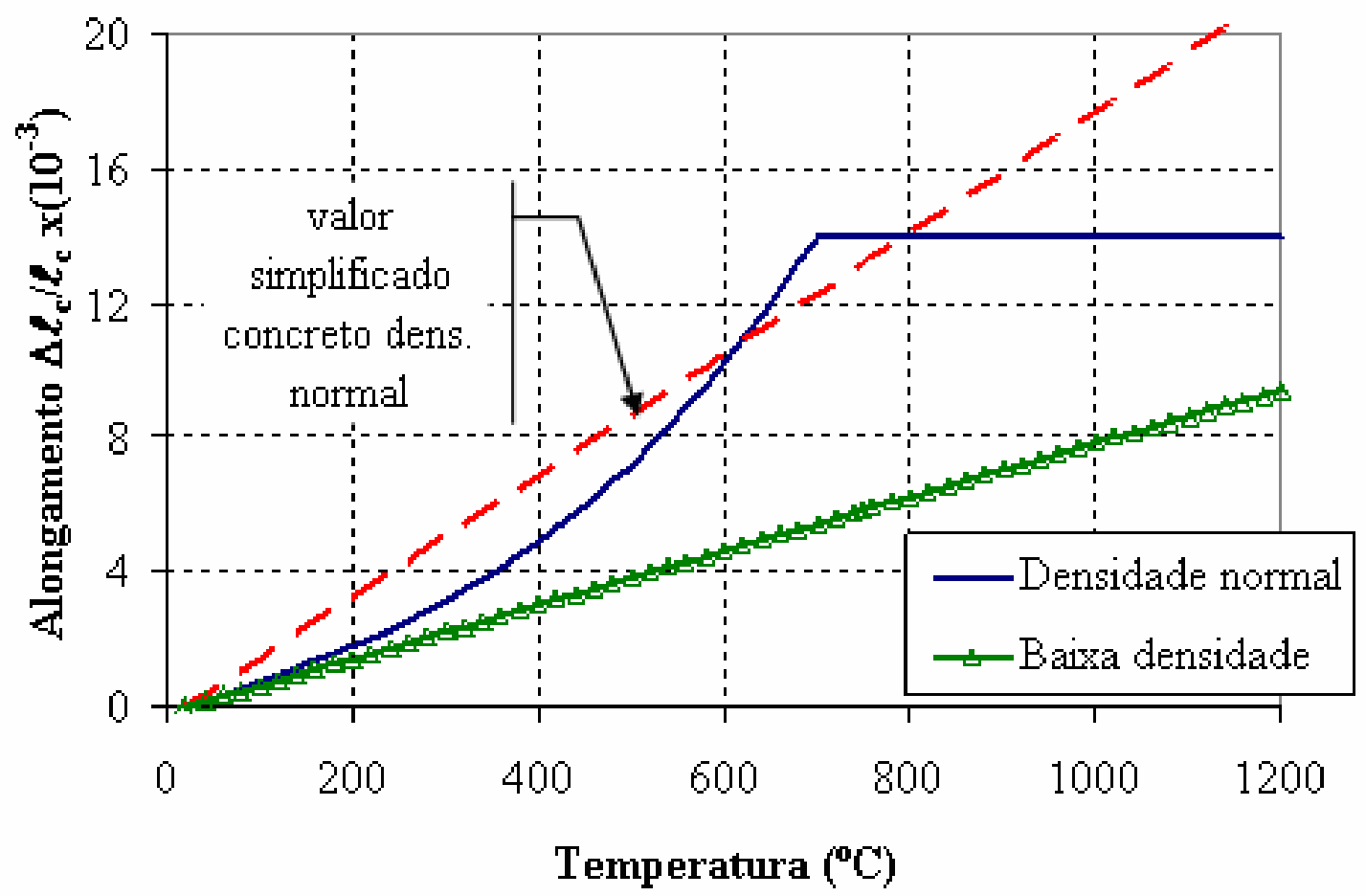

Figura 3.4 - Alongamento relativo do concreto em função da temperatura. 
Na equação $3.5, \ell_{\text {cn }}$ é o comprimento da peça de concreto de densidade normal a $20^{\circ} \mathrm{C}, \Delta \ell_{\mathrm{cn}}$ é a expansão térmica da peça de concreto de densidade normal provocada pela temperatura e $\theta_{a}$ é a temperatura do concreto $\left(\mathrm{em}^{\circ} \mathrm{C}\right)$.

De forma simplificada, o projeto de revisão da NBR 14323:1999 permite que o alongamento relativo do concreto de densidade normal em função da temperatura seja considerado constante (linha tracejada, figura 3.4). Neste caso, a equação (3.6) pode ser adotada para o alongamento relativo.

$$
\frac{\Delta \ell_{\mathrm{cn}}}{\ell_{\mathrm{cn}}}=1,8 \cdot 10^{-6}\left(\theta_{\mathrm{c}}-20\right)
$$

\section{- Concreto de baixa densidade}

$\mathrm{O}$ alongamento relativo do concreto de baixa densidade $\left(\Delta \ell_{\mathrm{cb}} / \ell_{\mathrm{cb}}\right)$ pode ser determinado por meio da aplicação da equação (3.7), em que $\ell_{\mathrm{cb}}$ é o comprimento da peça de concreto de baixa densidade a $20^{\circ} \mathrm{C}$ e $\Delta \ell_{\mathrm{cb}}$ é a expansão térmica da peça de concreto de densidade normal provocada pela variação de temperatura.

$$
\frac{\Delta \ell_{\mathrm{cb}}}{\ell_{\mathrm{cb}}}=8.10^{-6}\left(\theta_{\mathrm{c}}-20\right)
$$

\subsubsection{Calor específico}

\section{- Concreto de densidade normal}

O calor específico do concreto de densidade normal $\left(\mathrm{c}_{\mathrm{n}}\right)$, em joule por quilograma e por grau Celsius $\left(\mathrm{J} / \mathrm{kg}^{\circ} \mathrm{C}\right)$, possui variação com a temperatura conforme esquematiza a figura 3.5, e determinado por meio da equação (3.8), em que $\theta_{c}$ é a temperatura do concreto $\left(\mathrm{em}^{\circ} \mathrm{C}\right)$. O calor específico, admitido dependente da umidade do concreto, pode sofrer um aumento brusco de valor a partir de $100{ }^{\circ} \mathrm{C}$, atingindo um pico a $130^{\circ} \mathrm{C}$ e voltando rapidamente à curva dada em (3.8) a $200{ }^{\circ} \mathrm{C}$. 


$$
\mathrm{c}_{\mathrm{cn}}=900+80 \frac{\theta_{\mathrm{c}}}{120}-4\left(\frac{\theta_{\mathrm{c}}}{120}\right)^{2} \quad 20{ }^{\circ} \mathrm{C} \leq \theta_{\mathrm{c}} \leq 1200^{\circ} \mathrm{C}
$$

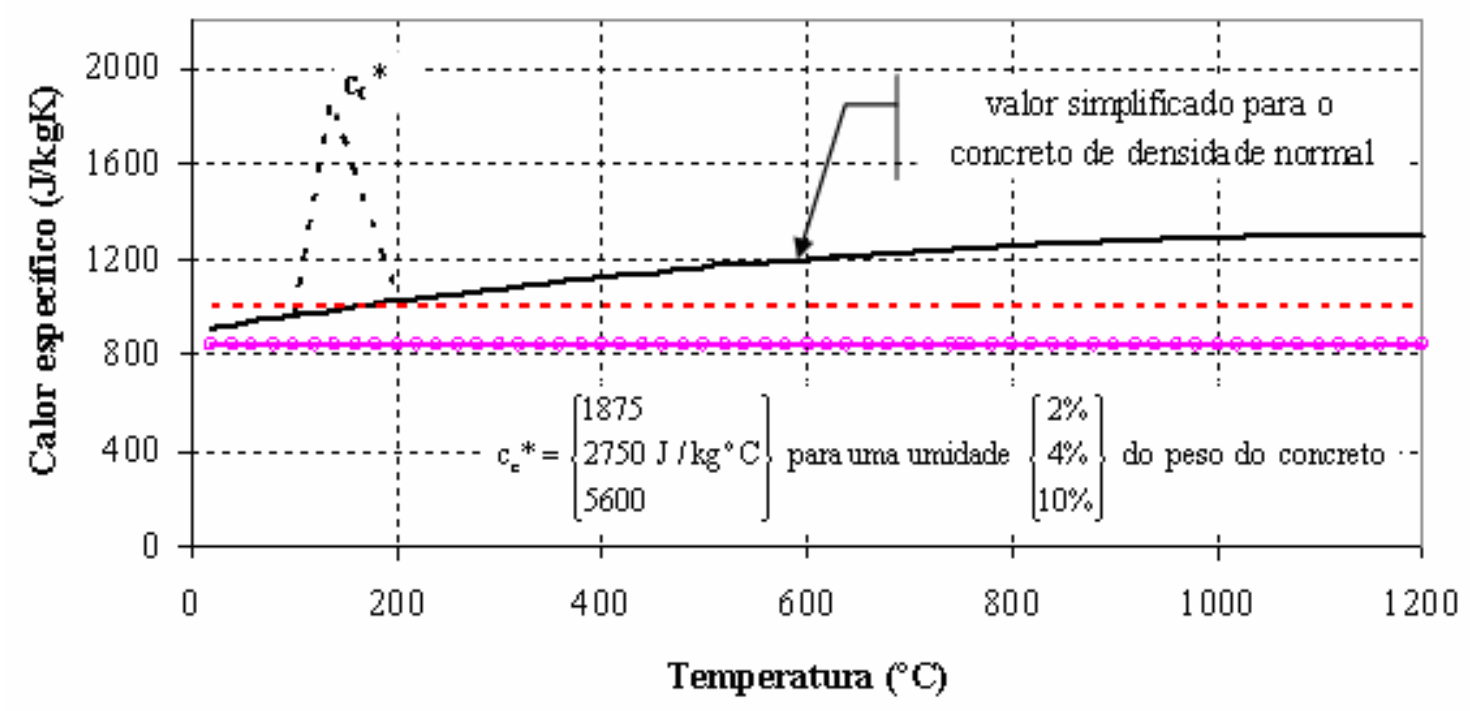

- Densidade normal $\rightarrow$ Baixa densidade

Figura 3.5 - Calor específico do concreto em função da temperatura.

Segundo o projeto de revisão da NBR 14323:1999 e o EUROCODE 4 (2005), de forma simplificada, o valor do calor específico pode ser considerado independente da temperatura do concreto. Neste caso, o valor deve ser igual a $\mathbf{c}_{\mathbf{c n}}=\mathbf{1 0 0 0} \mathbf{J} / \mathbf{k g}^{\mathbf{o}} \mathbf{C}$, conforme esquematiza a figura 3.5 , por meio de reta tracejada.

\section{- Concreto de baixa densidade}

O valor do calor específico do concreto de baixa densidade $\left(\mathrm{c}_{\mathrm{cb}}\right)$ é considerado independente da temperatura e igual a $\mathbf{c}_{\mathbf{c b}}=\mathbf{8 4 0} \mathbf{J} / \mathbf{k g}^{\mathbf{}} \mathbf{C}$.

\subsubsection{Condutividade térmica}

\section{- Concreto de densidade normal}

A condutividade térmica do concreto de densidade normal $\left(\lambda_{\mathrm{cn}}\right)$, em watt por metro e por grau Celsius $\left(\mathrm{W} / \mathrm{m} .{ }^{\circ} \mathrm{C}\right)$, conforme figura 3.6 , pode ser determinada por: 


$$
\lambda_{\mathrm{cn}}=2-0,24 \frac{\theta_{\mathrm{c}}}{120}-0,012\left(\frac{\theta_{\mathrm{c}}}{120}\right)^{2} \quad 20{ }^{\circ} \mathrm{C} \leq \theta_{\mathrm{c}}<1200{ }^{\circ} \mathrm{C}
$$

$\mathrm{Na}$ equação $\theta_{\mathrm{c}}$ é a temperatura do concreto, em grau Celsius. De forma simplificada, o valor da condutividade térmica pode ser considerado independente da temperatura do aço. Neste caso, o tal o valor pode ser tomado como $\lambda_{\mathrm{cn}}=1,6 \mathrm{~W} / \mathrm{m}^{\circ} \mathrm{C}$, conforme esquematiza a figura 3.6 por meio de reta tracejada.

\section{- Concreto de baixa densidade}

Valores de condutividade térmica para concreto de baixa densidade $\left(\lambda_{\mathrm{cb}}\right)$, em watt por metro e por grau Celsius $\left(\mathrm{W} / \mathrm{m} .{ }^{\circ} \mathrm{C}\right)$, estão esquematizados na figura 3.6, e podem ser determinados pelas seguintes igualdades:

$$
\lambda_{\mathrm{cb}}=\left\{\begin{array}{lc}
1,0-\frac{\theta \mathrm{c}}{1600} & 20{ }^{\circ} \mathrm{C} \leq \theta_{\mathrm{c}} \leq 800{ }^{\circ} \mathrm{C} \\
0,5 & \theta_{\mathrm{c}} \leq 800^{\circ} \mathrm{C}
\end{array}\right.
$$

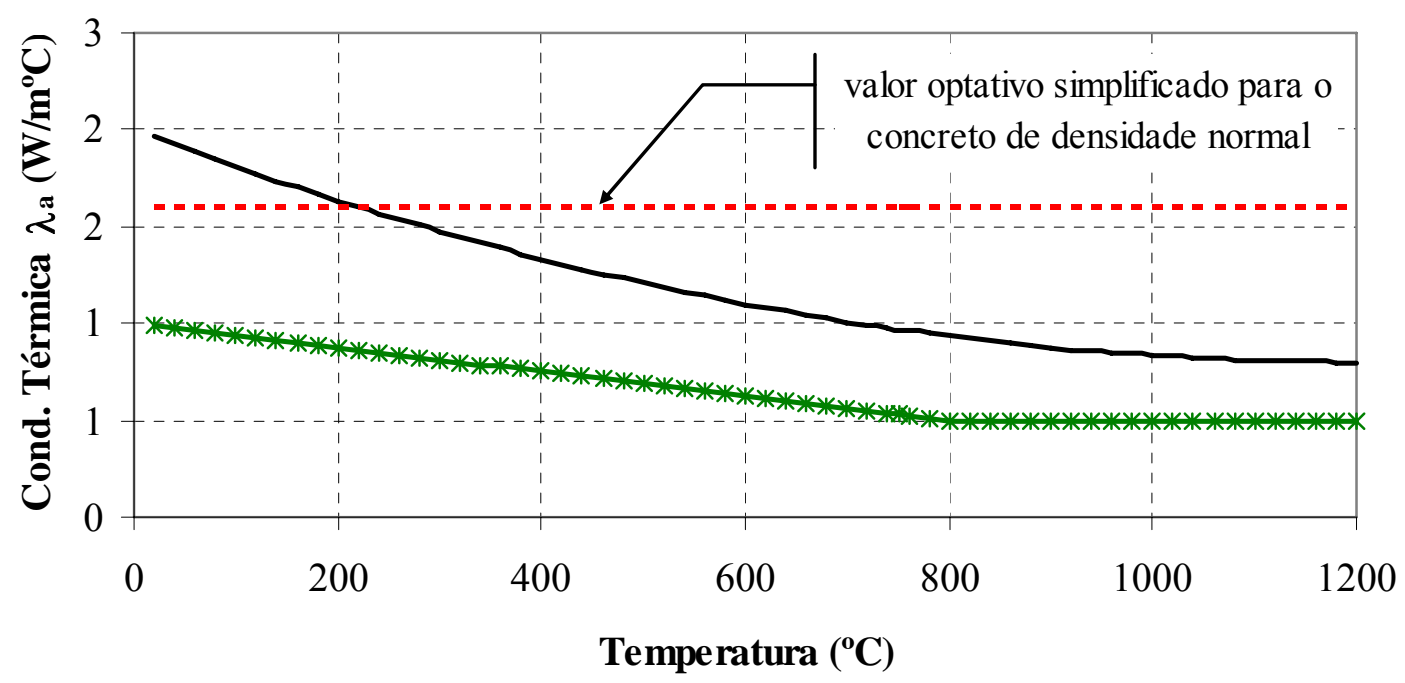

— Densidade normal $\rightarrow$ * Baixa densidade

Figura 3.6 - Condutividade térmica do concreto em função da temperatura. 


\subsection{MATERIAIS DE PROTEÇÃO CONTRA FOGO}

Conforme mencionado anteriormente, as propriedades mecânicas do aço (resistência ao escoamento e módulo de elasticidade) e do concreto (resistência à ruptura e módulo de elasticidade) sofrem reduções com o aumento de temperatura, podendo ocasionar o colapso prematuro de um elemento estrutural ou de suas ligação em aço, causando inclusive a perda de vidas humanas.

Para evitar o colapso, em situação de incêndio, faz-se o dimensionamento da estrutura para resistir a temperaturas elevadas ou, como procedimento alternativo, faz-se uso de materiais que, ao envolverem os elementos constituintes da estruturas de interesse, atuam como proteção contra o fogo.

Segundo FAKURI (1999) inicialmente eram empregados materiais já usados na construção com técnicas simples, como a execução de alvenarias contornando pilares ou o embutimento de vigas e pilares em concreto (Figura 3.7).
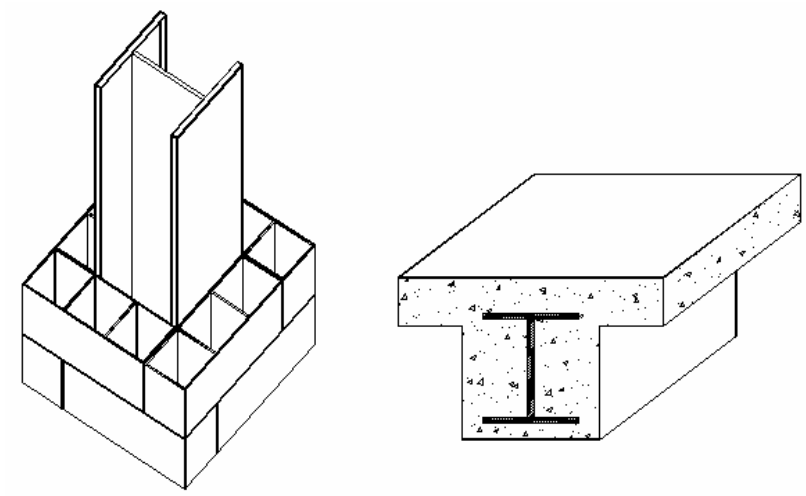

Figura 3.7 - Proteções térmicas inicialmente utilizadas nas estruturas de aço.

Extraído de FAKURI (1999).

Atualmente, atualmente é grande a gama de materiais de proteção térmica. Em termos gerais, segundo MENDES (2004) e VARGAS e SILVA (2003), os materiais de proteção térmica devem apresentar:

- baixa massa específica aparente;

- baixa condutividade térmica;

- alto calor especifico;

- adequada resistência mecânica (quando expostos ao impacto);

- garantia de integridade durante a evolução do incêndio;

- custo compativel com a realidade da obra. 


\subsubsection{Classificação dos materiais de proteção contra fogo}

Os materiais para proteção contra fogo podem ser classificados segundo três fatores, de acordo com FAKURI (1999):

- Quanto ao material constituinte: alvenaria, concreto de cimento portland, concreto leve, argamassas à base de cimento, de fibras minerais, de vermiculita ou de gesso, mantas de fibras cerâmicas, de fibras minerais ou de lã de rocha, tintas intumescentes, entre outros;

- Quanto à morfologia: tipo contorno, caixa com vãos e caixa sem vãos, ilustrados na figura 3.8;

- Quanto à técnica de colocação: moldados com o uso de formas, aplicados manualmente, aplicados por jateamento (ou projetados), fixados por dispositivos específicos ou montados.

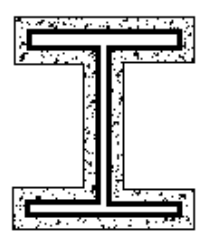

Tipo contomo

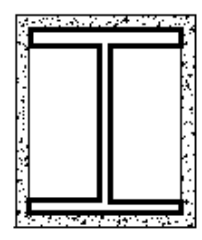

Tipo caixa

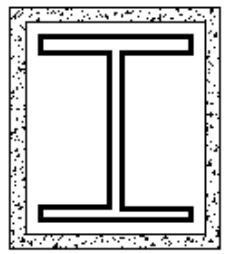

Tipo caixa com vão

\section{Pilares}

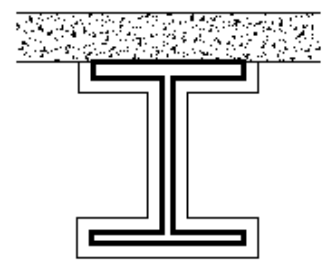

Tipo contomo

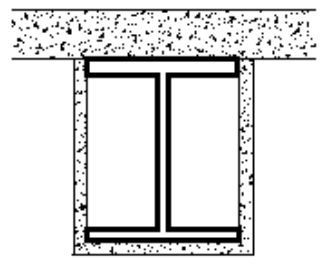

Tipo caixa

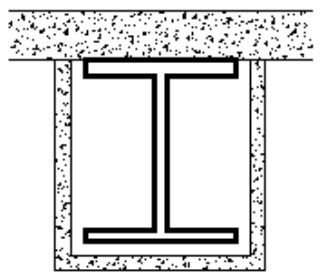

Tipo caixa com vão

\section{Vigas sobrepostas por lajes de concreto}

Figura 3.8 - Classificação quanto à morfologia. Tipo contorno e tipo caixa.

Muitos fabricantes não apresentam em seus catálogos, de maneira satisfatória, as propriedades mecânicas e térmicas de seus materiais. Apenas como referência, apresenta-se na tabela 3.1 as propriedades de alguns dos materiais mais comuns empregados como proteção contra fogo. 
Tabela 3.1 - Propriedades dos principais materiais de proteção contra fogo.

Fonte: VILA REAL (2003)

\begin{tabular}{|c|c|c|c|c|}
\hline MATERIAL & $\begin{array}{c}\text { Massa } \\
\text { específica } \\
\left(\mathbf{k g} / \mathbf{m}^{3}\right)\end{array}$ & $\begin{array}{c}\text { Teor de } \\
\text { umidade } \\
(\%)\end{array}$ & $\begin{array}{c}\text { Condutividade } \\
\text { térmica } \\
\left(\mathrm{W} / \mathbf{m}^{\circ} \mathrm{C}\right)\end{array}$ & $\begin{array}{c}\text { Calor } \\
\text { específico } \\
\left(\mathrm{J} / \mathrm{kg}^{\circ} \mathrm{C}\right)\end{array}$ \\
\hline \multicolumn{5}{|c|}{ Materiais projetados } \\
\hline - fibra mineral & 300 & 1 & 0,12 & 1200 \\
\hline - argamassa de vermiculita & 350 & 15 & 0,12 & 1200 \\
\hline - perlita & 350 & 15 & 0,12 & 1200 \\
\hline \multicolumn{5}{|c|}{ Materiais projetados de alta de alta densidade } \\
\hline $\begin{array}{l}\text { - vermiculita (ou perlita) e } \\
\text { cimento }\end{array}$ & 550 & 15 & 0,12 & 1100 \\
\hline $\begin{array}{l}\text { - vermiculita (ou perlita) e } \\
\text { gesso }\end{array}$ & 650 & 15 & 0,12 & 1100 \\
\hline \multicolumn{5}{|c|}{ Placas } \\
\hline $\begin{array}{l}\text { - vermiculita (ou perlita) e } \\
\text { cimento }\end{array}$ & 800 & 15 & 0,20 & 1200 \\
\hline $\begin{array}{l}\text { - silicato fibroso ou silicato } \\
\text { de cálcio fibroso }\end{array}$ & 600 & 3 & 0,15 & 1200 \\
\hline - fibrocimento & 800 & 5 & 0,15 & 1200 \\
\hline - placas de gesso & 600 & 20 & 0,20 & 1700 \\
\hline \multicolumn{5}{|c|}{ Placas de fibra compactada } \\
\hline $\begin{array}{l}\text { - silicato fibroso, lã } \\
\text { mineral, lã de rocha }\end{array}$ & 150 & 2 & 0,20 & 1200 \\
\hline Concreto & 2300 & 4 & 1,60 & 1000 \\
\hline Concreto leve & 1600 & 5 & 0,80 & 840 \\
\hline Blocos de Concreto & 2200 & 8 & 1,00 & 1200 \\
\hline Tijolo cerâmico vazado & 1000 & - & 0,40 & 1200 \\
\hline Tijolo cerâmico maciço & 2000 & - & 1,20 & 1200 \\
\hline
\end{tabular}




\subsubsection{Materiais projetados}

Os materiais projetados têm este nome em razão de aplicados por jateamento, como ilustra a figura 3.9a. São produtos econômicos, porém, considerados sem acabamento adequado, por exemplo, aspecto de chapisco (figura 3.9b).

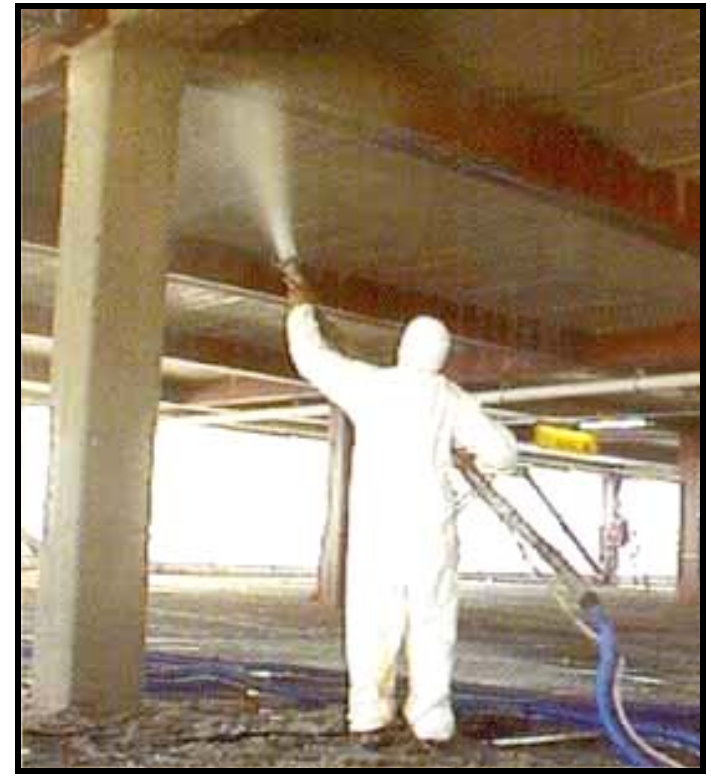

(a)

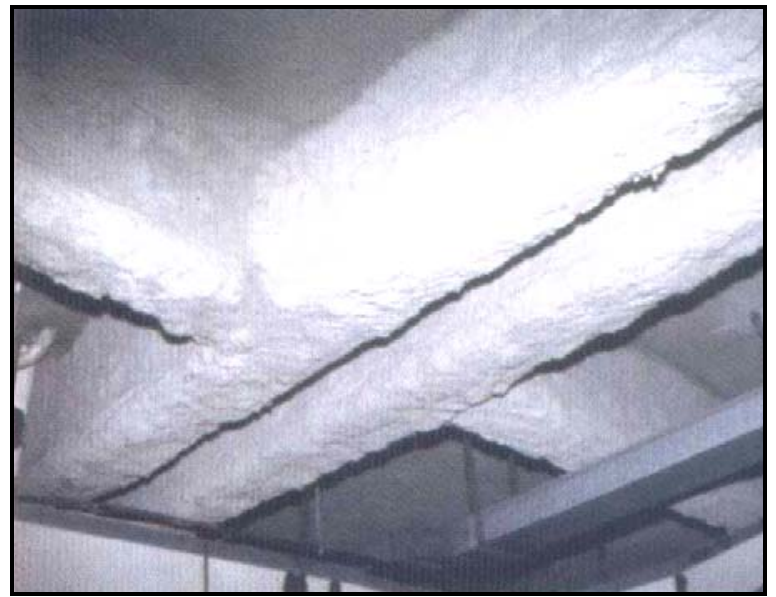

(b)

Figura 3.9-Materiais projetados: (a) Operação de jateamento. Fonte: MENDES (2004); (b) Detalhe do acabamento. Fonte: DIAS (2002)

Segundo REFRASSOL (2006), estes materiais são os mais utilizados no mundo para a proteção de estruturas metálicas. Os edifícios Sears Towers (Chicago - EUA) e as Torres Petronas (Kuala Lumpur - Malásia), são protegidos com este tipo de material.

Ainda, segundo a REFRASSOL (2006), no Brasil, alguns dos maiores edifícios e prédios comerciais como o Shopping Center Frei Caneca em São Paulo - SP e a Central dos Correios em Santo Amaro - SP, Aeroporto Internacional de Brasília - DF e o Centro Empresarial Aeroporto em Porto Alegre - RS, receberam proteção passiva contra fogo com materiais projetados em áreas internas, aparentes ou não. Esses materiais são certificados de acordo com algumas exigências de normas estrangeiras, como apresentado na tabela 3.2.

Em países como os Estados Unidos existem variados tipos destes materiais projetados, os quais são classificados com relação à composição química, utilização, 
fornecedor, custos, entre outros aspectos. Já no Brasil, segundo MENDES (2004), eles são encontradas apenas de três formas diferentes, descritas a seguir.

Tabela 3.2 - Propriedades físicas e recomendações para materiais projetados.

Fonte: MENDES (2004) e GRACE (2006)

\begin{tabular}{|c|c|c|c|}
\hline \multirow[t]{2}{*}{ Propriedades Físicas } & $\begin{array}{c}\text { Mínimos } \\
\text { Recomendados }\end{array}$ & $\begin{array}{c}\text { Mínimos } \\
\text { Recomendados }\end{array}$ & \multirow[t]{2}{*}{ Métodos de Ensaio } \\
\hline & baixa densidade & $\begin{array}{l}\text { média e alta } \\
\text { densidades }\end{array}$ & \\
\hline $\begin{array}{c}\text { Densidade seca (média } \\
\text { mínima) }\end{array}$ & $240 \mathrm{~kg} / \mathrm{m}^{3}$ & Não apresenta & $\begin{array}{c}\text { ASTM E } 605 \text { e UBC } \\
\text { STD7-6 }\end{array}$ \\
\hline Aderência ao aço & $9,6 \mathrm{kPa}$ & $9,6 \mathrm{kPa}$ & ASTM E 736 \\
\hline $\begin{array}{c}\text { Compressão (10\% } \\
\text { deformação máxima) }\end{array}$ & $57 \mathrm{kPa}$ & $57 \mathrm{kPa}$ & ASTM E 761 \\
\hline Erosão ao ar a $24 \mathrm{~km} / \mathrm{h}$ & Máximo $0,05 \mathrm{~g} / \mathrm{ft}^{2}$ & Máximo $0,05 \mathrm{~g} / \mathrm{ft}^{2}$ & ASTM E 859 \\
\hline $\begin{array}{l}\text { Erosão ao ar em alta } \\
\text { velocidade } 46 \mathrm{~km} / \mathrm{h}\end{array}$ & $\begin{array}{c}\text { Não deve apresentar } \\
\text { após } 4 \text { horas }\end{array}$ & $\begin{array}{c}\text { Não deve apresentar } \\
\text { após } 4 \text { horas }\end{array}$ & $\begin{array}{c}\text { ASTM E } 859 \text { E UMC } \\
\text { STD 6-1 }\end{array}$ \\
\hline Corrosão & Não contribuir & Não contribuir & ASTM E 937 \\
\hline Impacto - aderência & $\begin{array}{l}\text { Não delaminar ou } \\
\text { desprender }\end{array}$ & $\begin{array}{l}\text { Não delaminar ou } \\
\text { desprender }\end{array}$ & ASTM E 760 \\
\hline Deformação & $\begin{array}{l}\text { Não delaminar ou } \\
\text { desprender }\end{array}$ & $\begin{array}{l}\text { Não delaminar ou } \\
\text { desprender }\end{array}$ & ASTM E 759 \\
\hline $\begin{array}{l}\text { Resistência à } \\
\text { penetração }\end{array}$ & $\begin{array}{l}\text { Deslocamento } \\
\text { máximo } 6 \mathrm{~cm}^{3}\end{array}$ & - & $\begin{array}{l}\text { Dir. Obras de San } \\
\text { Francisco }\end{array}$ \\
\hline Resistência à abrasão & $\begin{array}{l}\text { Máximo volume } \\
\text { removido } 15 \mathrm{~cm}^{3}\end{array}$ & - & $\begin{array}{c}\text { Dir. Obras de San } \\
\text { Francisco }\end{array}$ \\
\hline Resistência a fungos & $\begin{array}{c}28 \text { dias em usos } \\
\text { gerais ou } 60 \text { dias em } \\
\text { plenums }\end{array}$ & $\begin{array}{c}28 \text { dias em usos } \\
\text { gerais ou } 60 \text { dias em } \\
\text { plenums }\end{array}$ & ASTM G21 \\
\hline
\end{tabular}




\section{- Argamassas cimentícias}

De acordo com o descrito em MENDES (2004), os materiais projetados classificados como argamassas cimentícias são compostos por materiais aglomerantes, como gesso e cimento, em grande quantidade, e resinas acrílicas. As composições dos aglomerantes variam de acordo com a sua utilização. A argamassa de baixa densidade, em torno de $250 \mathrm{~kg} / \mathrm{m}^{3}$, é indicada para o interior das edificações, podendo permanecer expostas ou sob forro. Sua composição consiste de $80 \%$ de gesso e $20 \%$ de cimento Portland.

(a)
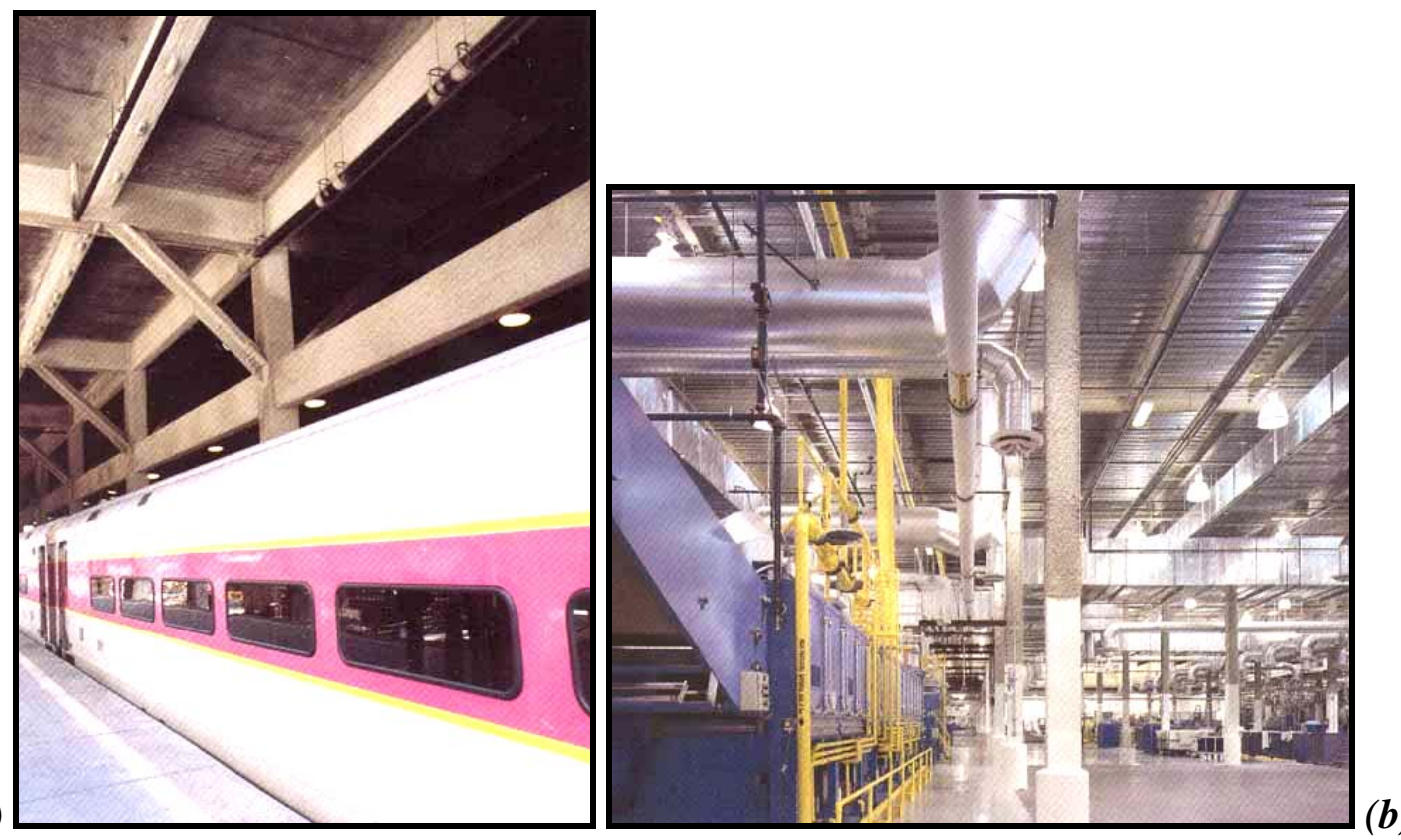

(b)

(c)
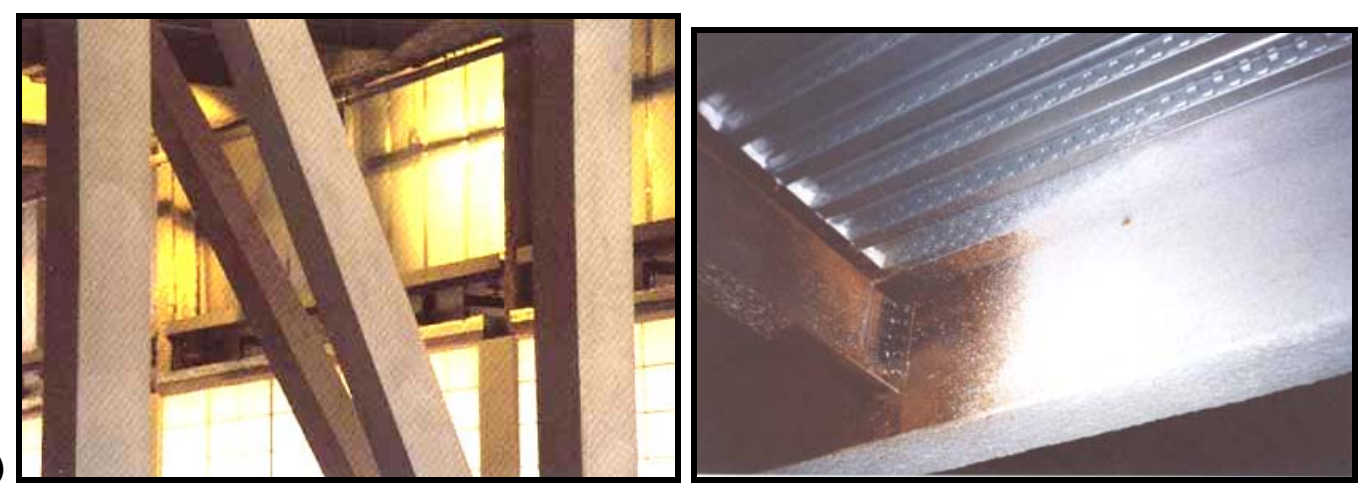

(d)

Figura 3.10 - Argamassas cimentícias: (a) de média densidade; (b) de alta densidade;

(c) de alta densidade desempenada e (d) de baixa densidade.

Fonte: MENDES (2004) 
As argamassas de média e alta densidade têm como aglomerante básico o cimento Portland. Apresentam densidades de $350 \mathrm{~kg} / \mathrm{m}^{3}$ e $650 \mathrm{~kg} / \mathrm{m}^{3}$, respectivamente. São indicadas para usos externos e locais que necessitem de materiais com alta resistência contra impactos e umidade. Todas elas podem ser aplicadas diretamente sobre o aço e apresentam elevada aderência, dispensando o uso de pinos e/ou telas. Podem ser coloridas em fábrica ou pintadas na obra, e não apresentam erosão sob corrente de ar.

As argamassas de média e alta densidade apresentam vantagens com relação à argamassa de baixa densidade. Elas possuem grande resistência a impactos e à umidade, podendo ficar expostas às intempéries, bem como podem ser desempenadas apresentando acabamento de superfície lisa.

Como exemplos de argamassas cimentícias de baixa, média e alta densidade citam-se, respectivamente, Monokote MK6, Z106 e Z146, produzidas pela Grace Construction Products. Maiores detalhes sobre estas argamassas podem ser vistos em GRACE (2006). A figura 3.10, extraída de MENDES (2004), apresenta algumas aplicações da argamassa cimentícia de baixa, média e alta densidade.

\section{- Argamassas à base de vermiculita}

Esse tipo de argamassa é composto de agregados leves à base de vermiculita, cimento e aglomerantes minerais. A vermiculita é comercializada na forma de flocos e misturada a seco aos demais componentes, na própria obra, com posterior adição de água. A figura 3.11, ilustra a vermiculita em flocos, enquanto a figura 3.12, extraída de SILVA (2001), ilustra a aparência desta argamassa após sua aplicação.

A vermiculita é um agregado mineral pertencente ao grupo dos minerais micáceos. É incombustível e apresenta ponto de fusão em torno de $1370^{\circ} \mathrm{C}$, segundo SILVA (2001). Sua estrutura é lamelar trifórmica e quando é aquecida, perde água, intumesce e se expande ortogonalmente. Sua densidade varia de 100 a $130 \mathrm{~kg} / \mathrm{m}^{3}$.

Sua aplicação deve ocorrer durante a etapa de montagem das estruturas, pois requer limpeza após a aplicação, que pode ser feita por jateamento ou com o uso de espátulas, porém, há necessidade de utilização de pinos soldados na estrutura e telas para sua adequada fixação. Depois de aplicada apresenta acabamento rústico e deve receber uma pintura a base de epóxi, uma vez decorrido o tempo de secagem. 


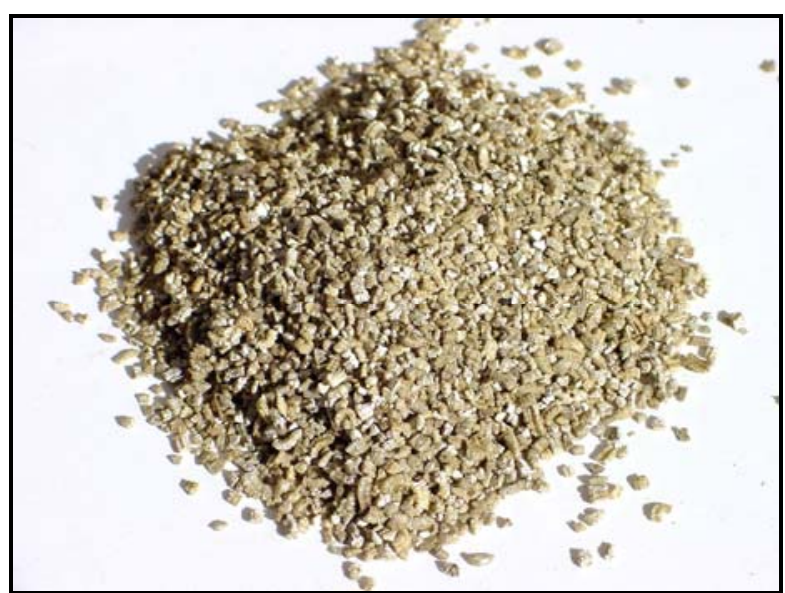

(a)

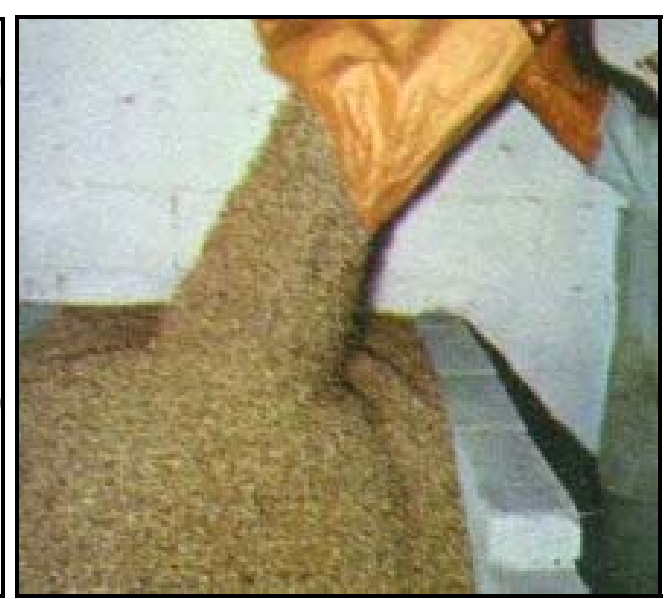

(b)

Figura 3.11 - Aspecto da vermiculita na forma de flocos.

$\begin{array}{lll}\text { (a) Fonte: aggie-horticulture.tamu.edu; } & \text { (b) Fonte: www.vermiculita.com.br. }\end{array}$

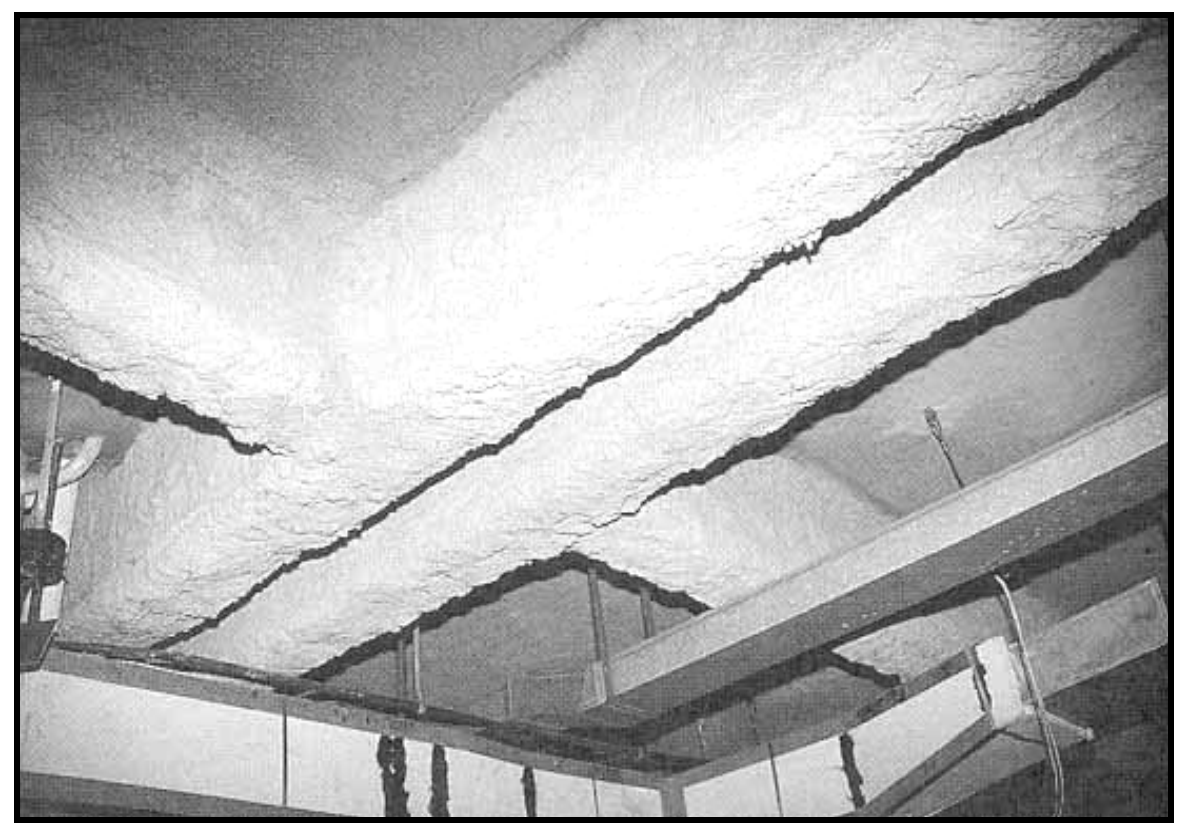

Figura 3.12 - Argamassa à base de vermiculita. Fonte: SILVA (2001).

Apresenta grande resistência mecânica, sendo muito utilizada na forma de concreto vermiculítico, em indústrias petroquímicas, em plataformas de petróleo, e em estruturas sujeitas a choques mecânicos elevados.

A vermiculita é um mineral abundante no Brasil, fato que gera um menor custo deste material, o que, por sua vez, contribui para a queda nos custos dos outros tipos de materiais para proteção passiva, muitos deles importados. Porém, a necessidade de uso de pinos e telas torna este sistema menos utilizado em obras convencionais. 


\section{- Fibras Projetadas}

As fibras projetadas são compostas por lã de rocha e materiais aglomerantes, sendo o último em menor quantidade. São de baixa densidade, em torno de 250 a 300 $\mathrm{kg} / \mathrm{m}^{3}$, e indicadas para usos interiores e exteriores, podendo permanecer expostas ou não (no caso, com forro).

Pode ser aplicada diretamente sobre o elemento estrutural, pois apresentam elevada aderência, dispensando o uso de pinos e/ou telas. Não necessitam revestimentos e não apresentam erosão sob corrente de ar. Permitem uma aplicação rápida, devendo ser realizada preferencialmente durante a fase de construção, porém, podendo também ser aplicada durante períodos de reformas. O material que a constitui não necessita mistura prévia e seca rapidamente.

Como exemplos de revestimento à base de fibras projetadas citam-se os produtos da Isolatek International, o Blaze-Shield II e Blaze-Shield HP, duas das marcas mais utilizadas no mundo.

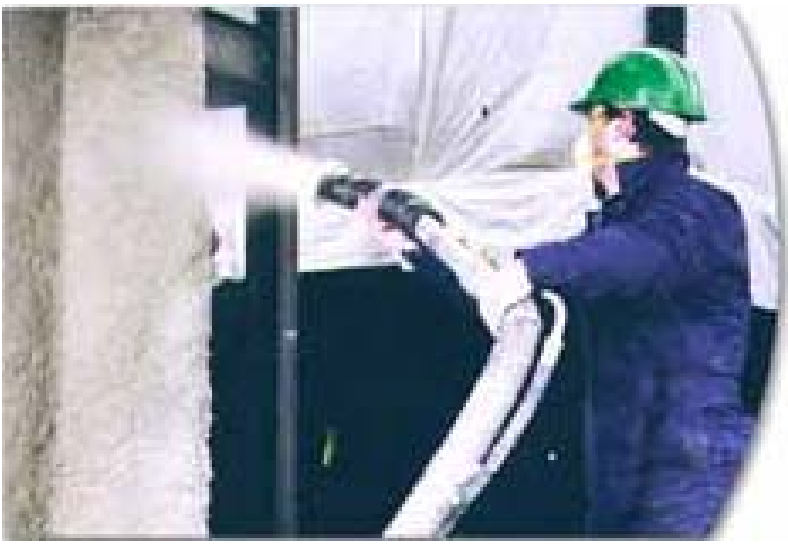

(a)

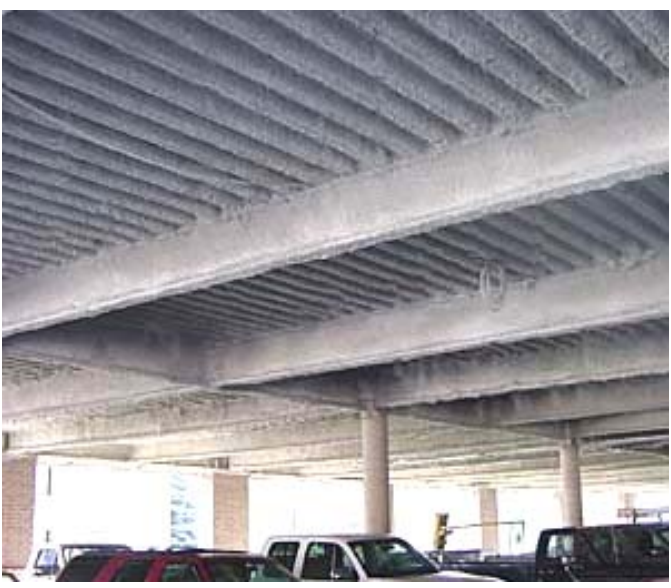

(b)

Figura 3.13 - Fibras projetadas (BLAZE-SHIELD®): (a) Operação de jateamento. Fonte: isolatek.com; (b) Detalhe do acabamento. Fonte: sweets.construction.com.

\section{- Propriedades Térmicas dos materiais projetados}

Dificilmente encontram-se disponíveis as propriedades térmicas dos materiais projetados de forma detalhada e levando em conta a variação das propriedades de acordo com a temperatura. Isto vale também para os outros materiais de proteção a 
serem discutidos a seguir. No entanto, quase todos os fabricantes de materiais para proteção passiva apresentam em seus catálogos técnicos, as Cartas de Cobertura.

As Cartas de Cobertura, tabelas construídas com base em resultados experimentais (ensaios de laboratório), apresentam a espessura necessária para o material de revestimento, em função do fator de massividade (u/A) e do TRRF, para uma temperatura crítica determinada. O fator de massividade, a ser discutido em detalhes no capítulo 4, nada mais é do que a relação entre o perímetro exposto ao fogo de um perfil metálico pela sua área. O TRRF foi definido no Capítulo 2.

A tabela 3.3 indica a espessura para a argamassa projetada do tipo Monokote MK6 (cimentícia) e a tabela 3.4 indica a espessura para a fibra projetada Blaze Shield II, para a temperatura de $550^{\circ} \mathrm{C}$. Vale lembrar que os fabricantes e órgãos que realizaram os ensaios são os responsáveis pelos valores apresentados nessas tabelas.

Tabela 3.3 - Espessura da argamassa MK6 (mm), em função de F e do TRRF, para $\theta_{\mathrm{cr}}=550^{\circ} \mathrm{C}$. Fonte: SILVA (2001).

\begin{tabular}{|c|c|c|c|c|c|}
\hline \multirow{2}{*}{$\mathbf{u} / \mathbf{A ~ ( \mathbf { m } ^ { - \mathbf { 1 } } )}$} & \multicolumn{5}{|c|}{ TRRF (minutos) } \\
\cline { 2 - 6 } & $\mathbf{3 0}$ & $\mathbf{6 0}$ & $\mathbf{9 0}$ & $\mathbf{1 2 0}$ & $\mathbf{1 9 0}$ \\
\hline $\mathbf{3 0}$ & 10 & 10 & 10 & 10 & 15 \\
\hline $\mathbf{6 0}$ & 10 & 10 & 14 & 18 & 27 \\
\hline $\mathbf{9 0}$ & 10 & 12 & 18 & 25 & 37 \\
\hline $\mathbf{1 2 0}$ & 10 & 15 & 22 & 30 & 45 \\
\hline $\mathbf{1 5 0}$ & 10 & 17 & 26 & 34 & 52 \\
\hline $\mathbf{1 8 0}$ & 10 & 19 & 28 & 38 & 57 \\
\hline $\mathbf{2 1 0}$ & 10 & 20 & 31 & 41 & 62 \\
\hline $\mathbf{2 4 0}$ & 11 & 22 & 33 & 44 & 66 \\
\hline $\mathbf{2 7 0}$ & 11 & 23 & 35 & 47 & - \\
\hline $\mathbf{3 2 0}$ & 12 & 25 & 37 & 50 & - \\
\hline
\end{tabular}

Em NIST (2004), por ocasião das investigações sobre o colapso do World Trade Center em decorrência do ataque terrorista de 11 de setembro de 2001, foram mensuradas as propriedades dos materiais de proteção contra fogo que eram utilizadas no respectivo edifício, com o intuito da elaboração de modelos numéricos detalhados sobre o colapso estrutural. 
Com base nas informações dos fabricantes, três materiais projetados foram identificados: CAFCO BLAZE-SHIELD DC/F, CAFCO BLAZE SHIELD II e Monokote MK-5.

Tabela 3.4 - Espessura de argamassa composta por fibras projetadas, Blaze Shield II, em mm, em função de $\mathrm{F}$ e do TRRF, para $\theta_{\mathrm{cr}}=550^{\circ} \mathrm{C}$. Fonte: IPT (1997).

\begin{tabular}{|c|c|c|c|c|c|}
\hline \multirow{2}{*}{$\mathbf{u} / \mathbf{A}\left(\mathbf{m}^{-\mathbf{1}}\right)$} & \multicolumn{5}{|c|}{ TRRF (min) } \\
\cline { 2 - 6 } & $\mathbf{3 0}$ & $\mathbf{6 0}$ & $\mathbf{9 0}$ & $\mathbf{1 2 0}$ & $\mathbf{1 9 0}$ \\
\hline $\mathbf{3 0}$ & 10 & 10 & 10 & 10 & 14 \\
\hline $\mathbf{6 0}$ & 10 & 10 & 12 & 16 & 25 \\
\hline $\mathbf{9 0}$ & 10 & 11 & 16 & 22 & 33 \\
\hline $\mathbf{1 2 0}$ & 10 & 13 & 20 & 27 & 40 \\
\hline $\mathbf{1 5 0}$ & 10 & 15 & 23 & 31 & 46 \\
\hline $\mathbf{1 8 0}$ & 10 & 17 & 26 & 34 & 51 \\
\hline $\mathbf{2 1 0}$ & 10 & 18 & 28 & 37 & 56 \\
\hline $\mathbf{2 4 0}$ & 10 & 20 & 30 & 40 & 60 \\
\hline $\mathbf{2 7 0}$ & 10 & 21 & 31 & 42 & 63 \\
\hline $\mathbf{3 2 0}$ & 11 & 22 & 34 & 45 & 68 \\
\hline
\end{tabular}

Dos três materiais, o BLAZE SHIELD II é ainda vendido nos Estados Unidos e o BLAZE SHIELD DC/F é vendido apenas no Canadá, sendo estes revestimentos à base de fibras projetadas. O produto Monokote MK-5, uma argamassa cimentícia à base de gesso, era produzido pela Grace Construction Products e teve sua produção interrompida na década de 1980.

Nas figuras 3.14 e 3.15, extraídas de NIST (2004), estão ilustradas a condutividade térmica e o calor específico dos três materiais de proteção contra fogo que eram utilizados no WTC. Analisando os gráficos, nota-se que as propriedades térmicas variam com a temperatura. É importante salientar novamente que estas propriedades não são fornecidas pelos fabricantes. O dimensionamento das espessuras destes materiais de proteção contra fogo, com as informações dos fabricantes, somente é possível por meio das Cartas de Cobertura discutidas anteriormente. 


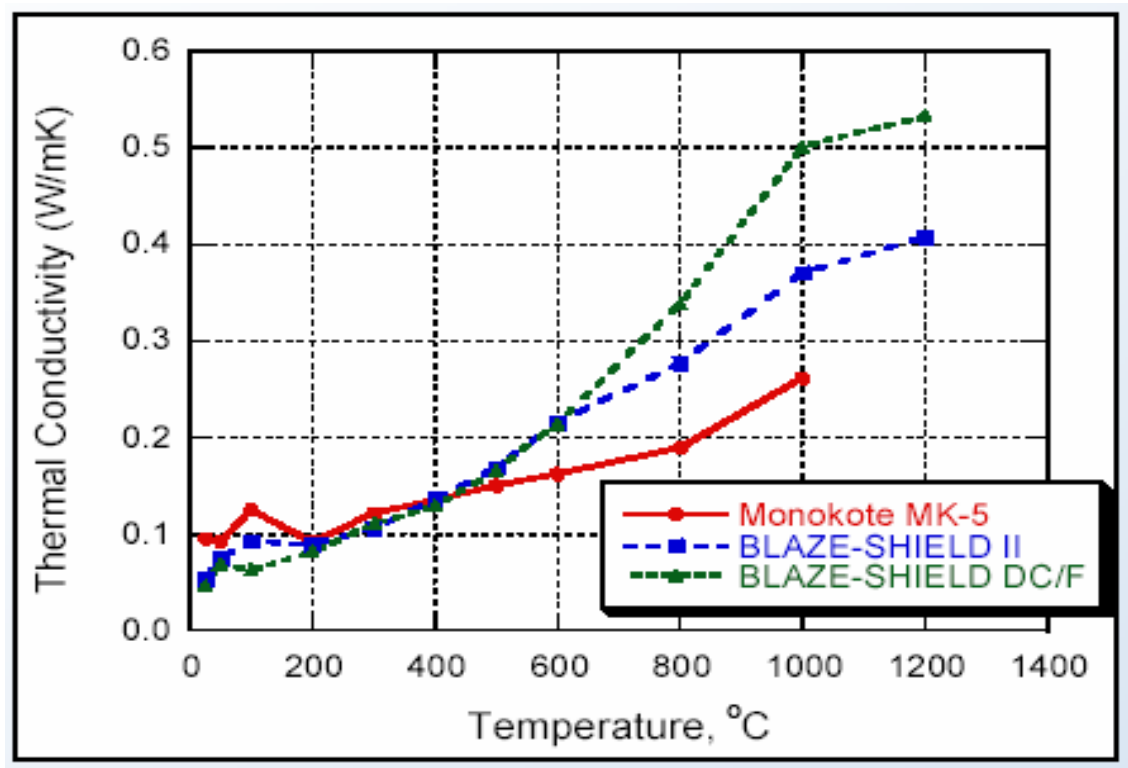

Figura 3.14 - Condutividade térmica dos materiais de proteção contra fogo que eram utilizados no WTC. Fonte: NIST (2004).

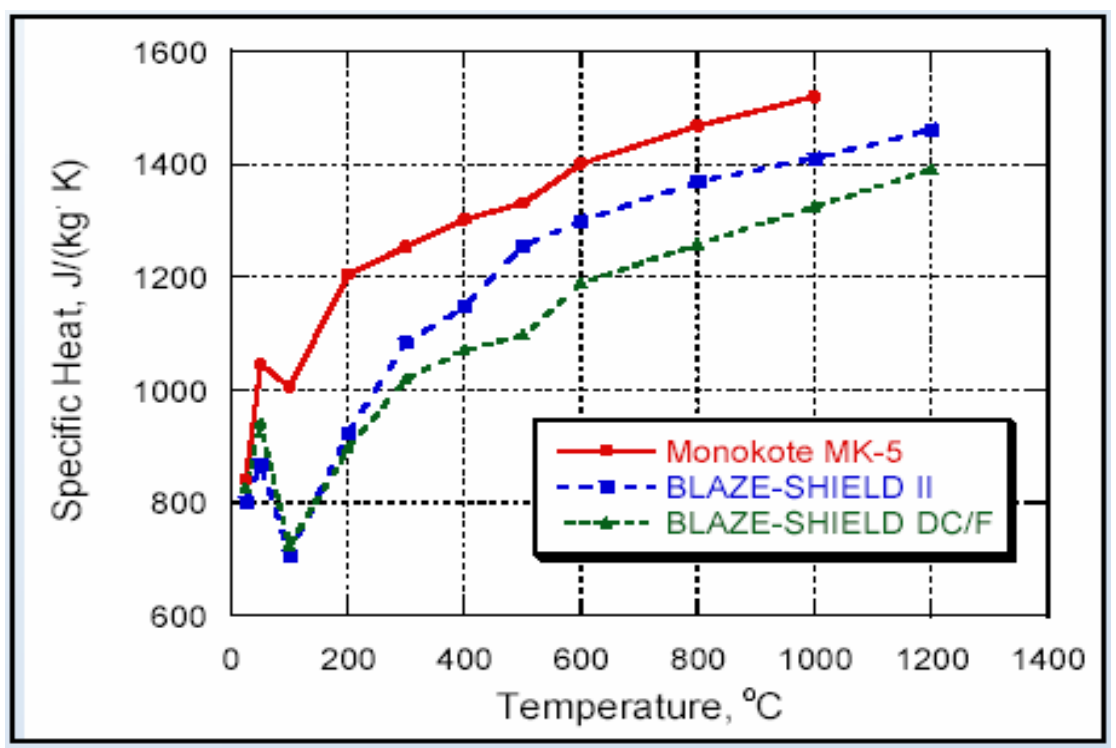

Figura 3.15 - Calor específico dos materiais de proteção contra fogo que eram utilizados no WTC. Fonte: NIST (2004).

\subsubsection{Placas Rígidas}

O revestimento em questão consiste de placas rígidas que envolvem a estrutura de aço, isolando-a das altas temperaturas. Normalmente apresentam acabamento satisfatório (visualmente agradável) por possuir superfície lisa. Podem ser encontradas de três formas diferentes: placas de gesso acartonado, placas de lã de rocha e os painéis de silicato autoclavados. 
A figura 3.16, extraída de DIAS (2002), ilustra uma utilização já antiga de placas rígidas, como no caso do Edifício Palácio do Comércio em São Paulo.
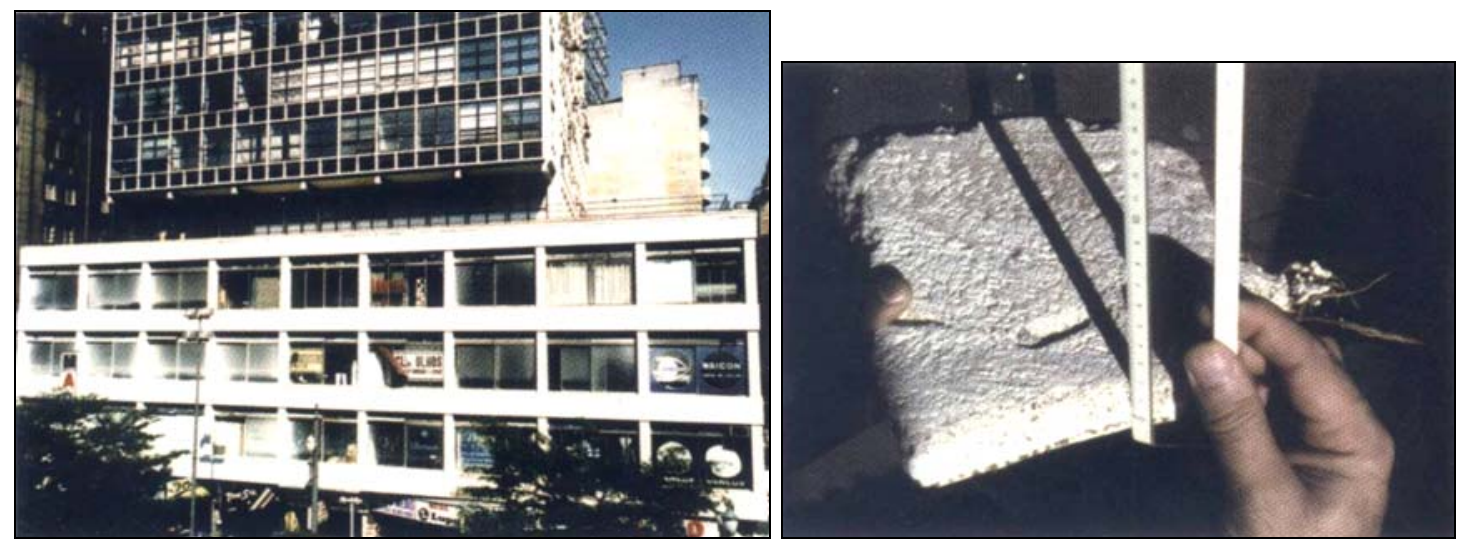

Figura 3.16 - Edifício Palácio do Comércio, São Paulo, 1959: vista geral e detalhe do revestimento com placas rígidas com $25 \mathrm{~mm}$ de espessura. Fonte: DIAS (2002).

\section{- Placas de gesso acartonado}

De acordo com VARGAS e SILVA (2003) e MENDES (2004) são placas semelhantes às placas de gesso convencional, porém possuem fibras de vidro $e$ vermiculita na sua composição, garantindo características específicas para a proteção contra incêndio.

Seu custo é superior quando comparado às placas convencionais "dry-wall", porém apresentam acabamento excelente, idêntico as placas "dry-wall", tornando-se uma solução adequada em situações que necessitam de bom acabamento, contribuindo ainda com o isolamento acústico e podendo trabalhar como paredes de compartimentação corta-fogo. Não podem permanecer expostas às intempéries devido à presença de gesso em sua composição.

Segundo VARGAS e SILVA (2003) apresentam condutividade térmica de 0,15 $\mathrm{W} / \mathrm{m}^{\circ} \mathrm{C}$ e calor específico de $1200 \mathrm{~J} / \mathrm{kg}^{\circ} \mathrm{C}$. Vale lembrar que as propriedades térmicas deste material, assim como as de quase todos os materiais, variam com a temperatura. Maiores detalhes sobre as propriedades térmicas deste material podem ser encontradas em JONES (2001).

A figura 3.17, ilustra a aplicação de placas de gesso em duas situações construtivas. 


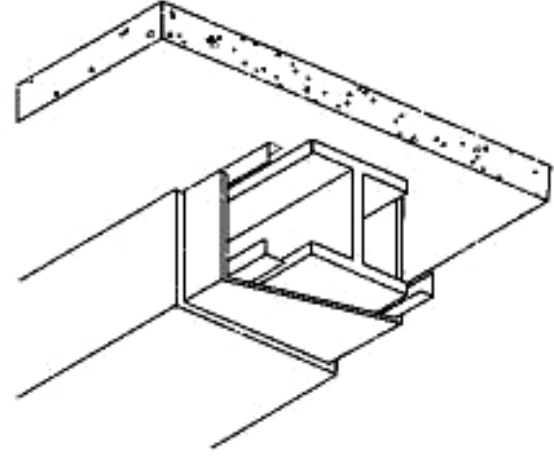

Montagem das placas de gesso

(a)

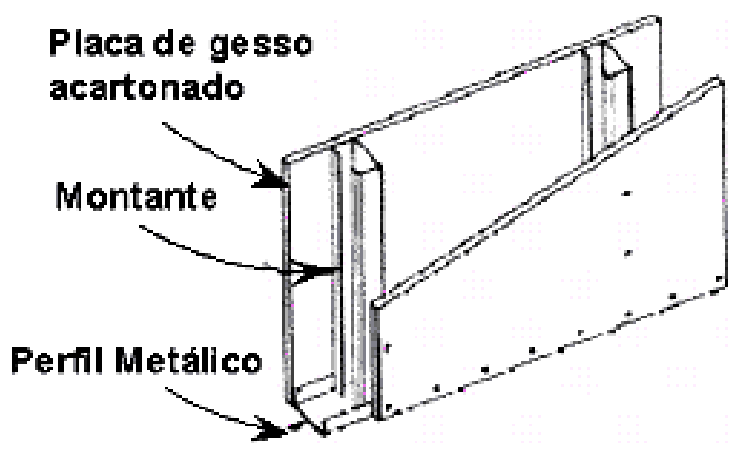

(b)

Figura 3.17 - Montagem das placas de gesso acartonado.

(a) Proteção de viga; Fonte: FAKURI (1999) e (b) Gesso acartonado no sistema light steel frame. Fonte: http://www.cbca-ibs.org.br/acos estruturais protecao.asp.

\section{- Placas de lã de rocha}

Esses painéis são compostos por materiais fibrosos, no caso, a lã de rocha, a qual é obtida pela fusão da rocha de origem basáltica. Constituem painéis aglomerados por pulverização de resinas termo-endurecíveis. São aplicados no sistema de caixa, fixados por pinos previamente soldados à estrutura ou por sistema de travamento de encaixe sob pressão, sem a utilização de soldas. Podem ser aplicados durante reformas, com a edificação em uso, pois geram menos sujeira que as argamassas projetadas. A figura 3.18, extraídas de ISAR (2006), apresentam placas que utilizam em sua composição lã de rocha e fibra cerâmica, respectivamente.

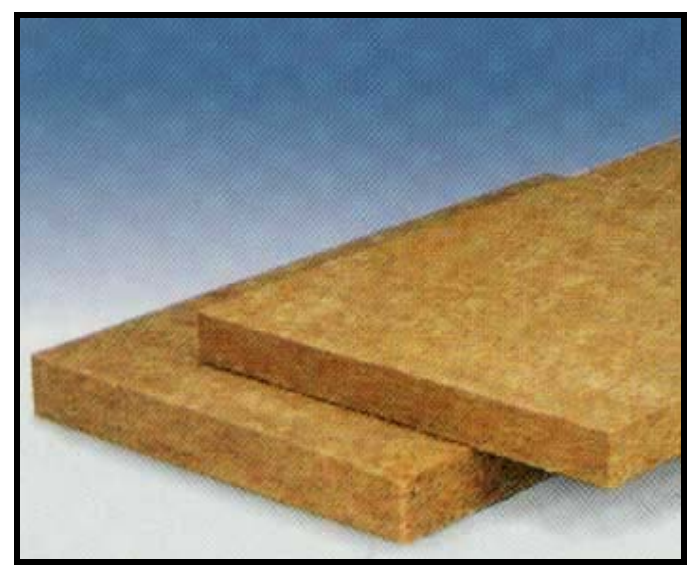

(a)

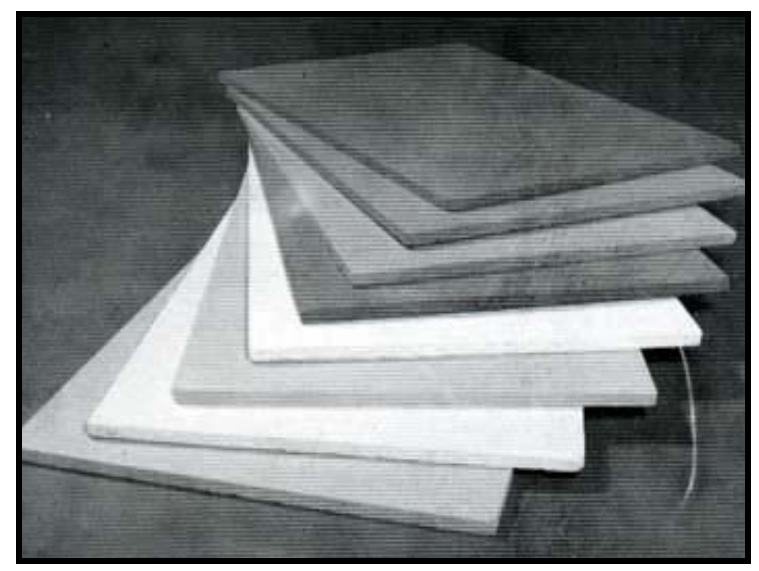

(b)

Figura 3.18 - Exemplos de placas com: (a) lã de rocha e (b) placas de fibra cerâmica. Fonte: ISAR (2006). 
Estes materiais não devem ficar expostos ao intemperismo ou exposição pública, pois apresentam acabamento rústico e baixa resistência mecânica. Porém, em estruturas aparentes de estacionamento e galpões podem ser fornecidos com várias opções de acabamento, como filmes PVC, não-tecido automotivo, alumínio reforçado, além de texturizações e cores.

Segundo MENDES (2004) e VARGAS e SILVA (2003), estas placas apresentam condutividade térmica igual a $0,099 \mathrm{~W} / \mathrm{m}^{\circ} \mathrm{C}\left(\mathrm{em} 300^{\circ} \mathrm{C}\right)$ e calor específico igual a $837,4 \mathrm{~J} / \mathrm{kg}^{\circ} \mathrm{C}$ (em temperatura ambiente). Devido à ausência de propriedades térmicas mais detalhadas, isto é, variando com a temperatura, o dimensionamento da espessura destas placas geralmente é feito por meio das Cartas de Cobertura fornecidas pelos fabricantes.

$\mathrm{Na}$ figura 3.19a ilustra-se o esquema de fixação de placas de lã de rocha num perfil metálico e em 3.19b temos um exemplo de estrutura protegida com placas de lã de rocha Thermax-PEM, da Rock Fibras do Brasil.

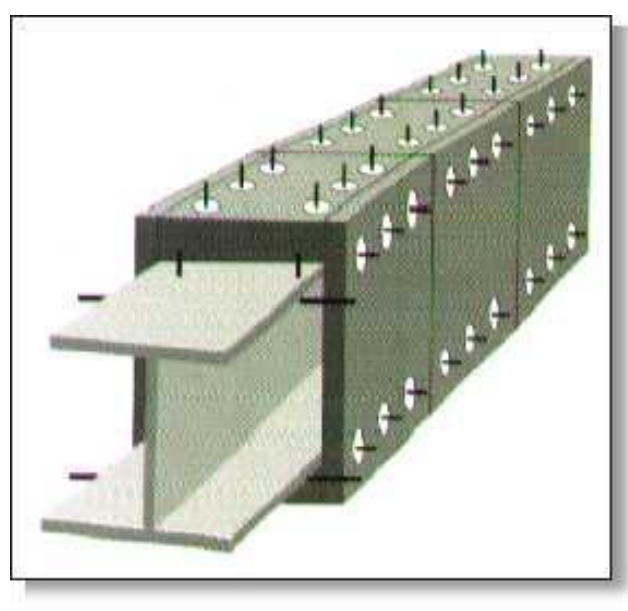

a)

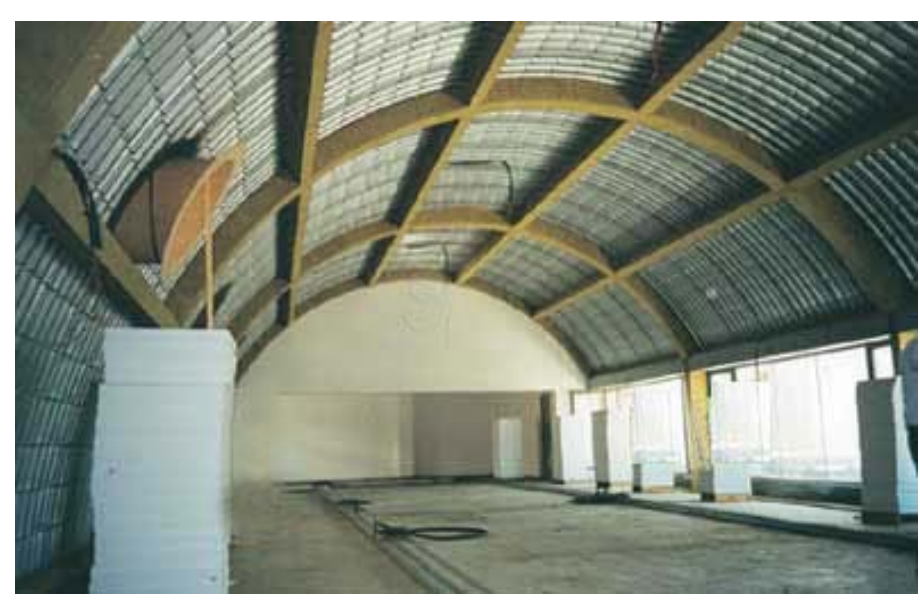

b)

Figura 3.19 - a) Exemplo de fixação de placa de lã de rocha por meio de pinos. Fonte: www.rockfibras.com/pemfogo.htm. b) Estrutura protegida com placas de lã de rocha. Fonte: www.guarutherm.com.br. 


\section{- Painéis de silicato autoclavados}

São constituídos por placas rígidas que apresentam elevada resistência mecânica e à abrasão. Podem ser aplicados nas edificações em serviço, pois são instalados por meio de travamentos com parafusos ou grampos, sem necessidade se soldas na estrutura. Seu acabamento é similar àquele obtido com a aplicação das placas de gesso acartonado, podendo receber massas e pinturas, conferindo boas soluções para os interiores das edificações. A figura 3.20 ilustra uma aplicação de painéis rígidos de silicato autoclavados.

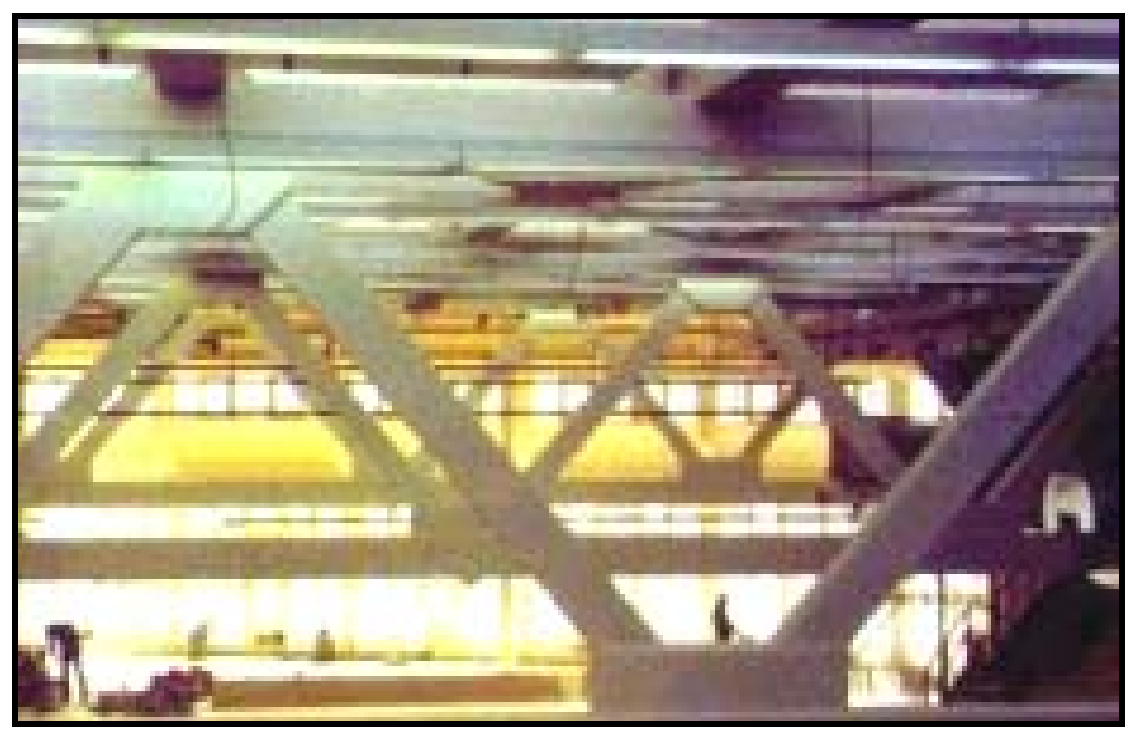

Figura 3.20 -Estrutura protegida com placas rígidas de painéis autoclavados. Fonte: REFRASOL (2006).

\subsubsection{Mantas}

As mantas são materiais flexíveis que podem ser compostas por aglomerados de fibra cerâmica, lã de rocha ou outro material fibroso. A figura 3.21, extraída de ISAR (2006), apresentam exemplos de mantas. Elas apresentam baixa densidade, em torno de $64 \mathrm{~kg} / \mathrm{m}^{3}$.

Essas mantas são aplicadas no contorno, envolvendo a estrutura, sendo fixadas por meio de pinos metálicos soldados previamente à estrutura. Esse sistema é adequado para edificações em funcionamento, pois geram pouca sujeira. A figura 3.22, extraída de DIAS (2002), ilustra as etapas de colocação de manta em estrutura protegida por este sistema. 


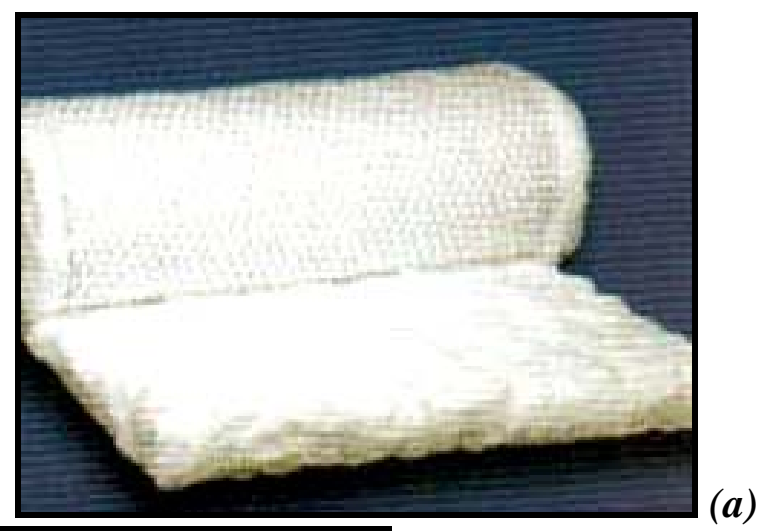

(b)
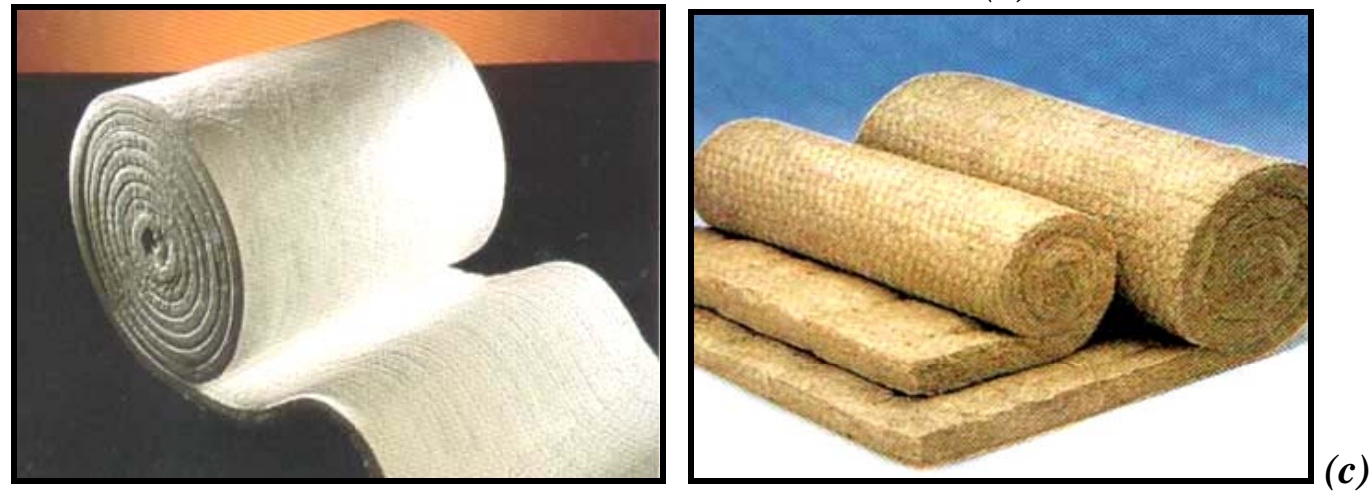

Figura 3.21 - Manta compostas por: (a) lã de vidro, (b) fibra cerâmica e (c) lã de rocha. Fonte: ISAR (2006).
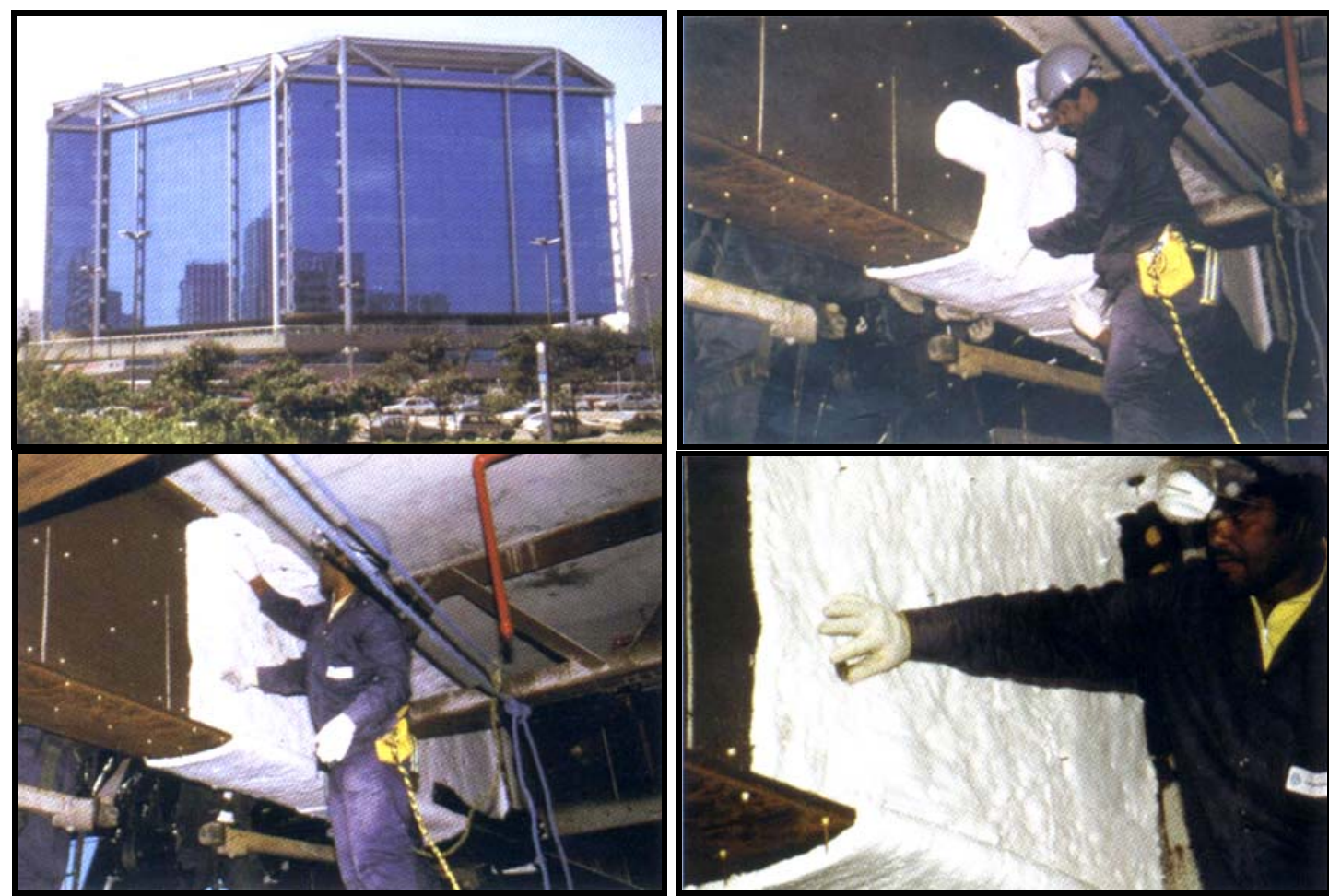

Figura 3.22 - Centro Empresarial do Aço protegido por manta de fibra cerâmica, São Paulo - SP: vista geral e detalhes da fixação da manta de fibra cerâmica em perfil soldado tipo I, por meio de pinos e arruelas de pressão. Fonte: DIAS (2002). 
Assim como as placas de lã de rocha, as mantas não devem ficar expostas ao intemperismo e ao público, já que apresentam baixa resistência mecânica e aparência rústica. Apesar desses aspectos, representa boa opção para revestimento de peças vazadas.

Sua condutividade térmica é de $0,087 \mathrm{~W} / \mathrm{m}^{\circ} \mathrm{C}\left(\mathrm{em} 427^{\circ} \mathrm{C}\right)$ e calor específico de $1130 \mathrm{~J} / \mathrm{kg} .{ }^{\circ} \mathrm{C}$. Para as mantas, assim como nas placas, a espessura de proteção varia em função das espessuras disponíveis comercialmente, e o dimensionamento da espessura também é feito por meio das Cartas de Cobertura.

\subsubsection{Tintas Intumescentes}

A tinta intumescente é um material específico para proteção passiva, o qual permanece inativo na estrutura, como uma tinta comum, até que seja exposto à temperatura superior a $200^{\circ} \mathrm{C}$. A partir desta temperatura inicia-se um processo de expansão volumétrica, ou seja, intumescem, tornando-se uma espuma rígida (devido às resinas que compõem a tinta) com poros preenchidos por gases atóxicos (Figura 3.23). O processo de expansão volumétrica retarda a elevação rápida de temperatura das estruturas metálicas.

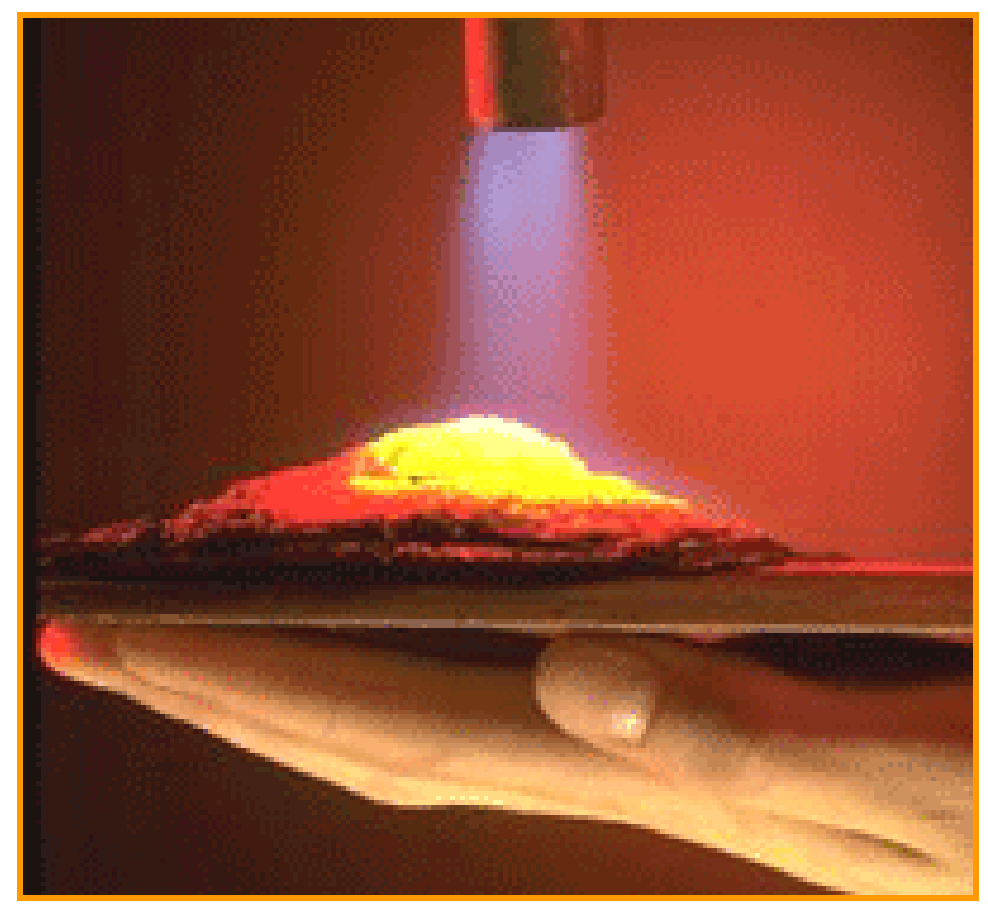

Figura 3.23 - Tinta intumescente - Processo de intumescimento devido à ação do calor. Fonte: www.cbca-ibs.org.br/acos estruturais protecao.asp 
Segundo MENDES (2004), a aplicação do material, ilustrada pela figura 3.24 extraída de DIAS (2002), inicia-se com a preparação da superfície do aço por meio de jato de areia, granalha de aço ou lixamento mecânico, sendo necessário remover qualquer substância indesejada, como carepas de laminação e soldagem, oxidações e manchas de óleos, graxas ou gorduras.

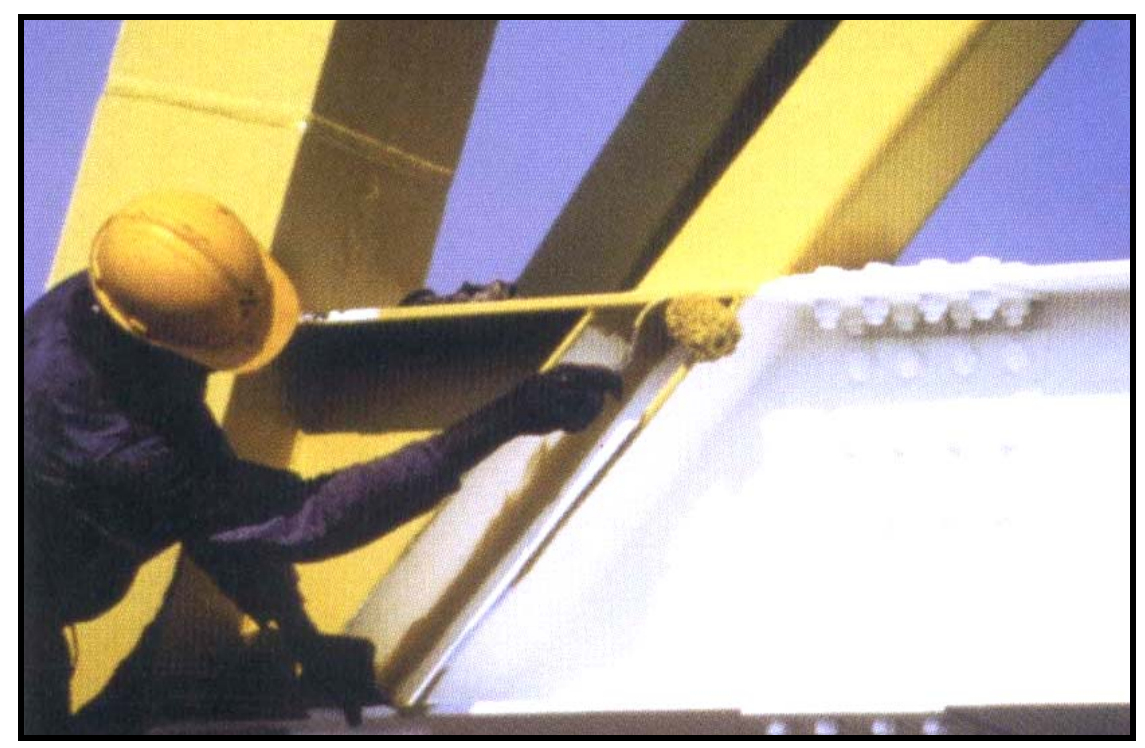

Figura 3.24 - Aplicação da tinta intumescente. Fonte: DIAS (2002).

Em seguida, aplica-se uma demão de primer epóxi compatível, com espessura de 50 a $60 \mu \mathrm{m}$, sendo que uma segunda demão deverá ser aplicada no local da edificação após a montagem. A tinta intumescente é aplicada, por meio de spray, pincel ou rolo, em várias demãos, até atingir a espessura necessária para a proteção passiva. A figura 3.25 ilustra a etapa de limpeza, aplicação e expansão do sistema intumescente.

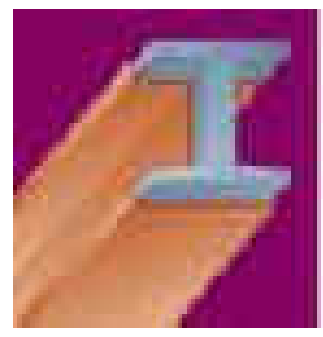

(a)

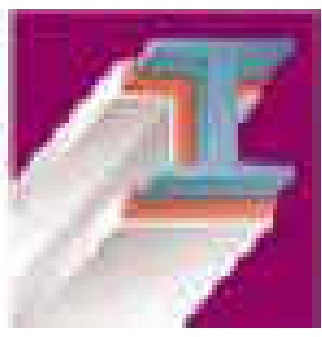

(b)

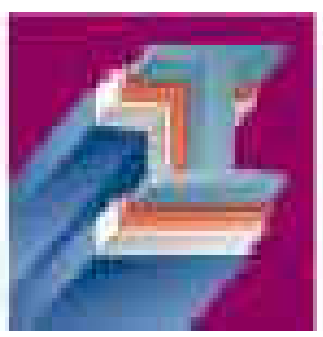

(c)

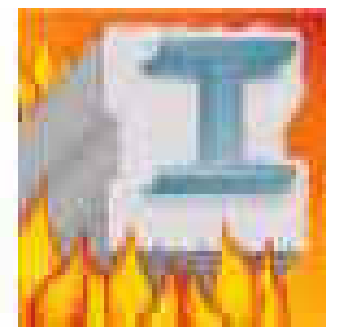

(d)

Figura 3.25 - (a) Limpeza e aplicação do primer epóxi; (b) Aplicação da tinta intumescente com espessura dependente do nível de exigência de proteção; (c) Pintura de acabamento na cor desejada e (d) Expansão do sistema em caso de incêndio. Fonte: REFRASOL (2006). 
A figura 3.26, extraída de DIAS (2002), ilustra um exemplo de edifício protegido com pintura intumescente.

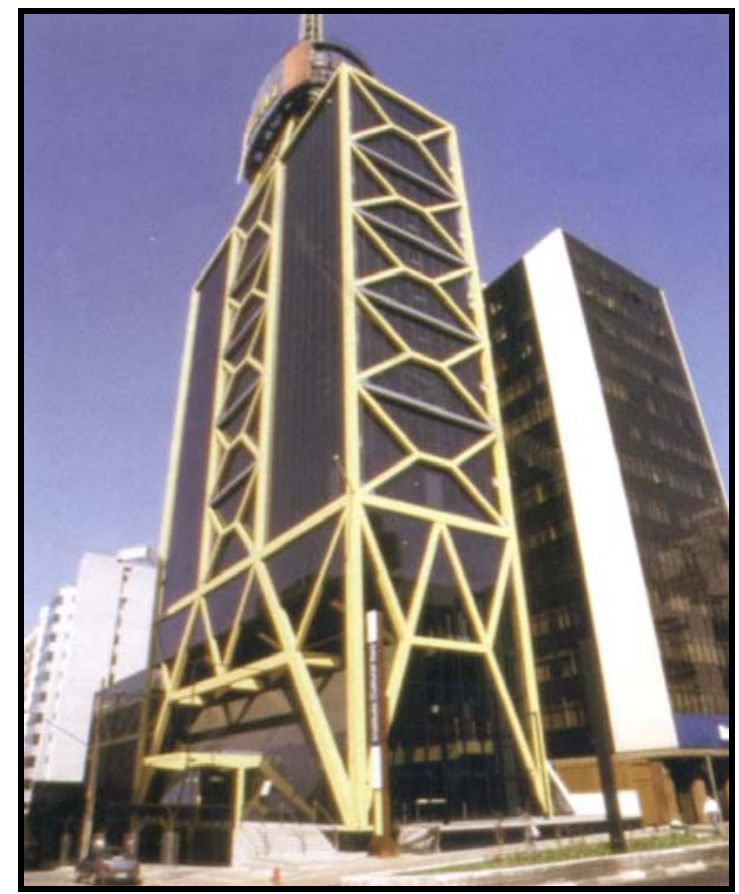

(a)

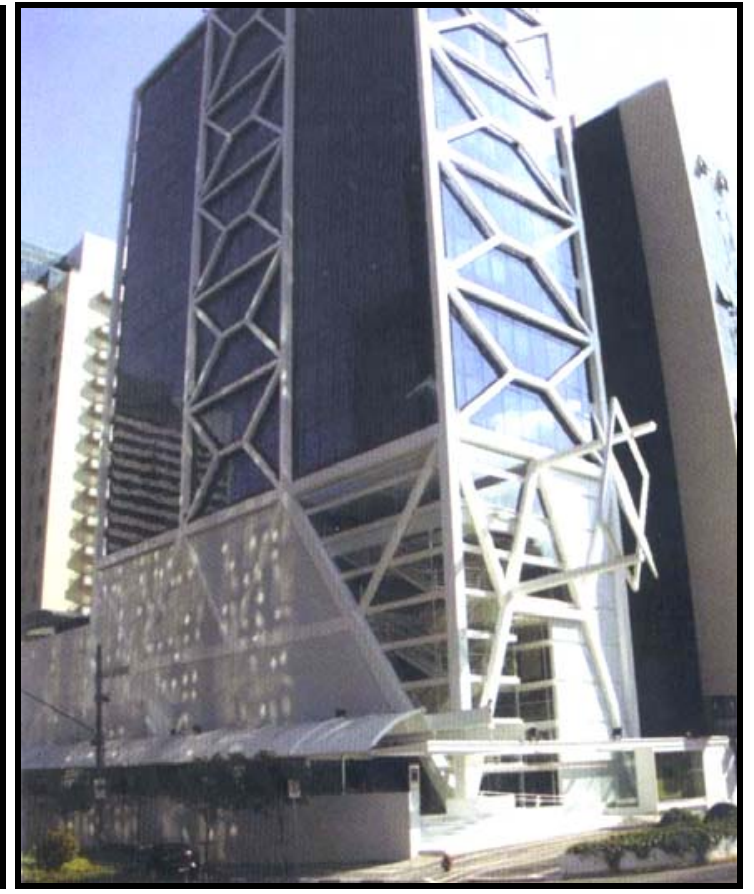

(b)

Figura 3.26 - (a) Edifício do ICI (Instituto Itaú Cultural), São Paulo, em 1992; (b) O edifício em 2002. Fonte: DIAS (2002).

\subsection{CUSTO DOS MATERIAIS DE PROTEÇÃO CONTRA FOGO}

A seguir, a título de informação, têm-se na tabela 3.5 valores de referência quanto ao custo genérico dos materiais de proteção contra fogo, cedidos por Valdir Pignatta e Silva e Fabio Domingos Pannoni, atualmente professor Doutor da Escola Politécnica da USP e Especialista em Engenharia de Proteção Estrutural da Gerdau Açominas S.A., respectivamente. Maiores informações devem ser obtidas diretamente com os fabricantes de tais materiais. 
Tabela 3.5 - Custo dos materiais de proteção térmica.

\begin{tabular}{|l|c|c|}
\hline \multicolumn{1}{|c|}{ Material } & Faixa de custo $\left(\mathbf{U S} \mathbf{/ \mathbf { m } ^ { 2 }}\right)$ & Faixa de TRRF \\
\hline \hline Materiais Projetados - Commercial SFRM & $9,00-15,00$ & $30-120$ minutos \\
\hline Materiais Projetados - Industrial SFRM & $120,00-380,00$ & $60-240$ minutos \\
\hline Tintas intumescentes (intumescent paint) & $16,00-210,00$ & $30-120$ minutos \\
\hline Placas / Mantas (Boards/Blankets) & $18,00-75,00$ & $30-120$ minutos \\
\hline \hline
\end{tabular}




\section{ELEVAÇÃO DA TEMPERATURA EM ELEMENTOS ESTRUTURAIS}

Neste capítulo serão apresentados aspectos conceituais e procedimentos referentes à obtenção da elevação de temperatura nos perfis estruturais de aço e mistos de aço e concreto, envolvidos ou não por revestimento contra fogo. Os modelos que permitem obter a evolução da temperatura dividem-se, basicamente, em duas categorias:

a) Os modelos simplificados de cálculo: permitem obter a elevação de temperatura de modo homogêneo para toda a seção transversal e ao longo do comprimento do elemento de interesse, por meio de simples equações analíticas;

b) Os modelos avançados de cálculo: têm como base métodos numéricos como, por exemplo, diferenças finitas e elementos finitos. Permitem obter o campo de temperaturas no elemento ao longo do processo de aquecimento. Porém, para o emprego desses métodos, torna-se necessário o uso de computadores, diante da complexidade numérica inerente à resolução do problema.

No tocante aos modelos simplificados de cálculo, apresentam-se as equações simplificadas da NBR 14323:1999 e de seu projeto de revisão, bem como aquelas apresentadas no EUROCODES 3 (2005) e no EUROCODE 4 (2005).

Quanto aos modelos avançados de cálculo, faz-se um breve comentário da forma geral da resolução do problema com o emprego de pacotes computacionais construídos com base no método dos elementos finitos, disponíveis para tal fim. Discute-se ainda, de forma genérica, os princípios da aplicação do código ANSYS v9.0, utilizado neste trabalho, em problemas que envolvam transferência de calor, bem como as ferramentas disponíveis para tal finalidade. 


\subsection{MODELOS SIMPLIFICADOS DE CÁLCULO}

\subsubsection{Hipótese de temperatura homogênea na seção}

Para a obtenção da distribuição de temperatura num elemento estrutural em situação de incêndio é, geralmente, necessário o emprego de métodos avançados de cálculo (procedimentos numéricos). Entretanto, para os casos comuns de elementos de aço, com e sem revestimento, expostos ao fogo, simples soluções analíticas podem ser obtidas possibilitando o cálculo da evolução de temperaturas de forma bastante rápida.

Em WANG (2002) destaca-se que estas soluções analíticas foram desenvolvidas lançando-se mão do "Método da Massa Concentrada", isto é, toda a massa do aço é sujeita a mesma temperatura. A validade desta hipótese depende da taxa de transferência de calor intrínseca ao material, isto é, de sua condutividade térmica e de sua espessura.

Para, por exemplo, uma placa totalmente imersa num fluido submetido a um súbito aumento de temperatura, considerações teóricas apropriadas, como aquelas descritas em CARSLAW e JAEGUER (1959) apud WANG (2002), sugerem que se for assegurado que o número de Biot resulte menor que 0,1 , a placa em questão pode ser assumida com uma distribuição uniforme de temperatura e o método em questão pode ser aplicado.

$\mathrm{O}$ número de Biot (Bi) é um número adimensional empregado em análises transientes de transferência de calor. Sua denominação é uma homenagem ao físico Jean-Baptiste Biot (1774-1862). O número de Biot relaciona a resistência à transferência de calor dentro de um corpo e à superfície deste mesmo corpo.

Caso número de Biot resulte com valor maior que 0,1 , implica que a condução de calor dentro de um corpo é muito mais lenta que em sua superfície e, portanto, existem gradientes de temperaturas significativos neste corpo. O número de Biot (Bi), para o caso da placa em questão, é definido na forma da equação (4.1).

$$
\mathrm{Bi}=\frac{\alpha \mathrm{t}}{2 \lambda}
$$

Na equação (4.1), $\alpha$ é o coeficiente de transferência de calor total na superfície da placa, ou seja, é a soma dos coeficientes de transferência de calor por convecção $\left(\alpha_{c}\right)$ 
e radiação $\left(\alpha_{\mathrm{r}}\right)$, ambos definidos no capítulo 2 . Nessa mesma equação t é a espessura da placa e $\lambda$ é a condutividade térmica da placa. De maneira aproximada, a condutividade térmica do aço pode ser tomada igual a $45 \mathrm{~W} /\left(\mathrm{m}^{\circ} \mathrm{C}\right)$.

Como exemplo, para uma dada situação com a temperatura dos gases (ambiente em incêndio) igual a $\theta=727^{\circ} \mathrm{C}$, a temperatura no aço igual a aproximadamente $527{ }^{\circ} \mathrm{C}$ e emissividade resultante igual a 0,5 , o coeficiente de transferência de calor devido à radiação, $\alpha_{r}$, dado pela equação (2.17) apresentada no capítulo 2 , resulta:

$$
\begin{aligned}
& \alpha_{\mathrm{r}}=\varepsilon_{\text {res }} \sigma\left(\mathrm{T}_{2}^{2}+\mathrm{T}_{1}^{2}\right)\left(\mathrm{T}_{2}+\mathrm{T}_{1}\right) \\
& \alpha_{\mathrm{r}}=\varepsilon_{\text {res }} \sigma\left[\left(\theta_{2}+273\right)^{2}+\left(\theta_{1}+273\right)^{2}\right)\left[\left(\theta_{2}+273\right)+\left(\theta_{1}+273\right)\right] \\
& \alpha_{\mathrm{r}}=0,5 \times 5,67 \times 10^{-8}\left(1000^{2}+800^{2}\right)(1000+800) \cong 84 \mathrm{~W} /\left(\mathrm{m}^{2} \mathrm{C}\right)
\end{aligned}
$$

Assumindo um coeficiente de transferência de calor devido à convecção $\left(\alpha_{c}\right)$ igual a $25 \mathrm{~W} /\left(\mathrm{m}^{2}{ }^{\circ} \mathrm{C}\right)$, têm-se um coeficiente de transferência de calor total $\alpha$ igual a 109 $\mathrm{W} /\left(\mathrm{m}^{2}{ }^{\circ} \mathrm{C}\right)$. Por fim, para $\mathrm{Bi}<0,1$ resulta:

$$
\mathrm{t}<(0,1 \mathrm{x} 2 \mathrm{x} 45) / 109<0,083 \mathrm{~m} \quad \rightarrow \quad \mathrm{t}<\mathbf{8 3} \mathbf{~ m m}
$$

Nos perfis de aço usuais, a espessura das almas, mesas ou chapas de aço constituintes destes perfis, resulta, normalmente, bem menor que o valor obtido na última operação. Portanto, o “Método da Massa Concentrada” pode ser usado e a hipótese de temperatura homogênea na seção resulta coerente e representativa.

\subsubsection{Temperatura em elementos não-revestidos}

A figura 4.1 apresenta a seção transversal de um elemento submetido à ação do fogo por todos os lados. Assumindo que a temperatura no aço é $\mathrm{T}_{\mathrm{a}}$ (homogênea em toda a seção) e a temperatura dos gases é $\mathrm{T}_{\mathrm{g}}, \mathrm{o}$ equilíbrio térmico para essa situação apresentado em WANG (2002), é dado por meio da equação (4.2).

$$
\mathrm{V} \rho_{\mathrm{a}} \mathrm{c}_{\mathrm{a}} \frac{\mathrm{dT}_{\mathrm{a}}}{\mathrm{dt}}=\alpha\left(\mathrm{T}_{\mathrm{g}}-\mathrm{T}_{\mathrm{a}}\right) \mathrm{A}
$$




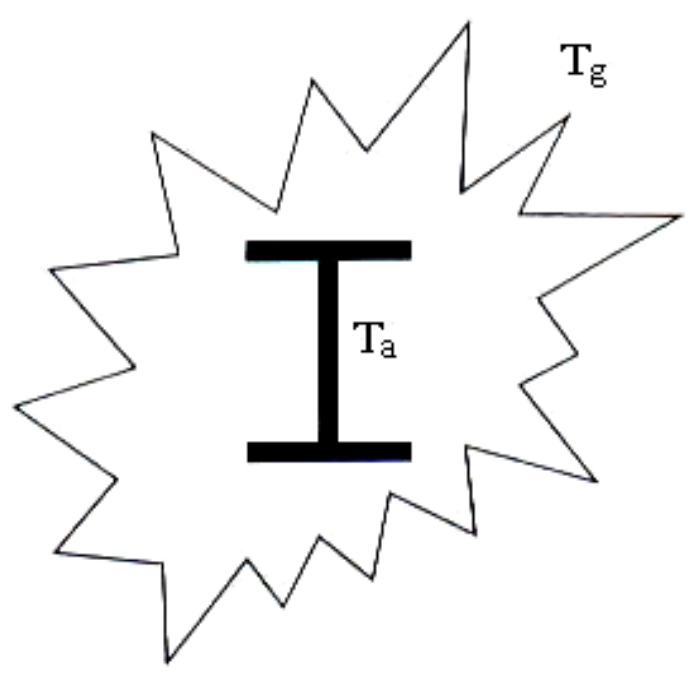

Figura 4.1 - Perfil de aço exposto ao incêndio por todos os lados.

Fonte: WANG (2002).

$\mathrm{Na}$ equação 4.2, V e A são o volume e a área exposta da superfície do elemento de aço, respectivamente, $\rho_{a}$ é a massa específica e $c_{a}$ o calor específico do aço. $\mathrm{O}$ parâmetro $\alpha$ deve ser interpretado como o coeficiente total de transferência de calor, da mesma forma como foi apresentado no item anterior, isto é, a soma dos coeficientes de transferência de calor por convecção $\left(\alpha_{c}\right)$ e radiação $\left(\alpha_{r}\right)$.

O lado esquerdo da equação (4.2) representa o calor absorvido pelo elemento de aço, enquanto o lado direito representa o calor fornecido ao elemento pelos gases quentes, na unidade de tempo.

Usando uma aproximação passo a passo, e assumindo um incremento de tempo compatível $(\Delta \mathrm{t} \leq 5 \mathrm{~s})$, o incremento da temperatura do aço durante o intervalo $\Delta \mathrm{t}$ pode ser calculado por meio da equação (4.3).

$$
\Delta \mathrm{T}_{\mathrm{a}}=\frac{\mathrm{A} / \mathrm{V}}{\rho_{\mathrm{a}} \mathrm{c}_{\mathrm{a}}} \alpha\left(\mathrm{T}_{\mathrm{g}}-\mathrm{T}_{\mathrm{a}}\right) \Delta \mathrm{t}
$$

O numerador A/V apresentado na equação (4.3) é denominado fator de massividade ou fator de forma do elemento de aço e será melhor discutido no item 4.1.4. A equação (4.3) é adotada de forma similar pela NBR 14323:1999 e pelos EUROCODE 3 (2005) Part 1-2 e EUROCODE 4 (2005) Part 1-2. A NBR 14323:1999 apresenta esta mesma equação, porém, reescrita na forma da equação (4.4). 


$$
\Delta \theta_{\mathrm{a}, \mathrm{t}}=\frac{(\mathrm{u} / \mathrm{A})}{\mathrm{c}_{\mathrm{a}} \rho_{\mathrm{a}}} \varphi \Delta \mathrm{t}
$$

$\mathrm{Na}$ equação (4.4), $\Delta \theta_{\mathrm{a}, \mathrm{t}}$ representa a variação da temperatura $\left(\mathrm{em}{ }^{\circ} \mathrm{C}\right)$ no elemento estrutural de aço durante um intervalo de tempo $\Delta \mathrm{t}(\mathrm{em} \mathrm{s})$, e u/A é o fator de massividade para elementos estruturais de aço sem revestimento contra incêndio, com unidade em $\mathrm{m}^{-1}$.

Com relação aos demais parâmetros da última equação, u é o perímetro exposto ao incêndio do elemento estrutural de aço (m), A é a área da seção transversal do elemento estrutural $\left(\mathrm{m}^{2}\right), \mathrm{c}_{\mathrm{a}}$ é o calor específico do aço $\left(\mathrm{J} / \mathrm{kg}^{\circ} \mathrm{C}\right), \rho_{\mathrm{a}}$ é a massa específica do aço $\left(\mathrm{kg} / \mathrm{m}^{3}\right)$ e $\varphi$ é o fluxo de calor por unidade de área $\left(\mathrm{W} / \mathrm{m}^{2}\right)$.

A equação do fluxo de calor é descrita pela equação (4.5).

$$
\varphi=\varphi_{\mathrm{c}}+\varphi_{\mathrm{r}}
$$

Das parcelas que constituem a equação (4.5), $\varphi_{c}$ é o componente do fluxo de calor devido à convecção $\left(\mathrm{W} / \mathrm{m}^{2}\right)$ e $\varphi_{\mathrm{r}}$ é o componente do fluxo de calor devido à radiação $\left(\mathrm{W} / \mathrm{m}^{2}\right)$, representados pelas equações (4.6) e (4.7), respectivamente.

$$
\begin{gathered}
\varphi_{\mathrm{c}}=\alpha_{\mathrm{c}}\left(\theta_{\mathrm{g}}-\theta_{\mathrm{a}}\right) \\
\varphi_{\mathrm{r}}=5,67 \times 10^{-8} \varepsilon_{\text {res }}\left\lfloor\left(\theta_{\mathrm{g}}+273\right)^{4}-\left(\theta_{\mathrm{a}}+273\right)^{4}\right\rfloor
\end{gathered}
$$

A equação (4.6) é a equação (2.4) reescrita para temperaturas em grau Celsius. Da mesma forma, a equação (4.7) é a equação (2.15), reescrita para temperaturas em graus Celsius e já apresentando o valor da constante de Stefan-Boltzman $\left(\sigma=5,67 \times 10^{-8}\right.$ $\left.\mathrm{W} / \mathrm{m}^{2}{ }^{\circ} \mathrm{C}^{4}\right)$.

Nas equações (4.6) e (4.7), $\alpha_{c}$ é o coeficiente de transferência de calor por convecção, podendo ser tomado para os casos práticos igual a $25 \mathrm{~W} / \mathrm{m}^{2 \circ} \mathrm{C}, \theta_{\mathrm{g}}$ é a temperatura dos gases $\left(\mathrm{em}^{\circ} \mathrm{C}\right), \theta_{\mathrm{a}}$ é a temperatura na superfície do aço $\left(\mathrm{em}{ }^{\circ} \mathrm{C}\right)$ e $\varepsilon_{\text {res }}$ é a emissividade resultante, podendo ser tomada para os casos práticos igual a 0,5 . 
A equação (4.7) resulta um pouco diferente daquela equação proposta pelo EUROCODE 1 (2002), quanto à forma de se considerar os valores para a emissividade. Enquanto a NBR 14323:1999 fala em emissividade resultante $\varepsilon_{\text {res, }}$ a qual pode ser tomada para situações práticas igual a 0,5, o EUROCODE 1 substitui a emissividade resultante pelo produto da emissividade do compartimento $\left(\varepsilon_{\mathrm{f}}\right)$ pela emissividade do material $\left(\varepsilon_{\mathrm{m}}\right)$, que pode assumir valor igual a 0,7 , no caso do aço carbono, e igual a 0,4 no caso do aço inoxidável.

Já a equação (4.4) difere basicamente daquela apresentada pelos EUROCODES 3 e 4, no referente à introdução de um fator de correção, para o efeito de sombra, denominado $\mathrm{k}_{\mathrm{sh}}$. $\mathrm{O}$ efeito de sombra é causado pela obstrução local à radiação térmica devido ao formato do perfil de aço. Têm influência em perfis de formato côncavo, tais como as seções I. Para as seções I, sujeitas as curvas de incêndio-padrão (definidas no Capítulo 2), o fator de correção para o efeito de sombra é dado pela equação (4.8).

$$
\mathrm{k}_{\mathrm{sh}}=0,9[\mathrm{u} / \mathrm{A}]_{\mathrm{b}} /[\mathrm{u} / \mathrm{A}]
$$

Na equação (4.8), [u / A $]_{b}$ é um fator de massividade calculado como se o perfil tivesse proteção tipo caixa (ver figura $4.3 \mathrm{~b}$ para o caso de perfil I isolado e tabela A.2 do anexo A para o caso de perfil sobreposto por laje de concreto). Em todos os outros casos, o valor de $k_{\text {sh }}$ deve ser tomado como o apresentado na equação (4.9).

$$
\mathrm{k}_{\mathrm{sh}}=[\mathrm{u} / \mathrm{A}]_{\mathrm{b}} /[\mathrm{u} / \mathrm{A}]
$$

Para seções transversais de formato convexo, tais como as seções caixão e circulares vazadas completamente envolvidas pelo incêndio, o efeito de sombra não tem influência e o fator de correção $\mathrm{k}_{\mathrm{sh}}$ deve ser tomado igual à unidade.

Em VILA REAL (2003) afirma-se que a não consideração do efeito de sombra na equação (4.4), isto é, fazer $\mathrm{k}_{\mathrm{sh}}=1$, conduz a resultados conservadores. $\mathrm{O}$ uso do fator $\mathrm{k}_{\mathrm{sh}}$ está relacionado com o fato de o EUROCODE 3 recomendar o valor de 0,7 para o produto da emissividade do compartimento $\varepsilon_{\mathrm{f}}$ pela emissividade do material $\varepsilon_{\mathrm{m}}$, no caso do aço carbono, em contraste com o valor de 0,5 adotado para a emissividade resultante $\varepsilon_{\text {res }}$ adotado pela NBR 14323:1999. 


\subsubsection{Temperatura em elementos com revestimento contra fogo}

A figura (4.2) ilustra a seção transversal de um perfil de aço revestido em situação de incêndio. Assumindo novamente que a temperatura do aço é $T_{a}$ (homogênea em toda a seção) e a temperatura dos gases é $T_{g}$, em WANG (2002) apresenta-se a equação (4.10), a qual busca representar o calor fornecido para o perfil de aço através do revestimento térmico.

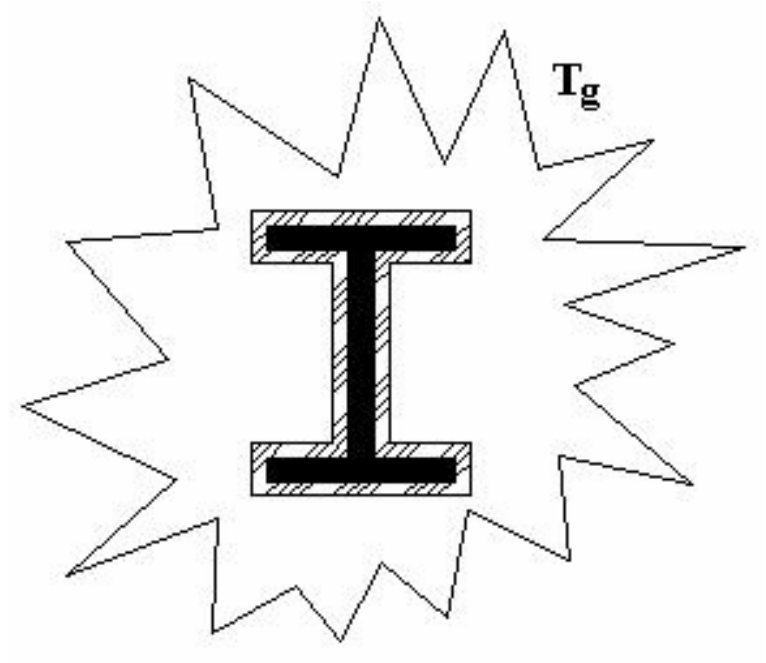

Figura 4.2 - Perfil de aço com revestimento contra fogo exposto a um incêndio.

$$
\mathrm{Q}=\frac{1}{1 / \alpha+\mathrm{t}_{\mathrm{m}} / \lambda_{\mathrm{m}}}\left(\mathrm{T}_{\mathrm{g}}-\mathrm{T}_{\mathrm{a}}\right) \mathrm{A} \Delta \mathrm{t}
$$

$\mathrm{Na}$ equação $4.10, \mathrm{t}_{\mathrm{m}}$ é a espessura do material de revestimento, $\lambda_{\mathrm{m}}$ é a condutividade térmica do material de revestimento e $\mathrm{h}$ é o coeficiente total da transferência de calor do incêndio para o perfil.

Como uma primeira aproximação, conforme WANG (2002), assume-se que a temperatura do revestimento contra fogo tem seu valor igual à média da temperatura dos gases e da temperatura do aço, isto é, $T_{m}=1 / 2\left(T_{g}+T_{a}\right)$. Assim, o calor absorvido pelo aço e pelo revestimento é dado pela equação (4.11).

$$
\mathrm{Q}_{\mathrm{abs}}=\mathrm{c}_{\mathrm{a}} \rho_{\mathrm{a}} \mathrm{V} \Delta \mathrm{T}_{\mathrm{a}}+\mathrm{c}_{\mathrm{m}} \rho_{\mathrm{m}} \mathrm{t}_{\mathrm{m}} \mathrm{A}_{\mathrm{m}} \frac{1}{2}\left(\Delta \mathrm{T}_{\mathrm{g}}+\Delta \mathrm{T}_{\mathrm{a}}\right)
$$


$\mathrm{Na}$ equação 4.11, $\mathrm{A}_{\mathrm{m}}$ é área exposta do revestimento contra fogo. Assumindo que o revestimento térmico é consideravelmente delgado, $A_{m}$ pode ser tomada como a área da superfície do elemento de aço. Igualando as equações (4.10) e (4.11), o aumento da temperatura no aço é obtido pela equação (4.12).

$$
\Delta \mathrm{T}_{\mathrm{a}}=\frac{\left(\mathrm{T}_{\mathrm{g}}-\mathrm{T}_{\mathrm{a}}\right) \mathrm{A}_{\mathrm{m}} / \mathrm{V}}{\left(1 / \alpha+\mathrm{t}_{\mathrm{m}} / \lambda_{\mathrm{m}}\right) \rho_{\mathrm{a}} \mathrm{c}_{\mathrm{a}}\left(1+\frac{1}{2} \phi\right)} \Delta \mathrm{t}-\frac{1}{\left(\frac{2}{\phi}+1\right)} \Delta \mathrm{T}_{\mathrm{g}}
$$

Na equação (4.12) o termo é $\phi$ dado pela equação (4.13).

$$
\phi=\frac{\mathrm{c}_{\mathrm{m}} \rho_{\mathrm{m}}}{\mathrm{c}_{\mathrm{a}} \rho_{\mathrm{a}}} \mathrm{t}_{\mathrm{m}} \frac{\mathrm{A}_{\mathrm{m}}}{\mathrm{V}}
$$

O termo $1 / \alpha$ na equação (4.12) é, geralmente, bastante pequeno quando comparado à resistência térmica do material de revestimento $\left(t_{m} / \lambda_{m}\right)$ e pode ser desprezado.

Considerações teóricas mais detalhadas apresentadas em WICKSTRON (1982) e WICKSTRON (1985), e mencionadas em WANG (2002), sugerem que a equação (4.14) pode ser usada para se obter resultados mais acurados de temperatura em elementos de aço com revestimento contra fogo.

$$
\Delta \mathrm{T}_{\mathrm{a}}=\frac{\lambda_{\mathrm{m}}\left(\mathrm{T}_{\mathrm{g}}-\mathrm{T}_{\mathrm{a}}\right) \mathrm{A}_{\mathrm{m}} / \mathrm{V}}{\mathrm{t}_{\mathrm{m}} \rho_{\mathrm{a}} \mathrm{c}_{\mathrm{a}}\left(1+\frac{1}{3} \phi\right)} \Delta \mathrm{t}-\left(\mathrm{e}^{\phi / 10}-1\right) \Delta \mathrm{T}_{\mathrm{g}}
$$

A equação (4.14) é a mesma adotada pela NBR 14323:1999 e pelos EUROCODE 3 (2005) Part 1.2 e EUROCODE 4 (2005) Part 1.2. Para a última equação, a NBR 14323:1999 emprega, para $\Delta \theta_{\mathrm{a}, \mathrm{t}} \geq 0$, a notação da equação (4.15).

$$
\Delta \theta_{\mathrm{a}, \mathrm{t}}=\frac{\lambda_{\mathrm{m}}\left(\mathrm{u}_{\mathrm{m}} / \mathrm{A}\right)}{\mathrm{t}_{\mathrm{m}} \mathrm{c}_{\mathrm{a}} \rho_{\mathrm{a}}} \frac{\left(\theta_{\mathrm{g}, \mathrm{t}}-\theta_{\mathrm{a}, \mathrm{t}}\right)}{1+\xi / 3} \Delta \mathrm{t}-\left(\mathrm{e}^{\xi / 10}-1\right) \Delta \theta_{\mathrm{g}, \mathrm{t}}
$$

Na equação (4.15) o termo $\xi$ é dado pela equação (4.16). 


$$
\xi=\frac{\mathrm{c}_{\mathrm{m}} \rho_{\mathrm{m}}}{\mathrm{c}_{\mathrm{a}} \rho_{\mathrm{a}}} \mathrm{t}_{\mathrm{m}}\left(\mathrm{u}_{\mathrm{m}} / \mathrm{A}\right)
$$

Para as equações (4.15) e (4.16), $\mathrm{u}_{\mathrm{m}} / \mathrm{A}$ é o fator de massividade para elementos estruturais envolvidos por material de revestimento contra incêndio $\left(\mathrm{m}^{-1}\right)$, enquanto $\mathrm{u}_{\mathrm{m}}$ é o perímetro efetivo do material de revestimento contra incêndio, igual ao perímetro da face interna do material de revestimento contra incêndio mais metade dos afastamentos desta face ao perfil de aço $(\mathrm{m})$.

Ainda, com relação à equação (4.16), A é a área da seção transversal do elemento estrutural $\left(\mathrm{m}^{2}\right), \mathrm{c}_{\mathrm{a}}$ é o calor específico do aço $\left(\mathrm{J} / \mathrm{kg}^{\circ} \mathrm{C}\right), \mathrm{cm}$ é o calor específico do material de revestimento incêndio $\left(\mathrm{J} / \mathrm{kg}^{\circ} \mathrm{C}\right), \theta_{\mathrm{a}, \mathrm{t}}$ é a temperatura do aço no tempo $\mathrm{t}$ $\left({ }^{\circ} \mathrm{C}\right)$ e $\theta_{g, t}$ é a temperatura dos gases no tempo $\mathrm{t}\left({ }^{\circ} \mathrm{C}\right)$.

Com relação as variáveis restantes, $\mathrm{t}_{\mathrm{m}}$ é a espessura do material de revestimento contra incêndio $(\mathrm{m}) ; \lambda_{\mathrm{m}}$ é a condutividade térmica do material de revestimento contra incêndio $\left(\mathrm{W} / \mathrm{m}^{\circ} \mathrm{C}\right) ; \rho_{\mathrm{a}}$ é a massa específica do aço $\left(\mathrm{kg} / \mathrm{m}^{3}\right) ; \rho_{\mathrm{m}}$ é a massa específica do material de revestimento contra incêndio $\left(\mathrm{kg} / \mathrm{m}^{3}\right) ; \Delta \mathrm{t}$ é o intervalo de tempo compatível $(\leq 30 \mathrm{~s})$.

Vale mencionar que A NBR 14323:1999 atualmente encontra-se em processo de revisão. Em substituição a equação (4.15), o Projeto de Revisão da NBR 14323:1999 prescreve a equação (4.17), proposta por SILVA (1999) e SILVA (2005).

$$
\Delta \theta_{\mathrm{a}, \mathrm{t}}=\frac{\lambda_{\mathrm{m}}\left(\mathrm{u}_{\mathrm{m}} / \mathrm{A}\right)}{\mathrm{t}_{\mathrm{m}} \mathrm{c}_{\mathrm{a}} \rho_{\mathrm{a}}} \frac{\left(\theta_{\mathrm{g}, \mathrm{t}}-\theta_{\mathrm{a}, \mathrm{t})}\right.}{1+\xi / 4} \Delta \mathrm{t}-\frac{\Delta \theta_{\mathrm{g}, \mathrm{t}}}{4 / \xi+1}
$$

Uma comparação entre os resultados obtidos com as equações (4.15) e (4.17) poderá ser vista na figura 5.8 do capítulo 6 .

\subsubsection{Fator de massividade}

As equações utilizadas por meio do método simplificado de cálculo para elevação da temperatura em perfis metálicos, discutidas nos itens anteriores, mostram claramente que o aumento de temperatura está diretamente relacionado com o fator de massividade da seção. 
Para elementos sem revestimento térmico, este fator é definido como a razão entre a área do elemento exposta ao fogo, A, e seu volume exposto ao fogo, V, ou seja, $\mathrm{A} / \mathrm{V}$. Para barras consideradas prismáticas, o fator de massividade resulta na relação entre o perímetro exposto ao fogo $(\mathrm{u})$ e a área da seção reta do elemento (A), em que $\ell$ é um dado comprimento do elemento considerado, conforme equação (4.18).

$$
\frac{\mathrm{A}}{\mathrm{V}}=\frac{\mathrm{u} \ell}{\mathrm{A} \ell}=\frac{\mathrm{u}}{\mathrm{A}}
$$

No caso de elementos revestidos, de acordo com a NBR 14323:1999, o perímetro $u$ na equação (4.18) é substituído por $\mathrm{u}_{\mathrm{m}}$, definido como o perímetro efetivo do material de revestimento contra incêndio, igual ao perímetro da face interna do material de revestimento contra incêndio, somado à metade dos afastamentos desta face ao perfil de aço. No Anexo A são apresentadas equações para a determinação do fator de massividade para diversas seções, com e sem revestimento térmico.

Dois exemplos típicos do cálculo do fator de massividade são apresentados na figura 4.3, em que b é a largura da seção de aço, d a altura da seção de aço, A é a área transversal de aço e $t_{w}$ a espessura da alma.

(a)
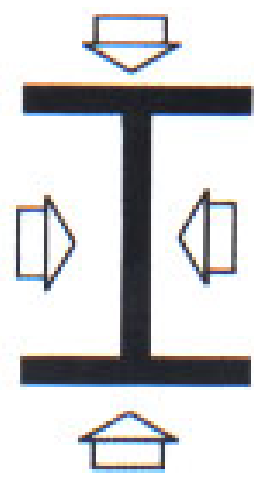

$\frac{\mathrm{u}}{\mathrm{A}}=\frac{2\left(2 \mathrm{~b}-\mathrm{t}_{\mathrm{w}}+\mathrm{d}\right)}{\mathrm{A}}$

(b)

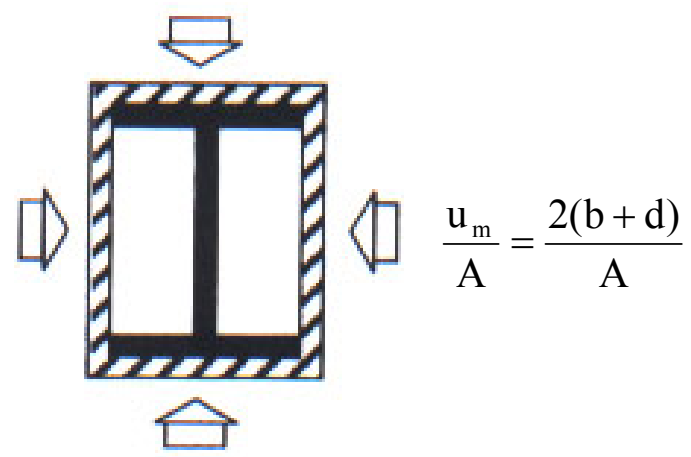

Figura 4.3 - Determinação do fator de massividade: (a) elemento não-revestido e (b) elemento com revestimento tipo caixa. Fonte: WANG (2002).

Em VILA REAL (2003) se salienta que, embora tradicionalmente se utilize o termo fator de "massividade" para definir este fator, deve-se ter em mente que o seu valor resulta tanto menor quanto maiores forem as espessuras das peças, ou seja, quanto maior a massa menor será o valor do fator em questão. 
Ou ainda, um dado elemento com baixo valor do fator de massividade aquecerá mais lentamente se comparado a outro com elevado fator de massividade e, por conseqüência, requer menos revestimento térmico para atingir a mesma resistência ao fogo. Portanto, a referida designação não parece ter sido a mais acertada, conduzindo, consequentemente, a uma interpretação não adequada do referido parâmetro.

\subsubsection{Determinação da elevação da temperatura em vigas mistas de aço e concreto}

O cálculo da elevação de temperaturas em vigas mistas de aço e concreto em situação de incêndio é previsto pela norma brasileira NBR 14323:1999 e pelo EUROCODE 4 (2005) Part 1-2.

A NBR 14323:1999 prescreve que quando a viga de aço não for envolvida por material de revestimento contra incêndio, ou possuir proteção tipo contorno, a distribuição de temperatura no mesmo deve ser tomada como não-uniforme, com a seção transversal dividida em três partes (mesa inferior, alma e mesa superior), de acordo com a figura 4.4 .

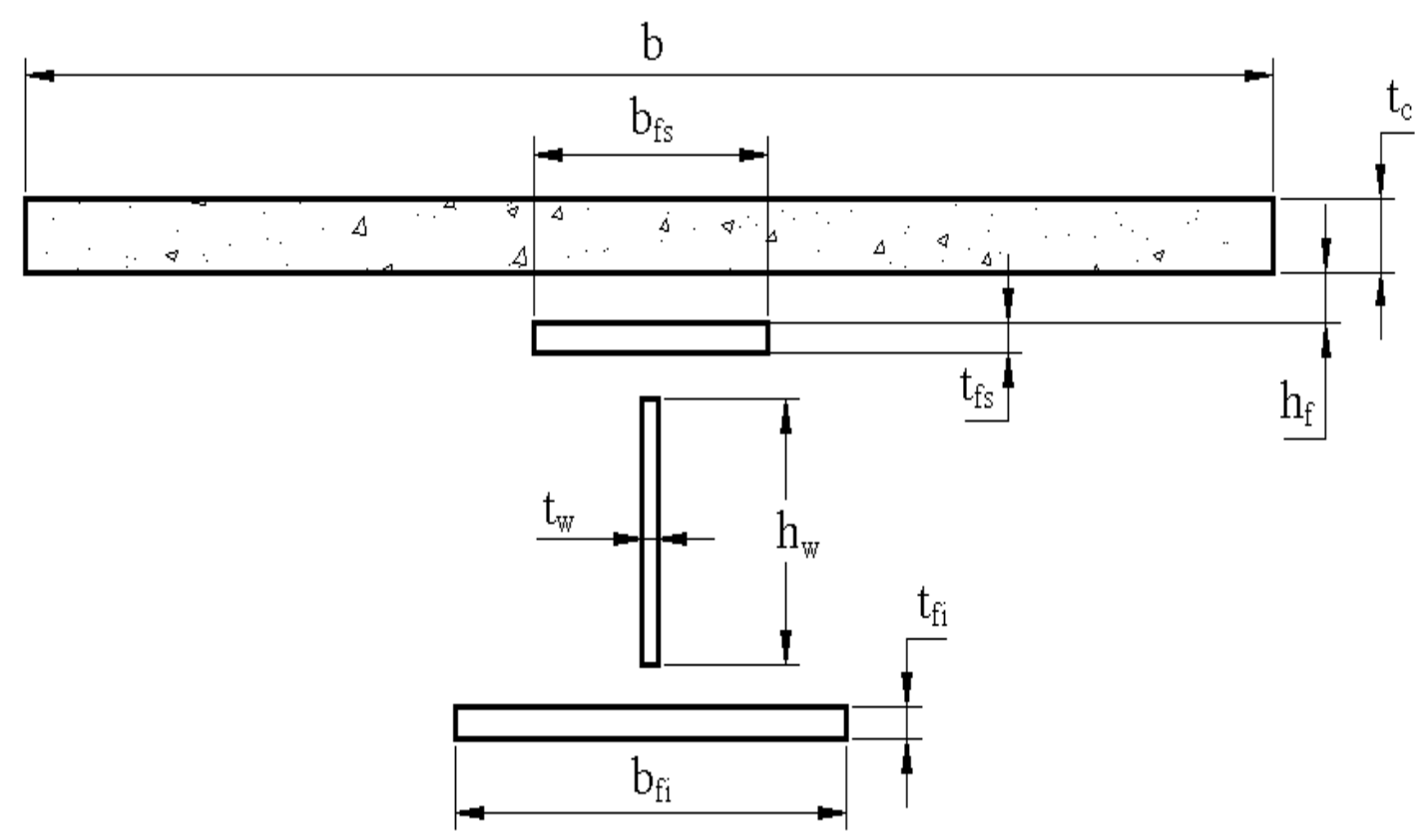

Figura 4.4 - Divisão do componente da seção mista para determinação de temperatura. Fonte: NBR 14323:1999. 
Neste caso, consideram-se os seguintes aspectos:

- considera-se que não ocorra transferência de calor entre estas partes e nem entre a mesa superior e a laje de concreto;

- a temperatura da alma pode ser considerada igual à temperatura da mesa inferior;

- o acréscimo de temperatura $\Delta \theta_{\mathrm{a}, \mathrm{t}}$ das mesas inferior e superior da viga de aço durante o intervalo de tempo $\Delta \mathrm{t}$ deve ser determinado conforme os itens 4.1.2 ou 4.1.3, respectivamente, se o perfil de aço não for revestido ou tiver revestimento tipo contorno;

$\mathrm{O}$ fator de massividade $\mathrm{u} / \mathrm{A}$, ou $\mathrm{u}_{\mathrm{m}} / \mathrm{A}$, deve ser determinado nas formas:

- para a mesa inferior: $\mathrm{u} / \mathrm{A}$ ou $\mathrm{u}_{\mathrm{m}} / \mathrm{A}=\frac{2\left(\mathrm{~b}_{\mathrm{fi}}+\mathrm{t}_{\mathrm{fi}}\right)}{\mathrm{b}_{\mathrm{fi}} \mathrm{t}_{\mathrm{fi}}}$

- para a mesa superior: $\mathrm{u} / \mathrm{A}$ ou $\mathrm{u}_{\mathrm{m}} / \mathrm{A}=\frac{\left(\mathrm{b}_{\mathrm{fs}}+\mathrm{t}_{\mathrm{fs}}\right)}{\mathrm{b}_{\mathrm{fs}} \mathrm{t}_{\mathrm{fs}}}$

- sobreposta por laje maciça: $u / A$ ou $u_{m} / A=\frac{2\left(b_{f s}+t_{f s}\right)}{b_{f s} t_{f s}}$

Para componentes de aço em perfil I com proteção tipo caixa, uma temperatura uniforme pode ser considerada no perfil. A elevação da temperatura para esse caso deve ser obtida conforme o item 4.1.2. O EUROCODE 4 adota procedimento similar, porém, com a introdução de um fator de correção na equação (4.4) para o efeito de sombra em elemento não-revestido, neste caso definido pela equação (4.19).

$$
\mathrm{k}_{\mathrm{sh}}=0,9 \frac{\mathrm{t}_{\mathrm{fi}}+\mathrm{t}_{\mathrm{fs}}+1 / 2 \mathrm{~b}_{\mathrm{fi}}+\sqrt{\mathrm{h}_{\mathrm{w}}{ }^{2}+1 / 4\left(\mathrm{~b}_{\mathrm{fi}}-\mathrm{b}_{\mathrm{fs}}\right)^{2}}}{\mathrm{~h}_{\mathrm{w}}+\mathrm{b}_{\mathrm{fi}}+1 / 2 \mathrm{~b}_{\mathrm{fs}}+\mathrm{t}_{\mathrm{fi}}+\mathrm{t}_{\mathrm{fs}}-\mathrm{t}_{\mathrm{w}}}
$$

Segundo a NBR 14323:1999 a temperatura da laje de concreto pode ser obtida no seu anexo A, pela tabela A.1, para concreto de densidade normal. A variação de temperatura na altura da laje pode ser obtida dividindo-se a altura da laje em um máximo de 14 fatias. Para cada fatia a tabela A.1 fornece a temperatura para um determinado período (TRRF) de incêndio. 


\subsection{MODELOS AVANÇADOS DE CÁLCULO}

Os modelos avançados de cálculo, os quais tomam geralmente como base métodos numéricos como o método das diferenças finitas e, principalmente, o método dos elementos finitos, permitem obter o campo de temperaturas no elemento ao longo do processo de aquecimento. Porém, para o emprego desses métodos, torna-se necessário o uso de programas adequados e computadores com configurações compatíveis com o esforço numérico necessário para a resolução do problema.

Existe um grande número de referências que tratam da análise numérica de transferência de calor (por exemplo, BATHE (1996)) e vários códigos de cálculo (programas para microcomputadores) conhecidos no campo da análise de transferência de calor na engenharia de incêndio. Entre os programas de interesse, podem ser citados o ADAPTIC, o SUPERTEMPCALC (TCD), o SAFIR e o VULCAN.

O principal problema é como lidar com a condição de contorno de radiação quando se necessita calcular o coeficiente de transferência de transferência de calor devido à radiação $\left(\alpha_{\mathrm{r}}\right)$, aspecto já discutido no capítulo 2. Nesses programas computacionais, por simplificação, é usualmente assumido que o fogo está em contato com os elementos da construção de modo que o fator de configuração pode ser tomado igual à unidade, e a emissividade resultante dada pela equação (2.14) pode ser usada.

A análise numérica da transferência de calor também pode ser realizada por meio de um dos vários pacotes comerciais elaborados com base no método dos elementos finitos como o ANSYS, ABAQUS, ADINA ou DIANA, todos conhecidos mundialmente. Segundo aspectos descritos em WANG (2002), estes programas apresentam uma acurácia similar. Portanto, disponibilidade (custo, suporte técnico) e amigabilidade (interação usuário/programa, produtividade, etc.) podem ser os principais fatores de decisão na aquisição de um destes programas para utilização em aplicações termo-estruturais.

Nas próximas seções serão discutidos aspectos de modelagem com o emprego do ANSYS v9.0, adotado neste trabalho, em problemas de análise térmica. Será apresentada a forma com a qual esse código lida com o problema de transferência de calor via método dos elementos finitos, as condições de contorno aplicáveis e os principais recursos disponíveis para elaboração de modelos numéricos com vistas a análises térmicas. 


\subsection{ANÁLISE DE FENÔMENOS TÉRMICOS}

Uma análise térmica tem por objetivo determinar a distribuição de temperatura e de outras variáveis de interesse, relacionadas a um sistema ou um componente desse sistema. As variáveis térmicas típicas de interesse são: $O$ campo e a evolução de temperaturas, a quantia de calor (absorvido ou perdido), os gradientes térmicos e os fluxos térmicos.

As análises térmicas desempenham um papel importante em muitos ramos da ciência e da engenharia. No projeto de permutadores de calor como, por exemplo, caldeiras, condensadores, radiadores, etc., a análise térmica é essencial no dimensionamento adequado desses equipamentos.

Na tecnologia aeroespacial, a determinação da distribuição de temperatura e o conhecimento dos problemas da transferência de calor são de fundamental importância, em virtude das limitações de peso e de considerações de segurança.

$\mathrm{Na}$ engenharia civil atualmente é de grande interesse a análise de edifícios em situação de incêndio para que se possa garantir a segurança do edifício quanto ao colapso prematuro. Nesta situação, análises térmicas são de fundamental importância para que possam ser levados em conta os efeitos da elevação de temperatura numa posterior análise estrutural.

Esse tipo de análise geralmente tem caráter transiente, tendo em vista o fato de a temperatura de um ambiente em situação de incêndio variar com o tempo. Notadamente, para os materiais aço e concreto, por exemplo, estas análises também possuem um caráter não-linear, uma vez que as propriedades desses materiais também variam de acordo com a temperatura, de acordo com o exposto no capítulo 3.

\subsection{ANÁLISE TÉRMICA TRANSIENTE}

Uma análise térmica transiente possibilita determinar temperaturas e outras grandezas térmicas em função do tempo. Engenheiros comumente usam as temperaturas calculadas numa análise térmica transiente como entrada de dados para viabilizar análise estrutural, pois neste caso, ocorrem tensões provenientes das deformações térmicas. 
Várias aplicações como problemas de tratamento térmico, mudanças de fase, análise de blocos de motores, análise de sistemas de encanamentos e vasos de pressão, estruturas em situação de incêndio, etc., envolvem análises térmicas transientes.

Uma análise térmica transiente segue basicamente os mesmos passos de uma análise térmica estacionária (sem dependência do tempo). A principal diferença é que as ações, ou solicitações numa análise térmica transiente ocorrem como funções do tempo.

\subsection{ANÁLISE TÉRMICA VIA MODELAGEM NUMÉRICA}

A base para as análises térmicas realizadas por meio do código computacional ANSYS v9.0 é a equação diferencial do balanço de energia num volume de controle, conforme já apresentado no capítulo 2 .

A solução pelo Método dos Elementos Finitos via ANSYS permite calcular as temperaturas nodais e, consequentemente, usar as temperaturas nodais para obter outras grandezas térmicas de interesse para um dado problema. O procedimento com o qual o código em questão aplica a equação diferencial do balanço de energia, para a resolução do problema de interesse, está apresentado no ANEXO B.

\subsubsection{Análise de Problemas de Condução de Calor}

Na análise de um problema de condução, os carregamentos aplicáveis são temperaturas nodais e fluxo de calor nos elementos do contorno do modelo. O fluxo de calor aplicado ao contorno pode ter como origem um processo de convecção ou radiação (admitidas como hipótese, por exemplo). As formas de aplicação de convecção e radiação ao contorno do modelo serão descritas nos próximos itens.

As propriedades físicas que devem ser fornecidas ao ANSYS para a resolução do problema térmico de condução são: a densidade do material e a condutividade térmica (nas direções $x$, y e z). 


\subsubsection{Análise de Problemas de Convecção}

Para análise de um problema de convecção, especifica-se a convecção como um carregamento de superfície em elementos finitos sólidos ou elementos finitos de casca, ou mesmo em elementos finitos de superfície. Para o cálculo da convecção, deve-se especificar ainda o coeficiente de transferência de calor por convecção $\left(\alpha_{c}\right)$ e a temperatura da massa fluida adjacente à superfície, permitindo ao ANSYS calcular a transferência de calor no contorno do modelo.

Se $\alpha_{c}$ é função da temperatura, especifica-se por meio de uma tabela as temperaturas com os correspondentes valores de $\alpha_{\mathrm{c}}$ para cada temperatura. $\mathrm{Na}$ análise de modelos com barras condutoras (que não permitem um carregamento por convecção na superfície), o ANSYS oferece como opção um elemento de convecção denominado

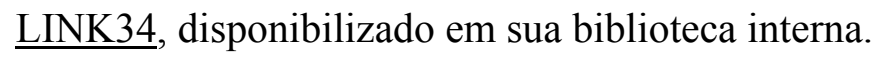

Podem também ser usados elementos específicos para CFD (Computational Fluid Dynamics) para simular detalhes do processo de convecção, tais como as velocidades do fluído, valores locais de $\alpha_{c}$ e de fluxo de calor, e as distribuições de temperatura nas regiões fluídas ou sólidas.

\subsubsection{Análise de Problemas de Radiação}

O código computacional ANSYS v9.0 oferece quatro métodos para análise de problemas de radiação. São os seguintes:

- Elemento de barra para radiação - LINK31. Para problemas envolvendo radiação entre dois pontos ou vários pares de pontos. A área radiante, o fator de visada (ver capítulo 2) e a emissividade podem ser especificados como constantes reais para cada ponto radiante. (ANSYS (2004), LINK31 - Radiation Link);

- Elementos de superfície - SURF151 em análises 2-D e SURF152 em análises 3-D para radiação entre uma superfície e um ponto. $O$ fator de visada entre a superfície e o ponto pode ser calculado a partir da orientação básica do elemento e da localização do ponto. (ANSYS (2004), SURF151 - 2-D Thermal Surface Effect and SURF152 - 3-D Thermal Surface Effect). 
- Método da Matriz de Radiação. Para problemas mais gerais de radiação envolvendo duas ou mais superfícies. O método prevê a geração de uma matriz de fatores de visada entre as superfícies radiativas, e usa a matriz como um superelemento na análise térmica. (ANSYS (2004), Radiation Matrix Method).

- Método da Solução da Radioatividade. Para problemas gerais em 3-D envolvendo duas ou mais superfícies. O método prevê o cálculo do fator de configuração para as superfícies radiantes usando o método do hemicubo e resolvendo a matriz de radiação acoplada com o problema da condução. (ANSYS (2004), Radiosity Solution Method).

\subsubsection{Fenômenos Térmicos}

Além dos três modos de transferência de calor, pode-se também levar em conta fenômenos térmicos como mudança de estado (fusão ou solidificação) e geração de calor interno (devido ao efeito Joule, por exemplo).

\subsubsection{Mudança de Estado}

Um dos aspectos do código ANSYS para análises térmicas consiste de sua capacidade de análise de problemas de mudança de estado que possam envolver fusão ou solidificação.

Um exemplo clássico de análise que podem envolver mudança de estado é a moldagem de metais, em que é importante a determinação de certas características como a distribuição de temperaturas em diferentes pontos durante a mudança de estado, a duração do fenômeno da mudança de estado, a eficiência térmica do molde, etc.

Para analisar um problema de mudança de estado, efetua-se uma análise térmica transiente não-linear, devendo-se atentar para o calor latente do material, o qual é a energia que o sistema armazena ou libera durante a mudança de estado. Para levar em conta o calor latente, define-se a entalpia do material como função da temperatura. Os aspectos anteriormente mencionados estão esquematizados na figura 4.5.

A entalpia, que tem unidade de calor/volume, é definida pela equação (4.20). 


$$
H=\int \rho c(T) d T
$$

$\mathrm{Na}$ equação (4.20), $\rho$ é a massa específica $\left(\mathrm{em} \mathrm{kg} / \mathrm{m}^{3}\right)$, c é o calor específico (em $\mathrm{J} / \mathrm{kg}^{\circ} \mathrm{C}$ ) e $\mathrm{T}$ é a temperatura no material (em ${ }^{\circ} \mathrm{C}$ ou $\mathrm{K}$ ). É interessante notar que a inclinação da curva de entalpia, exemplificada na figura (4.5), corresponde ao produto da massa específica pelo calor específico.

Para problemas que envolvam mudança de estado, a matriz de capacidade calorífica do elemento para análise térmica é obtida da curva de entalpia, fornecida pelo usuário como dado de entrada ao programa.

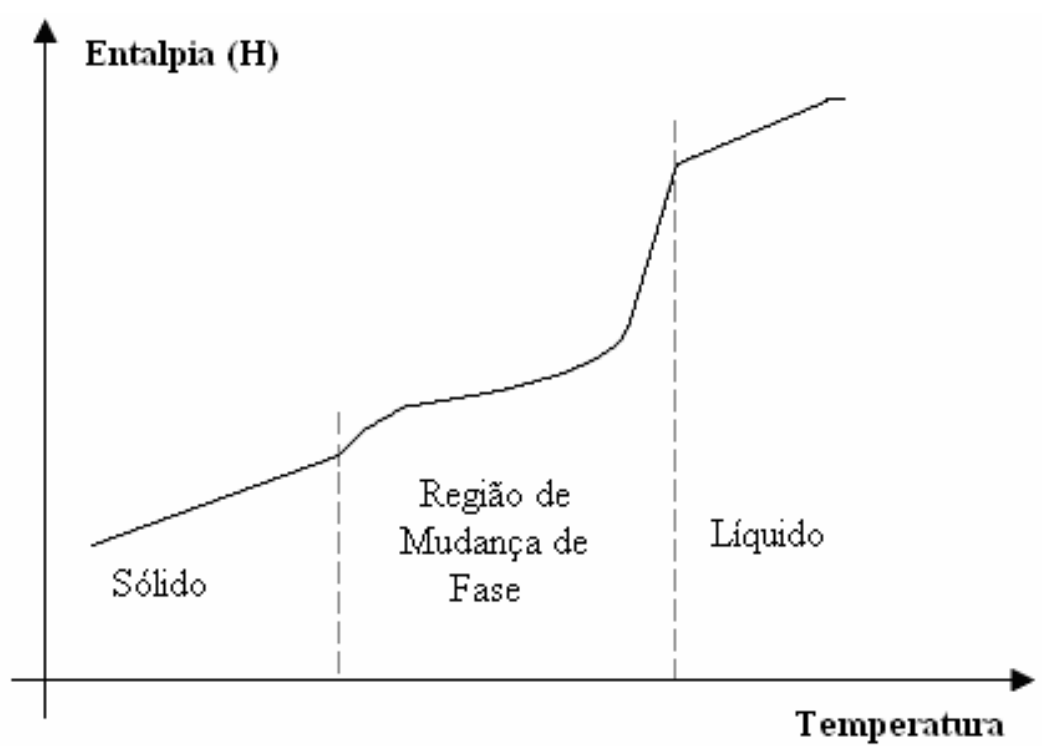

Figura 4.5 - Ilustração de uma curva de Entalpia vs. Temperatura.

Fonte: ANSYS (2004).

\subsubsection{Tipos de Análises Térmicas consideradas pelo ANSYS}

O programa ANSYS permite realizar, basicamente, dois tipos de análise térmica:

- Análise térmica estacionária: determina a distribuição de temperaturas e outras grandezas térmicas sob condições de carregamento estacionário. Uma condição de carregamento estacionário é uma situação onde os efeitos da retenção de calor variando num período de tempo podem ser ignorados. 
- Análise térmica transiente: determina a distribuição de temperatura e outras grandezas térmicas em condição que variam num dado período de tempo.

\subsubsection{Análises Acopladas}

O ANSYS possibilita a realização de análises acopladas. Uma análise acoplada é aquela que leva em conta a interação (acoplamento) entre duas ou mais áreas da engenharia.

Uma análise piezelétrica, por exemplo, lida com a interação entre as áreas elétrica e estrutural: ela determina uma distribuição de voltagem para deslocamentos aplicados, ou vice-versa. Como outros exemplos de análises acopladas, podem ser também citados: a análise termo-estrutural, a análise termoelétrica, e a análise fluidoestrutural.

\subsection{ELEMENTOS FINITOS PARA ANÁLISE TÉRMICA BIDIMENSIONAL}

O ANSYS v9.0 oferece ao usuário aproximadamente 40 elementos para aplicações de análise térmica. Na tabela 4.1 são apresentados os principais elementos finitos para análises térmicas bidimensionais (2-D). Informações mais detalhadas sobre estes elementos podem ser obtidas em ANSYS (2004) na parte intitulada ANSYS Elements Reference. Os elementos da tabela 4.1 são aplicáveis.

Tabela 4.1 - Elementos Planos para análise térmica

\begin{tabular}{|l|c|}
\hline \hline Elemento & Forma ou Característica \\
\hline \hline PLANE35 & Triangular, 6-nós \\
\hline PLANE55 & Quadrilateral, 4-nós \\
\hline PLANE77 & Quadrilateral, 8-nós \\
\hline \hline
\end{tabular}

Esses elementos servem tanto para análises térmicas estacionárias como para análises térmicas transientes, os quais possuem um único grau de liberdade, no caso, a temperatura em cada nó. As figuras 4.6 e 4.7 ilustram a geometria, os nós e o sistema de coordenadas dos elementos mencionados na última tabela. 

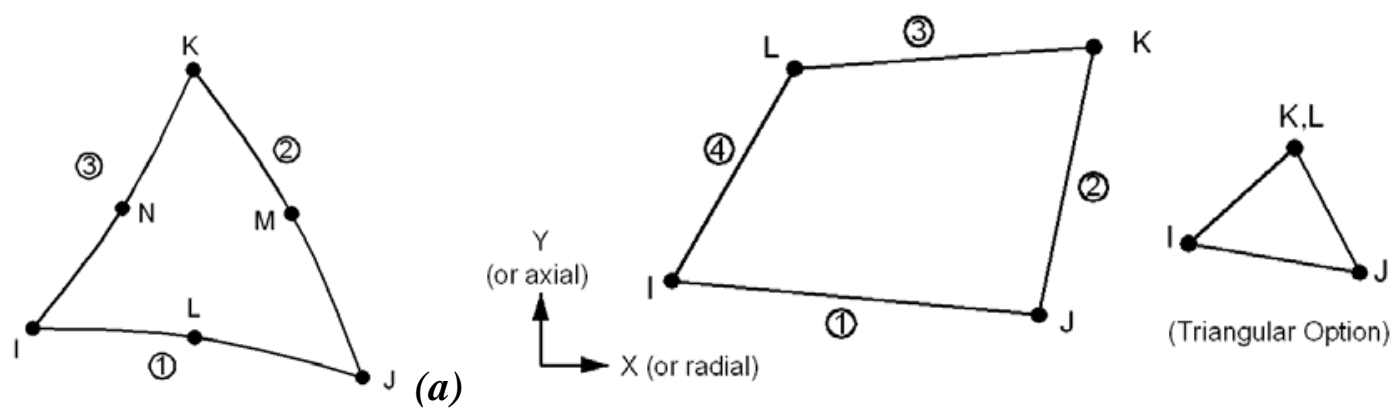

Figura 4.6 - Elementos Finitos: (a) PLANE35 e (b) PLANE55.

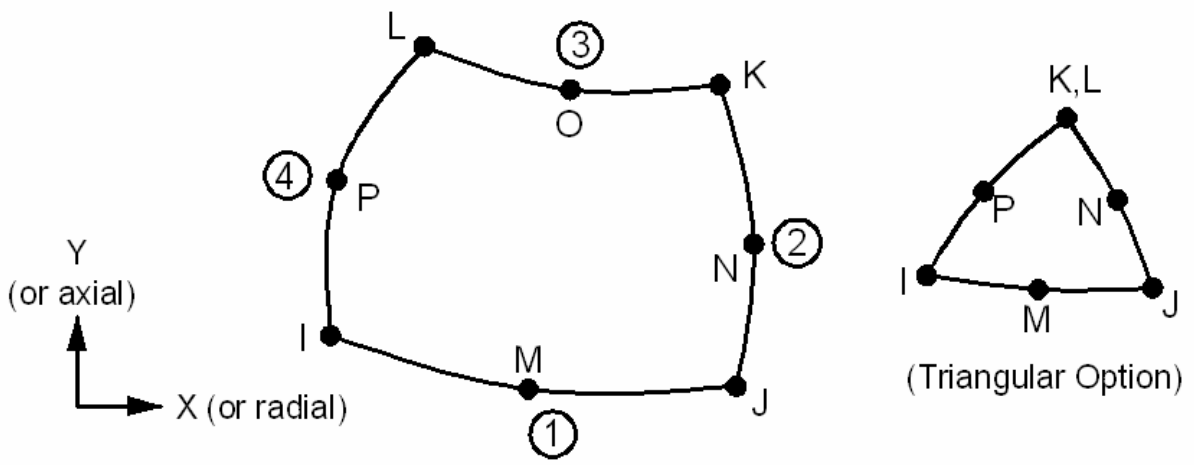

Figura 4.7 - Elemento Finito PLANE77.

\subsection{APLICAÇÃO DA AÇÃO TÉRMICA}

A aplicação da ação térmica no modelo é feita diretamente sobre contorno do volume de interesse ou com o auxilio do elemento finito de superfície SURF151. O elemento SURF151 pode ser usado para vários carregamentos e efeitos de superfície, em análises térmicas bidimensionais.

Ele pode ser sobreposto à face de qualquer daqueles elementos apresentados da tabela 4.1. Vários carregamentos e efeitos de superfície podem ser aplicados simultaneamente. O elemento de superfície SURF151, com suas características geométricas, nós e sistema de coordenadas, está ilustrado na figura 4.8.

O elemento SURF151, como mostrado na figura 4.8, pode ser definido com dois, três ou quatro nós. O nó extra, quando usado, serve para aplicação de efeitos de radiação ou convecção. Convecção ou fluxos de calor podem ser aplicados diretamente ao elemento. 
Na maior parte dos modelos a serem desenvolvidos neste trabalho, utilizar-se-á a opção do elemento SURF151 com o nó extra. A aplicação de temperatura ao nó extra é interpretada como uma temperatura ambiente externa ao modelo. Desta forma, é possível simular com este elemento finito os efeitos da elevação da temperatura dos gases do ambiente.

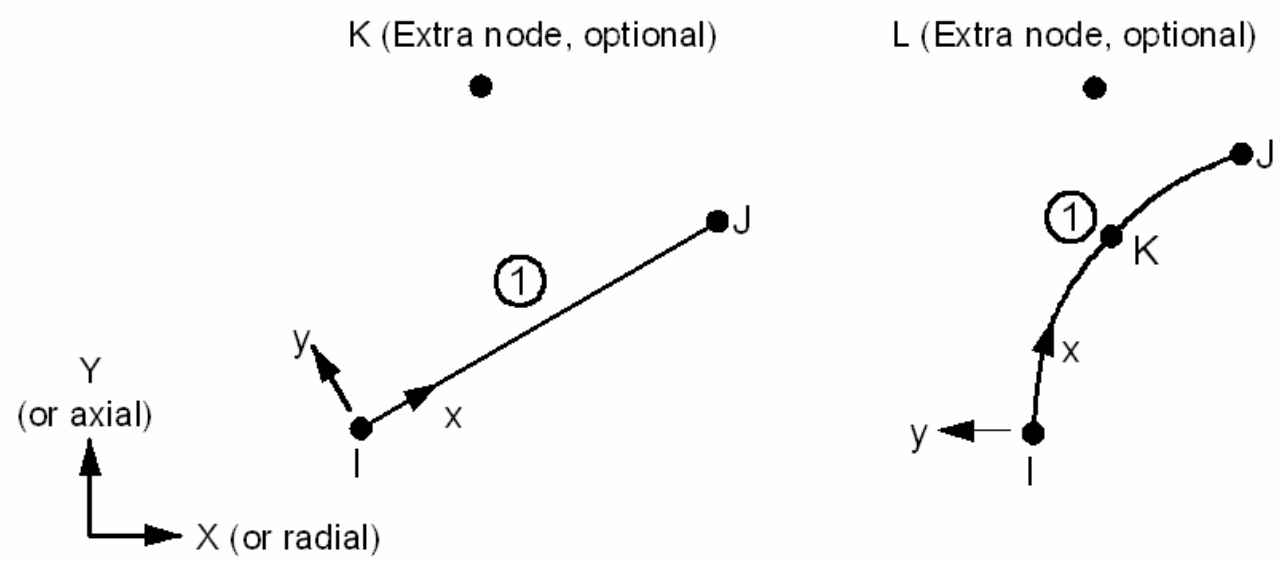

Figura 4.8 - Elemento finito SURF151.

Para simular os efeitos da convecção variando com a temperatura, a elevação de temperatura será fornecida ao nó extra. O cálculo da matriz de condutividade superficial devido à convecção emprega o coeficiente de transferência de calor por convecção que deve ser fornecido ao programa. O fluxo de calor devido à convecção é, então, calculado com base na diferença de temperatura da superfície do modelo e da suposta temperatura dos gases do ambiente.

Da mesma forma que para a convecção, os efeitos da radiação podem ser obtidos também com o uso de mais uma camada de elementos SURF151 aplicados à superfície do modelo. Para o cálculo da matriz de condutividade superficial devido à radiação é necessário fornecer a emissividade resultante, o fator de configuração, e a constante de

\section{Stefan-Boltzmann.}

Como nos problemas de estruturas em situação de incêndio se adota a hipótese da troca de calor entre duas superfícies paralelas e infinitas, o fator de configuração é aqui tomado igual 1,0. O fluxo de calor devido à radiação é então calculado com base na temperatura da superfície do modelo e da suposta temperatura dos gases do ambiente aplicada ao nó extra. 


\section{VALIDAÇÃO DA ESTRATÉGIA NUMÉRICA PARA OS MODELOS CONSTRUÍDOS}

Neste capítulo serão apresentados os resultados obtidos por meio de simulações numéricas realizadas com a utilização do programa ANSYS ${ }^{\circledR}$ v9.0, referentes à evolução de temperatura em seções transversais de aço e mistos de aço e concreto, quando submetidos ao incêndio-padrão ISO 834 (ISO 834-1:1999).

Para fim de validação dos resultados, inicialmente são elaborados modelos numéricos cujos resultados são comparados com resultados numéricos de trabalhos de outros pesquisadores, bem como comparados com resultados obtidos por meio de modelos simplificados de cálculo prescritos na norma brasileira NBR 14323:1999 e nos EUROCODES 3 e 4.

Em caráter complementar, com vistas à calibração dos modelos numéricos, apresenta-se também um modelo numérico para uma seção transversal de madeira Eucalyptus Citriodora cujos resultados numéricos foram confrontados com resultados experimentais apresentados em PINTO (2005).

Ainda com vista à validação da estratégia numérica, no capítulo 8 serão apresentadas diversas comparações de resultados obtidos com os códigos ANSYS v9.0 e TCD v5.0, sendo este último voltado para análise térmica de estruturas em situação de incêndio. Ressalta-se que os resultados do código TCD aqui utilizados foram gentilmente disponibilizados por Valdir Pignatta e Silva, professor da Escola Politécnica da USP.

O pacote computacional de elementos finitos ANSYS v9.0 oferece ferramentas que permitem analisar os três modos primários de transferência de calor, no caso, condução, convecção e radiação, e disponibiliza ao pesquisador os recursos necessários para a obtenção dos resultados de interesse. 


\subsection{ELEMENTOS FINITOS UTILIZADOS}

$\mathrm{Na}$ elaboração dos modelos numéricos aqui apresentados foram utilizados dois tipos de elementos finitos: um do tipo plano (PLANE77), para modelar a seção transversal da viga de aço e o material de proteção, e outro do tipo superfície (SURF151), para aplicar ao modelo as condições de contorno representativas da ação térmica referente à convecção e à radiação.

O elemento finito denominado PLANE77, ilustrado na figura 1a, é um elemento finito plano que possui oito nós, com apenas um grau de liberdade, temperatura, em cada nó. Já o elemento finito SURF 151, ilustrado na figura 1 b, possui 2 ou três nós, além de um nó extra para simular efeitos térmicos. Todos os nós deste elemento também possuem apenas um grau de liberdade, no caso, a temperatura.

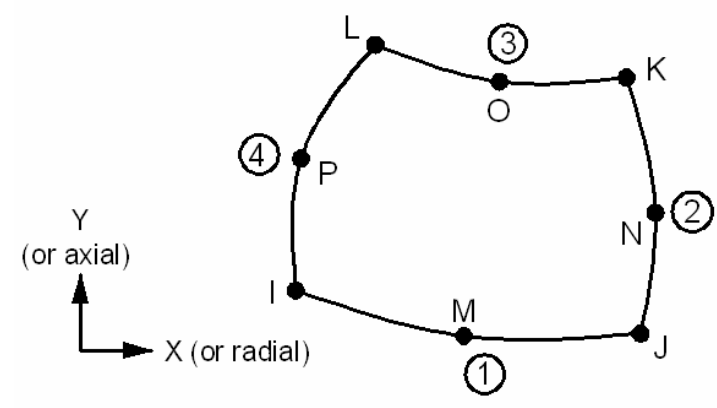

(a)

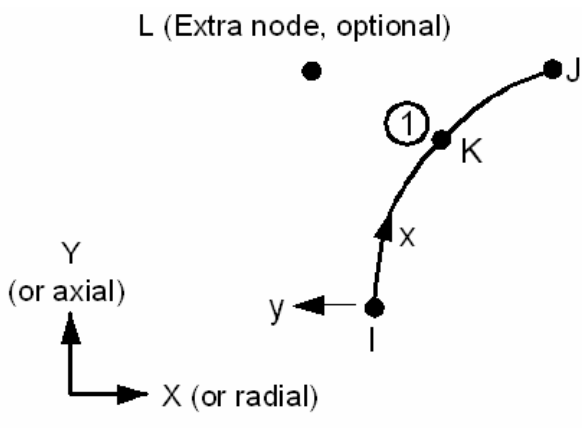

(b)

Figura 5.1 - (a) Elemento Finito PLANE77 e (b) Elemento Finito SURF151.

\subsubsection{Aplicação da ação térmica}

Para aplicação dos efeitos térmicos (convecção e radiação) nos modelos deste trabalho, o elemento SURF 151 (figura 5.1b) é utilizado com a opção do nó extra. Com a aplicação de temperatura diretamente no nó extra é possível simular a temperatura dos gases quentes do ambiente em situação de incêndio.

Assim, para simular os efeitos de convecção no contorno do modelo é necessário fornecer o coeficiente de transferência de calor por convecção $\left(\alpha_{c}\right)$. Além disso, é necessário definir para o elemento que o cálculo do fluxo de calor devido à convecção $\left(\varphi_{c}\right)$ seja dado com base na diferença entre a temperatura dos gases quentes do ambiente $\left(\theta_{\mathrm{g}}\right)$ e a temperatura na superfície do modelo $\left(\theta_{\mathrm{a}}\right)$, isto é: 


$$
\varphi_{\mathrm{c}}=\alpha_{\mathrm{c}}\left(\theta_{\mathrm{g}}-\theta_{\mathrm{a}}\right)
$$

Com relação aos efeitos da radiação térmica, para o cálculo do fluxo de calor devido à radiação $\left(\varphi_{\mathrm{r}}\right)$ é necessário fornecer a emissividade resultante $\left(\varepsilon_{\text {res }}\right)$, a constante de Stefan-Boltzmann $\left(\sigma=5,67 \times 10-8 \mathrm{~W} / \mathrm{m}^{2} \mathrm{~K}^{4}\right)$ e o fator de configuração $(\Phi)$. Nas aplicações em segurança contra incêndio é assumido que os gases da combustão e os elementos estruturais estejam em contato direto, de modo que este fenômeno pode ser tratado como o caso de duas superfícies (placas) infinitas. Neste caso, o fator de configuração $(\Phi)$, por definição, é igual à unidade.

Por último, no caso de se trabalhar com a escala de temperatura em grau Celsius, é necessário fornecer ao programa ANSYS a diferença entre o zero da escala Celsius e o zero absoluto (escala Kelvin), no caso, igual a 273. Assim, o fluxo de calor devido à radiação no contorno passa a ser dado por:

$$
\varphi_{\mathrm{r}}=5,67 \times 10^{-8} \varepsilon_{\text {res }}\left[\left(\theta_{\mathrm{g}}+273\right)^{4}-\left(\theta_{\mathrm{a}}+273\right)^{4}\right\rfloor
$$

As equações. (5.1) e (5.2) são idênticas às equações (4.6) e (4.7), adotadas pela NBR 14323:1999 para as ações térmicas de convecção e radiação, respectivamente, em elementos de aço sem revestimento contra fogo.

\subsection{VALIDAÇÃO DA ESTRATÉGIA NUMÉRICA}

A partir deste ponto, e nos capítulos que se seguem, serão convenientemente adotadas, no que se refere às características geométricas dos modelos numéricos, de acordo com a figura 5.2, a seguintes notações:

$\mathrm{d}=$ altura do perfil

$t_{\mathrm{f}}=$ espessura da mesa

$\mathrm{h}_{\mathrm{w}}=$ altura da alma, igual a d-2tf

$\mathrm{t}_{\mathrm{c}}=$ espessura da laje de concreto

$t_{\text {alv }}=$ espessura da alvenaria $\mathrm{b}_{\mathrm{f}}=$ largura da mesa do perfil

$\mathrm{t}_{\mathrm{w}}=$ espessura da alma

$\mathrm{b}=$ largura da laje de concreto

$\mathrm{h}_{\mathrm{alv}}=$ altura da alvenaria 
Ressalta-se ainda que, para os casos em que se considerar proteção contra fogo, a espessura da proteção será aqui denotada por $t_{\mathrm{m}}$.

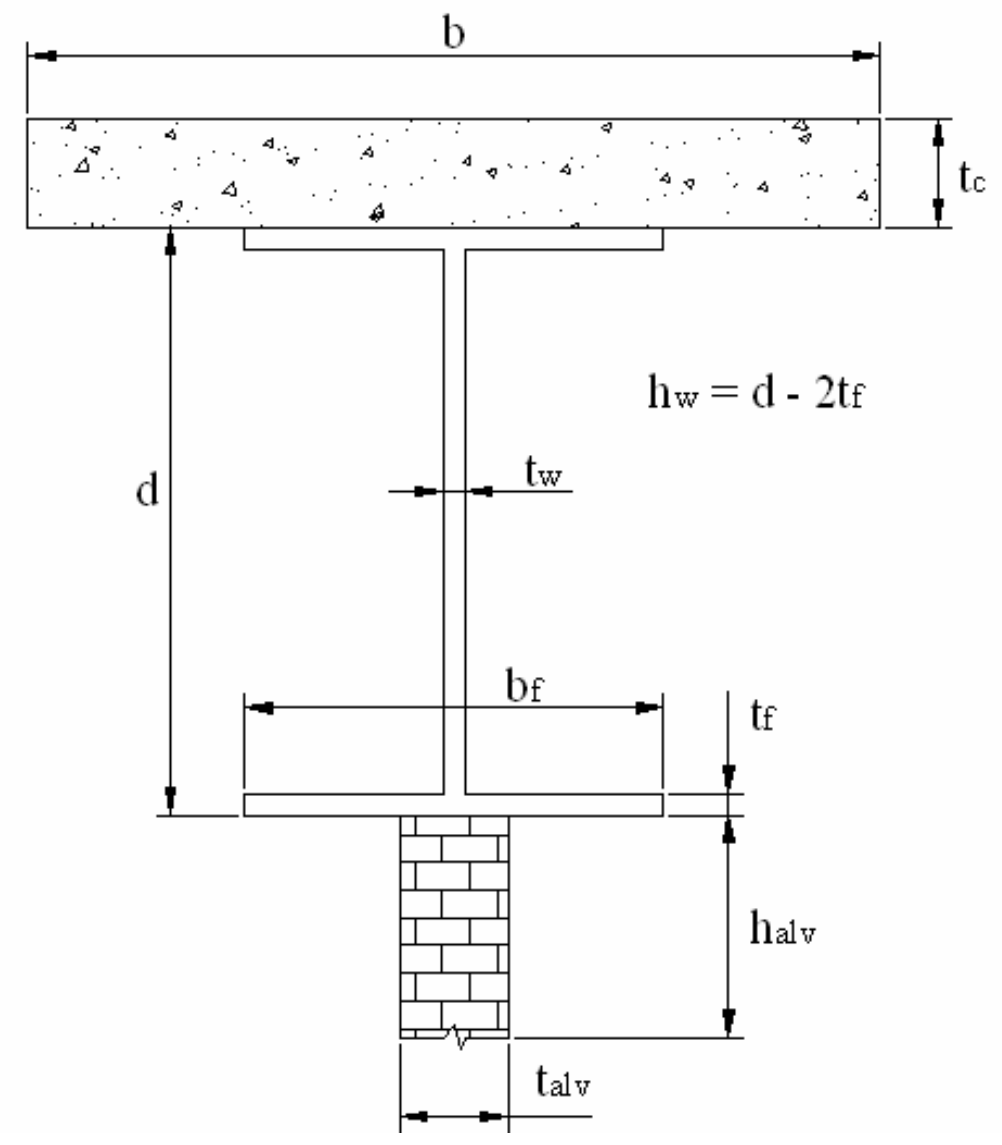

Figura 5.2 - Notação empregada para descrição da geometria dos modelos numéricos.

\subsubsection{MODELO 1 - Viga de aço sem revestimento contra fogo}

O primeiro modelo refere-se à seção transversal de uma viga de aço com perfil 180 UB 16, sem revestimento contra fogo, conforme esquematizado na figura 5.3. As propriedades térmicas do aço empregadas nos modelos estão de acordo com aquelas apresentadas na NBR 14323:1999 e no EUROCODE 3 - Part 1-2 (2005).

Neste modelo o perfil é exposto ao incêndio-padrão ISO 834 por todos os lados. $\mathrm{O}$ coeficiente de transferência de calor por convecção foi adotado com valor igual a $\alpha_{\mathrm{c}}=25 \mathrm{~W} / \mathrm{m}^{2 \mathrm{o}} \mathrm{C}$, e a emissividade resultante fornecida ao ANSYS foi $\varepsilon_{\mathrm{res}}=0,5$. Com relação à obtenção da malha de elementos finitos, procurou-se construir a mesma com dois elementos na espessura de cada componente dos perfil metálico (alma, mesa superior e mesa inferior). 


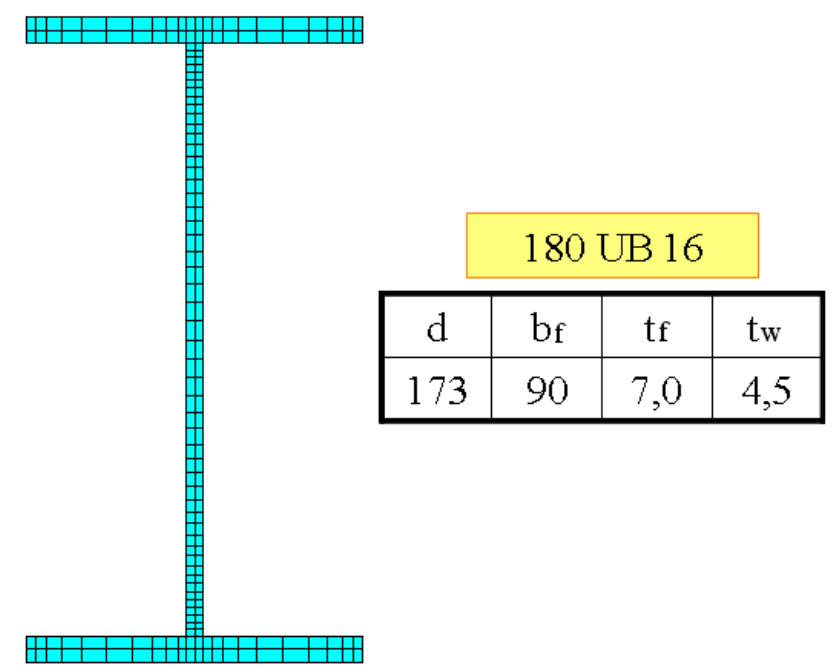

Figura 5.3 - Geometria e malha de elementos finitos do modelo 1 - Viga metálica sem revestimento contra fogo, perfil 180 UB 16.

Os resultados da elevação de temperatura média da seção transversal da viga de perfil 180 UB 16, quando exposta ao incêndio-padrão por todos os lados pode ser visto na figura 5.4. Nesta mesma figura têm-se os resultados obtidos com o programa SAFIR apresentados em LEWIS (2000), para a mesma viga. Nota-se uma boa aproximação entre os resultados numéricos fornecidos pelo ANSYS e pelo SAFIR.

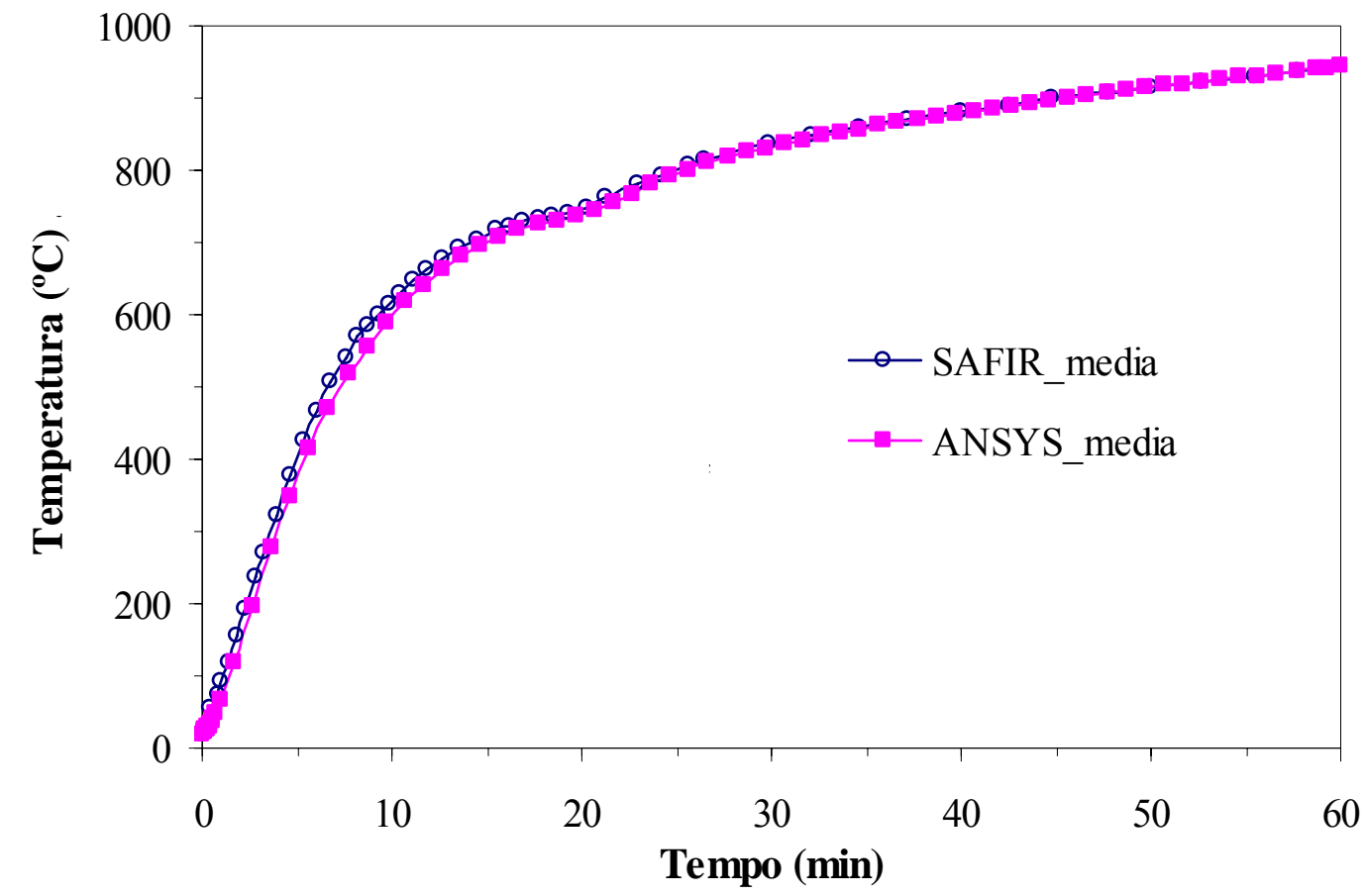

Figura 5.4 - Curva temperatura média x tempo para o perfil 180 UB 16 obtida via ANSYS 9.0 e os resultados do programa SAFIR. 
$\mathrm{Na}$ figura 5.5 têm-se os resultados de temperatura média da seção transversal obtidos via simulação numérica com o ANSYS, e aqueles obtidos por meio dos modelos simplificados de cálculo (equações) apresentados pela NBR 14323:1999 e pelo EUROCODE 3 - Part 1-2 (2005).

$\mathrm{Na}$ mesma figura é possível notar que os resultados obtidos com o modelo simplificado de cálculo da NBR 14323:1999 são os que melhor se aproximam daqueles obtidos via simulação numérica. Os resultados do modelo simplificado do EUROCODE 3 se mostraram um pouco acima daqueles resultados obtidos via simulação numérica, porém, apenas durante os primeiros 15 minutos.

A NBR 14323:1999 permite o emprego de um valor igual a $600 \mathrm{~J} / \mathrm{kg}^{\circ} \mathrm{C}$ (constante) para o calor específico do aço, $\mathrm{c}_{\mathrm{a}}$, no caso do emprego do modelo simplificado de cálculo. A curva obtida com o valor simplificado apresentou uma diferença máxima de aproximadamente $25^{\circ} \mathrm{C}$ quando comparado àquela obtida via simulação numérica, num curto trecho, para aproximadamente 20 min de exposição ao incêndio-padrão (ver figura 5.5).

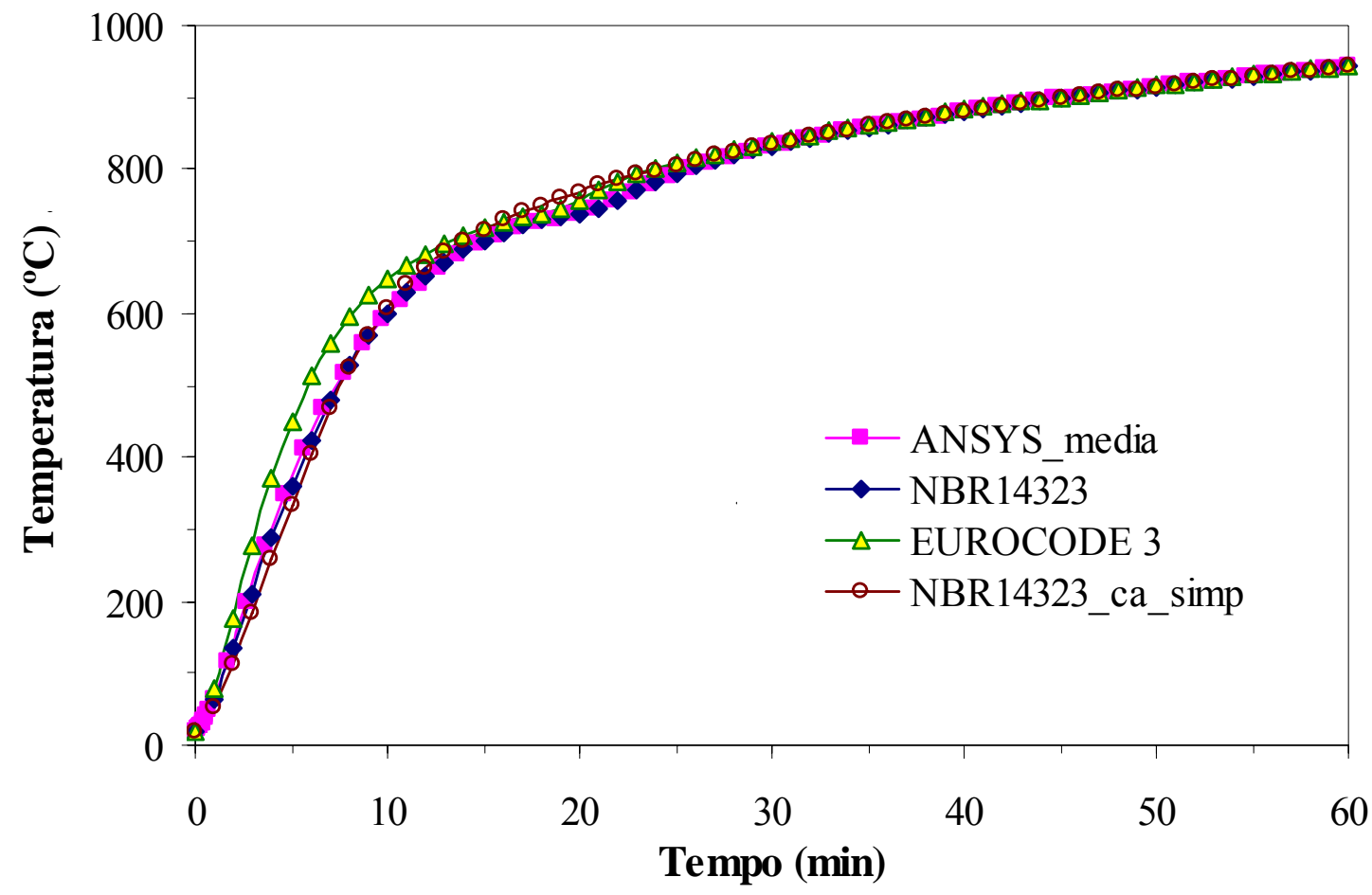

Figura 5.5 - Resultados obtidos via ANSYS (temperatura média da seção transversal) e obtidos por meio de modelos simplificados de cálculo. 


\subsubsection{MODELO 2 - Viga de aço com revestimento contra fogo}

O segundo modelo se refere à seção transversal de uma viga com perfil 530 UB 82 com revestimento contra fogo de argamassa projetada à base de cimento e vermiculita, com espessura $e_{p}$ igual a $20 \mathrm{~mm}$ (figura 5.6). As propriedades térmicas do aço empregadas nos modelos estão de acordo com aquelas apresentadas na NBR 14323:1999 e no EUROCODE 3 - Part 1-2 (2003). As propriedades do material de revestimento contra fogo, de acordo com LEWIS (2000), são: $\mathrm{c}_{\mathrm{m}}$ (calor específico) $=$ $1100 \mathrm{~J} / \mathrm{kg}^{\circ} \mathrm{C}, \lambda_{\mathrm{m}}($ condutividade térmica $)=0,19 \mathrm{~W} / \mathrm{m} \cdot{ }^{\circ} \mathrm{C}$ e $\rho_{\mathrm{m}}($ massa específica $)=775$ $\mathrm{kg} / \mathrm{m}^{3}$.

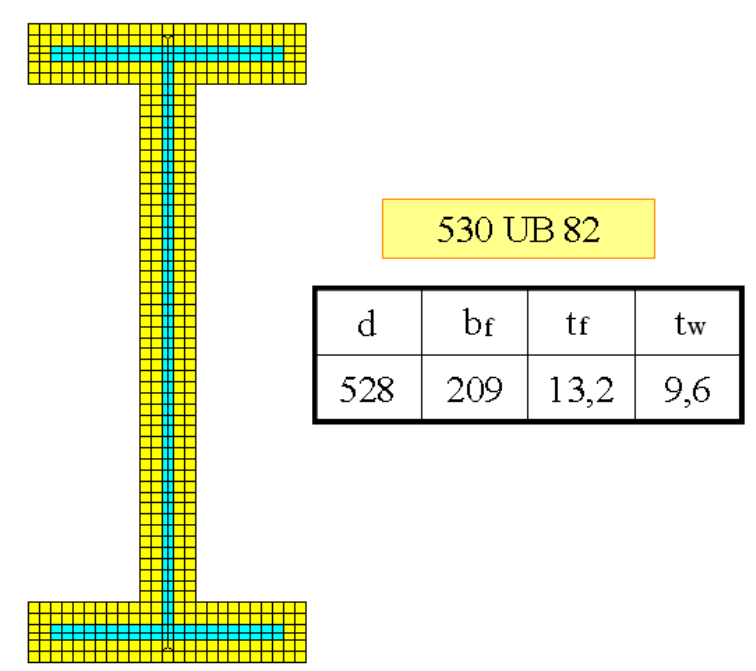

Figura 5.6 - Geometria e malha de elementos finitos do modelo 2 -

Viga metálica com revestimento contra fogo de argamassa projetada à base de cimento e vermiculita, perfil 530 UB 82.

O modelo é exposto ao incêndio-padrão ISO 834 por todos os lados. O valor adotado para o coeficiente de transferência de calor por convecção foi $\alpha_{c}=25 \mathrm{~W} / \mathrm{m}^{2 \circ} \mathrm{C}$. A emissividade resultante fornecida ao ANSYS foi $\varepsilon_{\text {res }}=0,5$. Com relação à malha de elementos finitos, foram considerados dois elementos na espessura de cada componente do perfil metálico com o intuito de se obter resultados mais precisos.

$\mathrm{Na}$ figura 5.7 são apresentados os resultados com relação à elevação de temperatura média da seção transversal da viga em questão. Nesta mesma figura, têm-se a comparação com os resultados obtidos com o programa SAFIR, apresentados em LEWIS (2000). Nota-se, por meio da figura 5.7, uma boa aproximação entre os resultados dos programas ANSYS e SAFIR. 
A pequena diferença entre os resultados obtidos com os programas ANSYS e SAFIR, observada na figura 5.7, pode ser a atribuída a um maior refinamento da malha de elementos finitos, empregando o ANSYS, quando comparada à malha apresentada em LEWIS (2000), empregando o programa SAFIR.

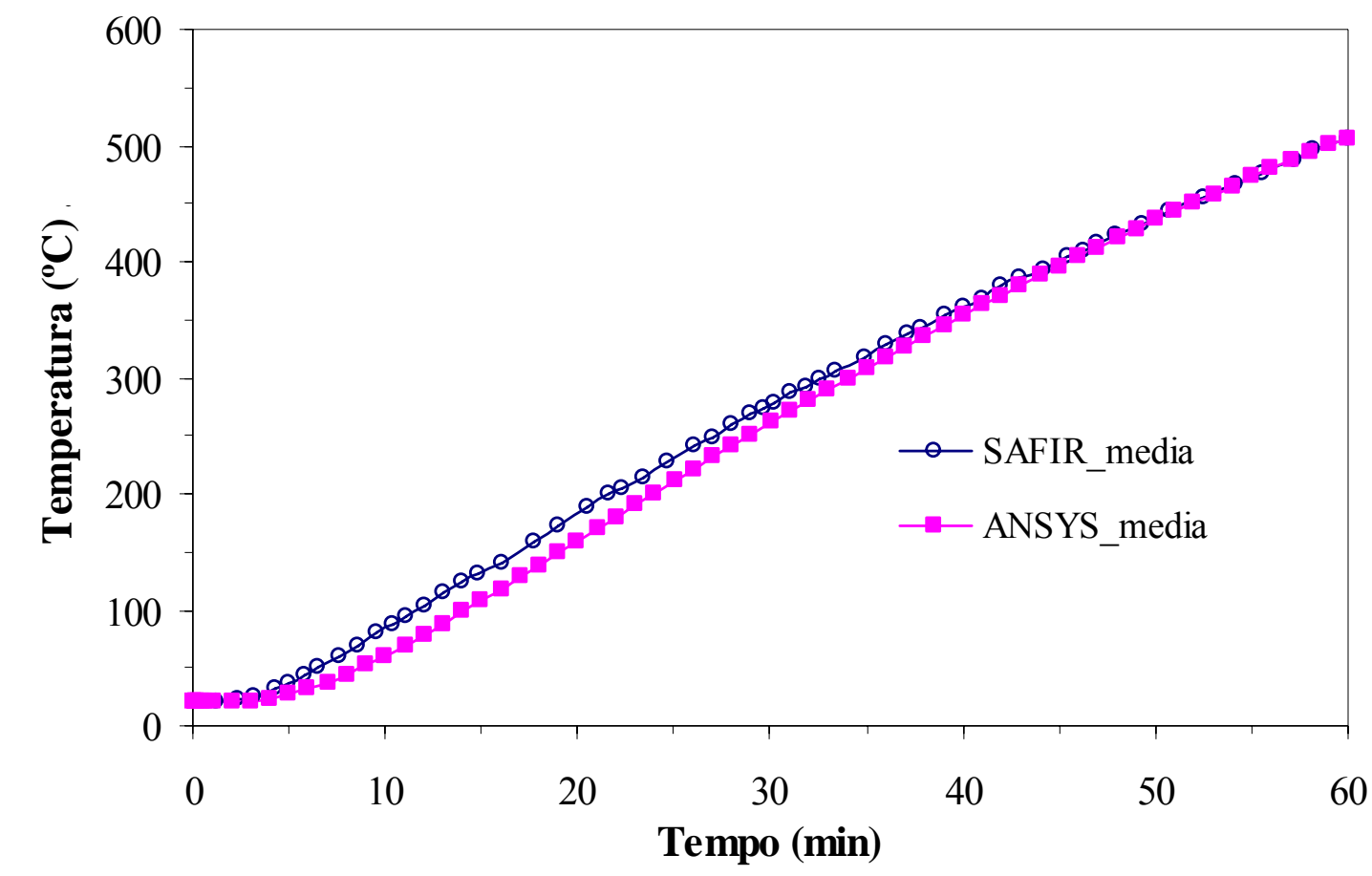

Figura 5.7 - Curva temperatura média x tempo obtida via ANSYS 9.0 para o perfil 530 UB 82 com revestimento contra fogo e os resultados do programa SAFIR.

Na figura 5.8 tem-se a comparação entre os resultados obtidos via ANSYS com aqueles obtidos por meio de modelos simplificados. O modelo simplificado de cálculo proposto pela NBR 14323:1999, para elementos com revestimento contra fogo, é idêntico ao proposto pelo EUROCODE 3 - Part 1-2 (2005). Na mesma figura, são apresentados os resultados obtidos com a equação proposta no Projeto de Revisão da NBR 14323:1999 para elementos com revestimento contra fogo.

Os resultados dos modelos simplificados apresentaram temperaturas superiores àquelas obtidas via simulação numérica durante quase todo o processo. Nota-se uma diferença muito pequena entre os resultados obtidos com a equação proposta pelo Projeto de Revisão da NBR 14323:1999, apresentada em SILVA (1999), em relação à equação prescrita pela NBR 14323:1999 e pelo EUROCODE 3 - Part 1-2 (2005). 


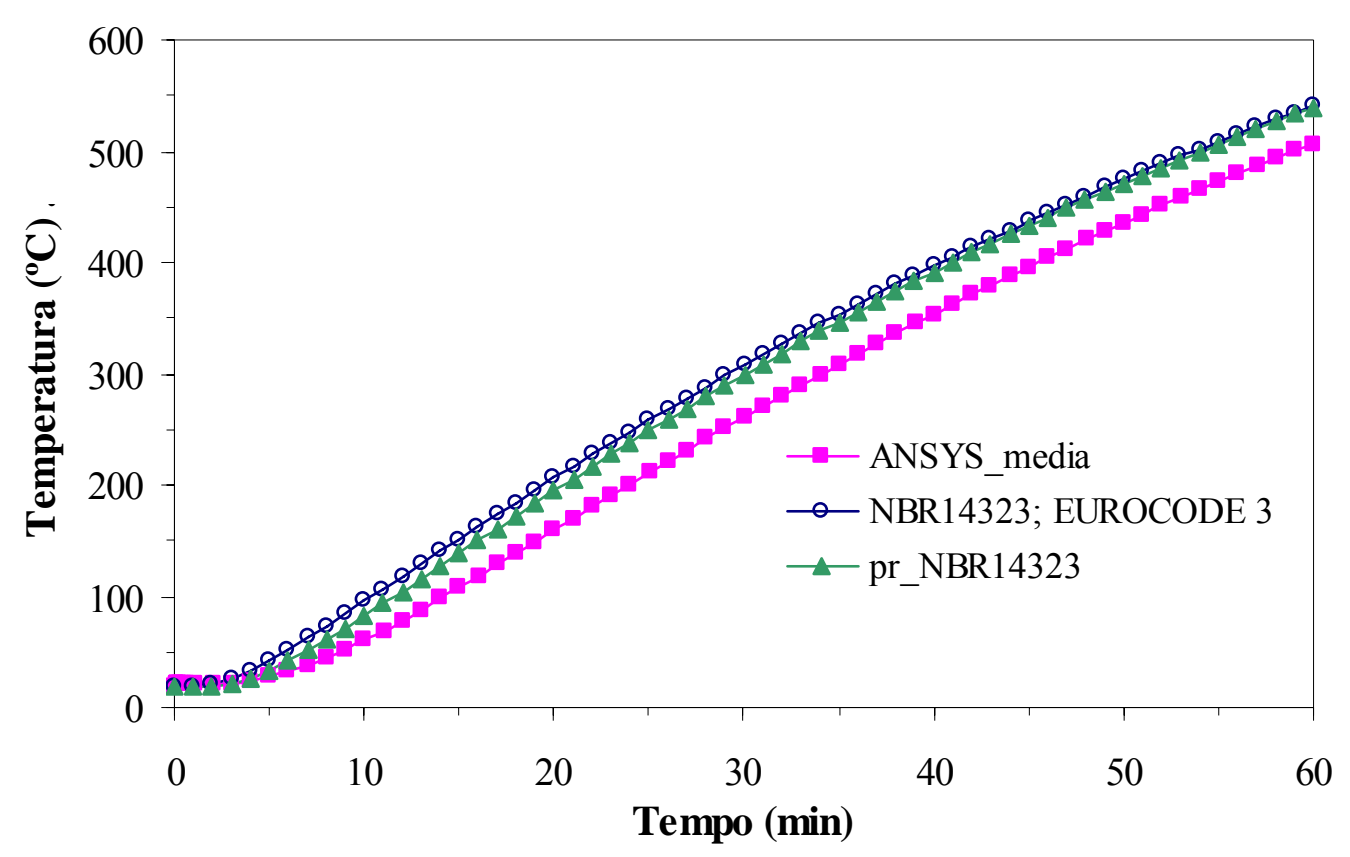

Figura 5.8 - Resultados obtidos: ANSYS e modelos simplificados de cálculo.

\subsubsection{MODELO 3 - Viga mista de aço e concreto}

O terceiro modelo refere-se à seção transversal de uma viga mista de aço e concreto (figura 5.9) sem revestimento. O perfil de aço da viga é do tipo VS 650x114 e a laje de concreto maciça de espessura $t_{c}$ igual a $100 \mathrm{~mm}$ e largura efetiva b igual a 1000 mm. Para esse modelo, fez-se a malha de elementos finitos com dois elementos na espessura de cada componente do perfil metálico.

As propriedades térmicas do aço empregadas nos modelos estão de acordo com aquelas apresentadas na NBR 14323:1999 e no EUROCODE 3 - Part 1-2 (2003). Para o concreto da viga mista utilizaram-se as mesmas propriedades apresentadas em SILVA (2002) para fins de comparação de resultados.

$\mathrm{O}$ calor específico do concreto foi igual a $\mathrm{c}_{\mathrm{m}}=1139 \mathrm{~J} / \mathrm{kg}^{\circ} \mathrm{C}$ e a massa específica $\rho_{\mathrm{m}}=2403 \mathrm{~kg} / \mathrm{m}^{3}$. A condutividade térmica varia com a temperatura, assumindo os seguintes valores:

$$
\lambda_{\mathrm{c}}(\theta)=\left\{\begin{array}{cc}
1,748 & \operatorname{se} \theta \in[20 ; 199]\left({ }^{\circ} \mathbf{C}\right) \\
1,748-1,246 \times 10^{-3} & \operatorname{se} \theta \in[199 ; 899]\left({ }^{\circ} \mathbf{C}\right) \\
0,876 & \operatorname{se} \theta>899\left({ }^{\circ} \mathbf{C}\right)
\end{array}\right.
$$




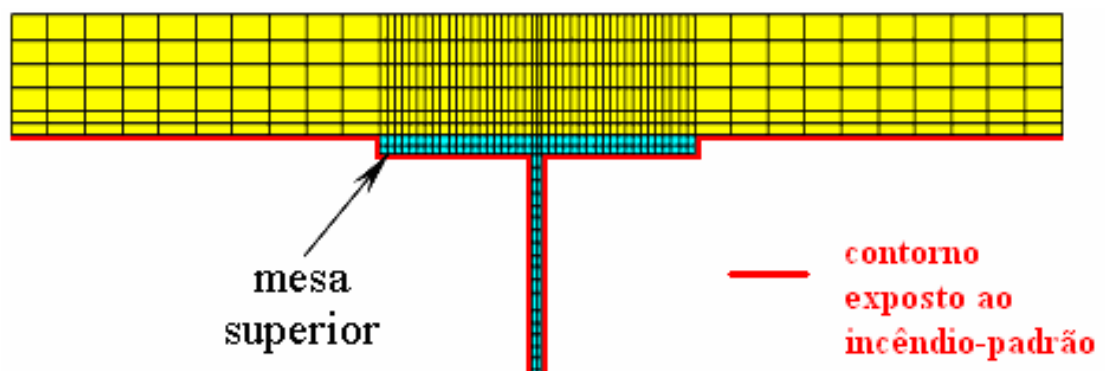

mesa inferior

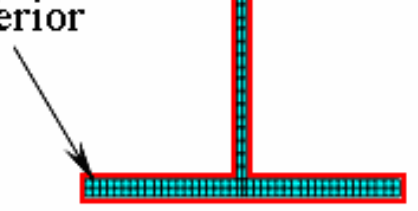

VS $650 \times 114$

\begin{tabular}{|c|c|c|c|}
\hline$d$ & bf & tf & tw \\
\hline 650 & 300 & 16,0 & 8,0 \\
\hline
\end{tabular}

Figura 5.9 - Geometria e malha de elementos finitos do Modelo 3: Viga mista de aço e concreto sem revestimento contra fogo.

O modelo 3 é submetido à exposição ao incêndio-padrão ISO 834 em apenas três lados, isto é, a face superior da laje de concreto não é exposta. $\mathrm{O}$ valor adotado para o coeficiente de transferência de calor por convecção foi $\alpha_{c}=25 \mathrm{~W} / \mathrm{m}^{2 \circ} \mathrm{C}$. A emissividade resultante fornecida ao ANSYS foi igual a $\varepsilon_{\text {res }}=0,522$.

Na figura 5.10 têm-se os resultados de evolução de temperatura para a viga mista de aço e concreto em questão. A evolução de temperatura da alma (Alma) corresponde ao ponto médio da alma e, no caso da mesa superior (MS) e da mesa inferior (MI), corresponde ao segundo nó a partir da extremidade esquerda da mesa (ver figura 5.9). Na mesma figura, apresentam-se os resultados obtidos com o programa PFEM_2D, apresentados em SILVA (2002), para a mesma viga mista. Nota-se uma boa aproximação entre os resultados obtidos com os programas ANSYS e PFEM_2D.

$\mathrm{Na}$ figura 5.11 tem-se a comparação entre os resultados obtidos via ANSYS e os obtidos por meio de modelos simplificados de cálculo da NBR 14323:1999 e pelo EUROCODE 4 - Part 1-2 (2003). Para alma, nota-se uma boa aproximação entre os resultados obtidos via ANSYS e aqueles obtidos com os modelos simplificados. Com relação à mesa superior, as temperaturas obtidas com os procedimentos normativos simplificados resultam superiores àquelas obtidas com simulação numérica via ANSYS. 
Com relação à mesa inferior, as temperaturas obtidas com os procedimentos normativos simplificados resultam inferiores àquelas obtidas com simulação numérica via ANSYS, em especial o EUROCODE 4, durante a fase inicial do aquecimento (até 25 minutos).

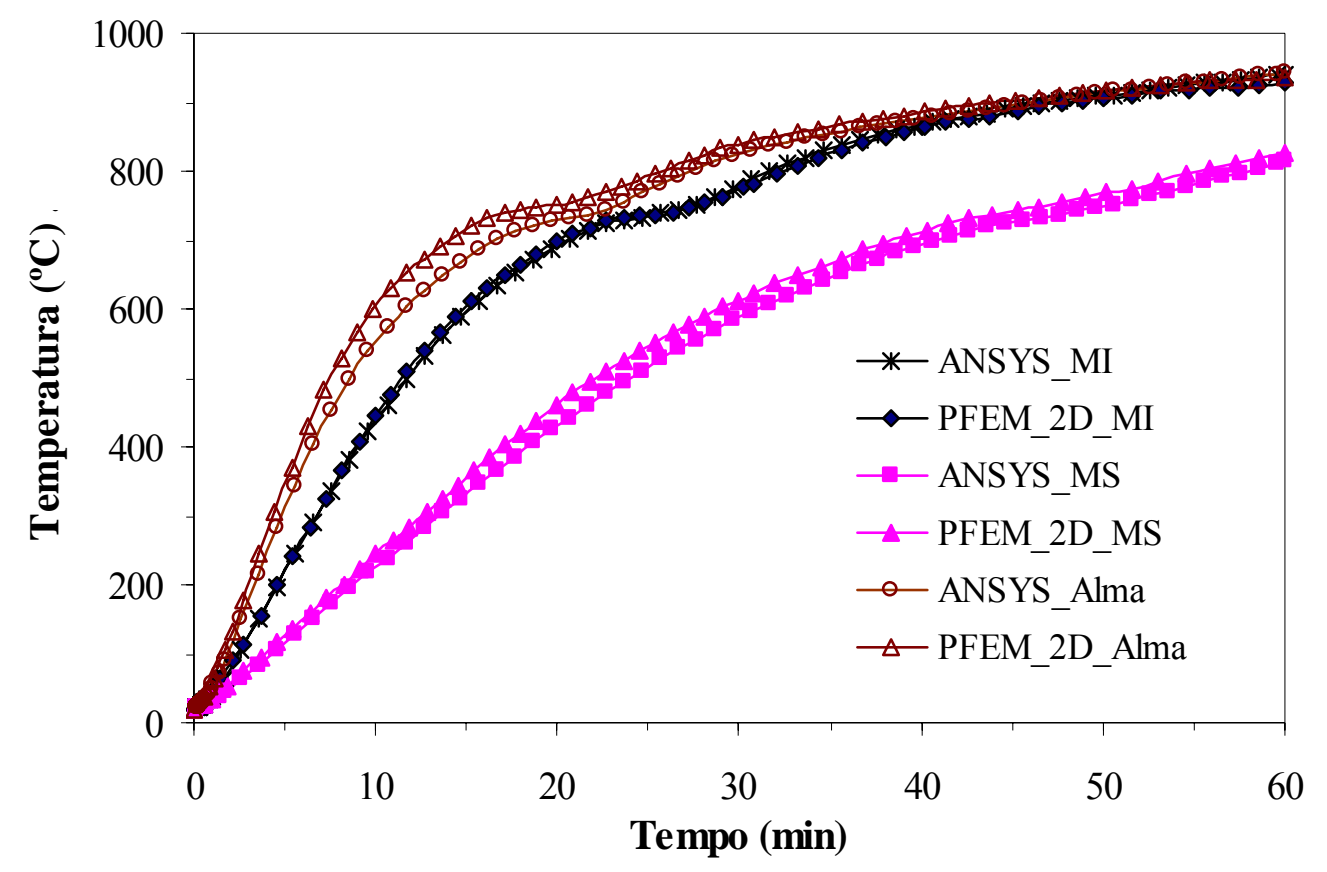

Figura 5.10 - Curva temperatura x tempo obtida via ANSYS 9.0 para uma viga mista sem revestimento contra fogo e os resultados do programa PFEM_2D.

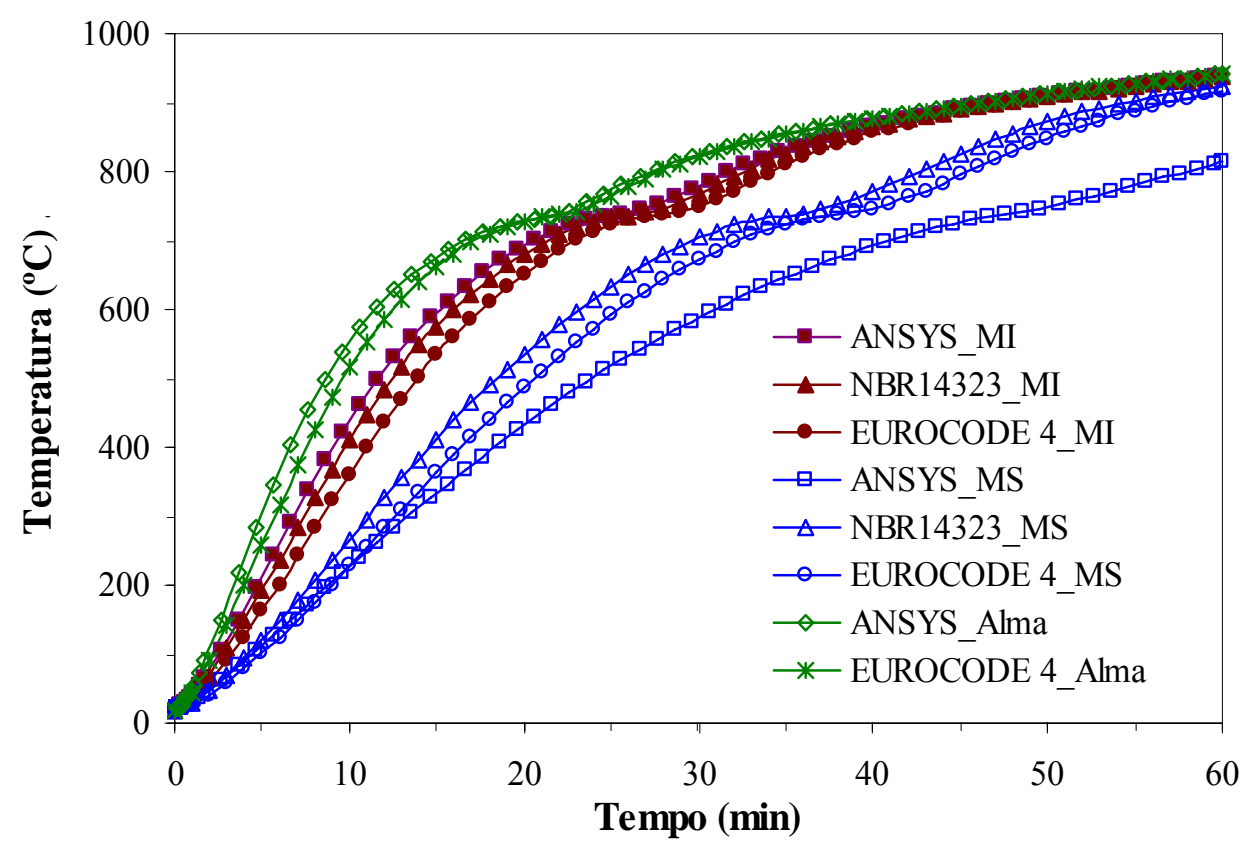

Figura 5.11 - Resultados obtidos via ANSYS e os obtidos por meio de modelos simplificados de cálculo. 


\subsubsection{MODELO 4 - Viga de madeira Eucalyptus citriodora}

Este modelo numérico refere-se a uma seção transversal de viga de madeira da espécie Eucaliptus citriodora, com dimensão $163 \mathrm{~cm}$ x $26 \mathrm{~cm}$ e exposta ao incêndiopadrão ASTM E 119 em todas as faces. Os resultados experimentais de elevação de temperatura na seção transversal estão apresentados em PINTO (2005).

Uma das maiores dificuldades da modelagem numérica de elementos estruturais de madeira em altas temperaturas está relacionada à obtenção de parâmetros térmicos representativos em função da temperatura. Para obtenção da densidade, recorreu-se a análise termogravimétrica apresentada em PINTO (2005). O resultado, figura 5.12, foi calibrado para inserção no modelo numérico, sendo adotado o valor residual de $10 \%$ para a densidade relativa.

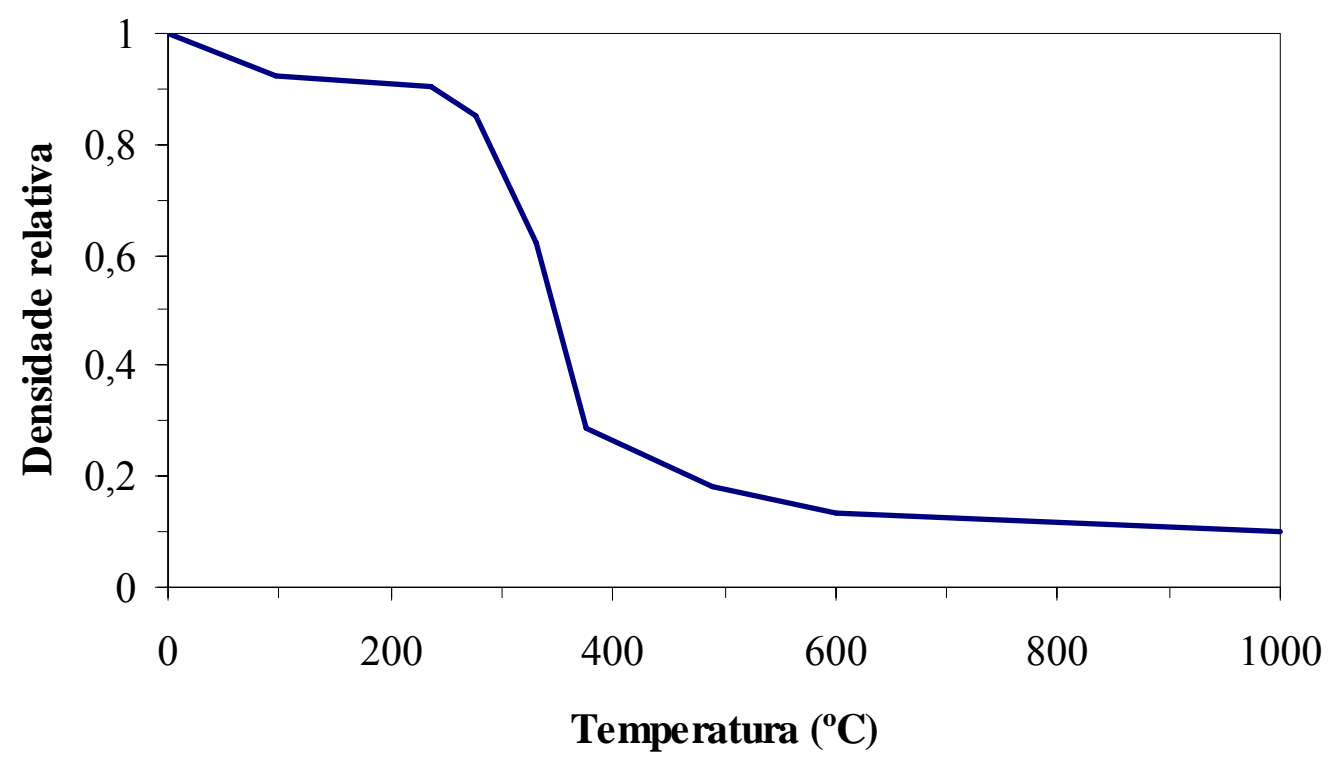

Figura 5.12 - Densidade relativa versus temperatura para o Eucalyptus citriodora.

O calor específico da madeira é dado pela curva da figura 5.13. Para temperaturas entre 0 e $200^{\circ} \mathrm{C}$, esta curva é construída com base na equação apresentada em POON (2003), conforme equação (5.4), em que c é dado em $\mathrm{kJ} / \mathrm{kg}^{\circ} \mathrm{C}$ e $\theta$ é a temperatura dada em ${ }^{\circ} \mathrm{C}$.

$$
c=1,125+0,00452 \theta
$$




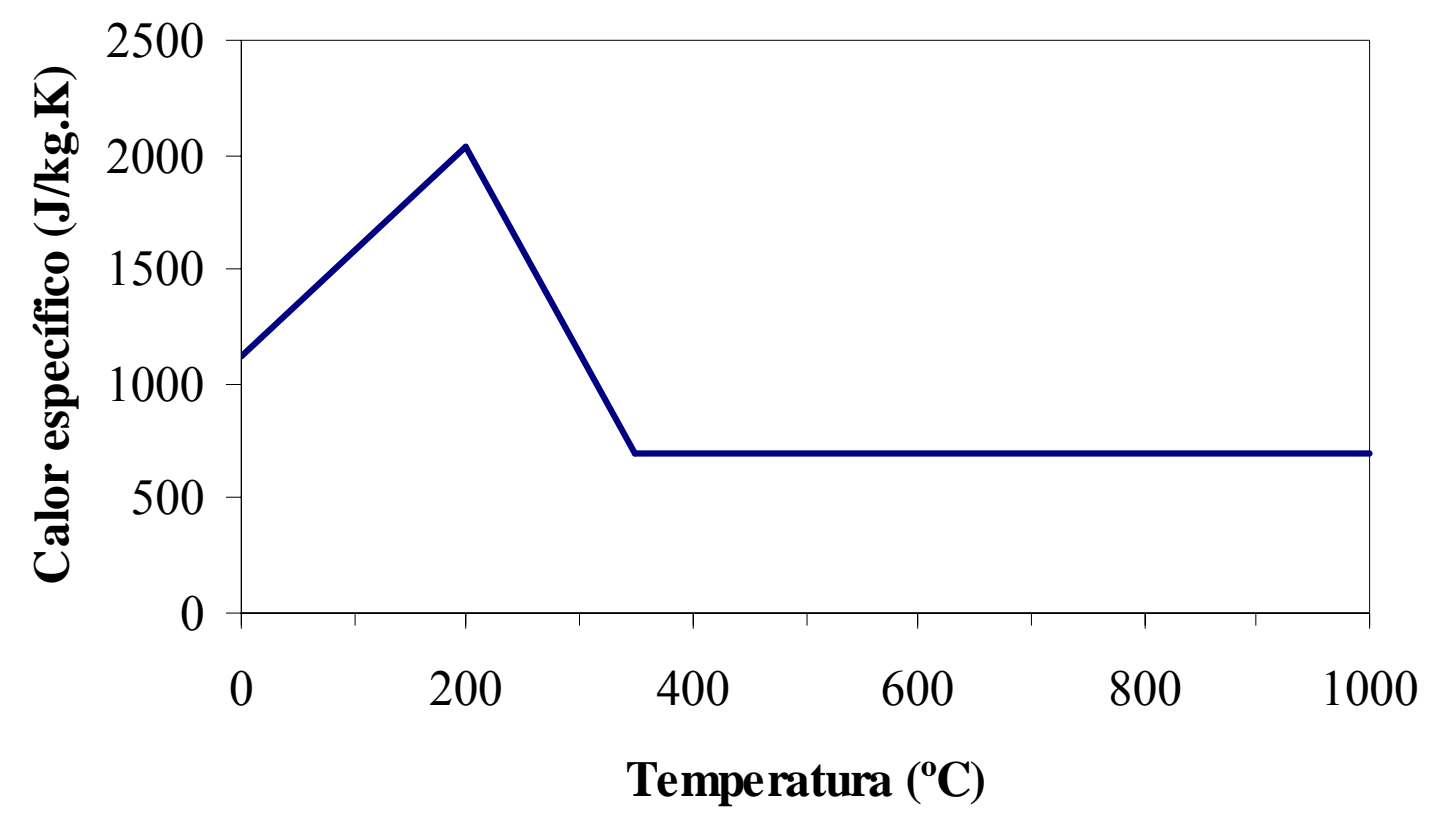

Figura 5.13 - Curva de calor específico da madeira versus temperatura adotada neste trabalho.

Para temperaturas acima de $350{ }^{\circ} \mathrm{C}$ (figura 5.13), os valores de calor específico adotados são os mesmos da curva proposta em KNUDSON et al. (1975) apud JONES (2001). Para valores de calor específico entre 200 e $350{ }^{\circ} \mathrm{C}$ tem-se apenas uma interpolação linear. Esta aproximação é similar àquela adotada em LAPLANCHE et al. (2004), quando da elaboração de modelos numéricos propostos na mesma referência.

A condutividade térmica adotada, conforme figura 5.14, foi calibrada para se obter uma correlação adequada e de interesse entre resultados experimentais e do modelo numérico. $\mathrm{O}$ valor inicial de condutividade, igual a $0,20 \mathrm{~W} / \mathrm{m} .{ }^{\circ} \mathrm{C}$, extraído do gráfico elaborado em URAKAMI e FUKAYAMA (1981) apud HARADA et al. (1998), correlaciona os valores de condutividade térmica a temperatura ambiente com a densidade da madeira.

No tocante aos parâmetros emissividade resultante e coeficiente de transferência de calor devido à convecção, uma aproximação similar àquela apresentada em THOMAS (1997) apud JONES (2001) foi usada para este estudo. A emissividade resultante foi tomada com valor de 0,6 . O coeficiente de convecção adotado foi 13,5 $\mathrm{W} / \mathrm{m}^{2 \circ} \mathrm{C}$, tal qual sugerido em POON (2003).

Com relação à modelagem numérica, fez-se a discretização da seção transversal da viga $(13 \times 26 \mathrm{~cm})$, figura 5.15a, com elementos finitos planos (PLANE77) padronizados com dimensão 1,0 x 1,0 cm. 


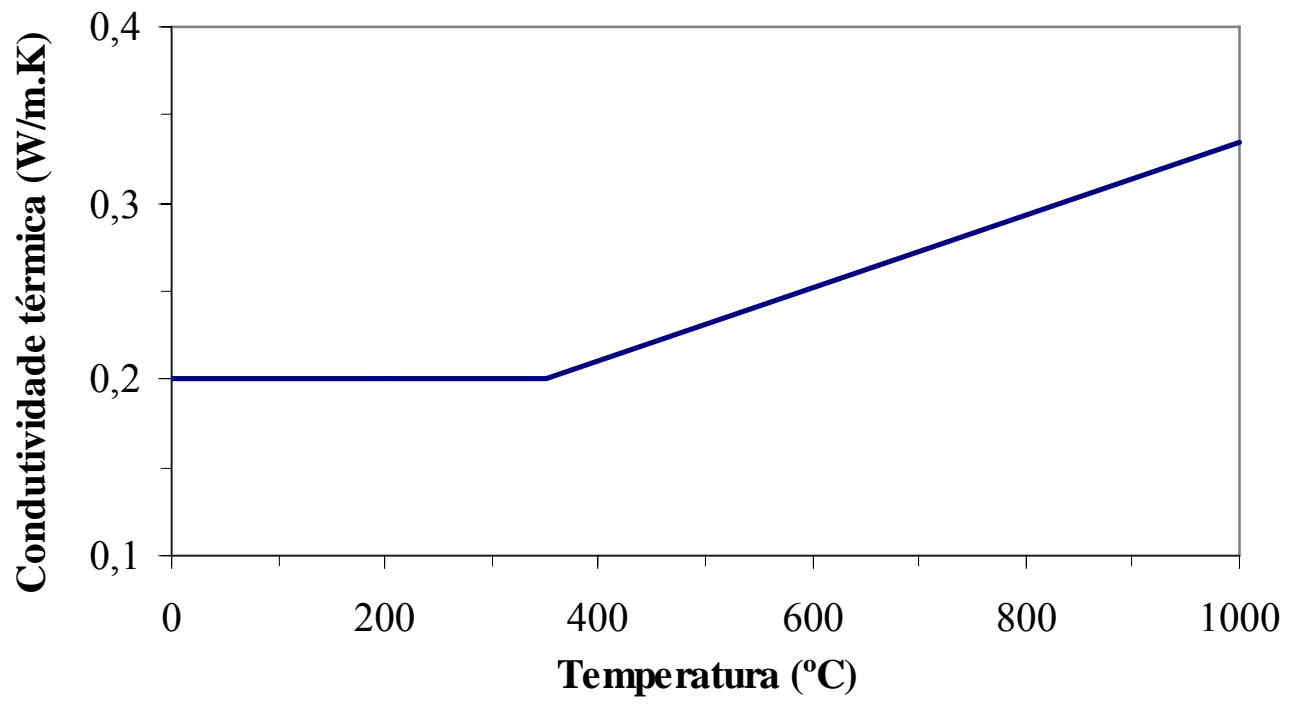

Figura 5.14 - Curva de condutividade térmica adotada para a madeira.
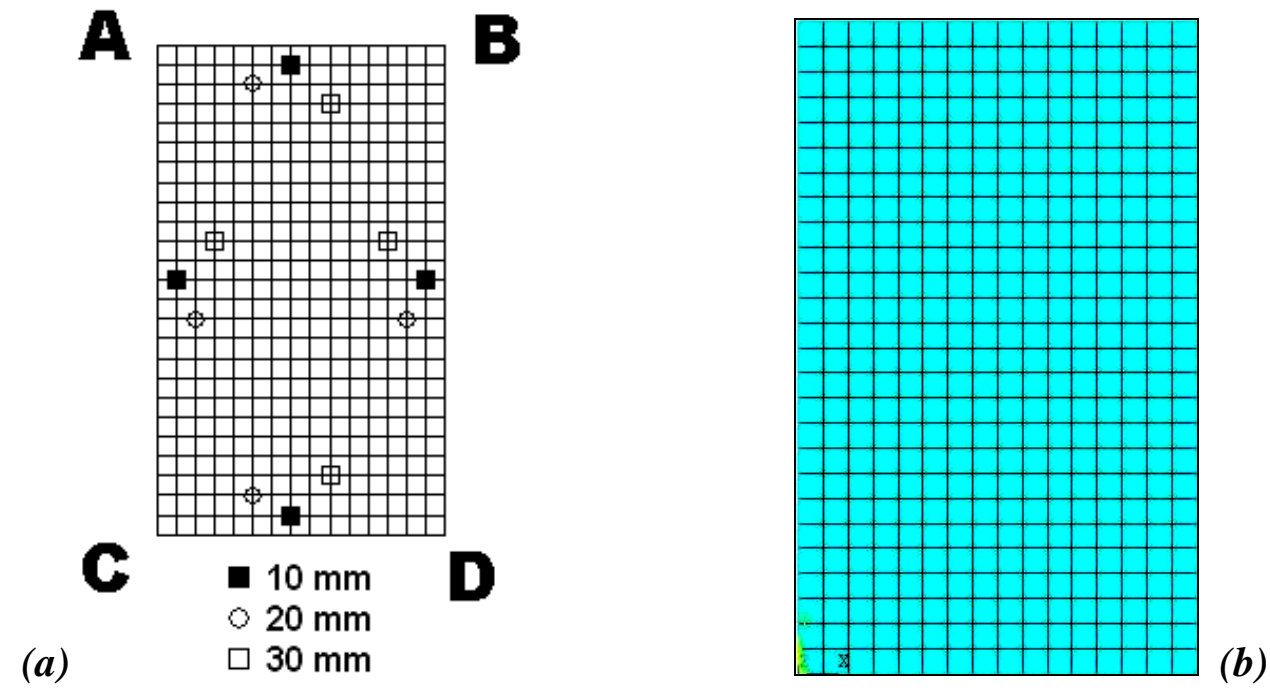

Figura 5.15 - (a) Seção transversal da viga (experimental) com a posição de fixação dos termopares e (b) Malha de elementos finitos.

Foram aplicados elementos SURF151 em todo o contorno, em duas camadas, uma destinada aos efeitos da radiação e outra aos efeitos da convecção na superfície do modelo. A malha de elementos é apresentada na figura 5.15b. Nas figuras 5.16, 5.17 e 5.18 são apresentados os resultados experimentais e os resultados numéricos por meio do programa ANSYS, em região próxima à posição de fixação dos termopares instalados em profundidades iguais a 10, 20 e $30 \mathrm{~mm}$. 


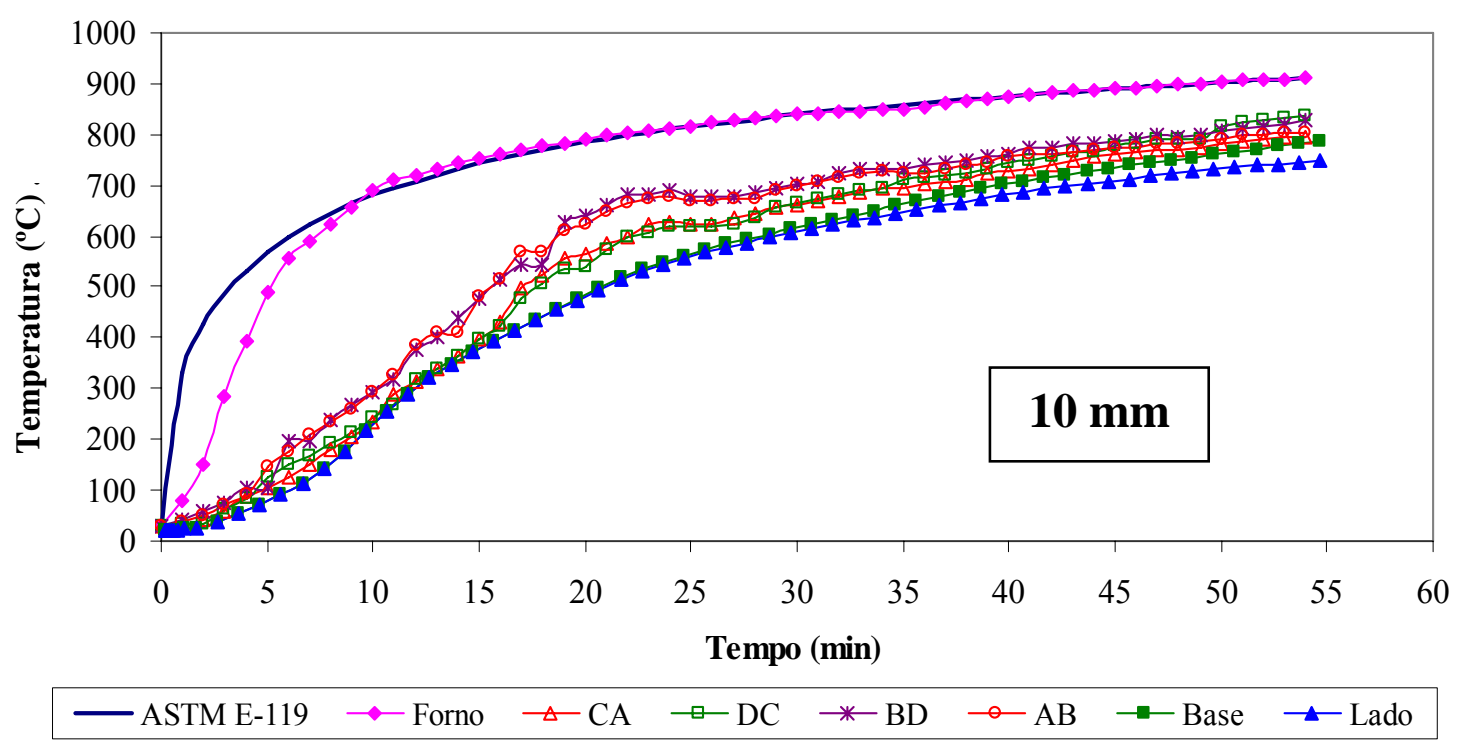

Figura 5.16 - Curva Evolução da temperatura versus tempo para a profundidade de 10 mm (posição relativa à fixação dos termopares).

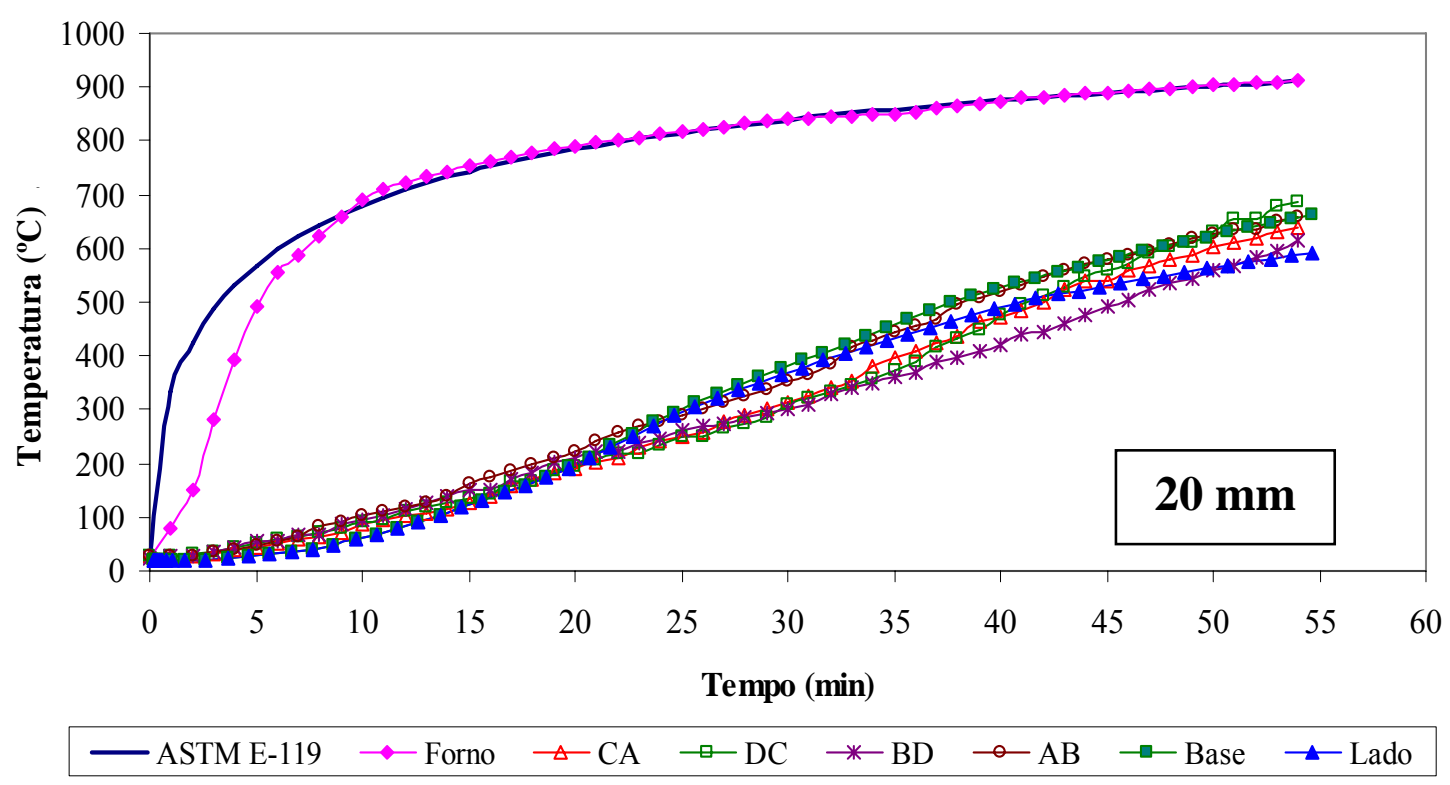

Figura 5.17 - Curva Evolução da temperatura versus tempo para a profundidade de $20 \mathrm{~mm}$ (posição relativa à fixação dos termopares).

Analisando as figuras 5.16, 5.17 e 5.18, nota-se que as aproximações obtidas para as profundidades dos termopares correspondentes a 20 e $30 \mathrm{~mm}$ resultaram melhores quando comparadas àquela obtida para a profundidade de $10 \mathrm{~mm}$, aspecto provavelmente atribuído à falta de dados específicos para a região carbonizada, ou mesmo de limitação do modelo numérico para tal situação. 


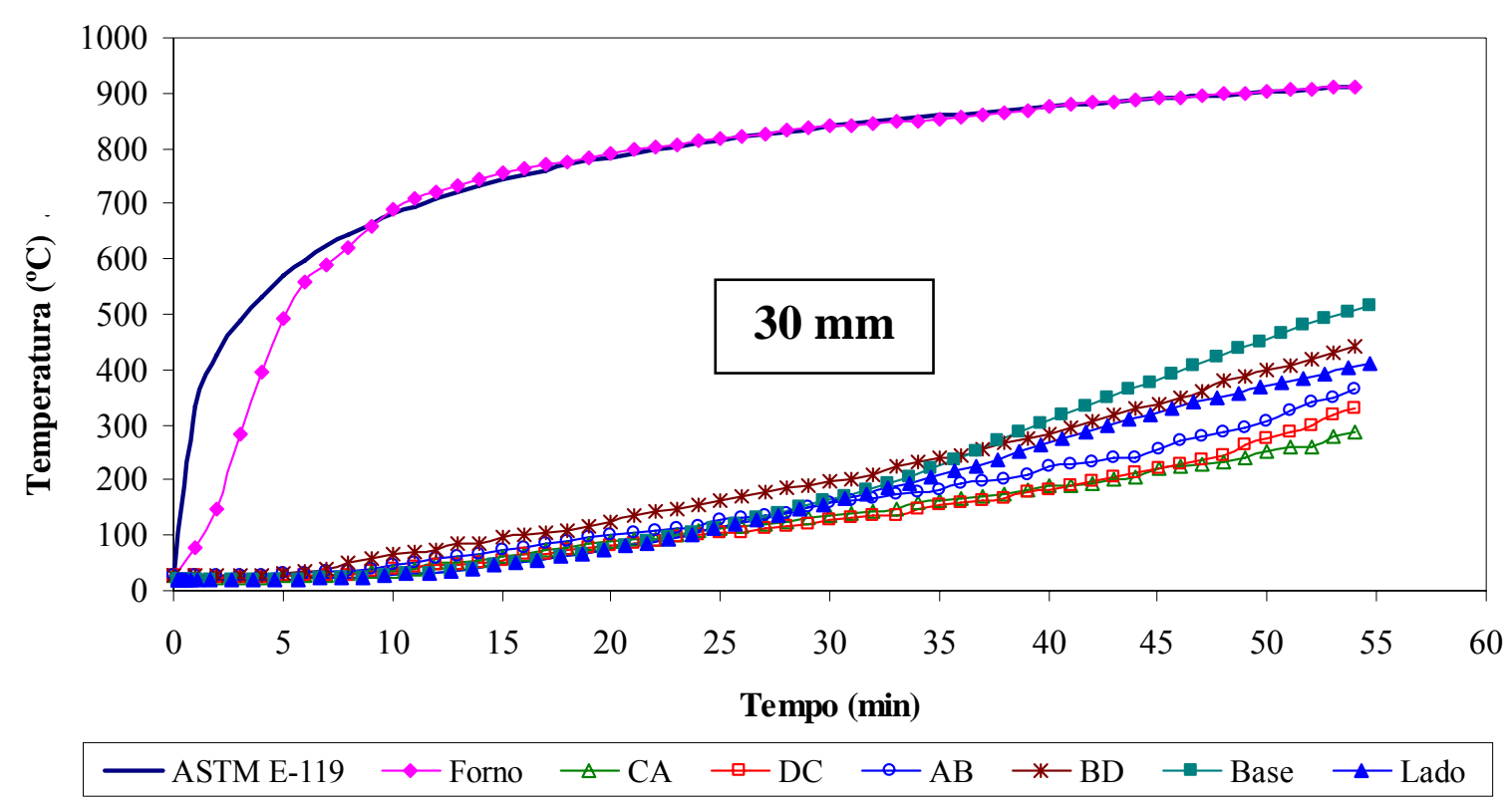

Figura 5.18 - Curva Evolução da temperatura versus tempo para a profundidade de $30 \mathrm{~mm}$ (posição relativa à fixação dos termopares).

A boa correlação obtida entre os dados experimentais e do modelo numérico 4, para as profundidades de 20 e $30 \mathrm{~mm}$, sugere que a estratégia de modelagem aqui utilizada pode ser empregada para se determinar a profundidade carbonizada da madeira com razoável aproximação, bastando adotar uma temperatura de referência para a carbonização da madeira como, por exemplo, $288{ }^{\circ} \mathrm{C}$ (a temperatura característica da base da camada carbonizada).

Os resultados obtidos com o pacote ANSYS na análise da elevação de temperaturas em seções transversais de elementos estruturais de aço, mistos de aço e concreto e de madeira, todos estes em situação de incêndio, apresentados neste capítulo, se mostraram suficientemente satisfatórios.

Diante dos resultados obtidos nesta etapa do trabalho, pode-se afirmar que a estratégia de modelagem adotada é eficiente para o emprego na proposta deste trabalho, que consiste no estudo de situações em que elementos de aço e mistos de aço e concreto são submetidos a um aquecimento não-uniforme em suas seções. 


\section{ESTUDO DE CASOS E RESULTADOS OBTIDOS}

Neste capítulo são apresentados resultados de 11 casos de estudo de elementos de aço e mistos de aço e concreto, sendo 6 deles referentes à NBR 14323:1999, os quais consistem basicamente em estudo de alguns casos, aqui de interesse, relacionados a elementos estruturais submetidos a um aquecimento não-uniforme em suas seções.

Os resultados das situações de interesse consideradas são obtidos por meio de simulações numéricas com a utilização do programa ANSYS ® v9.0, e consistem basicamente da determinação da evolução (considerando as temperaturas máximas, mínimas e médias) e do campo de temperatura nas seções transversais dos elementos, quando submetidos à exposição ao incêndio-padrão ISO 834.

\subsection{CASOS DE ESTUDO}

Neste item serão apresentados alguns casos de interesse para análise. Na tabela 6.1 se tem informações sobre os perfis adotados, enquanto que nas tabelas 6.2 e 6.3 são descritas e esquematizadas as situações a serem consideradas para fins de análise em temperaturas elevadas, para casos normativos e não normativos, respectivamente. Nestas tabelas estão indicados o tipo de elemento analisado e o esquema de exposição ao fogo a que foi submetido, considerando a elevação da temperatura dos gases de acordo com a curva de incêndio-padrão ISO 834.

Para cada caso analisado, a elevação de temperatura será obtida considerando-se quatro perfis do tipo I previamente escolhidos, contemplando, com vistas a fatores de massividade, uma faixa entre 50 e $400 \mathrm{~m}^{-1}$. No caso de análise de chapa de aço (caso 2) essa mesma pode ser idealizada com a mesa de um perfil I, e terá dimensões em conformidade com aquelas apresentadas na tabela 6.1. 
Tabela 6.1 - Perfis adotados para os casos analisados.

\begin{tabular}{|l|c|c|c|c|c|c|c|c|}
\hline \multicolumn{1}{|c|}{ Perfil } & $\begin{array}{c}\mathrm{d} \\
(\mathrm{mm})\end{array}$ & $\begin{array}{c}\mathrm{b}_{\mathrm{f}} \\
(\mathrm{mm})\end{array}$ & $\begin{array}{c}\mathrm{t}_{\mathrm{f}} \\
(\mathrm{mm})\end{array}$ & $\begin{array}{c}\mathrm{t}_{\mathrm{w}} \\
(\mathrm{mm})\end{array}$ & $\mathrm{u}(\mathrm{m})$ & $\begin{array}{c}\mathrm{A} \\
\left(\mathrm{cm}^{2}\right)\end{array}$ & $\begin{array}{c}\mathrm{u} / \mathrm{A} \\
\left(\mathrm{m}^{-1}\right)\end{array}$ & intervalo \\
\hline W 150x13 & 148 & 100 & 4,9 & 4,3 & 0,67 & 16,6 & 404 & - \\
\hline W 250x25,3 & 257 & 102 & 8,4 & 6,1 & 0,89 & 32,6 & 273 & 131 \\
\hline VS 400x78 & 400 & 200 & 19 & 6,3 & 1,59 & 98,8 & 161 & 112 \\
\hline CS 550x502 & 550 & 550 & 45 & 31,5 & 3,24 & 639,9 & 51 & 110 \\
\hline
\end{tabular}

Tabela 6.2 - Descrição e esquematização de casos normativos (NBR 14323:1999).

\begin{tabular}{|c|c|c|}
\hline Denominação & Descrição do Caso & Esquematização \\
\hline CASO 1 & $\begin{array}{l}\text { - Seção aberta exposta ao incêndio } \\
\text { por três lados }\end{array}$ & $\mathrm{fog}_{0}$ \\
\hline CASO 2 & $\begin{array}{l}\text { - Chapa exposta ao incêndio por } \\
\text { três lados }\end{array}$ & $=\frac{i_{\text {fogo }}}{=}$ \\
\hline CASO 3 & $\begin{array}{l}\text { - Mesa de seção I exposta ao } \\
\text { incêndio por três lados }\end{array}$ & $\frac{1}{\text { fogo }}$ \\
\hline CASO 4 & $\begin{array}{l}\text { - Seção I com reforço em caixão } \\
\text { exposta ao incêndio por todos os } \\
\text { lados }\end{array}$ & $f_{0}$ \\
\hline CASO 5 & $\begin{array}{l}\text { - Seção I com proteção tipo caixa, } \\
\text { de espessura uniforme, exposta } \\
\text { ao incêndio por todos os lados }\end{array}$ & $\mathrm{fog}_{\mathrm{fog} O} \mathrm{fog}_{0}$ \\
\hline CASO 6 & $\begin{array}{l}\text { - Seção I com proteção tipo caixa, } \\
\text { de espessura uniforme exposta ao } \\
\text { incêndio por três lados }\end{array}$ & $f_{\text {fogo }}$ \\
\hline
\end{tabular}


Tabela 6.3 - Descrição e esquematização dos casos não normativos (situações usuais).

\begin{tabular}{|c|c|c|}
\hline Denominação & Descrição do Caso & Esquematização \\
\hline CASO 7 & $\begin{array}{l}\text { - Viga I em contato com laje de } \\
\text { concreto e alvenaria, exposta ao } \\
\text { incêndio pelos dois lados da } \\
\text { parede de alvenaria }\end{array}$ & fogo $\underbrace{}_{\text {譼 }}$ fogo \\
\hline CASO 8 & $\begin{array}{l}\text { Pilar com mesas em contato } \\
\text { com paredes de alvenaria, } \\
\text { exposta ao incêndio pelos dois } \\
\text { lados da parede de alvenaria }\end{array}$ & 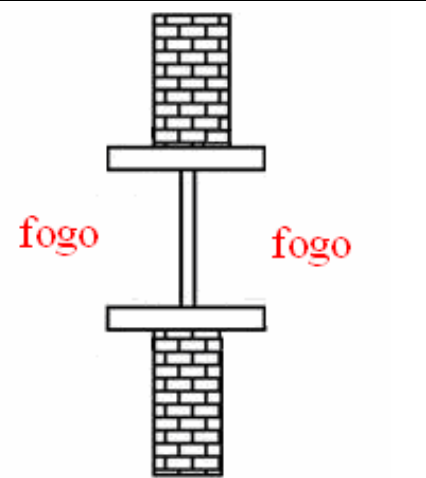 \\
\hline CASO 9 & $\begin{array}{l}\text { - Viga I em contato com laje de } \\
\text { concreto e alvenaria, exposta } \\
\text { ao incêndio em apenas um } \\
\text { lado da parede de alvenaria }\end{array}$ & 㯺 \\
\hline CASO 10 & $\begin{array}{l}\text { - Pilar com mesas em contato } \\
\text { com paredes de alvenaria, } \\
\text { exposta ao incêndio em apenas } \\
\text { um lado da parede de alvenaria }\end{array}$ & 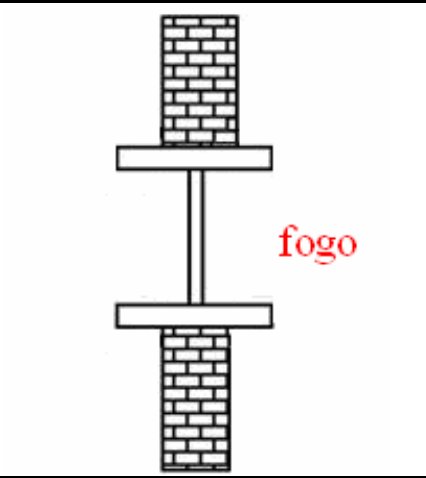 \\
\hline CASO 11 & $\begin{array}{l}\text { - Pilar com alma em contato } \\
\text { com paredes de alvenaria, } \\
\text { exposta ao incêndio em apenas } \\
\text { um lado da parede de alvenaria }\end{array}$ & 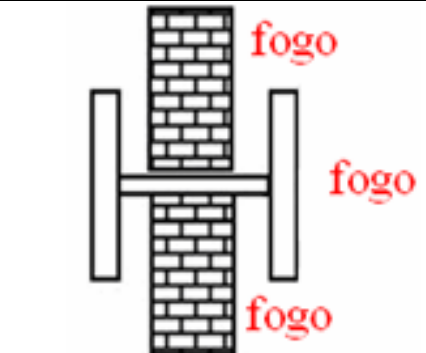 \\
\hline
\end{tabular}


Para os modelos numéricos referentes aos casos 1, 2, 3 e 6 (tabela 6.2), com relação às geometrias das lajes de concreto (superpostas aos perfis) e das alvenarias, se considera para ambas uma espessura com valor igual a $10 \mathrm{~cm}$ e um comprimento com valor igual a três vezes a largura das mesas dos perfis. Nos demais casos, conforme tabela 6.3, a alvenaria tem comprimento igual à largura da mesa do perfil.

As propriedades térmicas do aço e do concreto a serem consideradas nos modelos numéricos estão de acordo com as informações apresentadas no Capítulo 3 (propriedades térmicas dos materiais). Para as alvenarias, as propriedades térmicas correspondem àquelas de blocos cerâmicos de tijolo vazado, listadas na tabela 3.1.

\subsubsection{Considerações sobre as condições de contorno e malha de elementos finitos}

Seguindo a estratégia adotada em LEWIS (2000), em todos os modelos a emissividade resultante $\varepsilon_{\text {res }}$ adotada tanto para o aço quanto para o concreto, bem como para a alvenaria e para os materiais de proteção, foi igual 0,5 , lembrando que a NBR 14323:1999 menciona apenas o valor igual a 0,5 para a emissividade resultante do aço.

O coeficiente de transferência de calor por convecção $\left(\alpha_{c}\right)$ foi tomado igual a 25 $\mathrm{W} / \mathrm{m}^{20} \mathrm{C}$, conforme prescrito pela NBR 14323:1999. A favor da segurança, a face da laje não exposta ao fogo foi aqui considerada como parede adiabática, exceto para os casos de estudo de 9 a 11, em que a troca de calor entre as superfícies não expostas ao incêndio e o meio é considerada por meio de um coeficiente $\alpha_{c}$ igual a $9 \mathrm{~W} / \mathrm{m}^{20} \mathrm{C}$, conforme recomendações prescritas pelo EUROCODE 1 (2002).

Na discretização dos perfis de aço dos modelos numéricos procurou-se manter elementos finitos com tamanho máximo de $7 \mathrm{~mm}$, o que implica numa malha suficientemente refinada. A discretização adotada é compatível quando levadas em conta as considerações do item 4.1.1, que trata do número de Biot. Como as lajes e alvenaria são elementos secundários nas análises aqui efetuadas procurou-se apenas compatibilizar as malhas na interface perfil-alvenaria e perfil-laje, não adotando uma malha tão rigorosa para essas partes do modelo, porém, com grau de discretização, apesar de simplificado, suficiente para a obtenção dos resultados de interesse do trabalho.

Nos casos de 1 a 6 (tabela 6.2), para obtenção da elevação de temperatura por meio de procedimento simplificado de cálculo, os fatores de massividade são calculados 
de acordo com a NBR 14323:1999 e EUROCODE 3 (2005) para obtenção de suas respectivas curvas. Nos casos 7 a 11 a consideração do fator de massividade é feita no item que trata do respectivo caso.

\subsubsection{CASO 1 - Seção aberta e exposta ao incêndio por três lados}

A figura 6.1 ilustra a malha de elementos finitos e o campo de temperaturas para um tempo (TRRF) de 60 minutos de exposição ao incêndio-padrão para o caso de estudo 1, considerando um perfil W 150x13 sobreposto por laje de concreto. Tal qual mencionado no item anterior, para este caso, apenas a face inferior da laje é exposta ao incêndio. Isto pode ser verificado pela análise da figura 6.1b.

Na figura 6.2 estão apresentados os resultados da elevação de temperatura obtidos via modelo numérico e por meio de procedimentos simplificados de cálculo da NBR 14323:1999 e do EUROCODE 3 (2005).

Com relação à norma NBR 14323:1999 será apresentada, em vários dos modelos, uma curva referente à consideração de um valor simplificado (constante) para o calor específico do aço igual a $600 \mathrm{~J} /\left(\mathrm{kg}^{\circ} \mathrm{C}\right)$. Nas figuras 6.3 a 6.8 têm-se os resultados do estudo do caso 1 referentes aos demais perfis da análise.

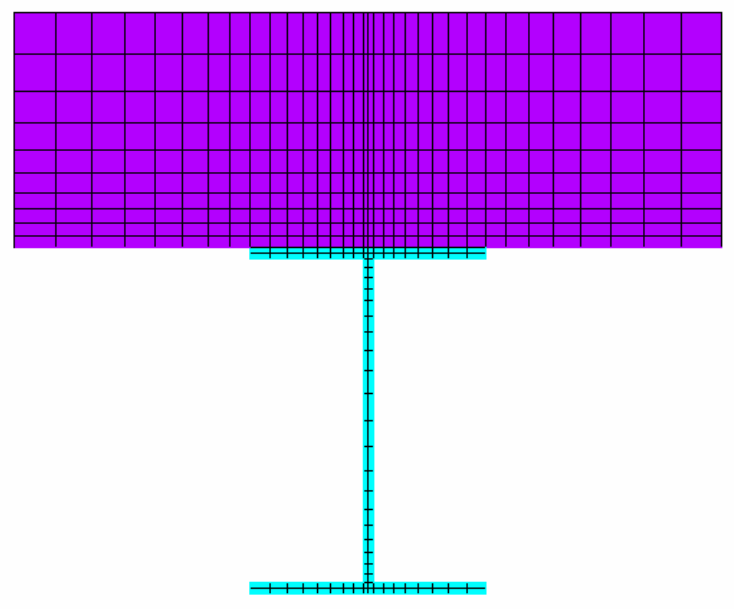

(a)

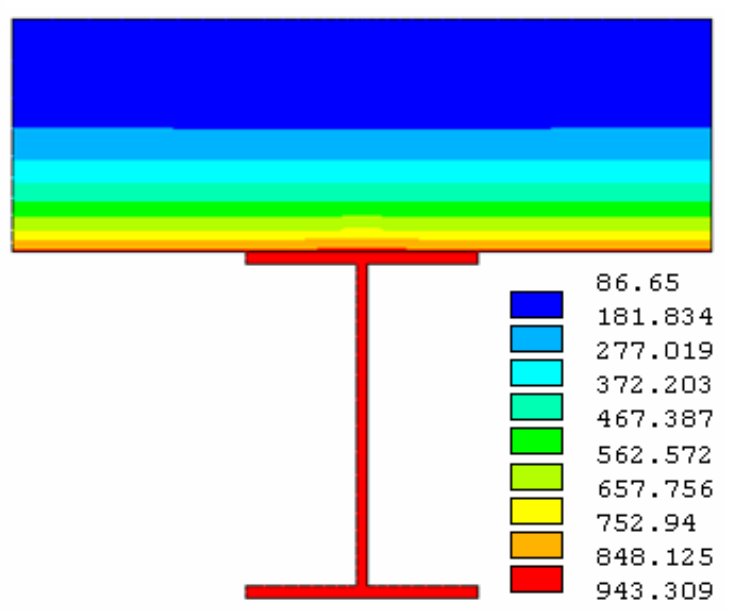

(b)

Figura 6.1 - (a) Malha de elementos finitos e (b) Campo de temperaturas correspondente a um tempo (TRRF) de 60 minutos para o perfil W 150x13. 


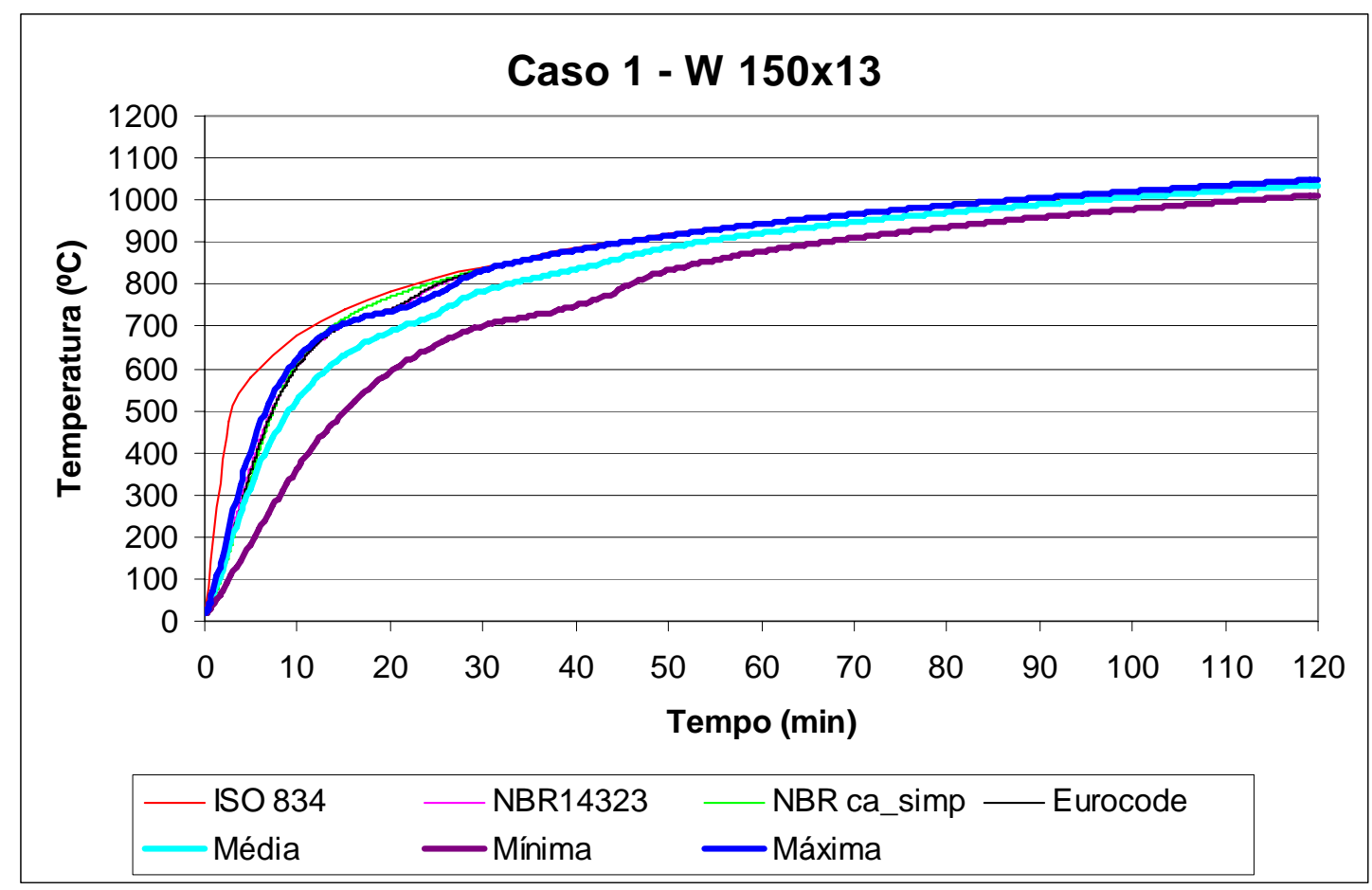

Figura 6.2 - Curvas da evolução da temperatura versus tempo para o caso 1 considerando-se o perfil W 150x13.

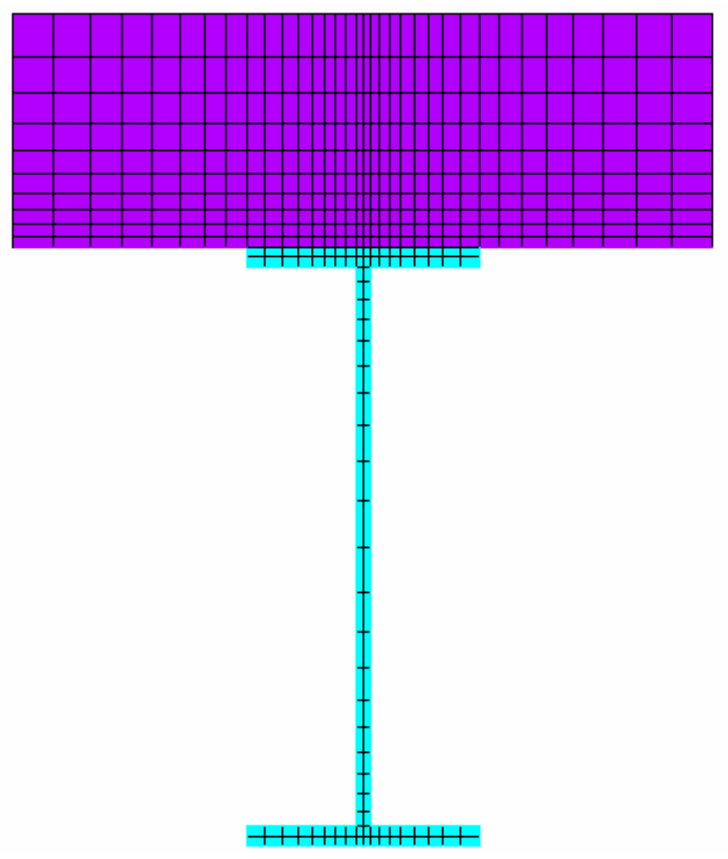

(a)

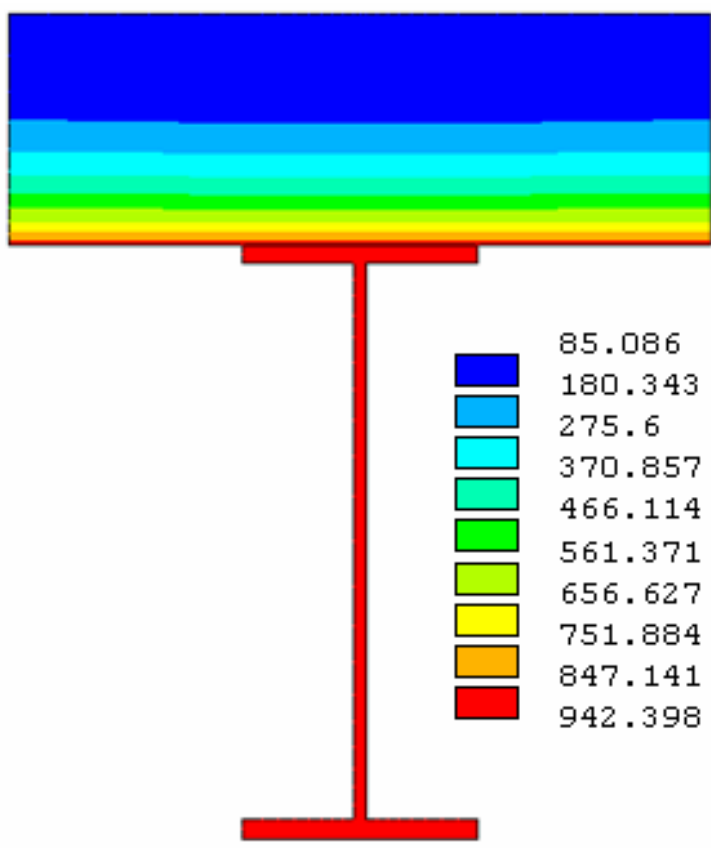

(b)

Figura 6.3 - Caso 1: (a) Malha de elementos finitos e (b) Campo de temperaturas correspondente a um tempo (TRRF) de 60 minutos para o perfil W 250x25,3. 


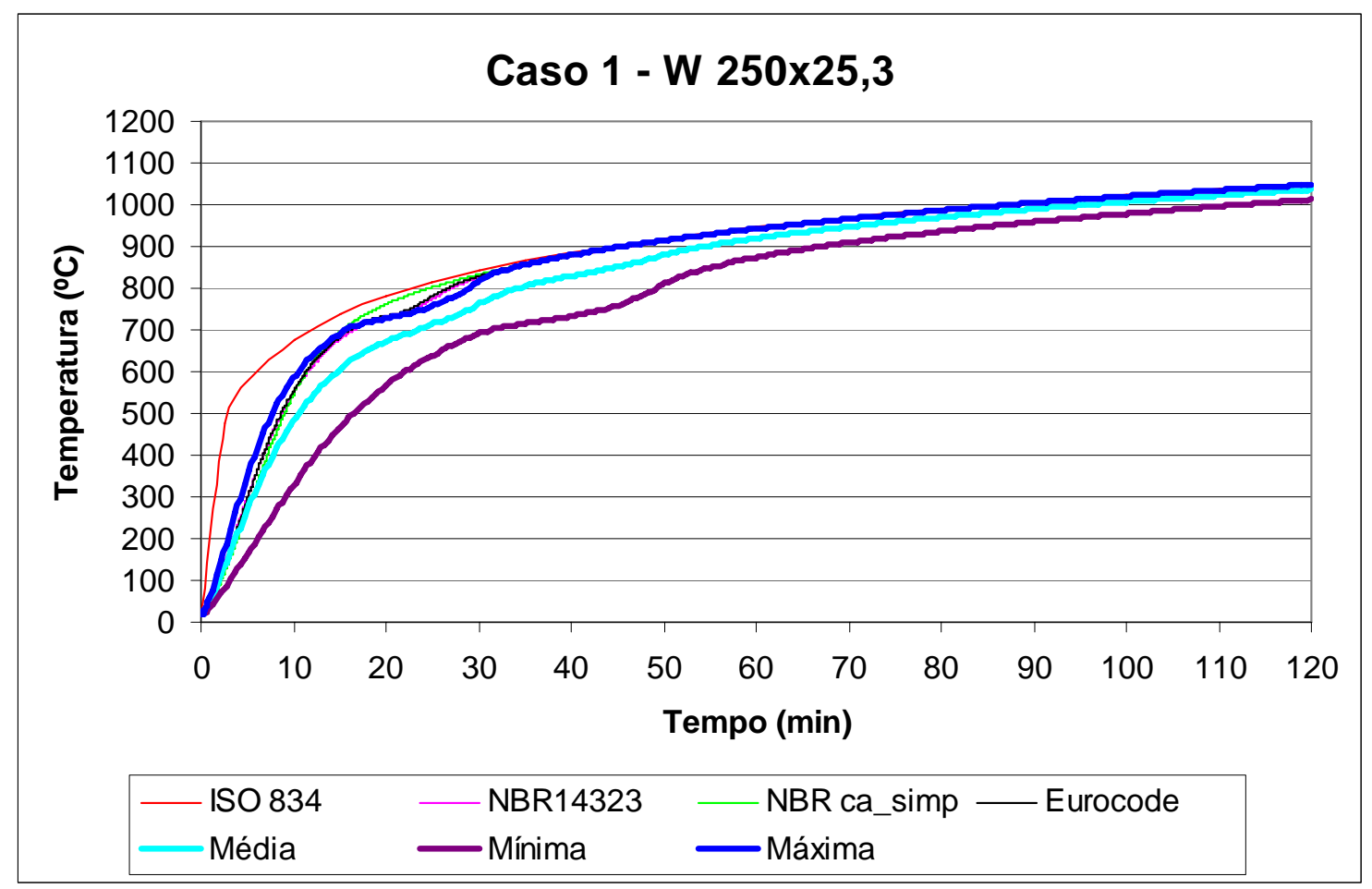

Figura 6.4 - Curvas da evolução da temperatura versus tempo para o caso 1 considerando-se o perfil W 250x25,3.

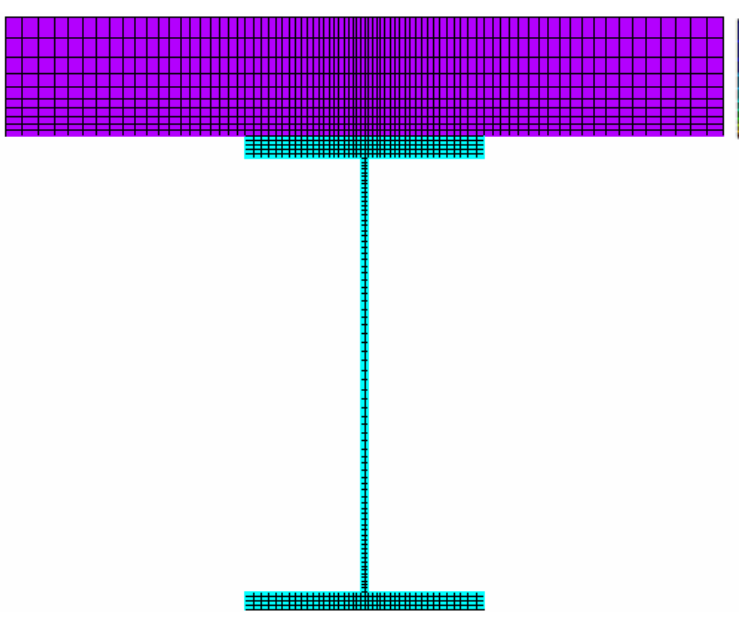

(a)

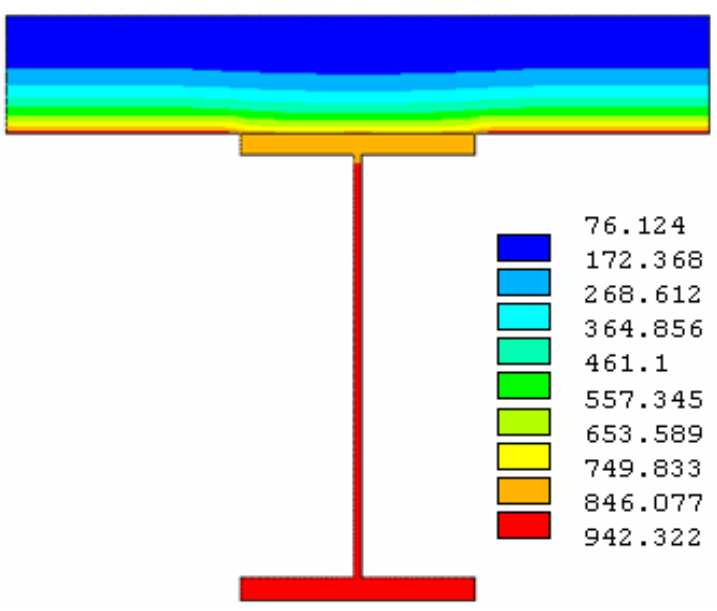

(b)

Figura 6.5 - Caso 1: (a) Malha de elementos finitos e (b) Campo de temperaturas correspondente a um tempo (TRRF) de 60 minutos para o perfil VS 400x78. 


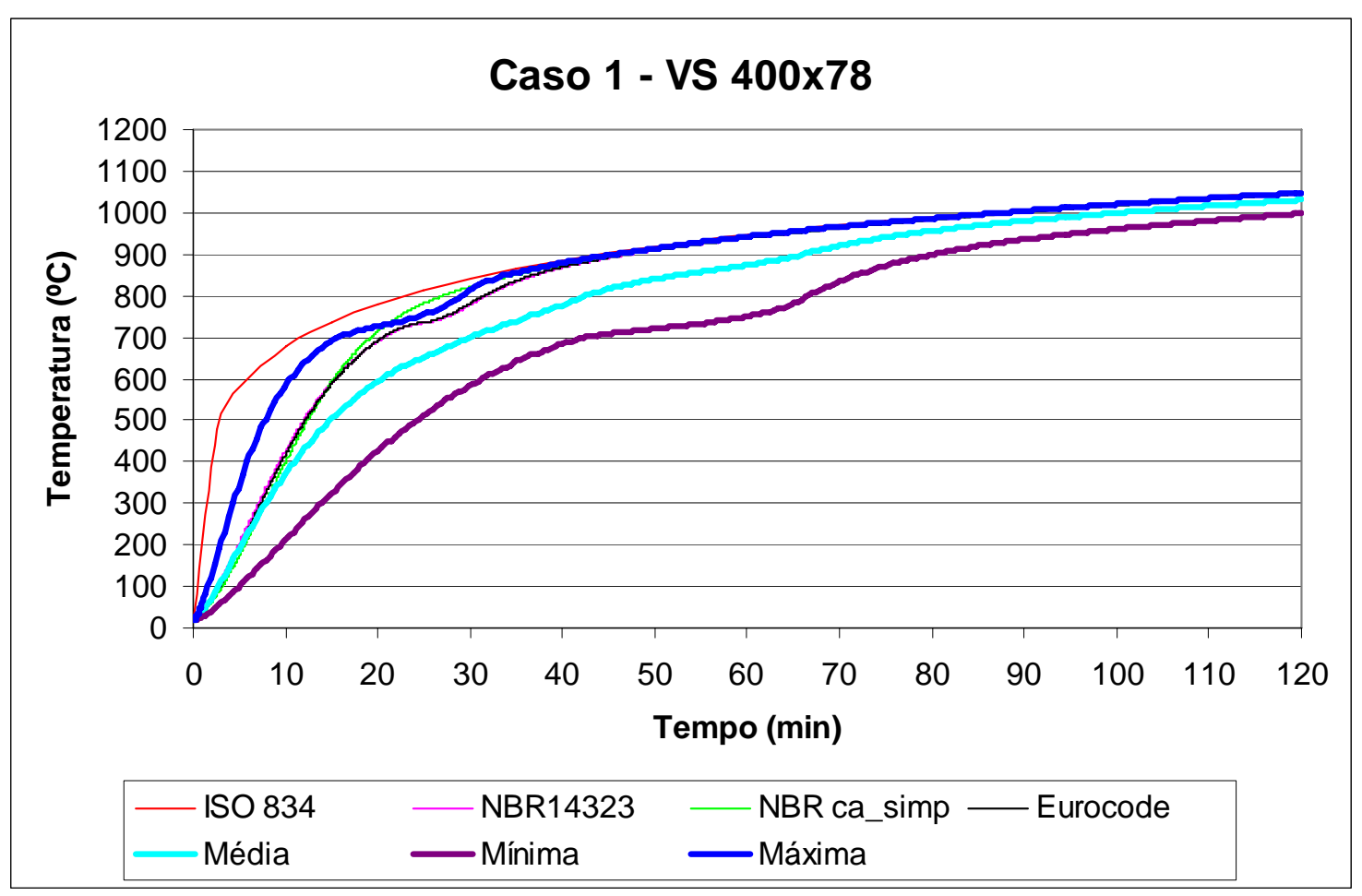

Figura 6.6 - Curvas da evolução da temperatura versus tempo para o caso 1 considerando-se o perfil VS 400x78.

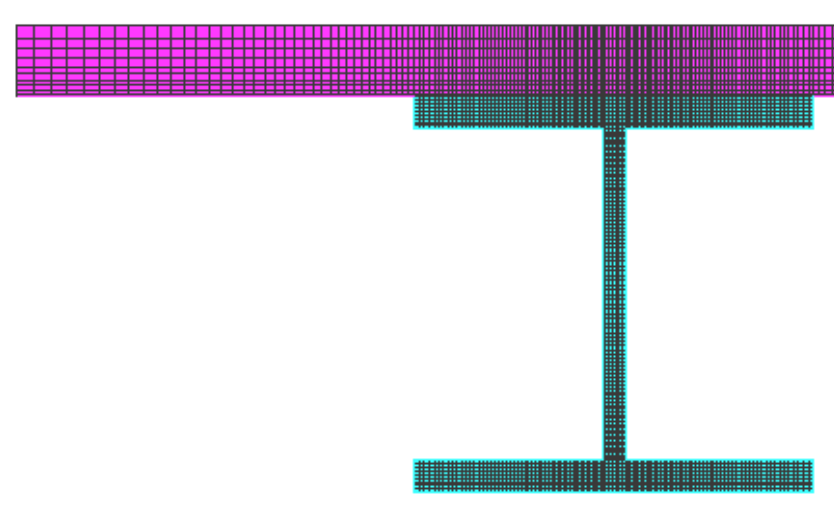

(a)

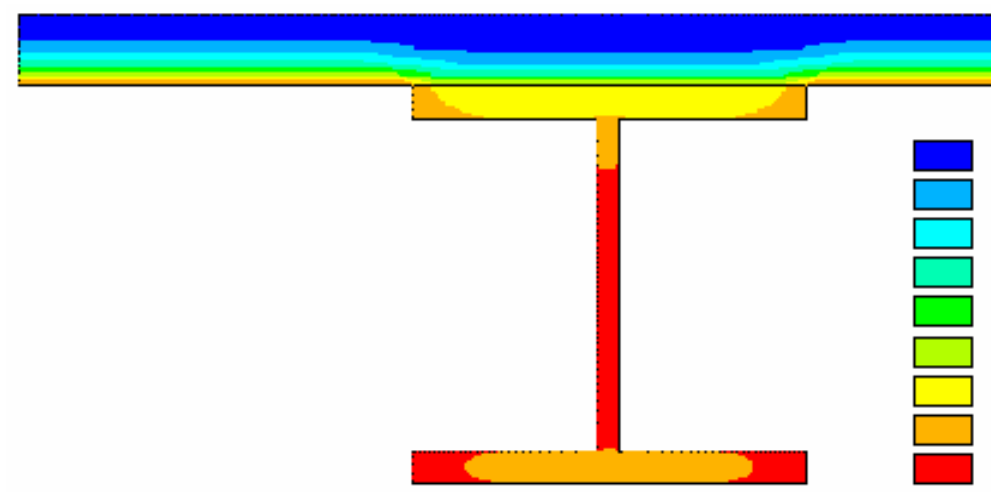

57.91

148.456

239.002

329.549

420.095

510.642

601.188

691.734

782.281

872.827

(b)

Figura 6.7 - Caso 1: $\boldsymbol{a})$ Malha de elementos finitos e b) Campo de temperaturas correspondente a um tempo (TRRF) de 60 minutos para o perfil CS 550x502. 


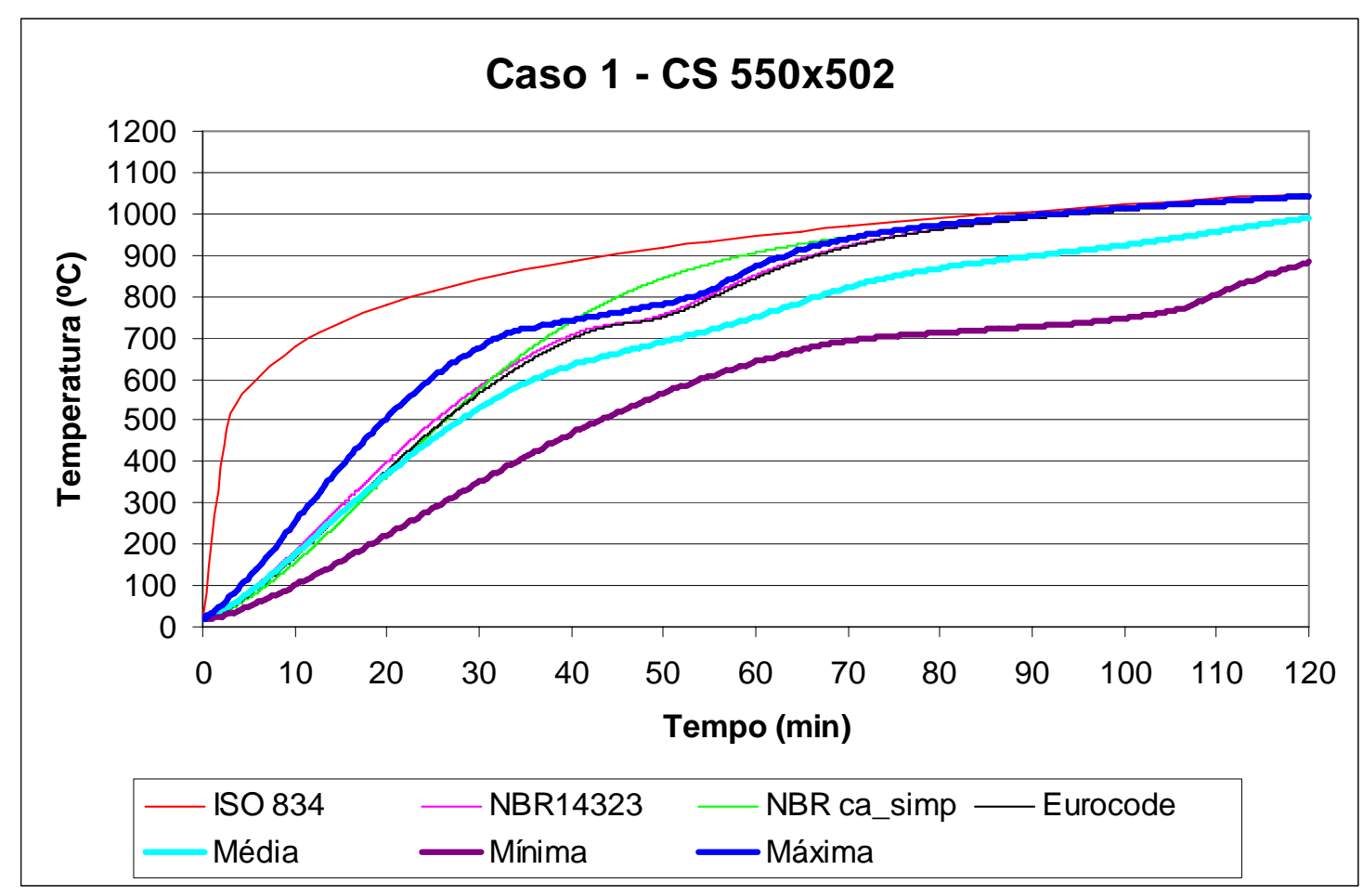

Figura 6.8 - Curvas da evolução da temperatura versus tempo para o caso 1 considerando-se o perfil CS 550x502.

Analisando os resultados obtidos para o CASO 1 tem-se que as curvas normativas de evolução de temperaturas obtidas por meio dos procedimentos simplificados de cálculo, tanto da NBR 14323:1999 quanto do EUROCODE 3 (2005), resultam muito próximas durante todo o processo de aquecimento, e consideravelmente próximas (quase coincidentes) quando comparadas àquela curva de temperatura máxima obtida via simulação numérica, e quando superadas por esta, ainda resultam acima das temperaturas médias da seção. Diferenças consideráveis entre essas curvas são identificadas somente para o perfil do tipo CS 550 x 502, situação em se tem espessuras de chapas bastante considerável para fins de aplicação em estruturas correntes.

Ressalta-se também que a consideração de um valor constante para o calor específico não ocasiona, na maioria das vezes, afastamento significativo da curva sem tal consideração. Porém quando ocorre, tal afastamento quase sempre está a favor da segurança. É importante ressaltar que tal aspecto também é notado para a maioria dos casos analisados. 


\subsubsection{CASO 2 - Chapa exposta ao incêndio por três lados}

Este caso consiste do estudo de chapa de aço exposta ao incêndio por três lados, com uma das faces protegida (por parede de alvenaria, por exemplo). Neste caso, a chapa de aço tem as dimensões das mesas dos perfis analisados.

As propriedades térmicas adotadas para alvenaria correspondem àquelas de blocos cerâmicos de tijolo vazado, listadas na tabela 3.1 do Capítulo 3. A escolha por alvenaria, neste caso, foi feita tendo em vista que em SILVA (2006) análise semelhante foi feita considerando laje de concreto ao invés da alvenaria. A alvenaria, por ser menos condutora que o concreto conduz, teoricamente, a resultados mais severos de temperatura no perfil.

Na figura 6.9 têm-se a malha de elementos finitos e o campo de temperaturas para um tempo (TRRF) de 60 minutos de exposição ao incêndio-padrão. Neste caso, apresenta-se como resultado de interesse apenas o campo de temperaturas da chapa de aço. Na figuras 6.10 está apresentado os resultados da elevação de temperatura obtidos via modelo numérico e por meio de procedimentos simplificados de cálculo da NBR 14323:1999 e do EUROCODE 3 (2005).

Nas figuras 6.11 a 6.16 são mostrados os resultados do caso 2 referentes aos demais perfis da análise.

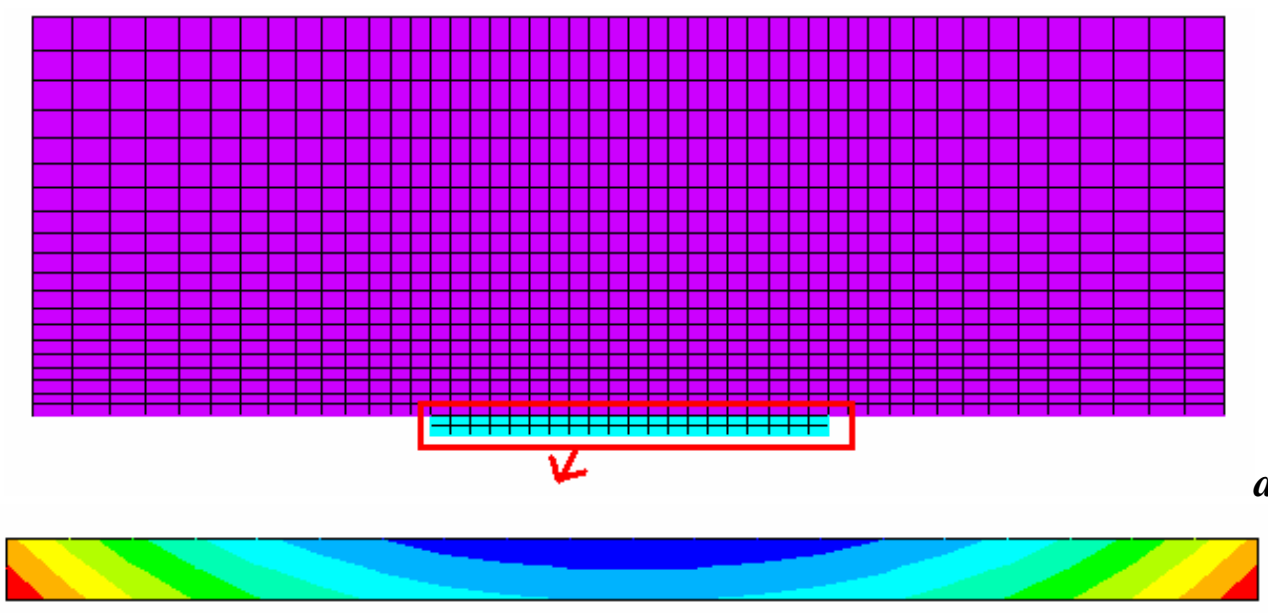

a)

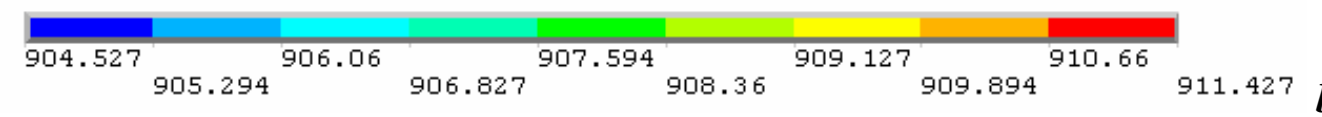

Figura 6.9 - Caso 2: $\boldsymbol{a}$ ) Malha de elementos finitos e b) Campo de temperaturas correspondente a um tempo (TRRF) de 60 minutos para a chapa de aço (mesa do perfil W 150x13). 


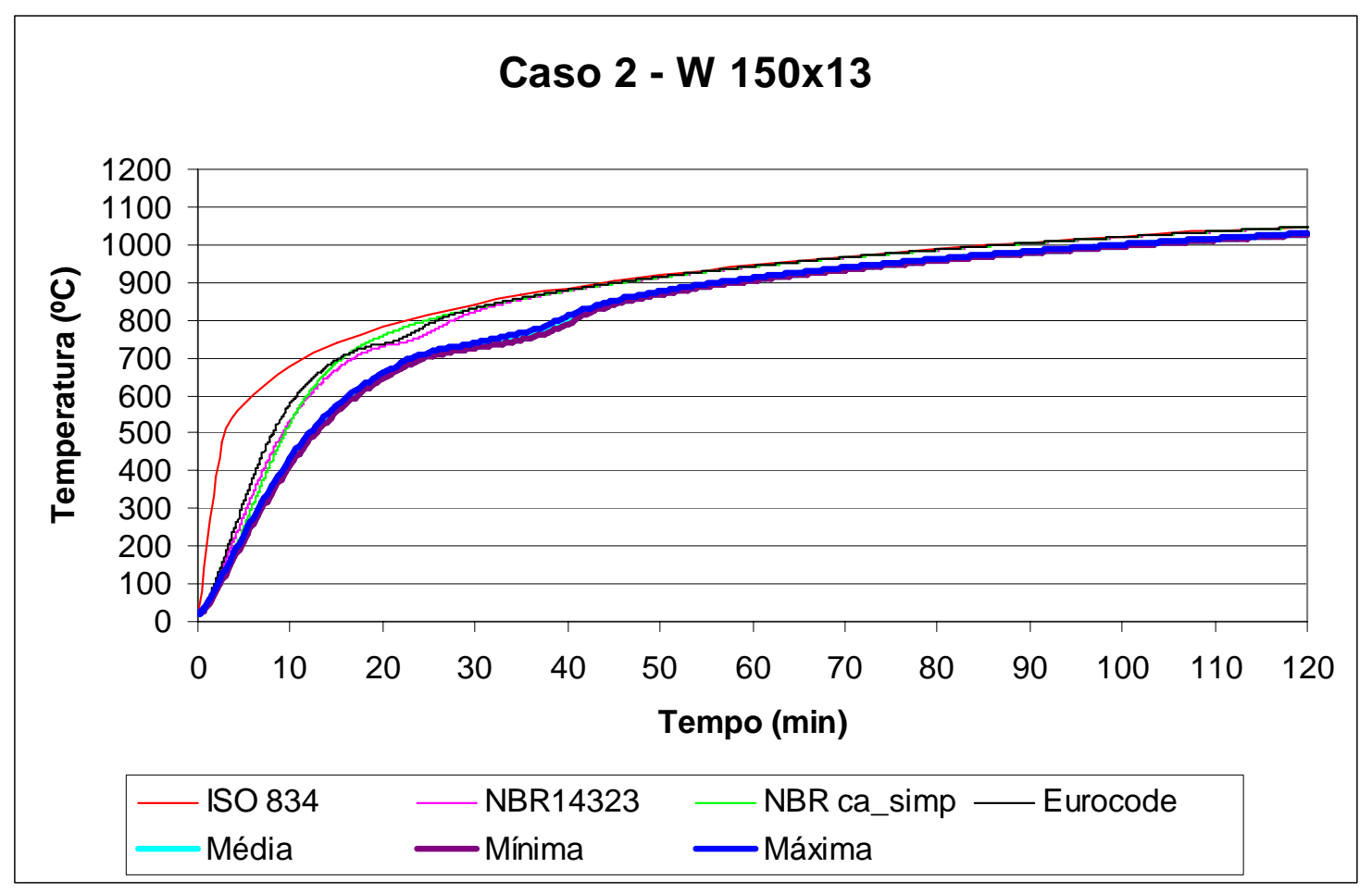

Figura 6.10 - Curvas da evolução da temperatura versus tempo para o caso 2 considerando-se o perfil (mesa do perfil) W 150x13.

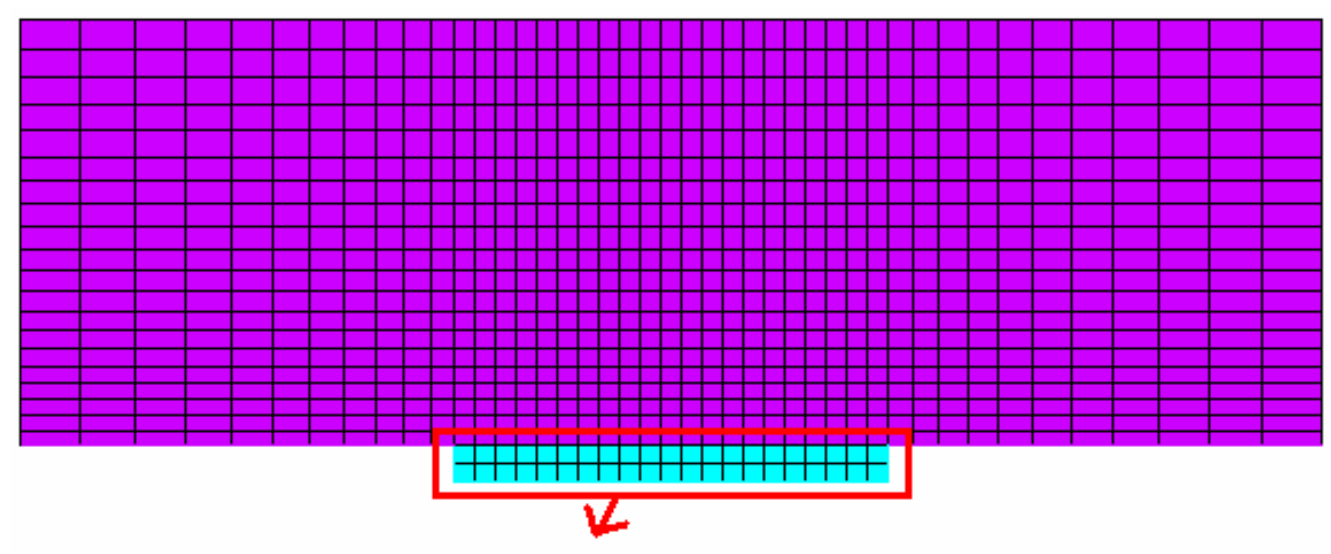

a)
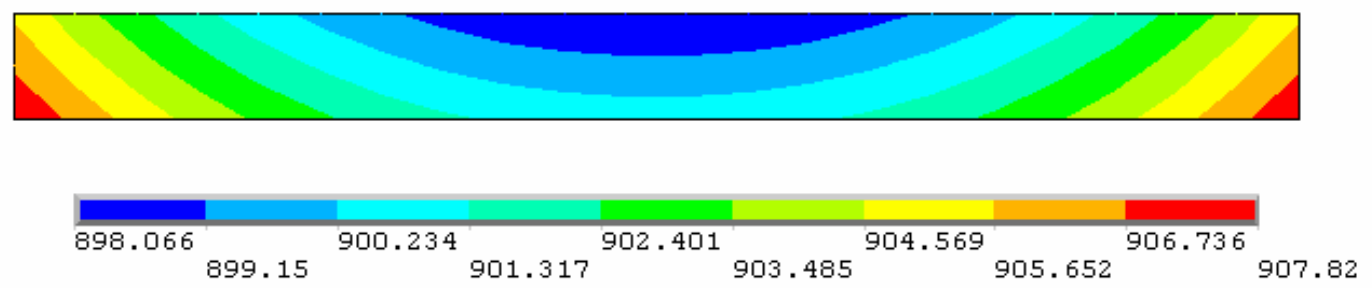

Figura 6.11 - Caso 2: a) Malha de elementos finitos e b) Campo de temperaturas correspondente a um tempo (TRRF) de 60 minutos para a chapa de aço (mesa do perfil W 250x25,3). 


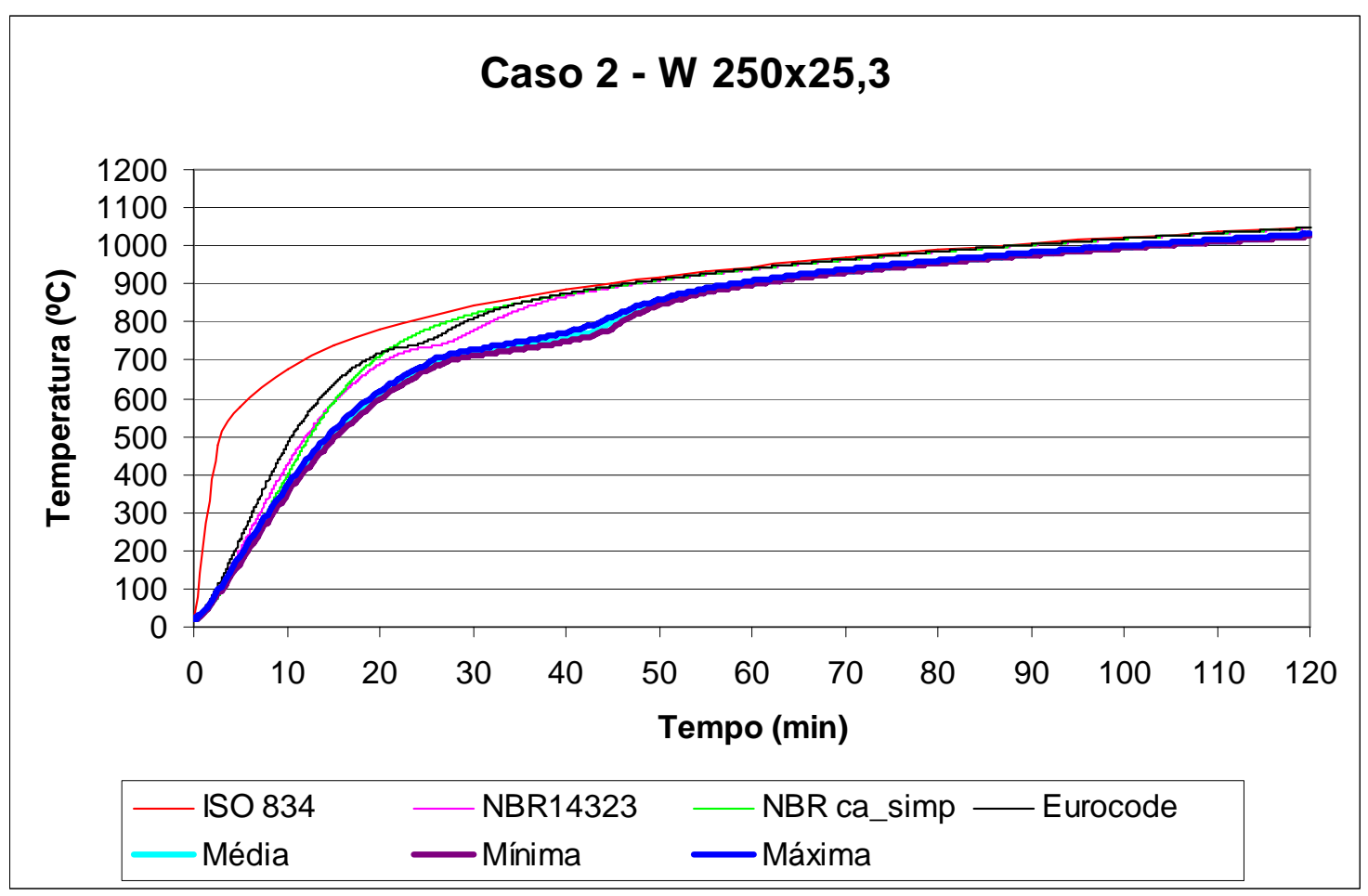

Figura 6.12 - Curvas da evolução da temperatura versus tempo para o caso 2 considerando-se o perfil (mesa do perfil) W 250x25,3.

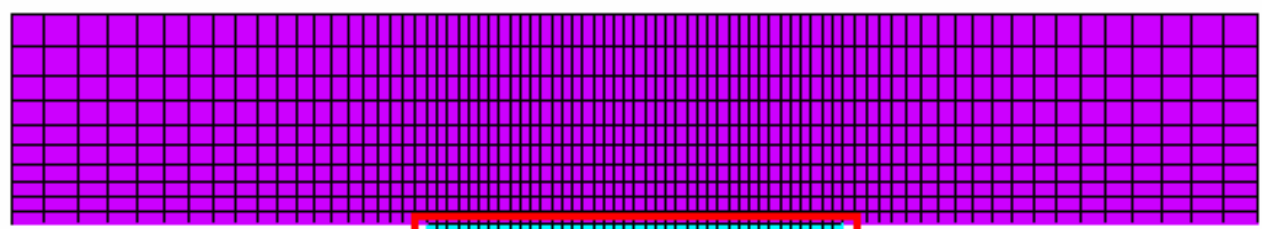

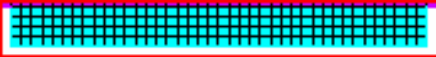

(a)
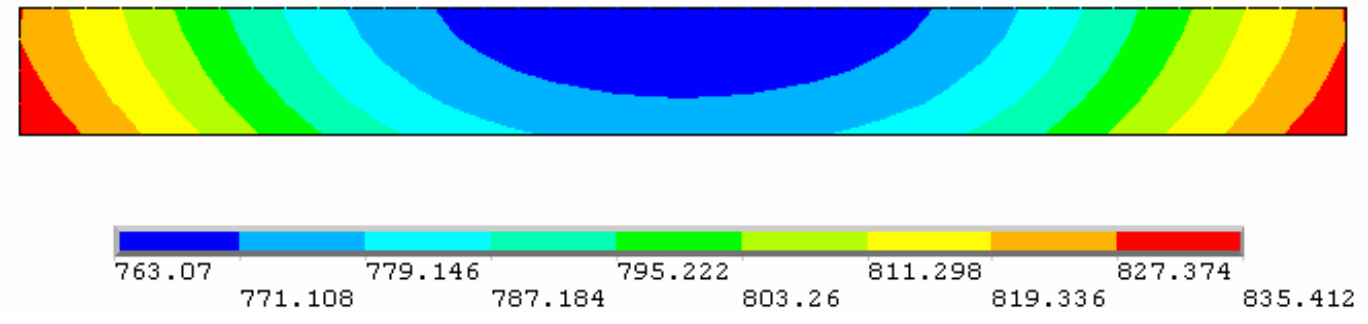

Figura 6.13 - Caso 2: (a) Malha de elementos finitos e (b) Campo de temperaturas correspondente a um tempo (TRRF) de 60 minutos para a chapa de aço (mesa do perfil W 250x25,3). 


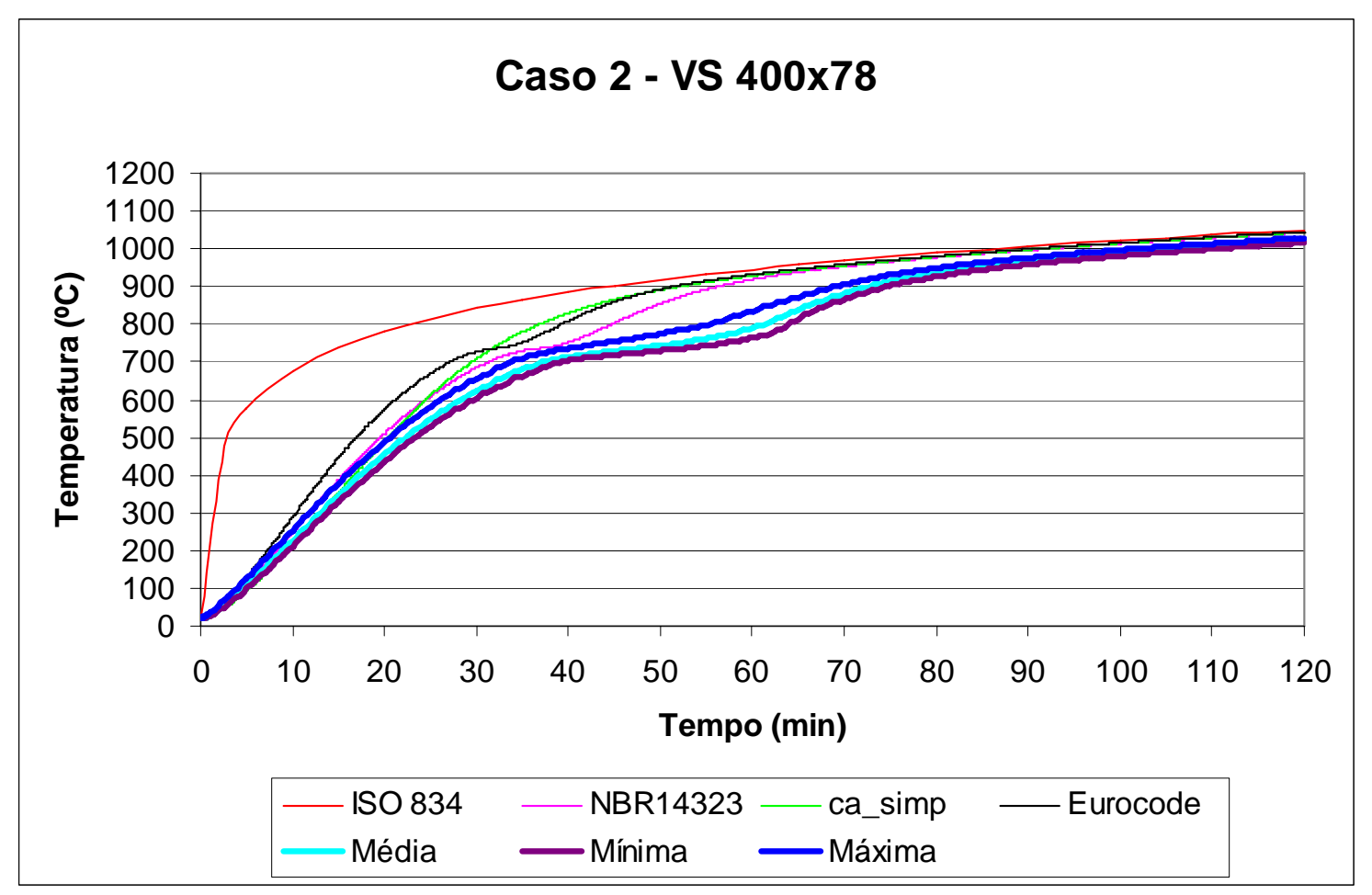

Figura 6.14 - Curvas da evolução da temperatura versus tempo para o caso 2 considerando-se o perfil (mesa do perfil) VS 400x78.

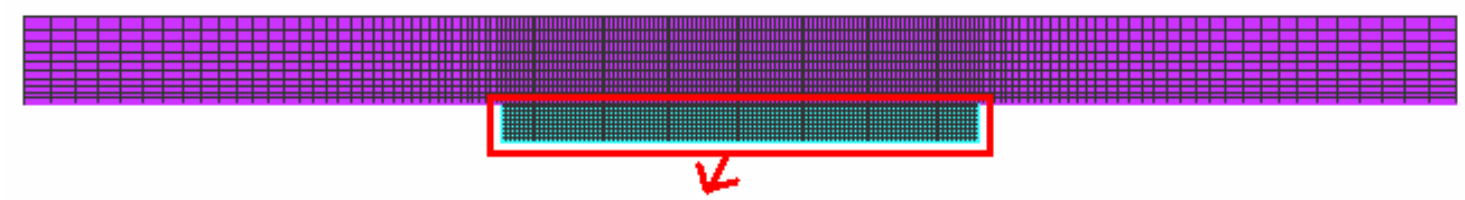

(a)

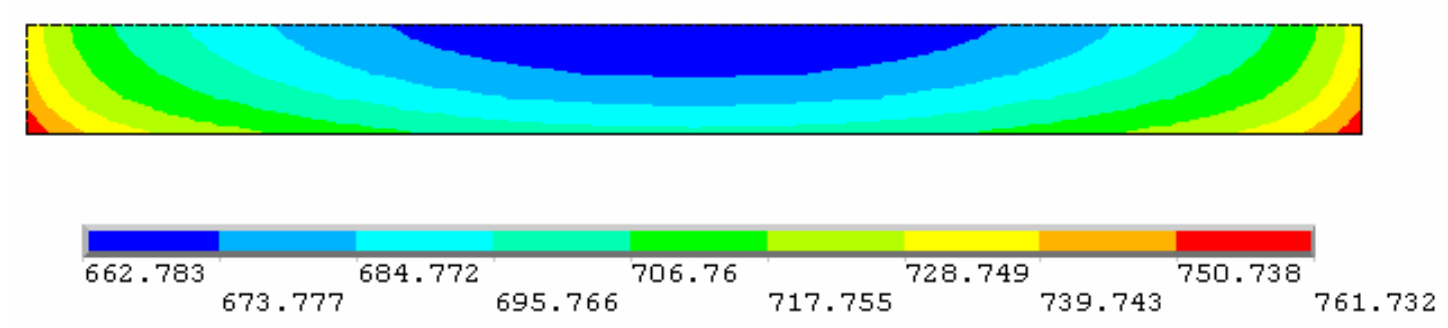

(b)

Figura 6.15 - Caso 2: (a) Malha de elementos finitos e (b) Campo de temperaturas correspondente a um tempo (TRRF) de 60 minutos para a chapa de aço (mesa do perfil CS 550x502). 


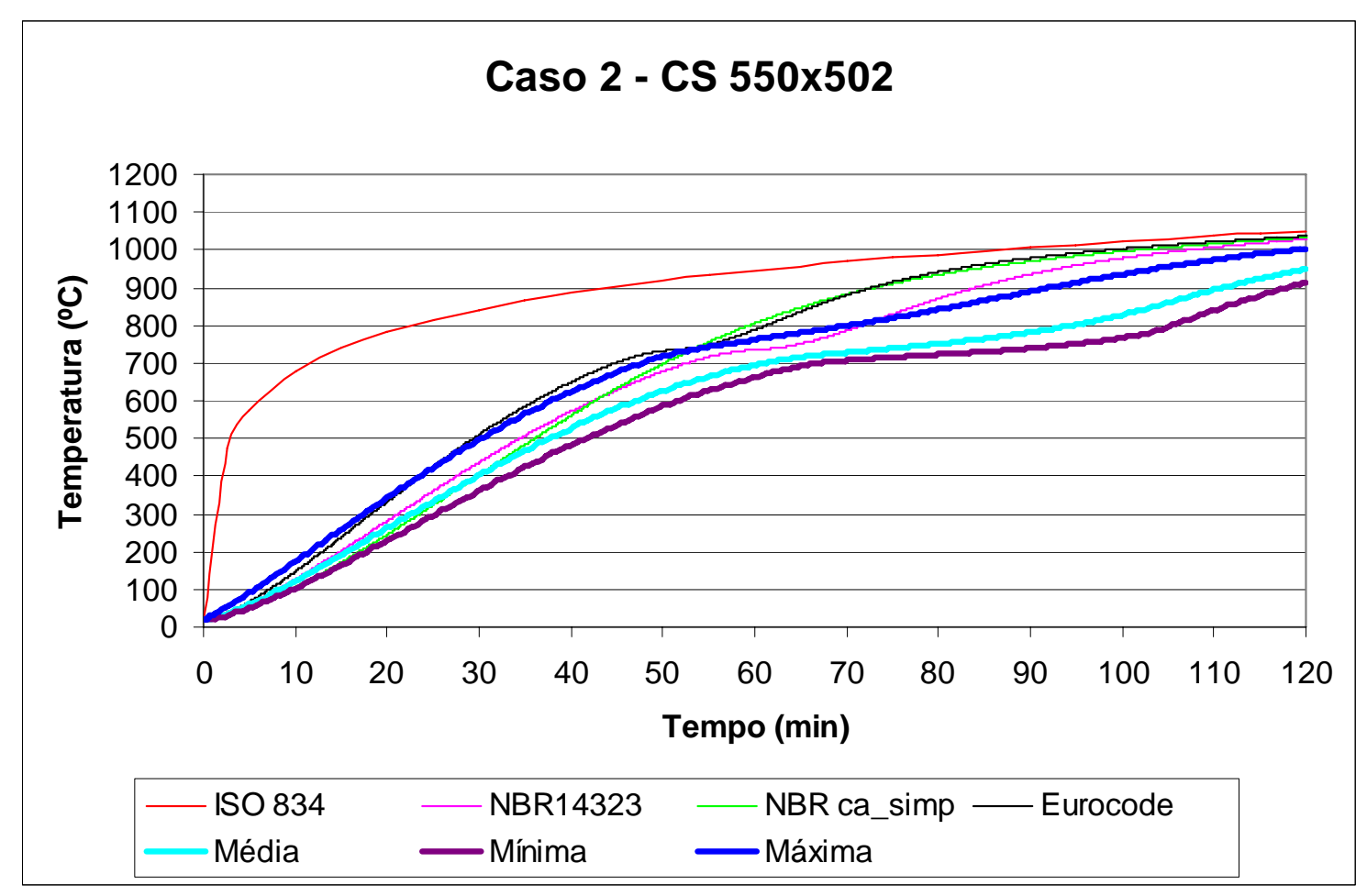

Figura 6.16 - Curvas da evolução da temperatura versus tempo para o caso 2 considerando-se o perfil (mesa do perfil) CS 550x502.

Para os resultados do CASO 2 nota-se que as curvas de evolução de temperaturas obtida por meio dos procedimentos da NBR 14323:1999 e do EUROCODE 3 (2005) resultam quase sempre acima da curva de temperatura máxima obtida via simulação numérica.

No caso da chapa com dimensões do perfil do tipo CS 550 x 502, a curva de elevação de temperatura obtida com procedimento da NBR 14323:1999 resulta com temperaturas inferiores às máximas obtidas numericamente, porém, maior que a temperatura média.

\subsubsection{CASO 3 - Mesa de seção I exposta ao incêndio por três lados}

Neste caso, tal qual no caso 2, a mesa do perfil é considerada em contato com alvenaria de blocos cerâmicos de tijolo vazado com espessura de $10 \mathrm{~cm}$.

A figura 6.17 ilustra a malha de elementos finitos e o campo de temperaturas para um tempo (TRRF) de 60 minutos de exposição ao incêndio-padrão para o caso de estudo 3, considerando um perfil W 150x13. Novamente, apresenta-se como resultado de interesse apenas o campo de temperaturas na mesa inferior. 


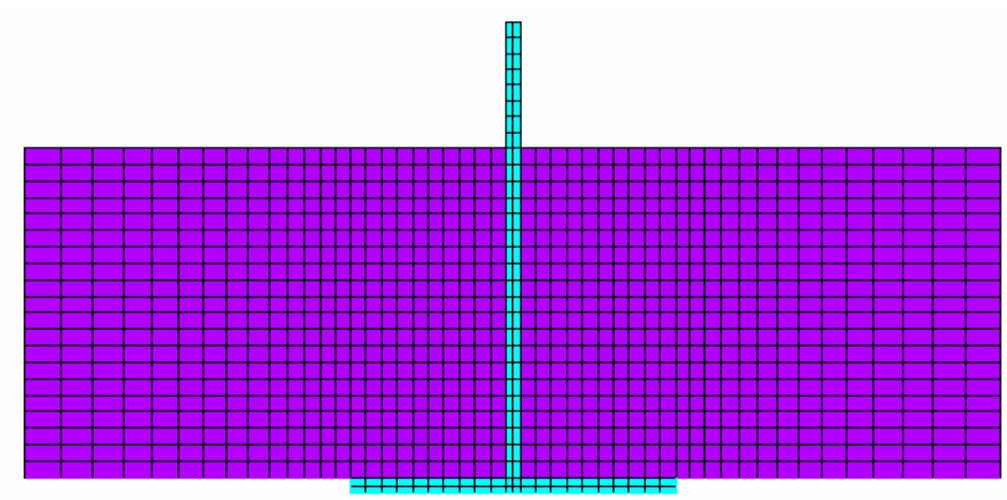

(a)

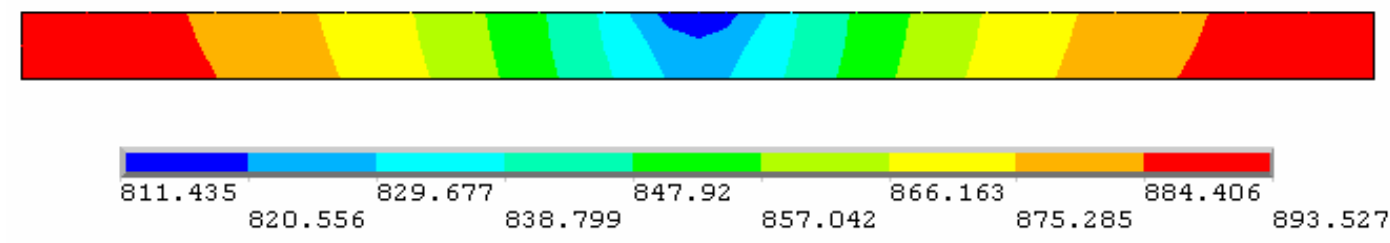

(b)

Figura 6.17 - Caso 3: (a) Malha de elementos finitos e (b) Campo de temperaturas correspondente a um tempo (TRRF) de 60 minutos para a mesa do perfil W 150x13.

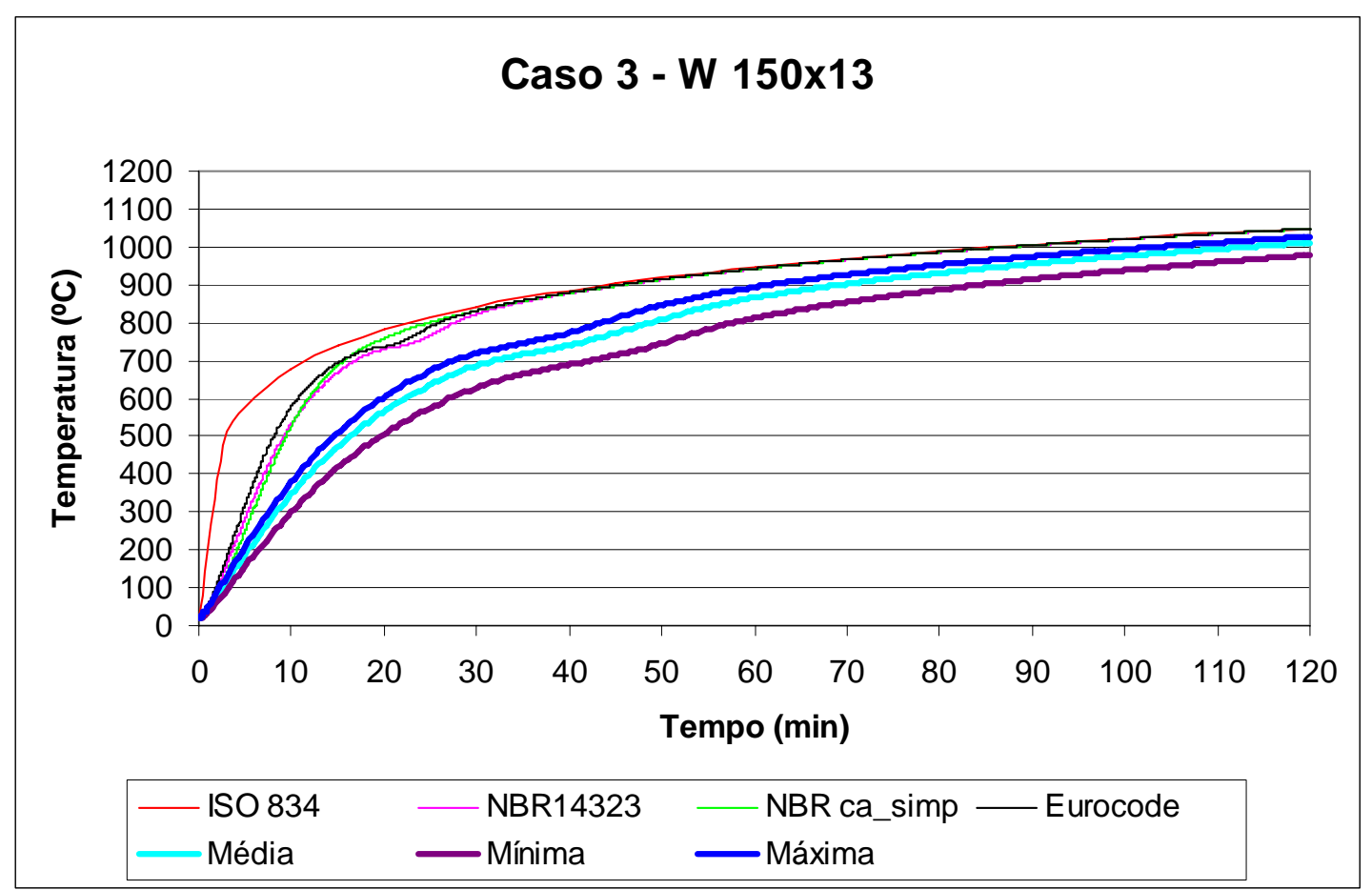

Figura 6.18 - Curvas da evolução da temperatura versus tempo para o caso 3 considerando-se a mesa do perfil W 150x13.

Na figuras 6.18 está apresentado os resultados da elevação de temperatura obtidos via modelo numérico e por meio de procedimentos simplificados de cálculo da 
NBR 14323:1999 e do EUROCODE 3 (2005). Nas figuras 6.19 a 6.24 têm-se os outros resultados deste caso considerando-se os demais perfis da análise.

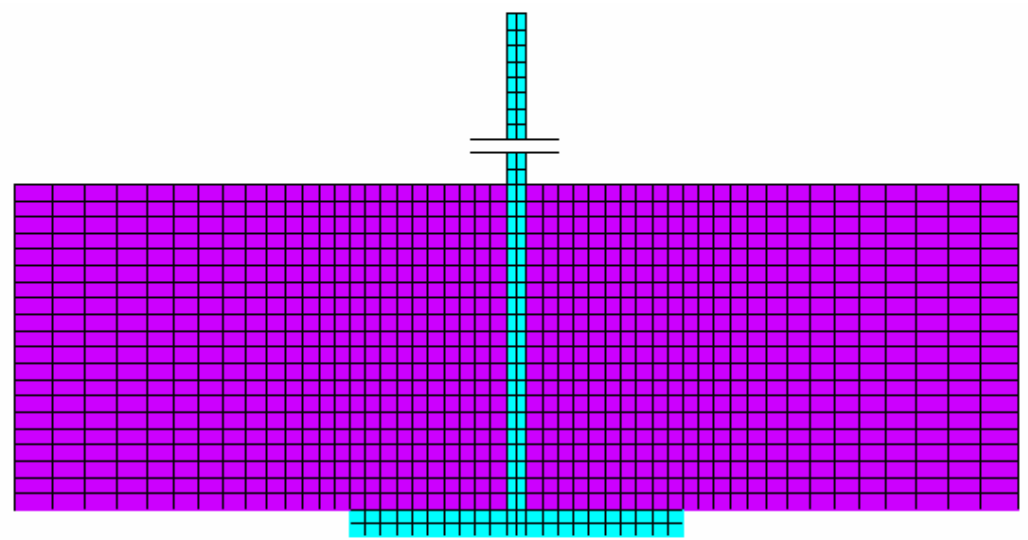

(a)
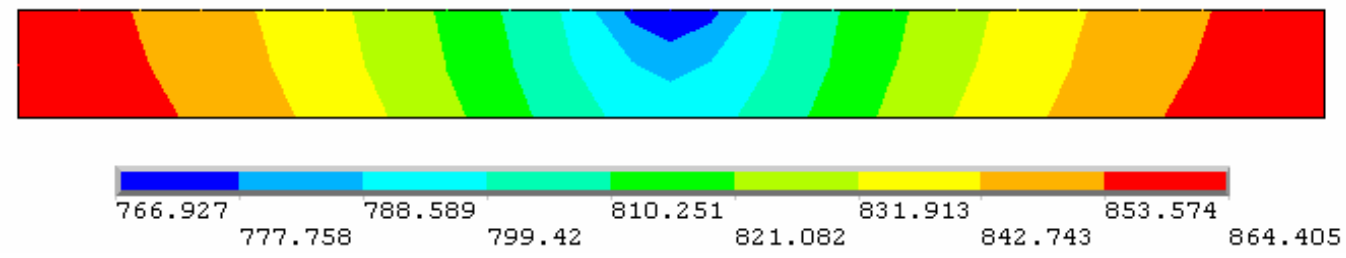

(b)

Figura 6.19 - Caso 3: (a) Malha de elementos finitos e (b) Campo de temperaturas correspondente a um tempo (TRRF) de 60 minutos para a mesa do perfil W 250x25,3.

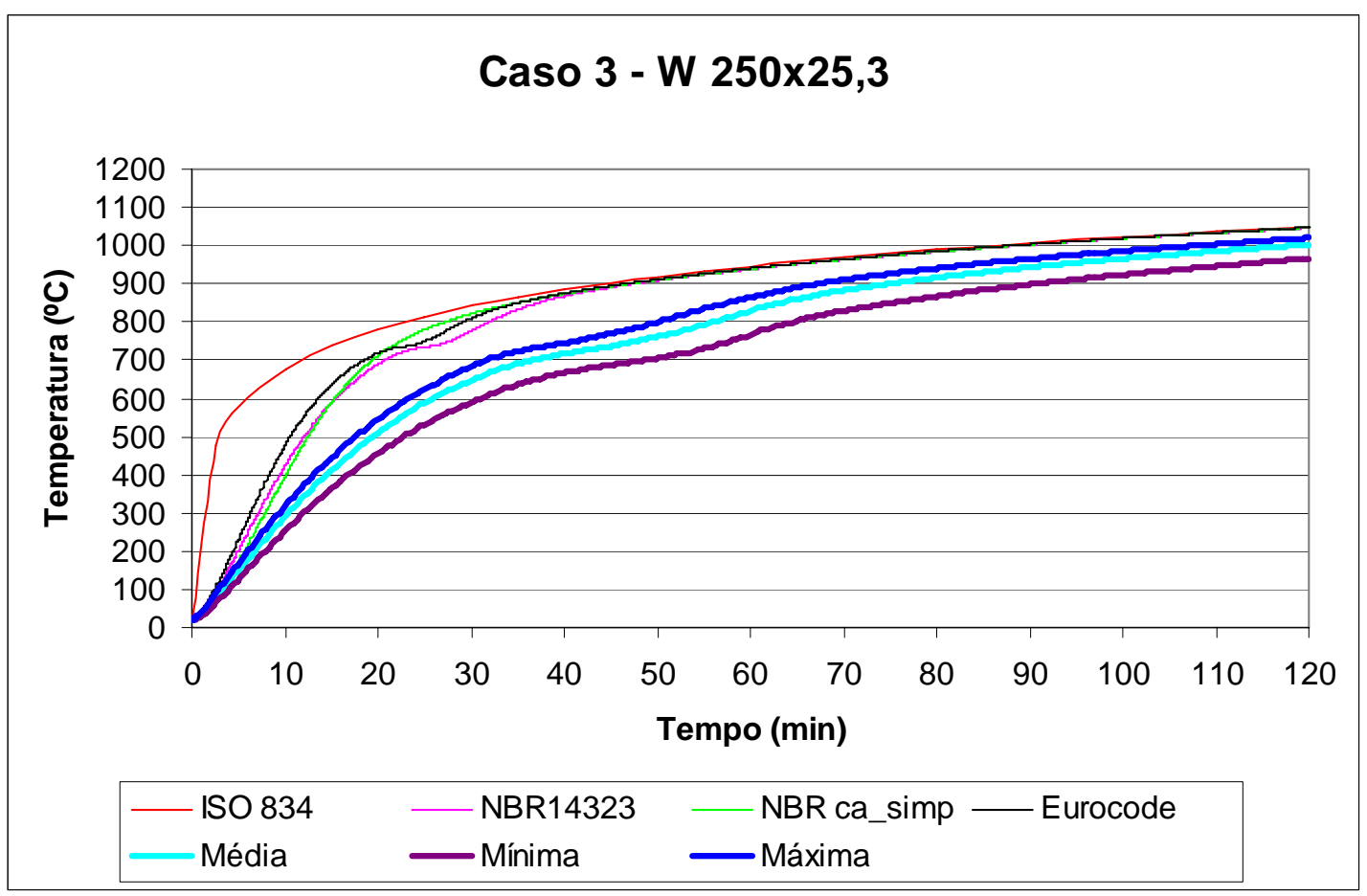

Figura 6.20 - Curvas da evolução da temperatura versus tempo para o caso 3 considerando-se a mesa do perfil W 250x25,3. 


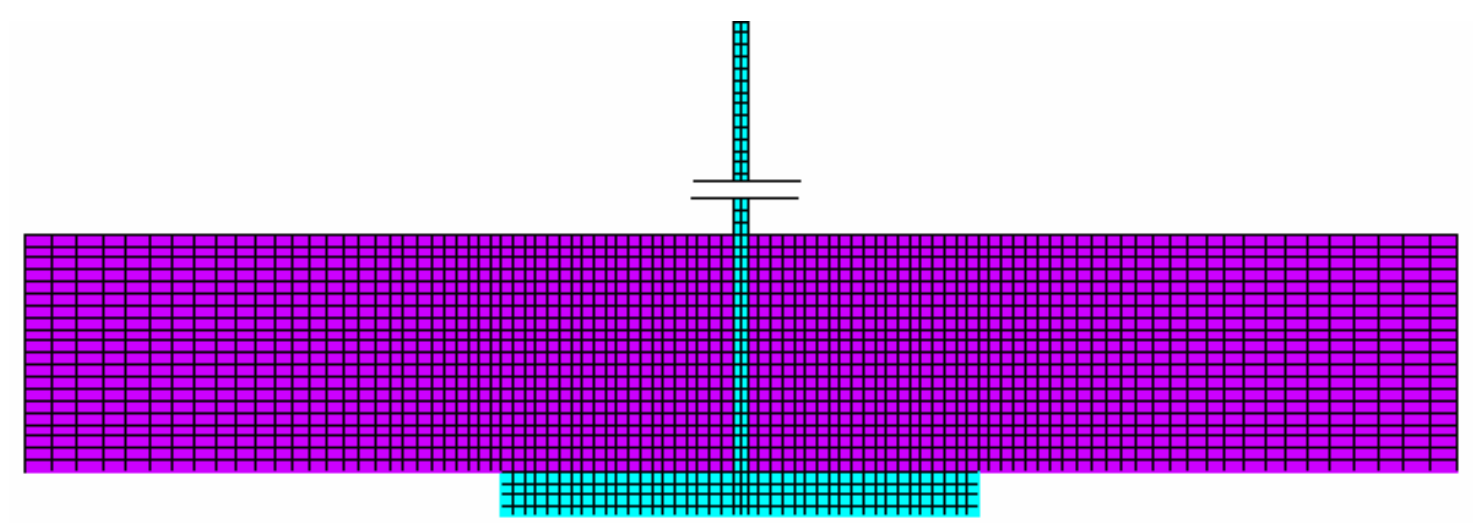

(a)
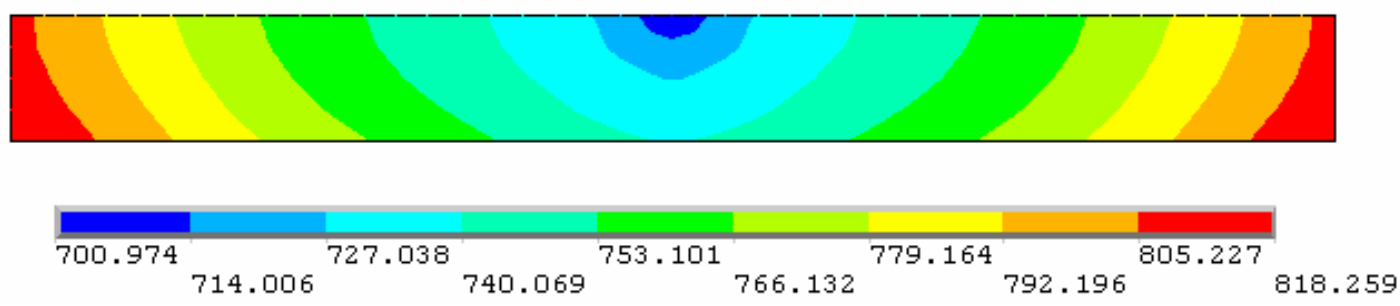

(b)

Figura 6.21 - Caso 3: (a) Malha de elementos finitos e (b) Campo de temperaturas correspondente a um tempo (TRRF) de 60 minutos para a mesa do perfil VS 400x78.

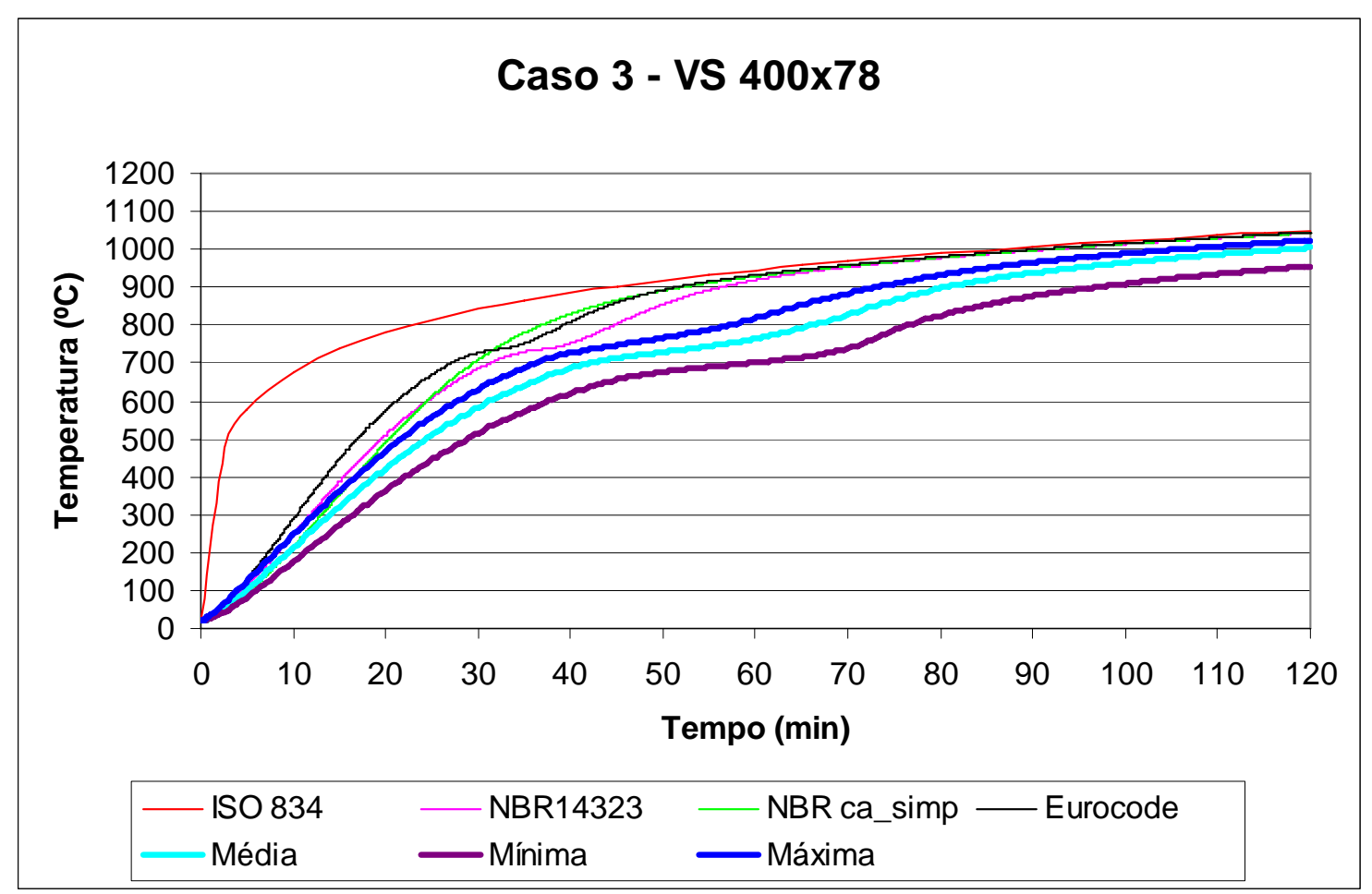

Figura 6.22 - Curvas da evolução da temperatura versus tempo para o caso 3 considerando-se a mesa do perfil VS 400x78. 


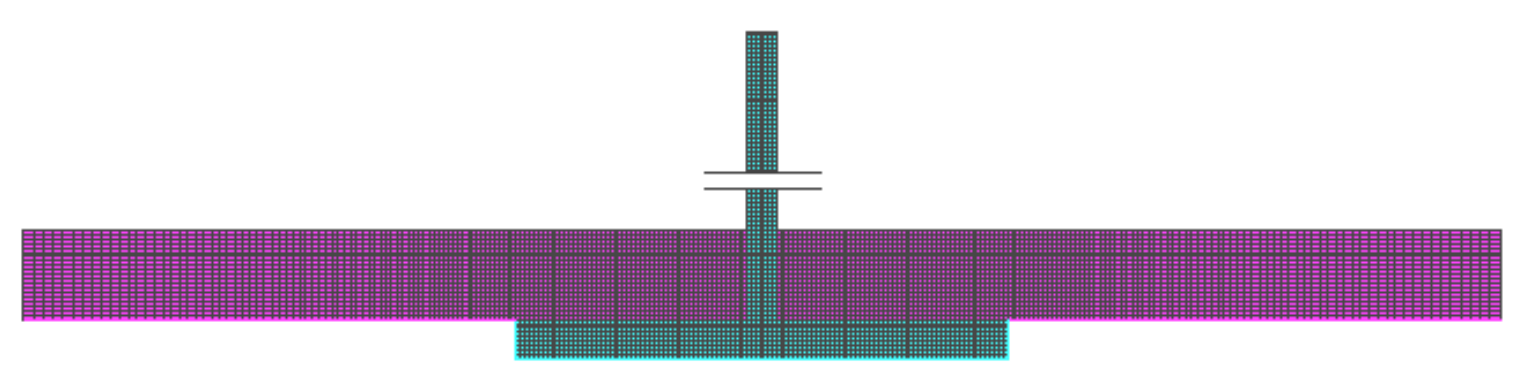

(a)

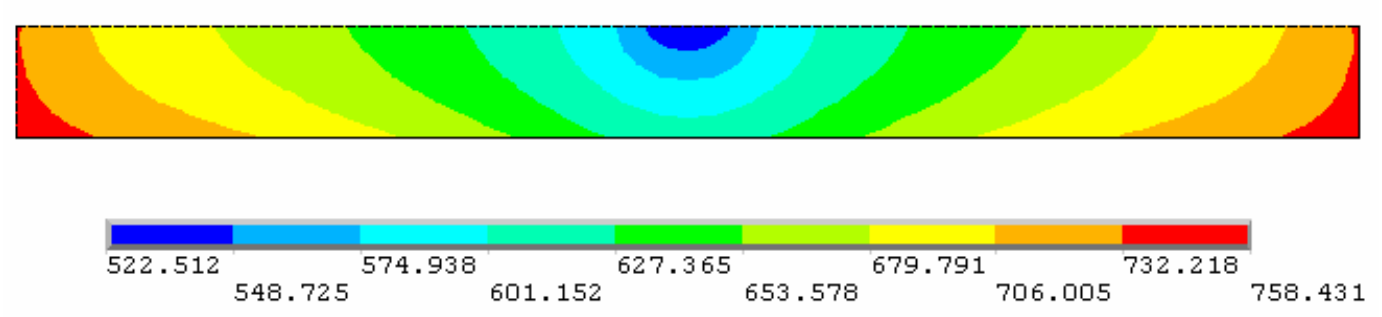

(b)

Figura 6.23 - Caso 3: (a) Malha de elementos finitos e (b) Campo de temperaturas correspondente a um tempo (TRRF) de 60 minutos para a mesa do perfil CS 550x502.

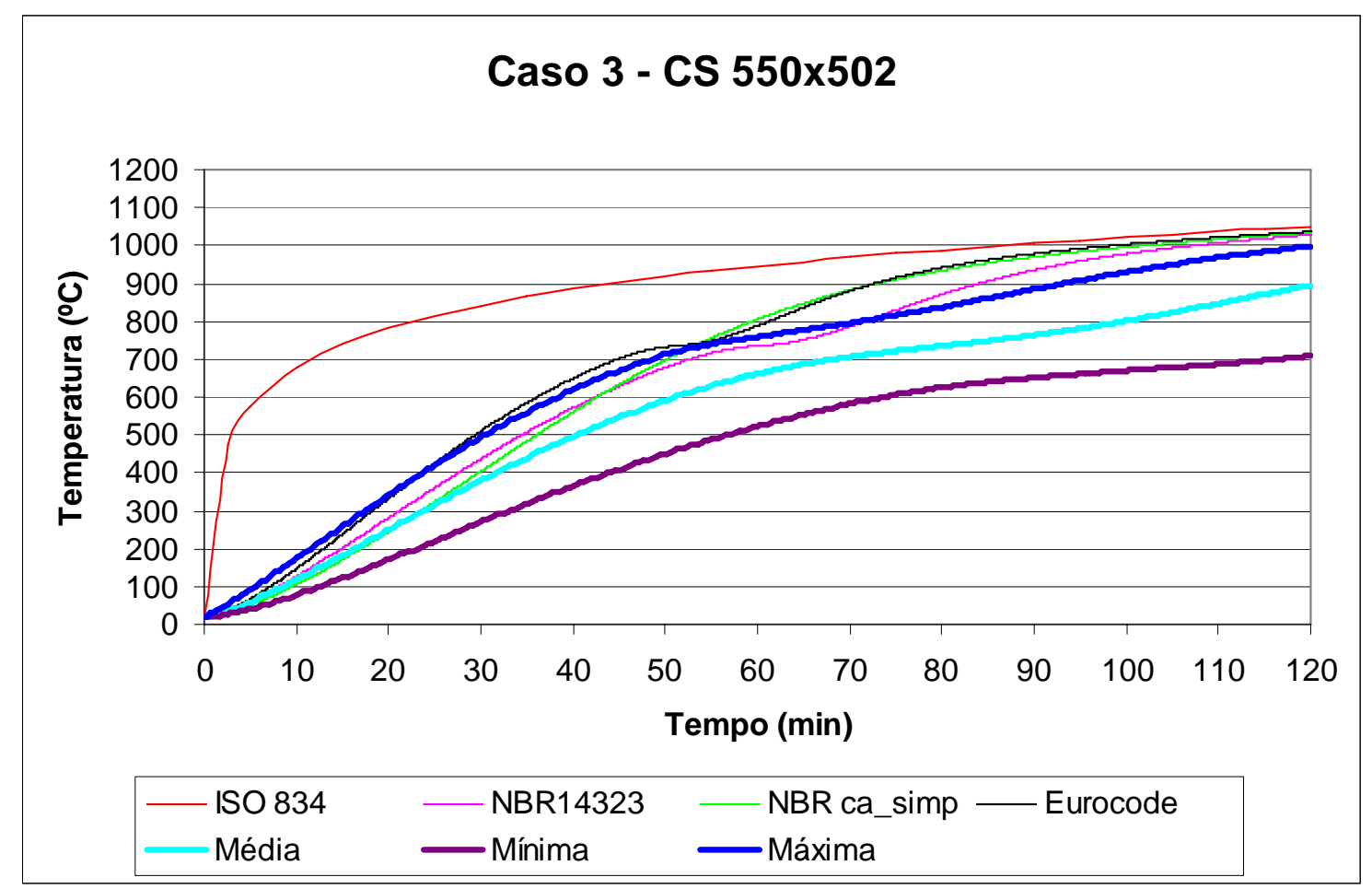

Figura 6.24 - Curvas da evolução da temperatura versus tempo para o caso 3 considerando-se a mesa do perfil CS 550x502.

Com a análise dos resultados obtidos para o CASO 3 podem ser feitas às mesmas considerações feitas para o caso 2, com a exceção da maior diferença entre as temperaturas máximas e mínimas obtidas via simulação numérica. 


\subsubsection{CASO 4 - Seção I com reforço em caixão exposta ao incêndio por todos os lados}

Este caso trata das seções I com reforço em caixão submetida à elevação de temperatura uniforme por todos os lados. O reforço das seções I foi considerado com a mesma espessura da alma dos perfis.

As condições de contorno no exterior do perfil estão de acordo com as considerações feitas no item 6.1.1. Porém, para levar em conta a troca de calor entre as paredes internas das cavidades do elemento de aço, definiu-se a emissividade ( $\varepsilon$ ) para as superfícies internas (das cavidades) com valor igual a 0,7. Por meio da definição das paredes da cavidade irradiando uma para as outras, o ANSYS calcula o fluxo de calor em cada superfície com base nas temperaturas das referidas superfícies.

Nas figuras 6.25 a 6.32, têm-se a malha de elementos finitos, o campo de temperaturas para um tempo (TRRF) de 60 minutos e os resultados da elevação de temperatura obtidos via modelo numérico e por meio de procedimentos simplificados de cálculo da NBR 14323:1999 e do EUROCODE 3 (2005).

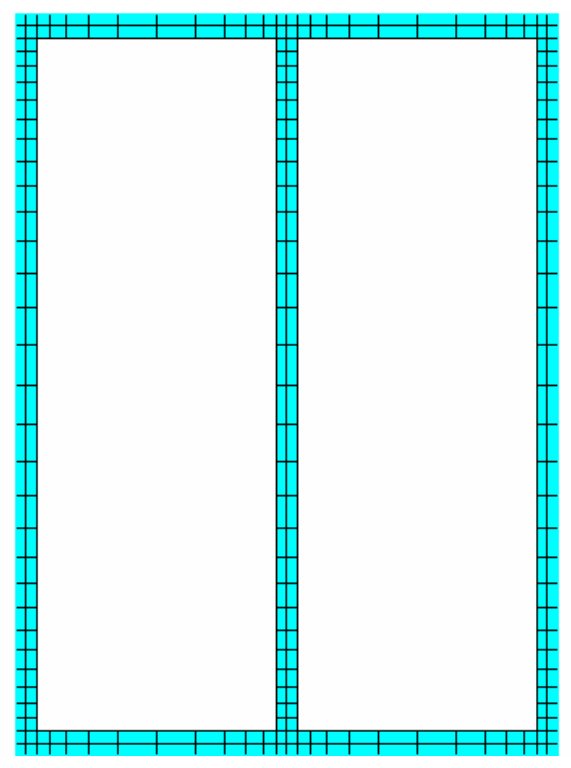

(a)

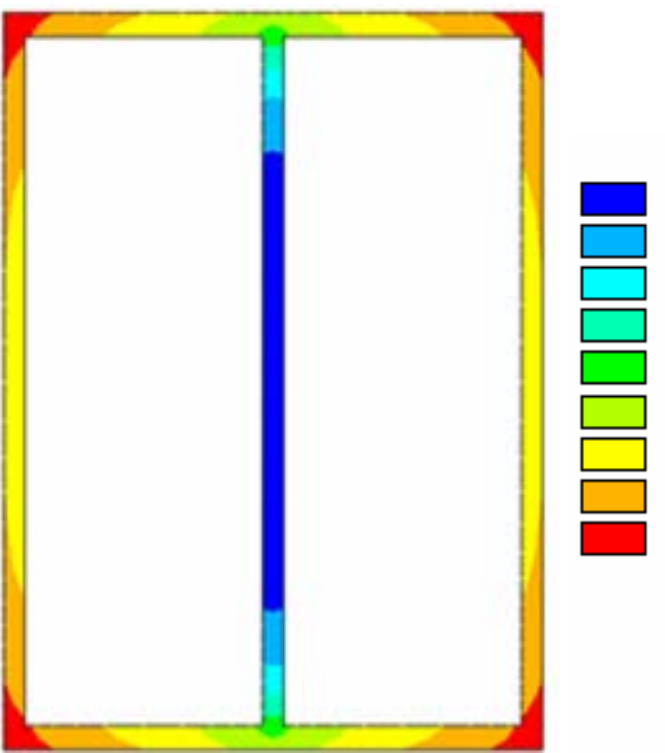

(b)
936.746

937.095

937.444

937.792

938.141

938.49

938.838

939.187

939.536

939.884

Figura 6.25 - Caso 4: (a) Malha de elementos finitos e (b) Campo de temperaturas correspondente a um tempo (TRRF) de 60 minutos para o perfil W 150x13. 


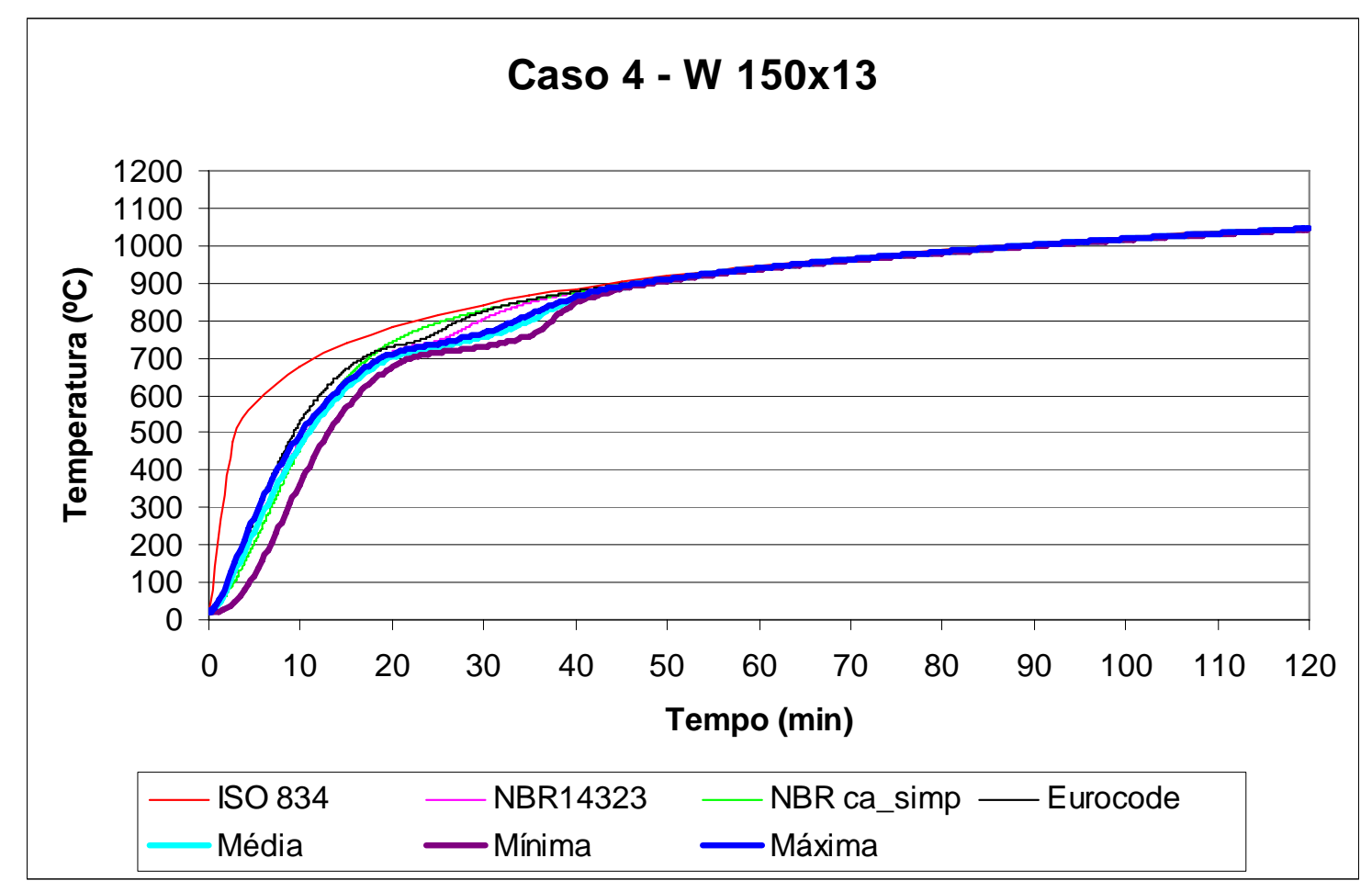

Figura 6.26 - Curvas da evolução da temperatura versus tempo para o caso 4 considerando-se o perfil W 150x13.

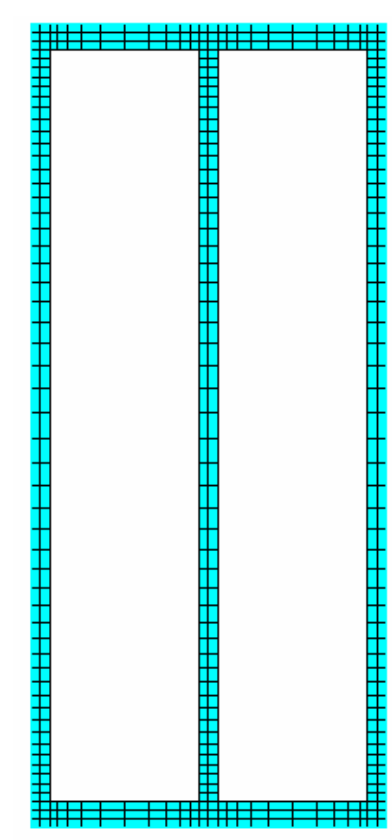

(a)

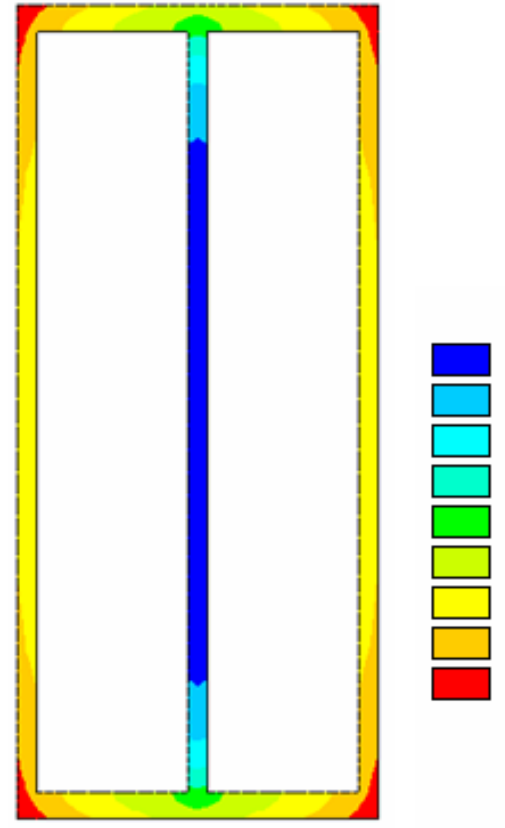

929.5

930.183

930.866

931.549

932.232

932.915

933.598

934.281

934.964

935.647

Figura 6.27 - Caso 4: (a) Malha de elementos finitos e (b) Campo de temperaturas correspondente a um tempo (TRRF) de 60 minutos para o perfil W 250x25,3. 


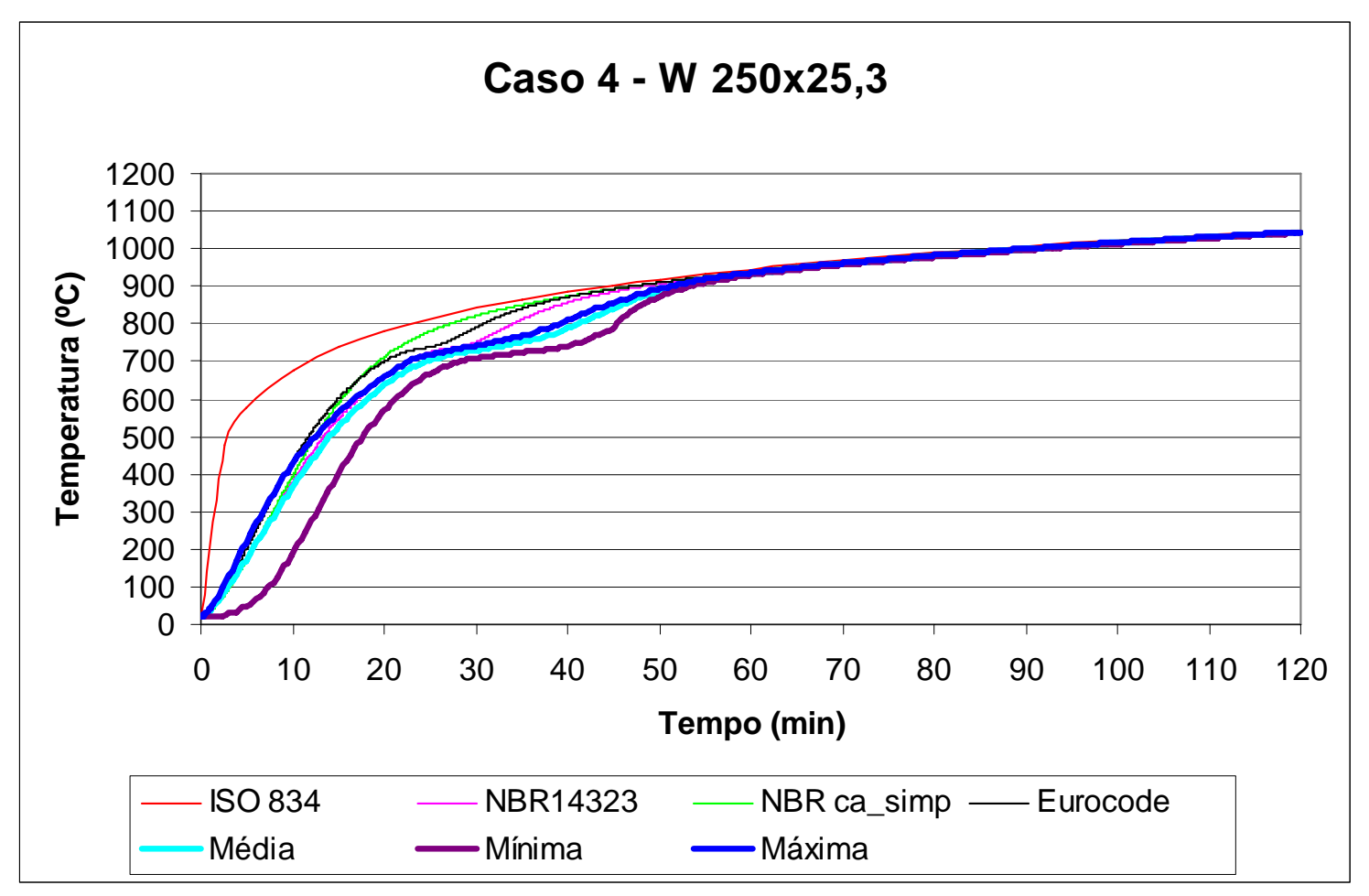

Figura 6.28 - Curvas da evolução da temperatura versus tempo para o caso 4 considerando-se o perfil W 250x25,3.
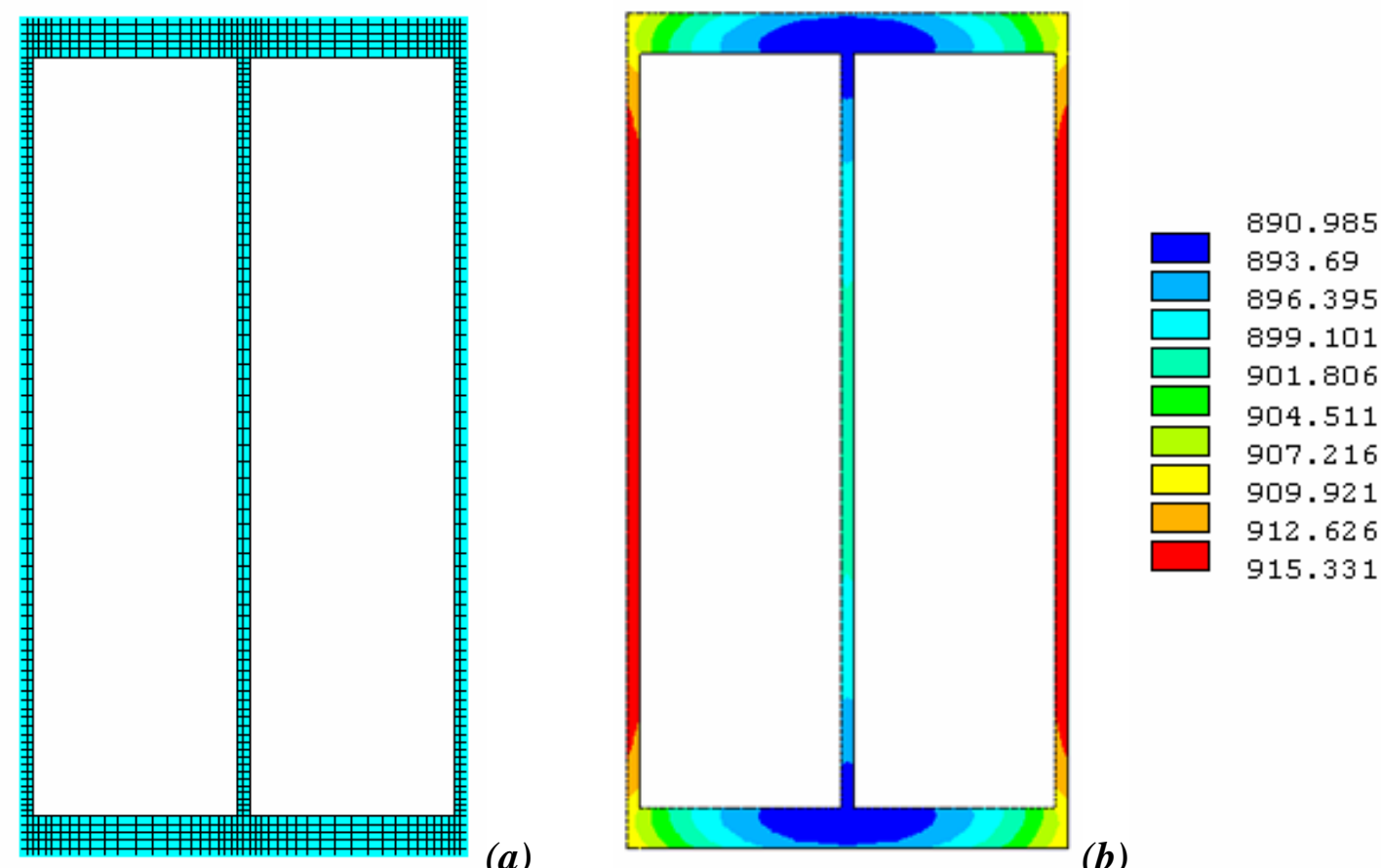

(a)

(b)

Figura 6.29 - Caso 4: (a) Malha de elementos finitos e (b) Campo de temperaturas correspondente a um tempo (TRRF) de 60 minutos para o perfil VS 400x78. 




Figura 6.30 - Curvas da evolução da temperatura versus tempo para o caso 4 considerando-se o perfil VS 400x78.

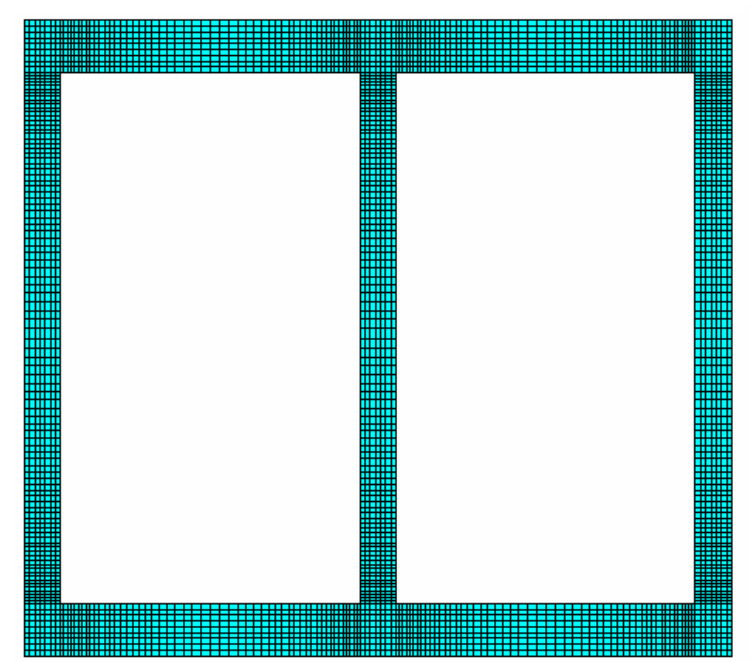

(a)

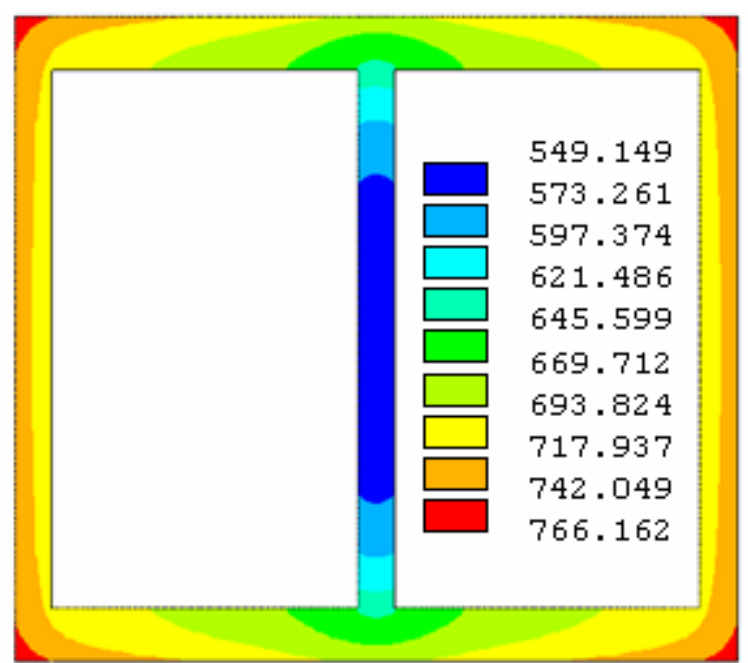

(b)

Figura 6.31 - Caso 4: (a) Malha de elementos finitos e (b) Campo de temperaturas correspondente a um tempo (TRRF) de 60 minutos para o perfil CS 550x502. 


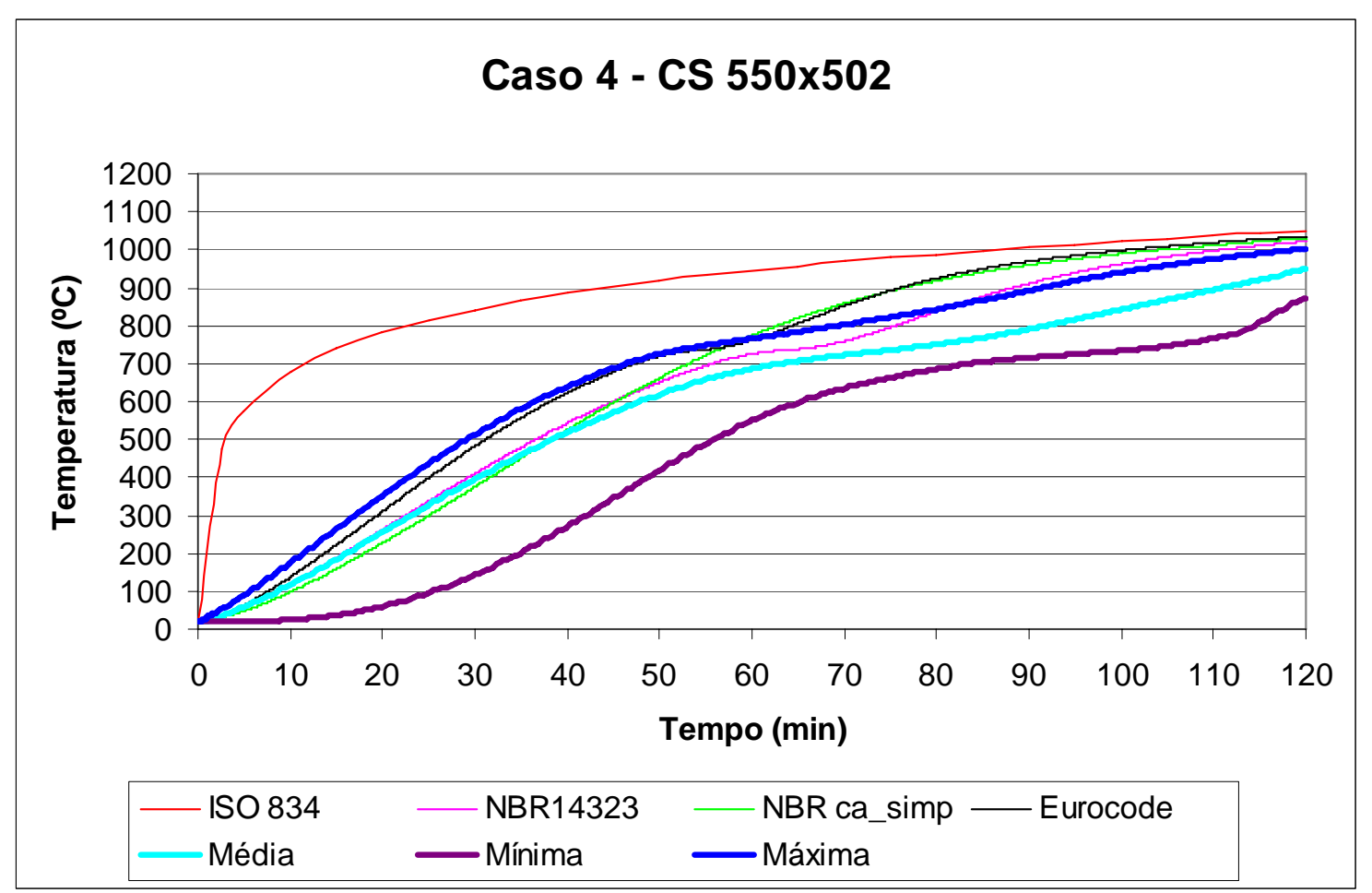

Figura 6.32 - Curvas da evolução da temperatura versus tempo para o caso 4 considerando-se o perfil CS 550x502.

Com relação aos resultados obtidos para o CASO 4 é importante notar que a curvas de evolução de temperaturas obtida por meio do procedimento do EUROCODE 3 (2005) acompanha quase sempre a curva de temperatura máxima obtida via simulação numérica. A curva de elevação de temperatura obtida com procedimento da NBR 14323:1999, no entanto, acompanha a curva de temperatura média da seção obtida via simulação numérica na etapa inicial de aquecimento, porém, superando essas em fases intermediárias.

Tanto para o CASO 2 quanto para os CASOS 3 e 4, as temperaturas obtida por meio do procedimento do EUROCODE 3 (2005) são ligeiramente superiores àquelas obtidas por meio do procedimento da NBR 14323:1999. Isto se deve ao fato do EUROCODE 3 adotar 0,7 para o valor da emissividade resultante em contraste com o valor de 0,5 adotado pela NBR 14323:1999. Além disso, para o EUROCODE 3, estes são casos de seções transversais de forma convexa, e o fator de correção para o efeito de sombra, definido no capítulo 4 e empregado na equação do procedimento do EUROCODE 3, não tem influência e consequentemente deve ser tomado igual a unidade. 


\subsubsection{CASO 5 - Seção I com proteção tipo caixa, de espessura uniforme, exposta ao incêndio por todos os lados}

A proteção adotada para as seções de aço, considerando o caso em questão, consiste de placa de gesso acartonado RF (resistente ao fogo) com espessura de 12,5 mm, usual no Brasil. As propriedades térmicas da placas foram extraídas de VARGAS e SILVA (2003). A massa específica é de $800 \mathrm{~kg} / \mathrm{m}^{3}$, o calor específico igual 1200 $\mathrm{J} /\left(\mathrm{kg}^{\circ} \mathrm{C}\right)$ e a condutividade térmica igual a $0,15 \mathrm{~W} /\left(\mathrm{m}^{\circ} \mathrm{C}\right)$.

Este caso, do ponto de vista geométrico e das condições de contorno, é similar ao caso 4. Para levar em conta a troca de calor entre as paredes internas das cavidades do elemento definiu-se uma emissividade $\varepsilon$ para as superfícies internas das cavidades com valor igual a 0,7 , tanto para o material aço quanto para o revestimento.

Como no caso anterior, por meio da definição das paredes da cavidade irradiando uma para as outras o ANSYS calcula o fluxo de calor em cada superfície com base nas temperaturas das referidas superfícies.

Nas figuras que se seguem (figuras 6.33 a 6.42) têm-se a malha de elementos finitos, o campo de temperaturas para um tempo (TRRF) de 60 minutos e os resultados da elevação de temperatura obtidos via modelo numérico e por meio de procedimentos simplificados de cálculo da NBR 14323:1999 e EUROCODE 3 (2005), que para o caso de elementos revestidos são idênticos. Apresenta-se ainda resultados obtidos com o procedimento do projeto de revisão da NBR 14323, que adota a equação da elevação de temperatura em elementos protegidos proposta em SILVA (1999) e SILVA (2005).
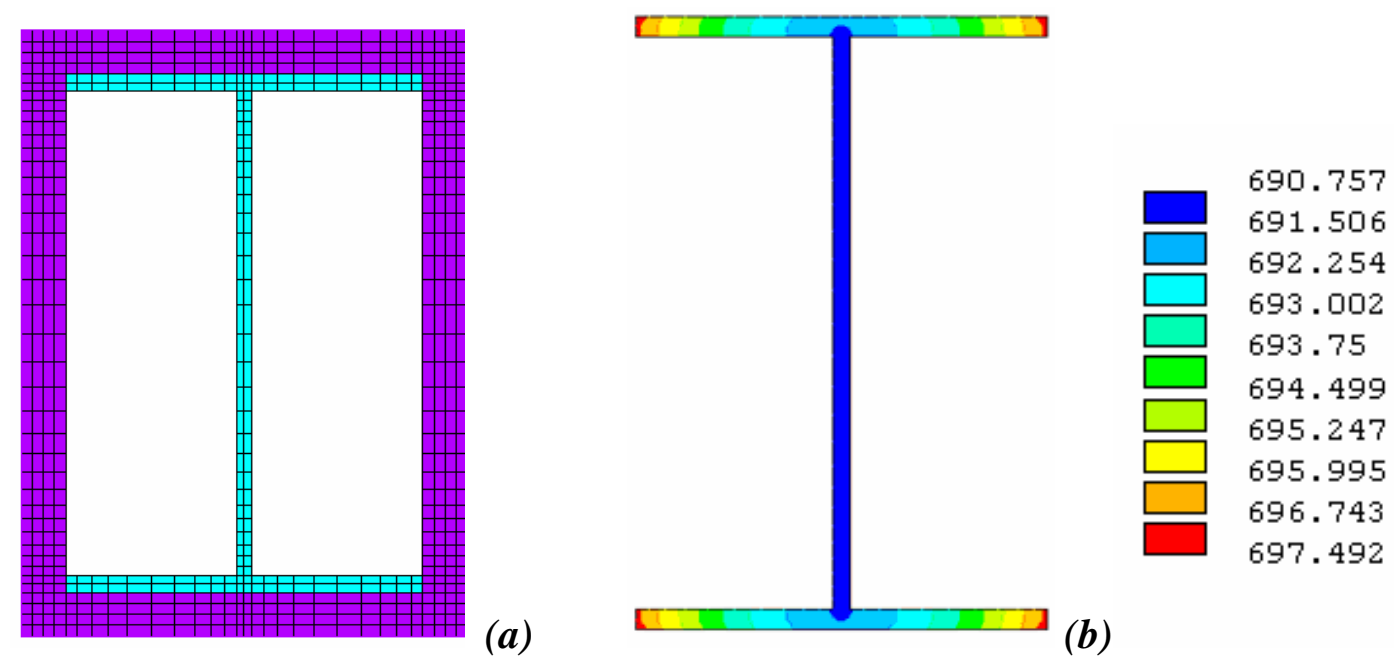

Figura 6.33 - Caso 5: (a) Malha de elementos finitos e (b) Campo de temperaturas correspondente a um tempo (TRRF) de 60 minutos para o perfil W 150x13. 


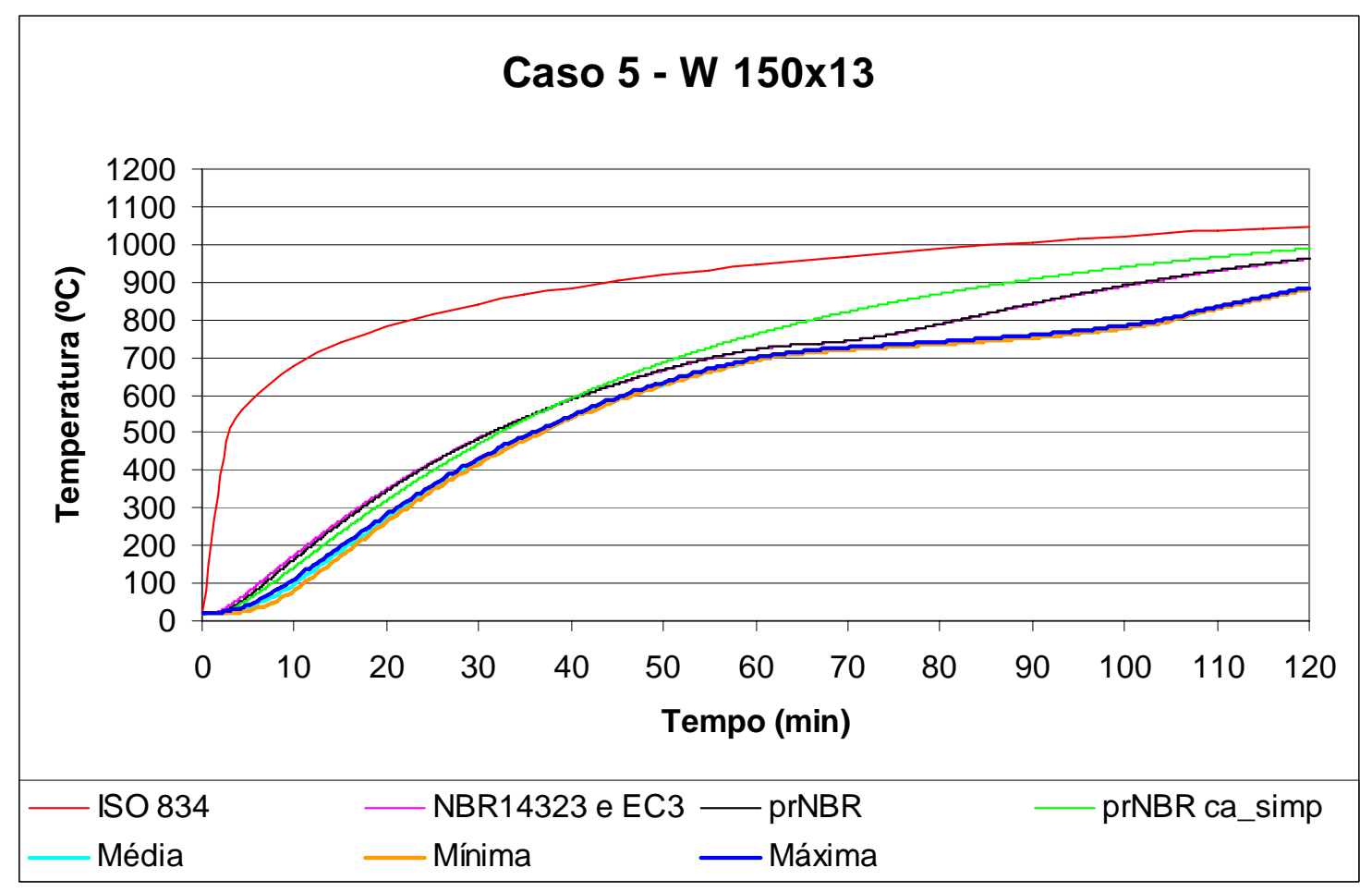

Figura 6.34 - Curvas da evolução da temperatura versus tempo para o caso 5 considerando-se o perfil W 150x13.

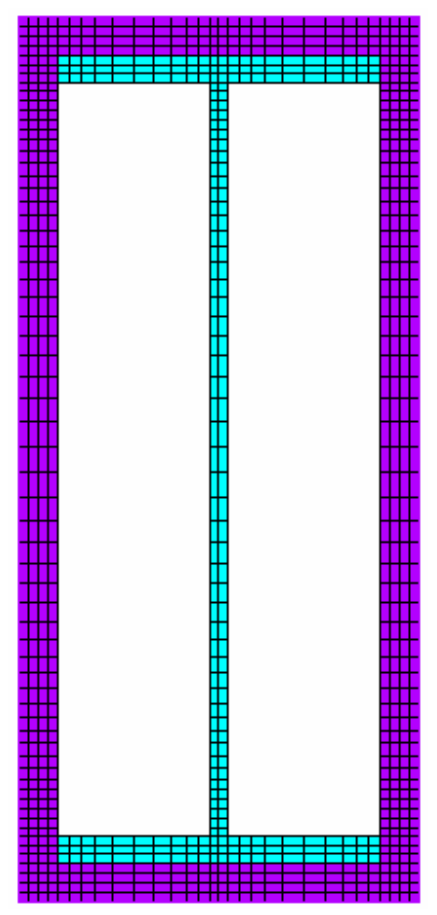

(a)

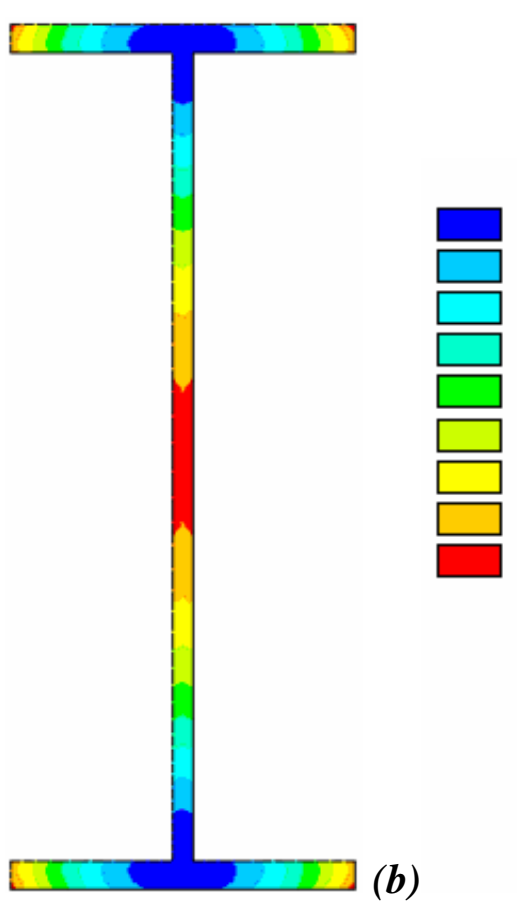

612.992

613.648

614.304

614.96

615.616

616.272

616.928

617.584

618.24

618.896

Figura 6.35 - Caso 5: (a) Malha de elementos finitos e (b) Campo de temperaturas correspondente a um tempo (TRRF) de 60 minutos para o perfil W 250x25,3. 


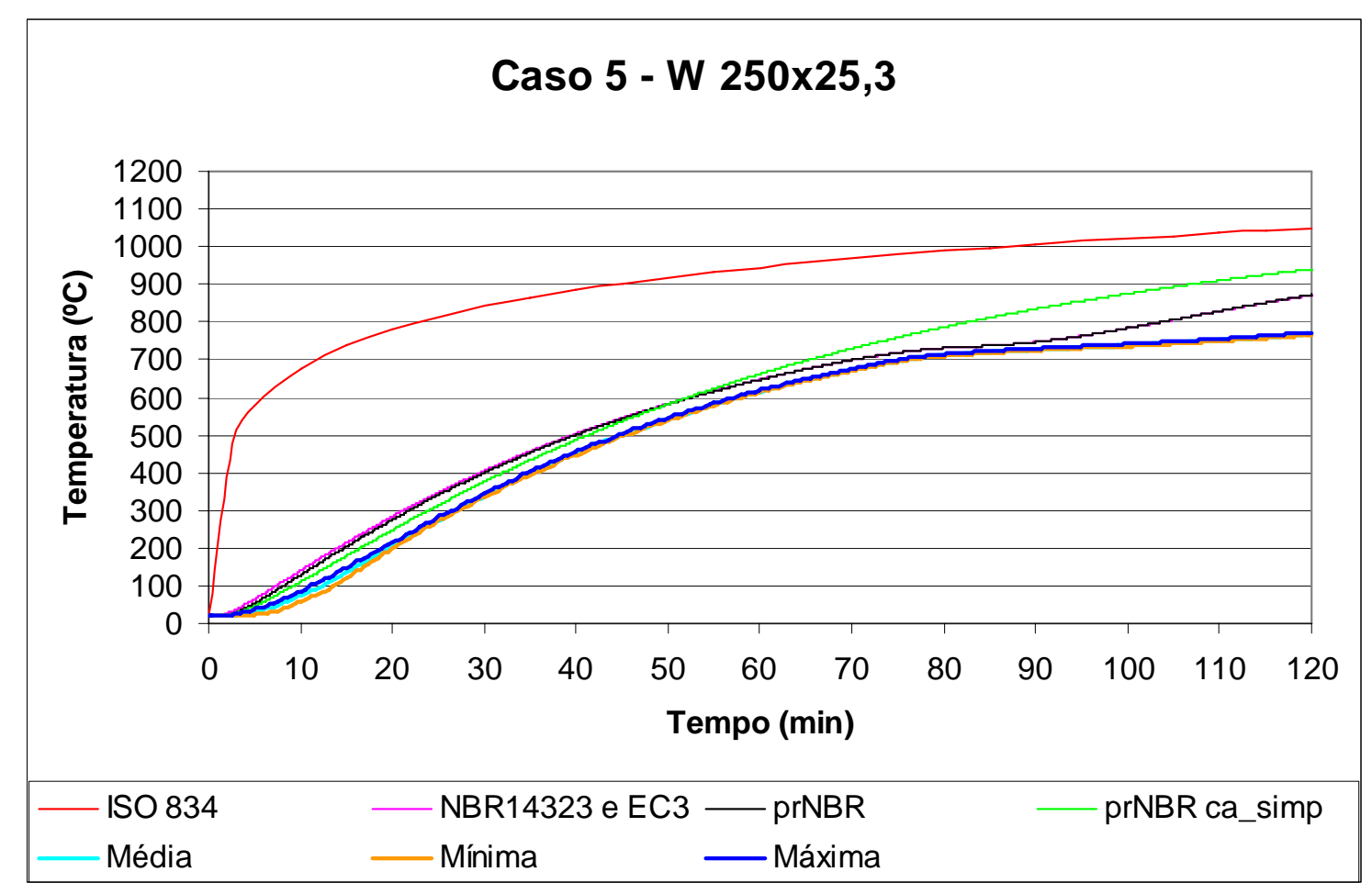

Figura 6.36 - Curvas da evolução da temperatura versus tempo para o caso 5 considerando-se o perfil W 250x25,3.
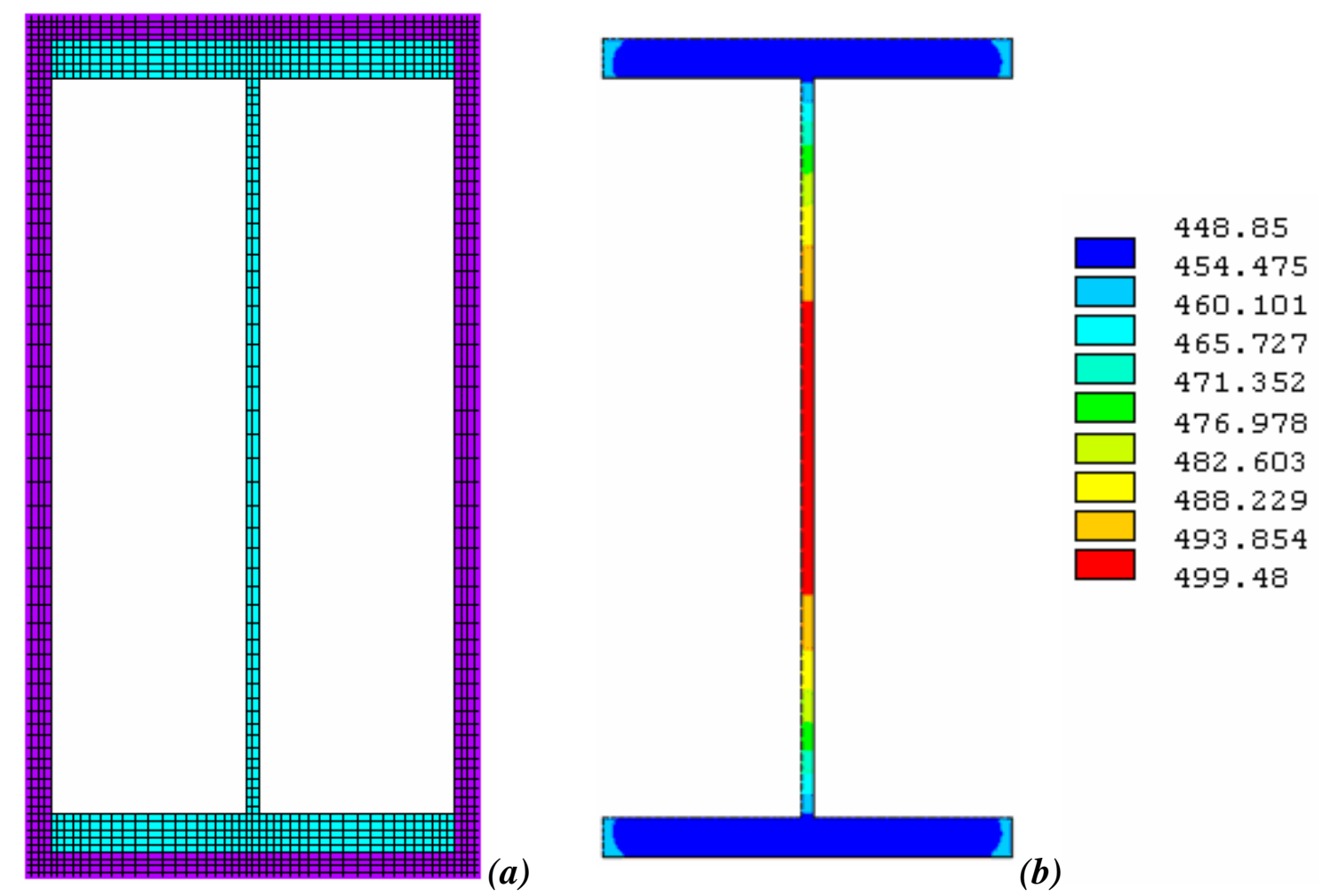

Figura 6.37 - Caso 5: (a) Malha de elementos finitos e (b) Campo de temperaturas correspondente a um tempo (TRRF) de 60 minutos para o perfil VS 400x78. 


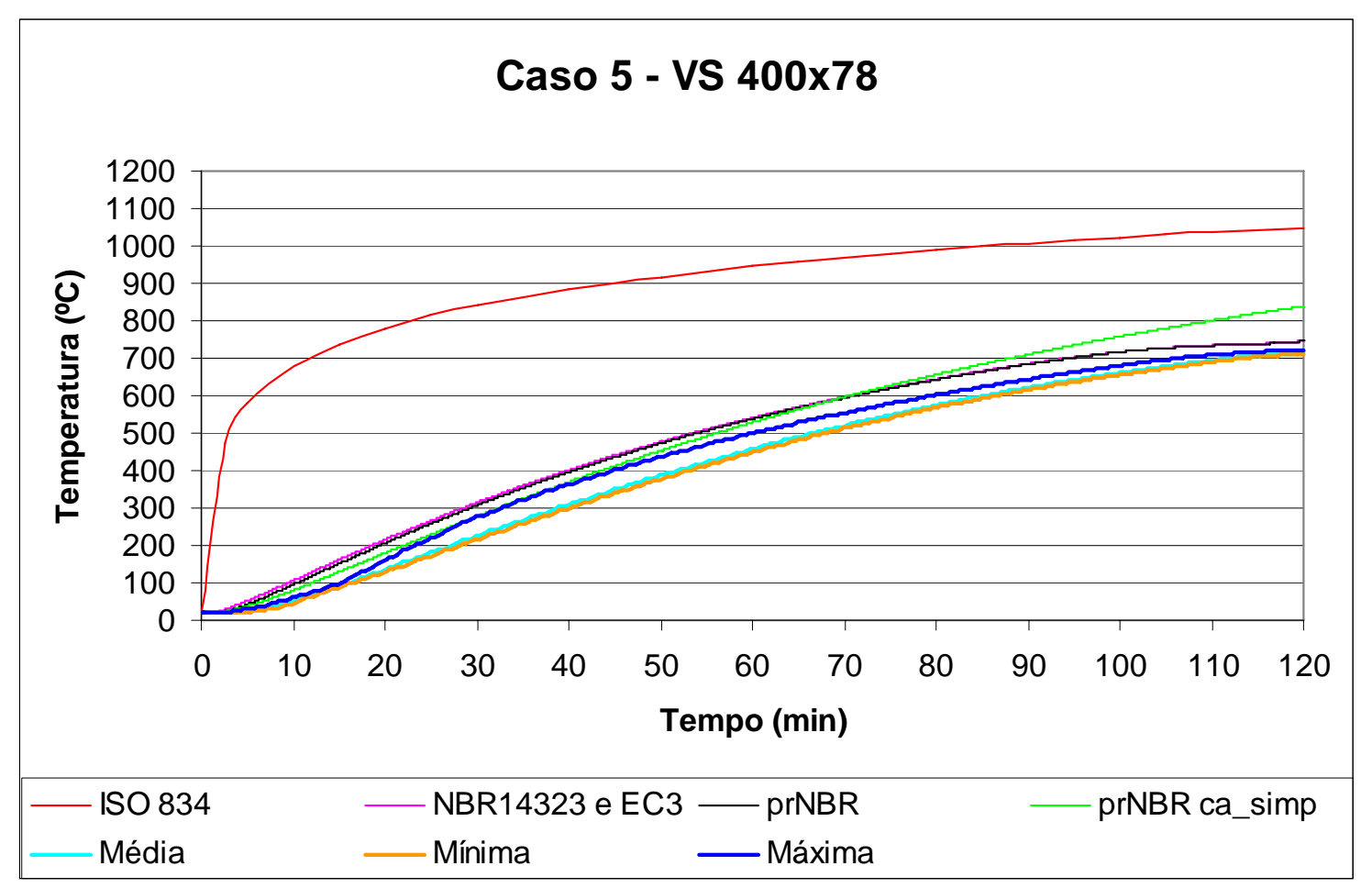

Figura 6.38 - Curvas da evolução da temperatura versus tempo para o caso 5 considerando-se o perfil VS 400x78.

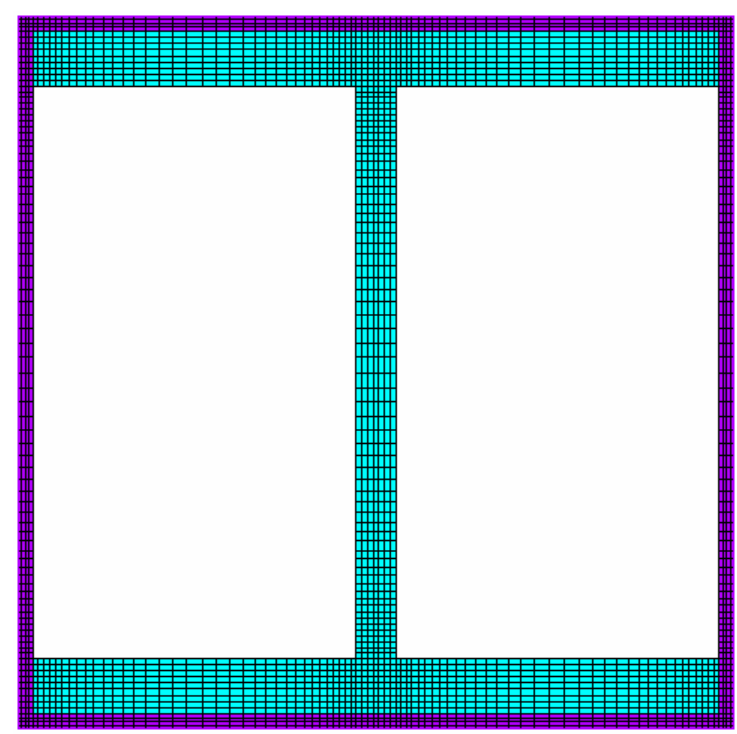

(a)

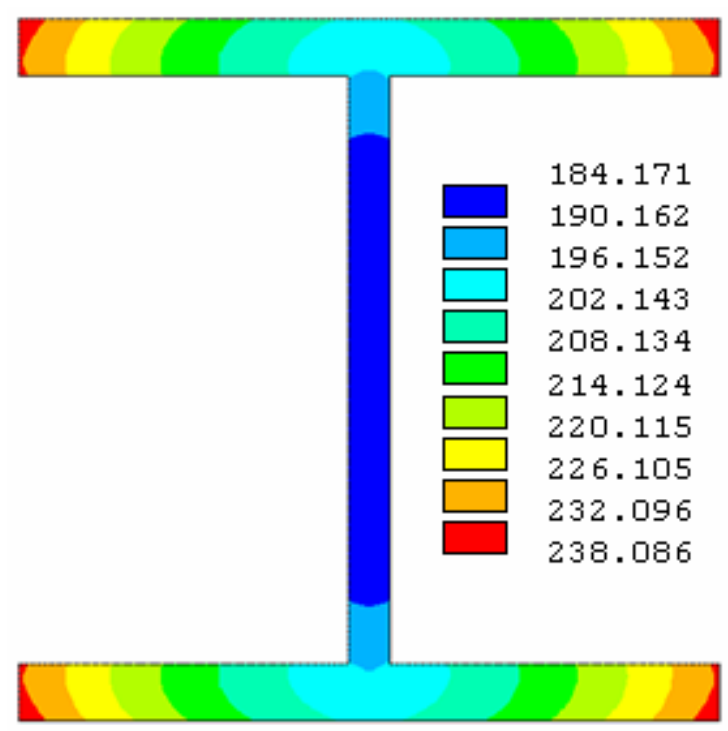

(b)

Figura 6.39 - Caso 5: (a) Malha de elementos finitos e (b) Campo de temperaturas correspondente a um tempo (TRRF) de 60 minutos para o perfil CS 550x502. 


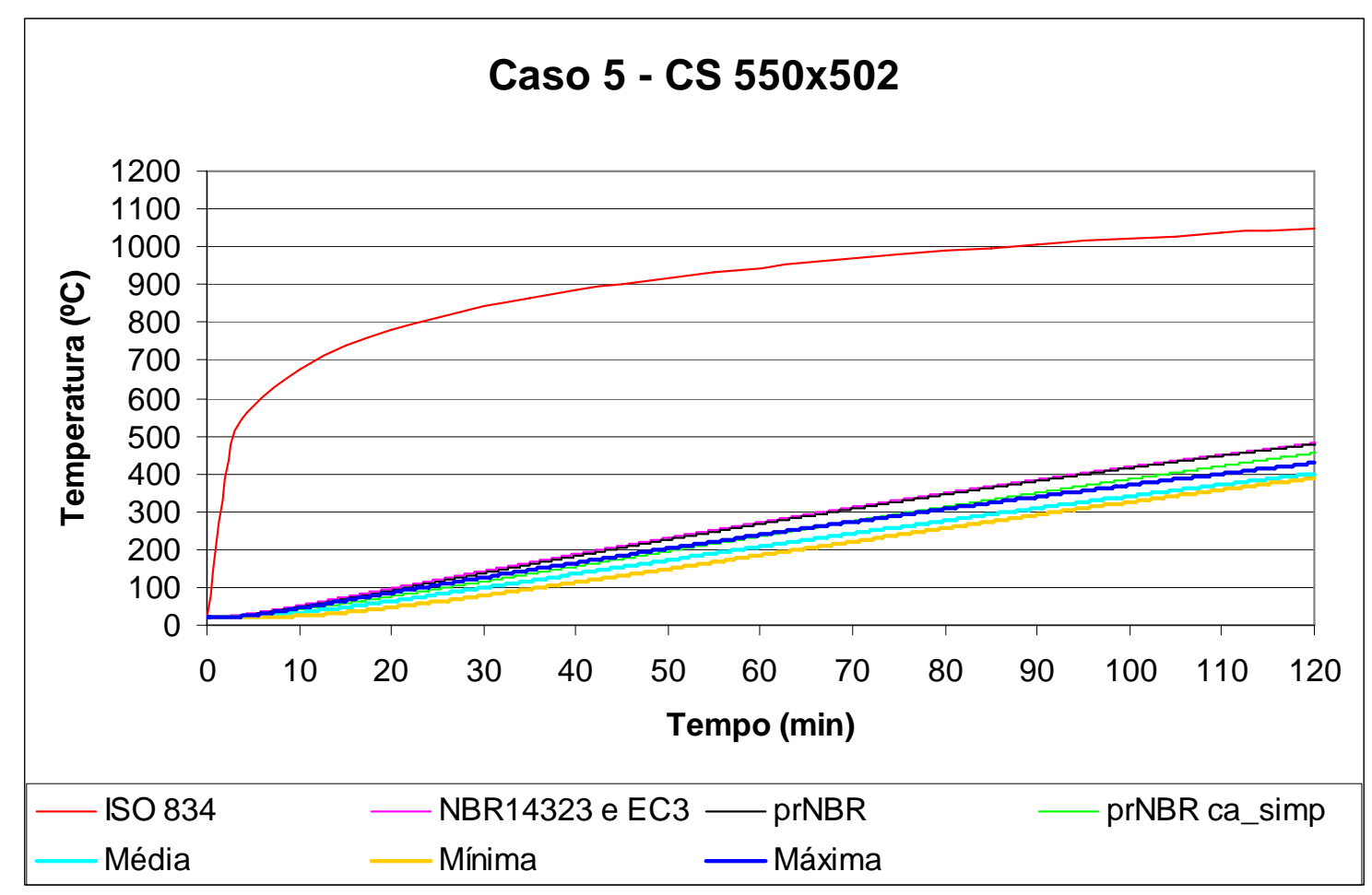

Figura 6.40 - Curvas da evolução da temperatura versus tempo para o caso 5 considerando-se o perfil CS 550x502.

Na análise dos resultados do CASO 5 constata-se que as curvas obtidas com os procedimentos normativos resultam sempre próximas (quase coincidentes) com aquela curva de temperatura máxima obtida numericamente. Nota-se ainda que a curva de elevação de temperatura obtida com o procedimento do projeto de revisão da NBR 14323:1999 apresenta boa concordância com os resultados obtidos com os procedimentos da NBR 14323:1999 e do EUROCODE 3 (2005). Vale salientar que os casos tratam de elementos com proteção contra fogo, casos 5 e 6, os procedimentos simplificados da NBR 14323:1999 e do EUROCODE 3 (2005) são idênticos.

Ainda com relação ao caso 5, na figura 6.41 têm-se um modelo numérico considerando o perfil W 250x25,3 com um espaçamento (“gap”) de 25 mm entre a mesa e a proteção. Este caso tem por objetivo avaliar a proposição do projeto de revisão da NBR 14323:1999, que adiciona ao perímetro considerado para o cálculo do fator de massividade o espaçamento entre o perfil de aço e a proteção contra o fogo no caso de proteção tipo caixa.

Na tabela 6.4 têm-se as equações para cálculo do fator de massividade de acordo com a NBR 14323:1999, o projeto de revisão e com o EUROCODE 3 (2005) . 
Tabela 6.4 - Cálculo do fator de massividade para seção tipo caixa

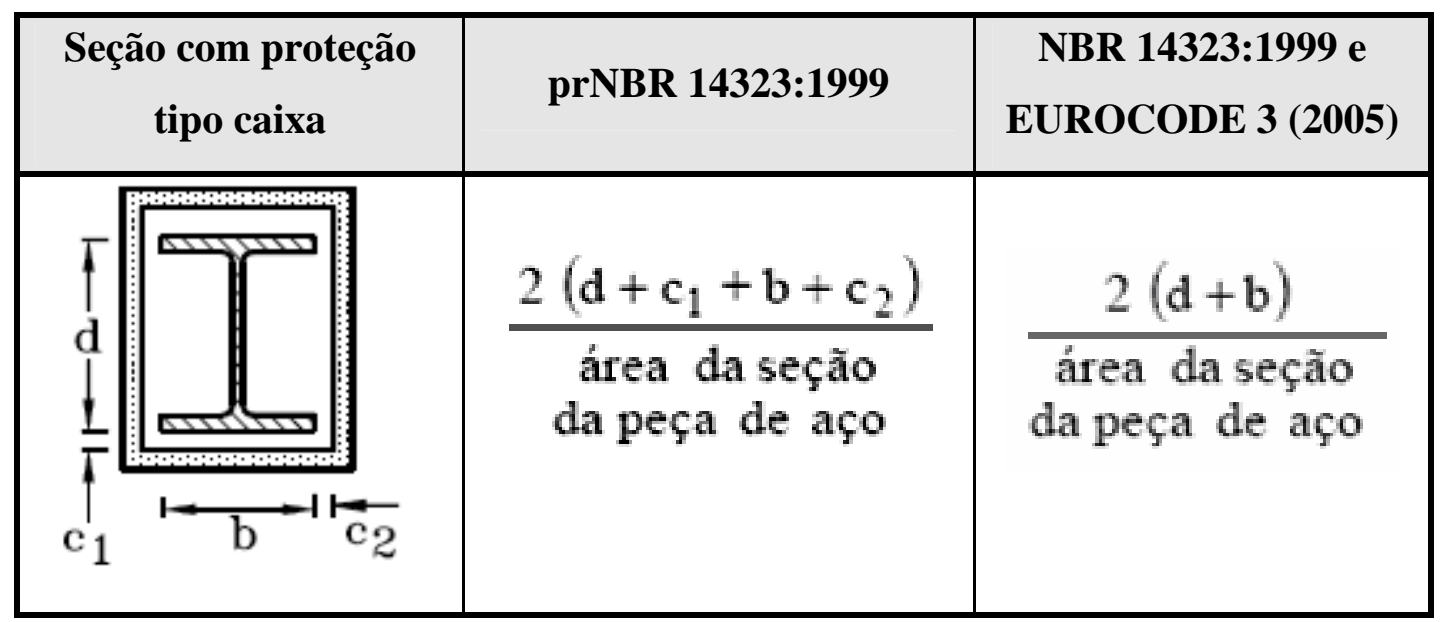
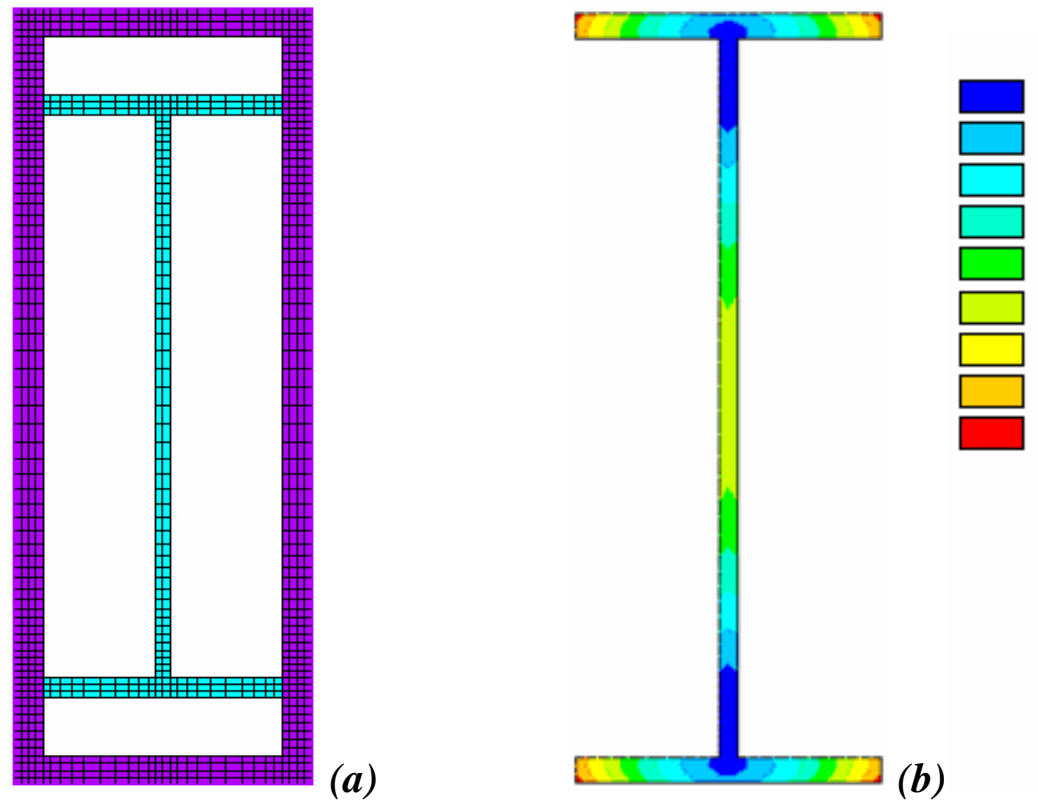

611.716

612.316

612.917

613.518

614.118

614.719

615.319

615.92

616.521

617.121

Figura 6.41 - Caso 5: (a) Malha de elementos finitos e (b) Campo de temperaturas correspondente a um tempo (TRRF) de 60 minutos para o perfil W 250x25,3.

Na figura 6.42 são apresentados os resultados obtidos via procedimento numérico para a situação considerada na figura 6.41 .

A análise dos resultados indica que a presença do espaçamento considerado não altera a resposta do modelo quanto à elevação de temperatura no perfil. Para o projeto de revisão da NBR 14323:1999 a consideração do "gap" no cálculo do fator de massividade para tal caso deve ser mais bem estudada. 


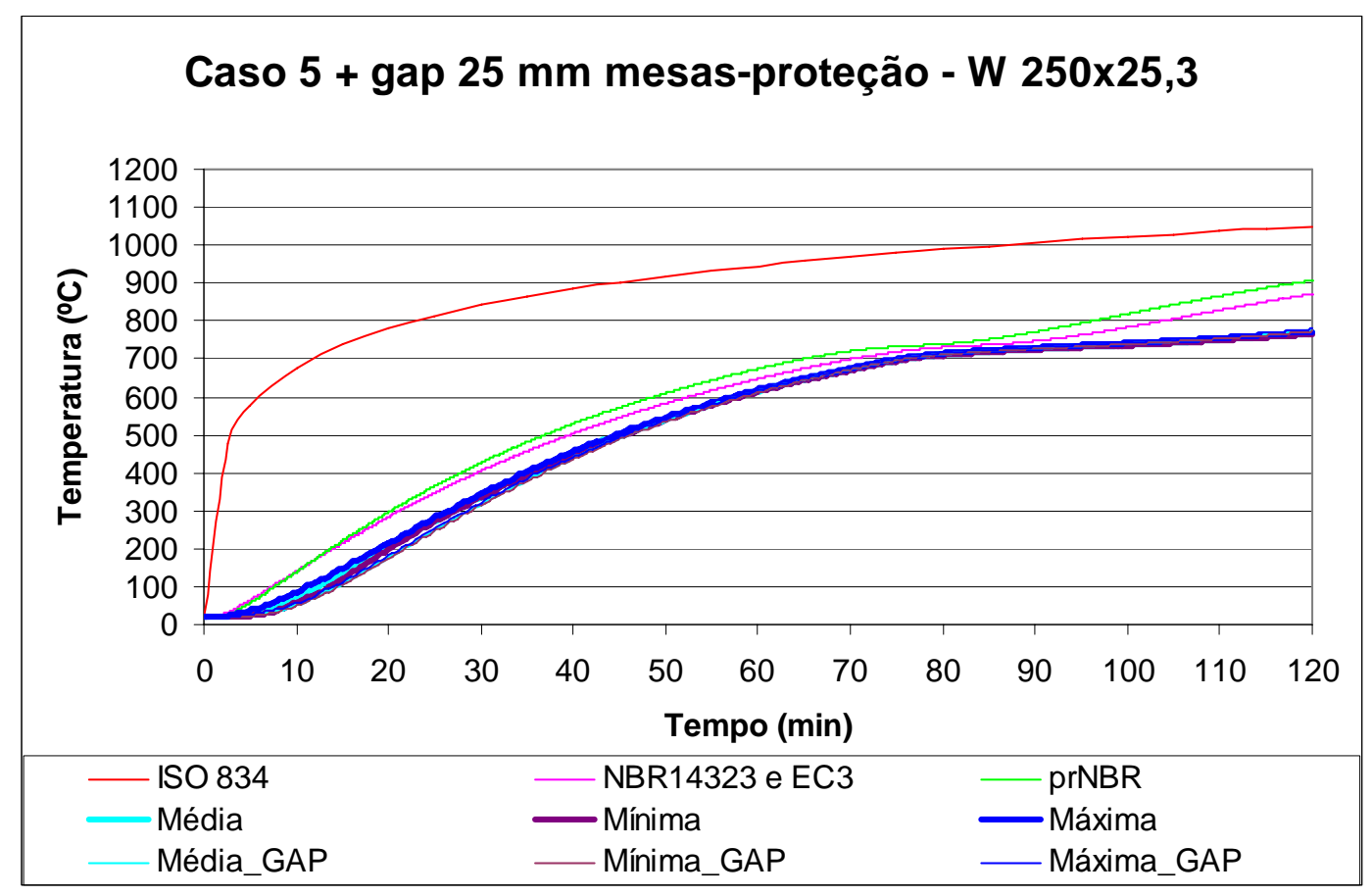

Figura 6.42 - Curvas da evolução da temperatura versus tempo para o caso 5 com “gap”, considerando-se o perfil W 250x25,3.

\subsubsection{CASO 6 - Seção I com proteção tipo caixa, de espessura uniforme exposta ao} incêndio por três lados

Para este caso, com relação à geometria e as condições de contorno, valem as mesmas considerações feitas para o caso anterior, com a única diferença que aqui o perfil de aço é sobreposto por laje maciça de concreto. As figuras 6.43 a 6.60 apresentam os resultados obtidos para este caso.

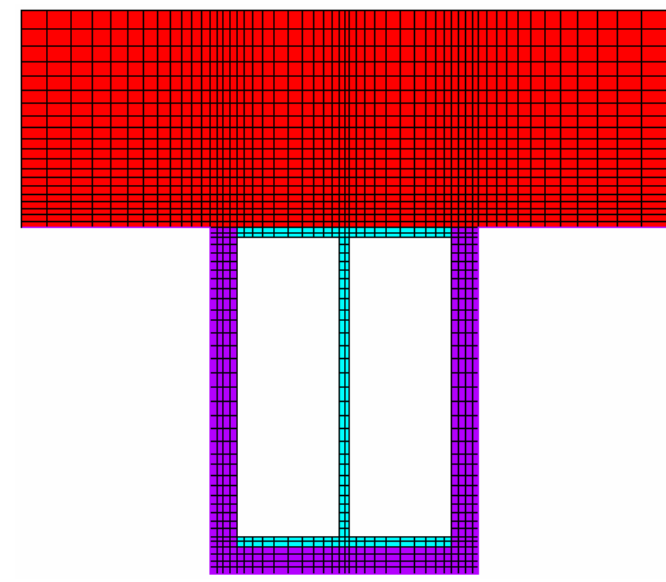

(a)

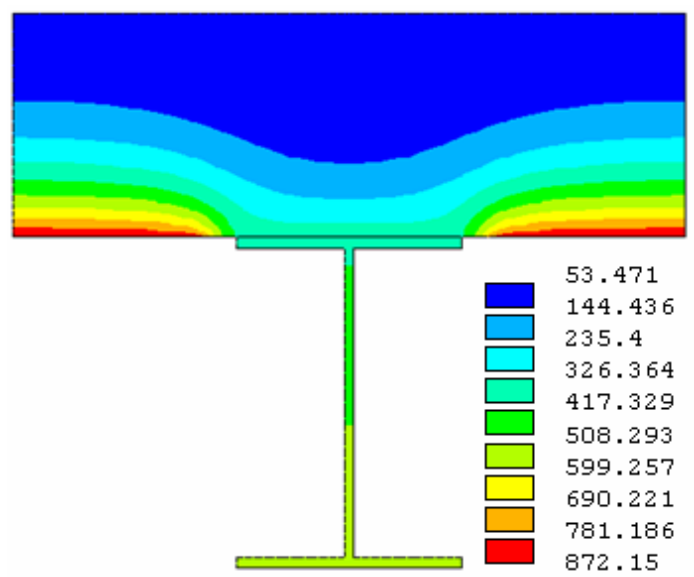

(b)

Figura 6.43 - Caso 6: (a) Malha de elementos finitos e (b) Campo de temperaturas correspondente a um tempo (TRRF) de 60 minutos para o perfil W 150x13. 


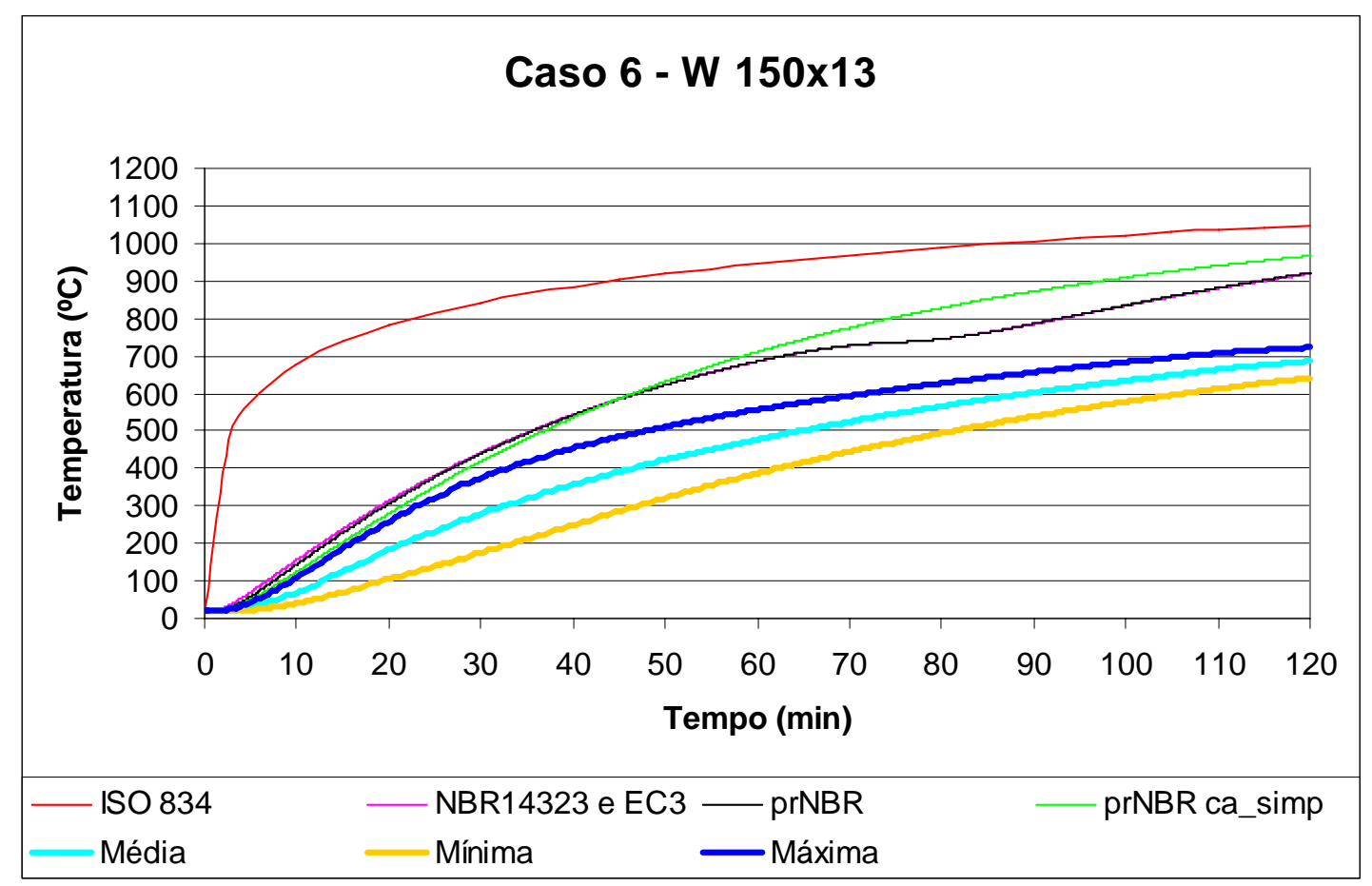

Figura 6.44 - Curvas da evolução da temperatura versus tempo para o caso 6 considerando-se o perfil W 150x13.

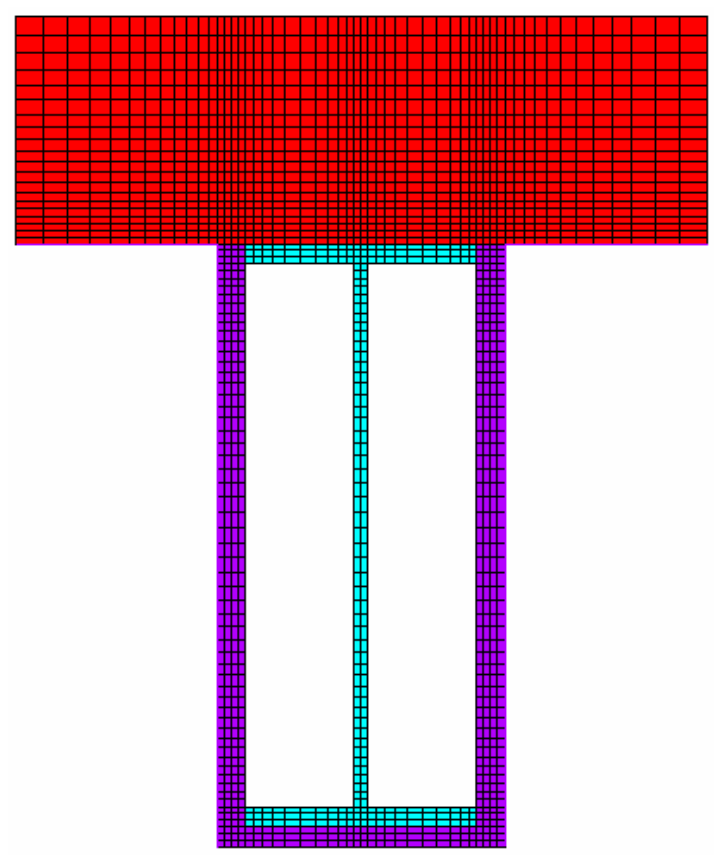

(a)

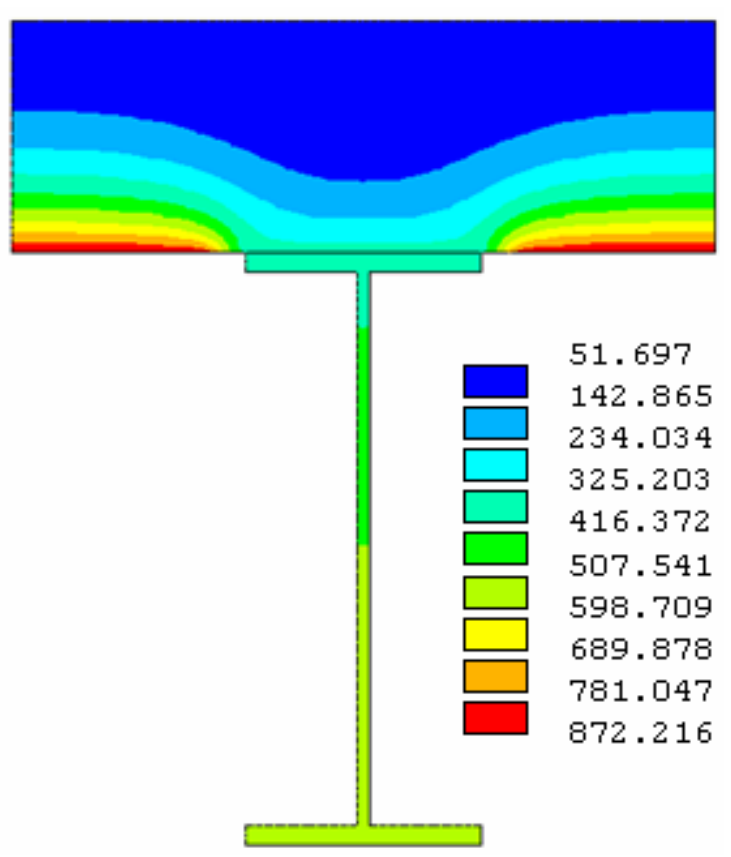

(b)

Figura 6.45 - Caso 6: (a) Malha de elementos finitos e (b) Campo de temperaturas correspondente a um tempo (TRRF) de 60 minutos para o perfil W 250x25,3. 


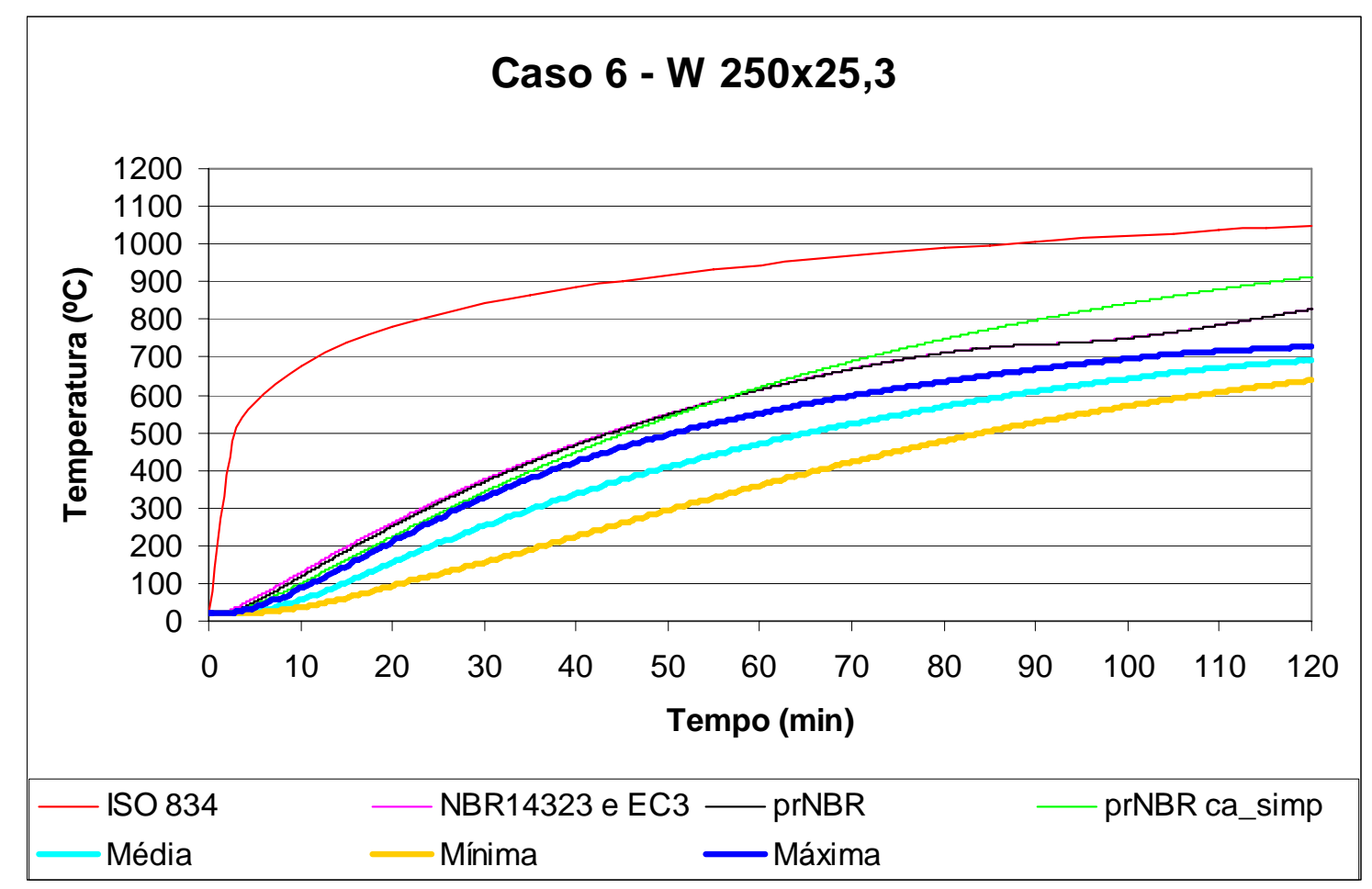

Figura 6.46 - Curvas da evolução da temperatura versus tempo para o caso 6 considerando-se o perfil W 250x25,3.

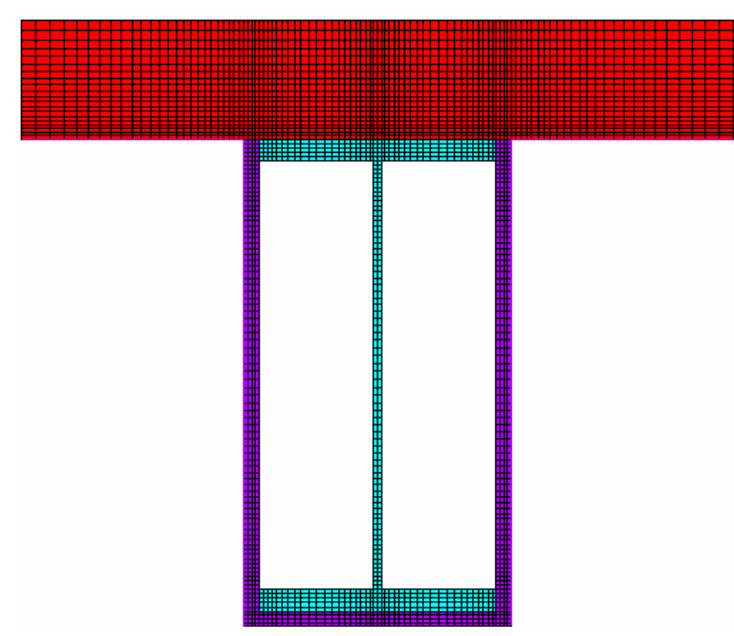

(a)

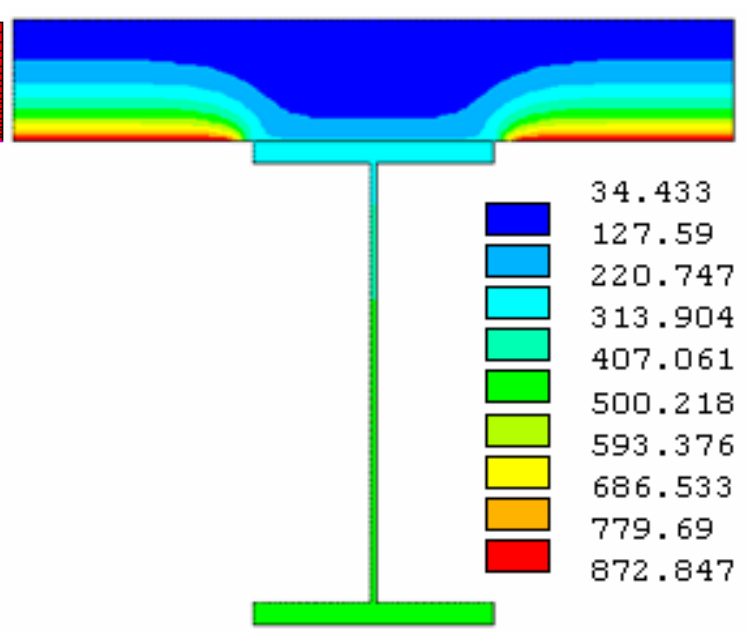

(b)

Figura 6.47 - Caso 6: (a) Malha de elementos finitos e (b) Campo de temperaturas correspondente a um tempo (TRRF) de 60 minutos para o perfil VS 400x78. 


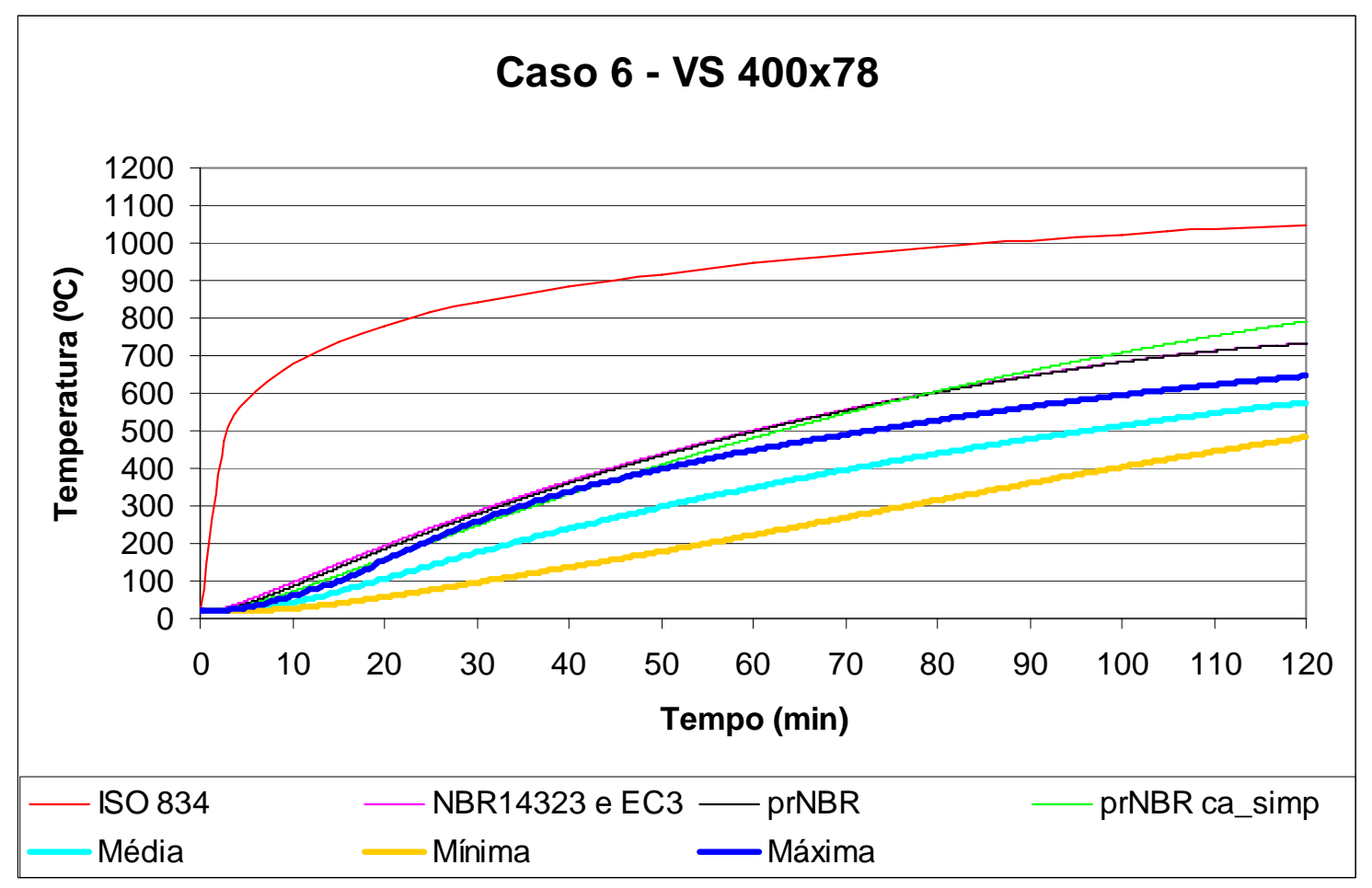

Figura 6.48 - Curvas da evolução da temperatura versus tempo para o caso 6 considerando-se o perfil VS 400x78.
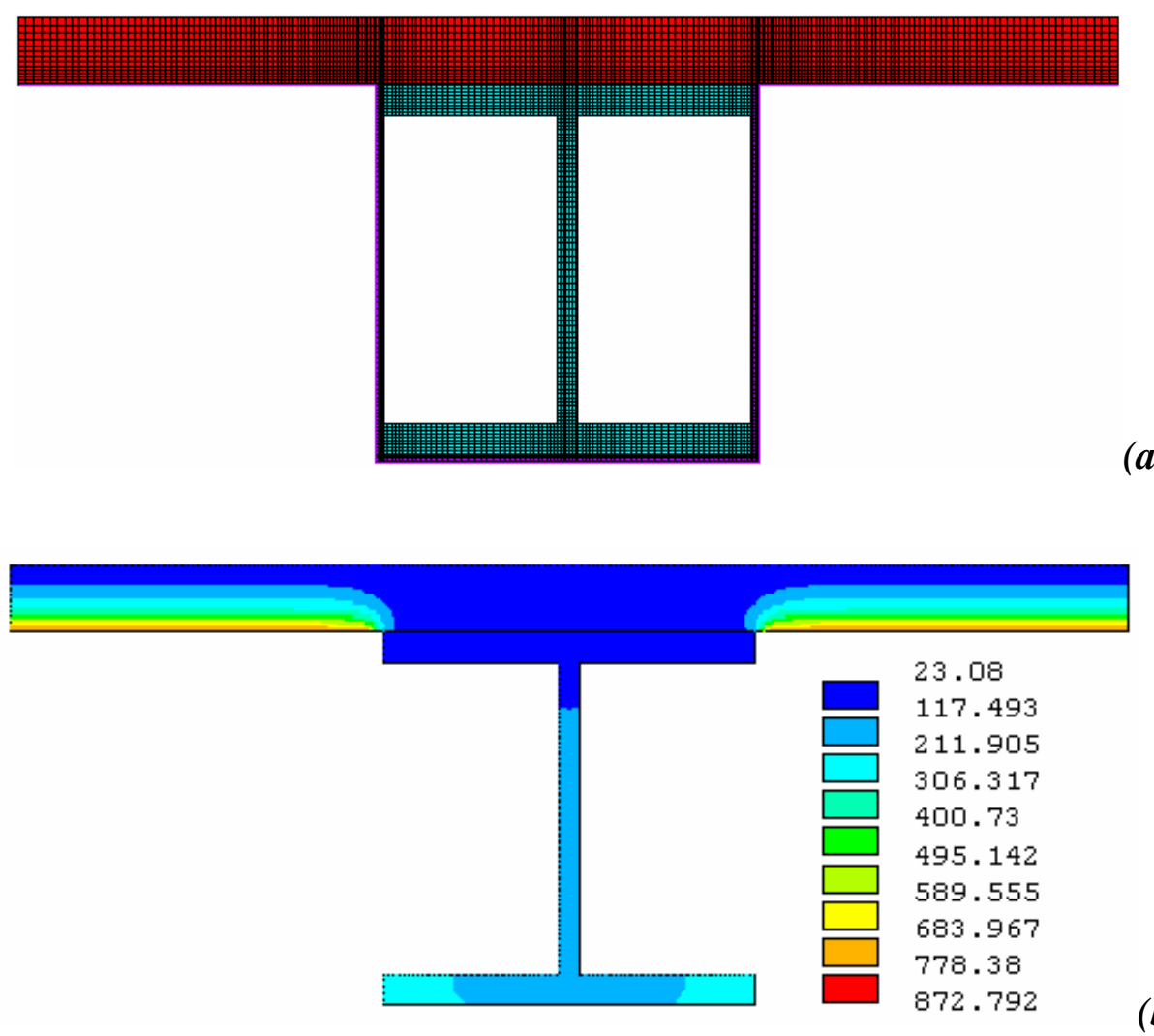

(b)

Figura 6.49 - Caso 6: (a) Malha de elementos finitos e (b) Campo de temperaturas correspondente a um tempo (TRRF) de 60 minutos para o perfil CS 550x502. 


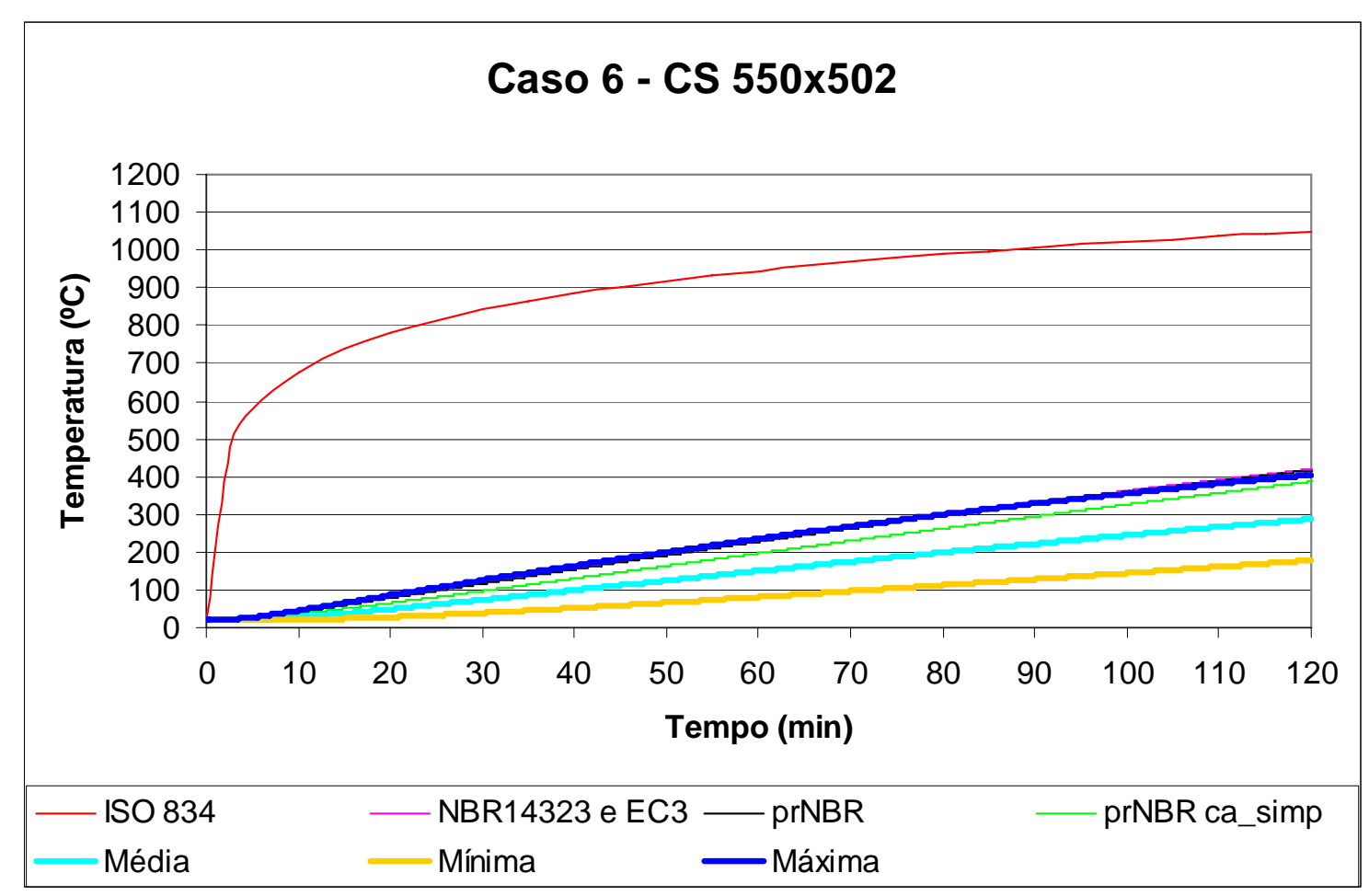

Figura 6.50 - Curvas da evolução da temperatura versus tempo para o caso 6 considerando-se o perfil CS 550x502.

Os resultados numéricos obtidos para o CASO 6 evidenciam um afastamento considerável entre as curvas de temperaturas máxima e mínima, o que indica a ocorrência de gradiente térmico na seção. Os resultados obtidos por procedimentos normativos apresentam boa concordância entre si e resultam acima ou próximos da curva de temperatura máxima obtida via simulação numérica.

Para os casos 5 e 6, vale destacar que a consideração de um valor constante para o calor específico (valor simplificado) para o procedimento do projeto de revisão da NBR 14323:1999 conduz a temperaturas um pouco abaixo daquelas obtidas com o procedimento da NBR 14323:1999 e do EUROCODE 3 (2005), com relação ao perfil CS 550x502.

\subsubsection{CASO 7 - Viga I em contato com laje de concreto e alvenaria, exposta ao} incêndio pelos dois lados da parede de alvenaria

A figura 6.51 ilustra a malha de elementos finitos e o campo de temperaturas para um tempo (TRRF) de 60 minutos de exposição ao incêndio-padrão para o caso de estudo 7, considerando o perfil W 150x13. Na figura 6.52 estão apresentados os 
resultados da elevação de temperatura obtidos via modelo numérico e por meio do procedimento simplificado de cálculo adaptado da NBR 14323:1999.

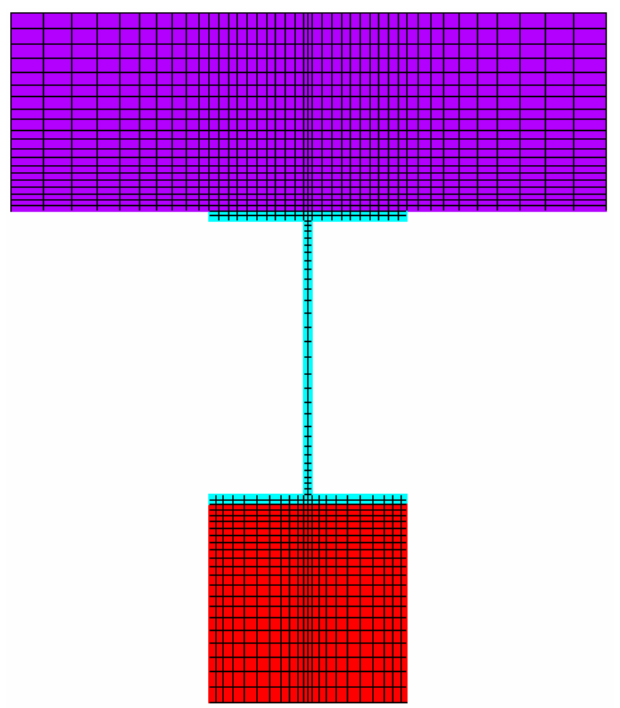

(a)

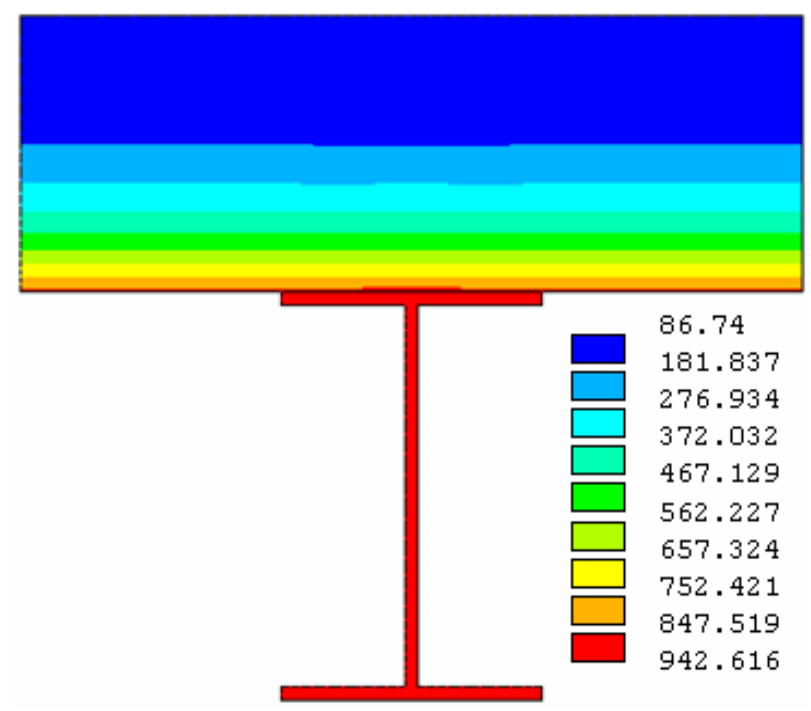

(b)

Figura 6.51 - Caso 7: a) Malha de elementos finitos e b) Campo de temperaturas correspondente a um tempo (TRRF) de 60 minutos para o perfil W 150x13.

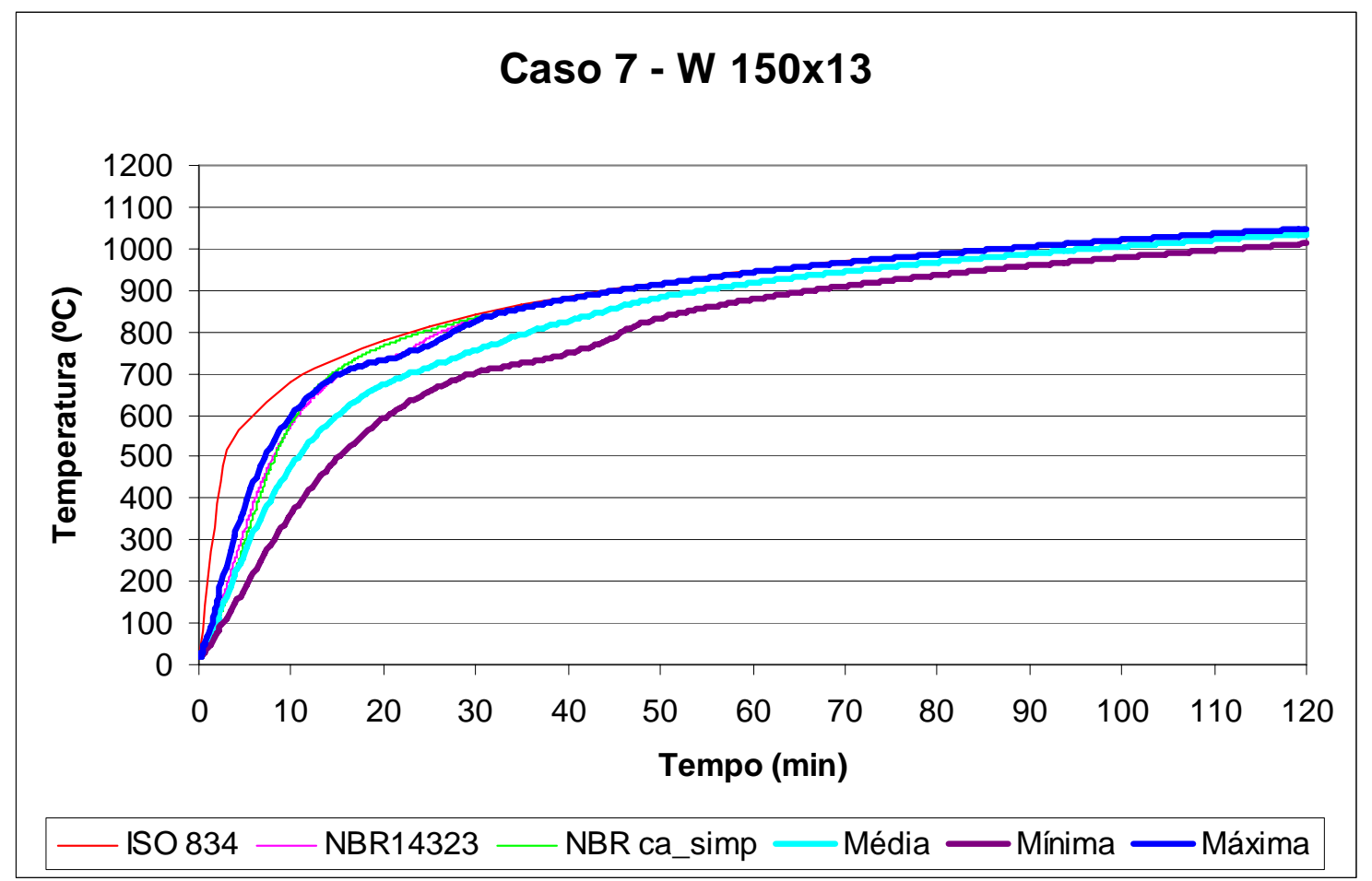

Figura 6.52 - Curvas da evolução da temperatura versus tempo para o caso 7 considerando-se o perfil W 150x13. 
Com relação ao procedimento simplificado de cálculo, em todos os perfis da análise, considerou-se no cálculo do fator de massividade todo o perímetro que não está em contato com a laje ou com a alvenaria. Nas figuras 6.53 a 6.58 têm-se os demais resultados obtidos para este caso.

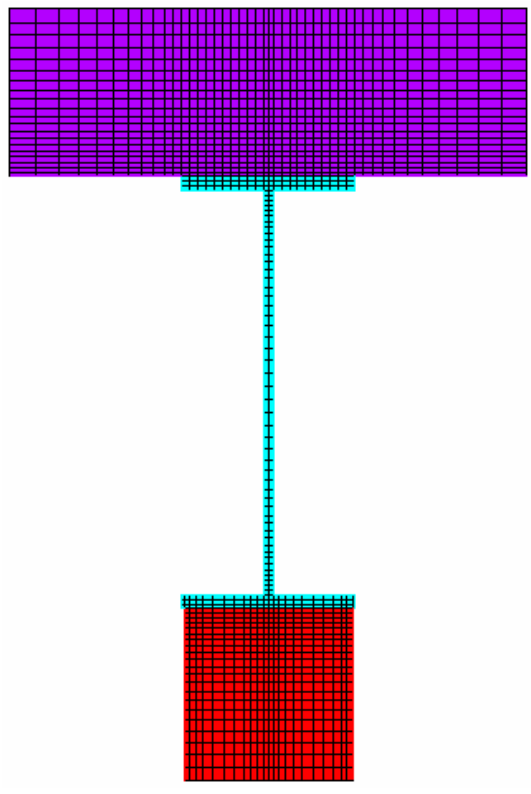

(a)

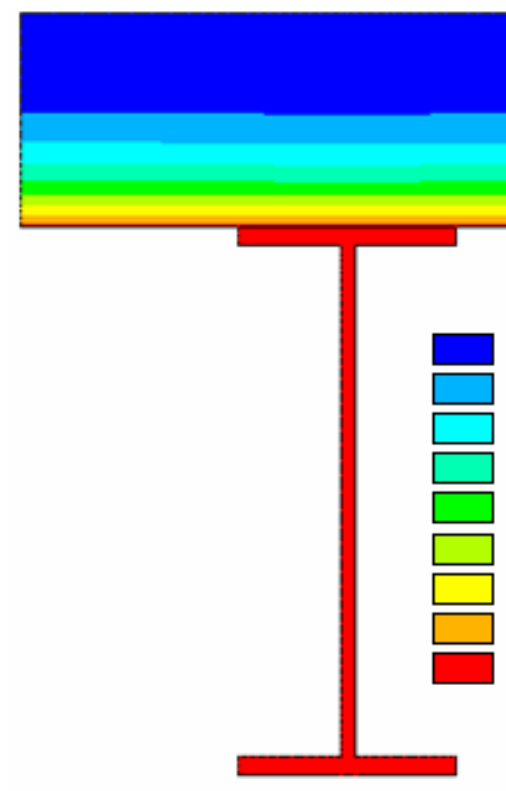

(b)

Figura 6.53 - Caso 7: (a) Malha de elementos finitos e (b) Campo de temperaturas correspondente a um tempo (TRRF) de 60 minutos para o perfil W 250x25,3.

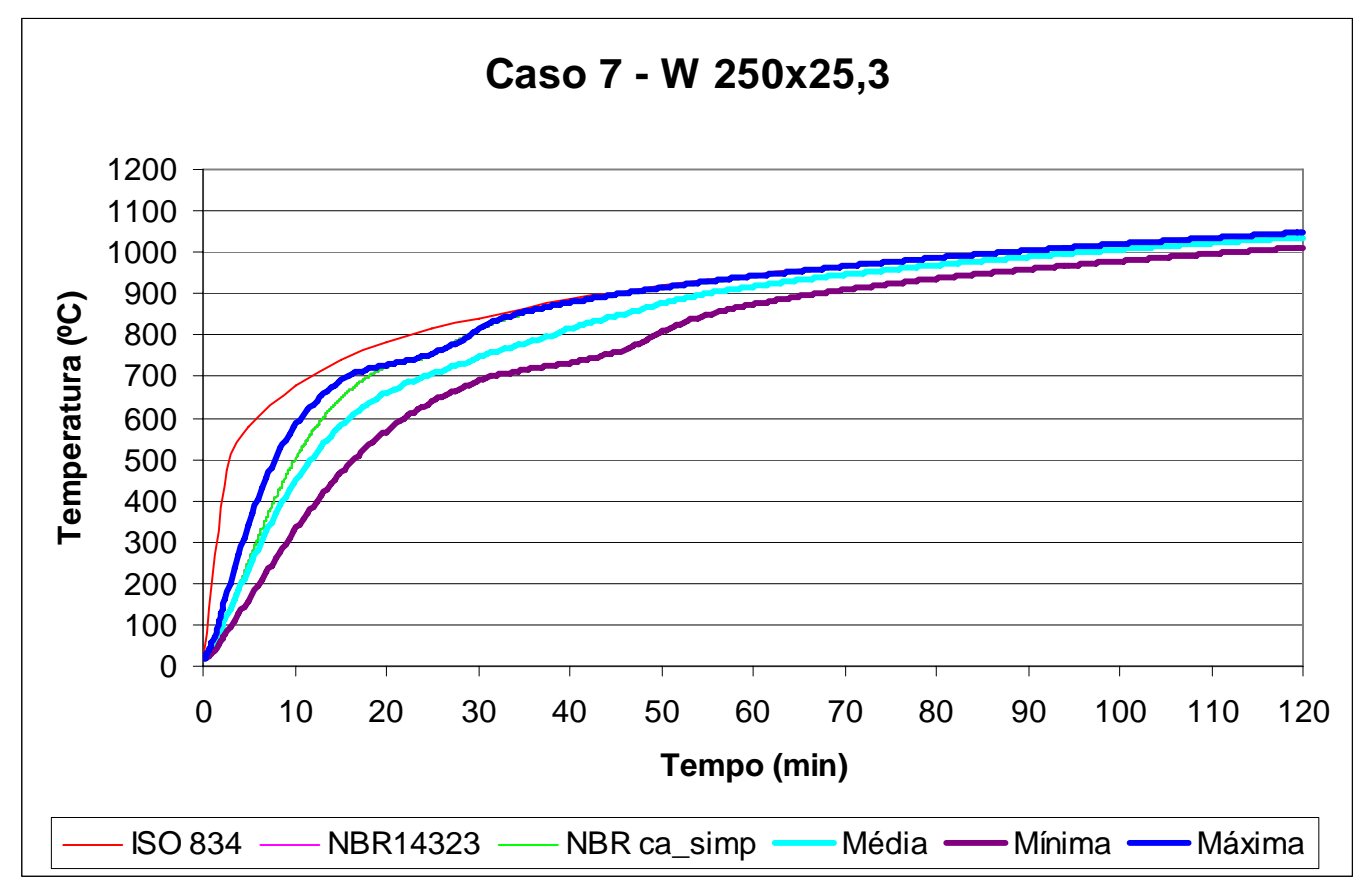

Figura 6.54 - Curvas da evolução da temperatura versus tempo para o caso 7 considerando-se o perfil W 250x25,3. 


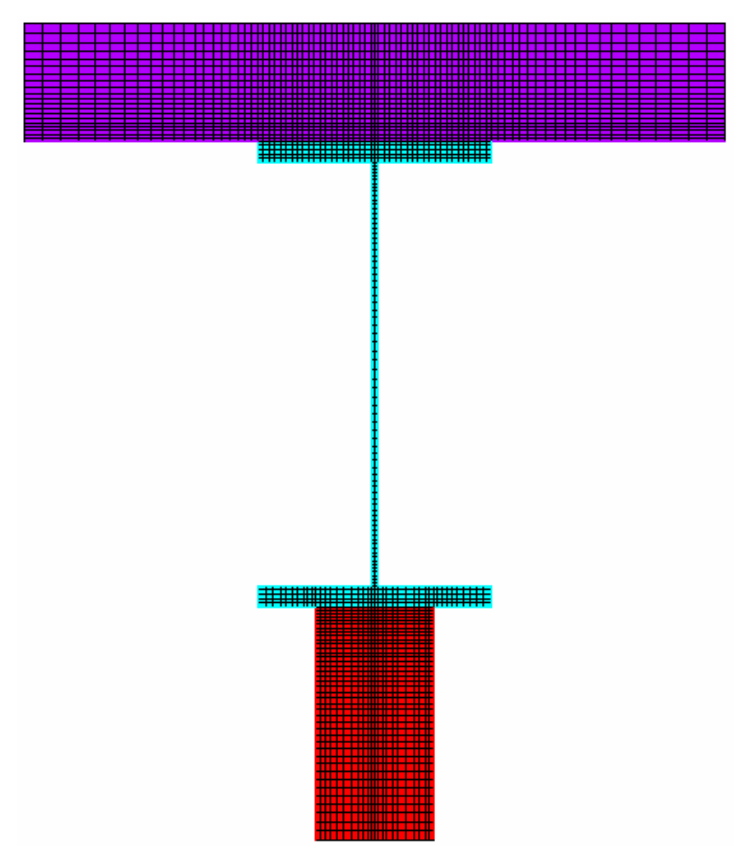

(a)

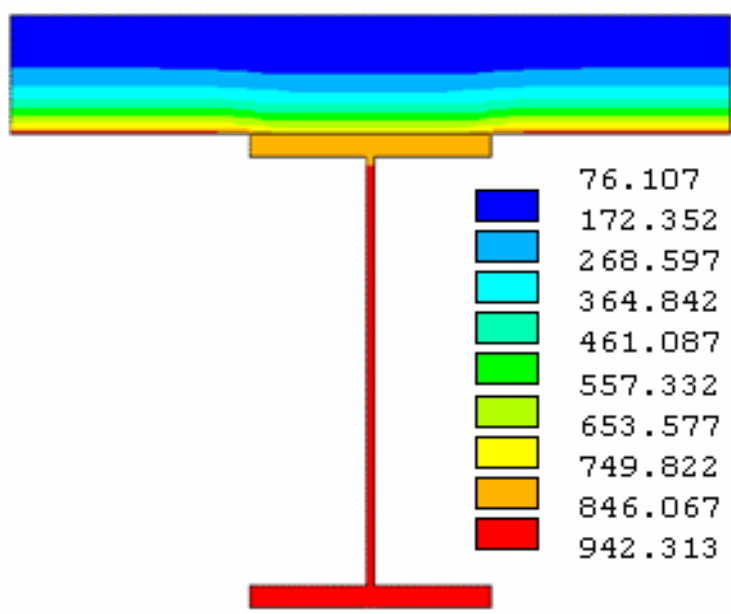

(b)

Figura 6.55 - Caso 7: (a) Malha de elementos finitos e (b) Campo de temperaturas correspondente a um tempo (TRRF) de 60 minutos para o perfil VS 400x78.

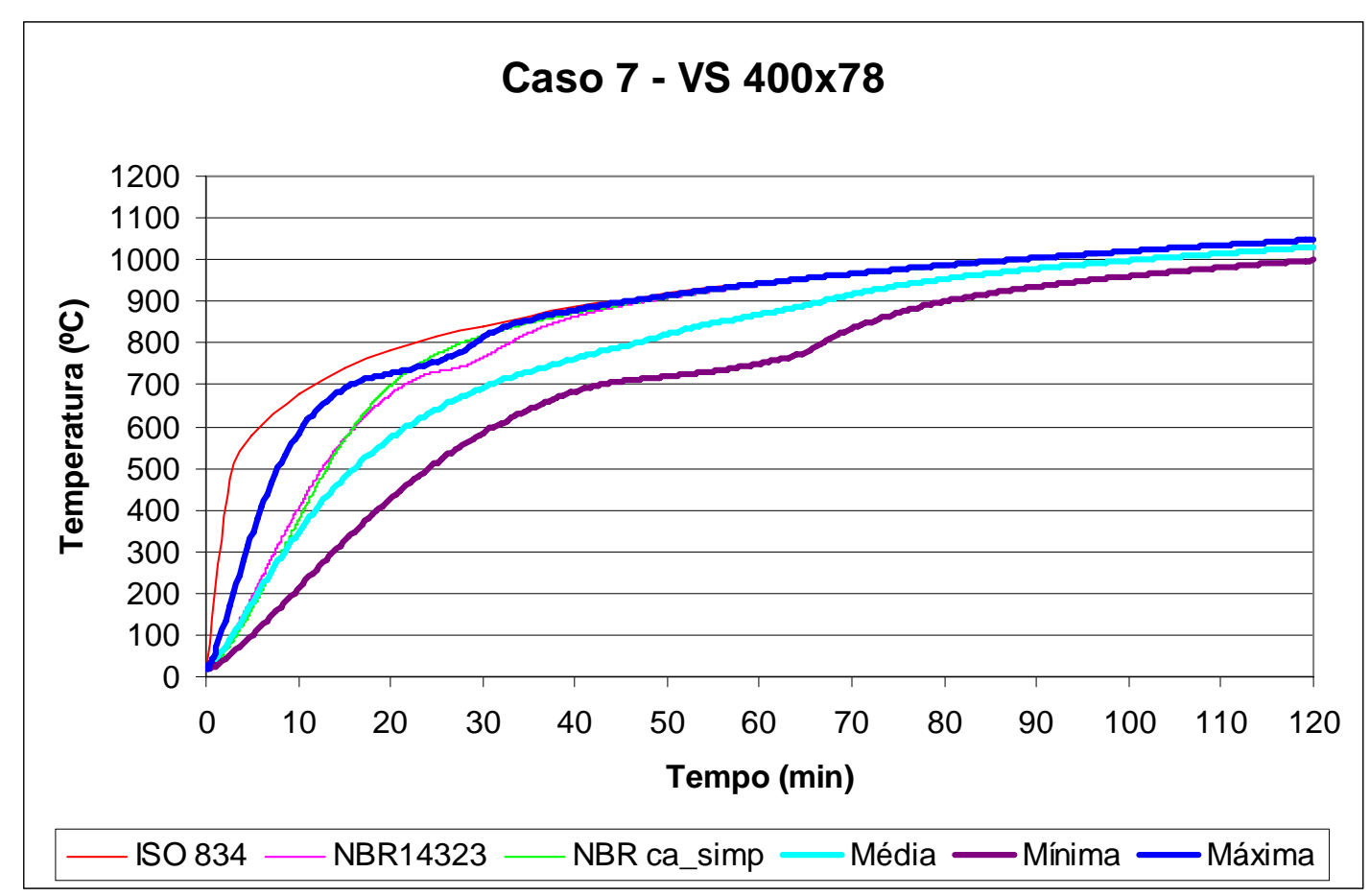

Figura 6.56 - Curvas da evolução da temperatura versus tempo para o caso 7 considerando-se o perfil VS 400x78. 


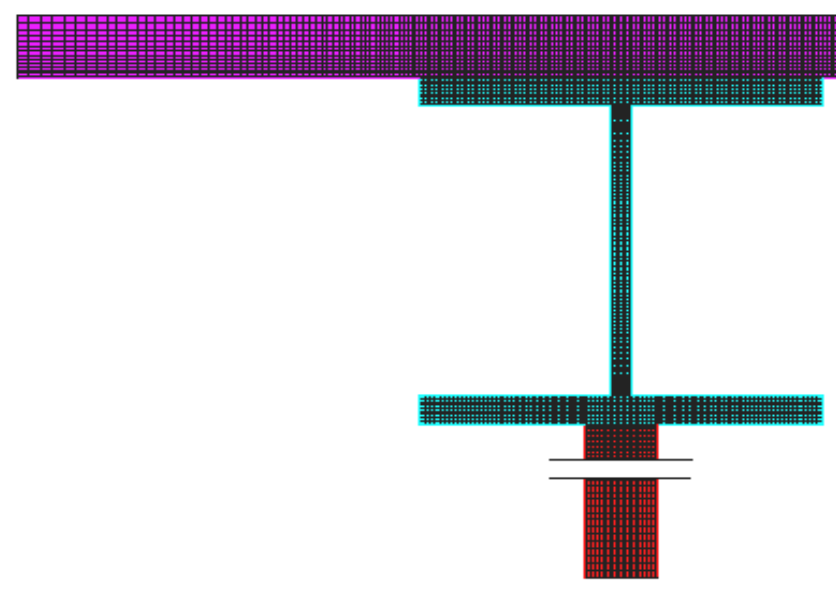

(a)

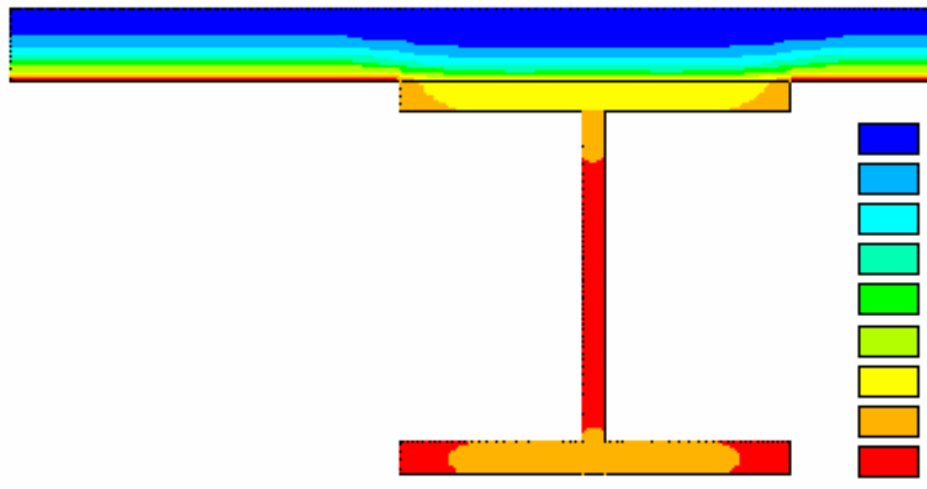

57.883

148.431

238.979

329.527

420.075

510.623

601.171

691.719

782.267

872.815

(b)

Figura 6.57 - Caso 7: (a) Malha de elementos finitos e (b) Campo de temperaturas correspondente a um tempo (TRRF) de 60 minutos para o perfil CS 550x502.

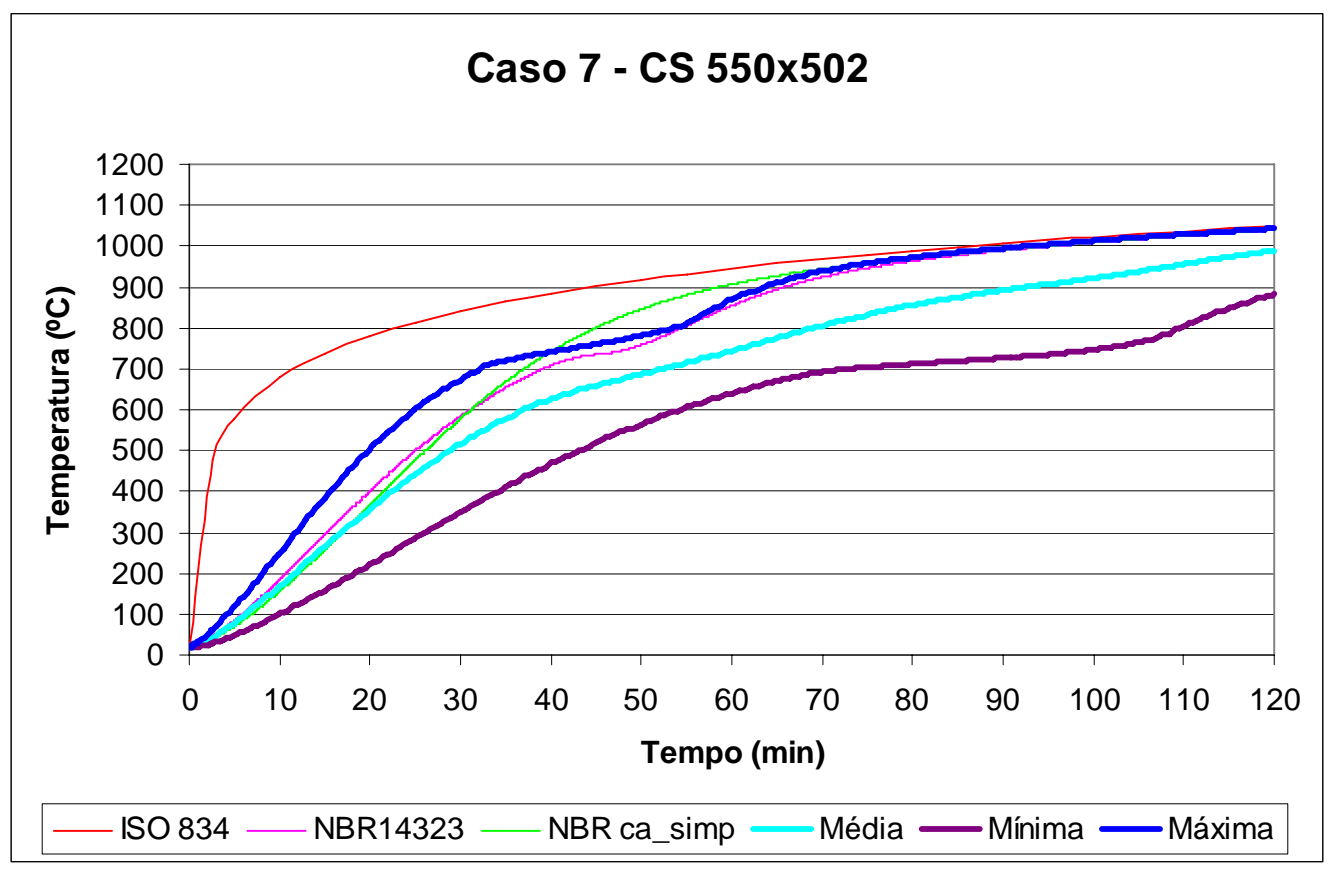

Figura 6.58 - Curvas da evolução da temperatura versus tempo para o caso 7 considerando-se o perfil CS 550x502. 
O CASO 7 é a primeira situação de interesse não contemplada pelos procedimentos normativos. Vale lembrar que para o cálculo do fator de massividade, com vistas ao emprego de procedimento simplificado, adaptado da NBR 14323:1999, adotou-se o perímetro do elemento exposto ao fogo que não esteja em contato com alvenaria ou laje.

Como resposta, a curva de elevação de temperatura obtida com o procedimento simplificado resulta abaixo daquela curva de temperatura máxima obtida numericamente nas etapas iniciais de aquecimento, porém, acima da curva de temperatura média da seção. Para tempos maiores que $30 \mathrm{~min}$, em todos os perfis analisados, as curvas de temperatura obtida com o procedimento simplificado se aproxima da curva de temperatura máxima obtida numericamente.

\subsubsection{CASO 8 - Pilar com mesas em contato com paredes de alvenaria, exposta ao incêndio pelos dois lados da parede de alvenaria}

Assim como no caso 7, para todos os perfis estudados se considerou no cálculo do fator de massividade todo perímetro que não está em contato com a alvenaria.

Nas figuras 6.59 a 6.66 são apresentados os resultados obtidos para o caso 8.

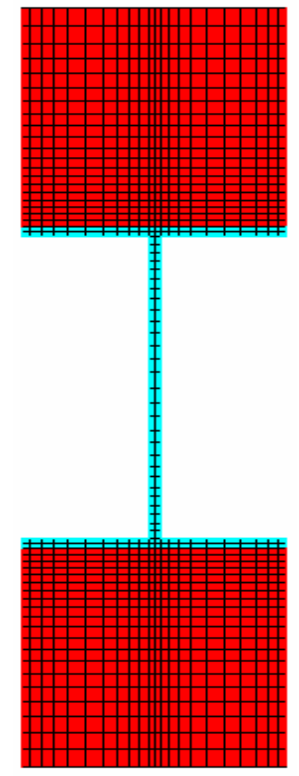

(a)

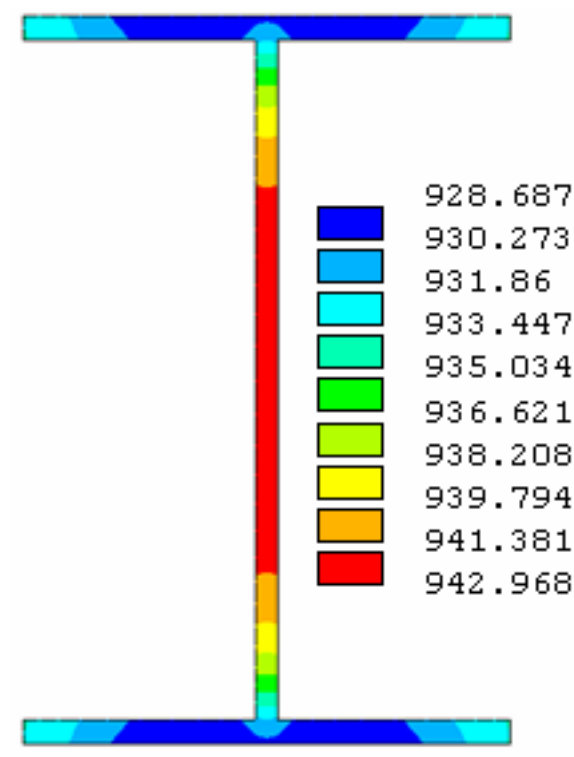

(b)

Figura 6.59 - Caso 8: (a) Malha de elementos finitos e (b) Campo de temperaturas correspondente a um tempo (TRRF) de 60 minutos para o perfil W 150x13. 


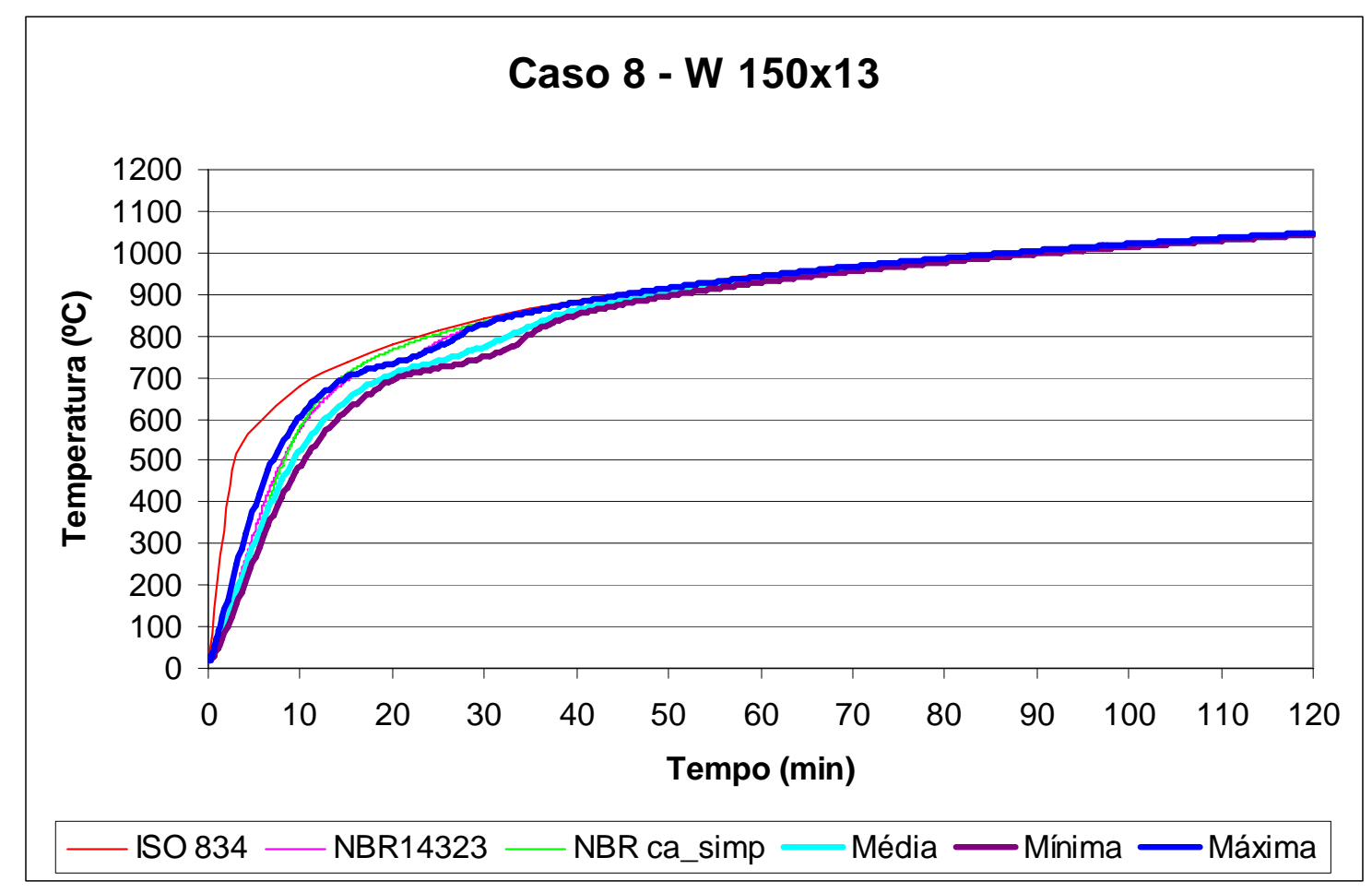

Figura 6.60 - Curvas da evolução da temperatura versus tempo para o caso 8 considerando-se o perfil W 150x13.

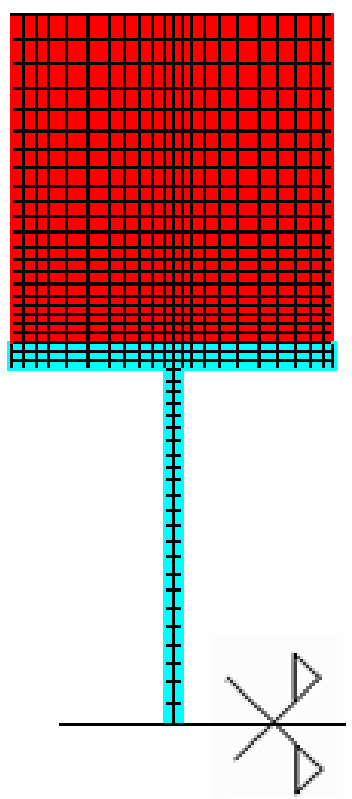

(a)

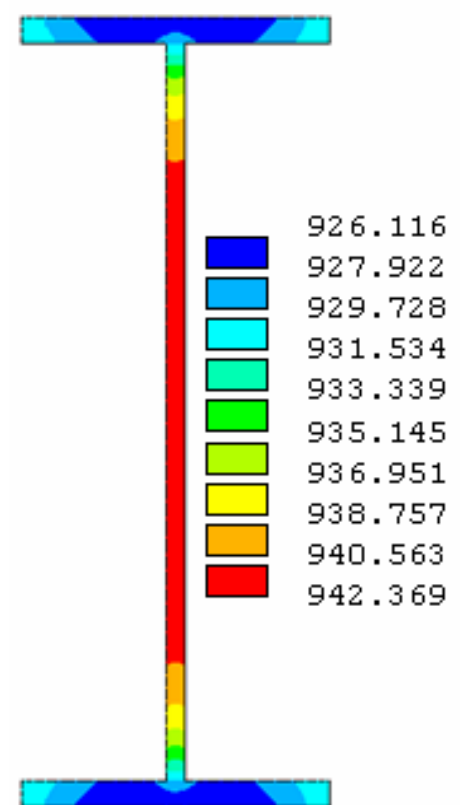

(b)

Figura 6.61 - Caso 8: (a) Malha de elementos finitos e (b) Campo de temperaturas correspondente a um tempo (TRRF) de 60 minutos para o perfil W 250x25,3. 


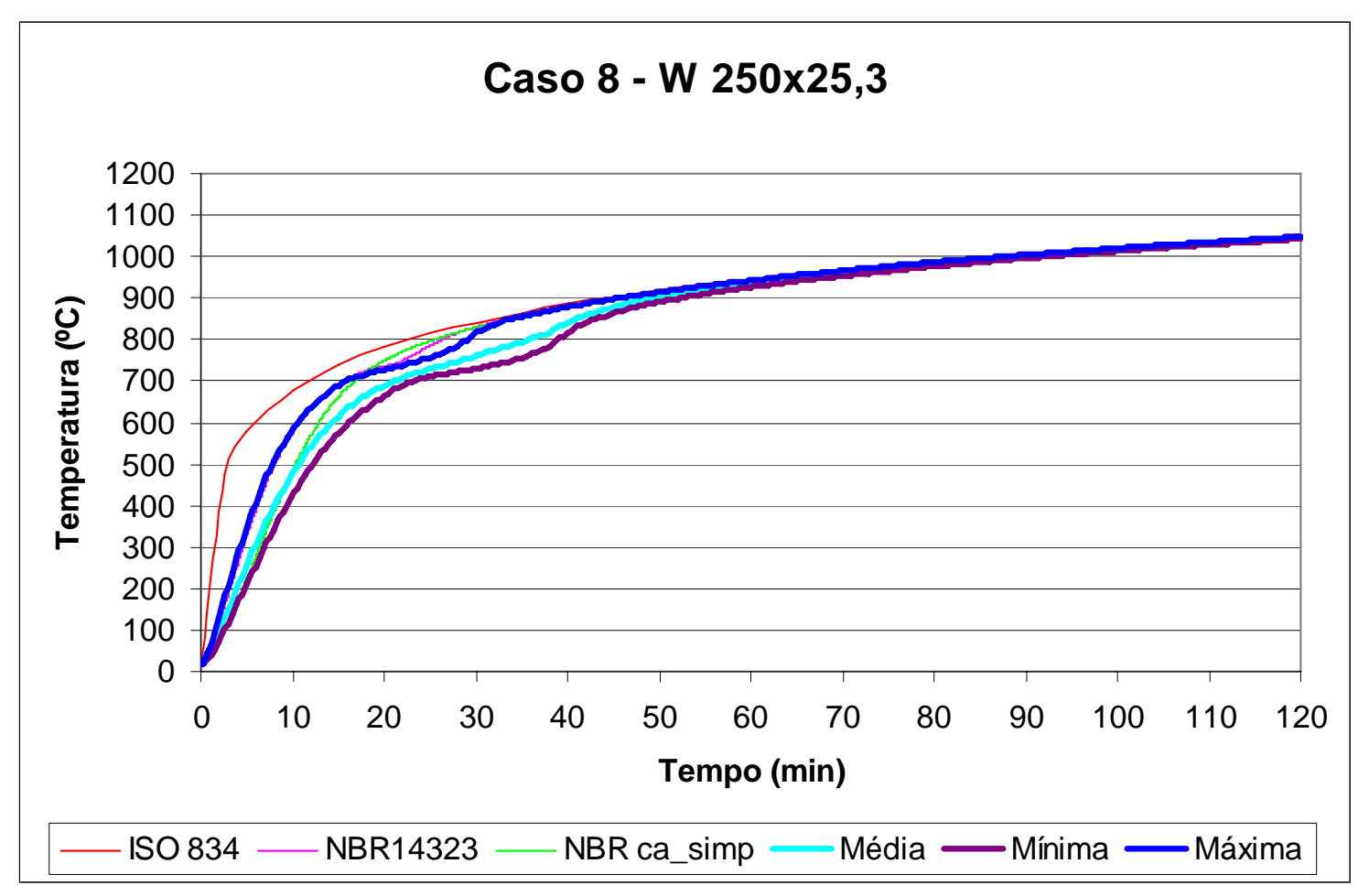

Figura 6.62 - Curvas da evolução da temperatura versus tempo para o caso 8 considerando-se o perfil W 250x25,3.

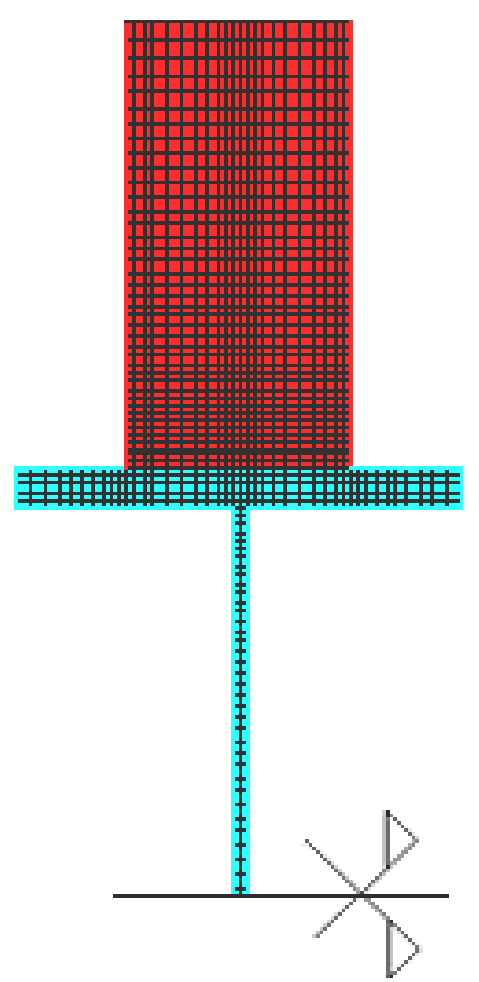

(a)

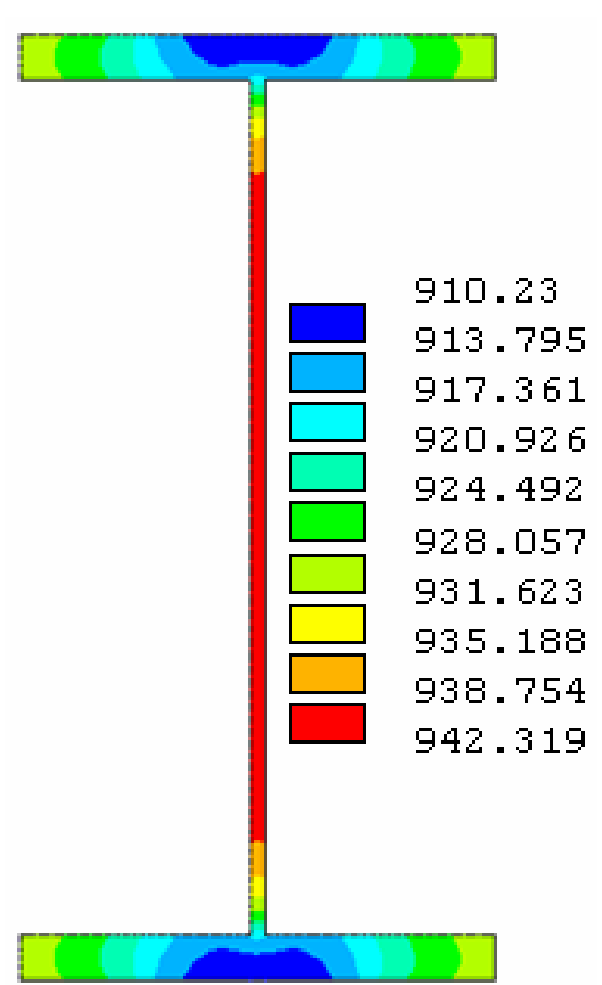

(b)

Figura 6.63 - Caso 8: (a) Malha de elementos finitos e (b) Campo de temperaturas correspondente a um tempo (TRRF) de 60 minutos para o perfil VS 400x78. 


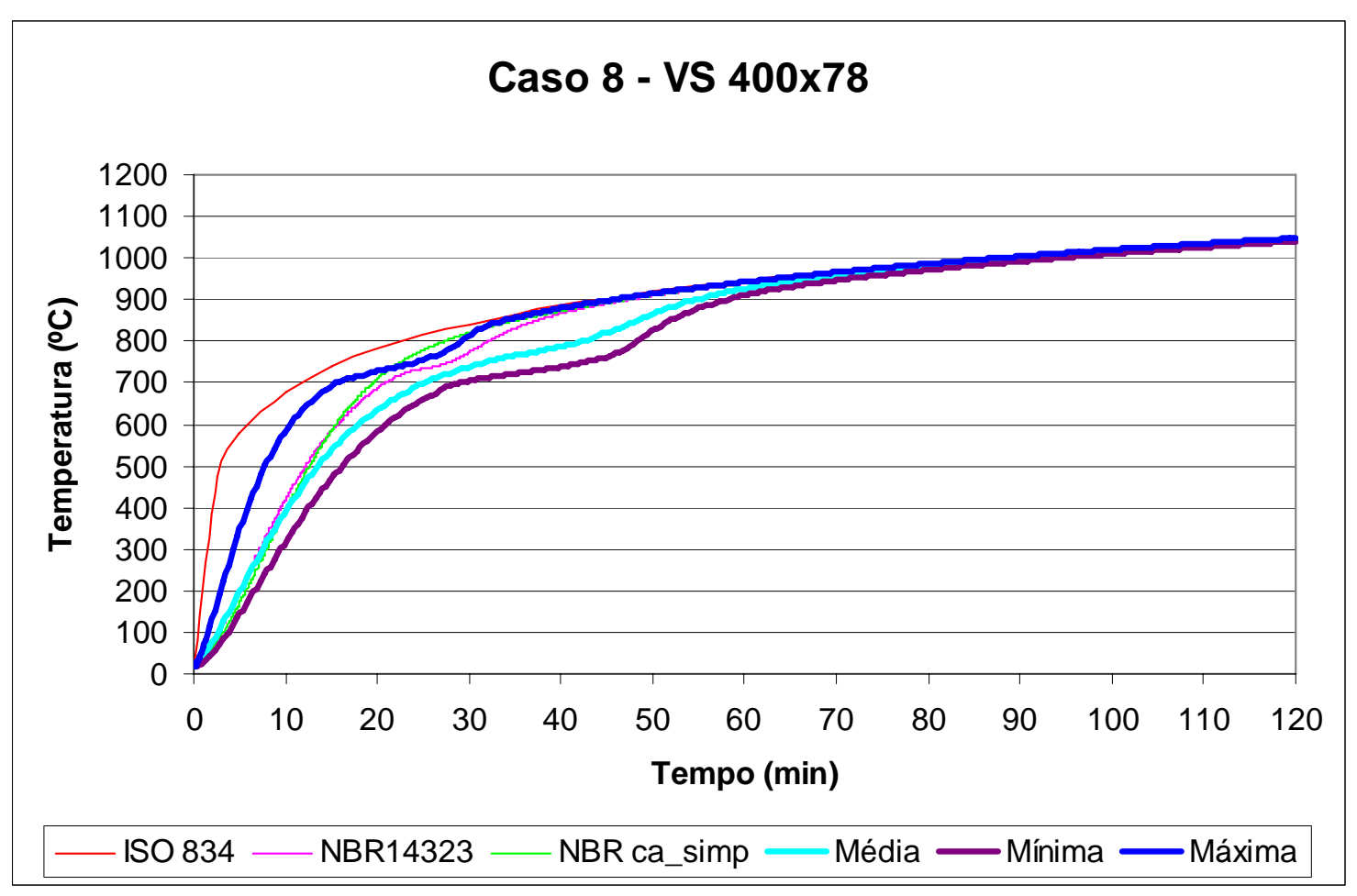

Figura 6.64 - Curvas da evolução da temperatura versus tempo para o caso 8 considerando-se o perfil VS 400x78.

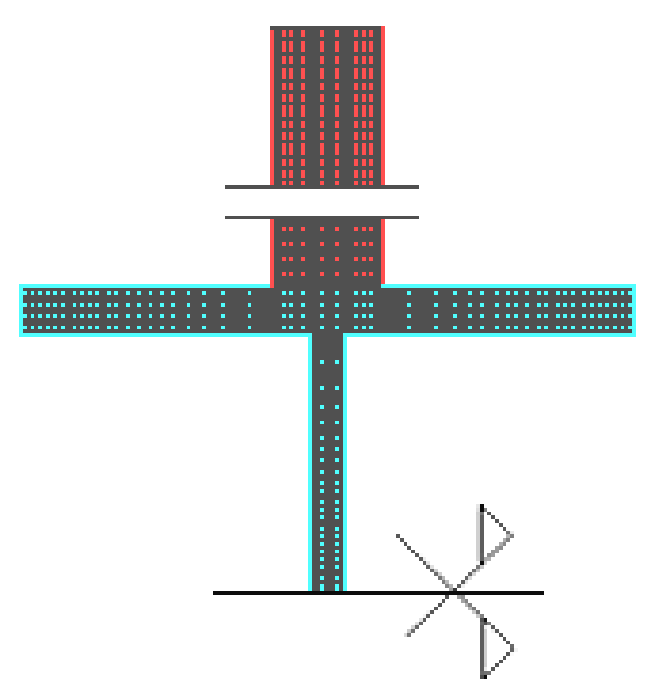

(a)

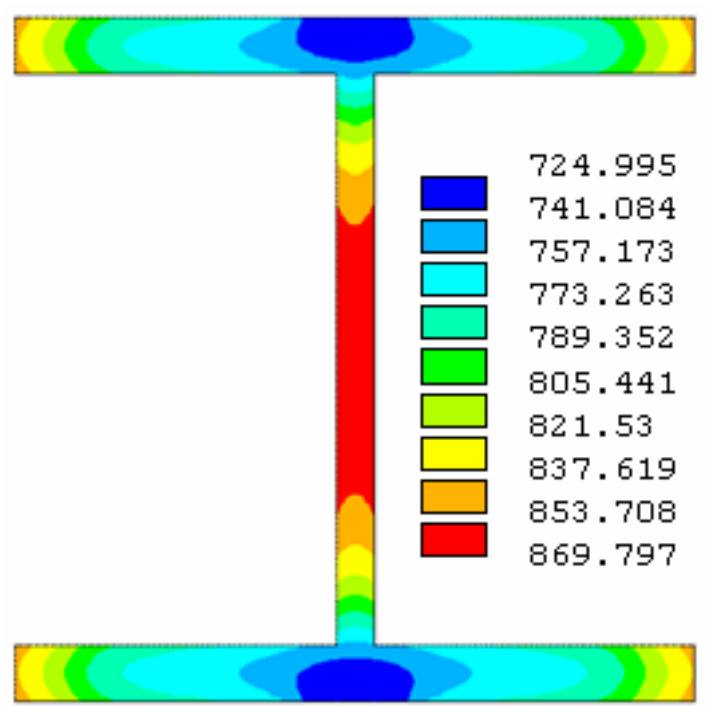

(b)

Figura 6.65 - Caso 8: (a) Malha de elementos finitos e (b) Campo de temperaturas correspondente a um tempo (TRRF) de 60 minutos para o perfil CS 550x502. 


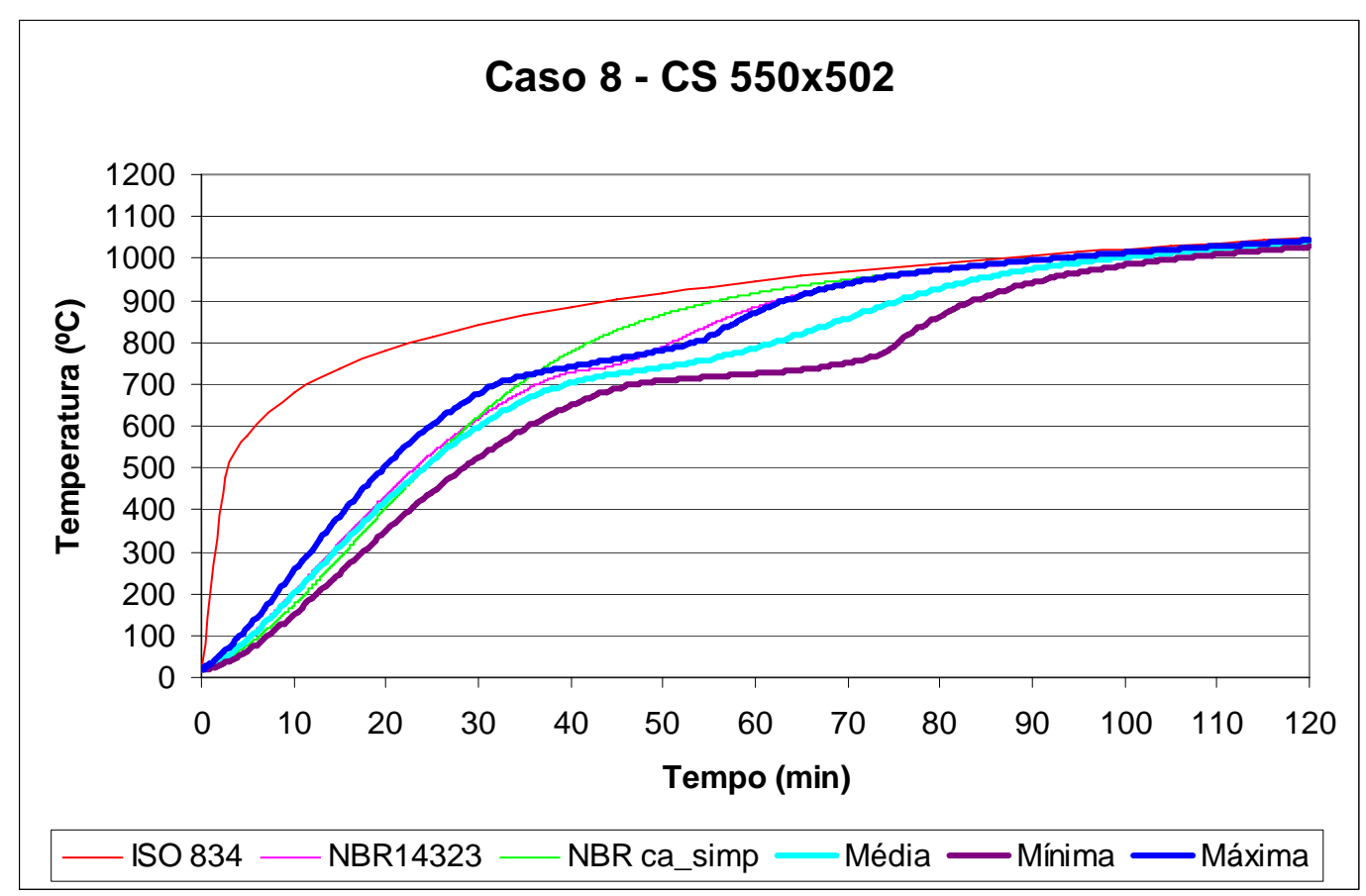

Figura 6.66 - Curvas da evolução da temperatura versus tempo para o caso 8 considerando-se o perfil CS 550x502.

Para o CASO 8 valem as mesmas observações feitas para o caso 7, porém, destacando-se apenas a menor distância entre as curvas de temperatura máximas e mínimas obtidas via simulação numérica.

Para os casos 7 e 8, pode se considerar ainda que os resultados obtidos com o fator de massividade adotado para esses casos são razoáveis para serem utilizados na falta de uma ferramenta numérica para obtenção do campo de temperaturas numa análise mais rigorosa. Deve-se ressaltar, porém, que nesses casos, perfis como VS 400x78 que apresenta alma bem mais delgada que a mesa, a alma atingirá uma temperatura muito maior que as mesas para um dado tempo na fase inicial de exposição ao incêndio.

\subsubsection{CASO 9 - Viga I em contato com laje de concreto e alvenaria, exposta ao incêndio em apenas um lado da parede de alvenaria}

Este caso é geometricamente idêntico ao caso 7. A diferença consiste nas condições de contorno do modelo. Aqui se considera a alvenaria como um caso efetivo de compartimentação, isto é, incêndio ocorrendo em apenas um lado da parede de alvenaria. A consideração da troca de calor com o meio nas superfícies não expostas do 
modelo é feita por meio da adoção de um coeficiente de transferência de calor por convecção com valor igual a $9 \mathrm{~W} / \mathrm{m}^{20} \mathrm{C}$.

Com relação ao procedimento simplificado, no cálculo do fator de massividade considera-se o perímetro do perfil que não está em contato com a alvenaria ou com a laje de concreto, no lado da parede exposta ao fogo, e a área total da seção.

Os resultados de interesse obtidos para o caso 9 são apresentados nas figuras que se seguem.

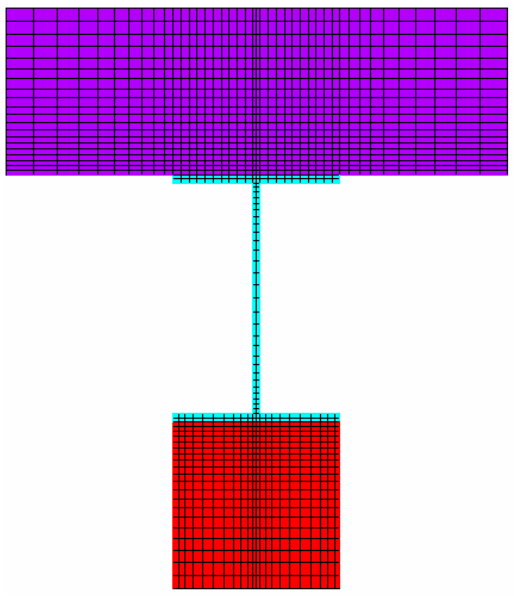

(a)

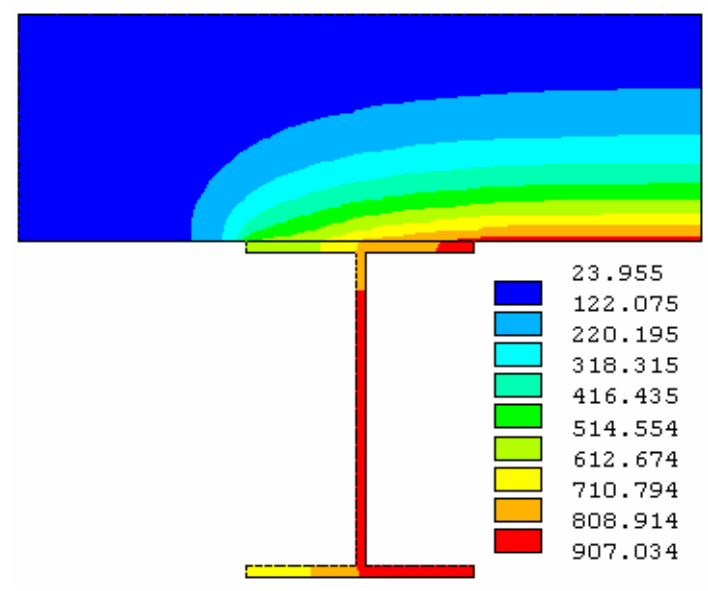

(b)

Figura 6.67 - Caso 9: (a) Malha de elementos finitos e (b) Campo de temperaturas correspondente a um tempo (TRRF) de 60 minutos para o perfil W 150x13.

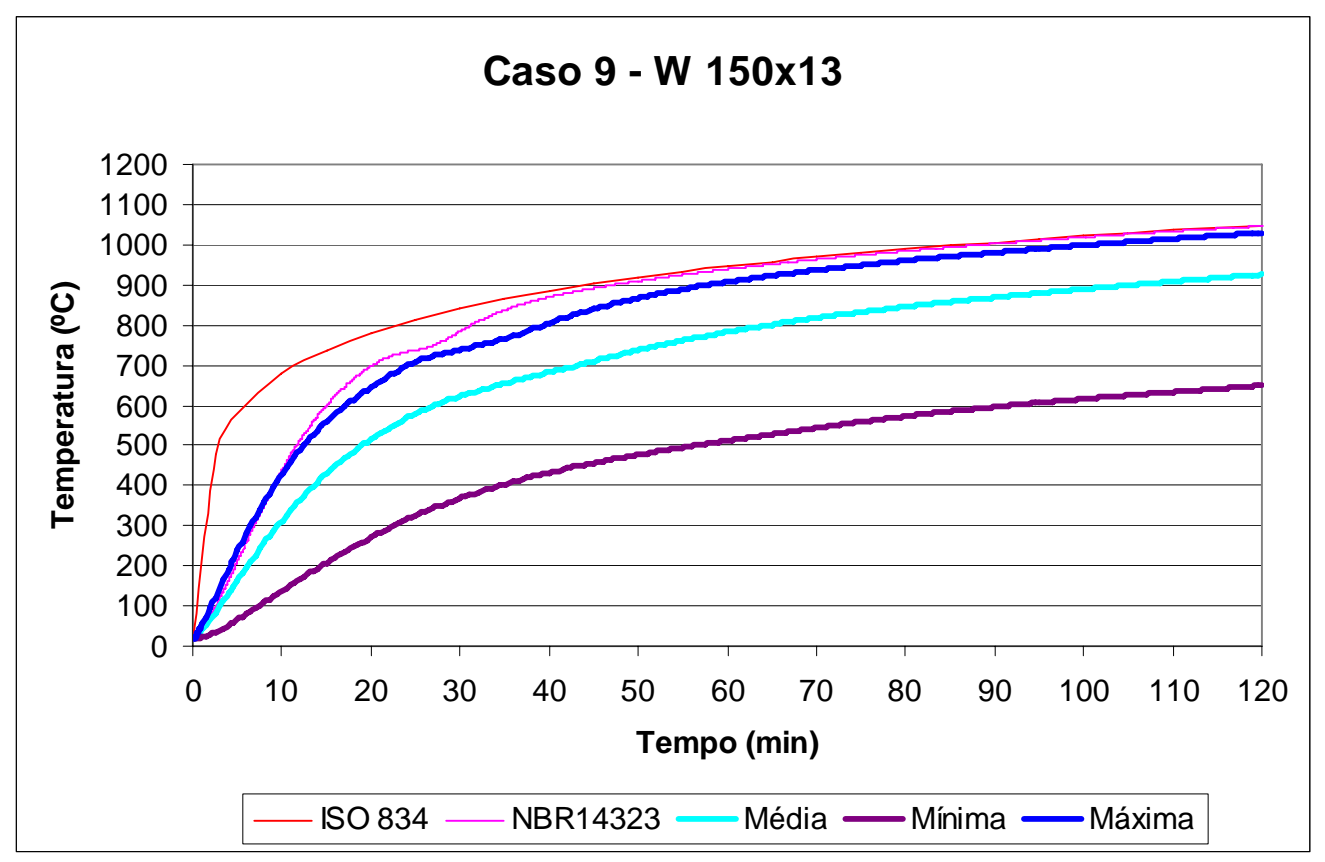

Figura 6.68 - Curvas da evolução da temperatura versus tempo para o caso 9 considerando-se o perfil W 150x13. 


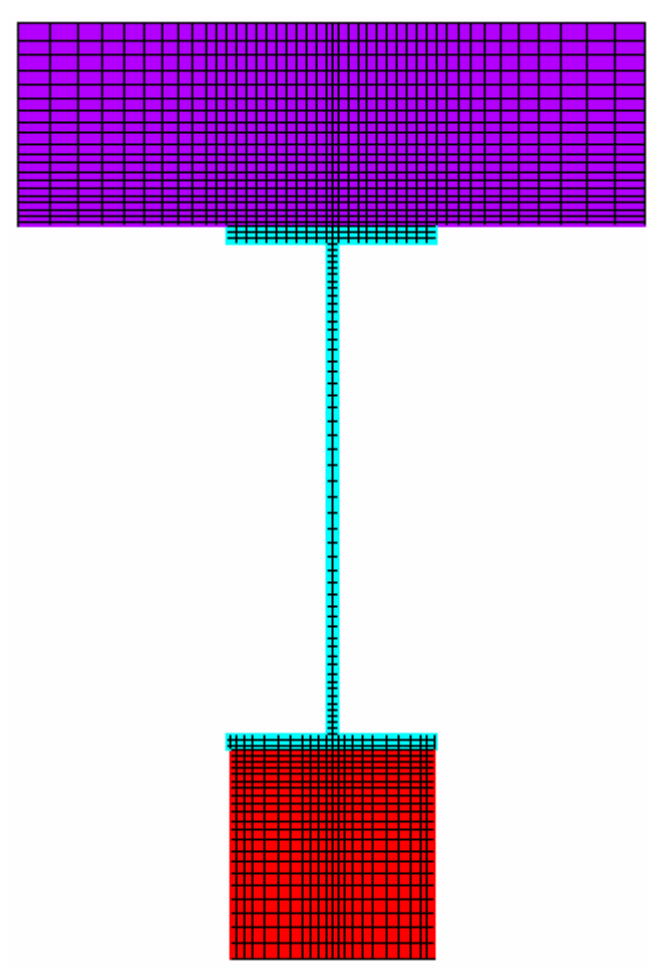

(a)

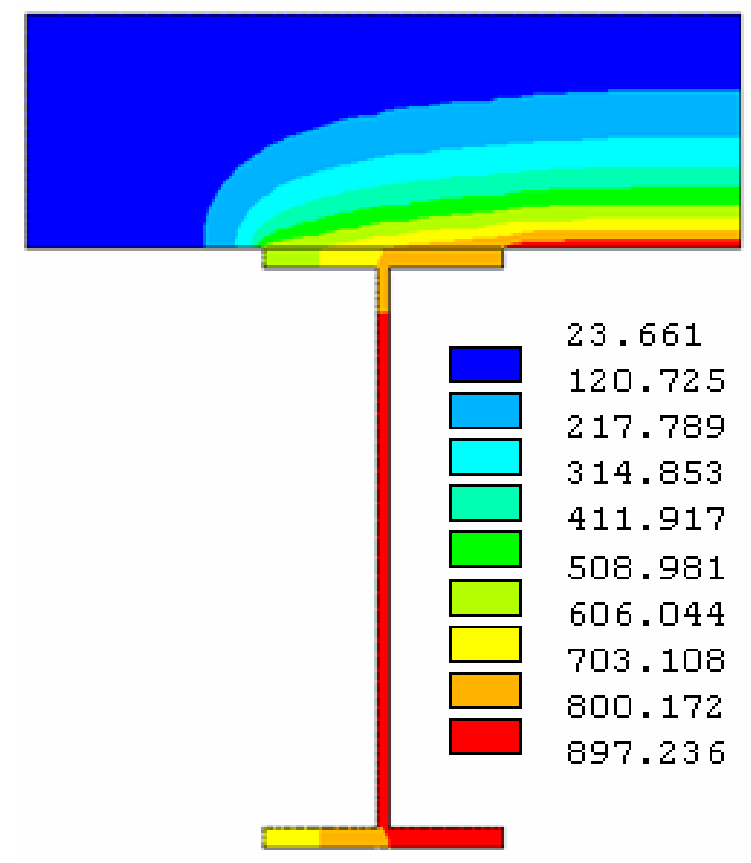

(b)

Figura 6.69 - Caso 9: (a) Malha de elementos finitos e (b) Campo de temperaturas correspondente a um tempo (TRRF) de 60 minutos para o perfil W 250x25,3.

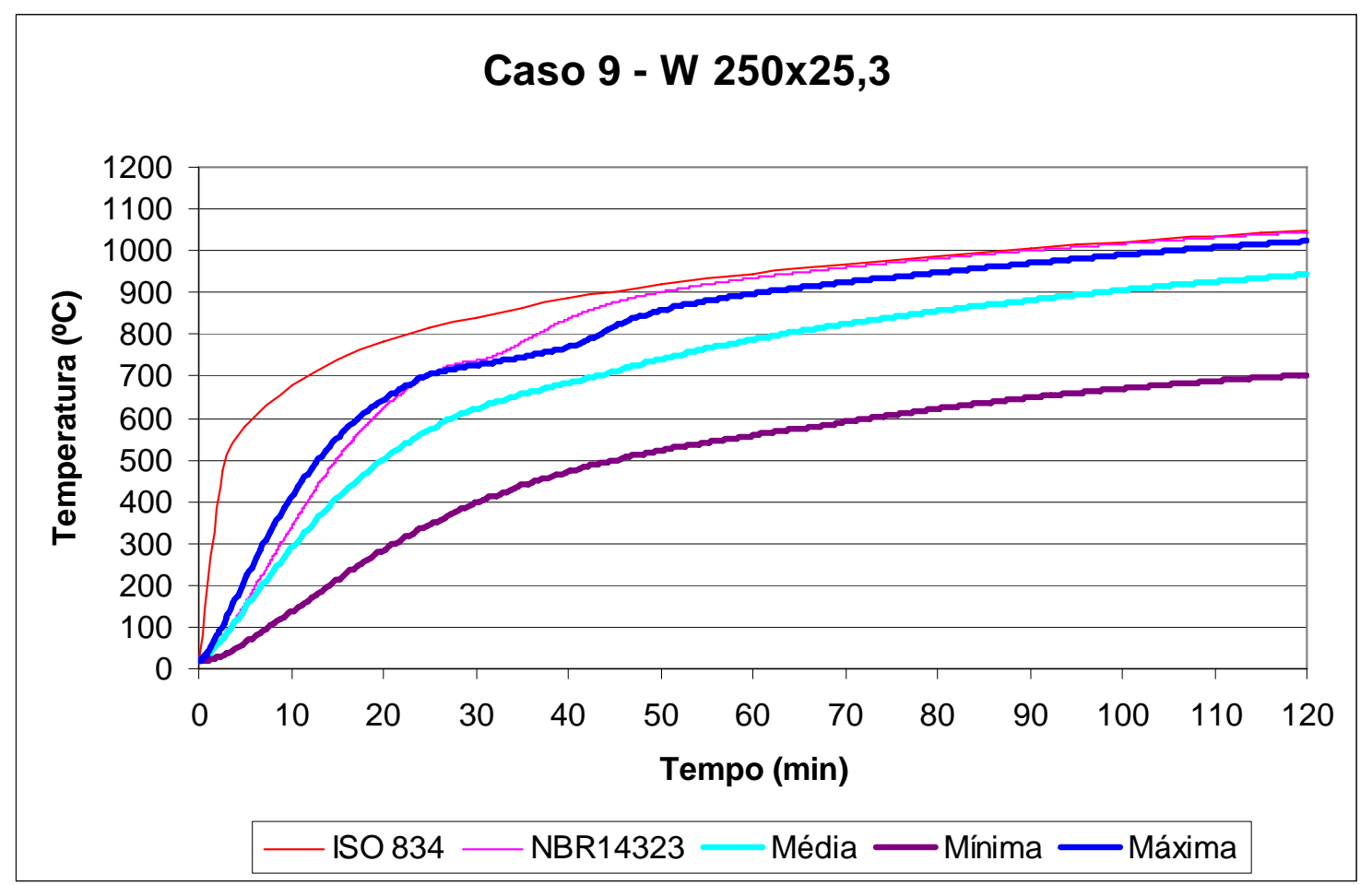

Figura 6.70 - Curvas da evolução da temperatura versus tempo para o caso 9 considerando-se o perfil W 250x25,3. 


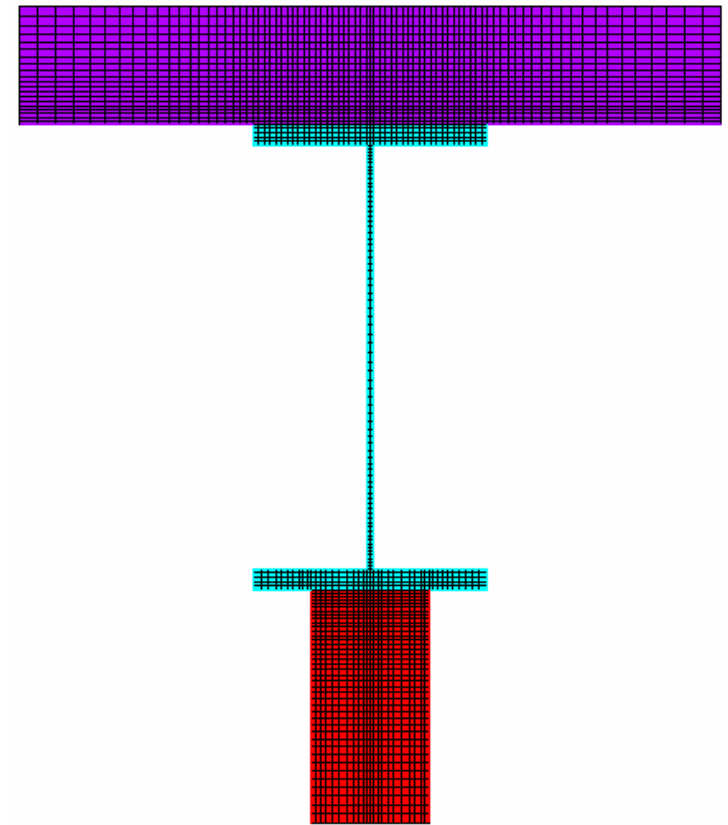

(a)

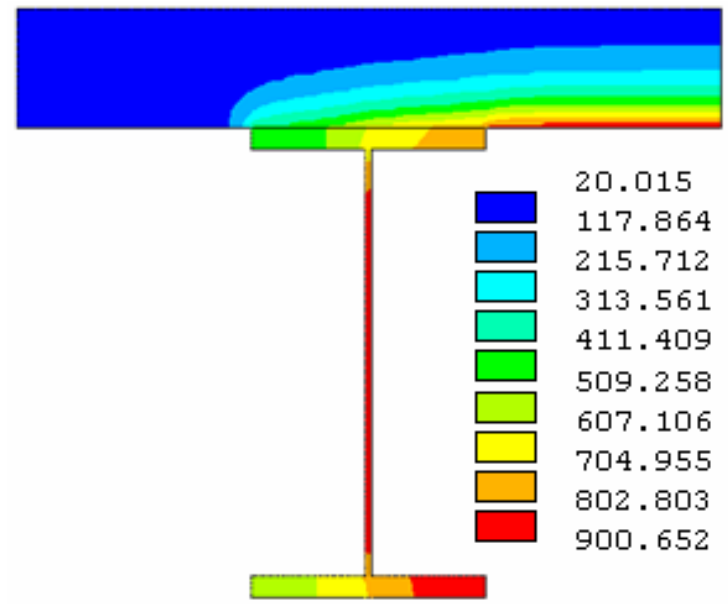

(b)

Figura 6.71 - Caso 9: (a) Malha de elementos finitos e (b) Campo de temperaturas correspondente a um tempo (TRRF) de 60 minutos para o perfil VS 400x78.

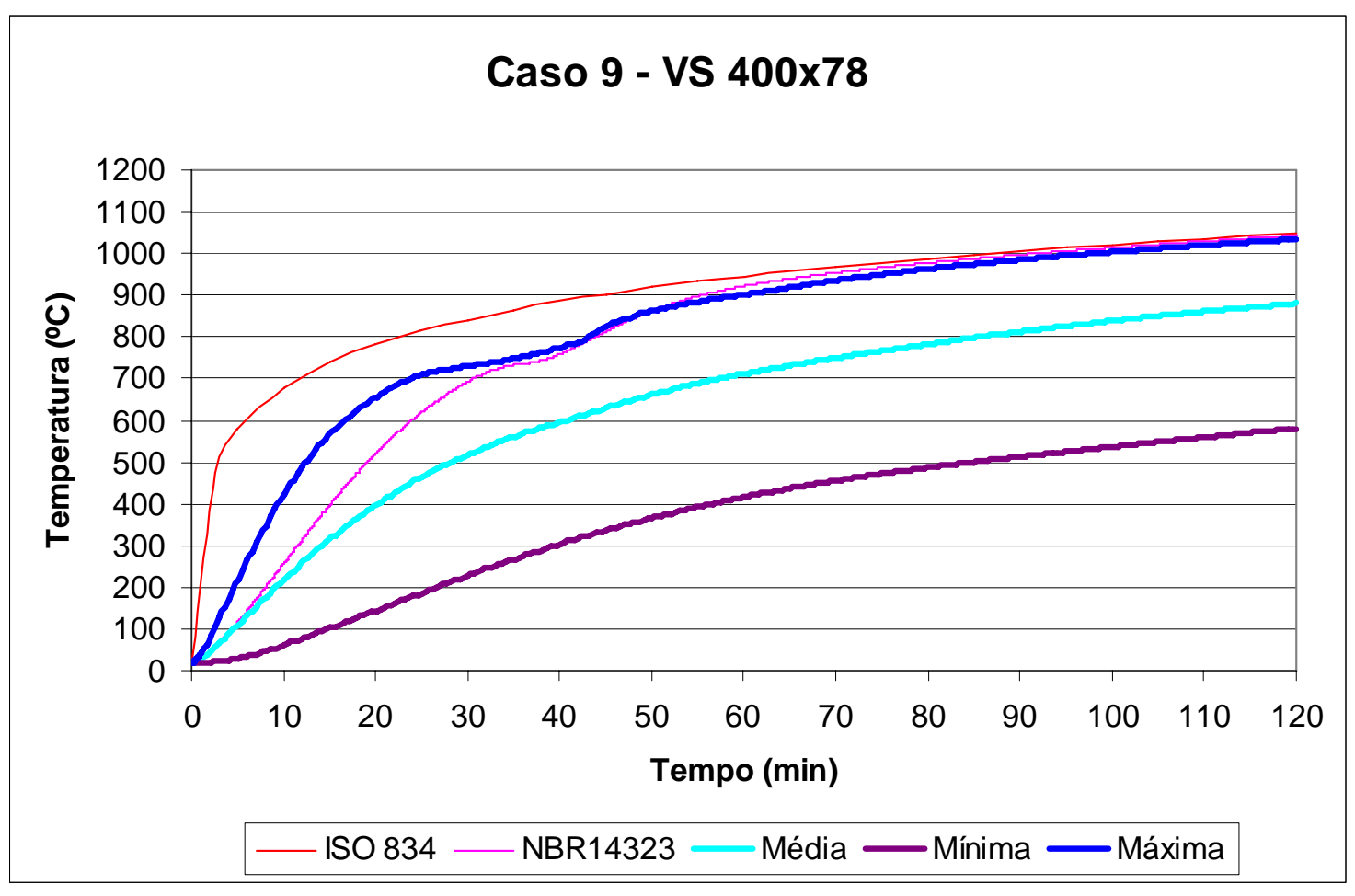

Figura 6.72 - Curvas da evolução da temperatura versus tempo para o caso 9 considerando-se o perfil VS 400x78. 

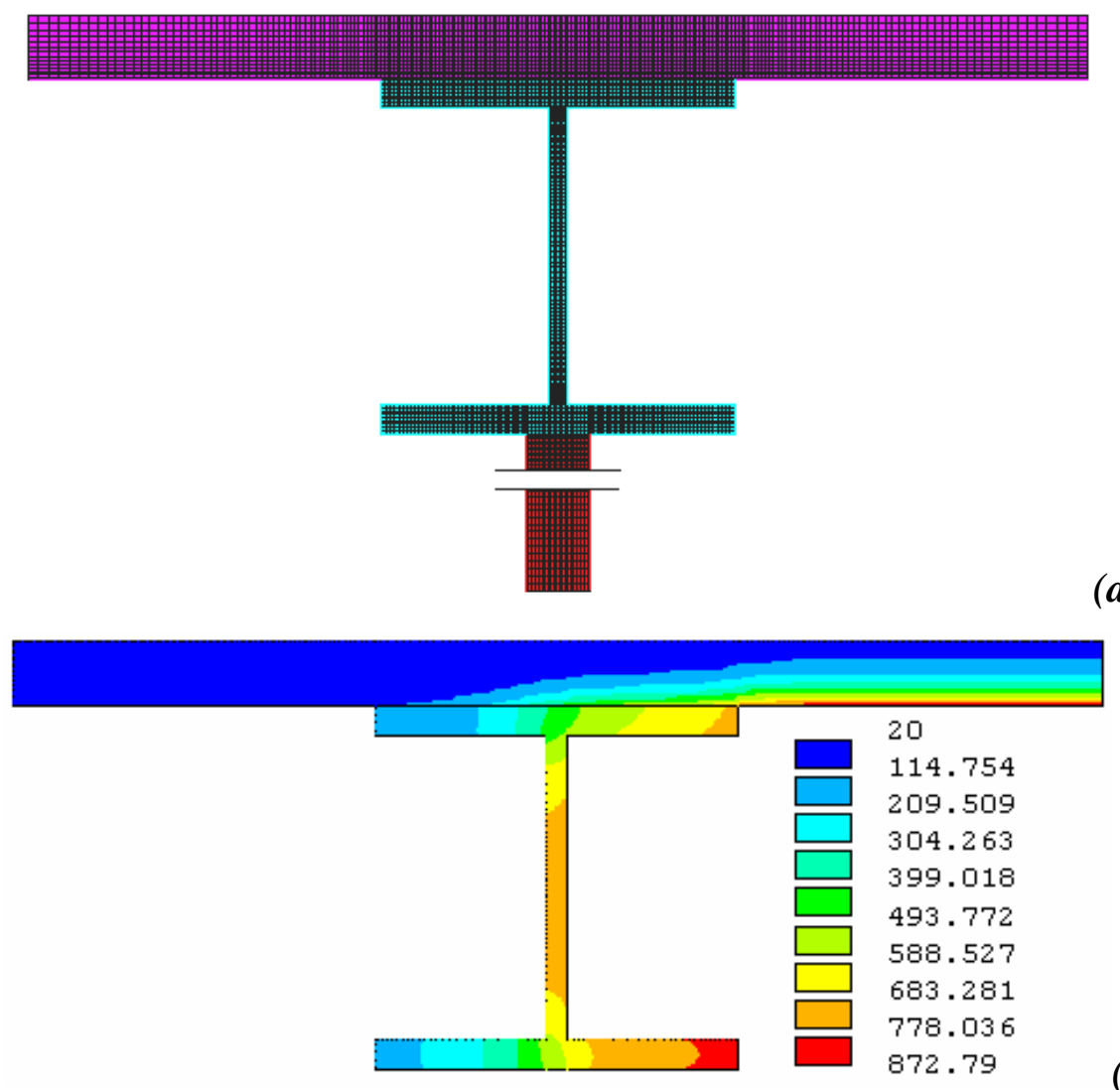

(b)

Figura 6.73 - Caso 9: (a) Malha de elementos finitos e (b) Campo de temperaturas correspondente a um tempo (TRRF) de 60 minutos para o perfil CS 550x502.

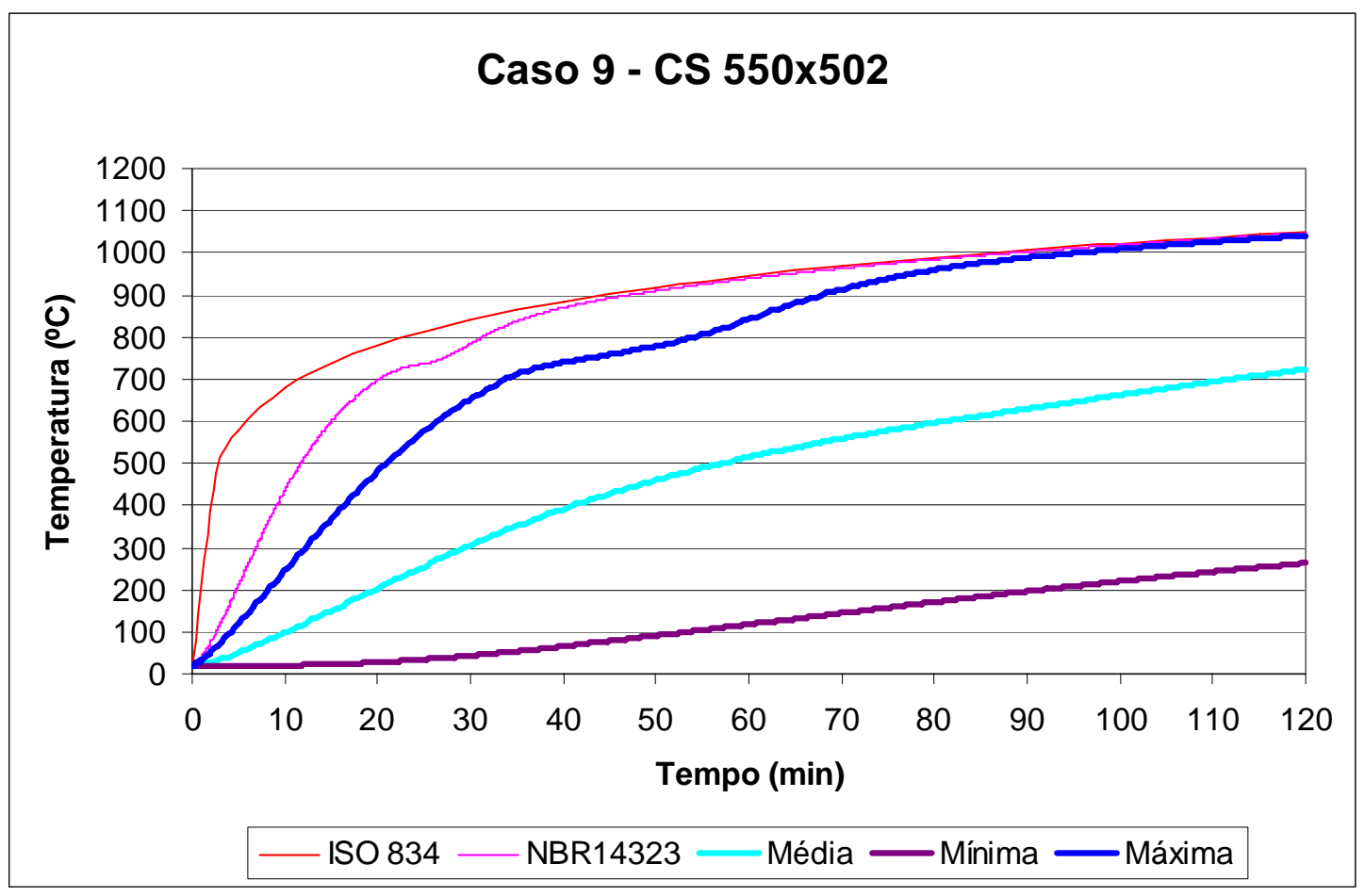

Figura 6.74 - Curvas da evolução da temperatura versus tempo para o caso 9 considerando-se o perfil CS 550x502. 
Com relação aos resultados obtidos para o CASO 9 nota-se que a curva de elevação de temperatura obtida por meio de adaptação do procedimento simplificado da NBR 14323:1999 se aproxima da curva de temperatura máxima obtida numericamente, porém, ora acima ora abaixo desta, para tempos de exposição inferiores a $30 \mathrm{~min}$.

Nota-se também uma grande distância entre as curvas de temperatura máxima e mínima na seção, o que pode sugerir uma provável limitação para abordagem do problema quando da aplicação da adaptação do procedimento simplificado proposto pela NBR 14323:1999.

\subsubsection{CASO 10 - Pilar com mesas em contato com paredes de alvenaria, exposta ao incêndio em apenas um lado da parede de alvenaria}

Este caso é geometricamente idêntico ao caso 8. A diferença está associada às condições de contorno do modelo. Da mesma forma que no caso anterior (caso 9), aqui se considera a alvenaria como um caso efetivo de compartimentação, isto é, incêndio ocorrendo em apenas um lado da parede de alvenaria.

A consideração da troca de calor com o meio nas superfícies não expostas do modelo é feita por meio da adoção de um coeficiente de transferência de calor por convecção igual a $9 \mathrm{~W} / \mathrm{m}^{20} \mathrm{C}$.

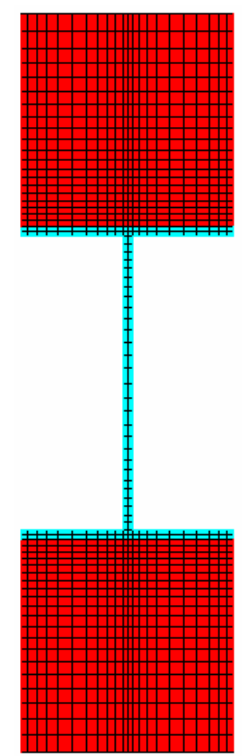

(a)

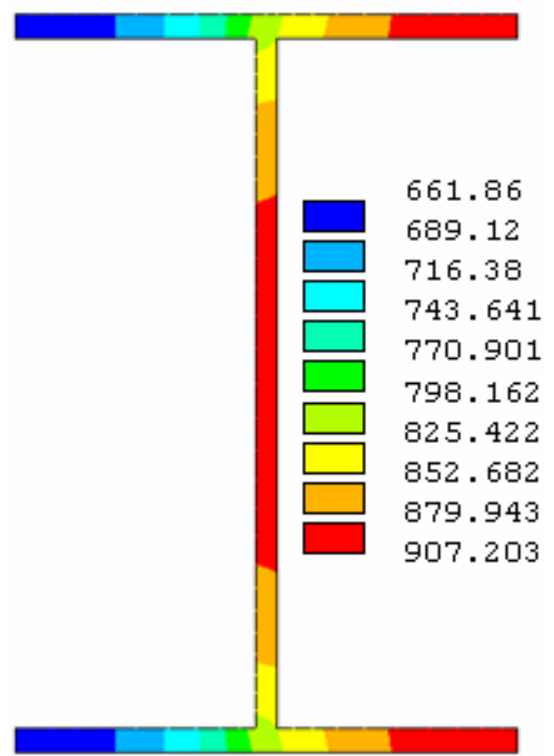

(b)

Figura 6.75 - Caso 10: (a) Malha de elementos finitos e (b) Campo de temperaturas correspondente a um tempo (TRRF) de 60 minutos para o perfil W 150x13. 
Novamente, como no caso 9, com relação ao procedimento simplificado, no cálculo do fator de massividade considera-se o perímetro do perfil que não está em contato com a alvenaria ou com a laje de concreto, no lado da parede exposta ao fogo, e a área total da seção. Os resultados de interesse obtidos para o caso 10 são apresentados nas figuras que se seguem.



Figura 6.76 - Curvas da evolução da temperatura versus tempo para o caso 10 considerando-se o perfil W 150x13.

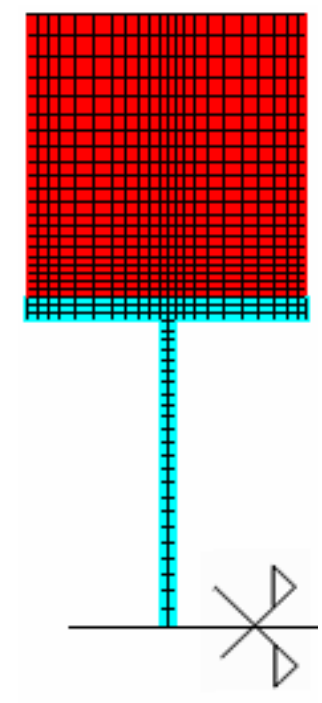

(a)

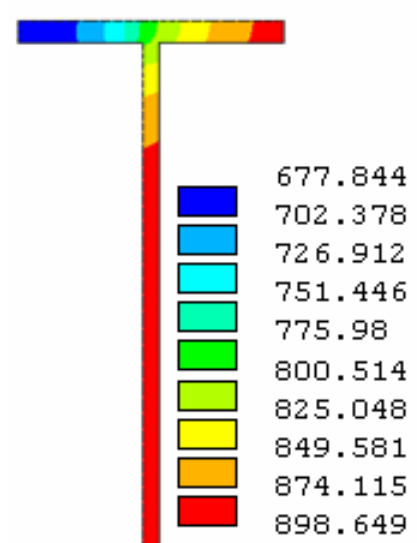

(b)

Figura 6.77 - Caso 10: (a) Malha de elementos finitos e (b) Campo de temperaturas correspondente a um tempo (TRRF) de 60 minutos para o perfil W 250x25,3. 


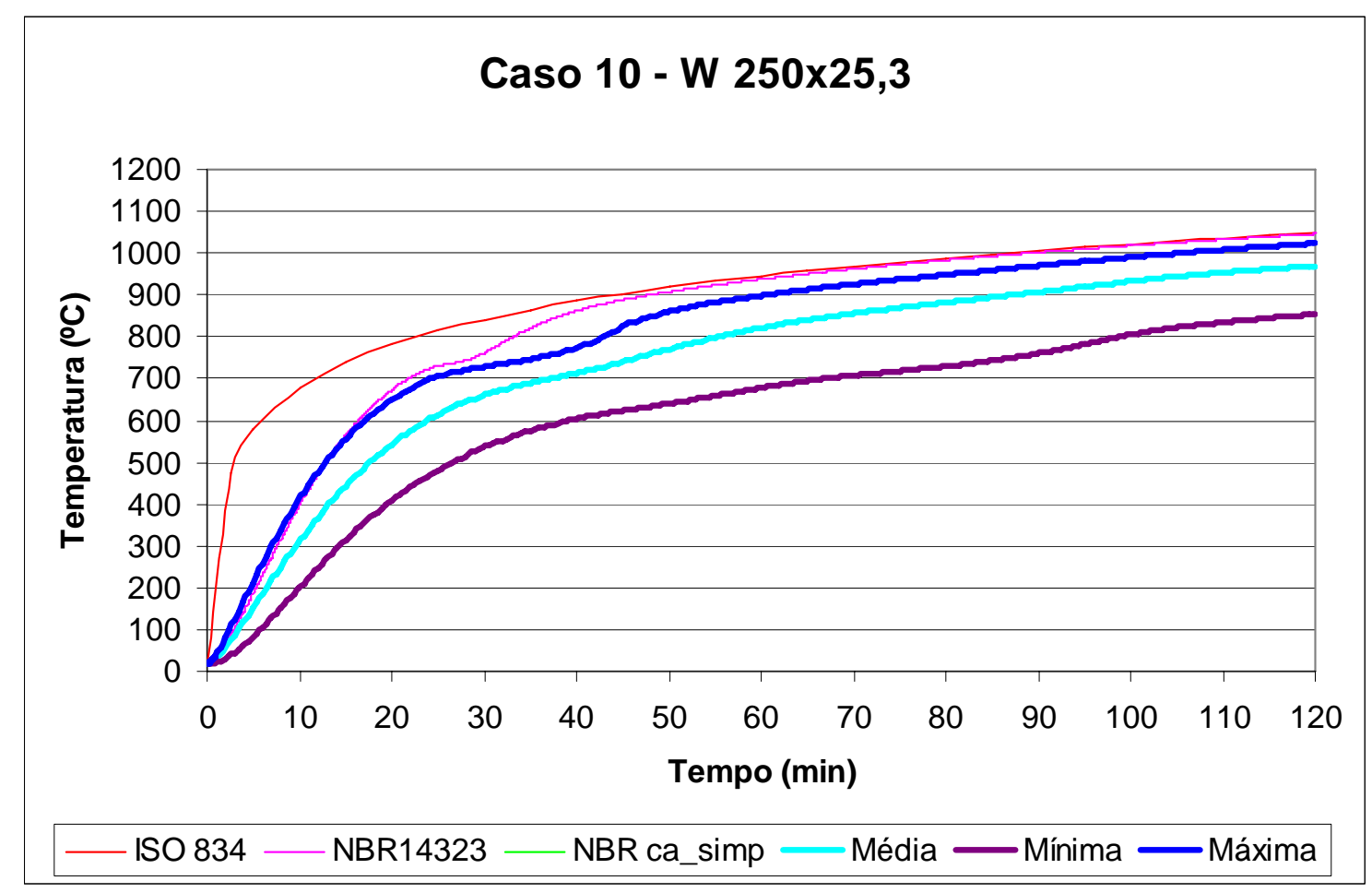

Figura 6.78 - Curvas da evolução da temperatura versus tempo para o caso 10 considerando-se o perfil W 250x25,3.

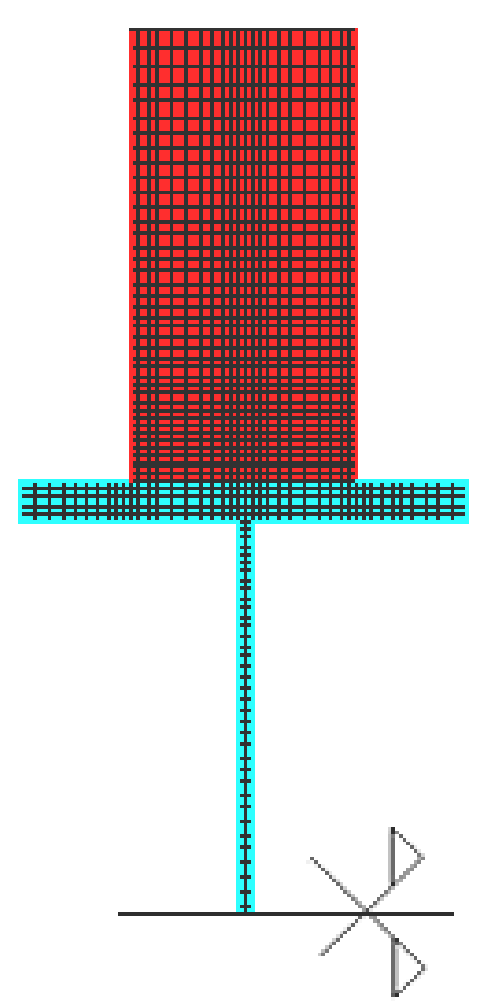

(a)

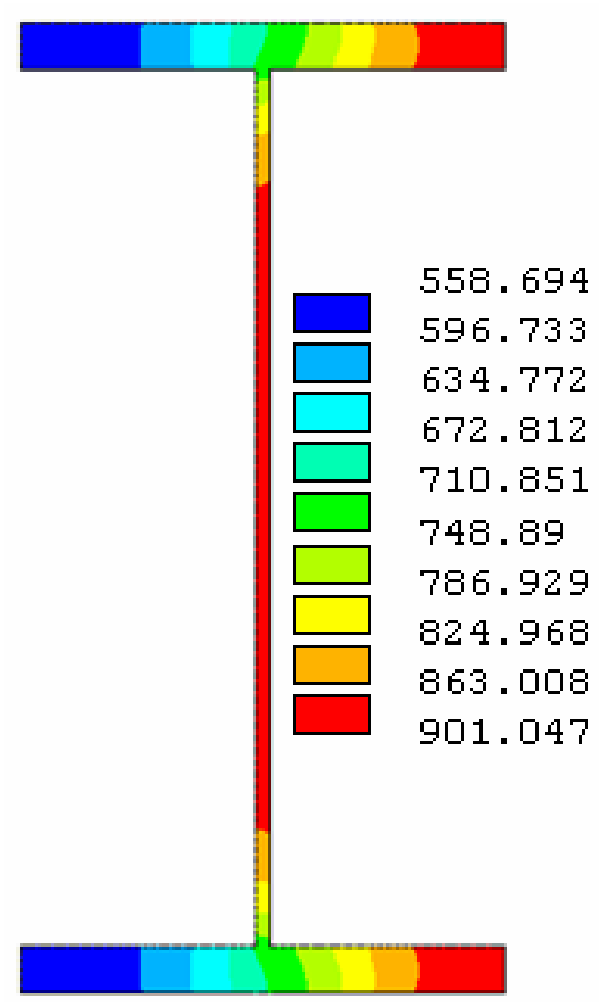

(b)

Figura 6.79 - Caso 10: (a) Malha de elementos finitos e (b) Campo de temperaturas correspondente a um tempo (TRRF) de 60 minutos para o perfil VS 400x78. 


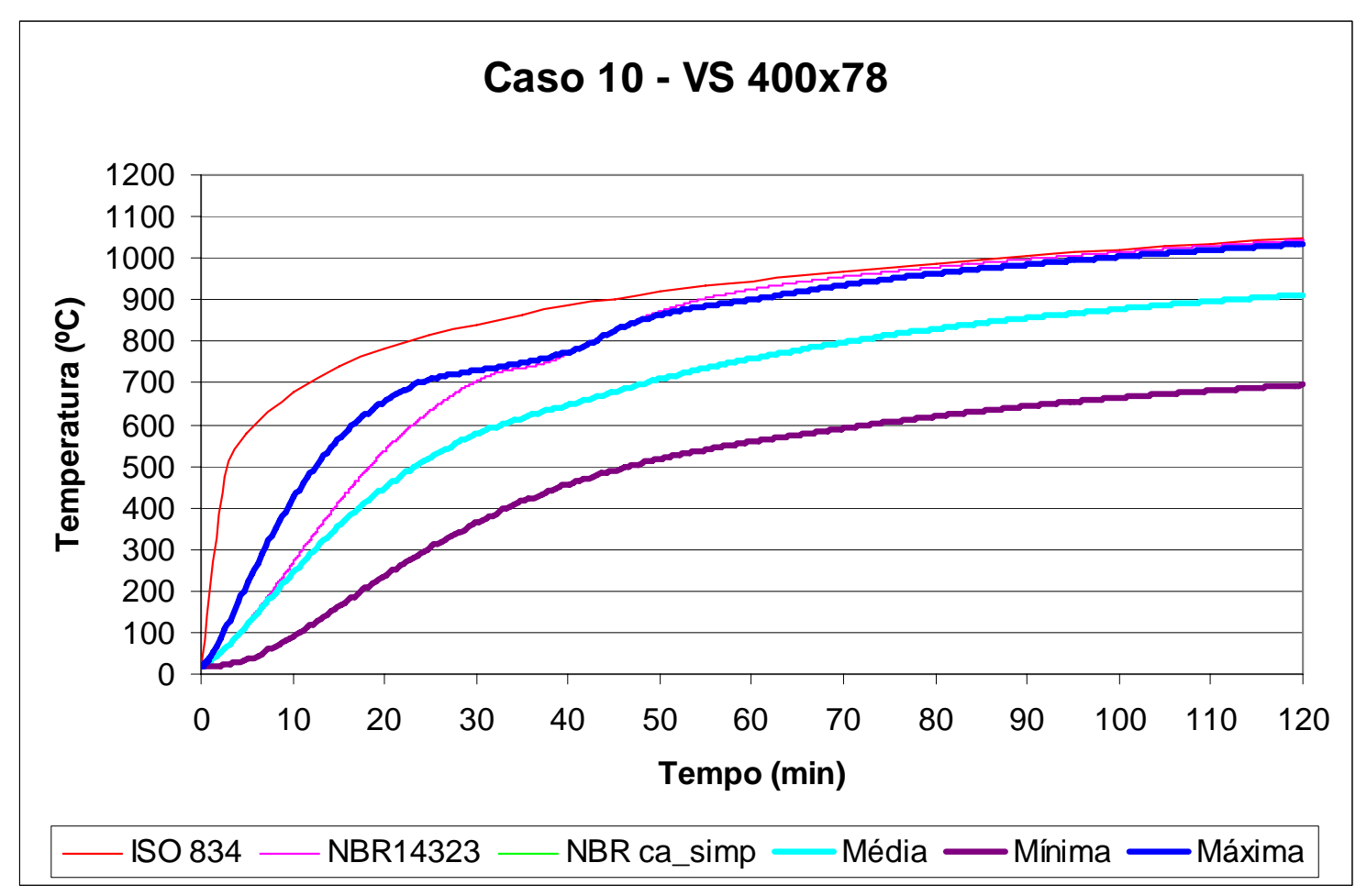

Figura 6.80 - Curvas da evolução da temperatura versus tempo para o caso 10 considerando-se o perfil VS 400x78.

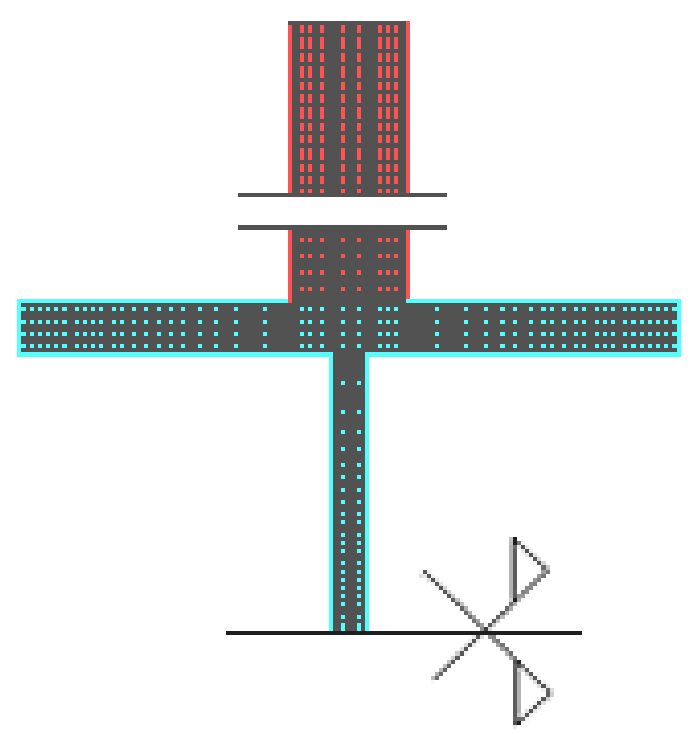

(a)

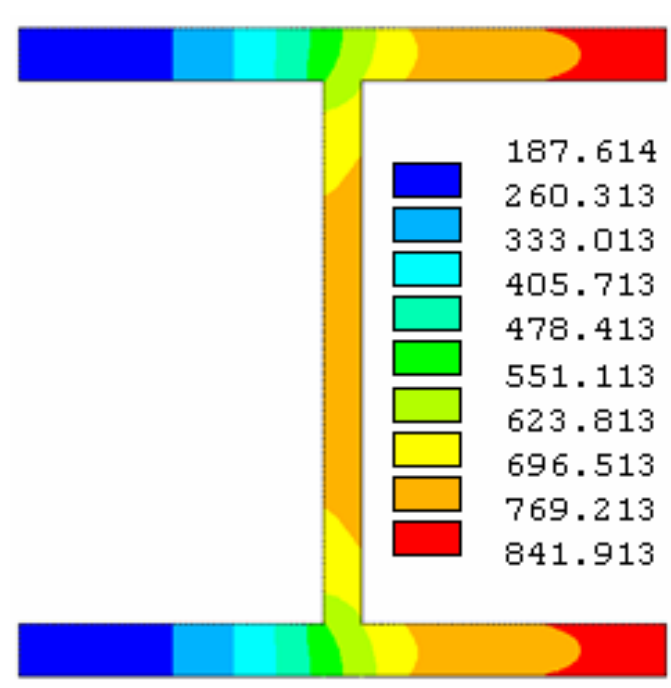

(b)

Figura 6.81 - Caso 10: (a) Malha de elementos finitos e (b) Campo de temperaturas correspondente a um tempo (TRRF) de 60 minutos para o perfil CS 550x502. 


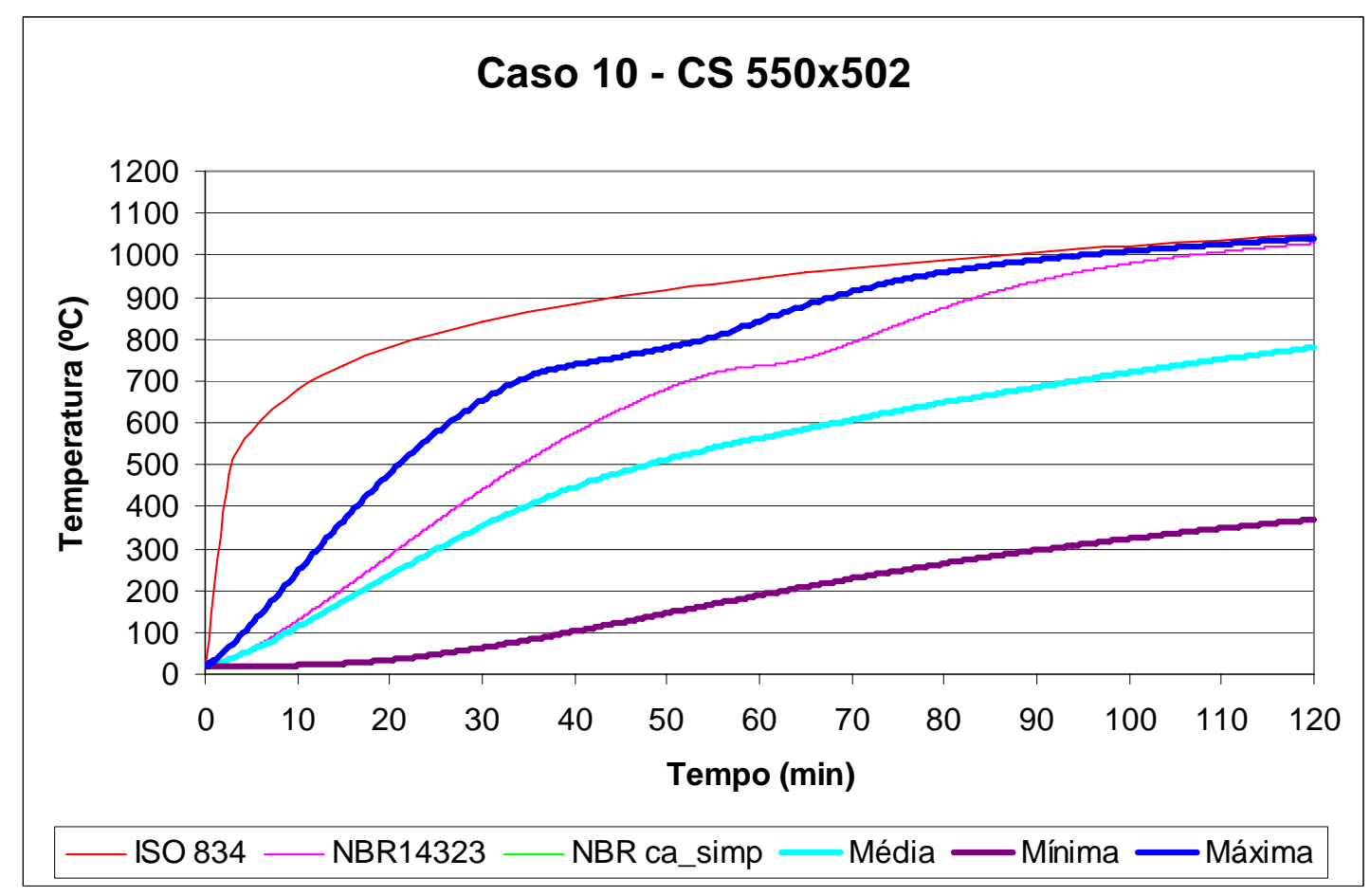

Figura 6.82 - Curvas da evolução da temperatura versus tempo para o caso 10 considerando-se o perfil CS 550x502.

Com relação aos resultados do CASO 10 valem as mesmas observações feitas para o caso 9, porém, para os perfis W 150x13 e W 250x25,3 a distância entre as curvas de temperatura máxima e mínima na seção resultam menos pronunciadas.

Para tais casos, deve-se ter em mente que a grande distância entre as curvas de temperaturas máximas e mínimas na seção obtidas numericamente leva a concluir que, para essas situações de aplicação, a hipótese de temperatura homogênea na seção, adotada pelos procedimentos simplificados, não é a mais adequada.

Mesmo que para os fatores de massividade adotados os procedimentos simplificados conduzam a resultados a favor da segurança, do ponto de vista da análise térmica, os efeitos do gradiente térmico instalado na seção podem ser bastante nocivos à resposta estrutural do elemento e por isso, devem ser avaliados cuidadosamente. 


\subsubsection{CASO 11 - Pilar com alma em contato com paredes de alvenaria, exposta ao incêndio em apenas um lado da parede de alvenaria}

Trata-se de um caso de difícil analise por meio de procedimento simplificado de cálculo quando se considera a alvenaria como um caso efetivo de compartimentação, com o incêndio ocorrendo em apenas um lado da parede de alvenaria.

No cálculo do fator de massividade considera-se o perímetro da parte do perfil exposta ao fogo e a are total da seção. As curvas de elevação de temperatura considerando-se a área total da seção no cálculo do fator de massividade para o procedimento simplificado, adaptado da NBR 14323:1999, deverão apresentar uma grande diferença entre a máxima e mínima temperatura instalada na seção.

A consideração da troca de calor com o meio nas superfícies não expostas do modelo é feita por meio da adoção de um coeficiente de transferência de calor por convecção igual a $9 \mathrm{~W} / \mathrm{m}^{20} \mathrm{C}$. Os resultados de interesse obtidos para o caso 11 são apresentados nas figuras que se seguem.

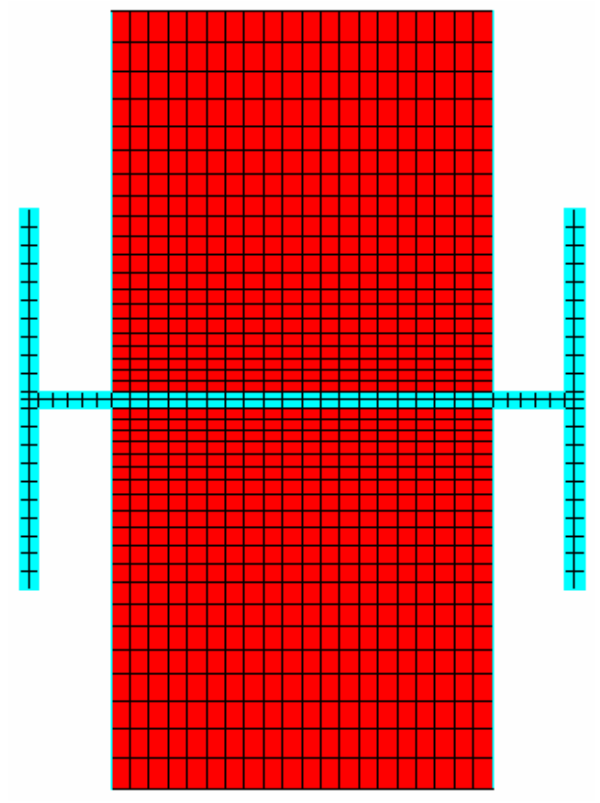

(a)

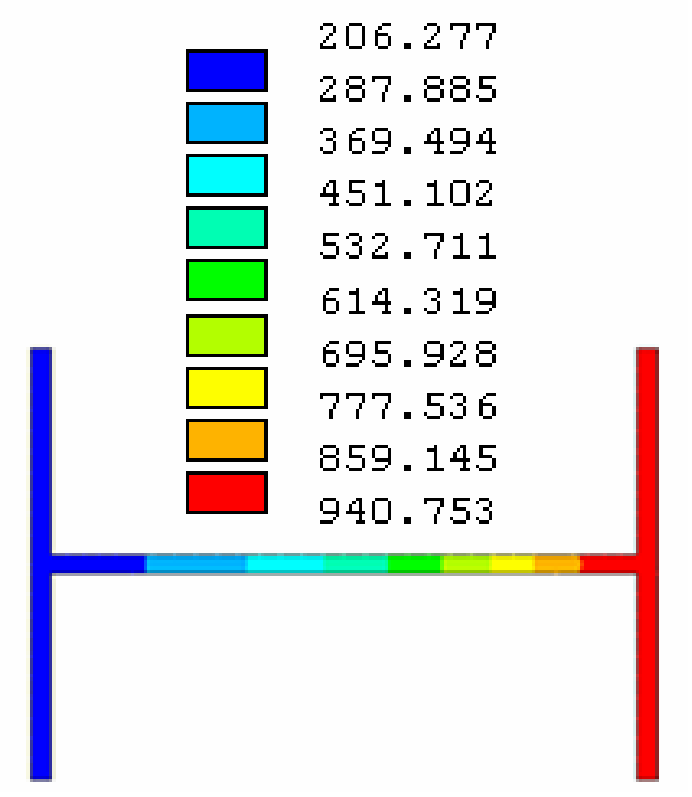

(b)

Figura 6.83 - Caso 11: (a) Malha de elementos finitos e (b) Campo de temperaturas correspondente a um tempo (TRRF) de 60 minutos para o perfil W 150x13. 


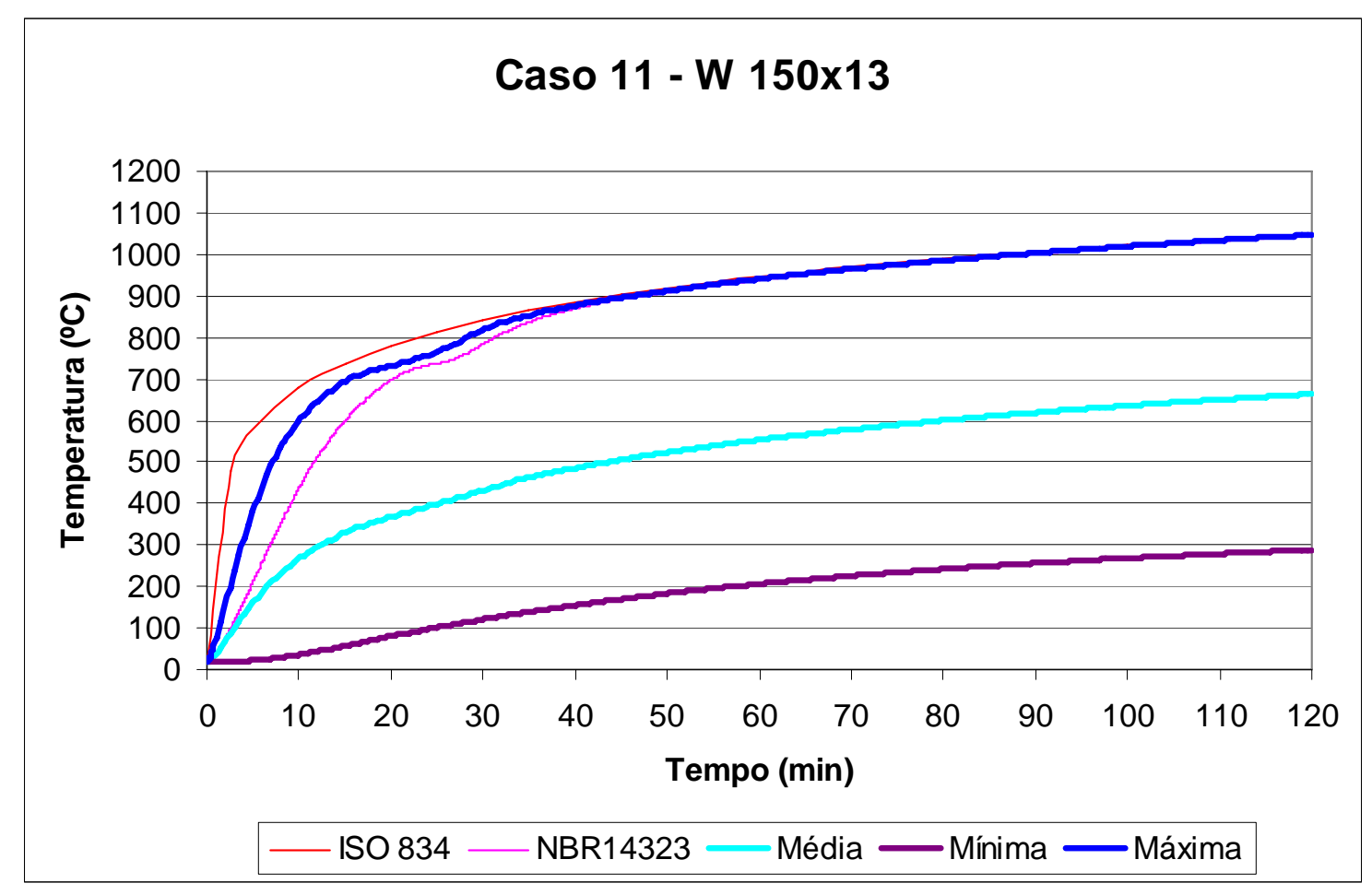

Figura 6.84 - Curvas da evolução da temperatura versus tempo para o caso 11 considerando-se o perfil W 150x13.

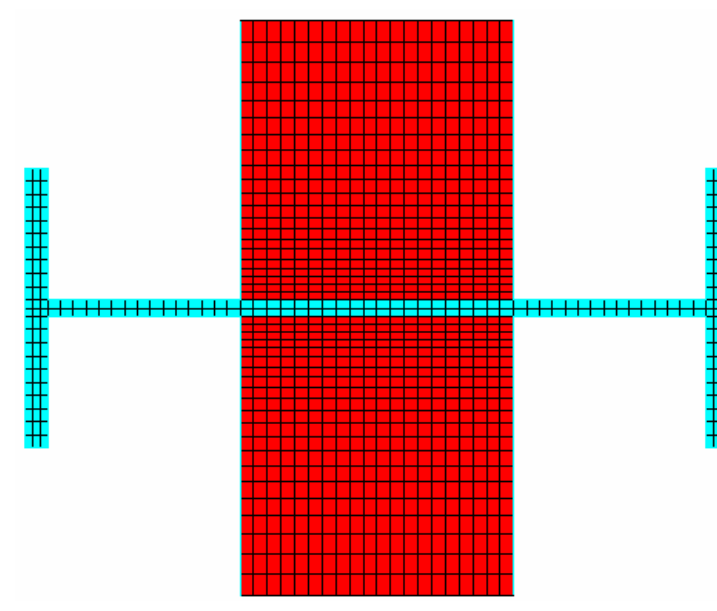

(a)

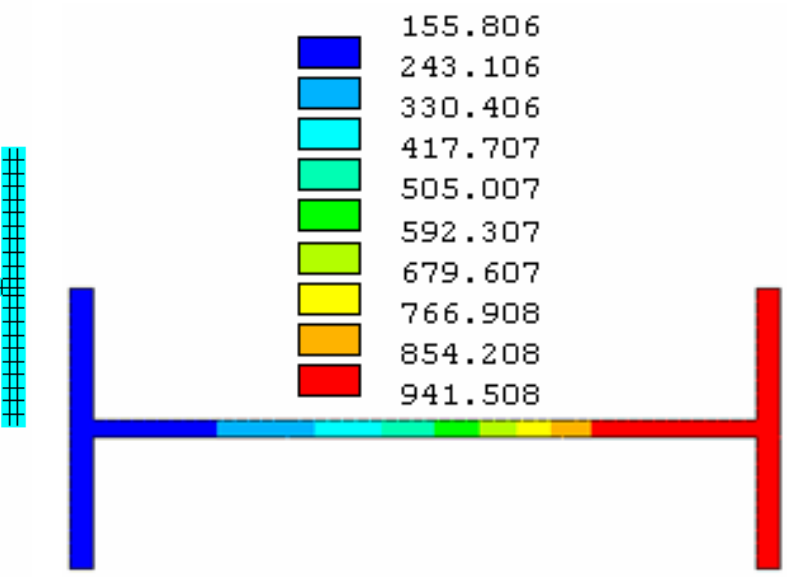

(b)

Figura 6.85 - Caso 11: (a) Malha de elementos finitos e (b) Campo de temperaturas correspondente a um tempo (TRRF) de 60 minutos para o perfil W 250x25,3. 


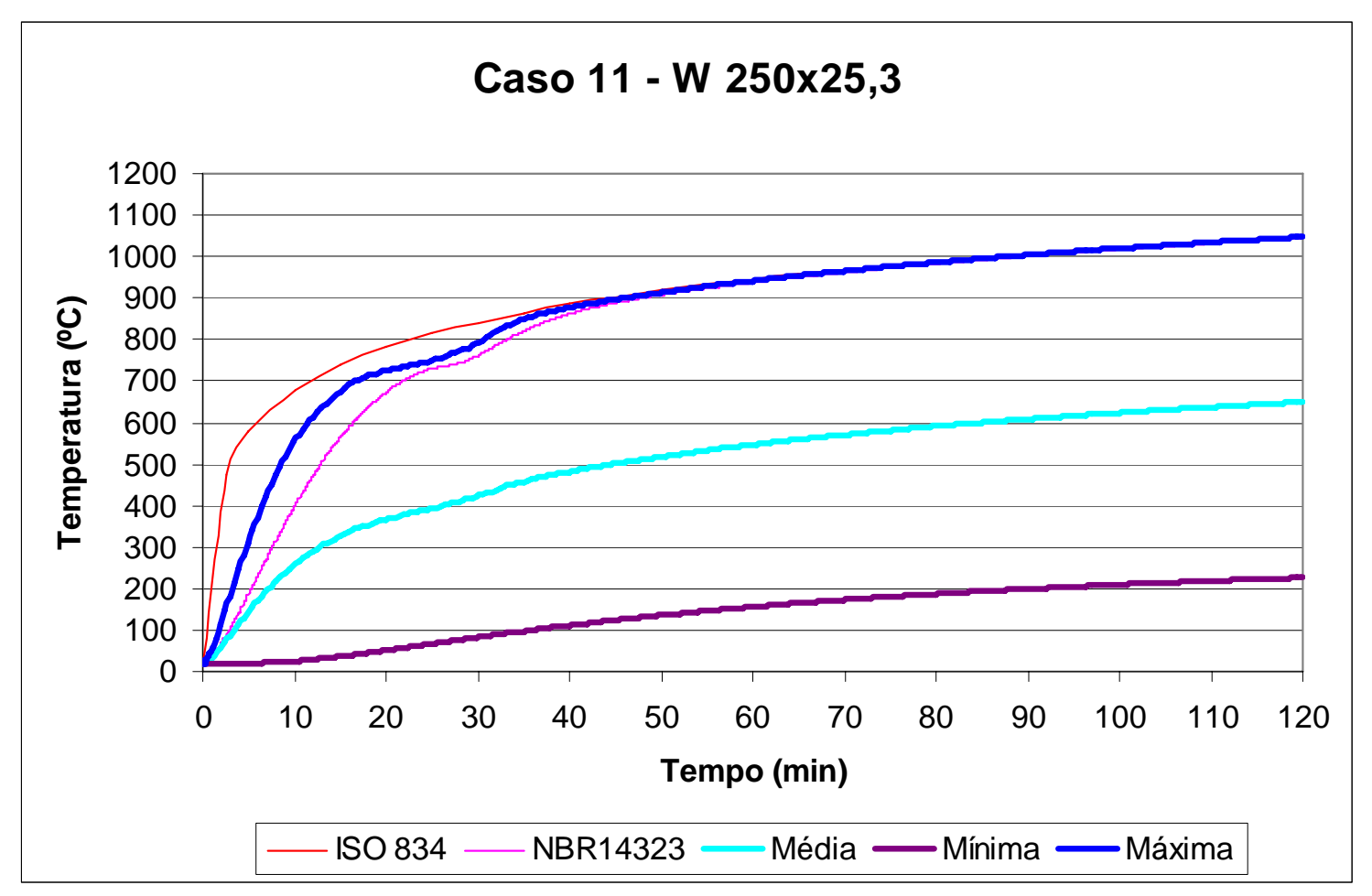

Figura 6.86 - Curvas da evolução da temperatura versus tempo para o caso 11 considerando-se o perfil W 250x25,3.

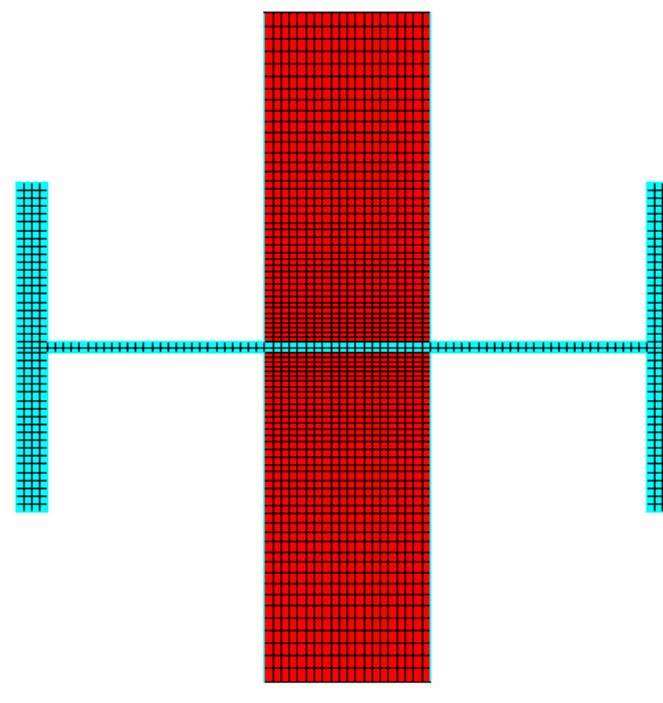

(a)

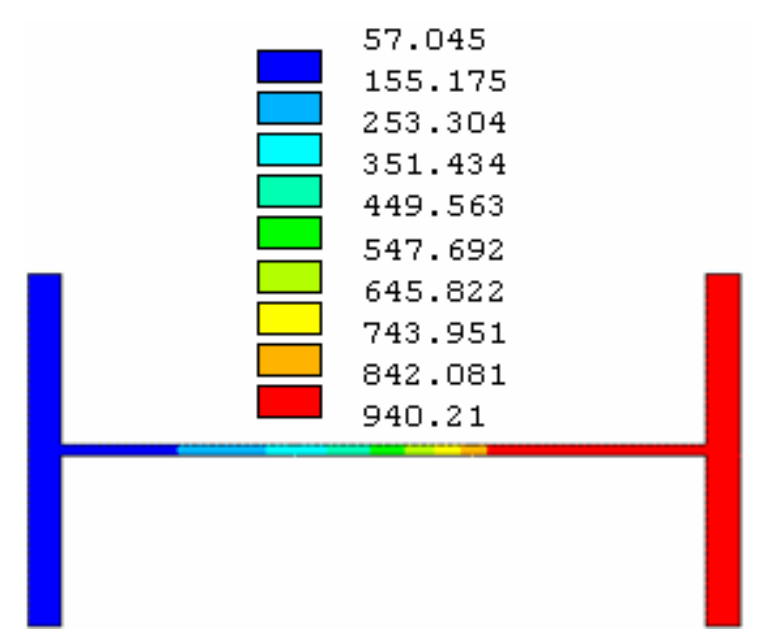

(b)

Figura 6.87 - Caso 11: (a) Malha de elementos finitos e (b) Campo de temperaturas correspondente a um tempo (TRRF) de 60 minutos para o perfil VS 400x78. 


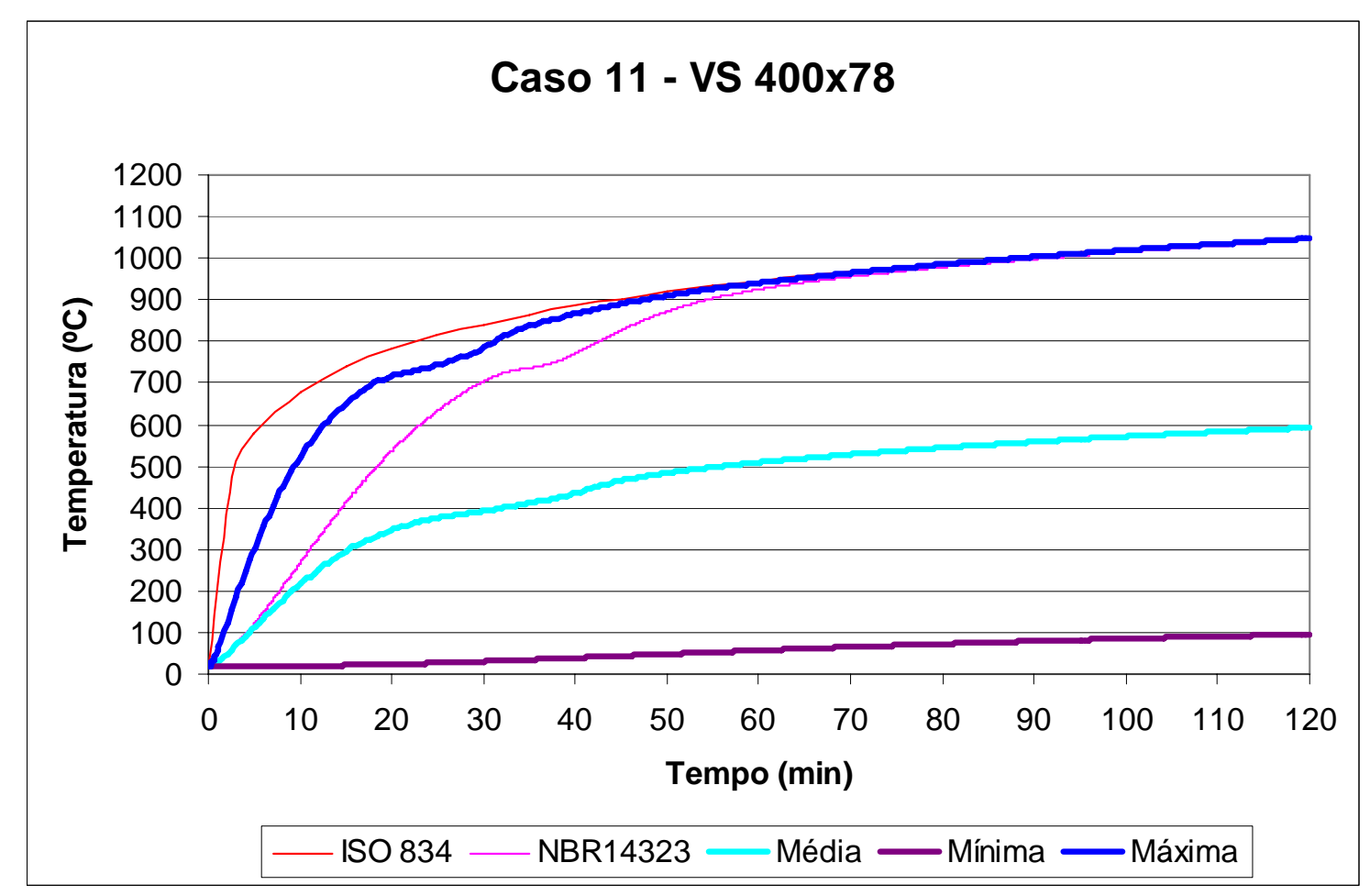

Figura 6.88 - Curvas da evolução da temperatura versus tempo para o caso 11 considerando-se o perfil VS 400x78.

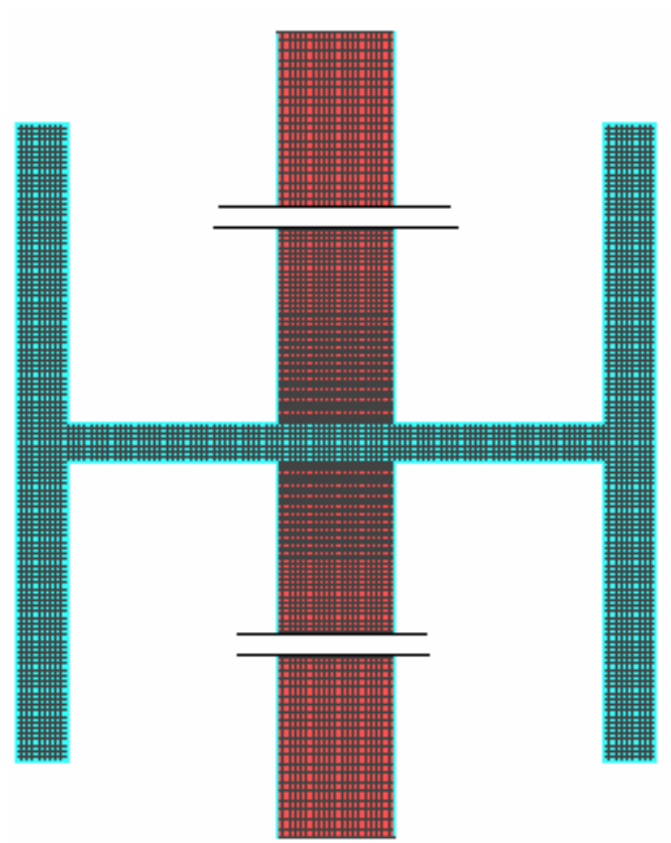

(a)

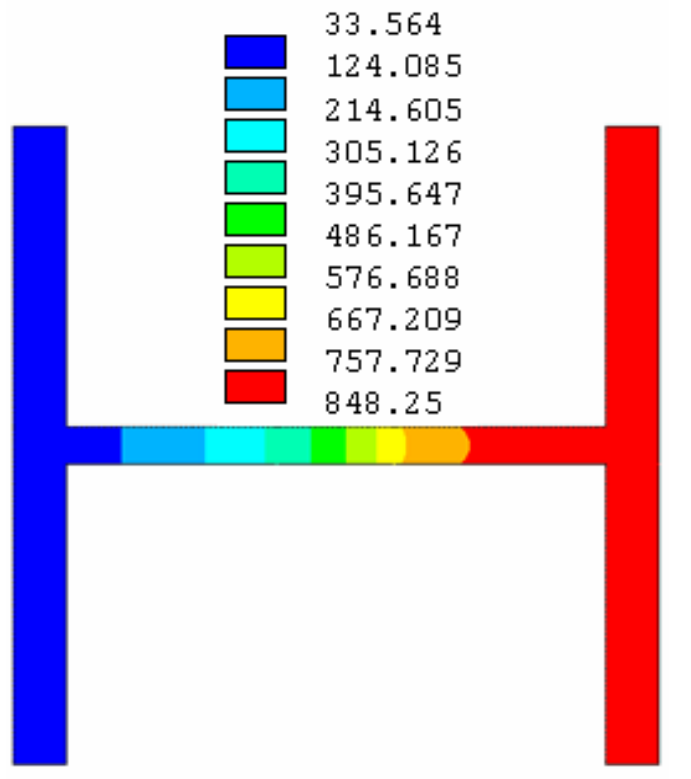

(b)

Figura 6.89 - Caso 11: (a) Malha de elementos finitos e (b) Campo de temperaturas correspondente a um tempo (TRRF) de 60 minutos para o perfil CS 550x502. 


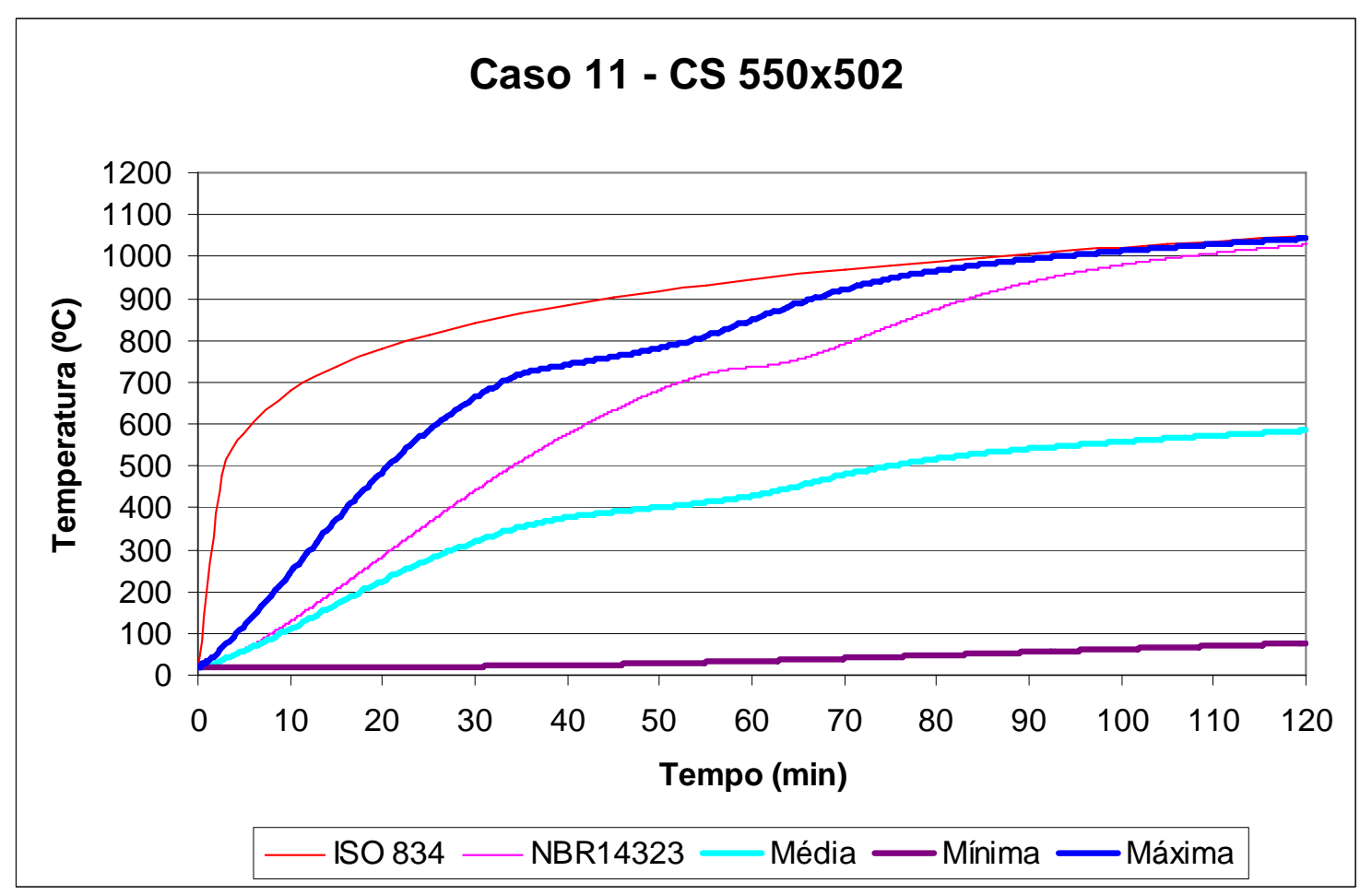

Figura 6.90 - Curvas da evolução da temperatura versus tempo para o caso 11 considerando-se o perfil CS 550x502.

No CASO 11, a consideração da seção total para análise conduziu a uma grande distância entre as curvas de temperaturas máxima e mínima na seção, o que evidencia, assim como nos casos 9 e 10, uma limitação para abordagem do problema quando da aplicação de adaptação do procedimento simplificado proposto pela NBR 14323:1999. Este caso, assim como os casos 9 e 10, são casos em que se faz necessário o emprego de procedimento numérico para uma avaliação mais adequada.

Conclusões e demais comentários inerentes aos casos aqui analisados serão apresentados no Capítulo 8. No Anexo $\boldsymbol{C}$ são apresentados outros campos de temperatura em caráter complementar àqueles aqui apresentados e analisados, em que serão considerados tempos de exposição iguais a 15, 30, 90 e 120 min. 


\section{EFEITOS DA ELEVAÇÃO DE TEMPERATURA NA RESPOSTA ESTRUTURAL}

No presente capítulo tem-se análises em que são considerados os efeitos da elevação de temperatura na resposta de uma dada estrutura, ou mesmo de um elemento estrutural de interesse. Inicialmente, é importante ressaltar que a análise acoplada é, por definição, aquela que leva em conta a interação entre duas ou mais áreas da engenharia.

Uma análise piezelétrica, por exemplo, lida com a interação entre as áreas elétrica e estrutural: ela determina uma distribuição de voltagem para deslocamentos aplicados, ou vice-versa. Entre exemplos de análise acoplada podem ser citadas a análise termo-estrutural, a análise termoelétrica, e a análise fluido-estrutural.

Em estruturas em situação de incêndio realiza-se uma análise acoplada quando, a partir de um campo de temperaturas obtido por meio de análise térmica, se determina os conseqüentes efeitos da elevação de temperatura na análise estrutural, seja de um elemento isolado ou de um sistema estrutural.

Atualmente é de grande interesse a realização de análises acopladas em estruturas submetidas a altas temperaturas, em que se faz possível considerar efeitos mecânicos causadas pelas restrições axiais aos deslocamentos e os efeitos dos gradientes térmicos na seção, que podem ocasionar o surgimento de forças de compressão ou de tração nas vinculações bem como introduzir esforços adicionais de flexão.

Para tanto, são apresentados resultados da análise numérica de vigas de aço pertencentes a um edifício (em fase de projeto), com vistas a se obter o valor da resistência máxima à flexão de cada viga em função de elevação da temperatura. Como suporte para fins de validação, serão paralelamente utilizados resultados de análises térmicas e de fatores de redução de resistência, obtidos com o programa TCD Temperature Calculation and Design v5.0, ANDERBERG (1997), e cedidos por Valdir Pignatta e Silva, atualmente professor Doutor da Escola Politécnica da USP. 


\subsection{CASOS ANALISADOS}

Foram analisados sete casos correspondentes a vigas de aço, representativas do edifício de interesse, consideradas sempre como biengastadas (uma extremidade com engaste fixo e outra com engate móvel). Na tabela 7.1 são estabelecidas situações de interesse para análise, em que se considerada ou não a existência de lajes de concreto sobre as vigas de aço, cuja seção transversal é do tipo seção caixão (seção tubular retangular constituída por composição de perfis formados a frio), bem como a existência ou não de alvenarias sob as mesmas vigas analisadas.

A denominação dada a cada caso, assim como a descrição de cada um deles, está apresentada na tabela 7.1, em que são considerados casos de carregamentos térmicos considerando a ação do fogo (ação térmica) em toda a seção ou em partes previamente estabelecidas.

\subsection{CONSIDERAÇÕES REFERENTES À GEOMETRIA DAS VIGAS}

As vigas de aço constituídas por perfis formados a frio analisadas no presente trabalho possuem, conforme já mencionado, seção do tipo caixão, sendo compostas por dois perfis formados a frio do tipo U-enrijecido, conforme esquematiza a figura 7.1.

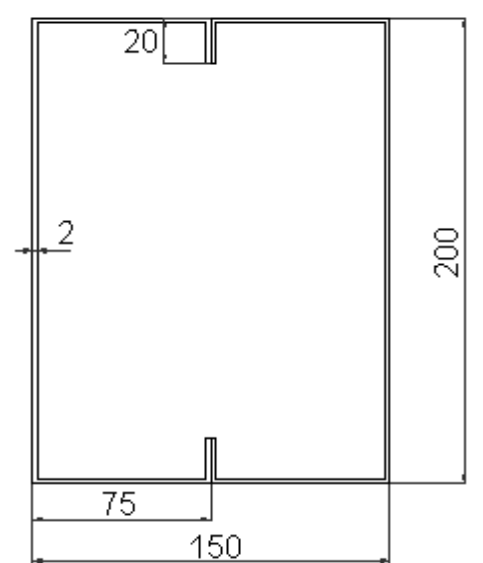

Figura 7.1 - Dimensões geométricas da seção transversal das vigas, comprimento e condições de vinculação. 
Tabela 7.1 - Denominação, descrição e esquematização dos casos analisados

\begin{tabular}{|c|c|c|c|}
\hline Denominação & Descrição & \multicolumn{2}{|c|}{ Esquematização } \\
\hline U5-V-EIST & $\begin{array}{l}\text { - Viga Isolada } \\
\text { - Exposição inferior e superior } \\
\text { total }\end{array}$ & fogo & fogo \\
\hline U5-VL-EIT & $\begin{array}{l}\text { - Viga e Laje } \\
\text { - Exposição inferior total }\end{array}$ & 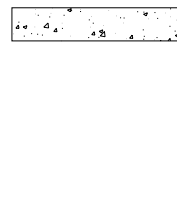 & 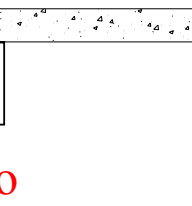 \\
\hline U5-VLA9-EIT & $\begin{array}{l}\text { - Viga, Laje e Alvenaria de } 9 \mathrm{~cm} \\
\text { - Exposição inferior total }\end{array}$ & $\begin{array}{ll}\ldots \\
\end{array}$ & 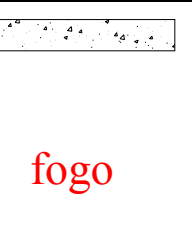 \\
\hline U5-VLA9-EIP & $\begin{array}{l}\text { - Viga, Laje e Alvenaria de } 9 \mathrm{~cm} \\
\text { - Exposição inferior parcial }\end{array}$ & 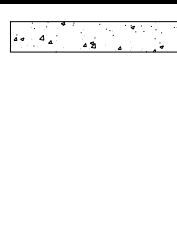 & $\cdots \omega_{n}$ \\
\hline U5-VLA14-EIT & $\begin{array}{l}\text { - Viga, Laje e Alvenaria de } 14 \mathrm{~cm} \\
\text { - Exposição inferior total }\end{array}$ & 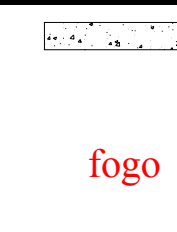 & $+\ldots$ \\
\hline U5-VLA14-EIP & $\begin{array}{l}\text { - Viga, Laje e Alvenaria de } 14 \mathrm{~cm} \\
\text { - Exposição inferior parcial }\end{array}$ & 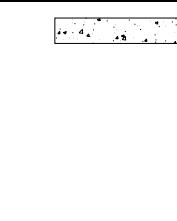 & 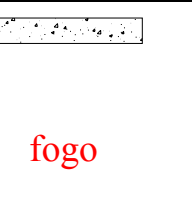 \\
\hline U5-VLBA14-EII & $\begin{array}{l}\text { - Viga, Laje de borda e Alvenaria } \\
\text { de } 14 \mathrm{~cm} \\
\text { - Exposição inferior interna }\end{array}$ & & $\because \because$ \\
\hline
\end{tabular}


O comprimento (padrão) estabelecido para análise numérica das vigas foi considerado igual a 3,8 metros, assim como as espessuras de lajes e alvenarias, tendo em vista serem esses valores (de referência) representativos se comparados àqueles geralmente identificados em estruturas correntes da engenharia civil.

\subsection{MATERIAIS CONSTITUINTES DOS MODELOS}

As propriedades dos materiais, tanto térmicas quanto estruturais, foram adotadas em concordância ao utilizado na primeira etapa do trabalho.

\subsubsection{Propriedades do aço - Considerações}

a) Massa Específica (de acordo com a NBR 8800:1986), Emissividade Resultante, Coeficiente de Transferência de Calor por Convecção e Alongamento do aço em função da temperatura (de acordo com a NBR 14323:1999)

$\rho_{\mathrm{a}}=7850 \mathrm{~kg} / \mathrm{m}^{3} \quad \varepsilon_{\mathrm{res}}=0,5 \quad \alpha_{\mathrm{c}}=25 \mathrm{~W} / \mathrm{m}^{2}{ }^{\mathrm{o}} \mathrm{C} \quad \frac{\Delta \ell_{\mathrm{a}}}{\ell_{\mathrm{a}}}=14 \times 10^{-6}\left(\theta_{\mathrm{a}}-20\right)$

b) Calor Específico e Condutividade Térmica (de acordo com a NBR 14323:1999)

Tabela 7.2 - Calor específico e Condutividade térmica.

\begin{tabular}{|c|c|c|}
\hline $\boldsymbol{\theta}\left({ }^{\mathbf{}} \mathbf{C}\right)$ & $\mathbf{c}_{\mathbf{a}}\left(\mathbf{J} / \mathbf{k g}^{\mathbf{}} \mathbf{C}\right)$ & $\begin{array}{c}\lambda_{\mathbf{a}} \\
\left(\mathbf{W} / \mathbf{m}^{\mathbf{}} \mathbf{C}\right)\end{array}$ \\
\hline 20 & 425,0000 & 54,0000 \\
\hline 100 & 487,6200 & 50,6700 \\
\hline 200 & 529,7600 & 47,3400 \\
\hline 300 & 564,7400 & 44,0100 \\
\hline 400 & 605,8800 & 40,6800 \\
\hline 500 & 666,5000 & 37,3500 \\
\hline 600 & 759,9200 & 34,0200 \\
\hline 700 & 1008,1580 & 30,6900 \\
\hline 735 & 5000,0000 & 29,5245 \\
\hline 736 & 4109,0000 & 29,5245 \\
\hline 800 & 803,2609 & 27,3000 \\
\hline 900 & 650,4438 & 27,3000 \\
\hline 1000 & 650,0000 & 27,3000 \\
\hline 1100 & 650,0000 & 27,3000 \\
\hline 1200 & 650,0000 & 27,3000 \\
\hline
\end{tabular}


c) Relação constitutiva adotada para o aço

A relação constitutiva adotada para o aço, representada por meio da figura 7.2, foi do tipo bilinear. A variação da relação constitutiva em função da temperatura foi obtida com base em valores de módulo de elasticidade e tensão de escoamento, ambos apresentados na tabela 7.3 .



Figura 7.2 - Relação constitutiva adotada para o aço.

Tabela 7.3 - Módulo de elasticidade, tensão de escoamento e coeficientes de redução.

\begin{tabular}{|c|c|c|c|c|}
\hline \multirow{2}{*}{$\boldsymbol{\theta}\left({ }^{\mathbf{o}} \mathbf{C}\right)$} & \multicolumn{2}{|c|}{ NBR 14323:1999 } & \multicolumn{2}{c|}{$\begin{array}{c}\text { Eurocode 3 Part 1.2 (2005) } \\
\text { (para perfis classe 4) }\end{array}$} \\
\cline { 2 - 5 } & $\mathbf{k}_{\mathbf{E}, \boldsymbol{\theta}}$ & $\mathbf{E}_{\boldsymbol{\theta}} \mathbf{( M P a )}$ & $\mathbf{k}_{\mathbf{y}, \boldsymbol{\theta}}$ & $\mathbf{f}_{\mathbf{y}, \boldsymbol{\theta}} \mathbf{( M P a )}$ \\
\hline 20 & 1 & 205000 & 1 & 300 \\
\hline 100 & 1 & 205000 & 1 & 300 \\
\hline 200 & 0,9 & 184500 & 0,89 & 267 \\
\hline 300 & 0,8 & 164000 & 0,78 & 234 \\
\hline 400 & 0,7 & 143500 & 0,65 & 195 \\
\hline 500 & 0,6 & 123000 & 0,53 & 159 \\
\hline 600 & 0,31 & 63550 & 0,3 & 90 \\
\hline 700 & 0,13 & 26650 & 0,13 & 39 \\
\hline 800 & 0,09 & 18450 & 0,07 & 21 \\
\hline 900 & 0,0675 & 13838 & 0,05 & 15 \\
\hline 1000 & 0,045 & 9225 & 0,03 & 6 \\
\hline 1100 & 0,0225 & 4613 & 0,02 & 0 \\
\hline 1200 & 0 & 0 & 0 & 9 \\
\hline
\end{tabular}




\subsubsection{Propriedades do concreto - Considerações}

a) Massa Específica, Emissividade Resultante e Coeficiente de Transferência de Calor por Convecção

$$
\rho_{\mathrm{c}}=2400 \mathrm{~kg} / \mathrm{m}^{3} \quad \varepsilon_{\mathrm{res}}=0,5 \quad \alpha_{\mathrm{c}}=25 \mathrm{~W} / \mathrm{m}^{2}{ }^{\mathrm{o}} \mathrm{C}
$$

b) Calor Específico (de acordo com expressões apresentadas no Eurocode 2 Part 1.2 2nd draft, 2002; para concreto com umidade de 3\%)

\begin{tabular}{|c|c|}
\hline$\theta_{\mathrm{c}}\left({ }^{\circ} \mathrm{C}\right)$ & $\mathrm{c}_{\mathrm{c}}\left(\mathrm{J} / \mathrm{kg}^{\mathrm{o}} \mathrm{C}\right)$ \\
\hline 20 & 900 \\
\hline 99 & 900 \\
\hline 100 & 2020 \\
\hline 115 & 2020 \\
\hline 200 & 980 \\
\hline 400 & 1045 \\
\hline 1200 & 968 \\
\hline
\end{tabular}

c) Condutividade Térmica (de acordo com expressões apresentadas no Eurocode 2 Part 1.2 - 2nd draft, 2002; limite inferior para concreto de densidade normal)

\begin{tabular}{|c|c|}
\hline$\theta_{\mathrm{c}}\left({ }^{\mathrm{o}} \mathrm{C}\right)$ & $\lambda_{\mathrm{c}}\left(\mathrm{W} / \mathrm{m}^{\circ} \mathrm{C}\right)$ \\
\hline 20 & 1,36 \\
\hline 100 & 1,23 \\
\hline 200 & 1,111 \\
\hline 300 & 1,003 \\
\hline 400 & 0,907 \\
\hline 500 & 0,823 \\
\hline 600 & 0,749 \\
\hline 700 & 0,687 \\
\hline 800 & 0,637 \\
\hline 900 & 0,598 \\
\hline 1000 & 0,57 \\
\hline 1100 & 0,554 \\
\hline 1200 & 0,549 \\
\hline
\end{tabular}




\subsubsection{Propriedades da alvenaria}

a) Massa Específica: $\quad \rho_{\mathrm{alv}}=1600 \mathrm{Kg} / \mathrm{m}^{3}$

b) Calor Específico: $\quad \mathrm{c}_{\mathrm{alv}}=840 \mathrm{~J} / \mathrm{kg}^{\circ} \mathrm{C}$

c) Condutividade Térmica: $\lambda_{\mathrm{alv}}=0,7 \mathrm{~W} / \mathrm{m}^{\circ} \mathrm{C}$

d) Emissividade Resultante: $\varepsilon_{\mathrm{res}}=0,5$

e) Coeficiente de Transferência de Calor por Convecção: $\alpha_{\mathrm{c}}=25 \mathrm{~W} / \mathrm{m}^{2}{ }^{\circ} \mathrm{C}$

\subsection{ASPECTOS DA MODELAGEM NUMÉRICA}

Para obtenção das resistências máximas das vigas em situação de incêndio foi necessário realizar duas análises distintas no programa ANSYS: térmica e estrutural.

Por meio da análise térmica foi determinado o campo de temperatura no perfil metálico em função da elevação da temperatura ao longo do tempo. Nessa fase, foi considerada a existência de laje de concreto nas situações em que elas aparecem.

Em seguida, por meio da análise estrutural, dado um carregamento uniformemente distribuído sobre a viga, obteve-se o máximo tempo de exposição dessa viga de acordo com o campo de temperaturas previamente obtido. Nessa fase, não foi considerada a existência de laje de concreto nas situações em que elas aparecem, ou seja, foi considerada apenas a rigidez da viga de aço na determinação dos deslocamentos.

Vale salientar que foi aqui utilizada a curva do incêndio-padrão para descrever a elevação da temperatura dos gases. Portanto, vale ressaltar que o tempo obtido se refere a um tempo fictício, e não real.

\subsubsection{Considerações com relação à ANÁLISE TÉRMICA}

Como mencionado, o objetivo da análise térmica consiste em determinar o campo de temperatura no perfil metálico e laje de concreto, em função da elevação da 
temperatura ao longo do tempo. No modelo de análise térmica foram consideradas, além do perfil metálico, parte da laje de concreto (1,15 m de largura) e da alvenaria (0,5 m de comprimento), já que proporcionam certa proteção térmica ao perfil.

Os elementos utilizados para representação do perfil, da laje e da alvenaria foi o solid70. Foi utilizado ainda o elemento surf152 para geração das superfícies de convecção e radiação nas faces expostas ao incêndio. Tais elementos possuem apenas um grau de liberdade por nó, a temperatura. A figura 7.3 ilustra um dos modelos elaborados para fins de análise térmica, no caso, U5-VLA9-EIP (ver tabela 7.1).

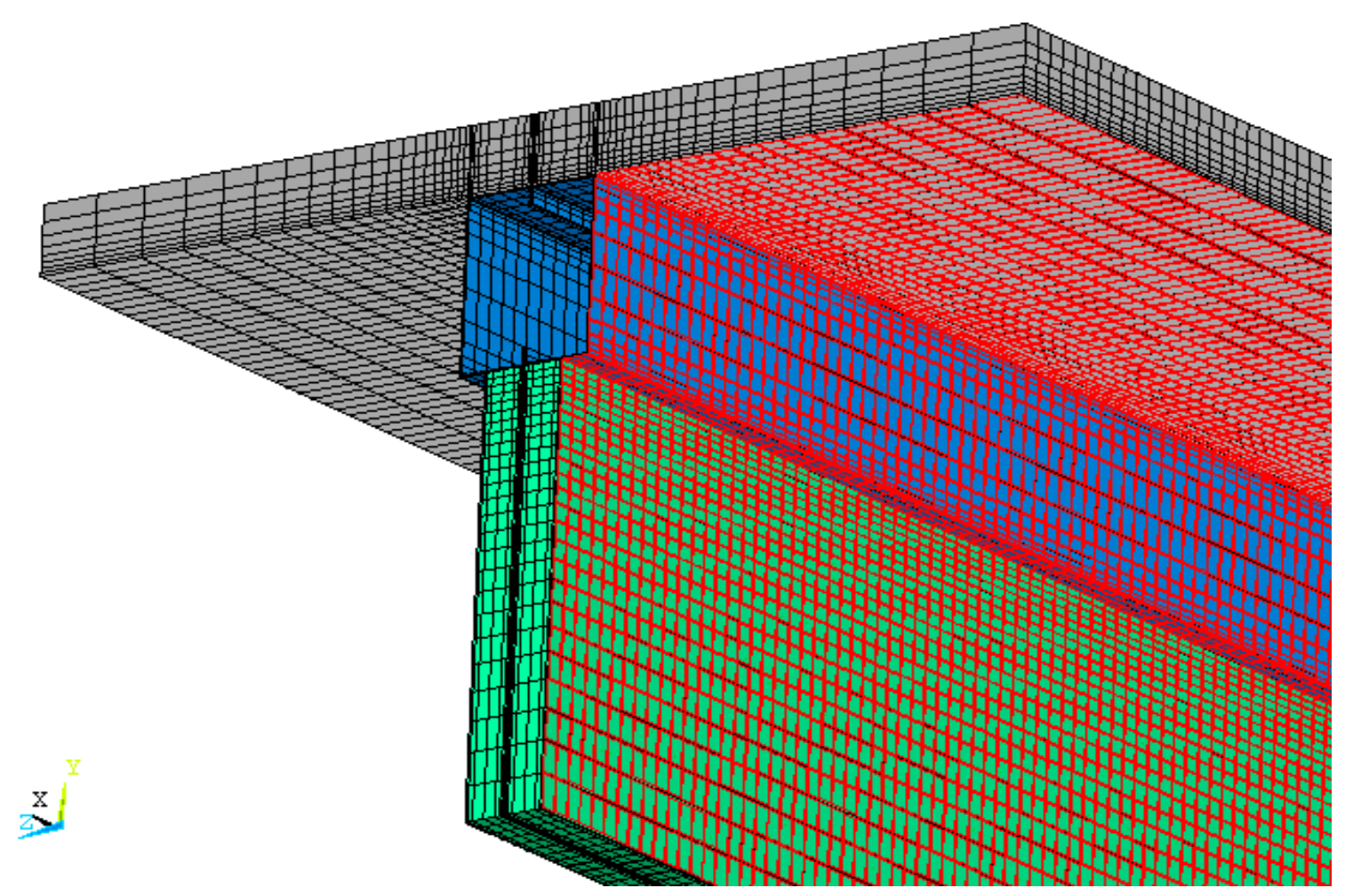

Figura 7.3 - Modelo para análise térmica: caso U5-VLA9-EIP.

\subsubsection{Considerações com relação à ANÁLISE ESTRUTURAL}

A análise estrutural foi realizada aplicando-se, inicialmente, um carregamento uniformemente distribuído, e de interesse, sobre a viga de aço. Em seguida, se considerou (foi acoplado) o campo de temperatura obtido previamente na análise térmica, conforme item 7.1. Para obtenção do carregamento máximo a ser utilizado como referência, foi realizada uma análise da viga de aço em temperatura ambiente. 
Ressalta-se novamente o fato de que, inicialmente, para análise estrutural, apenas o perfil metálico foi modelado, não sendo levada em consideração, portanto, a ação mista entre viga metálica e laje de concreto. Para representação do perfil foi utilizado o elemento solid45, cujos graus de liberdade em cada nó correspondem às translações nas direções $\mathrm{x}, \mathrm{y}$ e $\mathrm{z}$.

As vigas foram consideradas engastadas em suas extremidades, sendo um dos engastes móvel na direção longitudinal da viga, a fim de evitar restrições à expansão térmica, conforme figura 7.4. A restrição ao deslocamento transversal imposto pela laje de concreto foi representada por vínculos na direção $\mathrm{z}$, inseridos na posição dos conectores de cisalhamento.

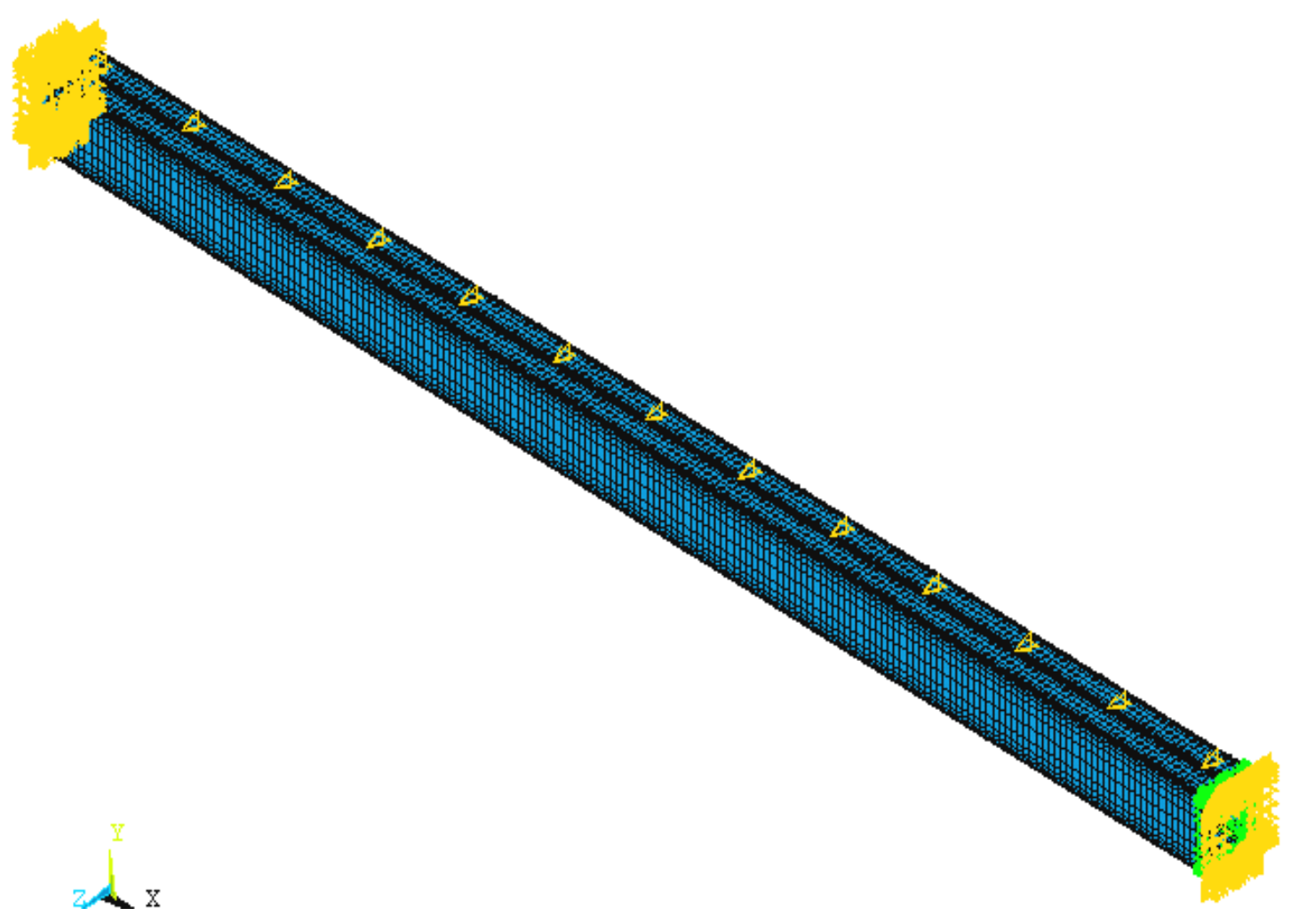

Figura 7.4 - Vinculações impostas no modelo para análise estrutural.

O carregamento foi aplicado na forma de força nos nós sobre a mesa superior do perfil metálico. Visando evitar problemas localizados em função da forma de aplicação do carregamento, o deslocamento vertical dos nós da mesa superior pertencentes a uma mesma seção transversal foi compatibilizado, acoplando-se tais nós na direção y (figura 7.5). 




Figura 7.5 - Aplicação do carregamento no modelo para análise estrutural.

\subsection{ANÁLISE ESTRUTURAL EM TEMPERATURA AMBIENTE}

Os resultados apresentados neste item correspondem à análise estrutural em temperatura ambiente. Essa análise foi realizada apenas uma vez, já que a geometria do perfil metálico não varia de caso para caso. O carregamento máximo alcançado numericamente para viga de aço em temperatura ambiente foi igual a $36,09 \mathrm{kN} / \mathrm{m}$, conforme ilustra o gráfico da figura 7.6.

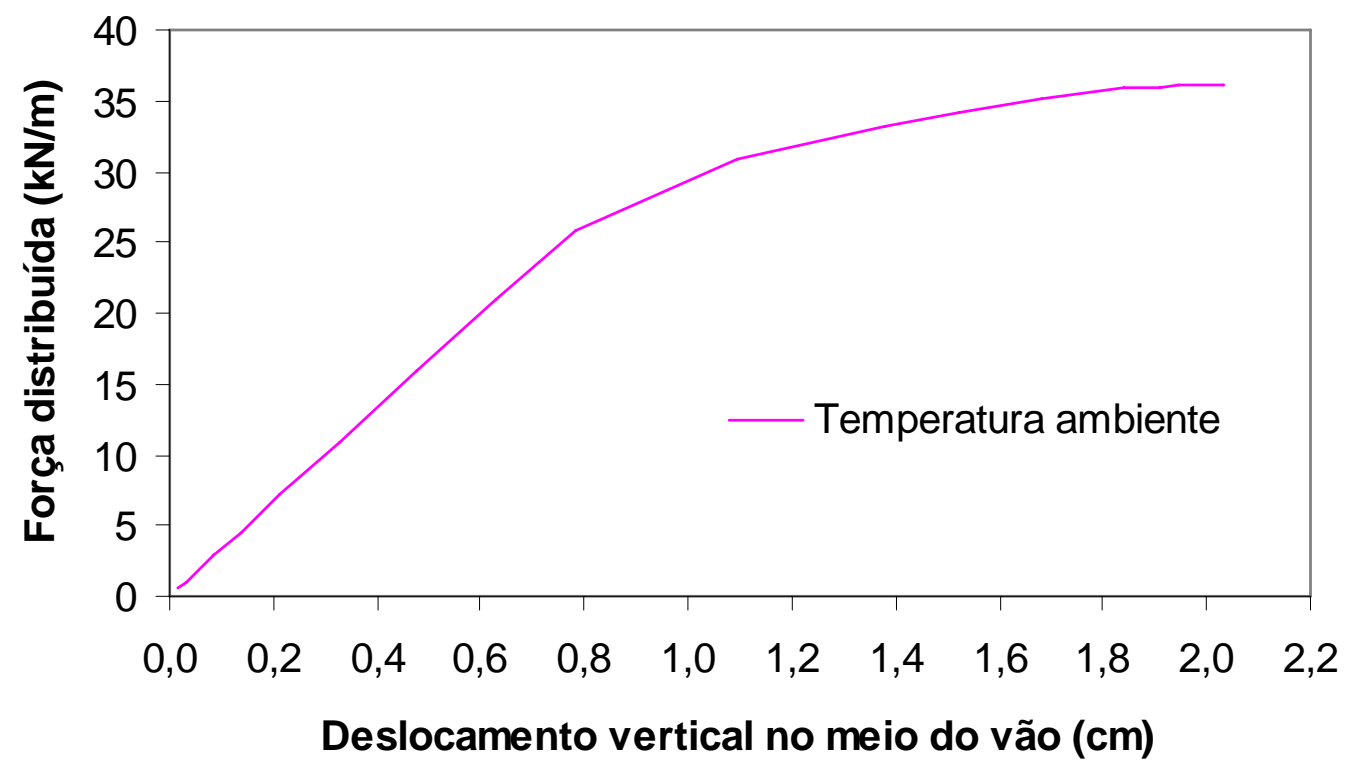

Figura 7.6 - Análise estrutural em temperatura ambiente: Força x Deslocamento vertical. 
A configuração deformada obtida, ilustrada de forma amplificada na figura 7.7, foi compatível com a vinculação adotada, ou seja, condição de engastes fixo e móvel.
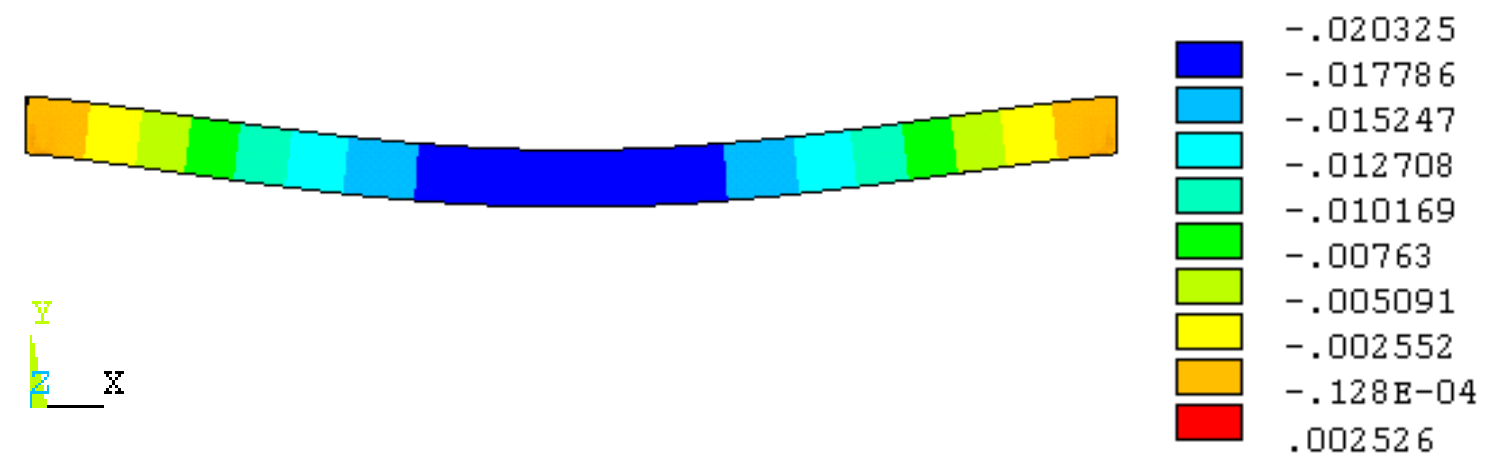

Figura 7.7 - Análise estrutural em temperatura ambiente: Configuração deformada e valores de deslocamento vertical, em metros, para último passo de carga alcançado $(36,09 \mathrm{kN} / \mathrm{m})$.

A figura 7.8 ilustra as deformações de von Mises para o último passo de carga alcançado $(36,09 \mathrm{kN} / \mathrm{m})$. Tomando-se como base o valor de deformação correspondente ao início de plastificação $\left(\mathrm{f}_{\mathrm{y}} / \mathrm{E}\right)$, igual a 0,0014286 nota-se, por meio da figura 7.8 , que a face superior e inferior da viga na região do meio do vão atingiu o início do escoamento. Nota-se ainda a ocorrência de plastificação total próximo às extremidades, como ilustrado em detalhe.

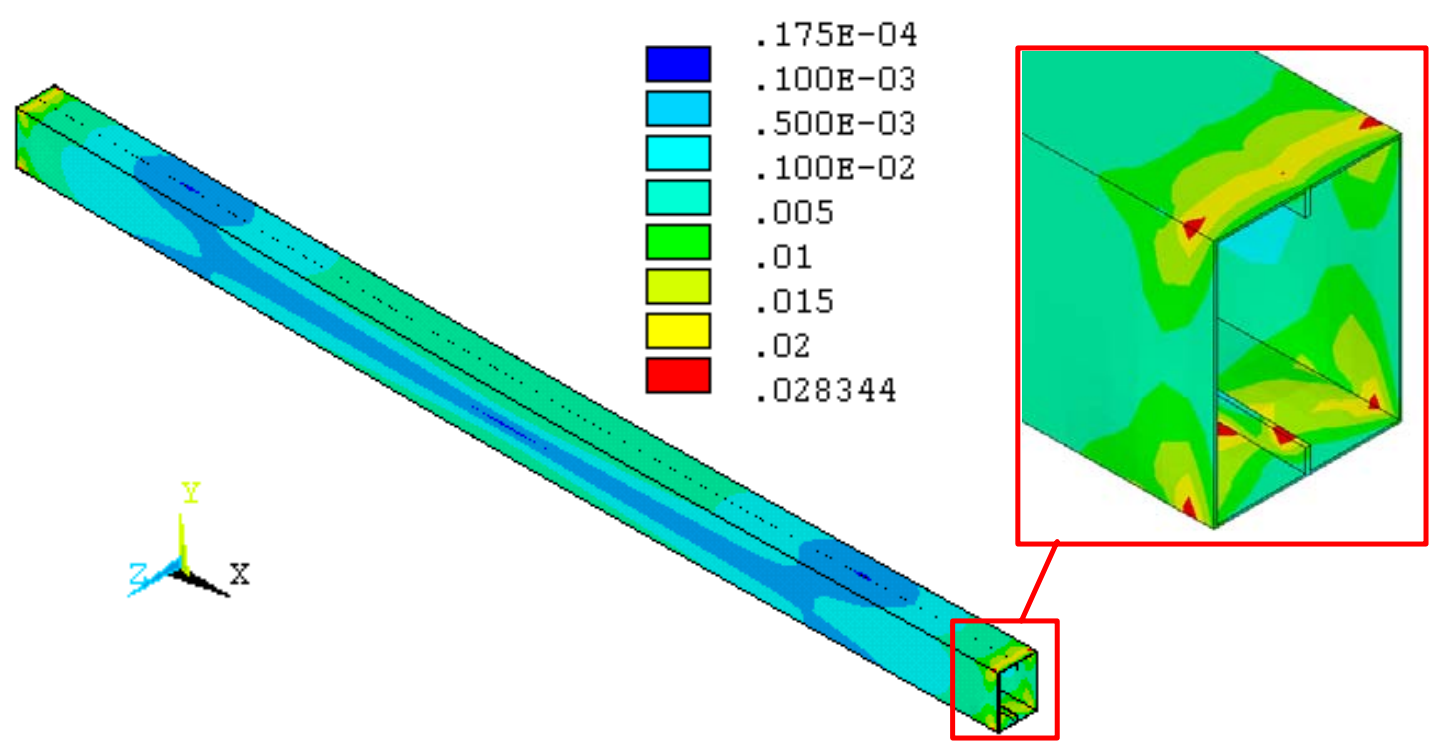

Figura 7.8 - Análise estrutural em temperatura ambiente com deformações de von Mises - detalhe indicando plastificação total próximo aos engastes. 
De acordo com as análises realizada no programa TCD (primeira etapa), o momento resistente máximo, correspondente à plastificação total da seção do perfil metálico, resultou igual a $33,19 \mathrm{kNm}$.

\subsection{ANÁLISE ESTRUTURAL EM SITUAÇÃO DE INCÊNDIO}

No que segue serão apresentados resultados para os casos de interesse apresentados na tabela 7.1, em que se consideram para a análise térmica situações de vigas de aço isoladas, vigas de aço com lajes de concreto sem alvenaria e, finalmente, vigas de aço com laje de concreto e com alvenaria.

Inicialmente, são apresentados campos de temperaturas nas seções transversais de interesse da tabela 7.1, em correspondência a TRRF iguais a 15, 30 e 60 minutos Em seguida, faz a comparação dos resultados obtidos via TCD com aqueles obtidos via ANSYS para a variação da temperatura em um dado ponto da seção ao longo do tempo.

Também é apresentado o deslocamento vertical no meio do vão em função do tempo de exposição ao incêndio para carregamentos pré-estabelecidos. Vale comentar que o deslocamento vertical foi tomado nos quatro vértices da seção caixão, cujo valor final apresentado é resultado de uma média daqueles observados.

Apresentam-se ainda o coeficiente de redução em função do tempo de exposição, sendo o fator de redução definido como a relação entre o carregamento aplicado para análise em situação de incêndio e o carregamento máximo alcançado em temperatura ambiente.

Informa-se aqui que o tempo máximo de exposição ao incêndio de cada modelo, utilizado na construção do gráfico 'Fator de Redução x Tempo', foi adotado como sendo aquele correspondente ao último passo de carga alcançado no modelo numérico. Vale ressaltar que para os últimos passos de carga os valores de tempo são praticamente assintóticos, como se pode notar nos gráficos ‘Tempo x Deslocamento no meio do vão', apresentados no item 7.6.

Já no caso do programa TCD v5.0, o mesmo obtém tal fator com base na análise plástica da seção, por meio de procedimento simplificado do EUROCODE 3, para a determinação do momento resistente plástico da seção de aço à temperatura ambiente e em situação de incêndio. 
Por fim, ilustra-se a configuração deformada da viga em situação se incêndio para carregamento distribuído igual a $15 \mathrm{kN} / \mathrm{m}$, estabelecida com relação a valores de deformações de von Mises para o último passo de carga. Nesse caso, nota-se a plastificação total próximo aos engastes, tomando-se como base a deformação correspondente ao escoamento em resposta aos coeficientes de redução $\mathrm{k}_{\mathrm{y}, \theta}$ e $\mathrm{k}_{\mathrm{E}, \theta}$ varia, de caso a caso, entre 0,00095238 e 0,0014286 .

\subsubsection{Caso: U5-V-EIST, Viga de aço isolada com fogo por todos os lados}

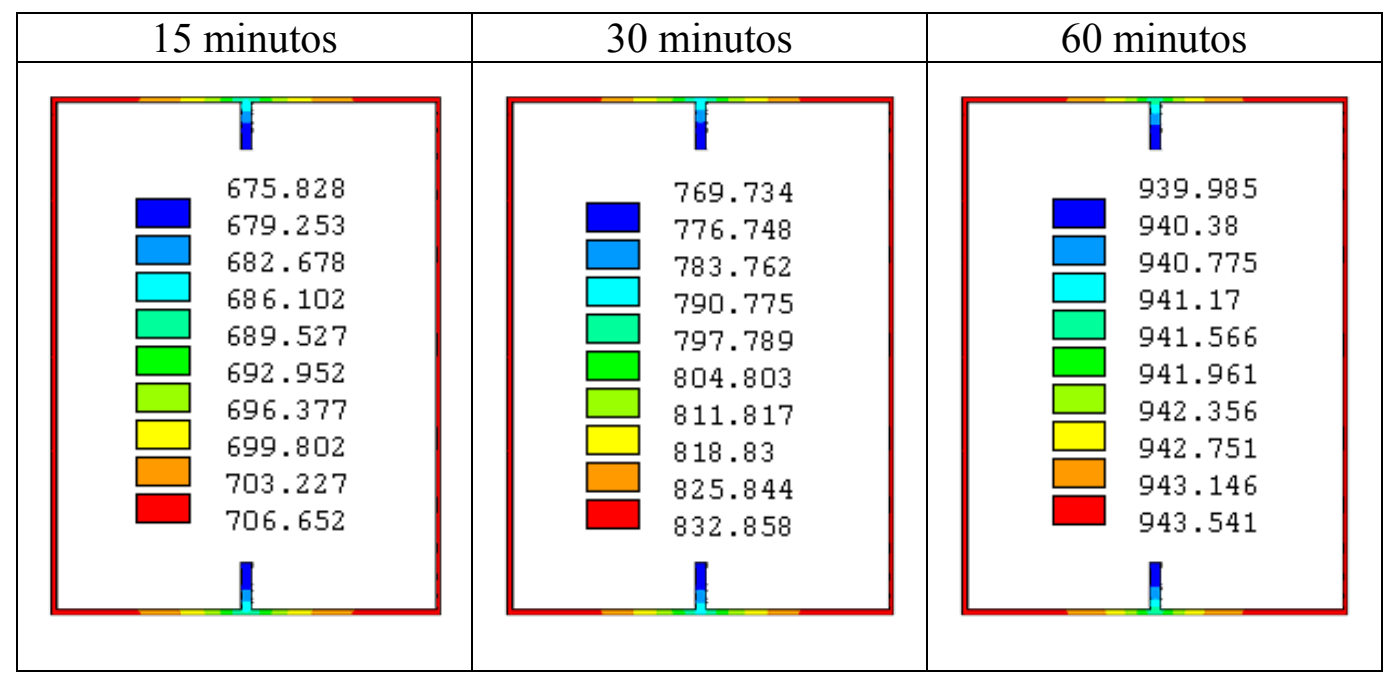

Figura 7.9 - Caso U5-V-EIST: Campos de temperaturas correspondentes a tempos (TRRF) iguais a 15, 30 e 60 minutos.

\section{Ponto 1}

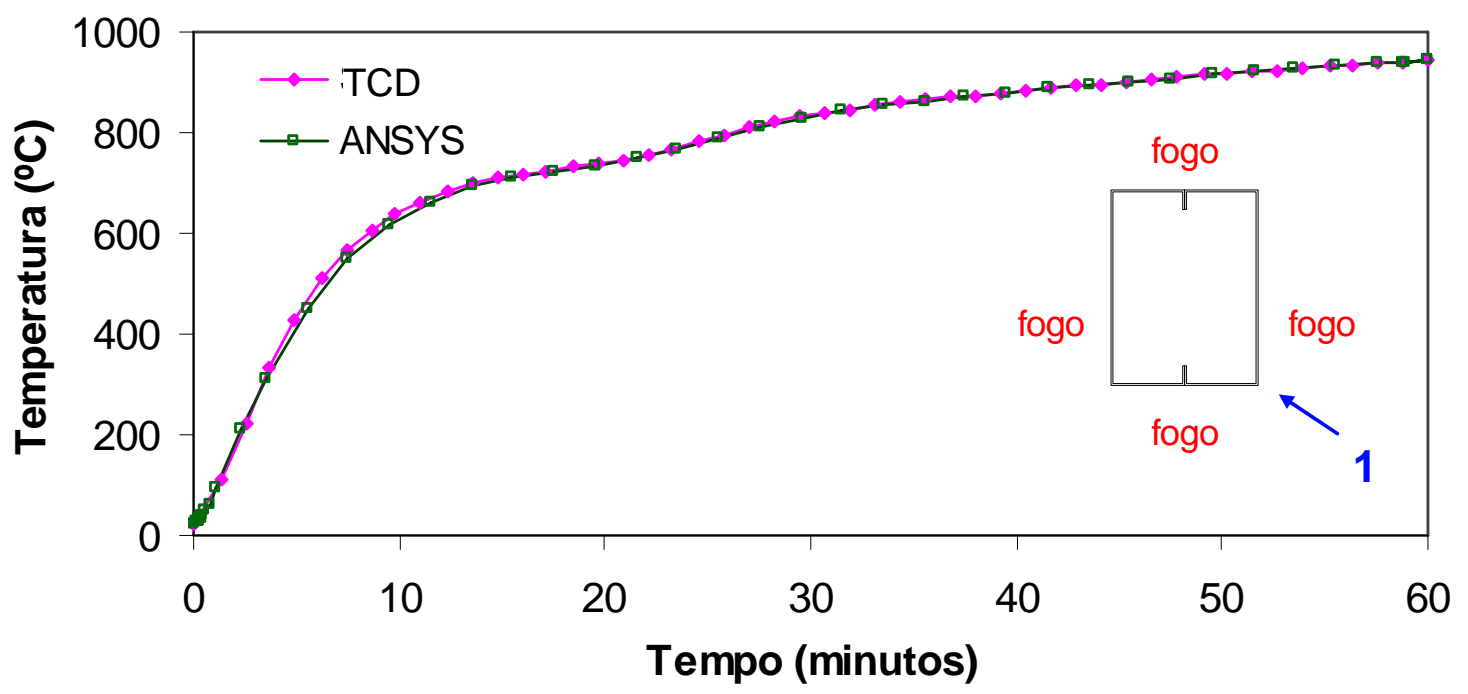

Figura 7.10 - Caso U5-V-EIST: Variação da temperatura no ponto 1 (indicado na Figura) ao longo do tempo. 


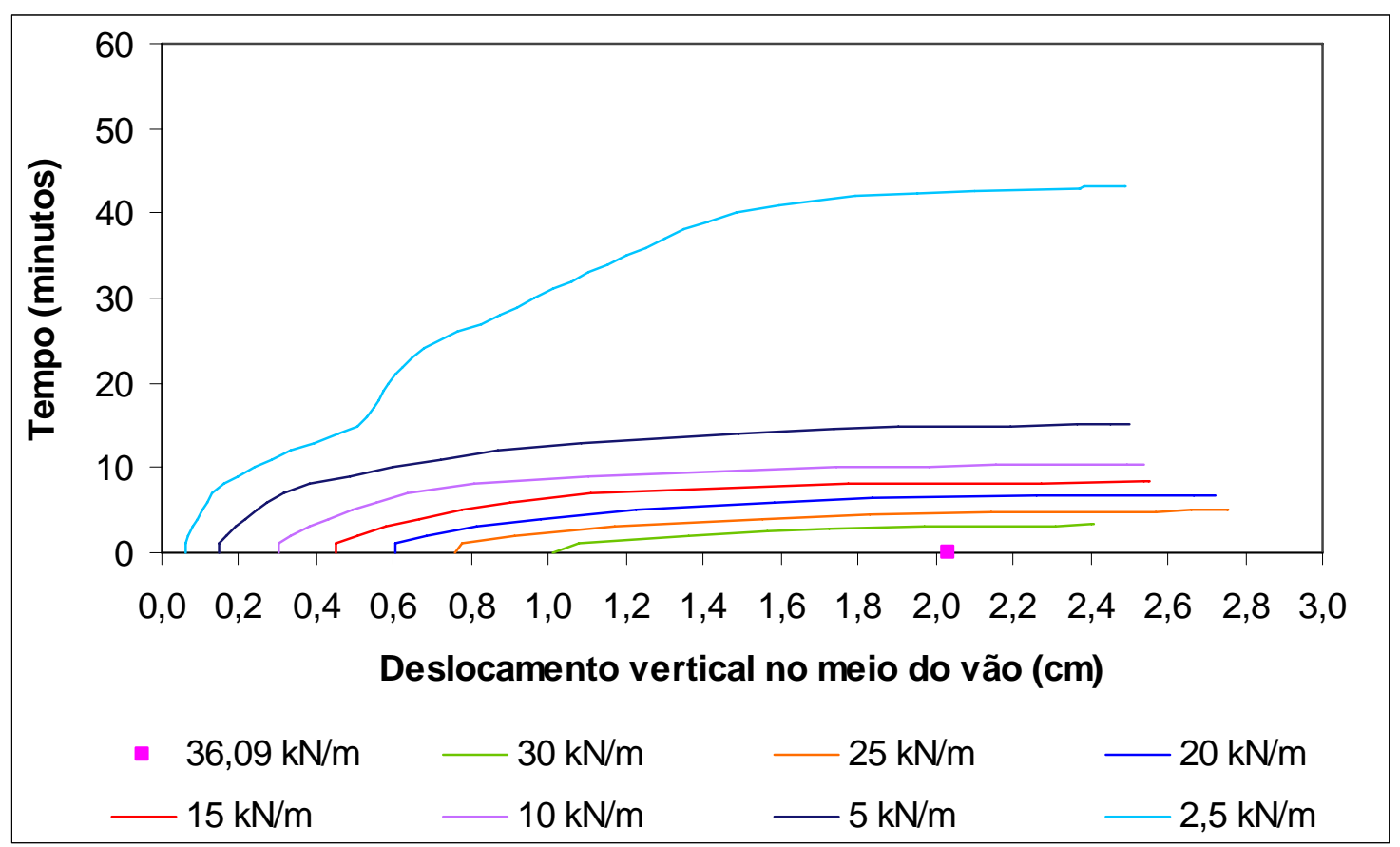

Figura 7.11 - Caso U5-V-EIST: Deslocamento vertical no meio do vão em função do tempo de exposição ao incêndio.

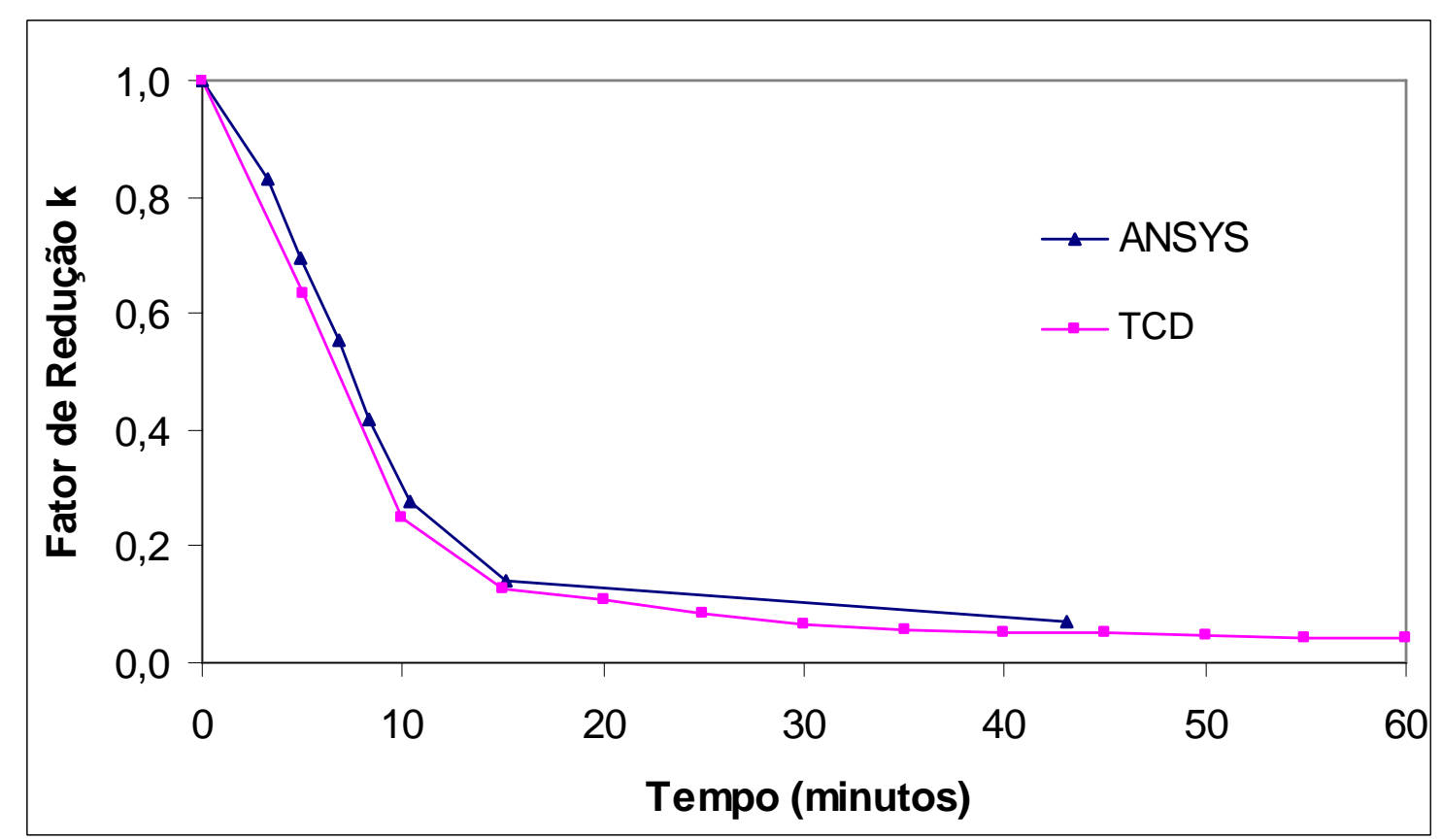

Figura 7.12 - Caso U5-V-EIST: Fator de Redução para a viga em função do tempo de exposição ao incêndio - Comparação ANSYS x TCD. 


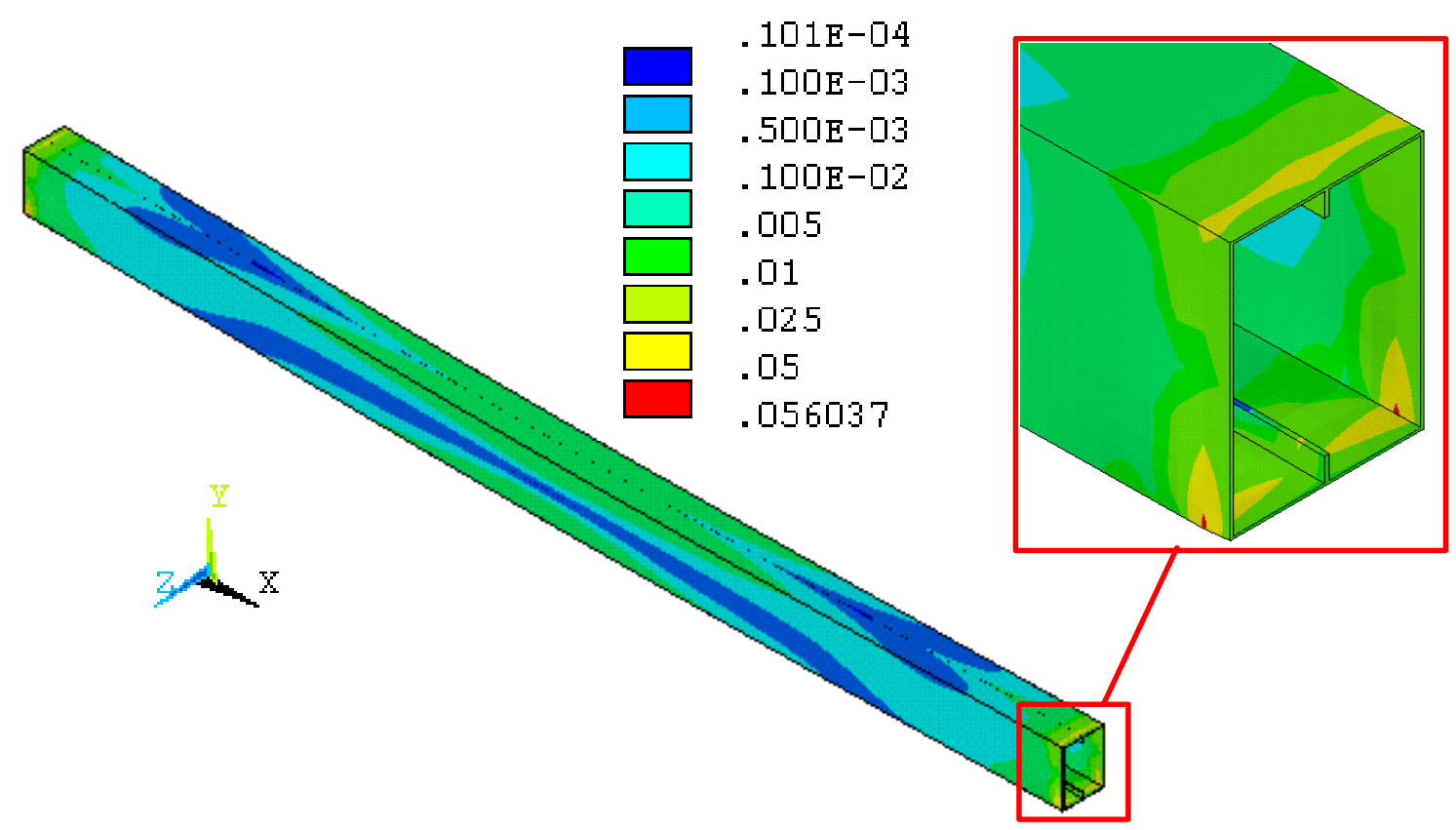

Figura 7.13 - Caso U5-V-EIST: Deformações de von Mises, com detalhe indicando plastificação nas regiões próximas aos engastes.

7.6.2 Caso: U5-VL-EIT, viga de aço com laje de concreto e sem alvenaria, com fogo por todos os lados da viga.

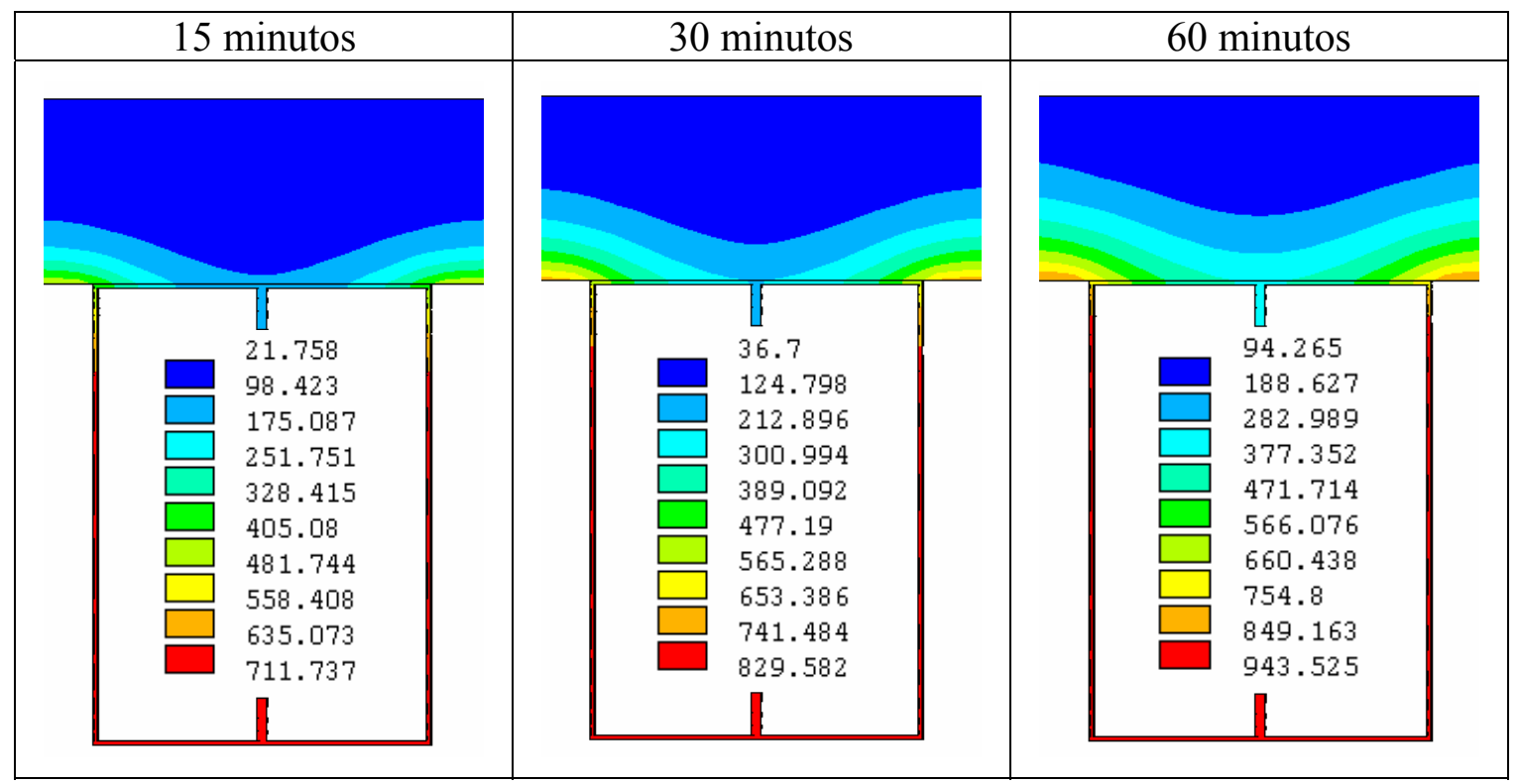

Figura 7.14 - Caso U5-VL-EIT: Campos de temperaturas correspondentes a tempos (TRRF) iguais a 15,30 e 60 minutos. 


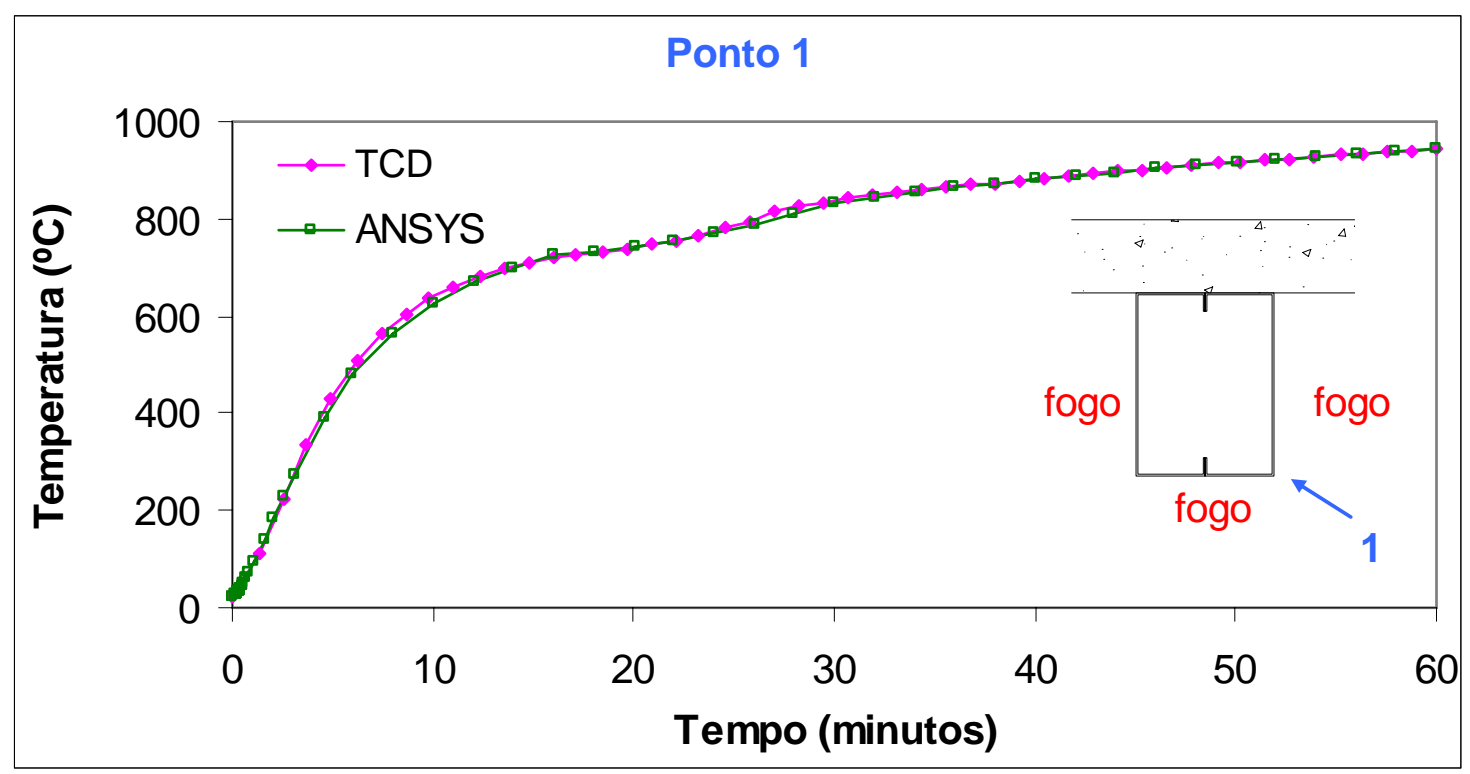

Figura 7.15 - Caso U5-VL-EIT: Variação da temperatura no ponto 4 ao longo do tempo.

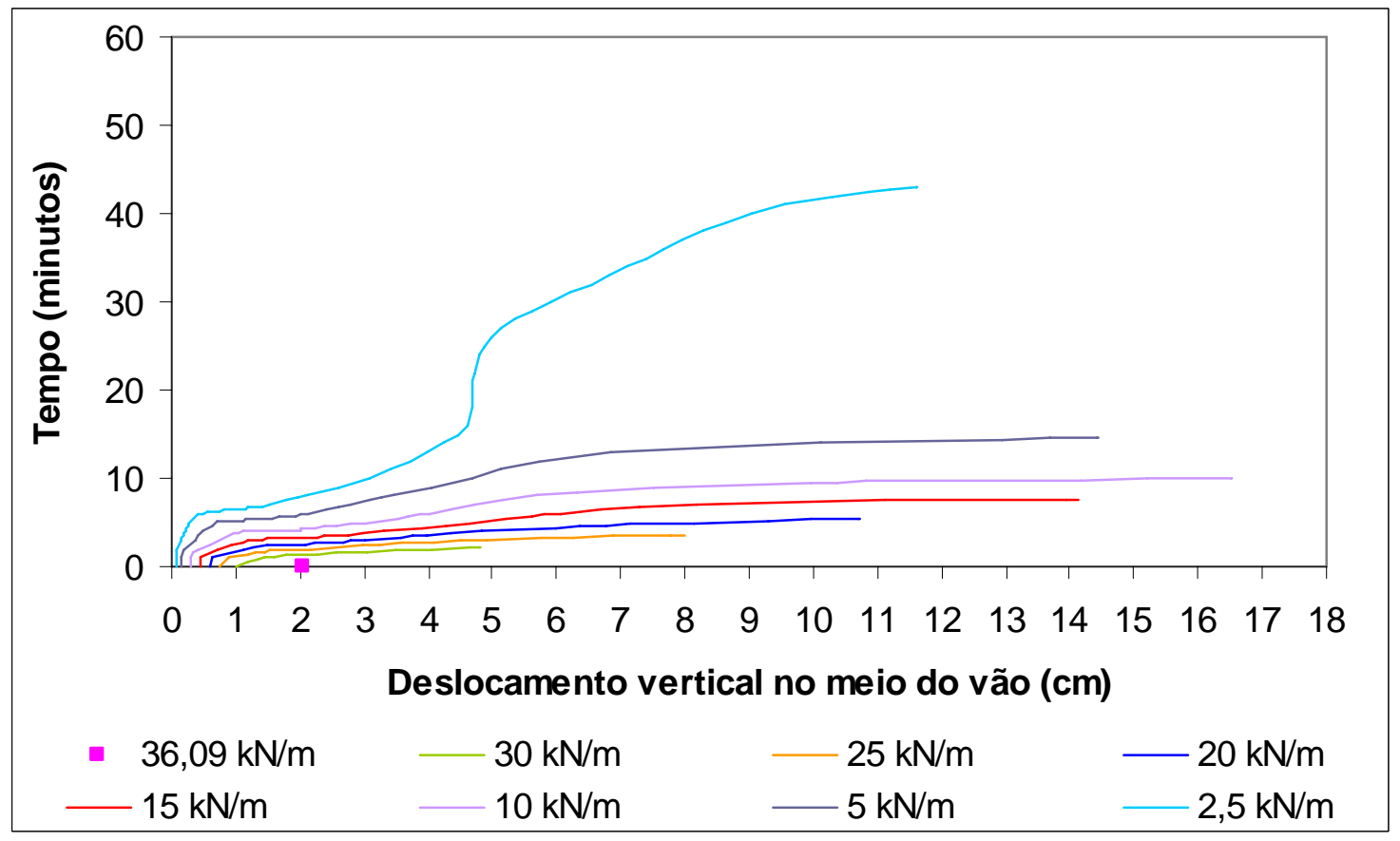

Figura 7.16 - Caso U5-VL-EIT: Deslocamento vertical no meio do vão em função do tempo de exposição ao incêndio. 


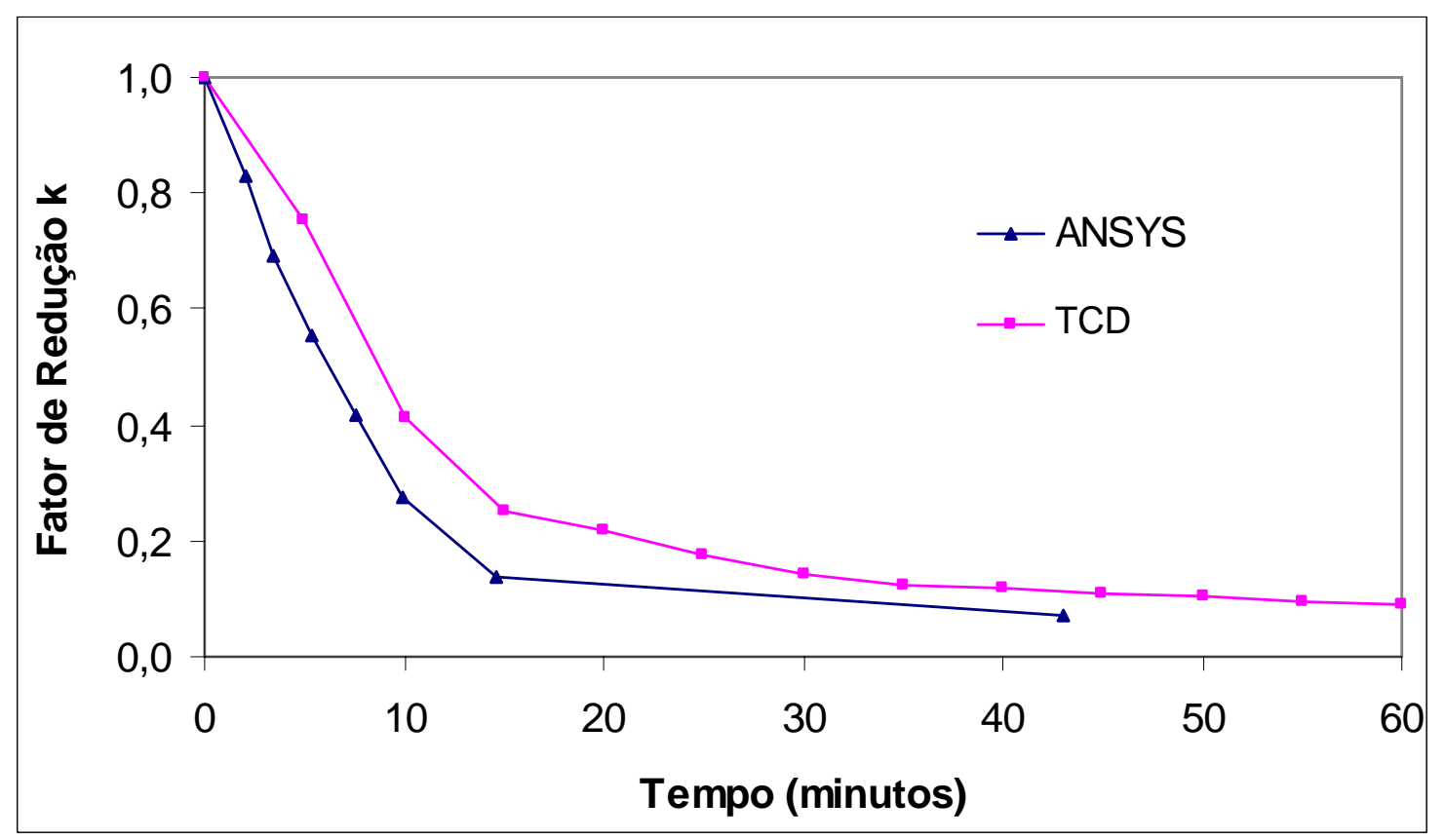

Figura 7.17 - Caso U5-VL-EIT: Fator de Redução para a viga em função do tempo de exposição ao incêndio - Comparação ANSYS x TCD.

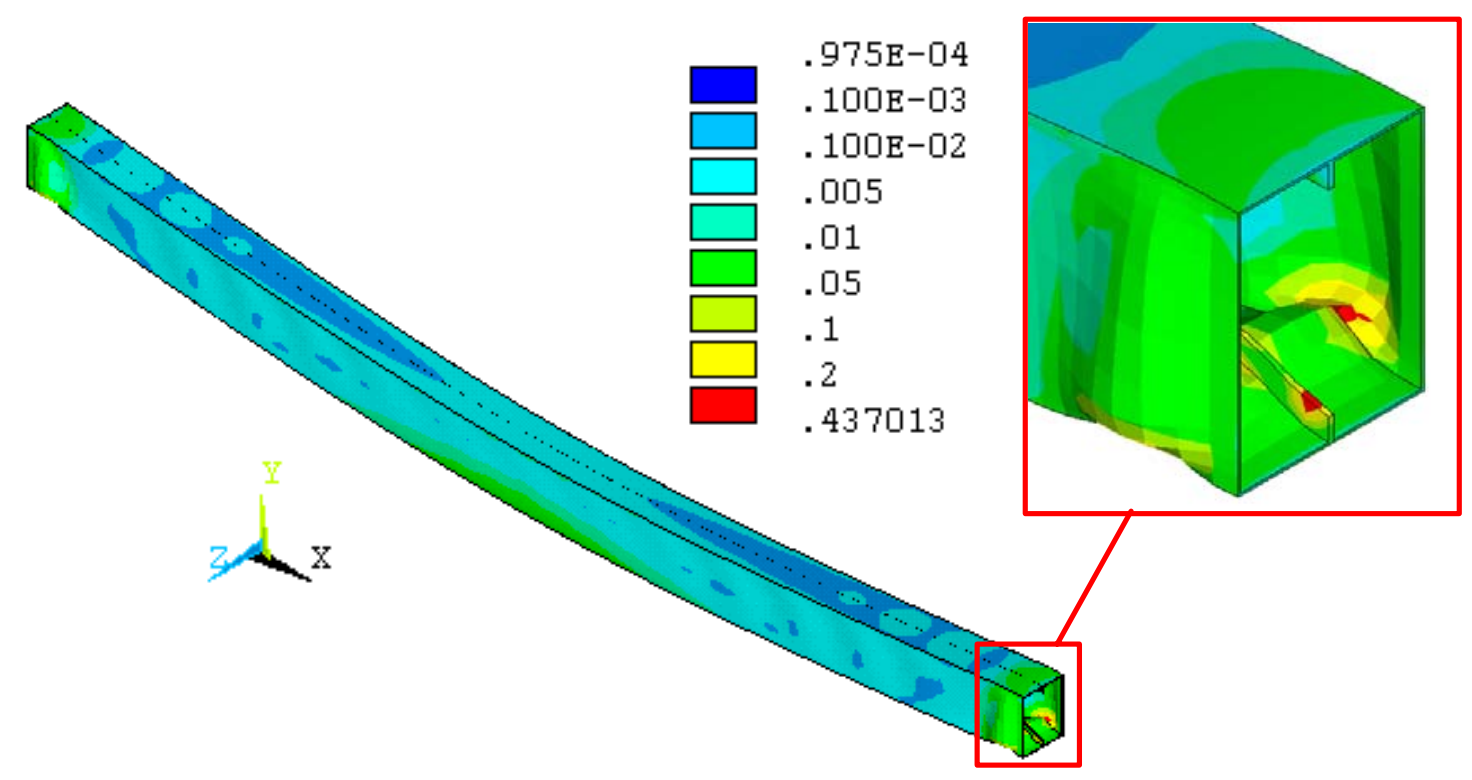

Figura 7.18 - Caso U5-VL-EIT: Deformações de von Mises, com detalhe indicando plastificação nas regiões próximas aos engastes. 
7.6.3 Caso: U5-VLA9-EIT, viga de aço com laje de concreto e alvenaria $(9 \mathrm{~cm}$ de espessura), com fogo por ambos os lados expostos da viga.

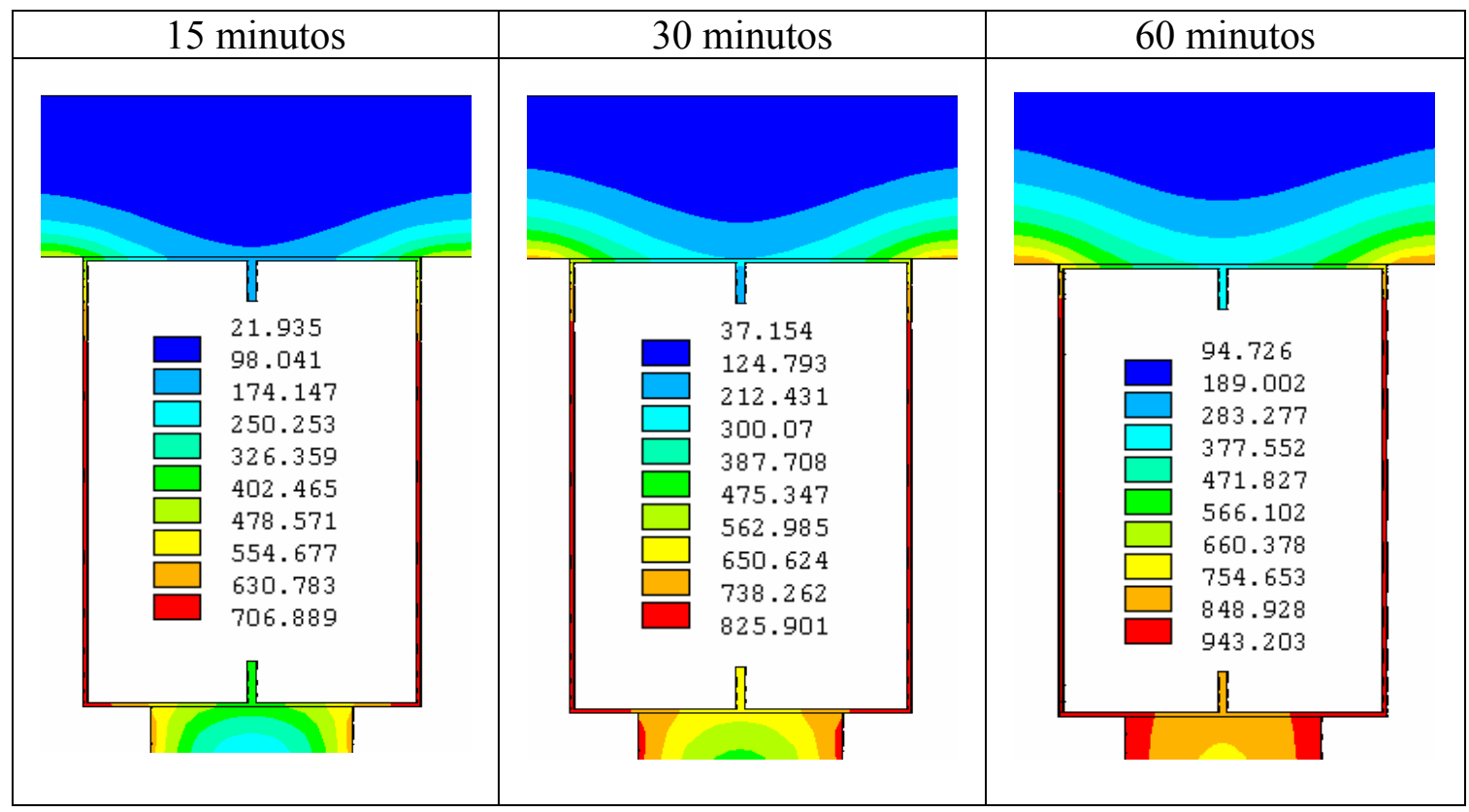

Figura 7.19 - Caso U5-VLA9-EIT: Campos de temperaturas correspondentes a tempos (TRRF) iguais a 15, 30 e 60 minutos.

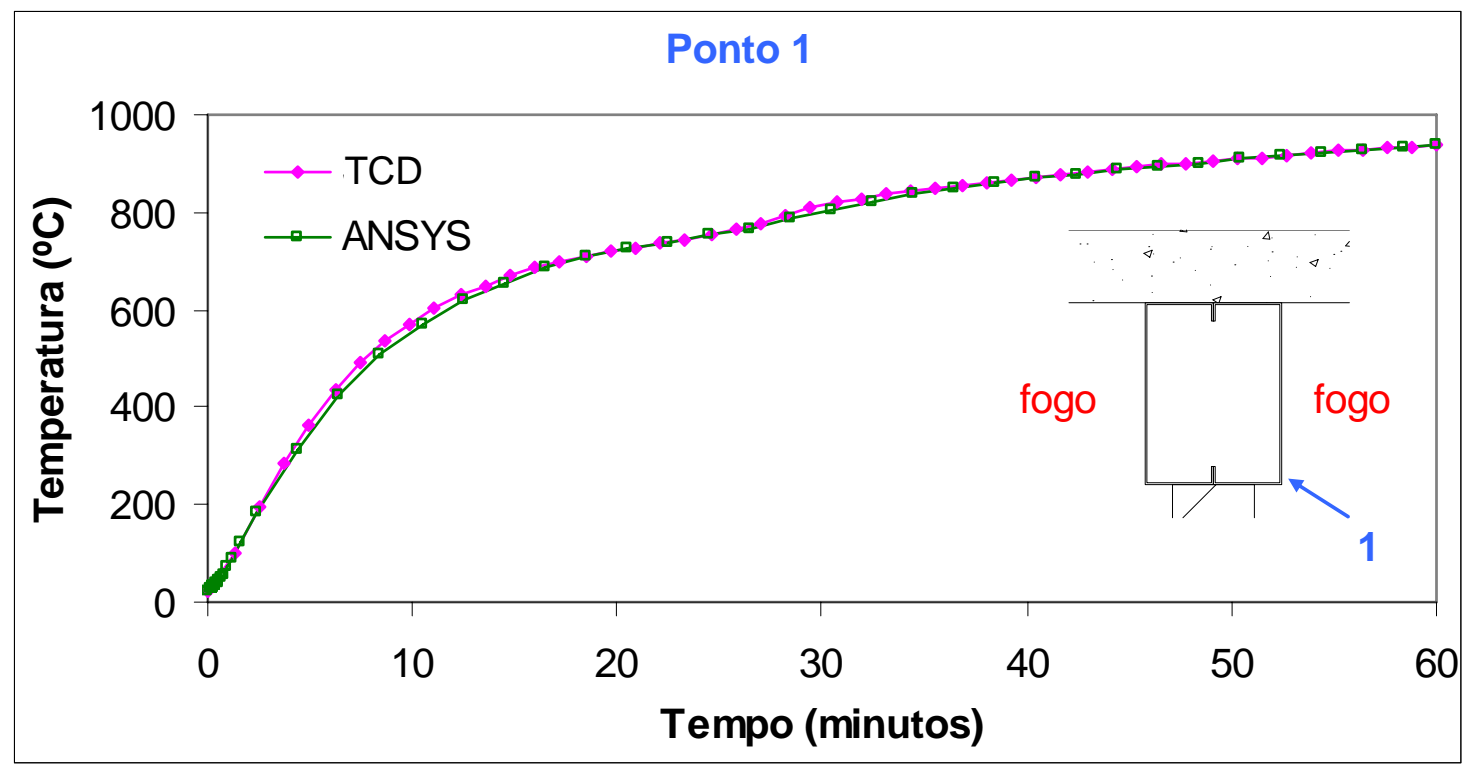

Figura 7.20 - Caso U5-VLA9-EIT: Variação da temperatura no ponto 1 ao longo do tempo. 


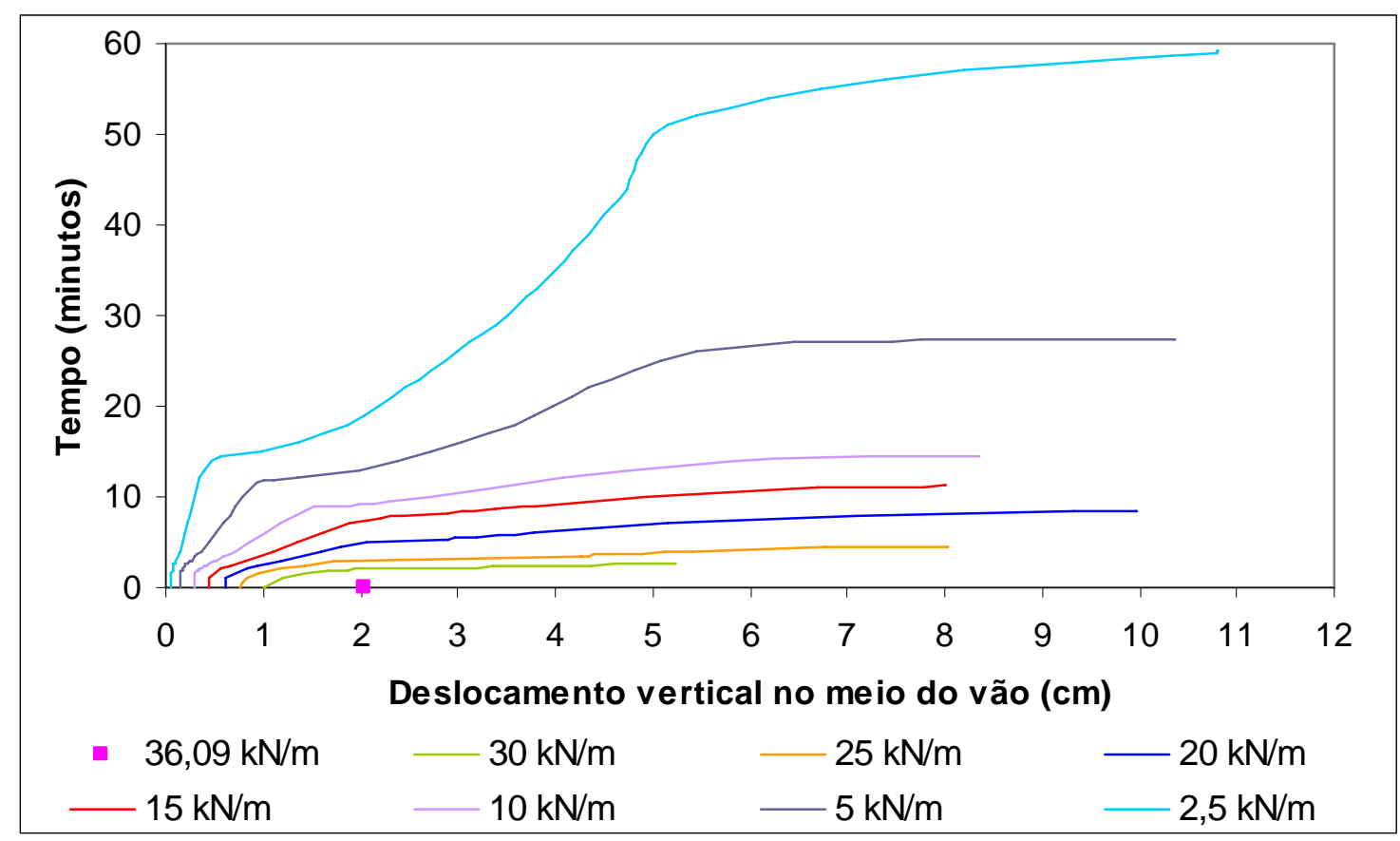

Figura 7.21 - Caso U5-VLA9-EIT: Deslocamento vertical no meio do vão em função do tempo de exposição ao incêndio.

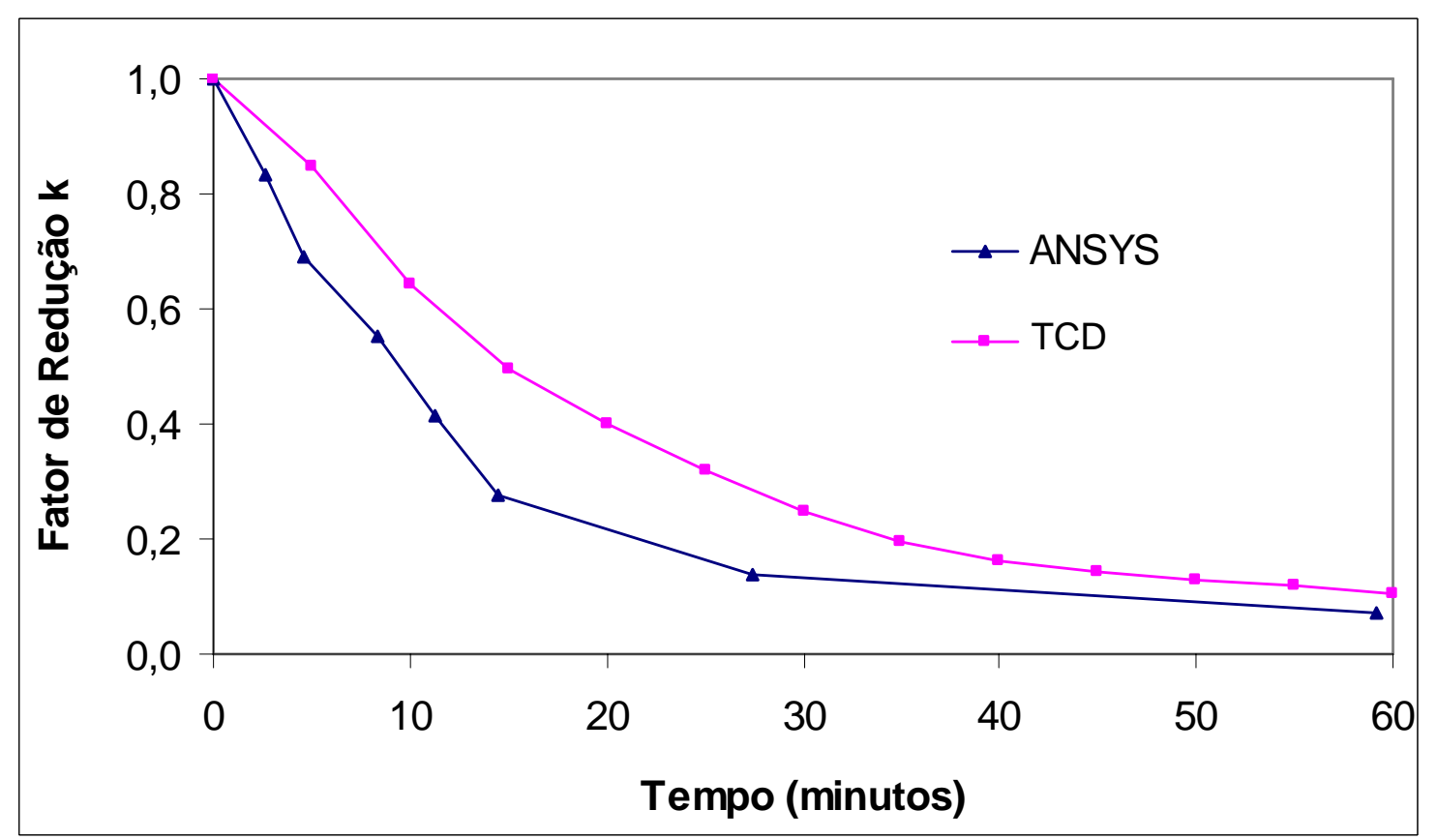

Figura 7.22 - Caso U5-VLA9-EIT: Fator de Redução para a viga em função do tempo de exposição ao incêndio - Comparação ANSYS x TCD. 


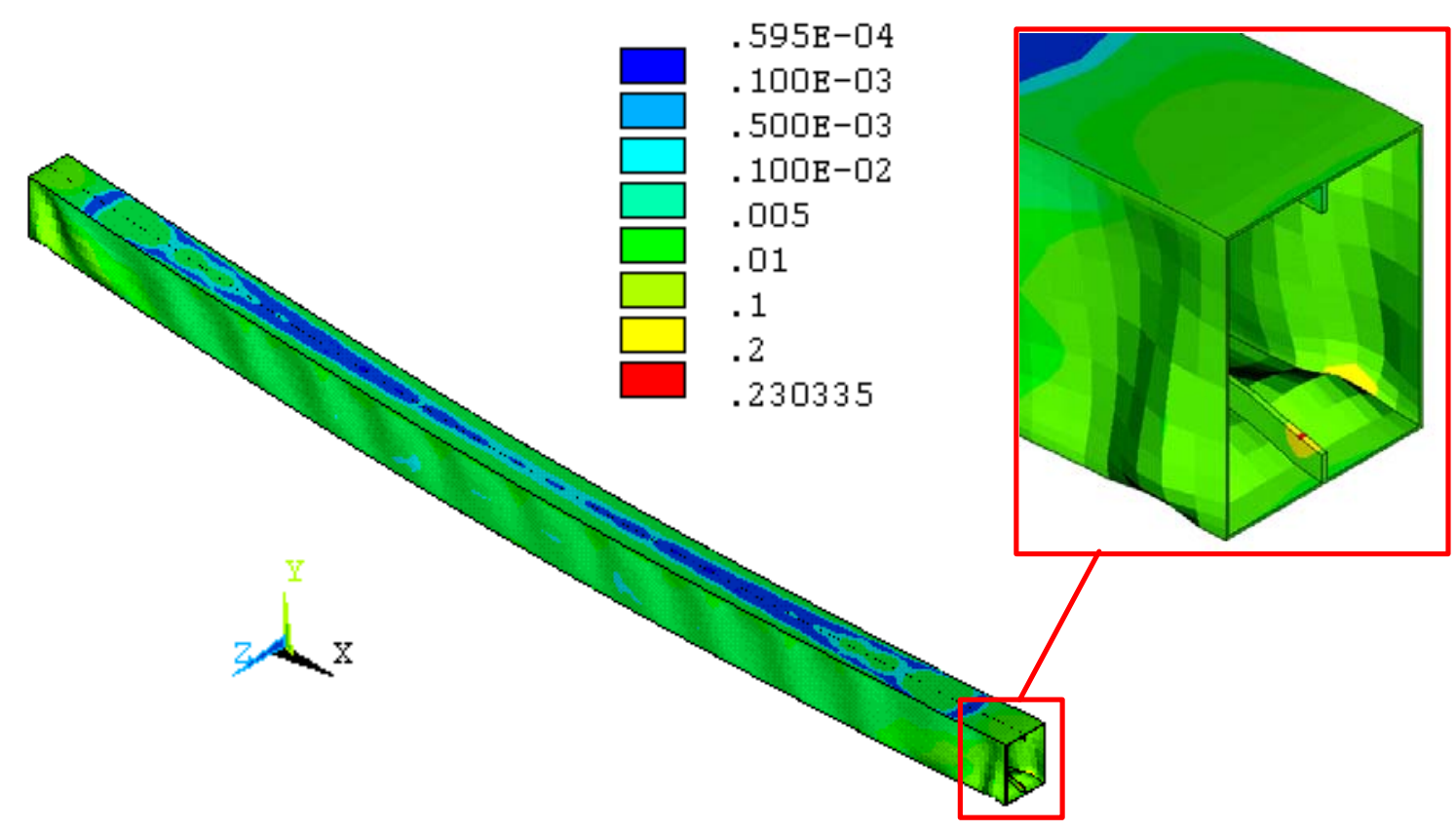

Figura 7.23 - Caso U5-VLA9-EIT: Deformações de von Mises, com detalhe indicando plastificação nas regiões próximas aos engastes.

7.6.4 Caso: U5-VLA9-EIP, viga de aço com laje de concreto e alvenaria $(9 \mathrm{~cm}$ de espessura), com fogo em apenas um dos lados expostos da viga.

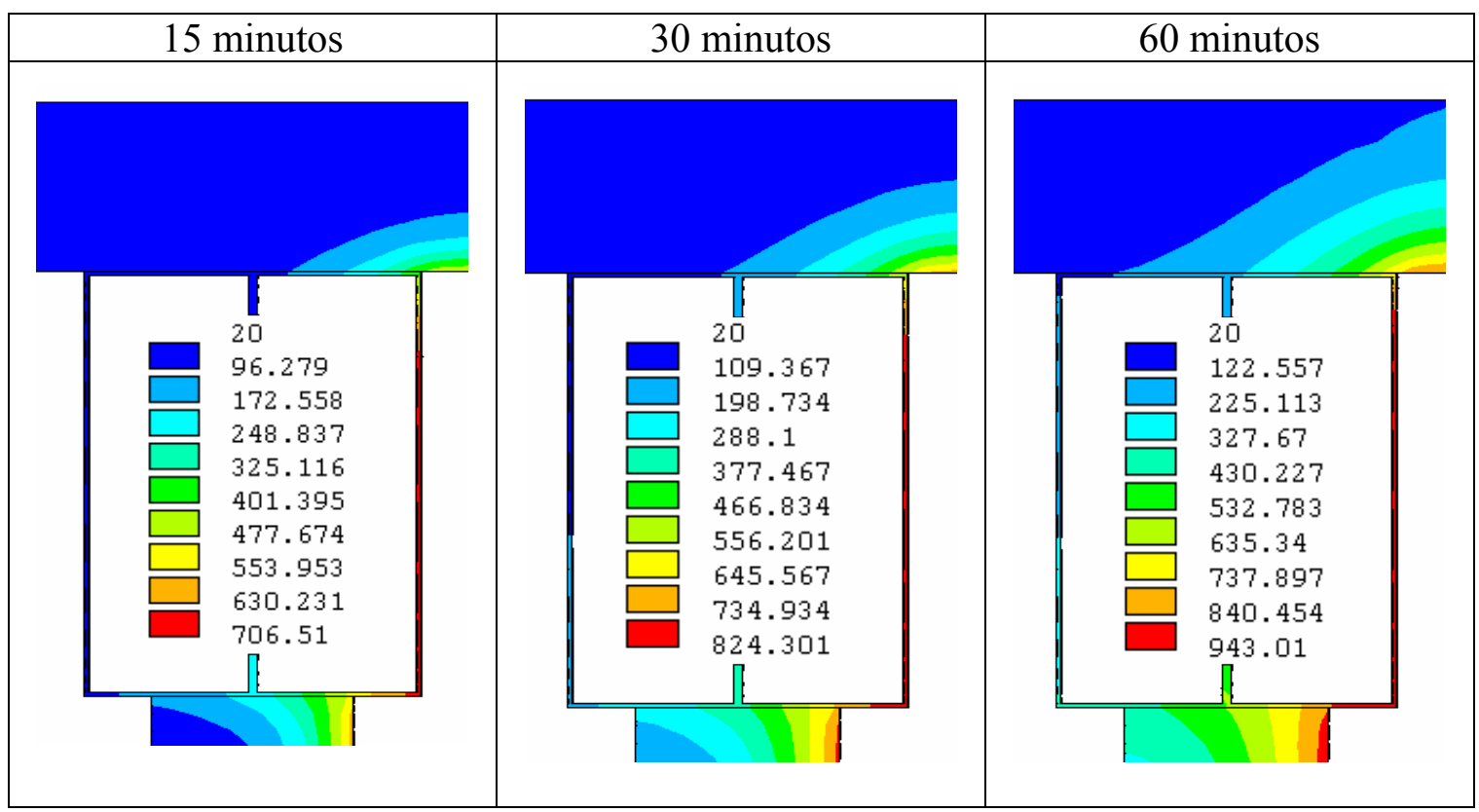

Figura 7.24 - Caso U5-VLA9-EIP: Campos de temperaturas correspondentes a tempos de 15,30 e 60 minutos. 


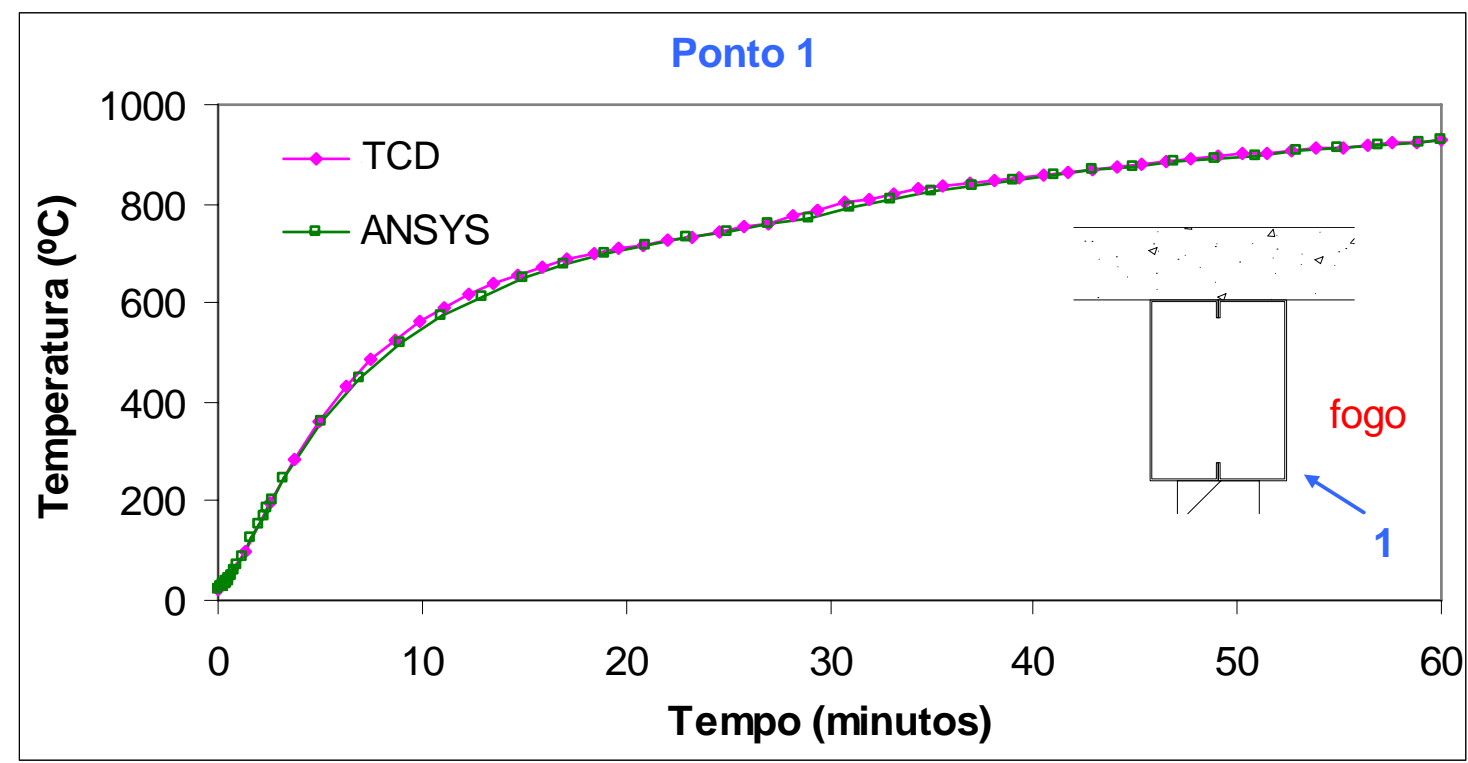

Figura 7.25 - Caso U5-VLA9-EIP: Variação da temperatura no ponto 1 ao longo do tempo.

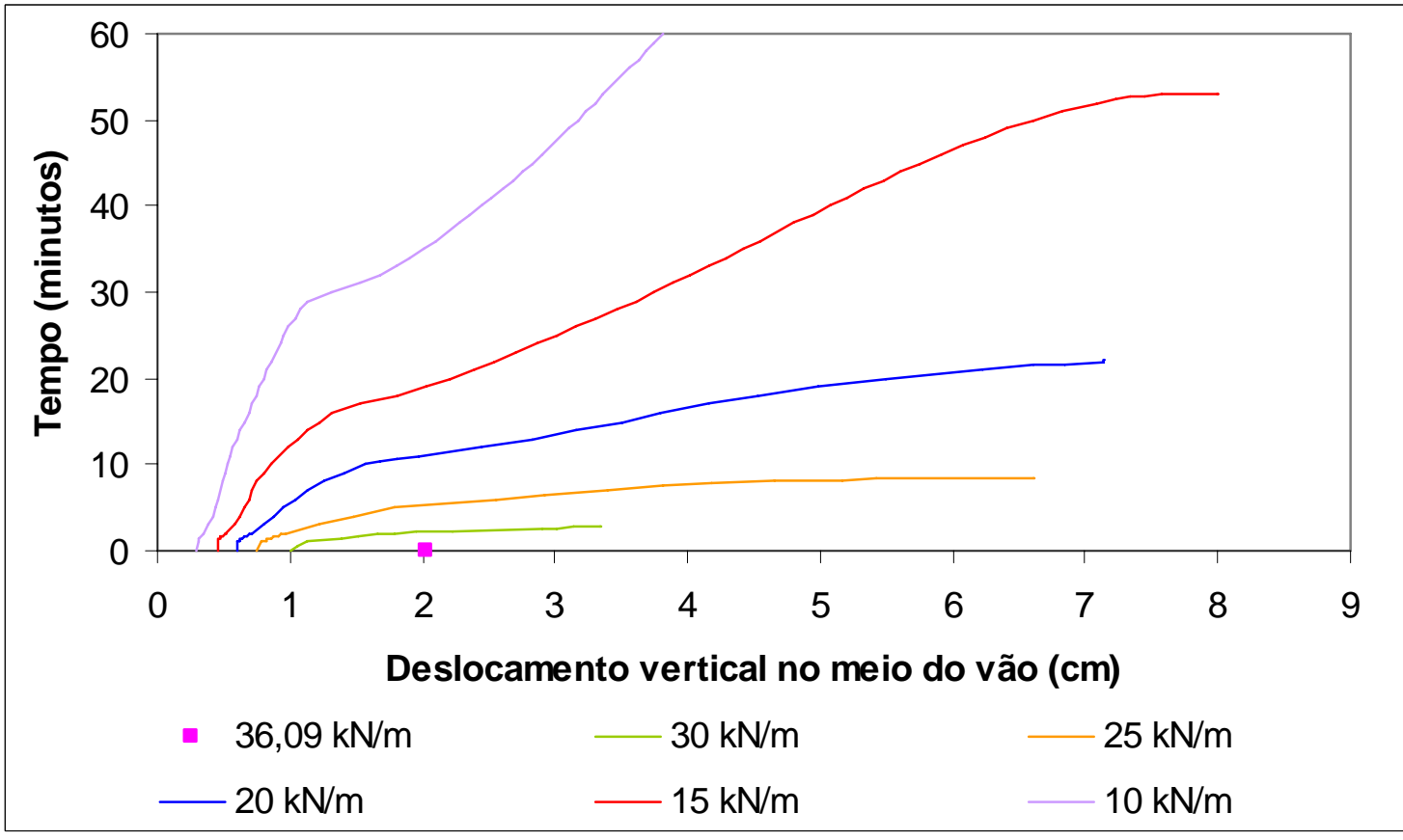

Figura 7.26 - Caso U5-VLA9-EIP: Deslocamento vertical no meio do vão em função do tempo de exposição ao incêndio. 


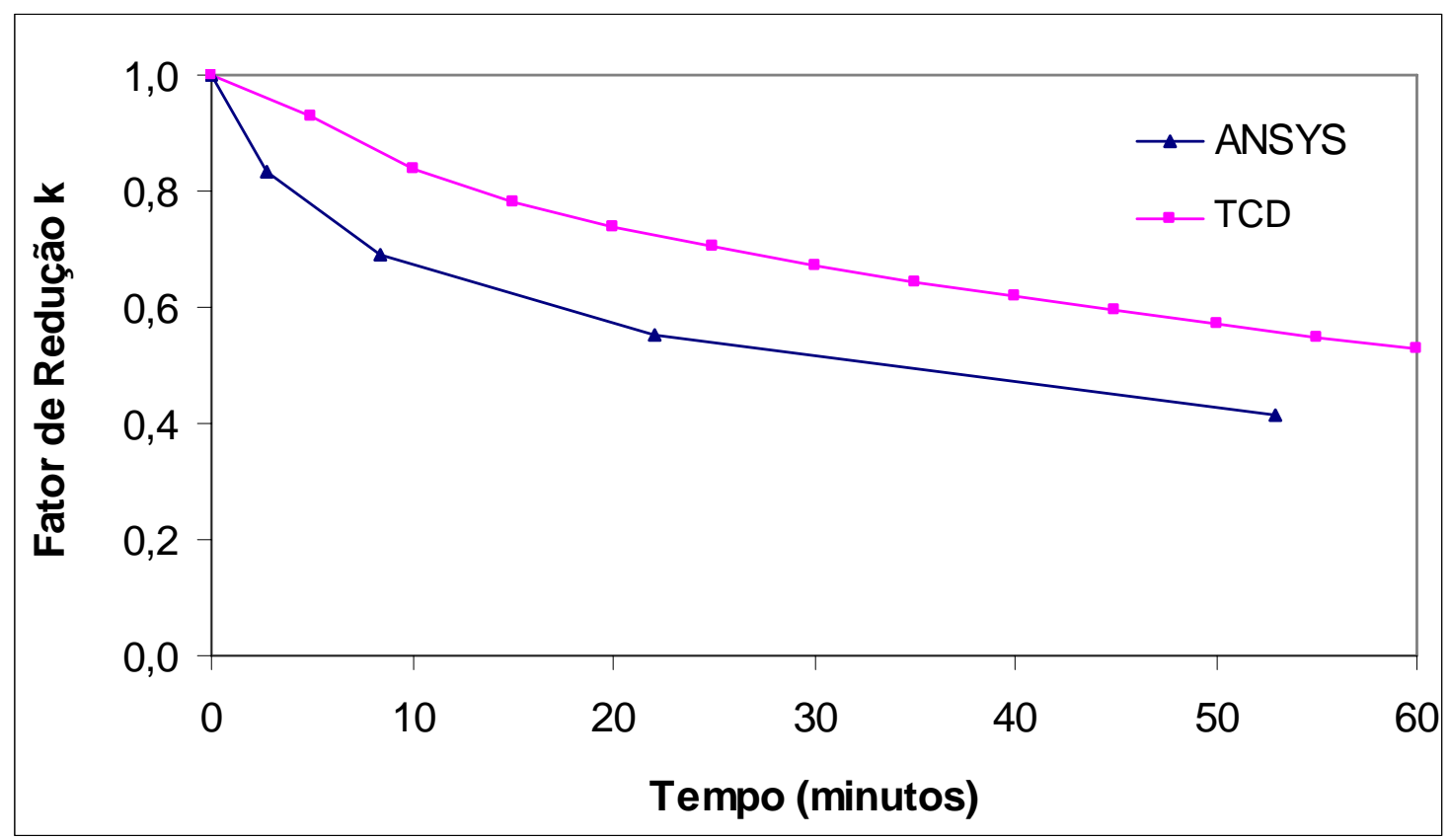

Figura 7.27 - Caso U5-VLA9-EIP: Fator de Redução para a viga em função do tempo de exposição ao incêndio - Comparação ANSYS x TCD.

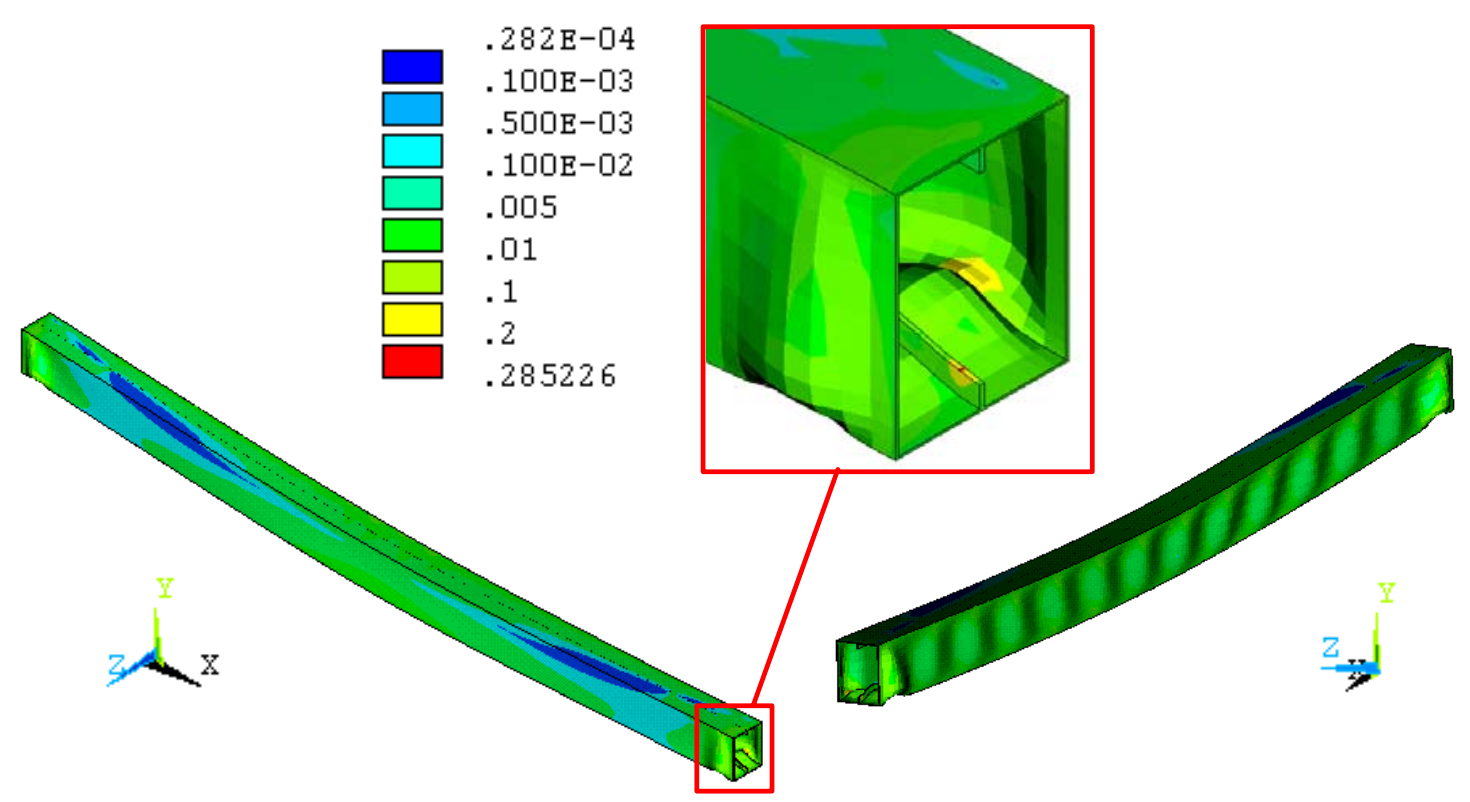

Figura 7.28 - Caso U5-VLA9-EIP: Deformações de von Mises, com detalhe indicando plastificação nas regiões próximas aos engastes. 
7.6.5 Caso: U5-VLA14-EIT, viga de aço com laje de concreto e alvenaria $(14 \mathrm{~cm}$ de espessura), com fogo por ambos os lados expostos da viga.

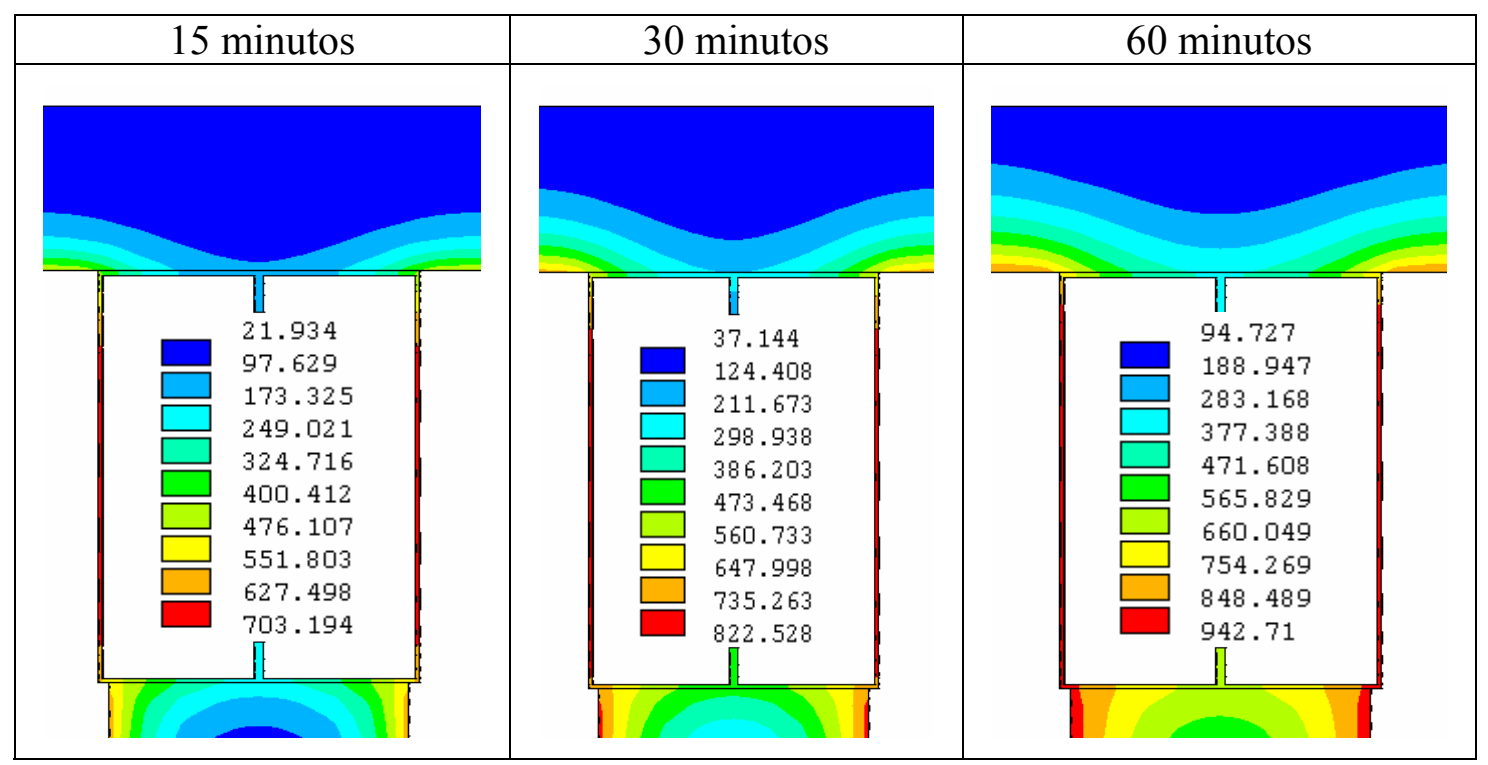

Figura 7.29 - Caso U5-VL14-EIT: Campos de temperaturas correspondentes a tempos (TRRF) iguais a 15,30 e 60 minutos.

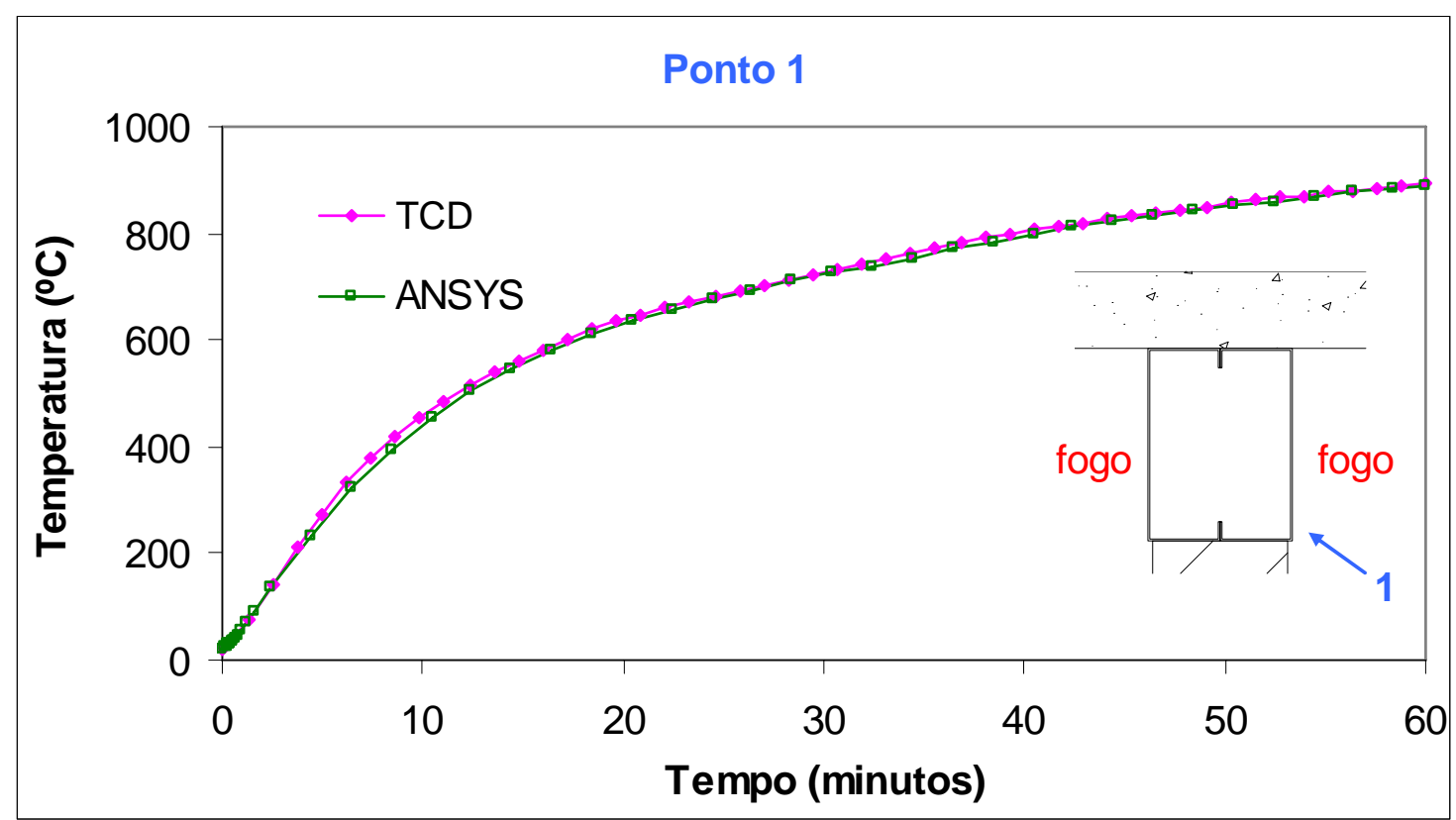

Figura 7.30 - Caso U5-VL14-EIT: Variação da temperatura no ponto 1 ao longo do tempo. 


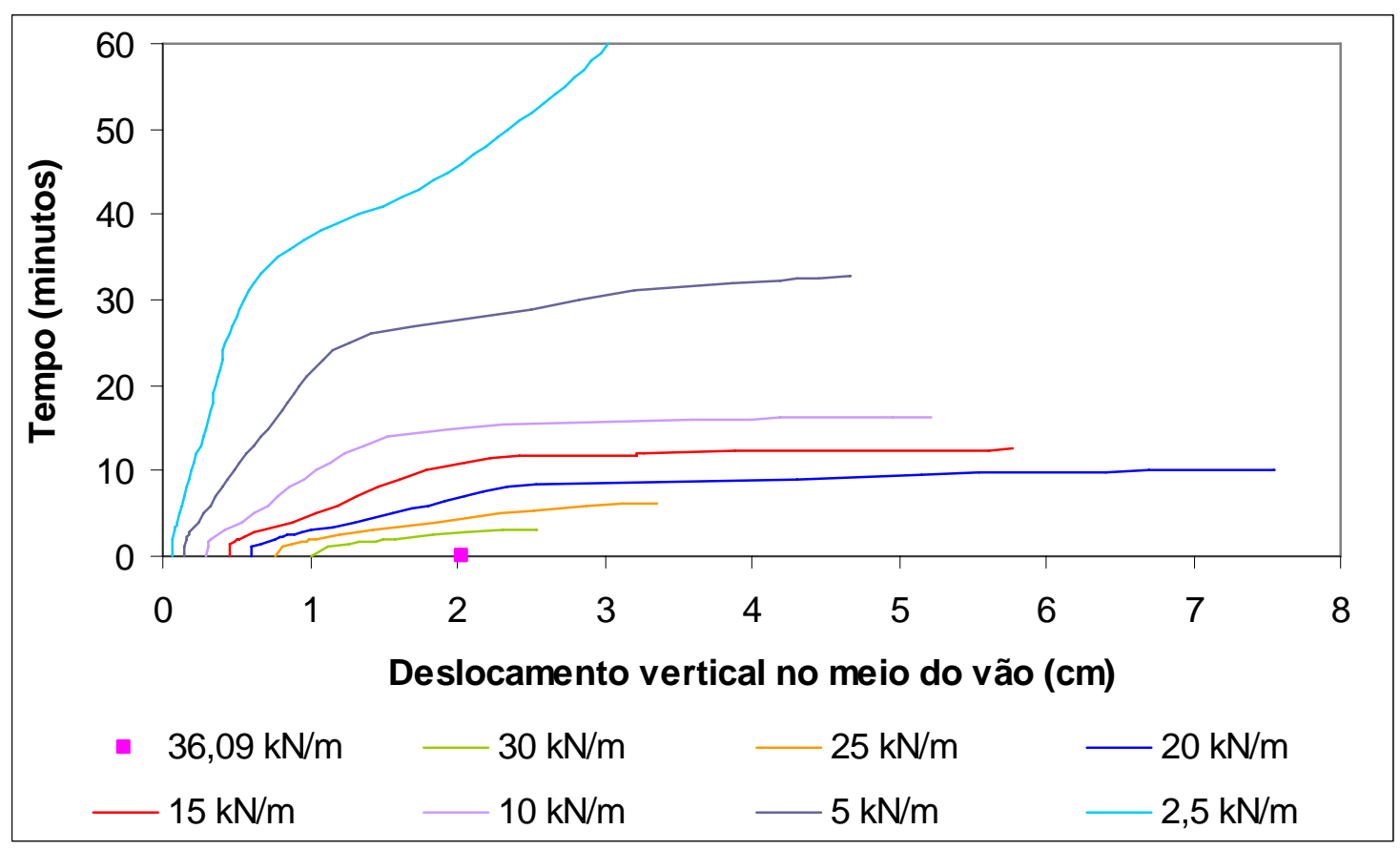

Figura 7.31 - Caso U5-VL14-EIT: Deslocamento vertical no meio do vão em função do tempo de exposição ao incêndio.

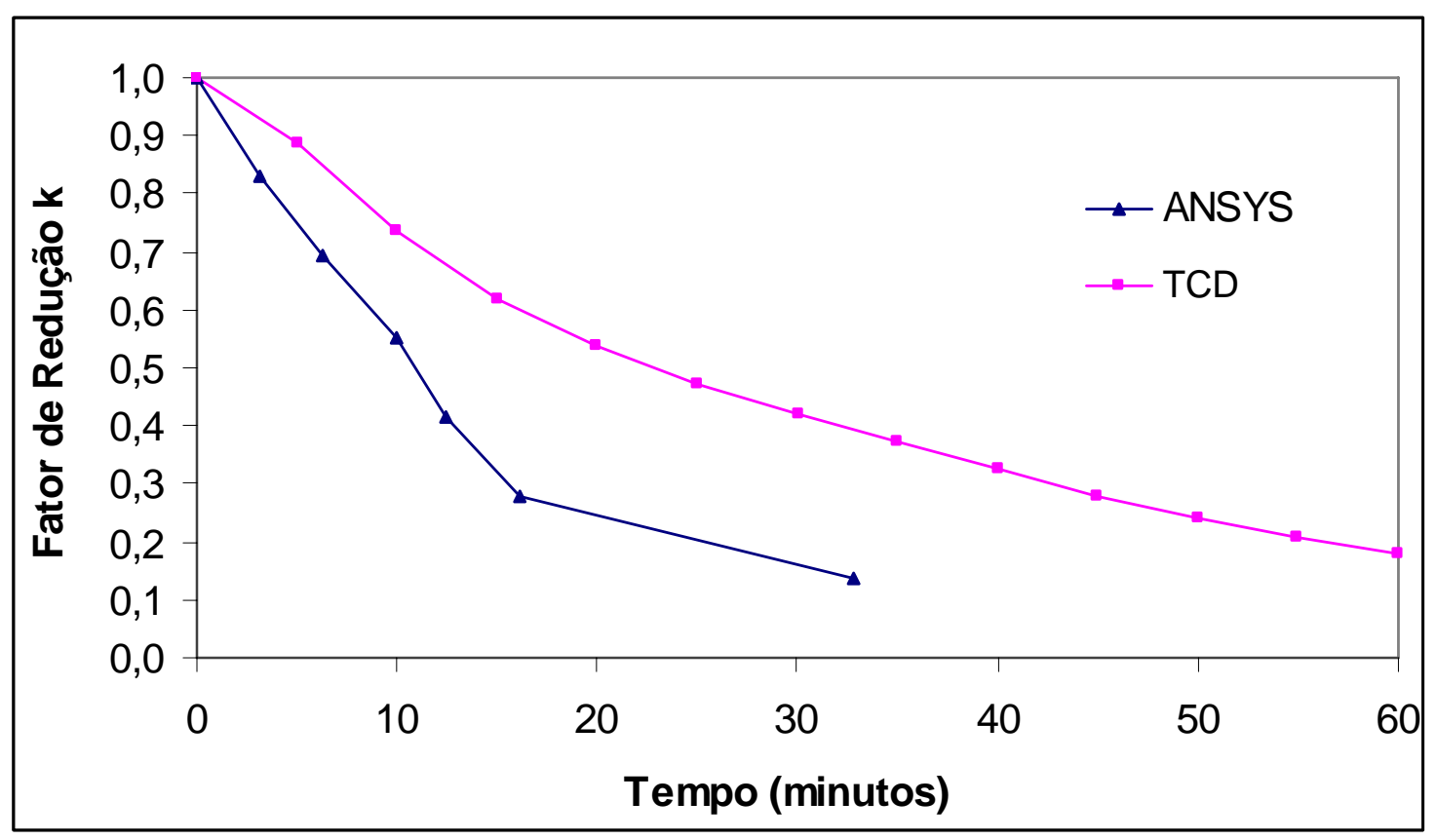

Figura 7.32 - Caso U5-VL14-EIT: Fator de Redução para a viga em função do tempo de exposição ao incêndio - Comparação ANSYS x TCD. 


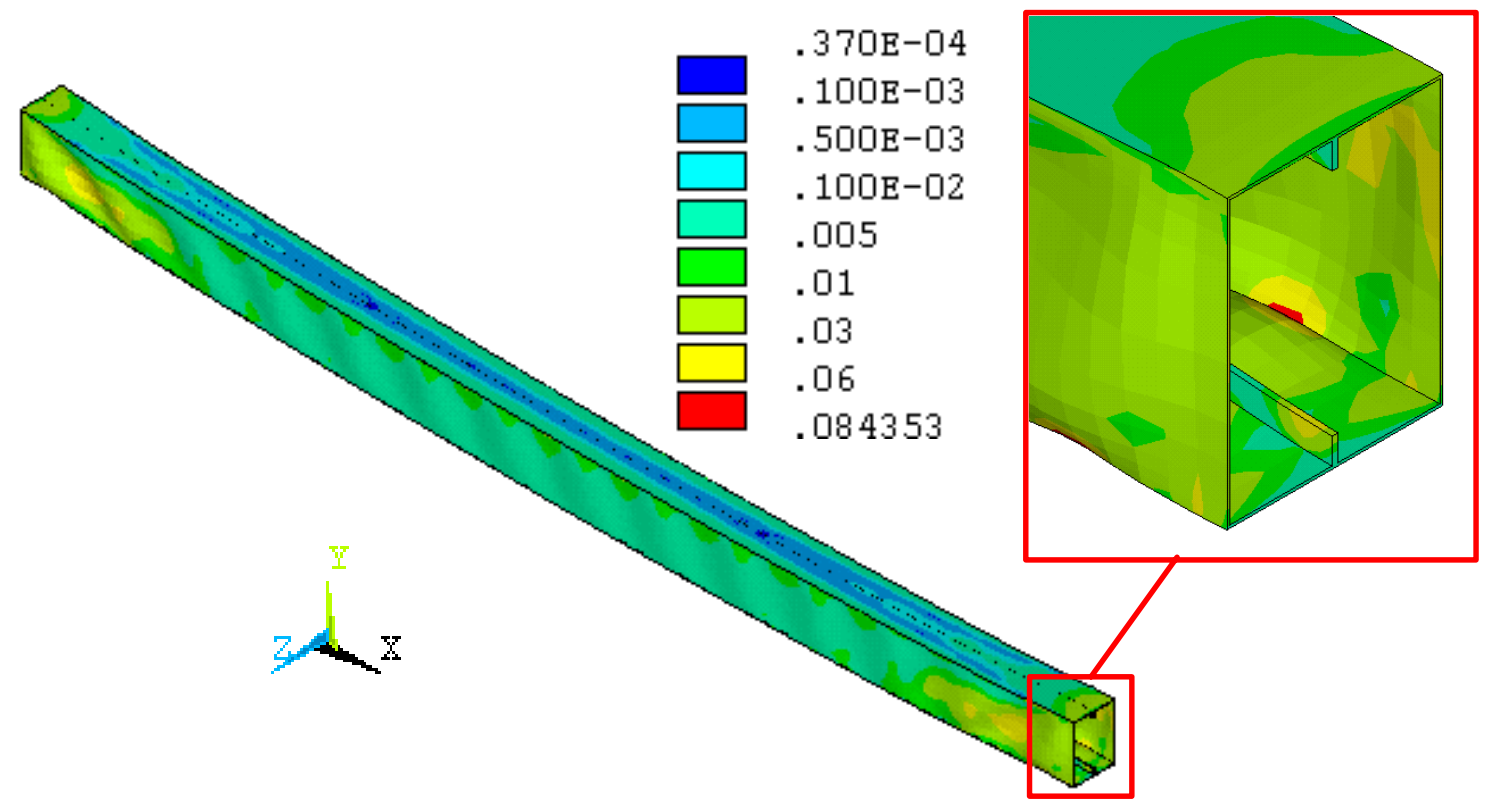

Figura 7.33 - Caso U5-VL14-EIT: Deformações de von Mises, com detalhe indicando plastificação nas regiões próximas aos engastes.

7.6.6 Caso: U5-VLA14-EIP, viga de aço com laje de concreto e alvenaria $(14 \mathrm{~cm}$ de espessura), com fogo em apenas um dos lados expostos da viga.

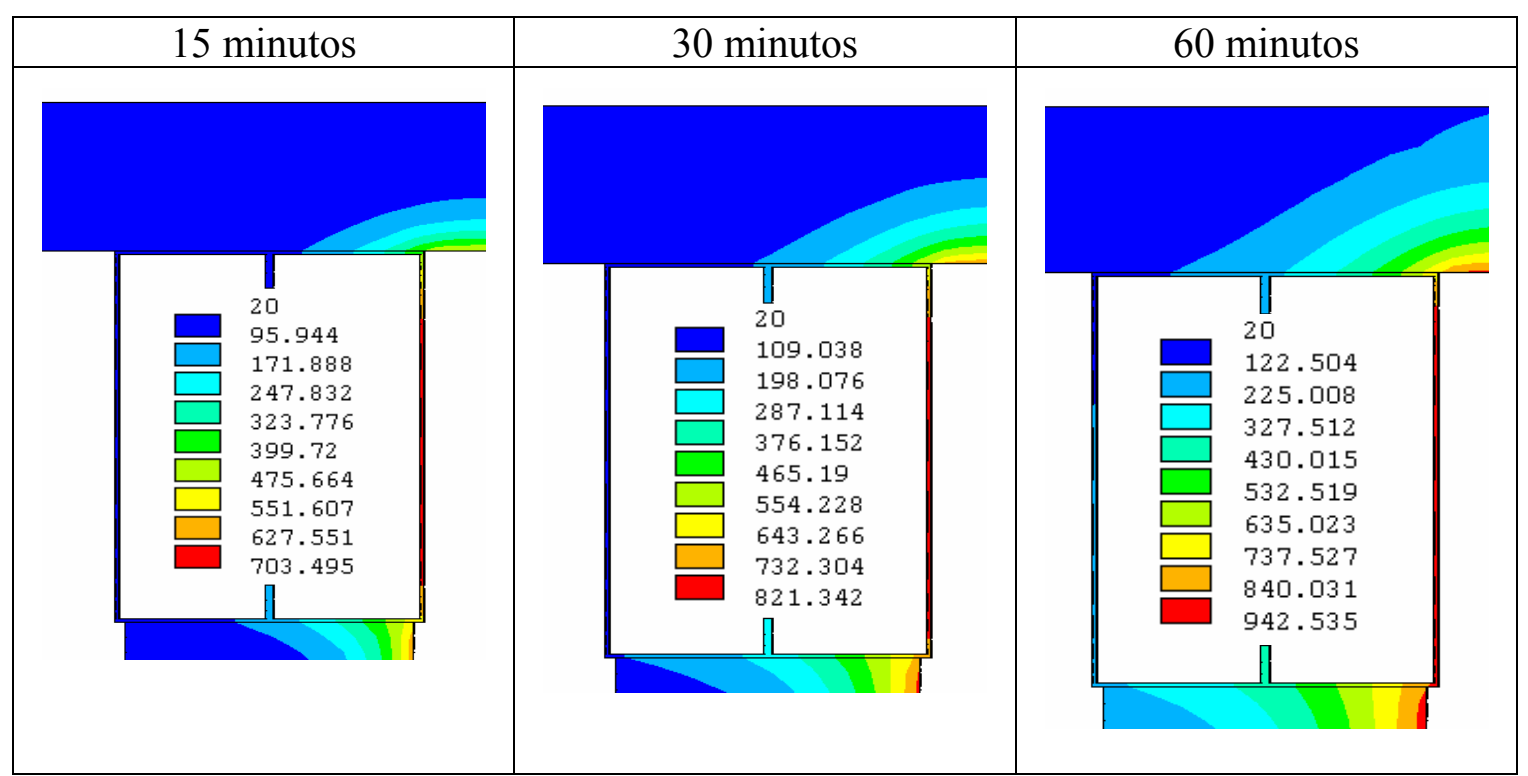

Figura 7.34 - Caso U5-VL14-EIP: Campos de temperaturas correspondentes a tempos de 15,30 e 60 minutos. 


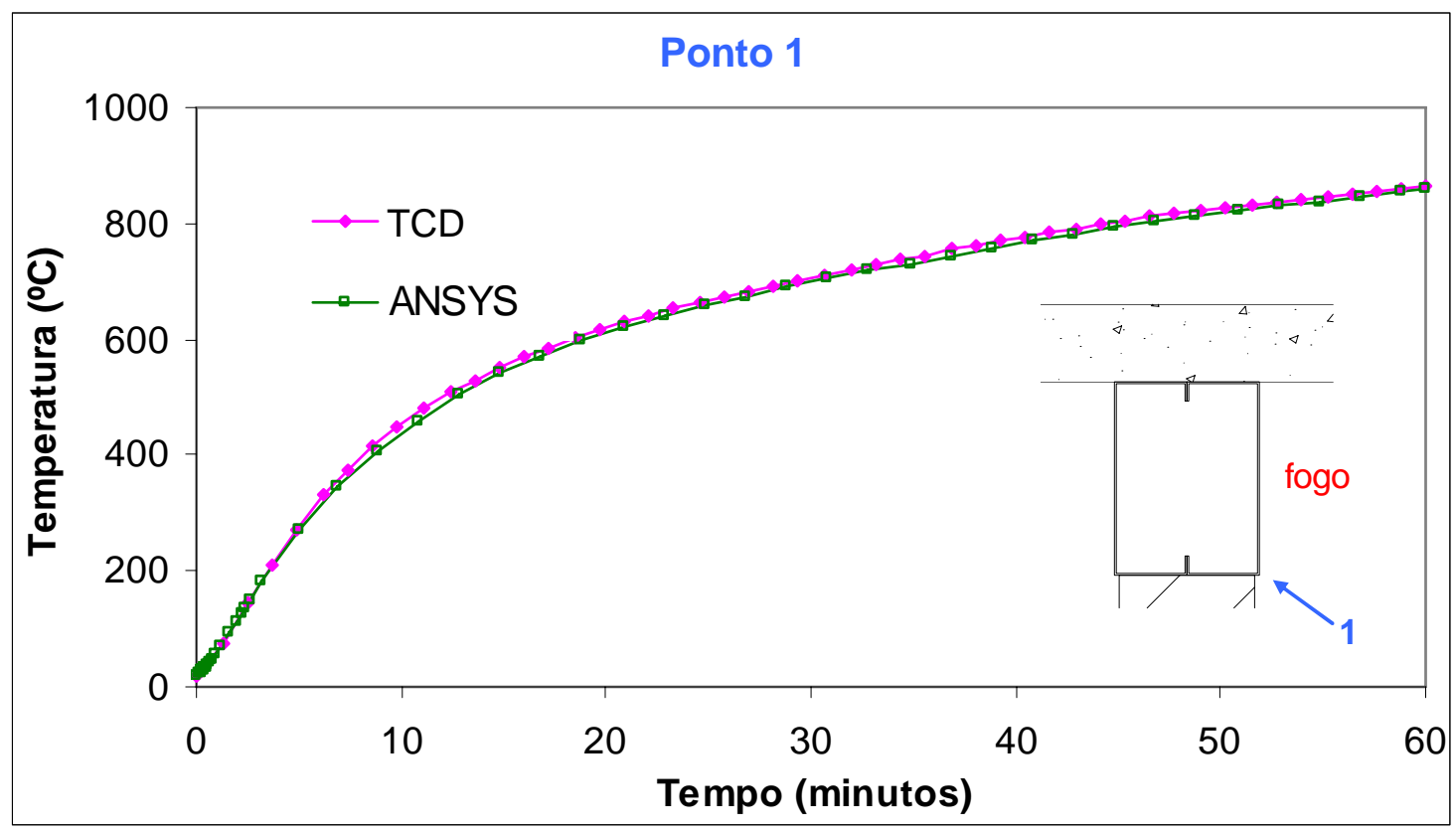

Figura 7.35 - Caso U5-VL14-EIP: Variação da temperatura no ponto 1 ao longo do tempo.

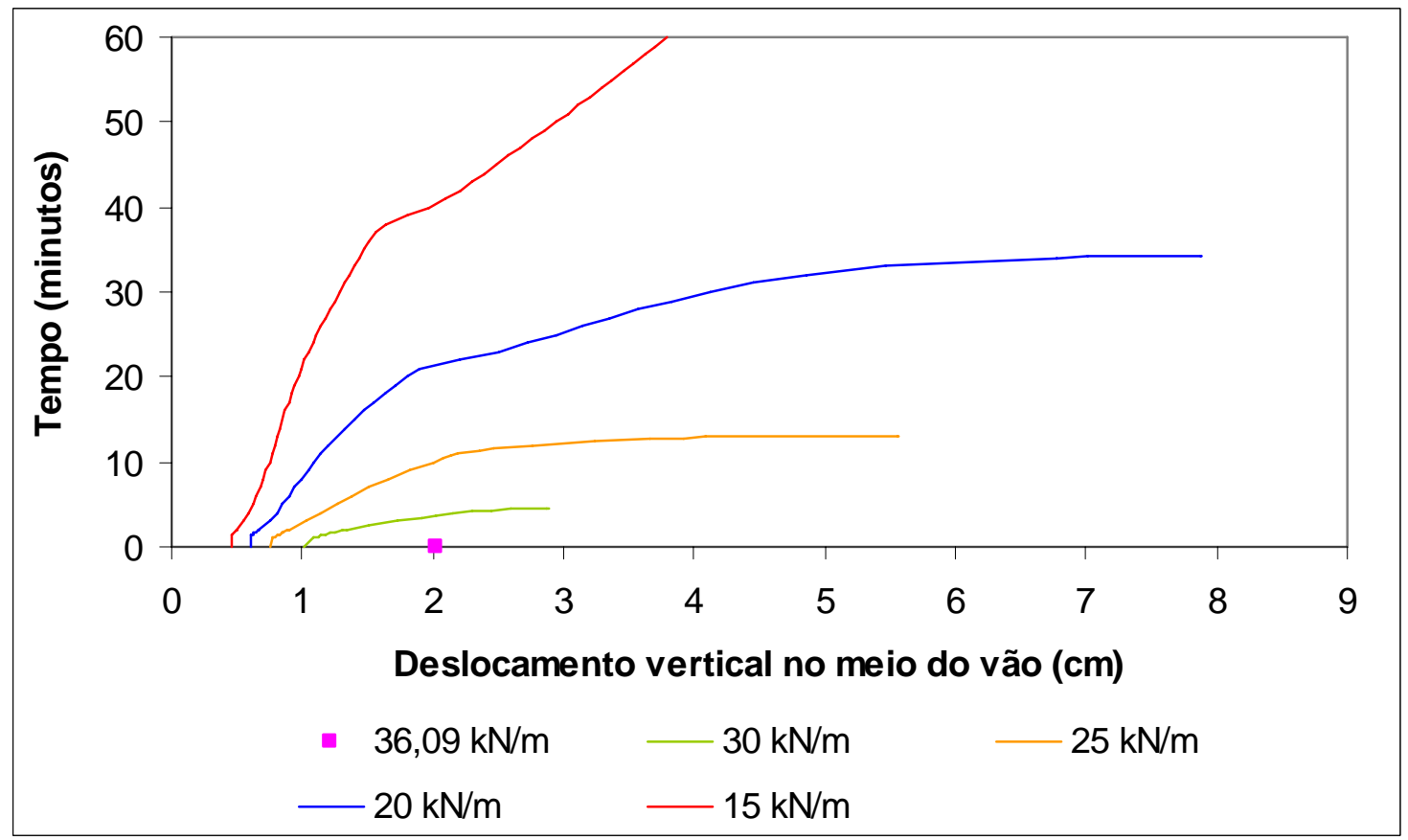

Figura 7.36 - Caso U5-VL14-EIP: Deslocamento vertical no meio do vão em função do tempo de exposição ao incêndio. 


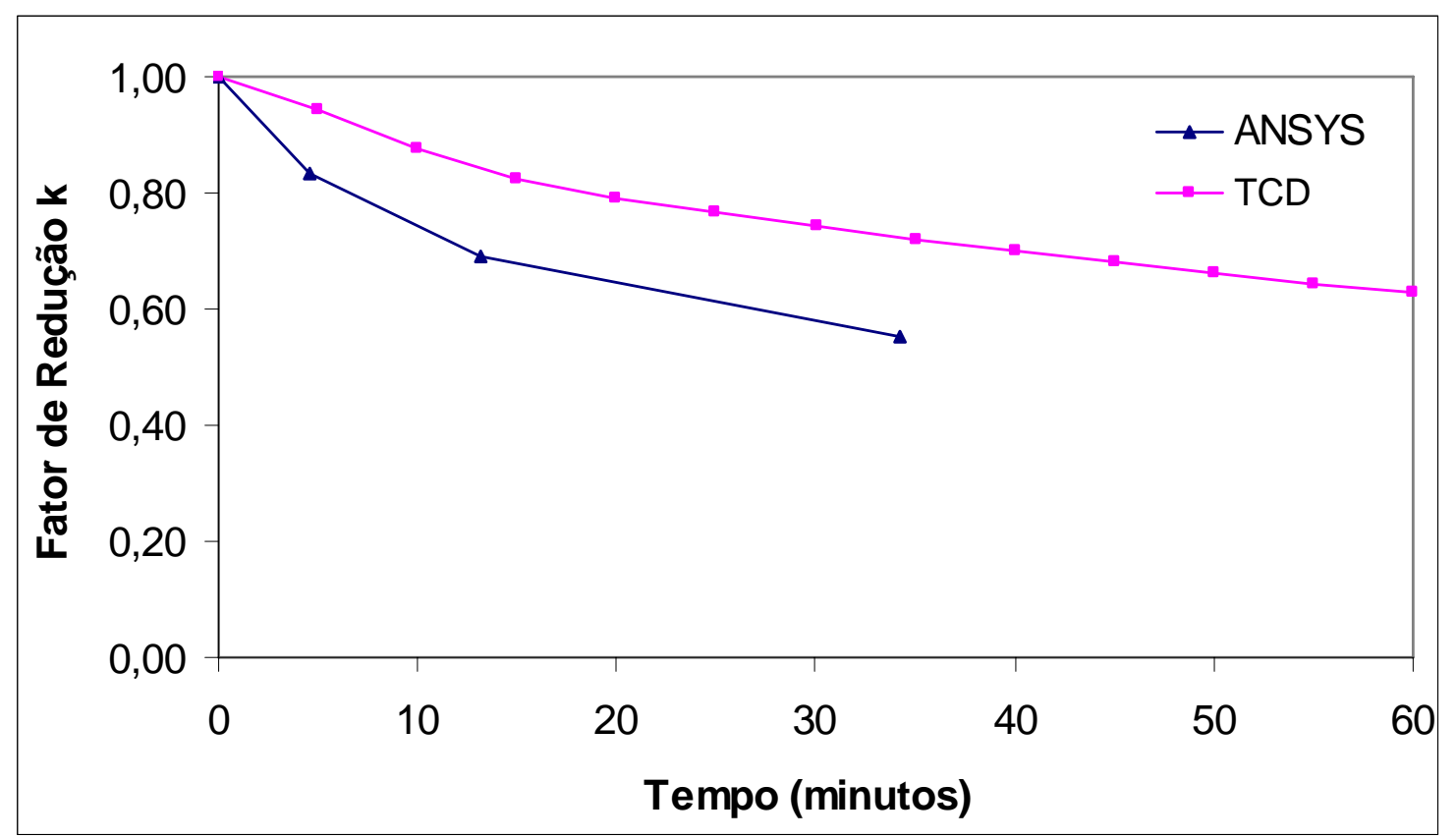

Figura 7.37 - Caso U5-VL14-EIP: Fator de Redução para a viga em função do tempo de exposição ao incêndio - Comparação ANSYS x TCD.

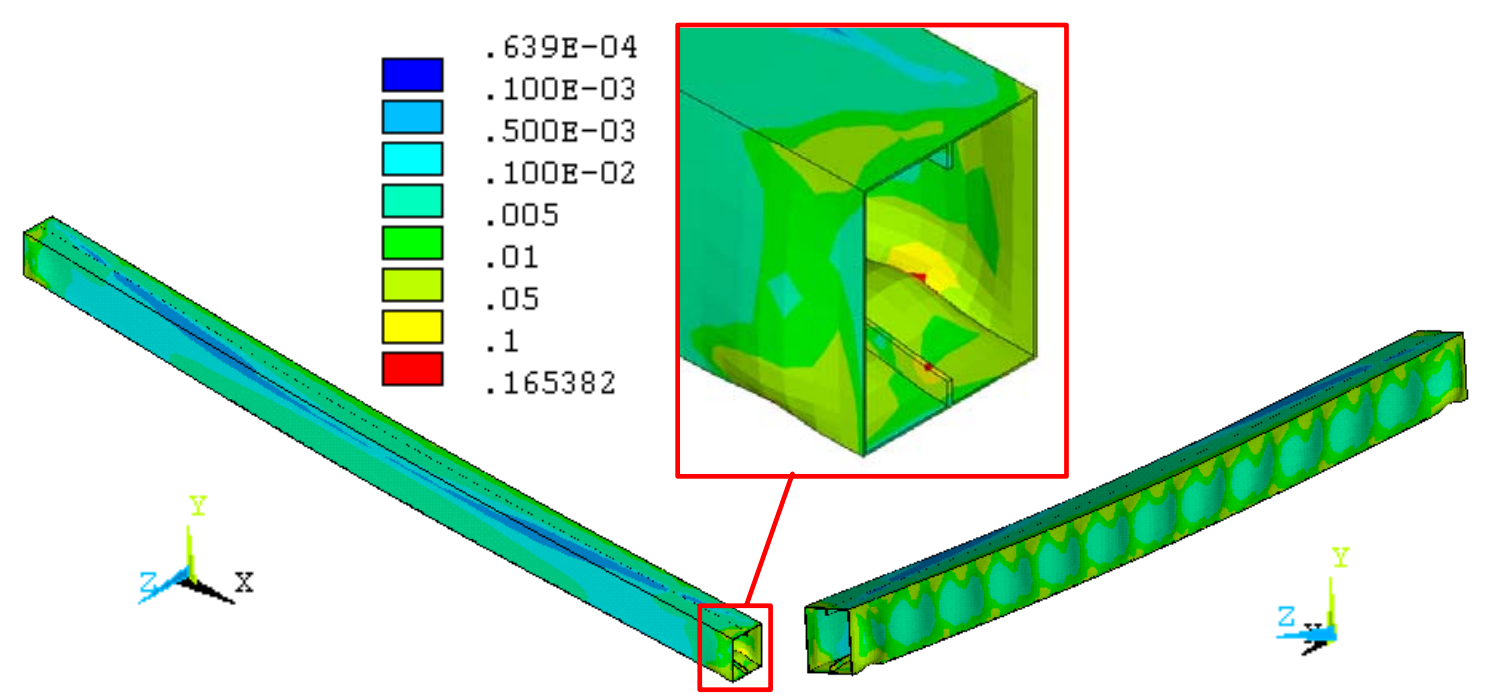

Figura 7.38 - Caso U5-VL14-EIP: Deformações de von Mises, com detalhe indicando plastificação nas regiões próximas aos engastes. 
7.6.7 Caso: U5-VLBA14-EII, viga de aço, de borda, com laje de concreto e alvenaria (14 cm de espessura), com fogo apenas no lado interno expostos da viga.

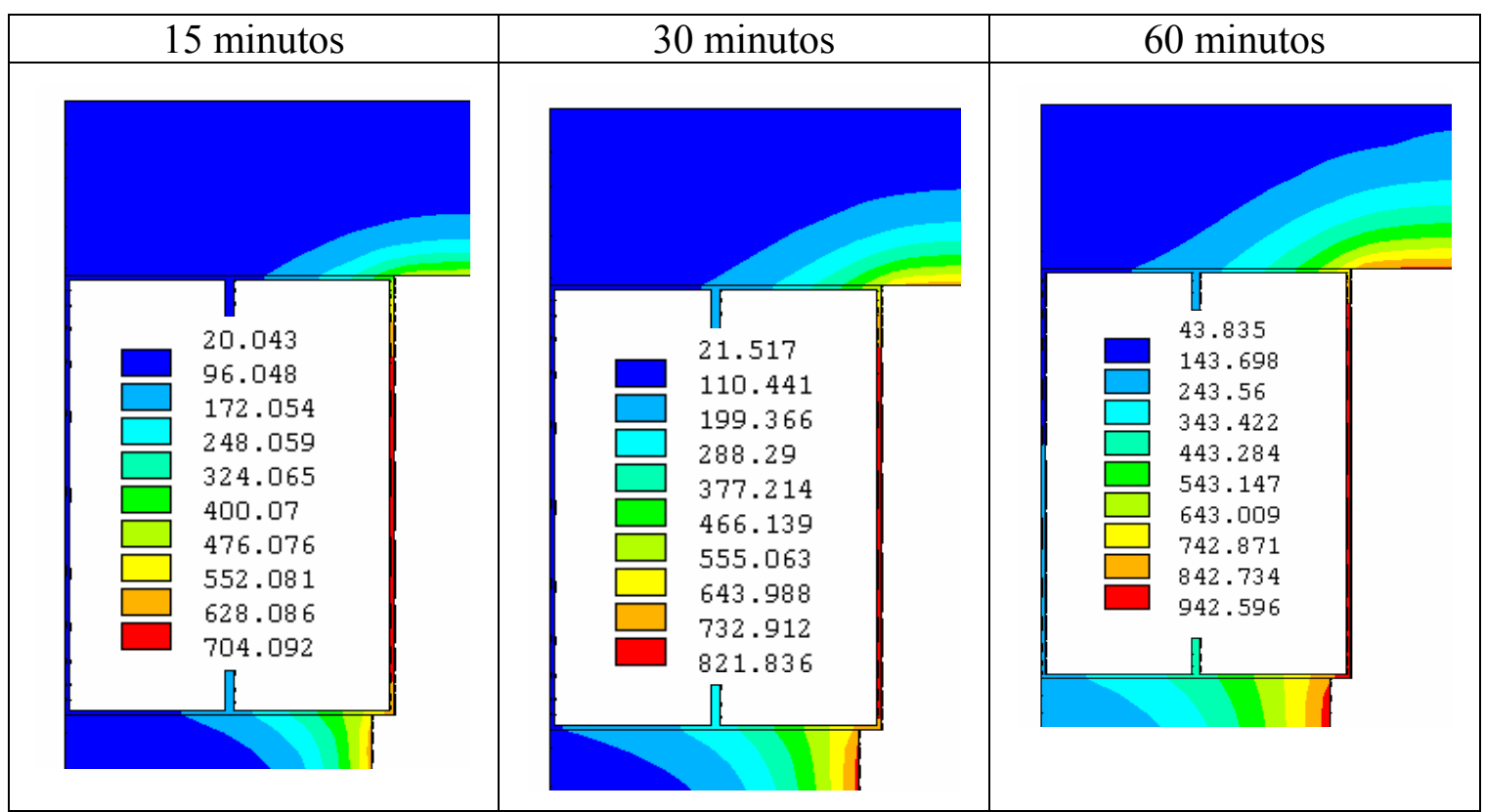

Figura 7.39 - Caso U5-VLB14-EII: Campos de temperaturas correspondentes a tempos de 15,30 e 60 minutos.

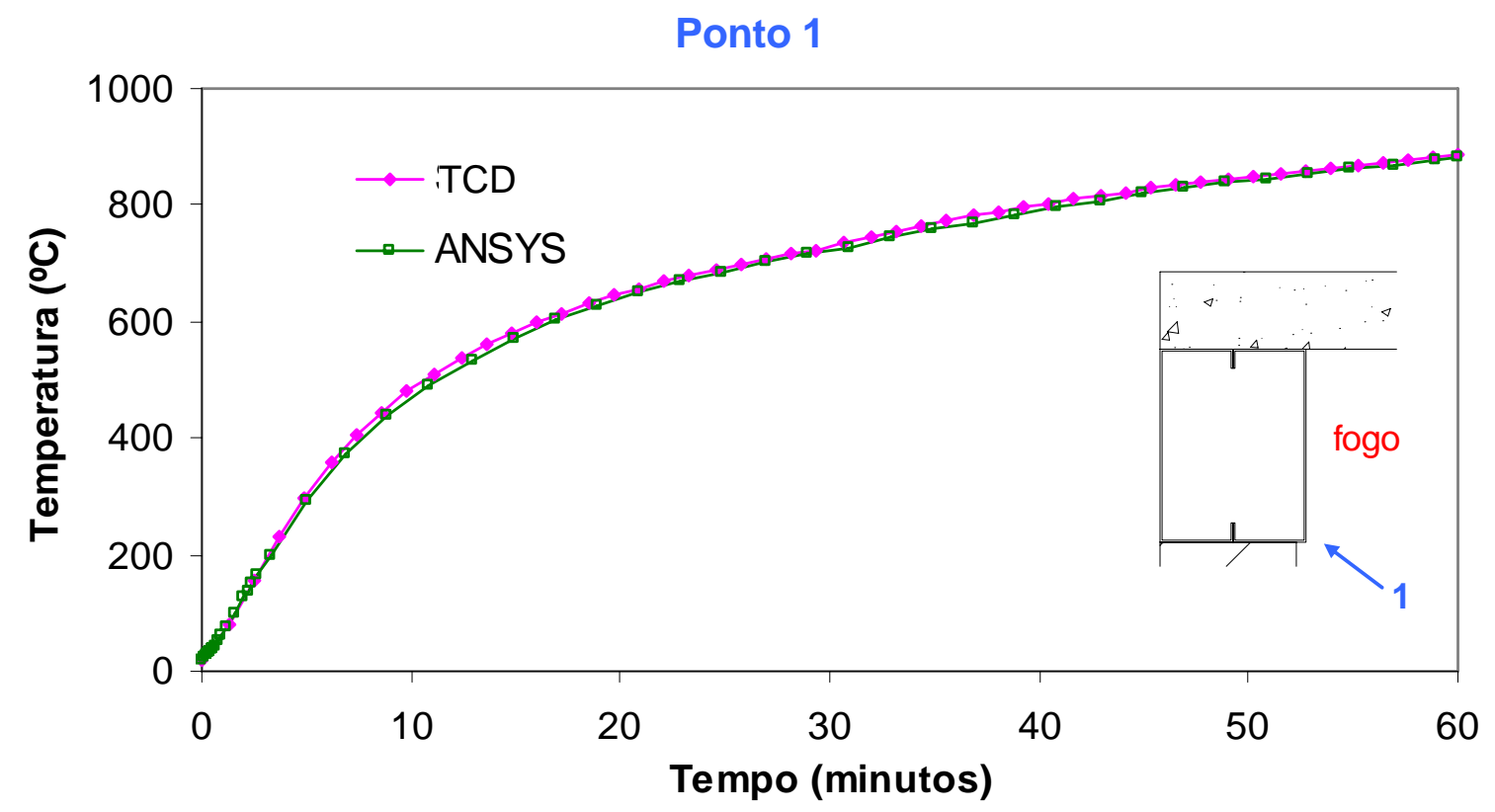

Figura 7.40 - Caso U5-VLB14-EII: Variação da temperatura no ponto 1 ao longo do tempo. 


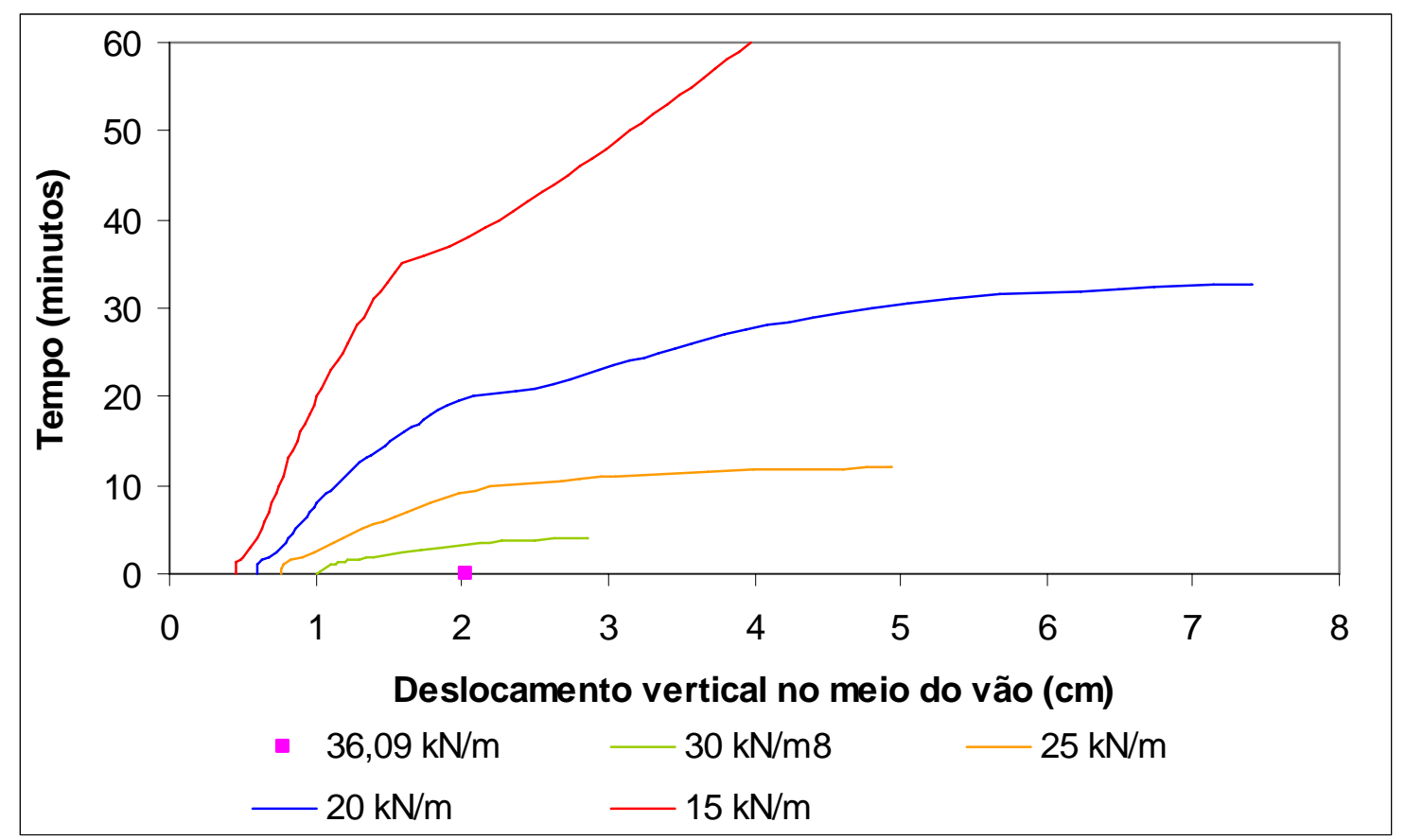

Figura 7.41 - Caso U5-VLB14-EII: Deslocamento vertical no meio do vão em função do tempo de exposição ao incêndio.

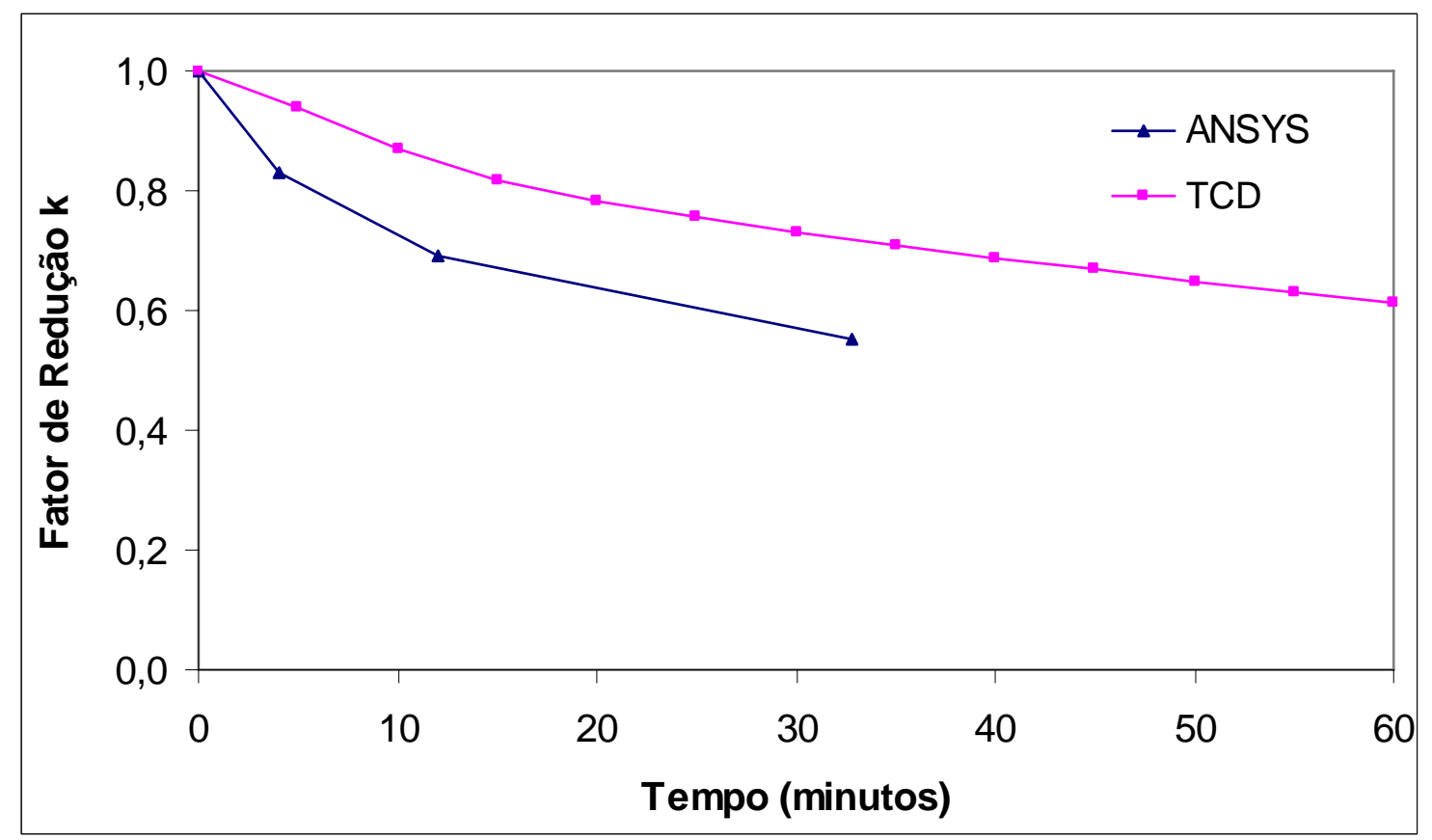

Figura 7.42 - Caso U5-VLB14-EII: Fator de Redução para a viga em função do tempo de exposição ao incêndio - Comparação ANSYS x TCD. 


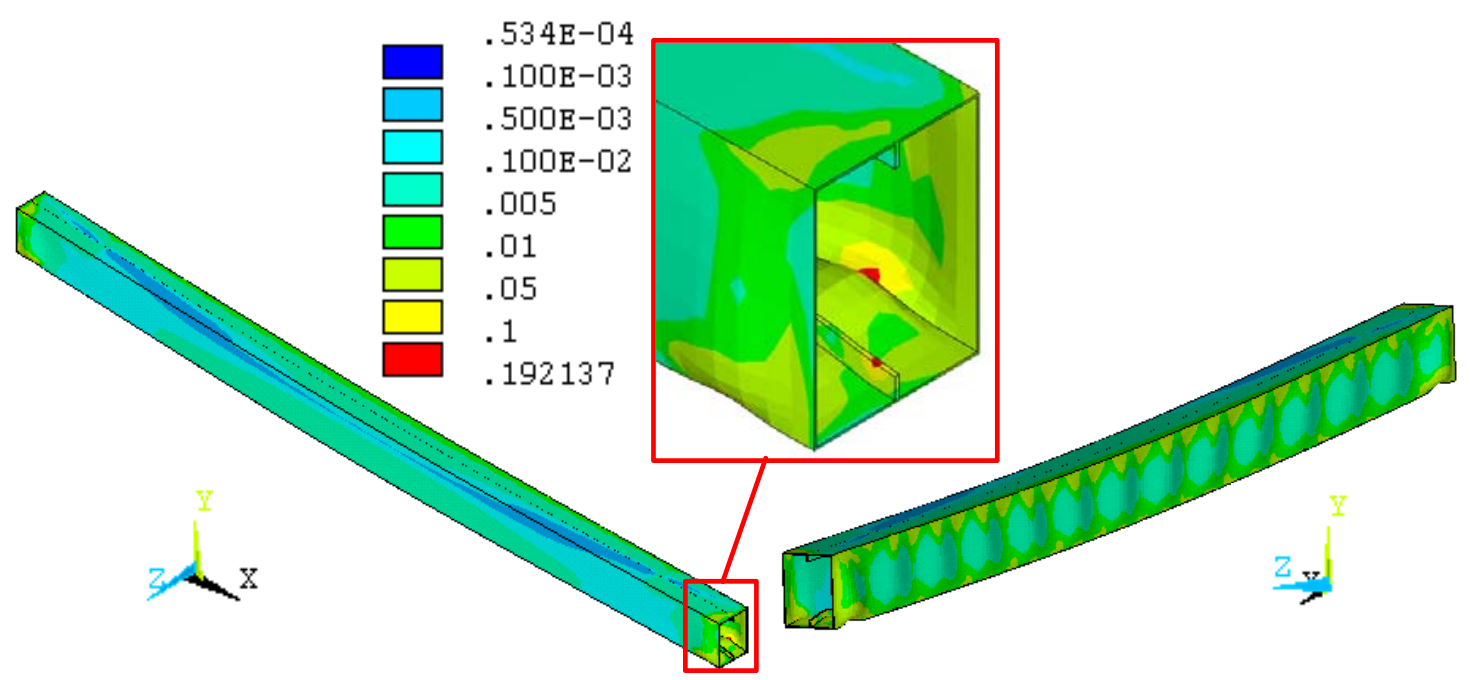

Figura 7.43 - Caso U5-VLB14-EII: Deformações de von Mises, com detalhe indicando plastificação nas regiões próximas aos engastes.

Com base nos resultados obtidos constata-se, com relação à obtenção dos campos de temperatura ao longo da seção transversal das vigas, concordância bastante satisfatória (praticamente coincidentes) dos resultados obtidos por meio do ANSYS quando comparados àqueles obtidos por meio do programa TCD.

Alguns modelos numéricos referentes à análise estrutural em situação de incêndio apresentaram dificuldade de convergência na fase inicial de aplicação do campo de temperaturas, exigindo redução considerável dos incrementos de carregamento para convergência do processamento. Tal aspecto pode ter relação direta com a plastificação prematura (para baixas temperaturas) que ocorre nas extremidades das vigas em resposta ao impedimento ao giro (engastes) naquelas seções.

Os fatores de redução de resistência obtidos por meio do código ANSYS resultaram inferiores àqueles obtidos via TCD, exceto para o caso U5-V-EIST. Essa redução na capacidade resistente, para os mesmos campos de temperatura, se deve à maior precisão na análise estrutural efetuada via ANSYS, que permite levar em conta as o desempenho do elemento durante a elevação de temperatura frente às condições de vinculação impostas, bem como quando da ocorrência de gradientes térmicos significativos ao longo da seção.

Outros comentários de interesse com relação aos resultados aqui obtidos, encontram-se descritos no Capitulo 8, referente às conclusões do presente trabalho. 


\section{CONCLUSÕES E SUGESTÕES PARA TRABALHOS FUTUROS}

Ao longo do presente trabalho, com base nos aspectos apresentados nos capítulos 1, 2, 3 e 4, procurou-se apresentar e descrever aspectos de interesse relacionados à ação térmica em elementos estruturais constituinte de sistemas estruturais correntes, tendo como conseqüência a elevação de temperatura, as quais provocam reduções de interesse para fins de dimensionamento.

Para tanto, foi estabelecido como objetivo principal estudar, em caráter essencialmente numérico, a elevação de temperatura em seções transversais de elementos estruturais de aço e mistos de aço e concreto, com vistas a uma avaliação das equações propostas pelo método simplificado de cálculo, para a determinação da temperatura, prescritas pela NBR 14323:1999.

Assim, ainda no capítulo 4, foram estabelecidas as ferramentas numéricas de interesse para a viabilização dos modelos de interesse, disponibilizadas por meio do código ANSYS v9.0, elaborado com base no método dos elementos finitos.

No capítulo 5, estabelecido ponto de partida para análise dos modelos numéricos, foram apresentados alguns resultados referentes à validação da estratégia numérica aqui adotada. Primeiramente, procurou-se identificar as ferramentas necessárias e suas potencialidades, bem como definir a estratégia para elaboração (construção) dos modelos numéricos de interesse.

Nessa etapa, os resultados, obtidos com o pacote ANSYS v9.0 na análise da elevação de temperaturas em seções transversais de elementos estruturais de aço e mistos de aço e concreto em situação de incêndio, se apresentaram bastante satisfatórios. Isso pode ser comprovado com a boa aproximação entre os resultados obtidos via ANSYS e os obtidos com o programa SAFIR para os Modelos 1 e 2, apresentados em LEWIS (2000), bem como com os resultados do programa PFEM_2D para o Modelo 3, apresentados em SILVA (2002). 
Os resultados obtidos com modelos simplificados de cálculo, quando comparados àqueles obtidos via modelos numéricos, com relação aos casos analisados, se mostraram satisfatórios. Apesar de diferirem em alguns pontos, os procedimentos presentes nas normas NBR 14323:1999, EUROCODE 3 (2005) e EUROCODE 4 (2005) conduzem a resultados muito próximos.

Em caráter complementar, com vistas à calibração dos modelos numéricos, o modelo 4 tratou da seção transversal de uma viga de madeira Eucalyptus citriodora, cujos resultados numéricos foram confrontados com resultados experimentais apresentados em PINTO (2005).

A boa correlação obtida entre os dados experimentais e do modelo numérico 4, para as profundidades de 20 e $30 \mathrm{~mm}$, sugere que a estratégia de modelagem aqui utilizada pode ser empregada para se determinar a profundidade carbonizada da madeira com razoável aproximação, bastando adotar uma temperatura de referência para a carbonização da madeira como, por exemplo, $288{ }^{\circ} \mathrm{C}$ (a temperatura característica da base da camada carbonizada).

Diante dos resultados obtidos no capítulo 5, referente à calibração da estratégia numérica, conclui-se que a estratégia de modelagem aqui adotada é eficiente para o estudo de situações em que elementos de aço e mistos de aço e concreto são submetidos a um aquecimento não-uniforme em suas seções transversais.

No capítulo 6 foram apresentados resultados de 11 casos de estudo de elementos de aço e mistos de aço e concreto, tabela 6.2 (previstos tanto pela NBR 14323:1999 quanto pelo EUROCODE 3 (2005)) e tabela 6.3 (outras situações de interesse), os quais consistem basicamente de estudo de alguns casos de interesse relacionados a elementos estruturais submetidos a um aquecimento não-uniforme em suas seções, para fins de determinação do campo de temperatura com vistas ao dimensionamento, por meio de

\section{"fatores de massividade".}

Com base nos resultados obtidos para os casos normativos estudados, referentes à tabela 6.2, é possível estabelecer, ainda que em caráter preliminar, os seguintes aspectos:

a-) A determinação dos níveis de temperatura em seções transversais de elementos estruturais correntes, obtidas com base nas prescrições normativas da NBR 14323:1999, conduzem a resultados satisfatórios, porém, com temperaturas próximas 
às temperaturas máximas obtidas numericamente, principalmente para os casos em que a espessura das chapas pode ser entendida como considerável, se comparada àquelas espessuras de chapas usualmente empregadas na prática das construções correntes;

b-) A consideração apresentada no item (a) permite estabelecer, apenas como sugestão para fins de ajuste dos fatores de massividade, a aplicação de um coeficiente de redução para tal parâmetro que seja função da espessura das chapas que constituem o perfil, de modo a estabelecer uma maior aproximação entre valores normativos $e$ numéricos. Pode-se, eventualmente, ser admitida a possibilidade de que valores normativos fiquem situados entre os valores de temperaturas máxima e média identificadas nos processamentos;

c-) No entanto, para os itens (a) e (b), a utilização de um coeficiente de redução em função da espessura das chapas deverá ser aplicado ao fator de massividade, desde que ocorra uma validação da necessidade deste por meio de análise experimental em elementos estruturais ou, eventualmente, em sistemas estruturais em incêndio.

Com base nos resultados obtidos para os casos não-normativos estudados, referentes à tabela 6.3, chama-se atenção para os seguintes aspectos:

a-) Quanto à análise térmica, a determinação dos níveis de temperatura em seções transversais de elementos estruturais correntes, obtidas com base nas adaptações das prescrições normativas da NBR 14323:1999 adotadas neste trabalho, evidenciam a necessidade da aplicação de modelos avançados de cálculo para tais situações ou estudos com vistas à obtenção de procedimentos simplificados mais adequados para estes casos, em razão de significativas diferenças entre temperaturas máximas e mínimas, obtidas numericamente;

b-) As diferenças significativas entre temperaturas máximas e mínimas nas seções transversais para as situações da tabela 6.3, evidenciam a presença de gradientes térmicos que devem avaliados cuidadosamente quanto a possibilidade da introdução de efeitos nocivos na análise estrutural. Tal aspecto deve ser objeto de estudo futuro. 
No capítulo 7 foram apresentados modelos tridimensionais de vigas de aço e seus resultados, com o objetivo de se estabelecer um procedimento numérico para análises termostruturais de elementos de aço em situação de incêndio.

Analisando os resultados obtidos e apresentados no item 7.6, foi possível constatar com relação à obtenção dos campos de temperatura ao longo da seção transversal das vigas, que os resultados obtidos com o ANSYS possuem concordância bastante satisfatória (praticamente coincidentes) quando comparados àqueles obtidos via TCD.

Vale lembrar que o coeficiente de redução em função do tempo de exposição obtido via ANSYS foi definido como a relação entre o carregamento aplicado para análise em situação de incêndio e o carregamento máximo alcançado em temperatura ambiente. No caso do programa TCD v5.0, o mesmo fator é obtido com base na análise plástica da seção, por meio de procedimento simplificado do EUROCODE 3, para a determinação do momento resistente plástico da seção de aço à temperatura ambiente e em situação de incêndio.

Os fatores de redução de resistência obtidos por meio do código ANSYS resultaram inferiores àqueles obtidos via TCD, exceto para o caso U5-V-EIST. Essa redução na capacidade resistente, para os mesmos campos de temperatura, se deve à maior precisão na análise estrutural efetuada via ANSYS, que permite levar em conta as o desempenho do elemento durante a elevação de temperatura frente às condições de vinculação impostas, bem como quando da ocorrência de gradientes térmicos significativos ao longo da seção.

Os aspectos mencionados neste capítulo, bem como ao longo do trabalho, sugerem para trabalhos futuros:

- Estudos complementares com relação ao fator de massividade para alguns dos casos normativos, apresentados na tabela 6.2, promovendo variações nas espessuras e no tipo de material constituinte das faces protegidas contra o fogo;

- Estudos com relação ao fator de massividade de casos não-normativos e de interesse para a aplicação na prática da construção civil; 
- Avaliação dos efeitos dos gradientes térmicos na análise estrutural dos casos nãonormativos da tabela 6.3.

- Estudo com relação ao comportamento da viga de aço do capítulo 7 em casos que apresentem, por exemplo, restrições axiais ao deslocamento nos apoios e nas posições dos conectores.

- Estudo da influência da laje de concreto na análise estrutural da viga do capítulo 7. 


\section{BIBLIOGRAFIA}

AMERICAN INSTITUTE OF STEEL CONSTRUCTION (2005). ANSI/AISC 360-05 Specification for Structural Steel Buidings. Chicago.

AMERICAN INSTITUTE OF STEEL CONSTRUCTION (2003). Steel Design Guide 19 - Fire Resistance of Structural Steel Framing. Chicago.

AMERICAN SOCIETY TESTING AND MATERIALS. (2000). ASTM E119 Standard test methods for fire tests of building construction and materials. West Conshohohocken.

ANDERBERG, Y. (1997). TCD 5.0 edition - User's Manual. Fire Safety Design. Lund.

ANSYS INC. (2004). Ansys Release 9.0 - Documentation.

ASSOCIAÇÃO BRASILEIRA DE NORMAS TÉCNICAS (2004) - NBR 15200: Projeto de estruturas de concreto em situação de incêndio. Rio de Janeiro.

ASSOCIAÇÃO BRASILEIRA DE NORMAS TÉCNICAS (2001). NBR 14762: Dimensionamento de estruturas de aço constituídas por perfis formados a frio. Rio de Janeiro.

ASSOCIAÇÃO BRASILEIRA DE NORMAS TÉCNICAS (2000). NBR 14432: Exigências de resistência ao fogo de elementos construtivos de edificações Procedimento. Rio de Janeiro.

ASSOCIAÇÃO BRASILEIRA DE NORMAS TÉCNICAS (1999). NBR 14323: Dimensionamento de estruturas de aço de edifícios em situação de incêndio Procedimento. Rio de Janeiro.

ASSOCIAÇÃO BRASILEIRA DE NORMAS TÉCNICAS (1998). NB 6355: Perfis estruturais de aço formados a frio. Rio de Janeiro.

ASSOCIAÇÃO BRASILEIRA DE NORMAS TÉCNICAS (1986). NBR 8800: Projeto e execução de estruturas de aço de edifícios. Rio de Janeiro.

ASSOCIAÇÃO BRASILEIRA DE NORMAS TÉCNICAS (1984). NBR 8681: Ações e segurança nas estruturas. Rio de Janeiro. 
ASSOCIAÇÃO BRASILEIRA DE NORMAS TÉCNICAS (1980). NBR 5628: Componentes construtivos estruturais - Determinação da resistência ao fogo. Rio de Janeiro.

BATHE, K. (1996). Finite Element Procedures, Prentice Hall. New Jersey.

BOLEY, B.A. (1985). Theory of thermal stresses, John Wiley \& Sons Inc. New York.

BRITISH STEEL (1997). Fire Resistance of Steel Framed Buildings. CAFCO Blaze Shield II. Spray Applied Fire Resistive Material. /folder/.

CHEN, J., YOUNG, B. (2004). Mechanical Properties of Cold-Formed Steel at Elevated Temperatures. Seventeenth Internacional Speciality Conference on ColdFormed Steel Structures, Orlando, Florida, U.S.A., November 4-5, 2004, p.437-465.

CLARET, A.M. (2000) Resistência ao fogo de vigas mistas aço-concreto modeladas pelo método dos elementos finitos. In: Jornadas Sudamericanas de Ingenieria Estructural, Anais. Punta Del Este.

DIAS, L. A. M. (2002). Estruturas de aço. Conceitos, técnicas e linguagem. Zigurate. São Paulo.

EUROPEAN COMMITTEE FOR STANDARDIZATION (2002). prEN 1991-1-2: Eurocode 1 - Basis of design and actions on structures. Part 1-2: Actions on structures - Actions on structures exposed to fire, final draft, Brussels.

EUROPEAN COMMITTEE FOR STANDARDIZATION (2005). EN 1993-1-1:2005 Eurocode 3 - Design of steel structures. Part 1-1: General rules and rules for buildings. Brussels.

EUROPEAN COMMITTEE FOR STANDARDIZATION (2005). EN 1993-1-2:2005 Eurocode 3 - Design of Steel Structures. Part 1-2: General rules - Structural Fire Design. Brussels.

EUROPEAN COMMITTEE FOR STANDARDIZATION (2005). EN 1994-1-1:2005 Eurocode 4 - Design of composite steel and concrete structures. Part 1-2: General rules - Structural Fire Design. Brussels.

EUROPEAN CONVENTION FOR CONSTRUCTIONAL STEELWORK (ECCS) (1985). Design manual on European Recomendations for the fire safety of steel structures. Brussels.

EUROPEAN CONVENTION FOR CONSTRUCTIONAL STEELWORK (ECCS) (1993). Composite Beams and Columns to Eurocode 4. Brussels.

EUROPEAN CONVENTION FOR CONSTRUCTIONAL STEELWORK (ECCS) (2001) - Technical Committee 3 - Model Code on Fire Engineering, № 111. Brussels. 
FAKURY, R.H.; SILVA, V.P.; MARTINS, M.M. (2000). Temperatura Crítica de Elementos Estruturais de Aço em Situação de Incêndio. In: Jornadas Suldamericanas de Ingenieria Estructural, Anais. Punta del Este.

FAKURY, R.H. (2000) Dimensionamento de estruturas de aço de edifícios em situação de incêndio. Trabalho produzido especialmente para o núcleo de excelência em estruturas metálicas e mistas. Vitória.

FERREIRA, W.G., CORREIA, E.L.S., AZEVEDO, M.S. (2006) Dimensionamento de Estruturas de Aço e Mistas em Situação deIncêndio. Grafer. Vitória.

GRACE CONSTRUCTION PRODUCTS (2006). Fire Proofing Products; Disponível em: <http://www.na.graceconstruction.com/custom/fire/downloads/>. Acesso em: 26 mar, 2006.

HARADA, T.; HATA, T.; ISHIHARA, S. (1998). Thermal constants of wood during the heating process measured with the laser flash method. J Wood Science 44:425-431. The Japan Wood Research Society.

INCROPERA, FRANK P. (1998). Fundamentos de transferência de calor e de massa. Livros Técnicos e Científicos. Rio de Janeiro.

INTERNATIONAL STANDARD (1999). Fire-resistance tests - Elements of building construction - Part 1: General requirements. ISO 834-1:1999.

INSTITUTO DE PESQUISAS TECNOLÓGICAS (1997). Caracterização de produto de proteção de estruturas de aço contra a ação do incêndio. Relatório Técnico n. 35687. São Paulo.

ISAR (2006). Isolamentos Térmicos. Disponível em: <http://www.isar.com.br>. Acesso em: 26/03/2006.

JONES, B. H. (2001). Performance of Gypsum Plasterboard Assemblies Exposed to Real Building Fires. A research report for the degree of Master of Engineering in Fire Engineering Department of Civil Engineering University of Canterbury. Christchurch.

KIRCHHOF, L. D. (2004). Uma contribuição ao estudo de vigas mistas aço-concreto simplesmente apoiadas em temperatura ambiente e em situação de incêndio. 141p. Dissertação de Mestrado - Universidade de São Paulo, Escola de Engenharia de São Carlos. São Carlos.

LAPLANCHE, K.; DHIMA, D.; RACHER, P. (2004). Predicting the behaviour of dowelled connections in fire: fire tests results and heat transfer modeling. In: Proceedings of the 8th World Conference on Timber Engineering, WCTE 2004,Finland, p. 335-340. Lathi.

LEWIS, K.R. (2000). Fire Design of Steel Members. Fire Engineering Research Report, Univesity of Canterbury. Christchurch. 
LIENHARD IV, J. H.; LIENHARD V, J. H. (2005). A heat transfer Textbook, Phlogiston Press. Massachusetts.

MALITE, M. (1990). Sobre o cálculo de vigas mistas aço-concreto: ênfase em edifícios. São Carlos. 144p. Dissertação (Mestrado) - Universidade de São Paulo. Escola de Engenharia de São Carlos. São Paulo.

MENDES, C. L. (2004). Estudo sobre perfis formados a frio em situação de incêndio. Dissertação (Mestrado) - Universidade de São Paulo, Escola de Engenharia de São Carlos. São Carlos.

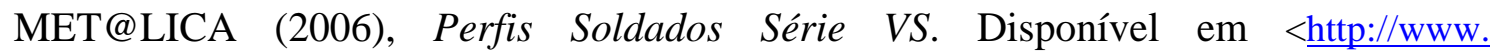
metalica.com.br/sistema/bin/pg_dinamica.php?id_pag=611>. Acesso em 04/02/2006.

NATIONAL INSTITUTE OF STANDARDS AND TECHNOLOGY (2004) NIST-SP 1000-5 Progress Report on the Federal Building and Fire Safety Investigation of the World Trade Center. Disponível em: $<$ http://wtc.nist.gov/progress_report_june04/ progress_report june04.htm>. Acesso em 02/04/2006.

PINTO, E. M. (2005). Determinação de um modelo de taxa de carbonização transversal a grã para o Eucalyptus citriodora e E grandis. São Carlos, SP. Tese de Doutorado - Universidade de São Paulo, Escola de Engenharia de São Carlos. São Carlos.

POON, L.; ENGLAND, J.P. (2003) Literature Review on the Contribution of Fire Resistant Timber Construction to Heat Release Rate. Warrington Fire Ressearch. Victoria.

REDDY, J.W. (1993) An Introduction to the finite element method. 2nd ed. McGrawHill. New York.

RIBEIRO, J.C.L. (2004). Simulação via método dos elementos finitos da distribuição tridimensional de temperatura em estruturas em situação de incêndio. 177p. Dissertação de Mestrado - Escola de Engenharia de UFMG. Belo Horizonte.

SECRETARIA DE ESTADO DOS NEGÓCIOS DA SEGURANÇA PÚBLICA DE SÃO PAULO. INSTRUÇÃO TÉCNICA N ${ }^{\mathrm{O}}$ 08/04 (2004). Segurança Estrutural nas Edificações -Resistência ao Fogo dos Elementos de Construção. São Paulo.

REFRASOL (2006). Estruturas metálicas - Produtos: Argamassas Projetadas Leves. Disponível em: < http://www.refrasol.com.br>. Acesso em: 26/03/2006.

SILVA, C.J., CALMON, J. L. (2000). Análise térmica bidimensional em regime transiente pelo método dos elementos finitos. Aplicação em estruturas metálicas e mistas em condição de incêndio. Revista Engenharia Ciência Tecnologia, v.17, p. 7282. Vitória. 
SILVA, C.J., CALMON, J. L. (2001). Análise térmica bidimensional em regime transiente pelo método dos elementos finitos. Aplicação às estruturas de concreto de alto desempenho. Revista Engenharia Ciência Tecnologia. Vitória.

SILVA, C. J. (2002). Comportamento de estruturas metálicas e mistas em situação de incêndio - modelagem e aplicações. 191p. Dissertação de Mestrado - Universidade Federal do Espírito Santo. Vitória.

SILVA, V.P. (2005). Determination of the steel fire protection material thickness by an analytical process - a simple derivation. Engineering Structures 27, p. 2036-2043.

SILVA, V.P. (2006). Determination of the temperature of thermally unprotected steel members under ${ }^{-}$re situations. Considerations on the section factor. Latin American Journal of Solids and Structures 3, p. 149-161.

SILVA, V.P. (2001). Estruturas de Aço em Situação de Incêndio. Zigurate. São Paulo.

SILVA, V.P. (2000). Exigências de Resistência ao Fogo de Elementos Construtivos de Edificações. Revista Construção, N. 43, p. 27-34.

SILVA, V.P. (1999). Ação térmica nas Estruturas: Determinação da Temperatura nos Elementos Estruturais de Aço com Proteção Térmica em Situação de Incêndio. Boletim Técnico da Escola Politécnica da USP, BT/PEF/9914. São Paulo.

SILVA, V.P.; FAKURY, R.H. (2000). Normas Brasileiras de Estruturas de Aço em Situação de Incêndio. In: Jornadas Sudamericanas de Ingenieria Estructural, Anais. Punta Del Este.

STEELWEB.INFO, Universal Beams. Disponível < $\underline{\text { www.steelweb.info }}>$. Accessado em 04/02/2006.

THE STEEL CONSTRUCTION INSTITUTE (2000). P259 Technical Report: The Fire Resistance of Concrete Filled Tubes to Eurocode 4. SCI Publication. Inglaterra.

THE STEEL CONSTRUCTION INSTITUTE (2000). P288 Fire Safe Design: A new approach to multi-storey steel framed buildings. SCI Publication. Inglaterra;

TIMOSHENKO, S. P.; GERE, J. M. (1961) Theory of elastic stability. 2.ed. McGrawHill. 541p. New York.

USMANI, A.S., ROTTER, J.M., LAMONT, S., SANAD, A.M., GILLIE, M. (2001) Fundamental principles of structural behaviour under thermal effects. Fire Safety Journal 36 (2001) 721-744. Elsevier Science.

VARGAS, M. R.; SILVA, V. P. (2003). Resistência ao Fogo das Estruturas de Aço. Centro Brasileiro da Construção em Aço - CBCA. Rio de Janeiro.

VILA REAL, P. (2003). Incêndio em Estruturas Metálicas - Cálculo Estrutural. Edições Orion. Mafra. 
WANG, Y. C. (1998). Composite Beams with Partial Fire Protection, Fire Safety Journal 30 (1998) 315-332, Elsevier Science.

WELSH, R. (2001). 2-D Analysis Of Composite Steel - Concrete Beams In Fire, A research report for the degree of Master of Engineering in Fire Engineering Department of Civil Engineering University of Canterbury. Christchurch.

WANG, Y. C. (2002). Steel and Composite Structures - Behaviour and Design for Fire Safety. Spon Press. London.

WICKSTROM, U. (1982). Temperature calculation of insulated steel columns exposed to natural fire. Fire Safety Journal 4 (4): 219-225 .

WICKSTROM, U. (1985). Temperature analysis of heavily-insulated steel structures exposed to fire. Fire Safety Journal 9: 281-285.

WONG, M.B. (2001). Elastic and plastic methods for numerical modelling of steel structures subject to fire. Journal of Constructional Steel Research, 57 (2001) 1-14, Elsevier Science. 


\section{ANEXO A - FATOR DE MASSIVIDADE PARA ALGUMAS SEÇÕES TRANSVERSAIS DE ELEMENTOS ESTRUTURAIS}

Tabela A.1 - Fator de massividade para alguns elementos estruturais sem proteção.

Fonte: NBR 14323:1999.

\begin{tabular}{|c|c|}
\hline $\begin{array}{l}\text { Seção aberta exposta ao incêndio por todos os } \\
\text { lados: } \\
\qquad \frac{\mathrm{u}}{\mathrm{A}}=\frac{\text { perímetro }}{\text { área da seção transversal }}\end{array}$ & $\begin{array}{l}\text { Seção tubular de forma circular exposta ao incêndio por } \\
\text { todos os lados: } \\
\qquad \frac{\mathrm{u}}{\mathrm{A}}=\frac{\mathrm{d}}{\mathrm{t}(\mathrm{d}-\mathrm{t})}\end{array}$ \\
\hline 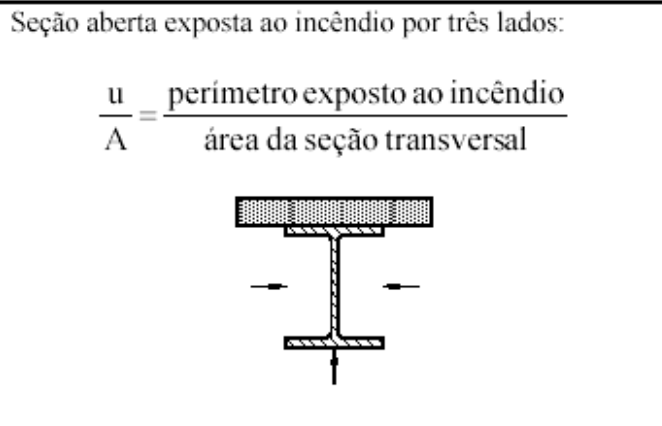 & $\begin{array}{l}\text { Seção tubular de forma retangular (ou seção caixão } \\
\text { soldada de espessura uniforme) exposta ao incêndio por } \\
\text { todos os lados: } \\
\qquad \frac{\mathrm{u}}{\mathrm{A}}=\frac{\mathrm{b}+\mathrm{d}}{\mathrm{t}(\mathrm{b}+\mathrm{d}-2 \mathrm{t})}\end{array}$ \\
\hline $\begin{array}{l}\text { Mesa de seção } \mathrm{I} \text { exposta ao incêndio por três lados: } \\
\qquad \frac{\mathrm{u}}{\mathrm{A}}=\frac{\mathrm{b}+2 \mathrm{t}_{\mathrm{f}}}{\mathrm{bt}_{\mathrm{f}}}\end{array}$ & $\begin{array}{l}\text { Seção caixão soldada exposta ao incêndio por todos os } \\
\text { lados: } \\
\qquad \frac{\mathrm{u}}{\mathrm{A}}=\frac{2(\mathrm{~b}+\mathrm{d})}{\text { área da seção transversal }}\end{array}$ \\
\hline $\begin{array}{l}\text { Cantoneira de exposta ao incêndio por todos os lados: } \\
\qquad \frac{\mathrm{u}}{\mathrm{A}}=\frac{2+\sqrt{2}}{2 \mathrm{t}}\end{array}$ & $\begin{array}{l}\text { Seção I com reforço em caixão exposta ao incêndio por } \\
\text { todos os lados: } \\
\qquad \frac{\mathrm{u}}{\mathrm{A}}=\frac{2(\mathrm{~b}+\mathrm{d})}{\text { área da seção transversal }}\end{array}$ \\
\hline $\begin{array}{l}\text { Chapa exposta ao incêndio por todos os lados: } \\
\qquad \frac{\mathrm{u}}{\mathrm{A}}=\frac{2(\mathrm{~b}+\mathrm{t})}{\mathrm{bt}}\end{array}$ & $\begin{array}{l}\text { Chapa exposta ao incêndio por três lados: } \\
\qquad \frac{\mathrm{u}}{\mathrm{A}}=\frac{\mathrm{b}+2 \mathrm{t}}{\mathrm{bt}}\end{array}$ \\
\hline
\end{tabular}


Tabela A.2 - Fator de massividade para alguns elementos estruturais com proteção.

Fonte: NBR 14323:1999.

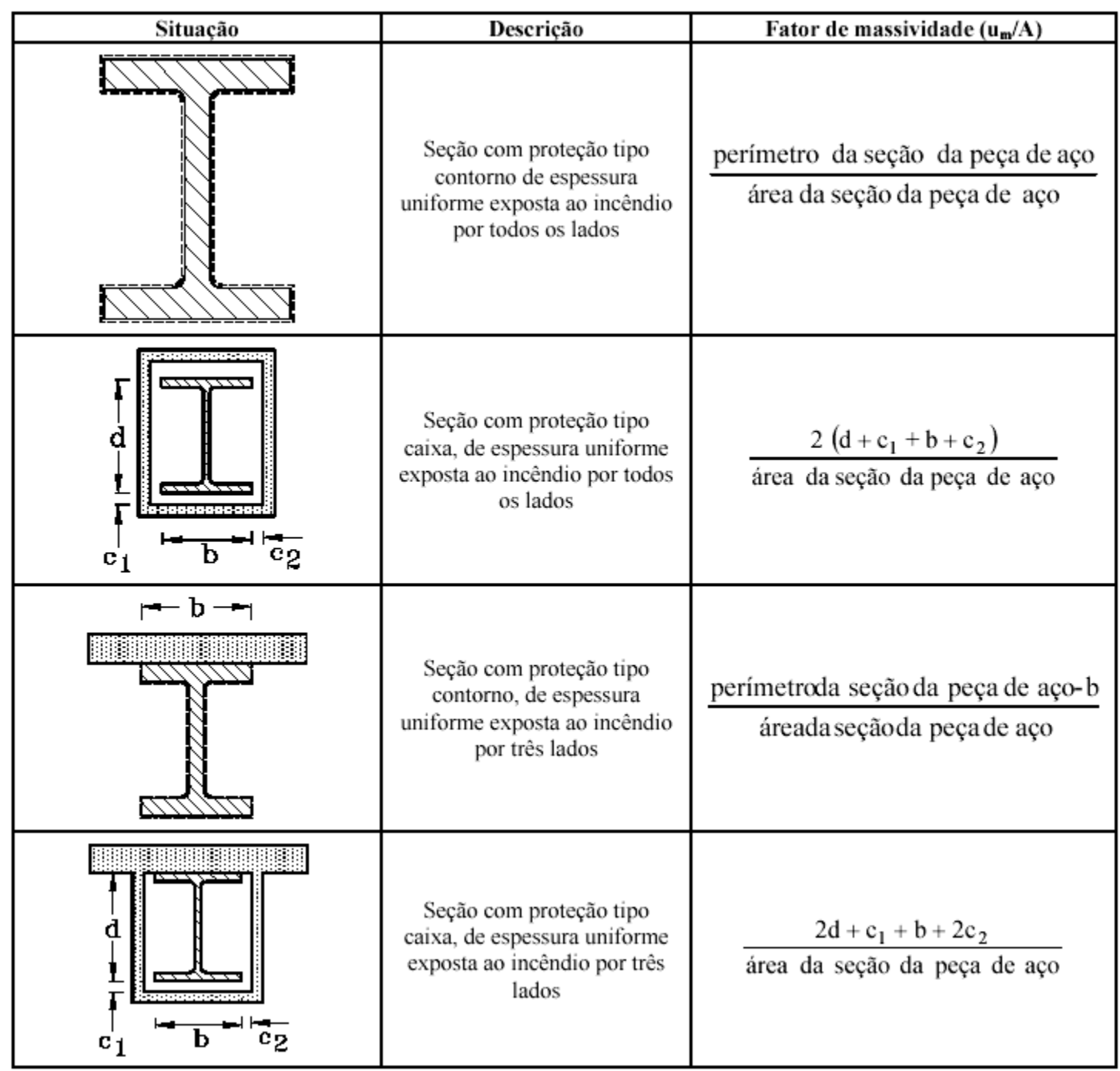




\section{ANEXO B - SOLUÇÃO NUMÉRICA DA EQUAÇÃO DIFERENCIAL DE EQUILÍBRIO DO FENÔMENO FÍSICO - FUNDAMENTAÇÃO TEÓRICA}

\section{B.1 - EQUAÇÃO DIFERENCIAL DE EQUILÍBRIO DO FENÔMENO FÍSICO}

Como afirmado no capítulo 2, a primeira lei da termodinâmica considera, por hipótese, que a energia térmica é conservativa (sem perda de calor por dissipação), e pode ser aplicada a um volume de controle qualquer, por exemplo, àquele esquematizado na figura B.1, com o objetivo de se estabelecer o balanço de energia deste volume de controle.

$\mathrm{Na}$ figura B.1, identifica-se o volume de controle R, uma superfície $\mathrm{S}$, um volume diferencial dR e uma superfície diferencial dS. À superfície dS estão associados dois vetores: o primeiro é o vetor unitário normal, $\vec{n}$ (com $|\vec{n}|=1)$, e o segundo, é o vetor de fluxo de calor, $\vec{\varphi}=-\lambda \nabla \mathrm{T}$, naquele ponto da superfície.

Neste volume de controle estão contidos um sólido dR sujeito a um campo de temperaturas, no caso, $\mathrm{T}=\mathrm{T}(\mathrm{x}, \mathrm{y}, \mathrm{z}, \mathrm{t})$, e um fluido com um campo de velocidades $\overrightarrow{\mathrm{v}}(\mathrm{x}, \mathrm{y}, \mathrm{z})$. Admite-se uma geração de calor interno $\dot{\mathrm{q}}\left(\mathrm{W} / \mathrm{m}^{3}\right)$ distribuída em toda região, o qual pode surgir em resposta a reações químicas, nucleares ou similares.

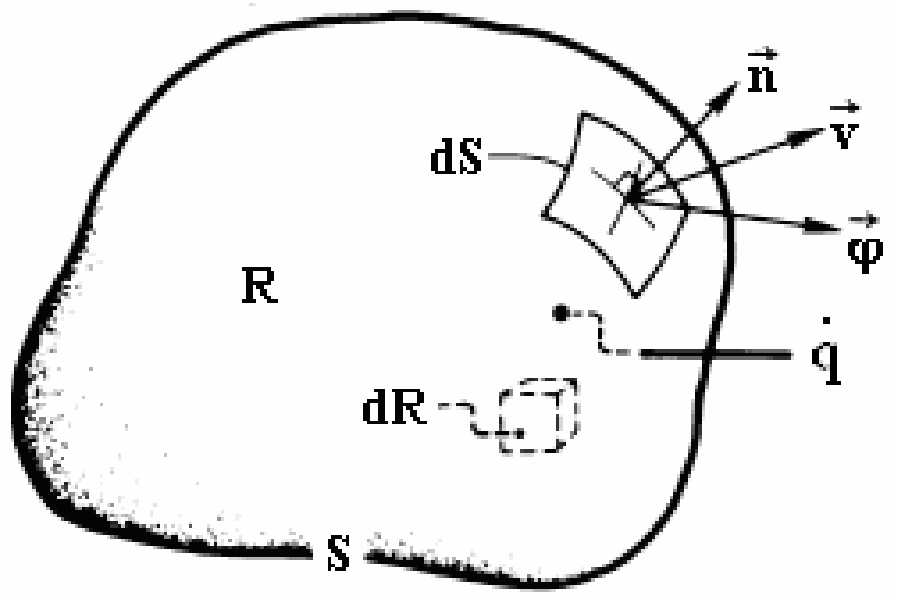

Figura B.1 - Volume de controle num campo de fluxo de calor e fluido. Extraído de LIENHARD IV e LIENHARD V (2005). 
Segundo LIENHARD IV e LIENHARD V (2005), antes de se efetuar o balanço de energia do volume de controle da figura B.1, devem ser consideradas as seguintes hipóteses para descrever o fenômeno de interesse:

- Variações da pressão p no fluxo não são grandes o bastante para afetar propriedades termodinâmicas. Esta aproximação é razoável para a maioria dos escoamentos de líquidos e gases com velocidade menor que $1 / 3$ da velocidade do som.

- Nessas condições, mudanças na massa específica resultam somente de mudanças de temperatura, e que também são pequenas; portanto, o fluido se comportará como incompressível.

- Variações de temperatura no escoamento não são grandes o bastante para mudar $k$ (condutividade) significativamente. Quando for considerado o campo de escoamento, também será considerado que a viscosidade cinemática $\mu$ não é afetada pela mudança de temperatura.

- Alterações nas energias potencial ou cinética são desprezíveis em comparação com as mudanças na energia térmica.

- As tensões viscosas não dissipam energia o bastante para aquecer o fluido significantemente.

Além das hipóteses adotadas, faz-se ainda necessário definir energia interna específica e entalpia específica de uma substância. Para isso, também devem ser levadas em conta as formas microscópicas de energia de uma substância.

As formas macroscópicas de energia de uma substância são as energias potencial e cinética. Com relação às formas microscópicas de energia de uma substância podemos incluir a rotação das moléculas, vibração, translação e todas as interações entre as moléculas desta substância. Estas formas microscópicas de energia são denominadas coletivamente de energia interna (U). A energia interna específica û de uma substância é sua energia interna por unidade de massa em $\mathrm{J} / \mathrm{kg}$. 
A entalpia específica é definida pela termodinâmica como $\widehat{\mathrm{h}}=\widehat{\mathrm{u}}+\mathrm{p} / \rho$, onde $\mathrm{p}$ é a pressão no fluido em $\mathrm{N} / \mathrm{m}^{2}$ e $\rho$ é massa específica em $\mathrm{kg} / \mathrm{m}^{3}$. A entalpia específica pode ser interpretada como a "energia total" por unidade de massa do fluido no ambiente em questão.

À pressão constante, é possível demonstrar que $d \widehat{h}=c_{p} d T+(1 / \rho) d p$, onde $c_{p}$ é o calor específico à pressão constante $(\mathrm{J} / \mathrm{kgK})$. Diante das hipóteses já estabelecidas, se forem desprezados os efeitos da pressão, pode-se assumir que $\mathrm{d} \widehat{\mathrm{h}} \cong \mathrm{c}_{\mathrm{p}} \mathrm{dT}$, o que será útil nas deduções que se seguem. Aplicando o princípio da conservação de energia ao volume de controle da figura B.1, uma vez que o processo é admitido como conservativo, resulta:

$$
\underbrace{\frac{\mathrm{d}}{\mathrm{dt}} \int_{\mathrm{R}} \rho \hat{\mathrm{u} d R}}_{\begin{array}{c}
\text { taxa de aumento da } \\
\text { enegia interna em } \mathrm{R}
\end{array}}=-\underbrace{\int_{\mathrm{s}}(\rho \widehat{\mathrm{h}}) \overrightarrow{\mathrm{v}} \cdot \overrightarrow{\mathrm{n}} \mathrm{d} S}_{\begin{array}{c}
\text { taxa de energia int erna e } \\
\text { fluxo de trabalho fora de } \mathrm{R}
\end{array}}-\underbrace{\int_{\mathrm{s}}(-\lambda \nabla \mathrm{T}) \cdot \overrightarrow{\mathrm{n}} \mathrm{dS}}_{\begin{array}{c}
\text { taxa de condução de } \\
\text { calor fora de } \mathrm{R}
\end{array}}+\underbrace{\int_{\mathrm{R}} \dot{\mathrm{q} d R}}_{\begin{array}{c}
\text { taxa de geração } \\
\text { de calor em } \mathrm{R}
\end{array}}
$$

Com relação à primeira integral do lado direito da igualdade da equação B.1, $\overrightarrow{\mathrm{V}} \cdot \overrightarrow{\mathrm{n}} \mathrm{dS}$ representa a vazão de fluido que passa por um elemento dS da superfície do volume de controle. A posição do volume R não muda com o tempo, de modo que se pode trazer a derivada de tempo dentro da primeira integral. Se for aplicado o teorema de Gauss para transformar as integrais de superfície em integrais de volume, e sendo $\nabla$. o operador divergente, a equação (B.2) pode ser reescrita como:

$$
\int_{R}\left(\frac{\partial(\rho \widehat{u})}{\partial t}+\nabla \cdot(\rho \vec{v} \widehat{h})-\nabla \cdot \lambda \nabla T-\dot{q}\right) d R=0
$$

Atentando para o fato de que a região $\mathrm{R}$ é arbitrária e admitida existente, para que a Equação (B.2) seja verdadeira qualquer que seja o limite de integração escolhido, o seu integrando precisa ser obrigatoriamente igual à zero, já que o sistema é, por hipótese, conservativo. Assim:

$$
\frac{\partial(\rho \widehat{\mathrm{u}})}{\partial \mathrm{t}}+\nabla \cdot(\rho \overrightarrow{\mathrm{v}} \widehat{\mathrm{h}})-\nabla \cdot \lambda \nabla^{2} \mathrm{~T}-\dot{\mathrm{q}}=0
$$


Para a primeira parcela da última equação, desde que desprezados o efeito da pressão, em concordância com hipóteses já estabelecidas, pode-se introduzir a seguinte aproximação:

$$
d(\rho \widehat{u})=d(\rho \widehat{h})-d p \approx d(\rho \widehat{h})=\rho d \widehat{h}+\widehat{h} d \rho
$$

Assim, manipulando e rearranjando os termos, resulta:

$$
\rho\left(\frac{\partial \widehat{\mathrm{h}}}{\partial \mathrm{t}}+\overrightarrow{\mathrm{v}} \cdot \nabla \widehat{\mathrm{h}}\right)+\widehat{\mathrm{h}} \underbrace{\left(\frac{\partial \rho}{\partial \mathrm{t}}+\nabla \cdot(\rho \overrightarrow{\mathrm{v}})\right)}_{\text {desprezível }}=\lambda \nabla^{2} \mathrm{~T}+\dot{\mathrm{q}}
$$

O termo que envolve derivadas da massa específica pode ser desprezado com base na hipótese de que as mudanças de massa específica são pequenas e o fluxo de fluido no volume de controle é aproximadamente incompressível.

Como mencionado anteriormente, se forem desprezados os efeitos da pressão, pode-se assumir que $\mathrm{d} \widehat{\mathrm{h}} \cong \mathrm{c}_{\mathrm{p}} \mathrm{dT}$, obtendo-se a equação de equilíbrio de energia térmica, para um volume de controle como aquele esquematizado na figura B.1, dado por meio da equação (B.3). A título de informação, a entalpia convectiva é o transporte de energia por convecção, ocasionado pela passagem de fluído no volume de controle. Também é assumido a notação c igual à $\mathrm{c}_{\mathrm{p}}$.

$$
\rho c(\underbrace{\frac{\partial \mathrm{T}}{\partial \mathrm{t}}}_{\begin{array}{c}
\text { energia } \\
\text { armazenada }
\end{array}}+\underbrace{\overrightarrow{\mathrm{v}} \cdot \nabla \mathrm{T}}_{\begin{array}{c}
\text { entalpia } \\
\text { convectiva }
\end{array}})=\underbrace{\lambda \nabla^{2} \mathrm{~T}}_{\text {condução }}+\underbrace{\dot{\mathrm{q}}}_{\begin{array}{c}
\text { geração } \\
\text { de calor }
\end{array}}
$$

Expandindo a equação B.3 em sua forma mais familiar têm-se a equação (B.4).

$$
\rho c\left(\frac{\partial \mathrm{T}}{\partial \mathrm{t}}+\mathrm{v}_{\mathrm{x}} \frac{\partial \mathrm{T}}{\partial \mathrm{t}}+\mathrm{v}_{\mathrm{y}} \frac{\partial \mathrm{T}}{\partial \mathrm{t}}+\mathrm{v}_{\mathrm{z}} \frac{\partial \mathrm{T}}{\partial \mathrm{t}}\right)=\frac{\partial}{\partial \mathrm{x}}\left(\lambda_{\mathrm{x}} \frac{\partial \mathrm{T}}{\partial \mathrm{x}}\right)+\frac{\partial}{\partial \mathrm{y}}\left(\lambda_{\mathrm{y}} \frac{\partial \mathrm{T}}{\partial \mathrm{y}}\right)+\frac{\partial}{\partial \mathrm{z}}\left(\lambda_{\mathrm{z}} \frac{\partial \mathrm{T}}{\partial \mathrm{z}}\right)+\dot{\mathrm{q}}
$$

Em ANSYS INC (2004), na parte intitulada Theory Reference, esta equação é apresentada em notação matricial. Para o emprego desta notação, faz-se as definições a seguir: 
$\{L\}=\left\{\begin{array}{lll}\frac{\partial}{\partial x} & \frac{\partial}{\partial y} & \frac{\partial}{\partial z}\end{array}\right\}^{\mathrm{T}} \rightarrow$ operador gradiente $\{\mathrm{v}\}=\left\{\begin{array}{lll}\mathrm{v}_{\mathrm{x}} & \mathrm{v}_{\mathrm{y}} \quad \mathrm{v}_{\mathrm{z}}\end{array}\right\}^{\mathrm{T}} \rightarrow$ vetor de velocidades dum fluido no volume de controle $\{\mathrm{q}\}=$ vetor fluxo de calor

$\dot{\mathrm{q}}=$ taxa de geração de calor por unidade de volume

Deve ficar claro que os termos $\{\mathrm{L}\} \mathrm{T}$ e $\{\mathrm{L}\}^{\mathrm{T}}\{\mathrm{q}\}$ também podem ser interpretados com $\nabla \mathrm{T}$ e $\nabla \cdot\{\mathrm{q}\}$, respectivamente, onde $\nabla$ representa o operador gradiente e $\nabla$. representa o operador divergente.

A lei de Fourier, usada para relacionar o vetor de fluxo de calor com o gradiente térmico, é definida como:

$$
\{\varphi\}=-[\mathrm{D}]\{\mathrm{L}\} \mathrm{T}
$$

A matriz [D] em (B.5) é a matriz de condutividade, dada por

$[\mathrm{D}]=\left[\begin{array}{ccc}\lambda_{\mathrm{xx}} & 0 & 0 \\ 0 & \lambda_{\mathrm{yy}} & 0 \\ 0 & 0 & \lambda_{\mathrm{zz}}\end{array}\right] \quad \begin{aligned} & \text { em que } \lambda_{\mathrm{xx}}, \lambda_{\mathrm{yy}}, \lambda_{\mathrm{zz}} \text { são as condutividade no elemento nas } \\ & \text { direções } \mathrm{x}, \mathrm{y}, \mathrm{e} z, \text { respectivamente. }\end{aligned}$

Feita as definições acima, a equação (B.3), ou (B.4), pode ser escritas na forma da equação (B.6), apresentada ANSYS INC (2004).

$$
\rho c\left(\frac{\partial \mathrm{T}}{\partial \mathrm{t}}+\{\mathrm{v}\}^{\mathrm{t}}\{\mathrm{L}\} \mathrm{T}\right)=\{\mathrm{L}\}^{\mathrm{t}}\{[\mathrm{D}]\{\mathrm{L}\} \mathrm{T}\}+\dot{\mathrm{q}}
$$

\section{B.2 - CONSIDERAÇÃO DAS CONDIÇÕES DE CONTORNO}

Seja um elemento sólido qualquer, por exemplo, aquele delimitado pelo volume de controle da figura B.1. Considere que neste sólido atuam três tipos de condição de contorno. Admita que estas condições sejam aplicáveis a todo o elemento. Assim, como condições de contorno têm-se: 
1. Temperaturas pré-determinadas atuando sobre uma superfície $S_{1}$ :

$$
\mathrm{T}=\mathrm{T}^{*}
$$

$\mathrm{T}^{*}$ é a temperaturas pré-determinada na superfície.

2. Fluxo de calor conhecido atuando sobre uma superfície $\mathrm{S}_{2}$ :

$$
\{\varphi\}^{\mathrm{t}}\{\eta\}=-\varphi^{*}
$$

Para esta condição:

$\{\eta\}$ - vetor unitário normal a superfície. Sentido positivo saindo da superfície;

$\varphi^{*}$ - fluxo de calor conhecido.

3. Condições convectivas conhecidas atuando sobre uma superfície $\mathrm{S}_{3}$ (lei de Newton do resfriamento):

$$
\{\varphi\}^{\mathrm{t}}\{\eta\}=\alpha\left(\mathrm{T}_{\mathrm{S}}-\mathrm{T}_{\mathrm{B}}\right)
$$

Na equação (B.9) $\alpha$ é coeficiente de transferência de calor, $T_{B}$ é a temperatura de uma massa de fluido escoando sobre a superfície do modelo e $\mathrm{T}_{\mathrm{S}}$ é a temperatura na superfície do sólido.

Ressalte-se que o fluxo de calor é positivo entrando no contorno (isto é, na direção oposta de $\{\eta\}$ ), o que é apontado pelos sinais negativos nas equações (B.8) e (B.9) .

Combinando a equação (B.5) com as equações (B.8) e (B.9) temos as equações (B.10) e (B.11).

$$
\begin{gathered}
\{\eta\}^{\mathrm{t}}[\mathrm{D}]\{\mathrm{L}\} \mathrm{T}=\varphi^{*} \\
\{\eta\}^{\mathrm{t}}[\mathrm{D}]\{\mathrm{L}\} \mathrm{T}=\alpha\left(\mathrm{T}_{\mathrm{B}}-\mathrm{T}\right)
\end{gathered}
$$


De acordo com o exposto em ANSYS (2004), pré-multiplicando-se a equação (B.6) por uma temperatura virtual, admissível compatível, integrando sobre o volume do elemento, e combinando com as equações (B.10) e (B.11), após algumas manipulações algébricas têm-se a equação (B.12).

$$
\begin{aligned}
& \int_{\text {vol }}\left(\rho \operatorname{coT}\left(\frac{\partial \mathrm{T}}{\partial \mathrm{t}}+\{\mathrm{v}\}^{\mathrm{t}}\{\mathrm{L}\} \mathrm{T}\right)+\{\mathrm{L}\}^{\mathrm{t}} \delta \mathrm{T}([\mathrm{D}]\{\mathrm{L}\} \mathrm{T})\right) \mathrm{d}(\mathrm{vol})= \\
& \int_{\mathrm{S} 2} \delta \mathrm{T} \varphi^{*} \mathrm{~d}\left(\mathrm{~S}_{2}\right)+\int_{\mathrm{S} 3} \delta \mathrm{T} \alpha\left(\mathrm{T}_{\mathrm{B}}-\mathrm{T}\right) \mathrm{d}\left(\mathrm{S}_{3}\right)+\int_{\text {vol }} \delta \mathrm{T} \dot{\mathrm{q}} \mathrm{d}(\mathrm{vol})
\end{aligned}
$$

$\mathrm{Na}$ equação (B.12) vol é volume do sólido ou elemento considerado e $\delta \mathrm{T}$ uma temperatura virtual admissível e compatível $(=\delta \mathrm{T}(\mathrm{x}, \mathrm{y}, \mathrm{z}, \mathrm{t}))$.

\section{B.3 - DEFINIÇÃO DO PROBLEMA NA FORMA MATRICIAL}

Como mencionado anteriormente, a variável $\mathrm{T}$ varia no espaço e no tempo. Esta dependência pode ser explicitada pela equação (B.13).

$$
\mathrm{T}=\{\mathrm{N}\}^{\mathrm{t}}\left\{\mathrm{T}_{\mathrm{e}}\right\}
$$

Em (B.13) têm-se:

$\mathrm{T}=\mathrm{T}(\mathrm{x}, \mathrm{y}, \mathrm{z}, \mathrm{t})=$ temperatura

$\{\mathrm{N}\}=\{\mathrm{N}(\mathrm{x}, \mathrm{y}, \mathrm{z})\}=$ funções de forma (funções de interpolação ou aproximadoras) do elemento

$\left\{\mathrm{T}_{\mathrm{e}}\right\}=\left\{\mathrm{T}_{\mathrm{e}}(\mathrm{t})\right\}=$ vetor de temperatura nodal do elemento

A derivada da equação (B.13) com relação ao tempo é escrita como:

$$
\dot{\mathrm{T}}=\frac{\partial \mathrm{T}}{\partial \mathrm{t}}=\{\mathrm{N}\}^{\mathrm{t}}\left\{\dot{\mathrm{T}}_{\mathrm{e}}\right\}
$$

$\delta \mathrm{T}$ é compatível com T. Assim temos:

$$
\delta \mathrm{T}=\left\{\delta \mathrm{T}_{\mathrm{e}}\right\}^{\mathrm{t}}\{\mathrm{N}\}
$$


A combinação $\{L\} T$ é escrita como:

$$
\{\mathrm{L}\} \mathrm{T}=[\mathrm{B}]\left\{\mathrm{T}_{\mathrm{e}}\right\}
$$

Vale lembrar que $[\mathrm{B}]=\{\mathrm{L}\}\{\mathrm{N}\} \mathrm{T}$

Agora, a forma variacional da equação (B.12) pode ser reescrita com a combinação das equações (B.14) a (B.16), resultando, de acordo com ASYS (2004), na equação B(17).

$$
\begin{aligned}
& \int_{\mathrm{vol}} \rho \mathrm{c}\left\{\delta \mathrm{T}_{\mathrm{e}}\right\}^{\mathrm{t}}\{\mathrm{N}\}\{\mathrm{N}\}^{\mathrm{t}}\left\{\dot{\mathrm{T}}_{\mathrm{e}}\right\} \mathrm{d}(\mathrm{vol})+\int_{\mathrm{vol}} \rho \mathrm{c}\left\{\delta \mathrm{T}_{\mathrm{e}}\right\}^{\mathrm{t}}\{\mathrm{N}\}\{\mathrm{v}\}^{\mathrm{t}}[\mathrm{B}]\left\{\mathrm{T}_{\mathrm{e}}\right\} \mathrm{d}(\mathrm{vol})+ \\
& +\int_{\mathrm{vol}}\left\{\delta \mathrm{T}_{\mathrm{e}}\right\}^{\mathrm{t}}[\mathrm{B}]^{\mathrm{t}}[\mathrm{D}][\mathrm{B}]\left\{\mathrm{T}_{\mathrm{e}}\right\} \mathrm{d}(\mathrm{vol})=\int_{\mathrm{S} 2}\left\{\delta \mathrm{T}_{\mathrm{e}}\right\}^{\mathrm{t}}\{\mathrm{N}\} \varphi^{*} \mathrm{~d}\left(\mathrm{~S}_{2}\right)+ \\
& +\int_{\mathrm{S} 3}\left\{\delta \mathrm{T}_{\mathrm{e}}\right\}^{\mathrm{t}}\{\mathrm{N}\} \alpha\left(\mathrm{T}_{\mathrm{B}}-\{\mathrm{N}\}^{\mathrm{t}}\left\{\mathrm{T}_{\mathrm{e}}\right\}\right) \mathrm{d}\left(\mathrm{S}_{3}\right)+\int_{\mathrm{vol}}\left\{\delta \mathrm{T}_{\mathrm{e}}\right\}^{\mathrm{t}} \dot{\mathrm{q}}\{\mathrm{N}\} \mathrm{d}(\mathrm{vol})
\end{aligned}
$$

Aplicando a equação (B.17) a um elemento finito, a variável $\rho$ é assumida como constante em todo o volume do elemento. Por outro lado, c e $\dot{\mathrm{q}}$ podem variar no elemento. Finalmente, $\left\{\mathrm{T}_{\mathrm{e}}\right\},\left\{\dot{\mathrm{T}}_{\mathrm{e}}\right\}$, e $\left\{\delta \mathrm{T}_{\mathrm{e}}\right\}$ são grandezas nodais e não variam no elemento, de modo que também podem ser removidas da integral. Agora, já que todas as parcelas estão sendo pré-multiplicadas pelo vetor arbitrário $\left\{\delta \mathrm{T}_{\mathrm{e}}\right\}$, este termo pode ser eliminado da equação resultante. Assim, a equação (B.16) reduz-se na equação (B.18).

$$
\begin{aligned}
& \rho \int_{\text {vol }} \mathrm{c}\{\mathrm{N}\}\{\mathrm{N}\}^{\mathrm{t}} \mathrm{d}(\mathrm{vol})\left\{\dot{\mathrm{T}}_{\mathrm{e}}\right\}+\rho \int_{\mathrm{vol}} \mathrm{c}\{\mathrm{N}\}\{\mathrm{v}\}^{\mathrm{t}}[\mathrm{B}] \mathrm{d}(\mathrm{vol})\left\{\mathrm{T}_{\mathrm{e}}\right\}+ \\
& +\int_{\mathrm{vol}}^{\mathrm{B}}[\mathrm{B}]^{\mathrm{t}}[\mathrm{D}][\mathrm{B}] \mathrm{d}(\mathrm{vol})\left\{\mathrm{T}_{\mathrm{e}}\right\}=\int_{\mathrm{S} 2}\{\mathrm{~N}\} \varphi^{*} \mathrm{~d}\left(\mathrm{~S}_{2}\right)+ \\
& +\int_{\mathrm{S} 3} \mathrm{~T}_{\mathrm{B}} \alpha\{\mathrm{N}\} \mathrm{d}\left(\mathrm{S}_{3}\right)-\int_{\mathrm{S} 3} \alpha\{\mathrm{N}\}\{\mathrm{N}\}^{\mathrm{t}}\left\{\mathrm{T}_{\mathrm{e}}\right\} \mathrm{d}\left(\mathrm{S}_{3}\right)+\int_{\mathrm{vol}} \dot{\mathrm{q}}\{\mathrm{N}\} \mathrm{d}(\mathrm{vol})
\end{aligned}
$$

E finalmente, a equação (B.18) pode ser reescrita na forma matricial da dada pela equação (B.19). 


$$
\left[\mathrm{C}_{\mathrm{e}}^{\mathrm{t}}\right]\left\{\dot{\mathrm{T}}_{\mathrm{e}}\right\}+\left(\left[\mathrm{K}_{\mathrm{e}}^{\mathrm{tm}}\right]+\left[\mathrm{K}_{\mathrm{e}}^{\mathrm{tb}}\right]+\left[\mathrm{K}_{\mathrm{e}}^{\mathrm{tc}}\right]\right)\left\{\mathrm{T}_{\mathrm{e}}\right\}=\left\{\mathrm{Q}_{\mathrm{e}}\right\}+\left\{\mathrm{Q}_{\mathrm{e}}^{\mathrm{c}}\right\}+\left\{\mathrm{Q}_{\mathrm{e}}^{\mathrm{g}}\right\}
$$

Para as parcelas componentes equação (B.19) tem-se as seguintes definições:

$$
\begin{aligned}
& {\left[\mathrm{C}_{\mathrm{e}}^{\mathrm{t}}\right]=\rho \int_{\text {vol }} \mathrm{c}\{\mathrm{N}\}\{\mathrm{N}\}^{\mathrm{t}} \mathrm{d}(\mathrm{vol}) \quad \rightarrow \quad \begin{array}{l}
\text { matriz de capacidade calorífica do } \\
\text { elemento }
\end{array}} \\
& {\left[\mathrm{K}_{\mathrm{e}}^{\mathrm{tm}}\right]=\rho \int_{\text {vol }} c\{\mathrm{~N}\}\{\mathrm{v}\}^{\mathrm{t}}[\mathrm{B}] \mathrm{d}(\mathrm{vol})\left\{\mathrm{T}_{\mathrm{e}}\right\} \rightarrow \begin{array}{l}
\text { matriz de condutividade do elemento } \\
\text { devido ao fluxo de fluído no volume de } \\
\text { controle }
\end{array}}
\end{aligned}
$$$$
\left[\mathrm{K}_{\mathrm{e}}^{\mathrm{tb}}\right]=\int_{\mathrm{vol}}[\mathrm{B}]^{\mathrm{t}}[\mathrm{D}][\mathrm{B}] \mathrm{d}(\mathrm{vol}) \rightarrow \begin{aligned}
& \text { matriz de condutividade do elemento devido à } \\
& \text { difusão térmica }
\end{aligned}
$$$$
\left[\mathrm{K}_{\mathrm{e}}^{\mathrm{tc}}\right]=\int_{\mathrm{S} 3} \alpha\{\mathrm{N}\}\{\mathrm{N}\}^{\mathrm{t}} \mathrm{d}\left(\mathrm{S}_{3}\right) \rightarrow \rightarrow \begin{aligned}
& \text { matriz de condutividade do elemento devido à } \\
& \text { convecção superficial }
\end{aligned}
$$$$
\left\{\mathrm{Q}_{\mathrm{e}}\right\}=\int_{\mathrm{S} 2}\{\mathrm{~N}\} \varphi^{*} \mathrm{~d}\left(\mathrm{~S}_{2}\right) \quad \rightarrow \quad \text { vetor de fluxo de calor no elemento }
$$$$
\left\{\mathrm{Q}_{\mathrm{e}}^{\mathrm{c}}\right\}=\int_{\mathrm{S} 3} \mathrm{~T}_{\mathrm{B}} \alpha\{\mathrm{N}\} \mathrm{d}\left(\mathrm{S}_{3}\right) \quad \rightarrow \quad \begin{aligned}
& \text { vetor do fluxo de calor superficial no elemento } \\
& \text { devido à convecção }
\end{aligned}
$$$$
\left\{\mathrm{Q}_{\mathrm{e}}^{\mathrm{g}}\right\}=\int_{\text {vol }} \dot{\mathrm{q}}\{\mathrm{N}\} \mathrm{d}(\mathrm{vol}) \quad \rightarrow \quad \text { vetor da geração de calor interno }
$$

Comentários e eventuais modificações sobre as definições acima:

1. $\left[\mathrm{K}_{\mathrm{e}}^{\mathrm{tm}}\right]$ é assimétrica.

2. $\left[\mathrm{K}_{\mathrm{e}}^{\mathrm{tc}}\right]$ é calculada como descrito acima somente para o elemento SOLID90 (ver SOLID90 em ANSYS(2004) ). Todos os outros elementos disponíveis usam uma matriz diagonal, com os termos da diagonal definidos pelo vetor $\int_{\mathrm{S}_{3}} \alpha\left\{\mathrm{N}_{\mathrm{d}} \mathrm{dS}_{3}\right.$. 
3. $\left[\mathrm{C}_{\mathrm{e}}^{\mathrm{t}}\right]$ é freqüentemente diagonalizada, como descrito em Matrizes de massa concentrada (Lumped Matrices - ANSYS (2004)).

4. Se $\left[\mathrm{C}_{\mathrm{e}}^{\mathrm{t}}\right]$ existe e foi diagonalizada e a análise é transiente, $\left\{\mathrm{Q}_{\mathrm{e}}^{\mathrm{g}}\right\}$ tem seus termos ajustados de modo que são proporcionais aos termos da diagonal principal de $\left[\mathrm{C}_{\mathrm{e}}^{\mathrm{t}}\right]$. O vetor $\left\{\mathrm{Q}_{\mathrm{e}}^{\mathrm{j}}\right\}$, da taxa de geração de calor devido ao efeito Joule é tratado similarmente, se presente. Este ajuste assegura que elementos sujeitos a um aquecimento uniforme terão um aumento de temperatura também uniforme. Entretanto, este ajuste também muda as entradas não uniformes de geração de calor para um valor médio no elemento.

5. Em problemas de mudança de estado, $\left[\mathrm{C}_{\mathrm{e}}^{\mathrm{t}}\right]$ é obtido da curva de entalpia, se a entalpia é um dado de entrada. Esta opção deve ser usada para problemas que envolvem mudança de estado. 


\section{ANEXO C - Campos de temperatura complementares obtidos}

\section{para os casos de estudo de 1 a 11}

Neste anexo são apresentados resultados referentes aos campos de temperatura, complementares àqueles obtidos e apresentados no Capítulo 6, para os casos apresentados nas tabelas 6.2 e 6.3, em que foram consideradas situações de interesse para estudo neste trabalho.

Naquele capítulo foi apresentado apenas o campo de temperatura em correspondência a um TRRF de 60 min. Neste anexo apresentam-se os demais campos de temperatura, obtidos para as temperaturas de 15, 30, 90 e 120 min, considerando os quatro perfis analisados em cada caso.

\section{C.1 CASO 1 - Seção aberta exposta ao incêndio por três lados}

\section{- Perfil W 150x13}

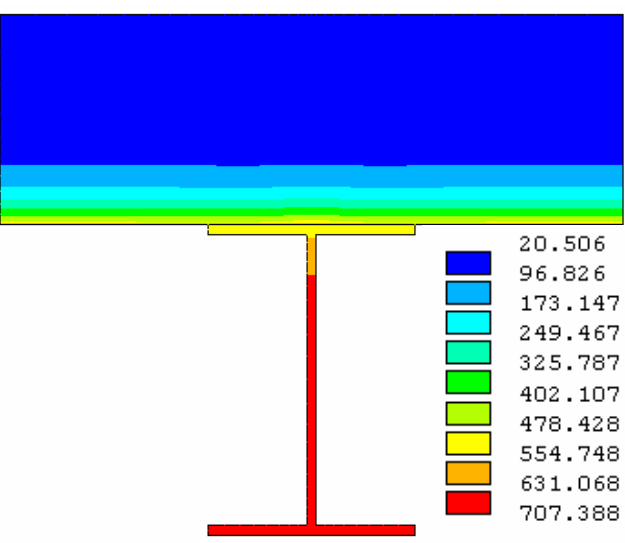

$15 \mathrm{~min}$

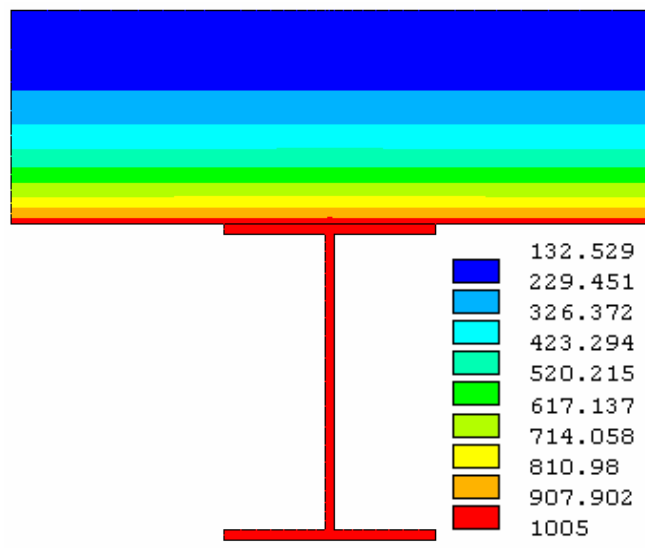

90 min

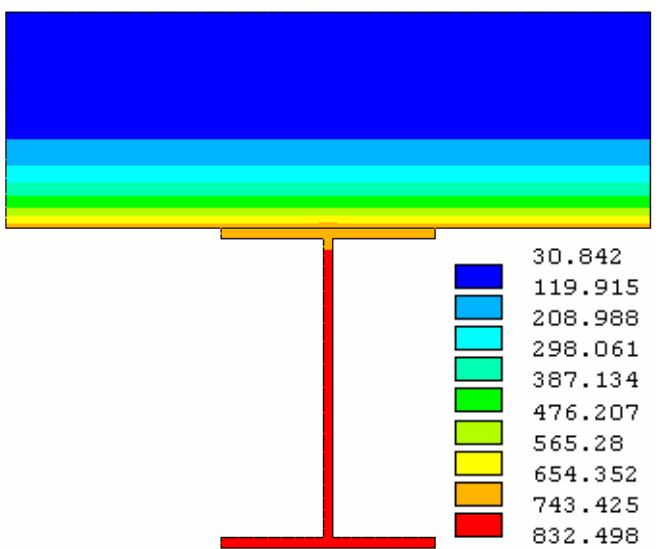

$30 \mathrm{~min}$

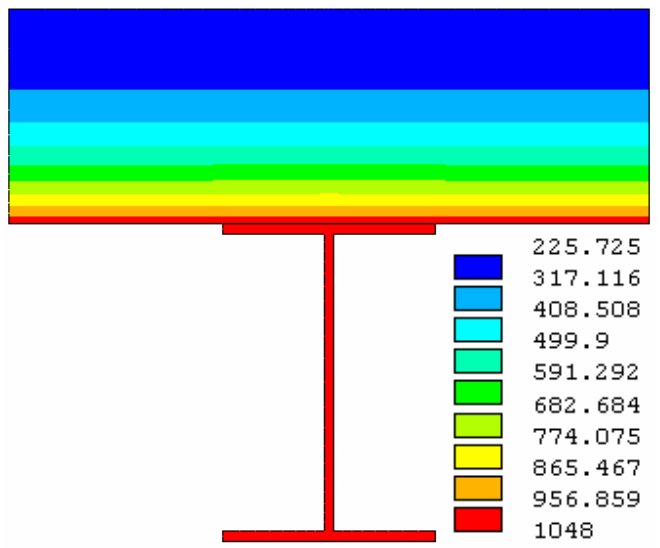

$120 \mathrm{~min}$ 
- Perfil W 250x25,3

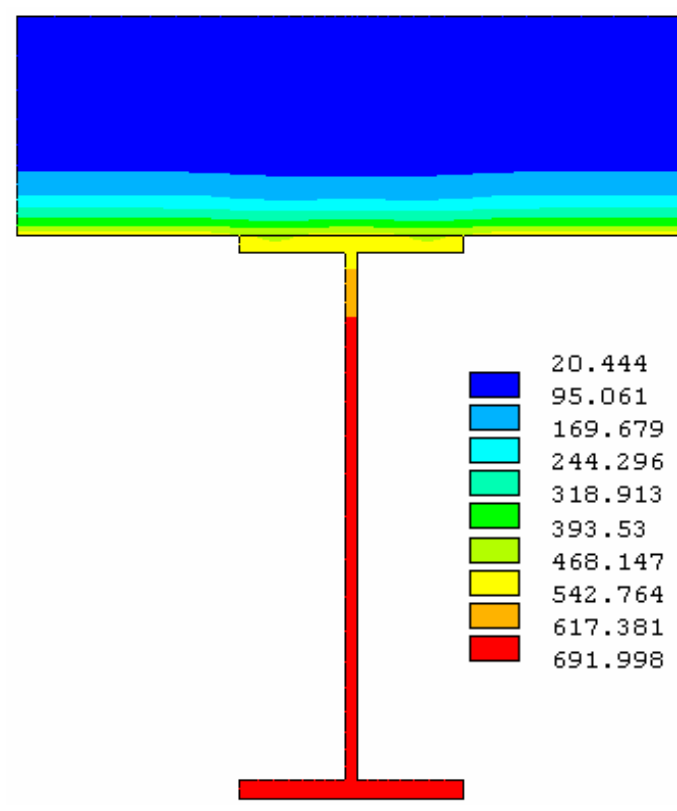

$15 \mathrm{~min}$
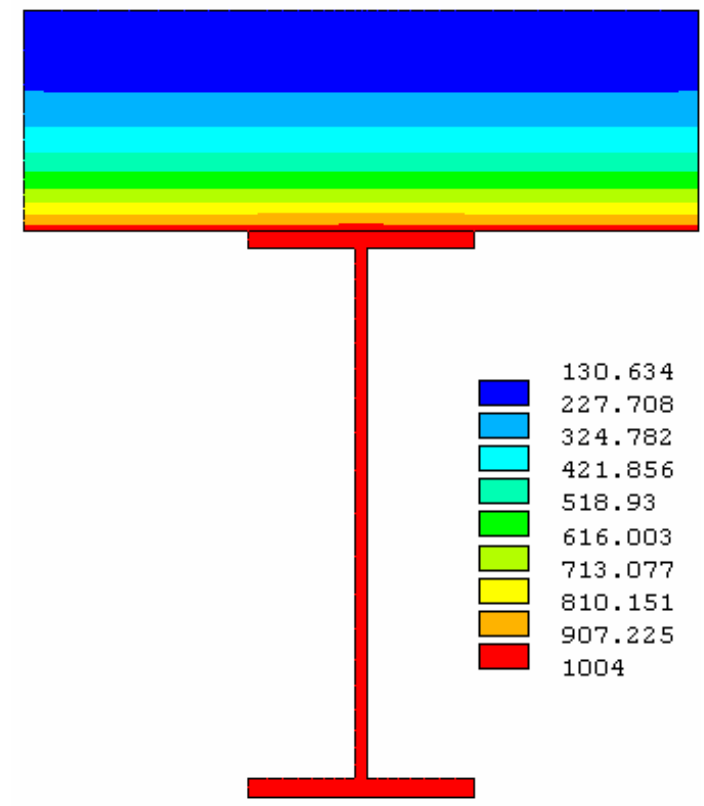

90 min

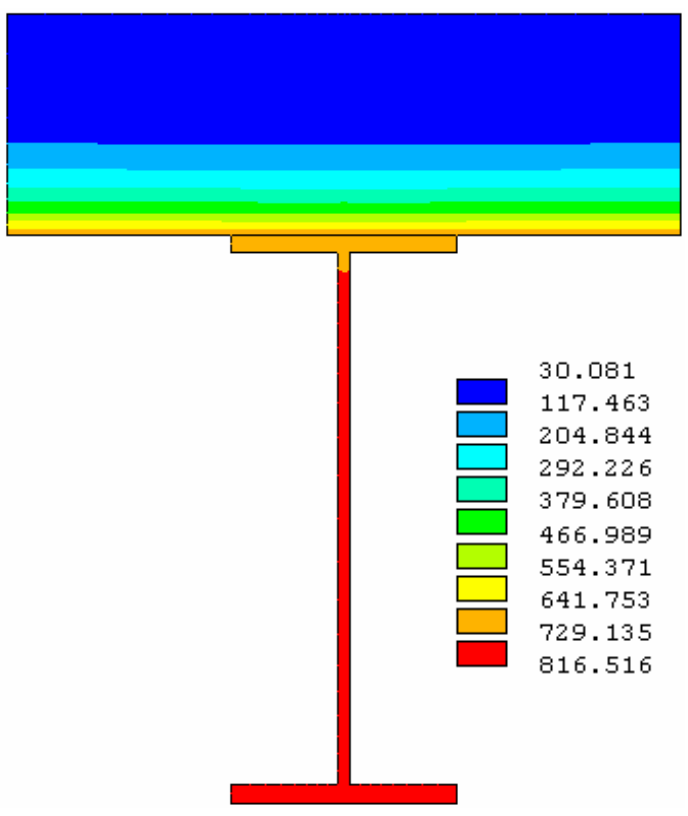

$30 \mathrm{~min}$

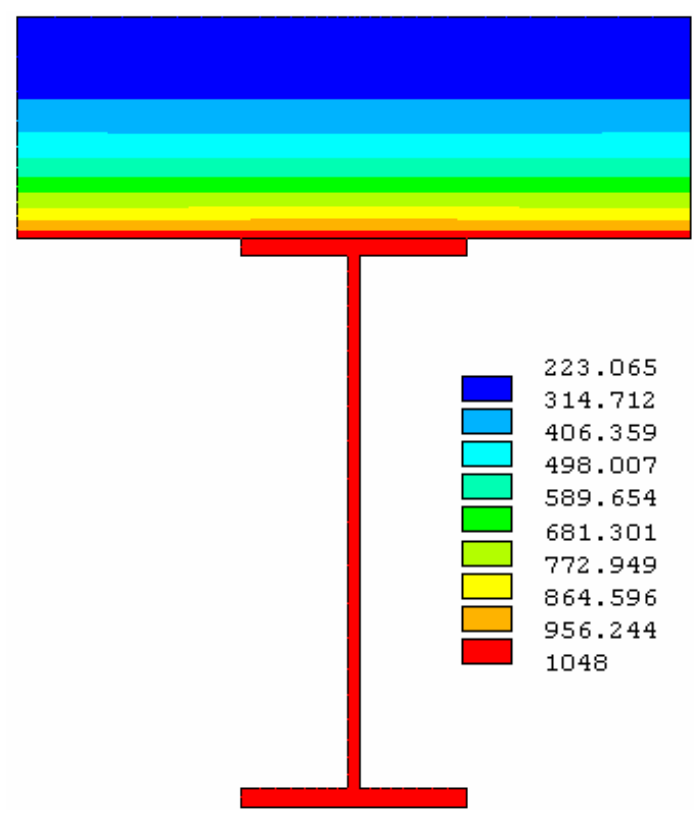

$120 \mathrm{~min}$ 
- Perfil VS 400x78

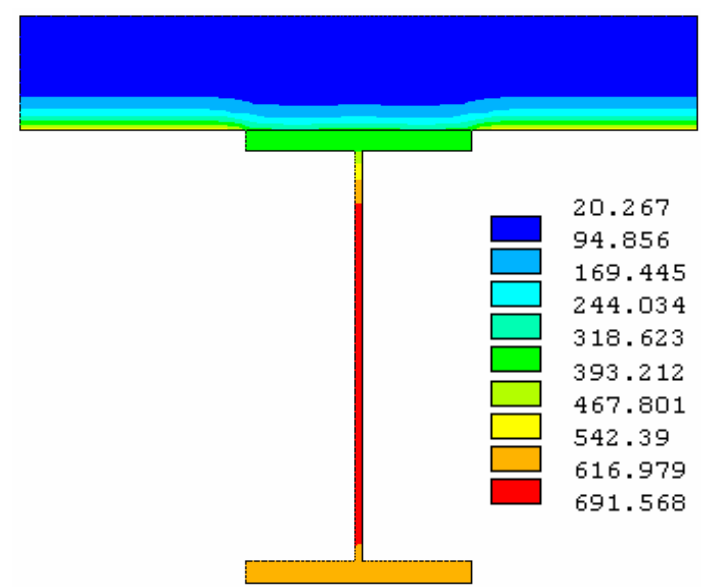

$15 \mathrm{~min}$

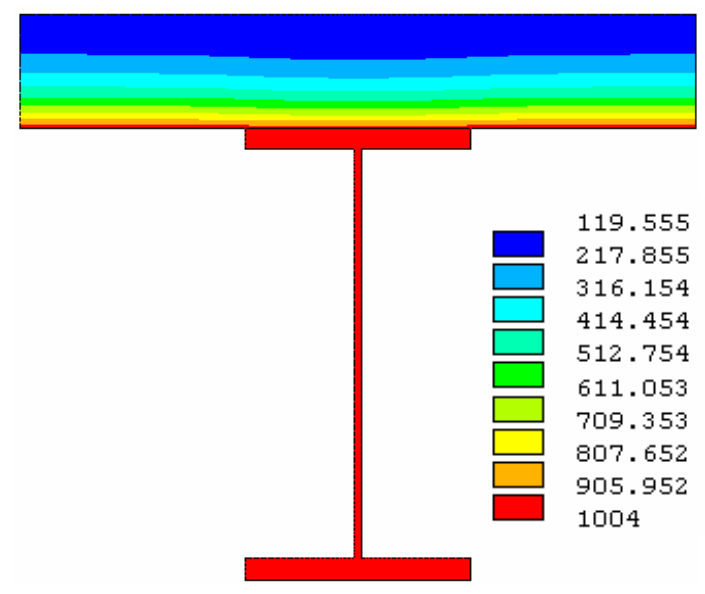

90 min

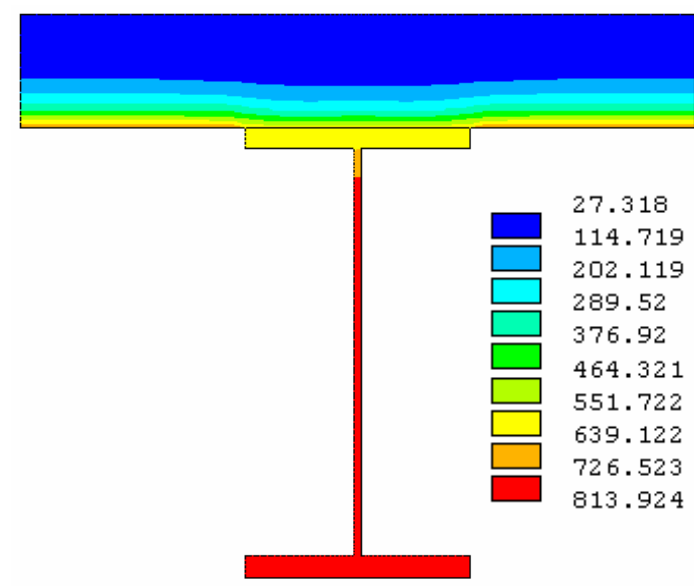

$30 \mathrm{~min}$

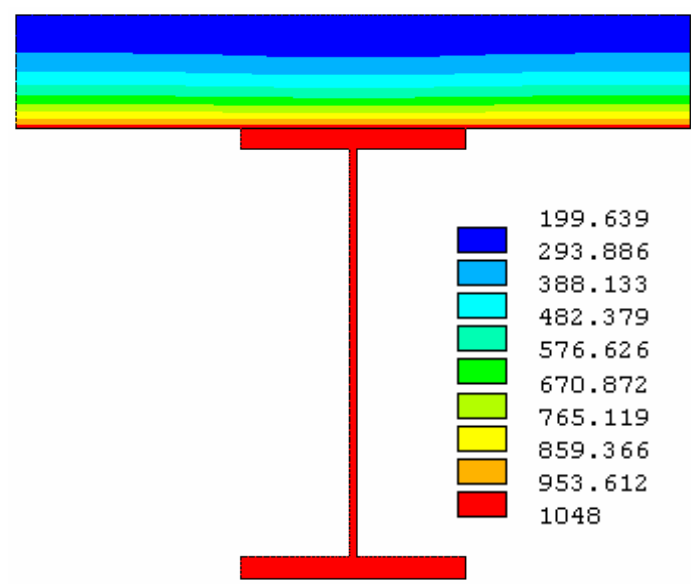

$120 \mathrm{~min}$

- Perfil CS 550x502

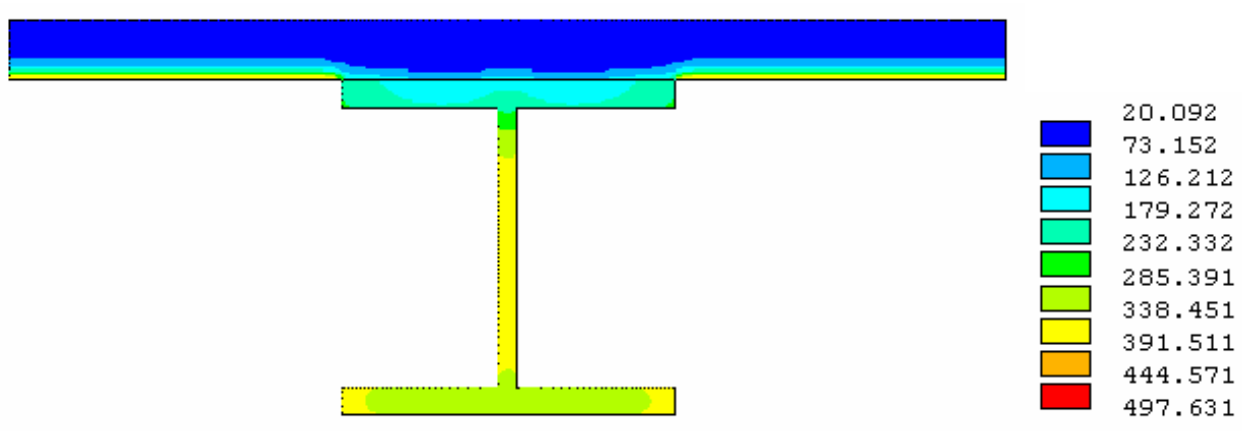

$15 \min$ 

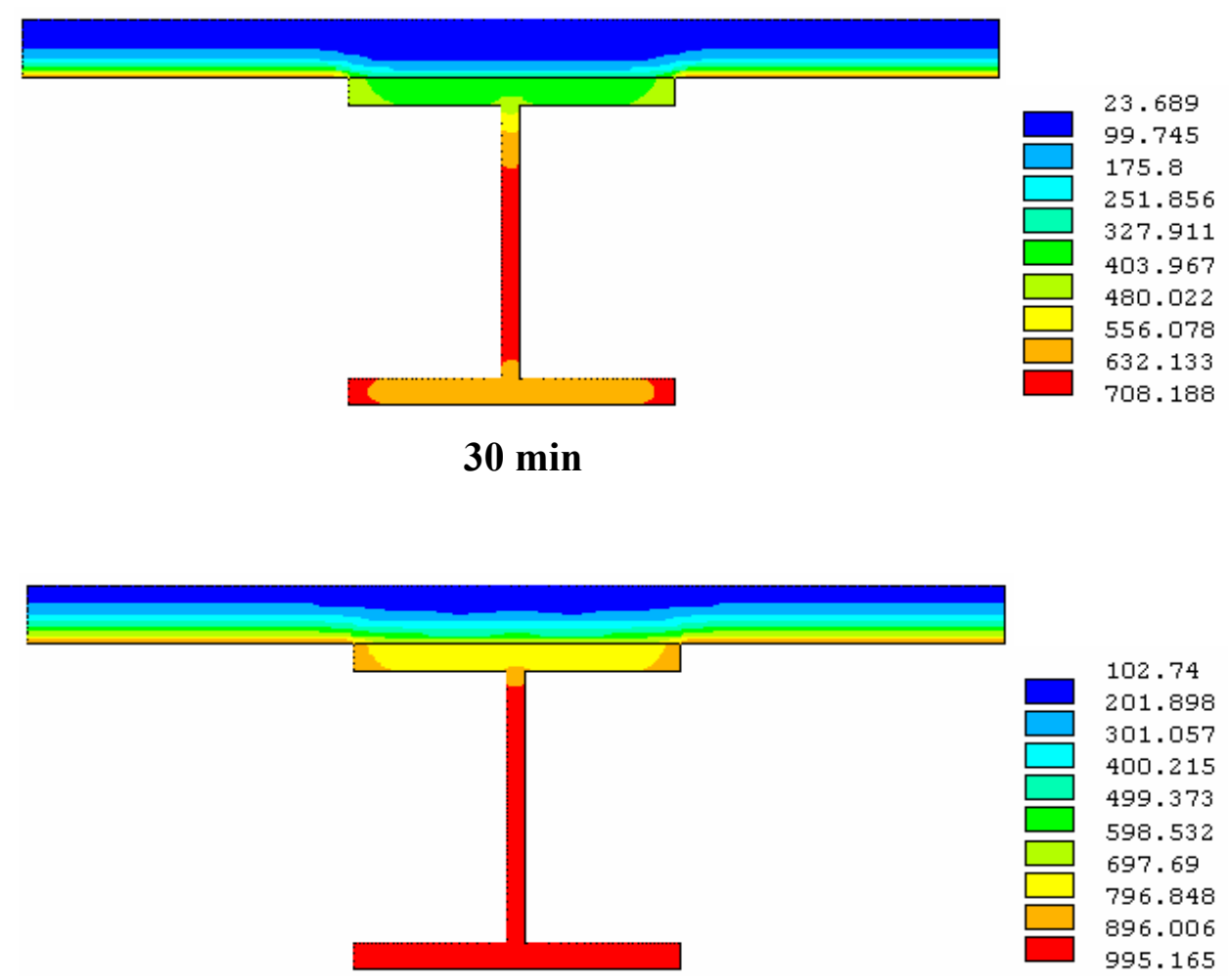

$90 \mathrm{~min}$

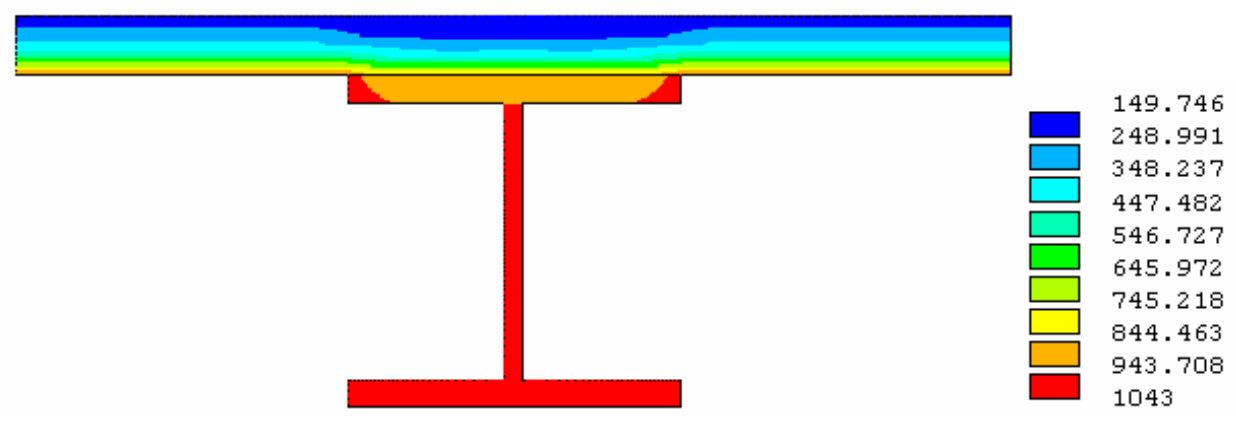

$120 \mathrm{~min}$

C.2 CASO 2 - Chapa exposta ao incêndio por três lados

- Perfil W 150x13
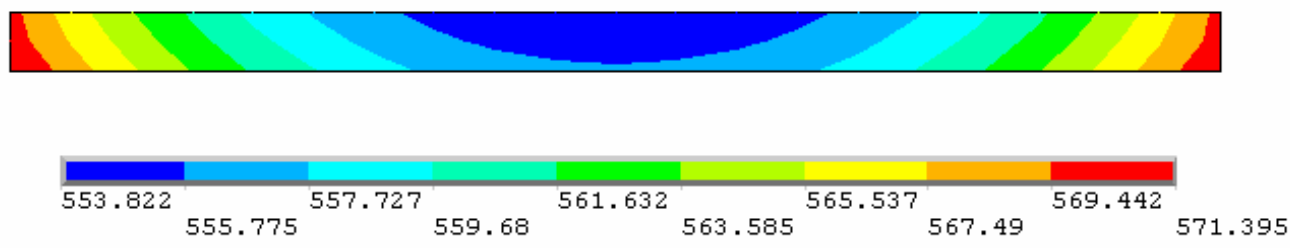

$15 \mathrm{~min}$ 

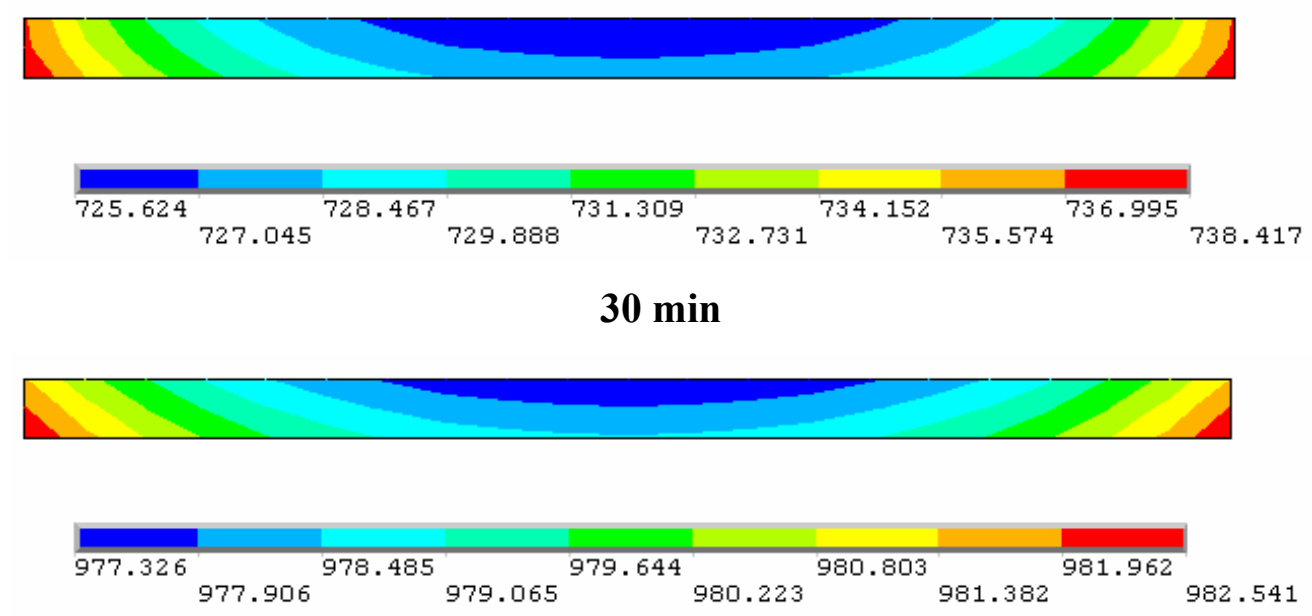

\section{0 min}

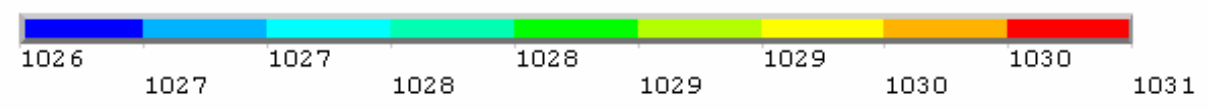

$120 \mathrm{~min}$

- Perfil W 250x25,3

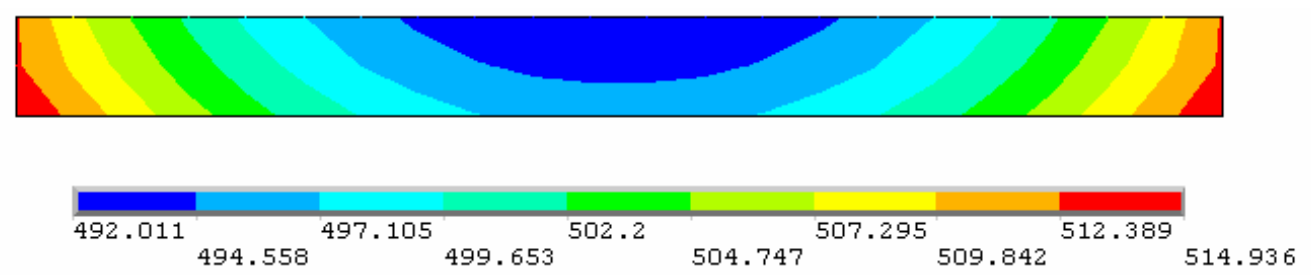

\section{5 min}
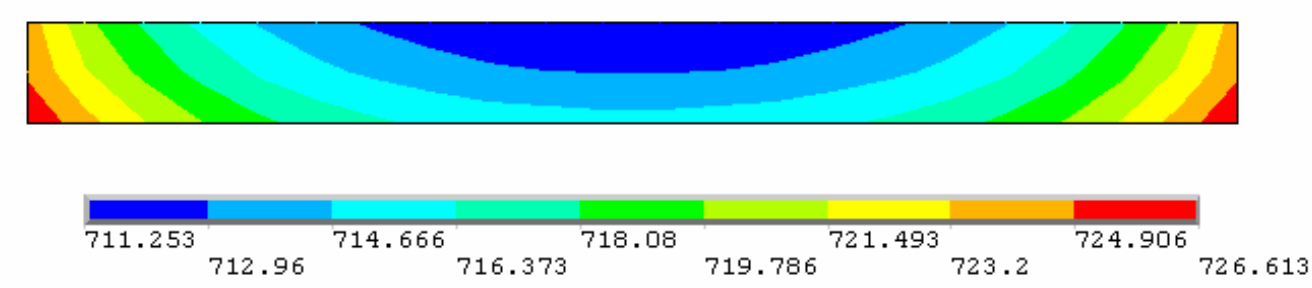

$30 \mathrm{~min}$
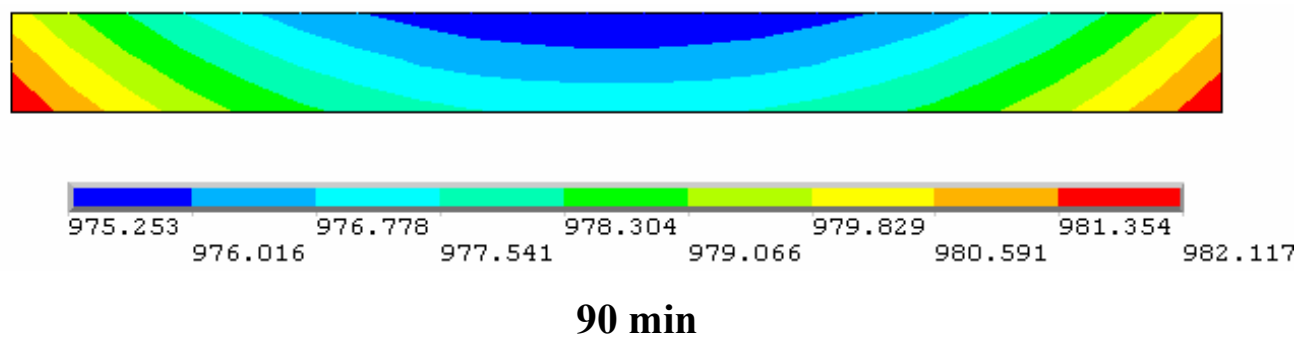

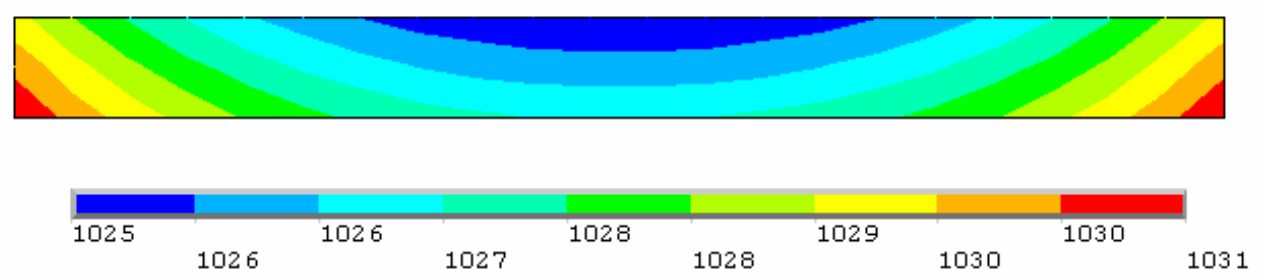

\section{$120 \mathrm{~min}$}

\section{- Perfil VS 400x78}
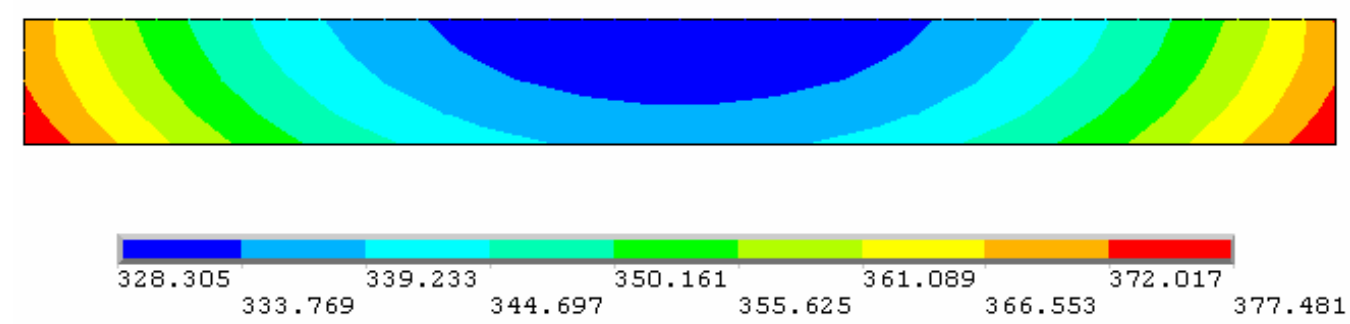

15 min
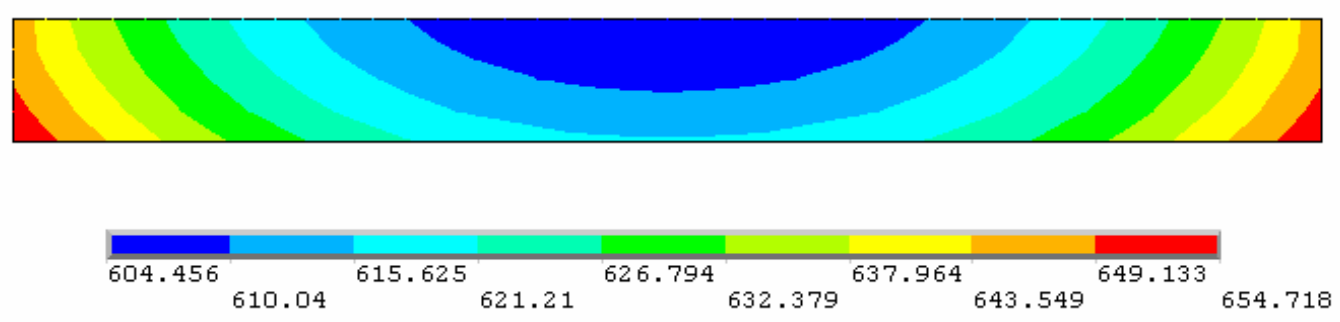

30 min
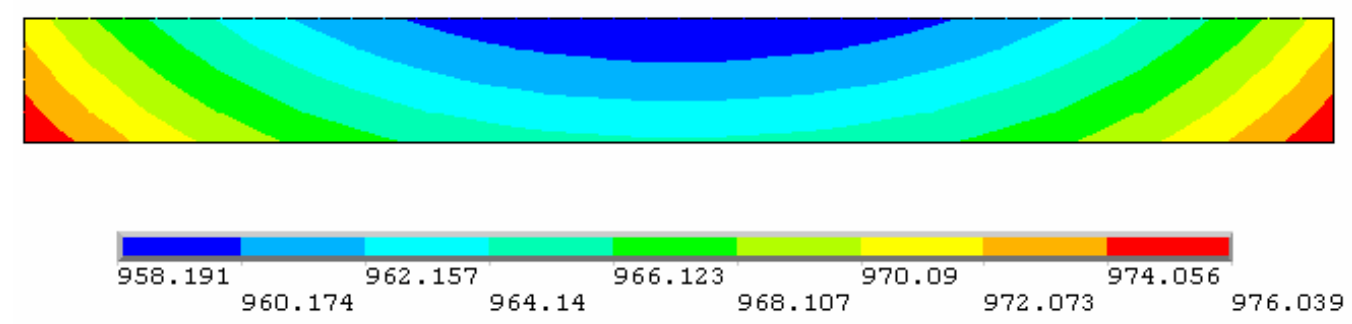

90 min
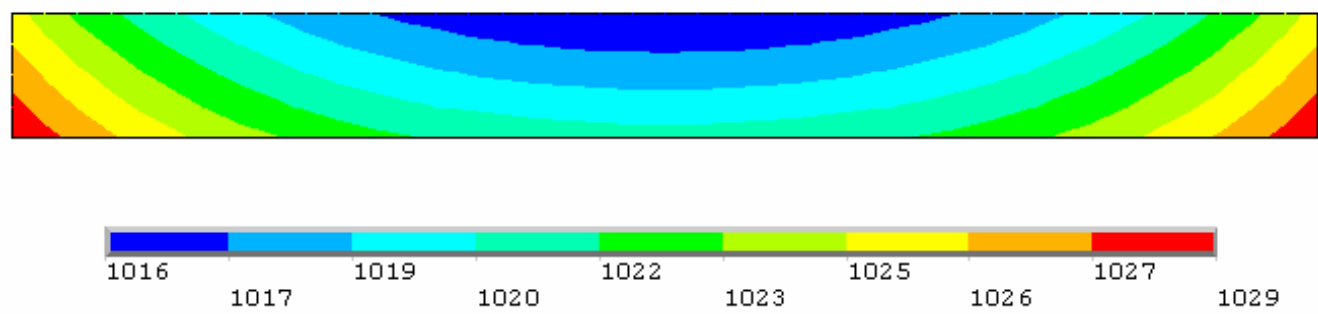

\section{$120 \mathrm{~min}$}


- Perfil CS 550x502

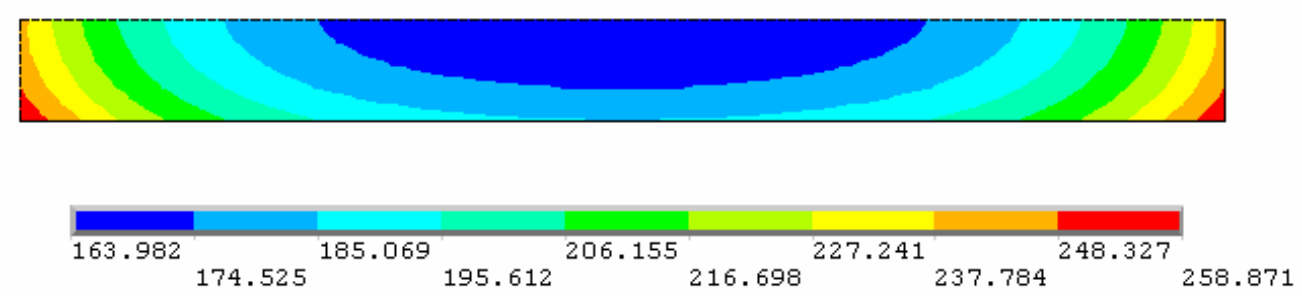

15 min

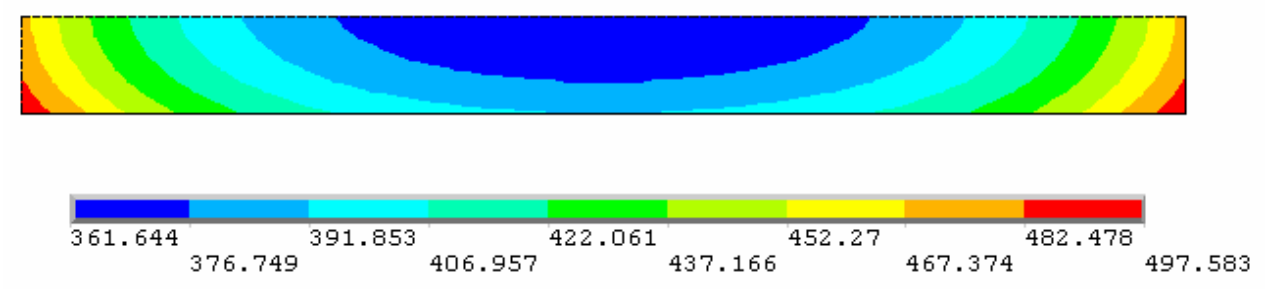

30 min
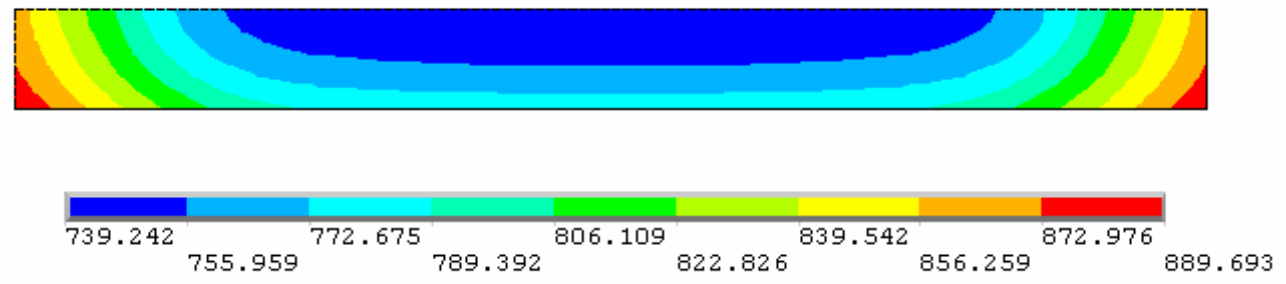

90 min
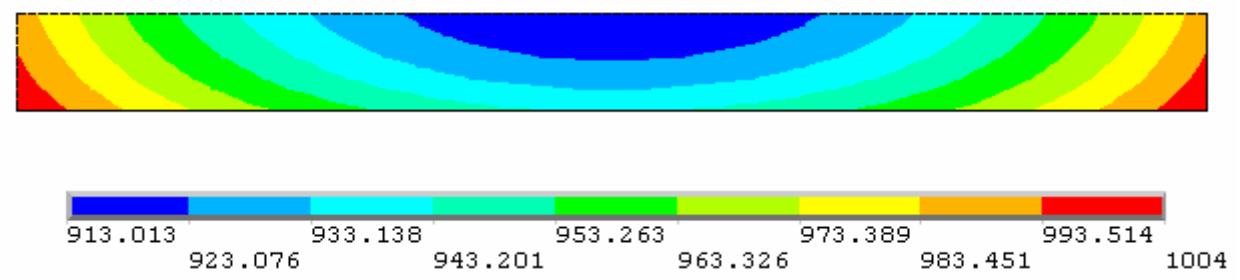

$120 \mathrm{~min}$

C.3 CASO 3 - Mesa de seção I exposta ao incêndio por três lados

- Perfil W 150x13

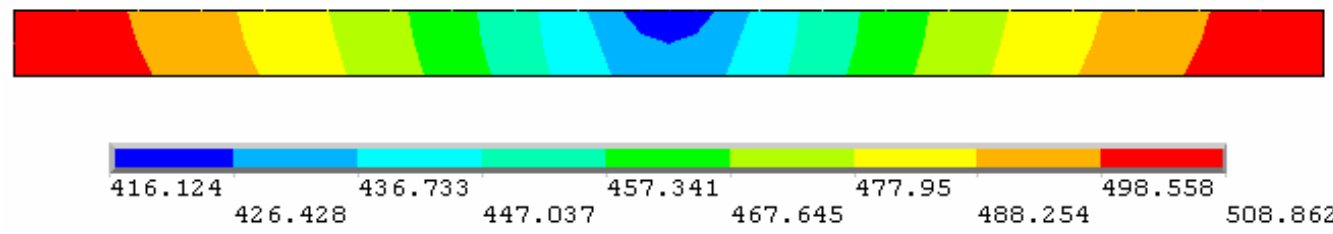

$15 \min$ 


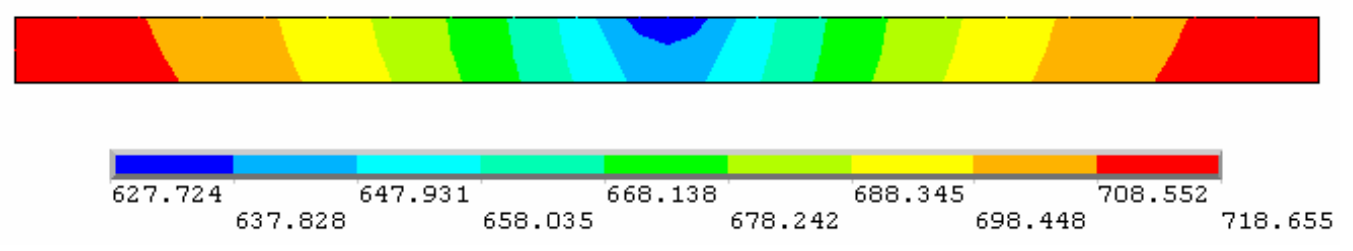

30 min

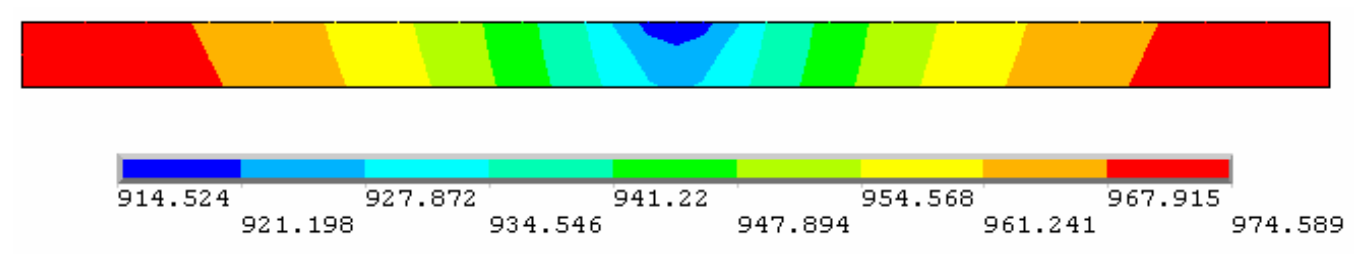

90 min

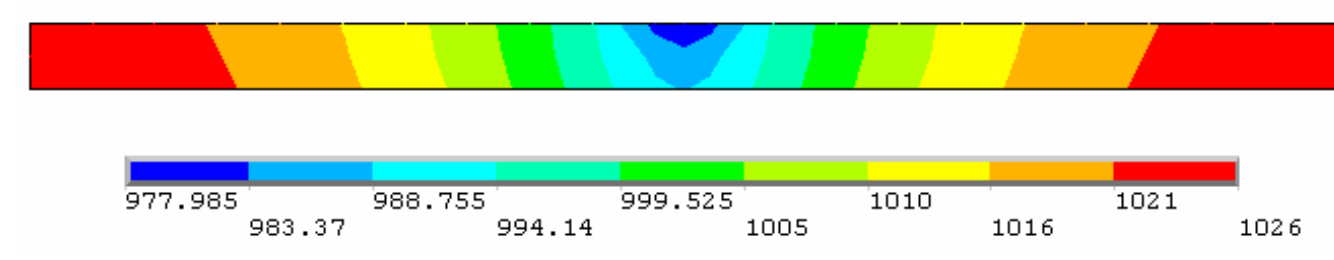

120 min

\section{- Perfil W 250x25,3}

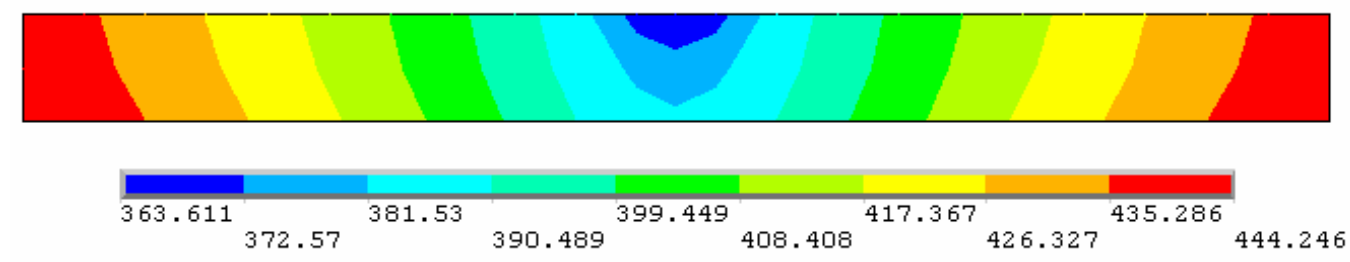

$15 \mathrm{~min}$

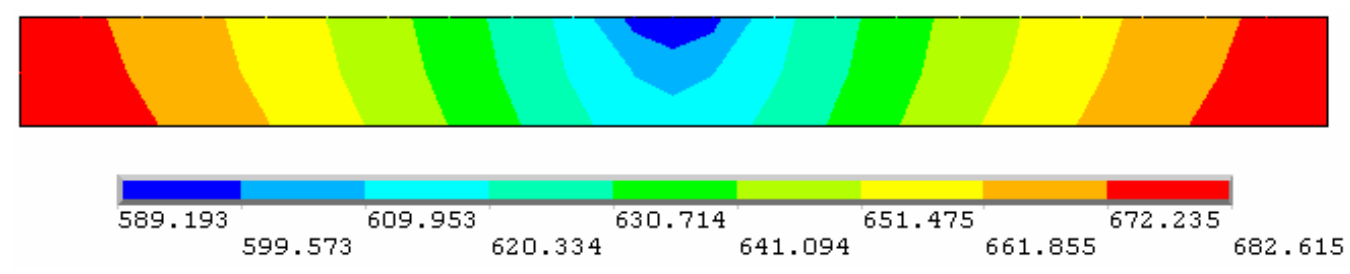

30 min

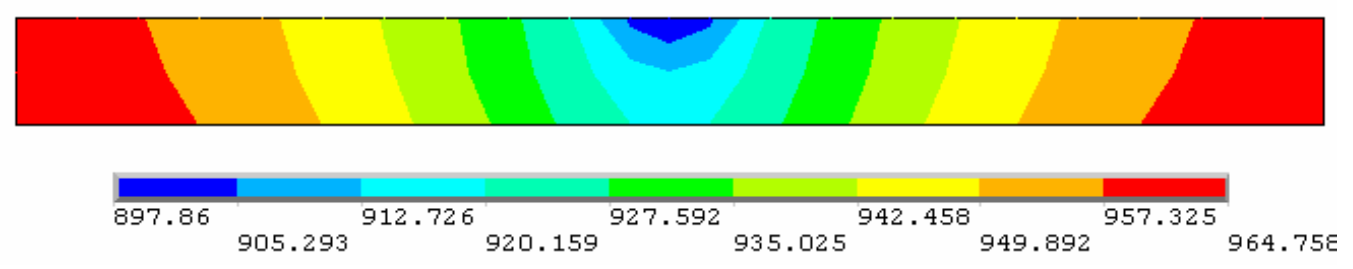

90 min 


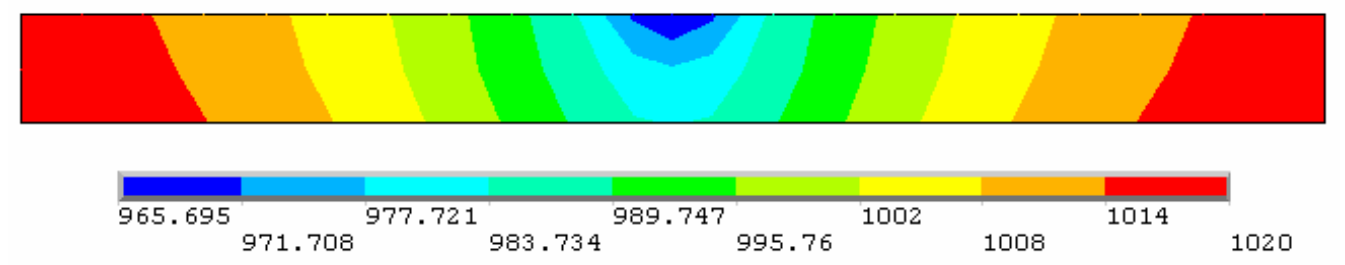

\section{$120 \mathrm{~min}$}

\section{- Perfil VS 400x78}

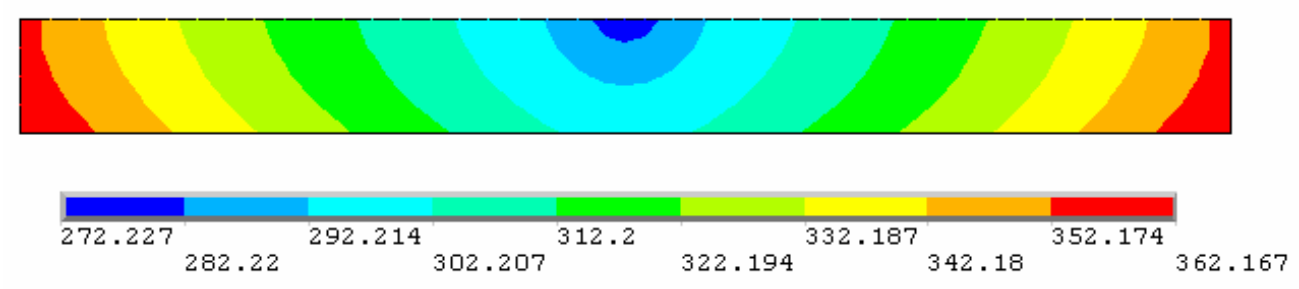

$15 \min$
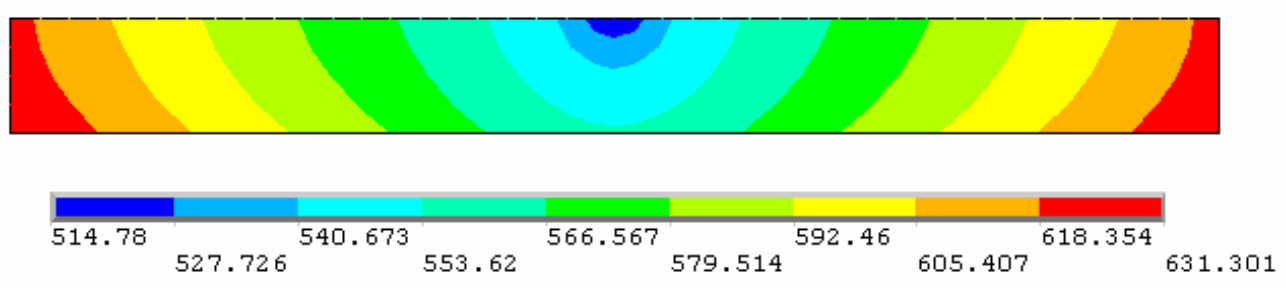

\section{$30 \mathrm{~min}$}

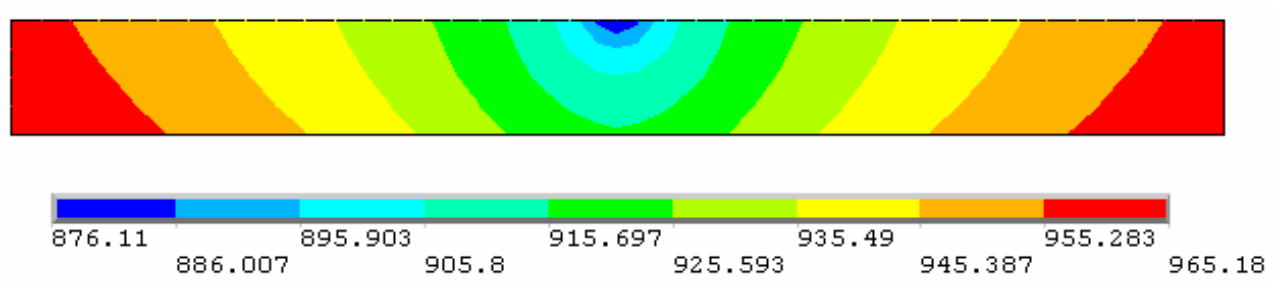

\section{0 min}

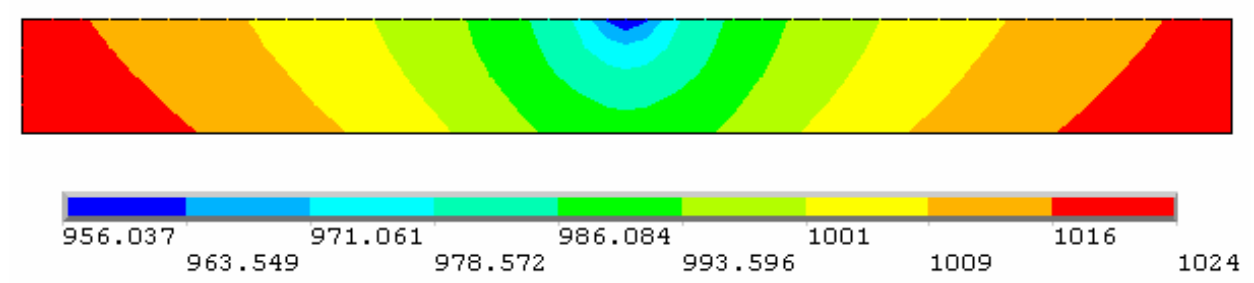

\section{$120 \mathrm{~min}$}




\section{- Perfil CS 550x502}

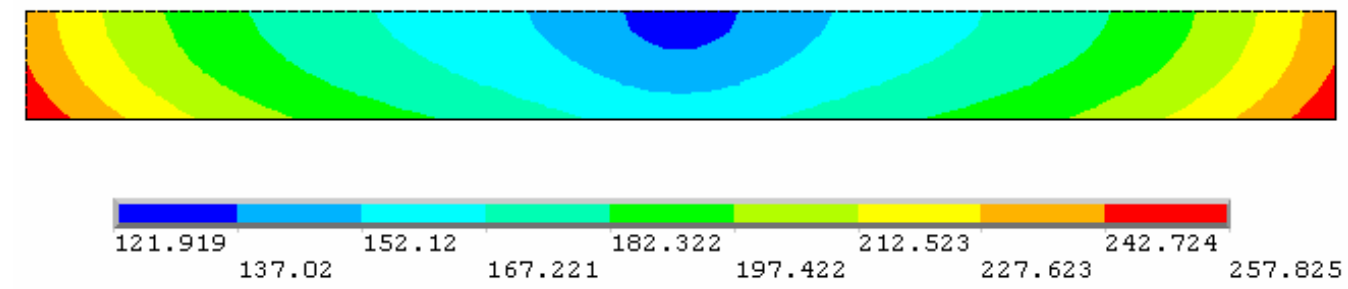

\section{5 min}
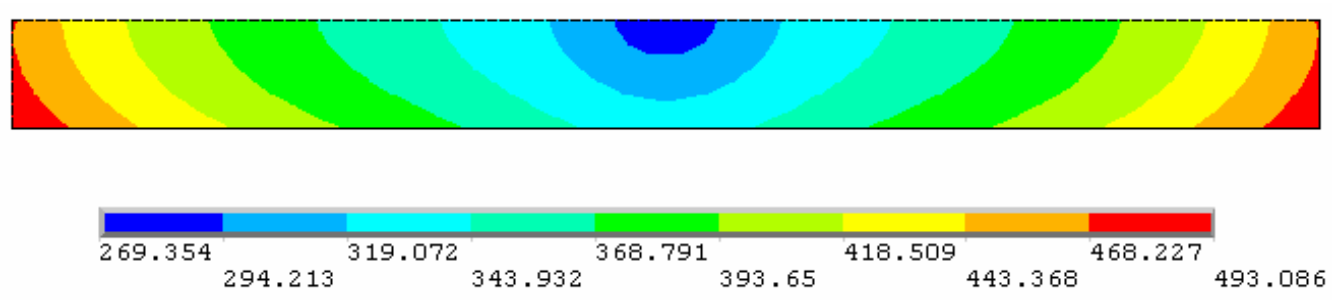

\section{0 min}

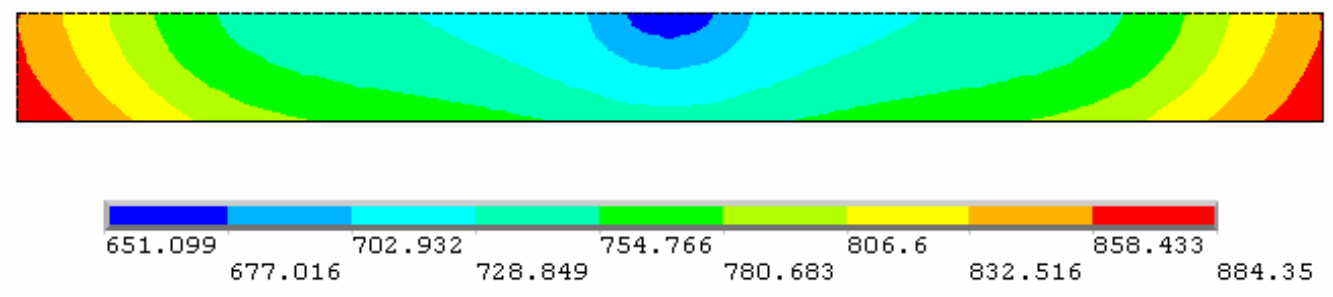

90 min
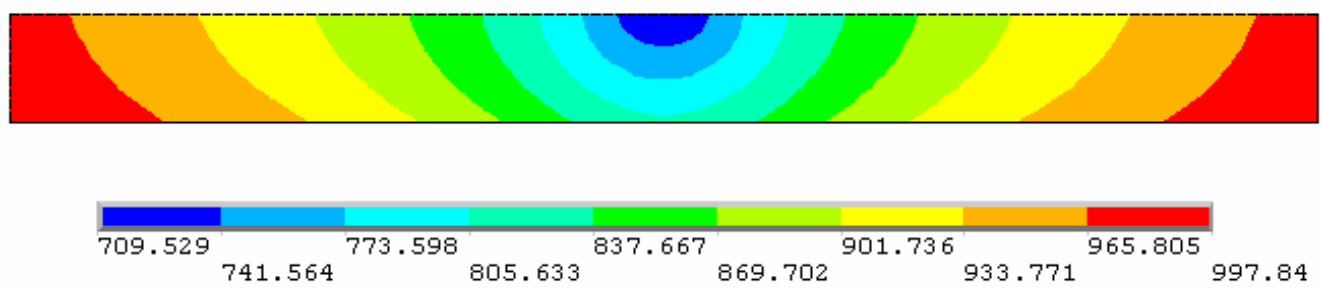

\section{$120 \mathrm{~min}$}


C.4 CASO 4 - Seção I com reforço em caixão exposta ao incêndio por todos os lados

- Perfil W 150x13

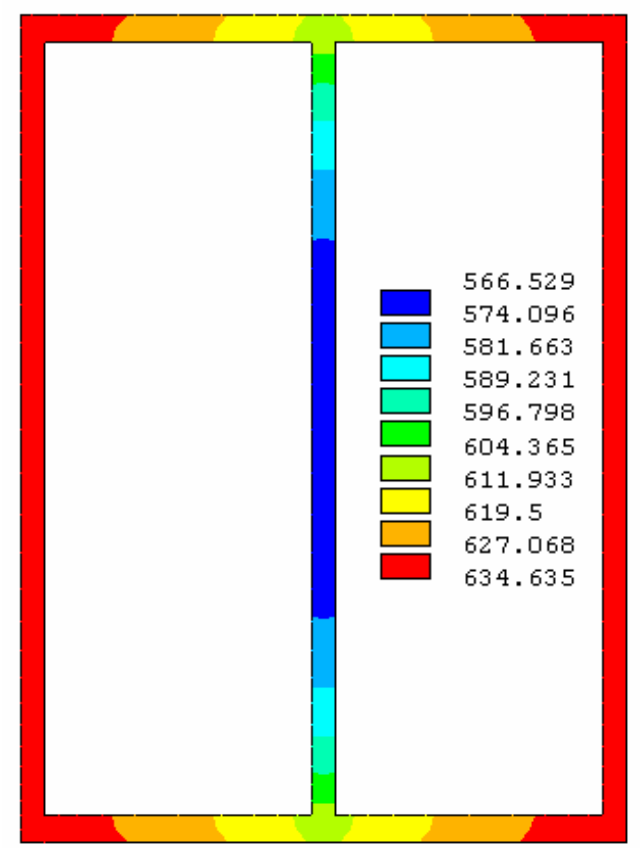

$15 \mathrm{~min}$

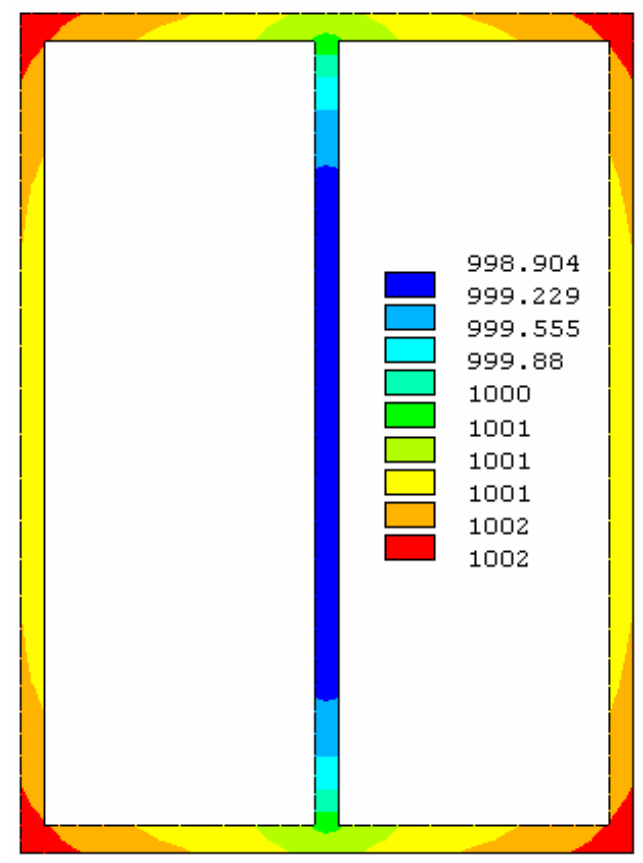

90 min

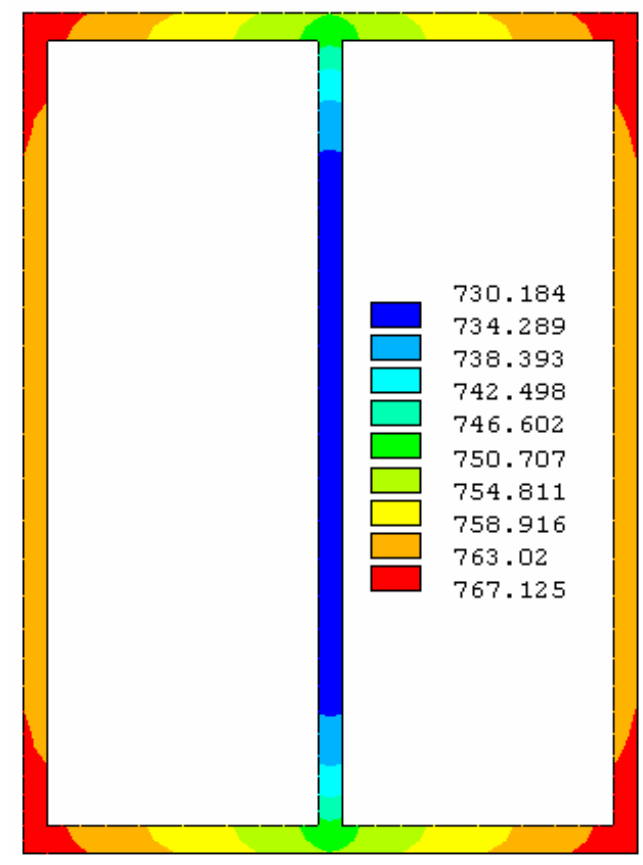

$30 \mathrm{~min}$

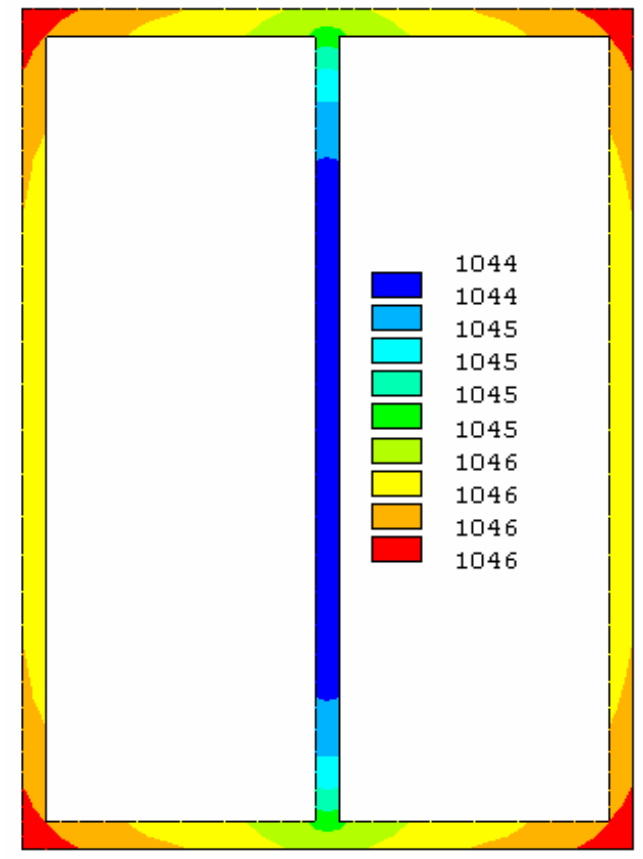

$120 \mathrm{~min}$ 


\section{- Perfil W 250x25,3}

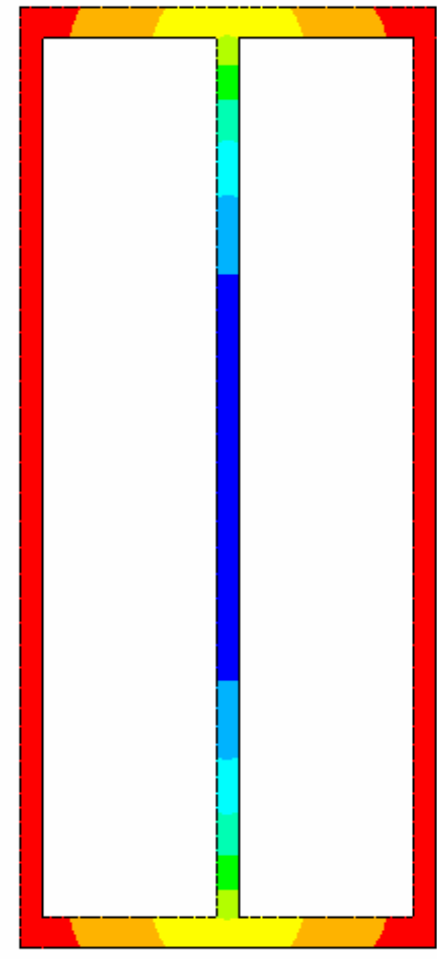

$15 \min$

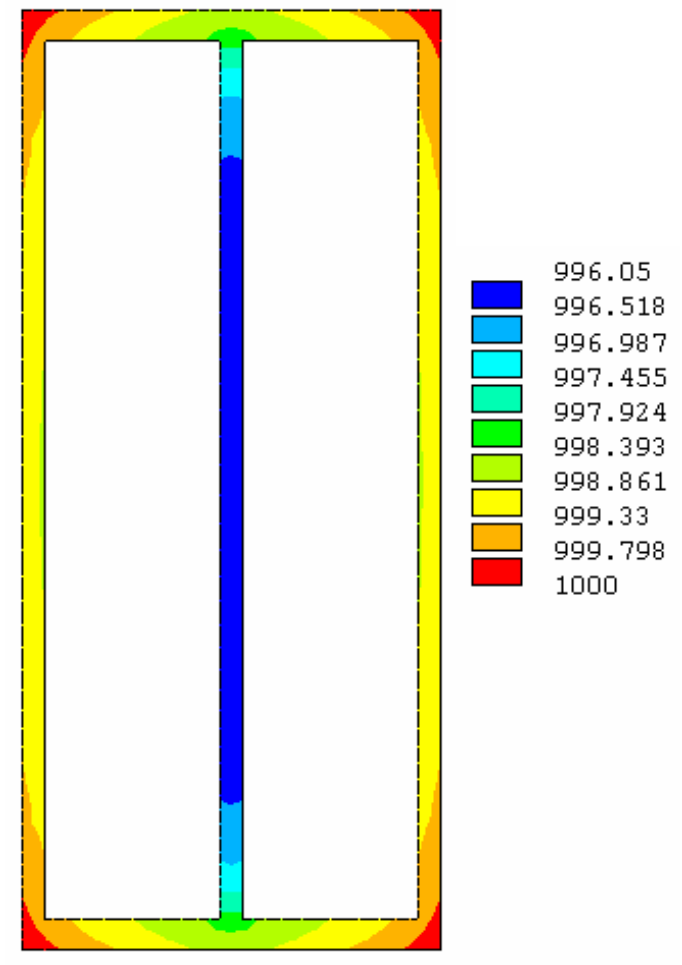

$90 \mathrm{~min}$
400.003

417.941

435.88

453.819

471.757

489.696

507.634

525.573

543.511

561.45

997.455

997.924

999.33

999.798

1000

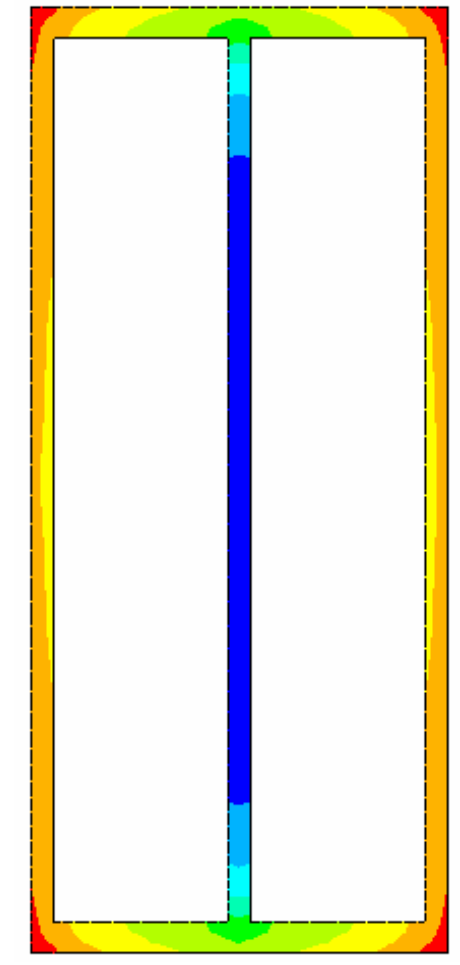

30 min

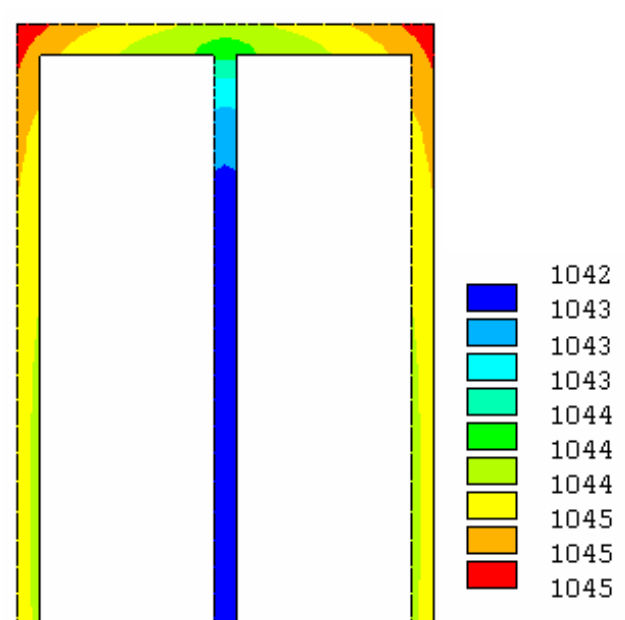

$120 \mathrm{~min}$
1042

1043

1043

1043

1044

1045

1045

1045
708.015

711.701

715.386

719.072

722.758

726.444

730.13

733.816

737.501

741.187 
- Perfil VS 400x78

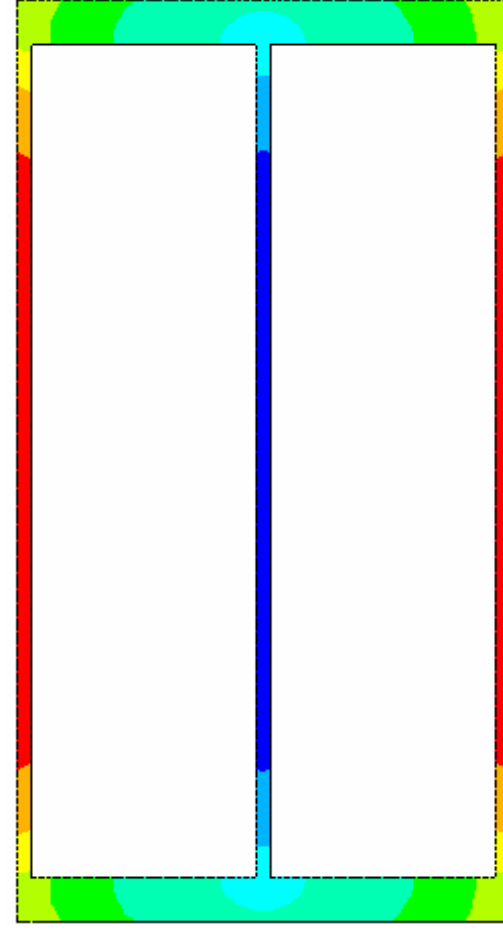

$15 \mathrm{~min}$

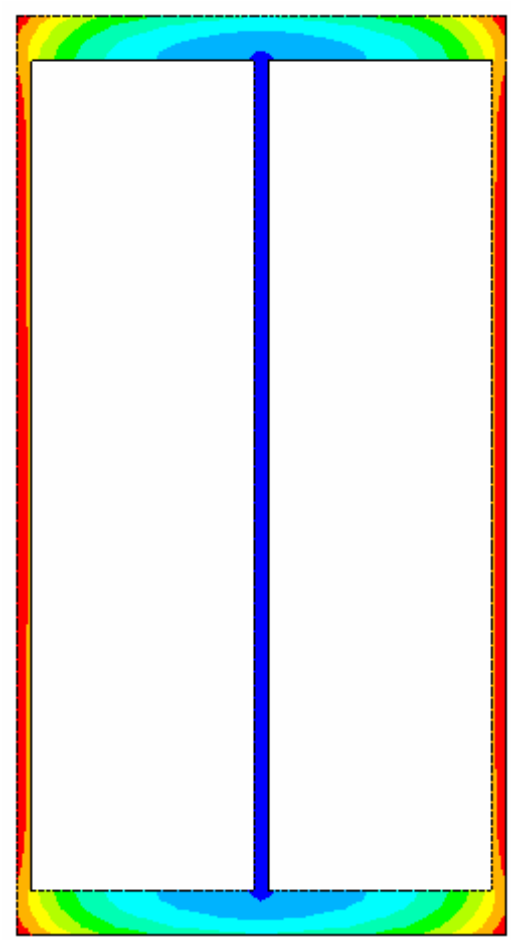

$90 \mathrm{~min}$
296.238

323.52

350.803

378.085

405.368

432.65

459.933

487.215

514.498

541.78

993.521

994.014

994.506

994.998

995.49

995.983

996.475

996.967

997.46

997.952

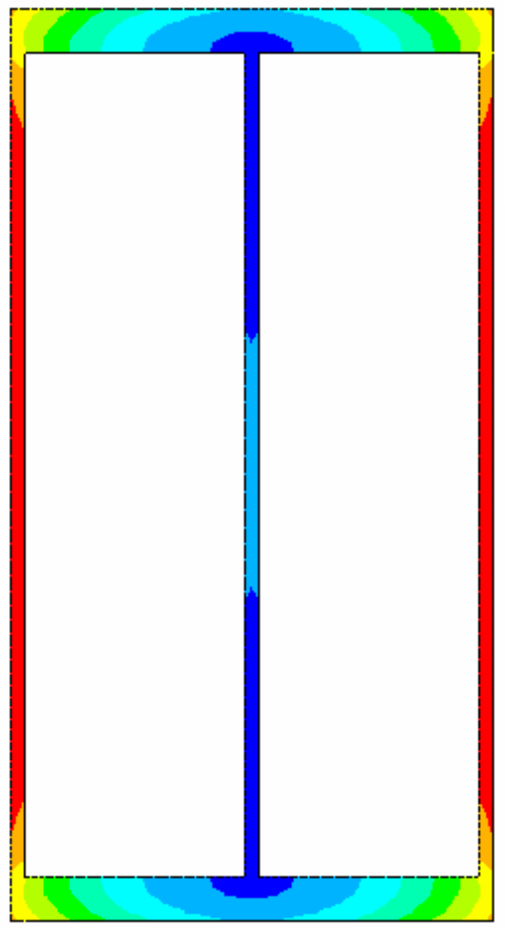

$30 \mathrm{~min}$

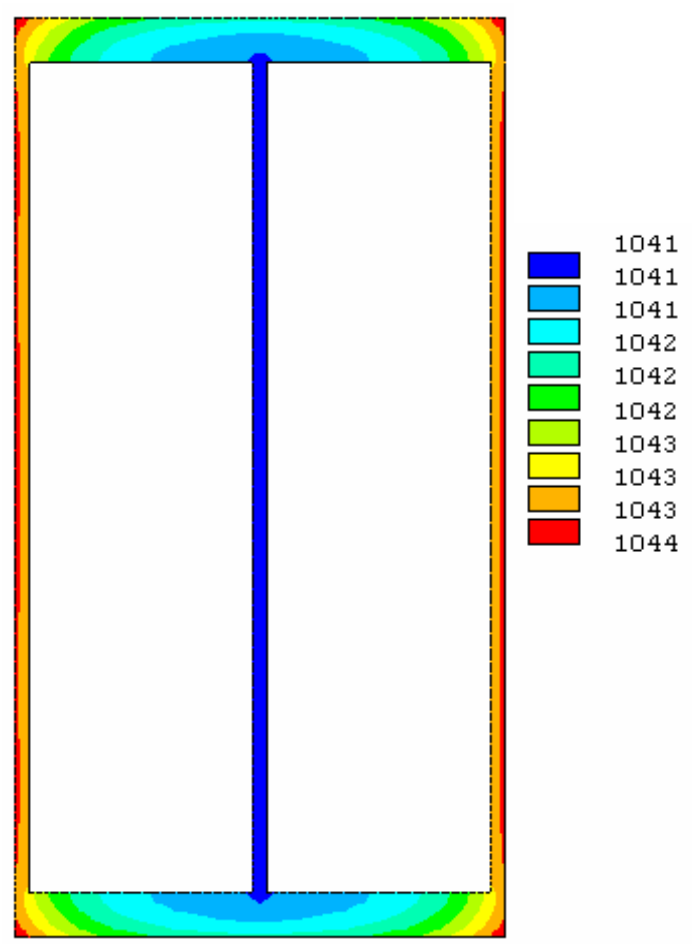

$120 \mathrm{~min}$
673.181

678.925

684.669

690.413

696.157

701.901

707.645

713.389

719.133

724.878 


\section{- Perfil CS 550x502}

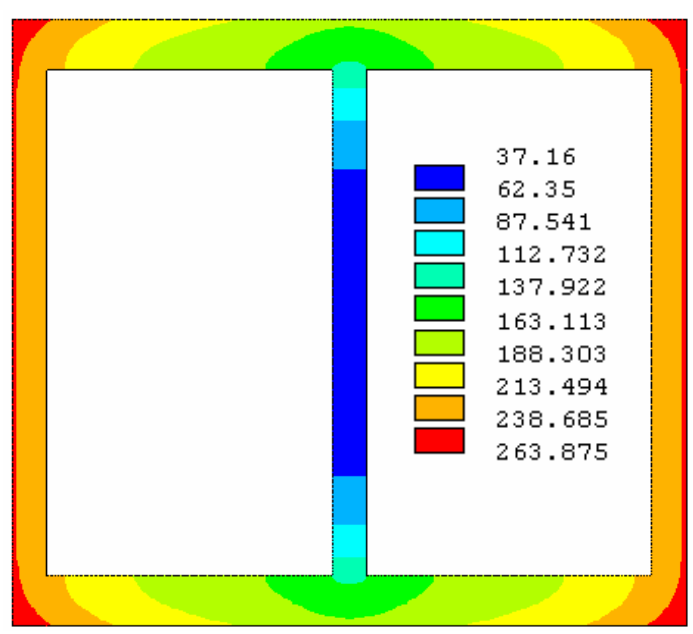

$15 \mathrm{~min}$

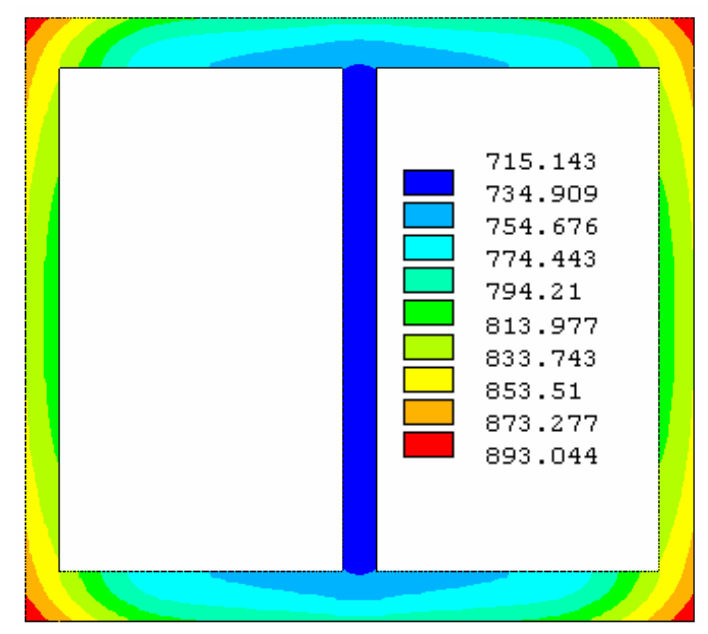

$90 \mathrm{~min}$

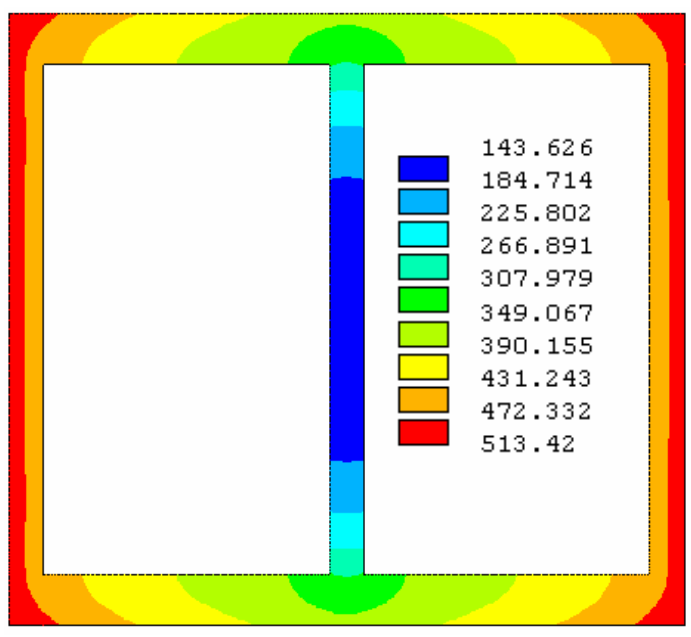

$30 \mathrm{~min}$

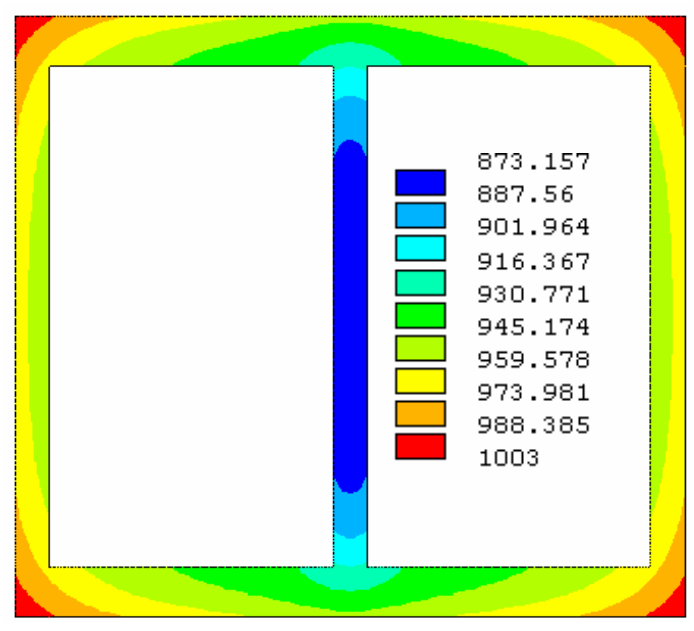

$120 \mathrm{~min}$ 
C.5 CASO 5 - Seção I com proteção tipo caixa, de espessura uniforme, exposta ao incêndio por todos os lados

- Perfil W 150x13

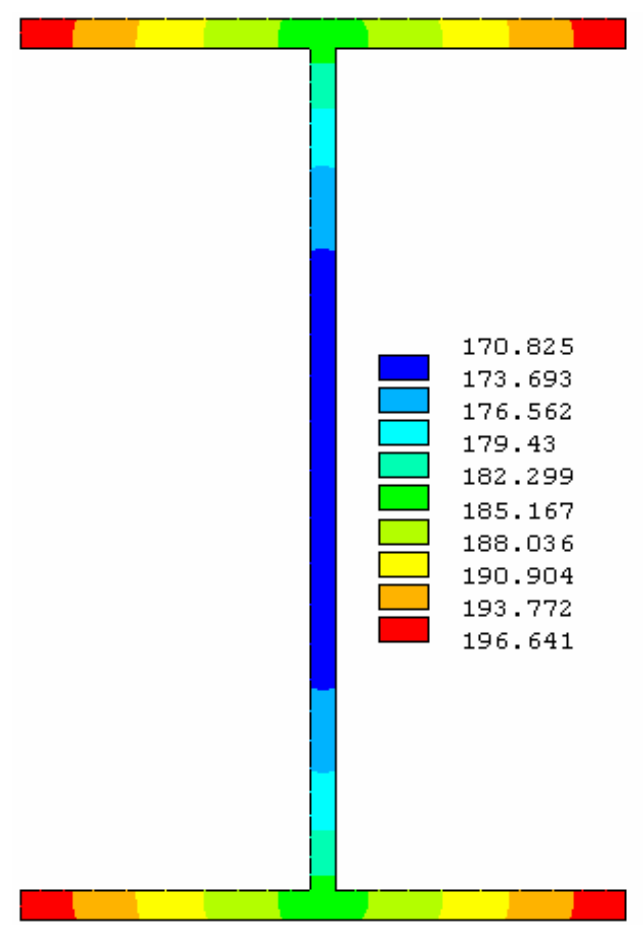

$15 \min$

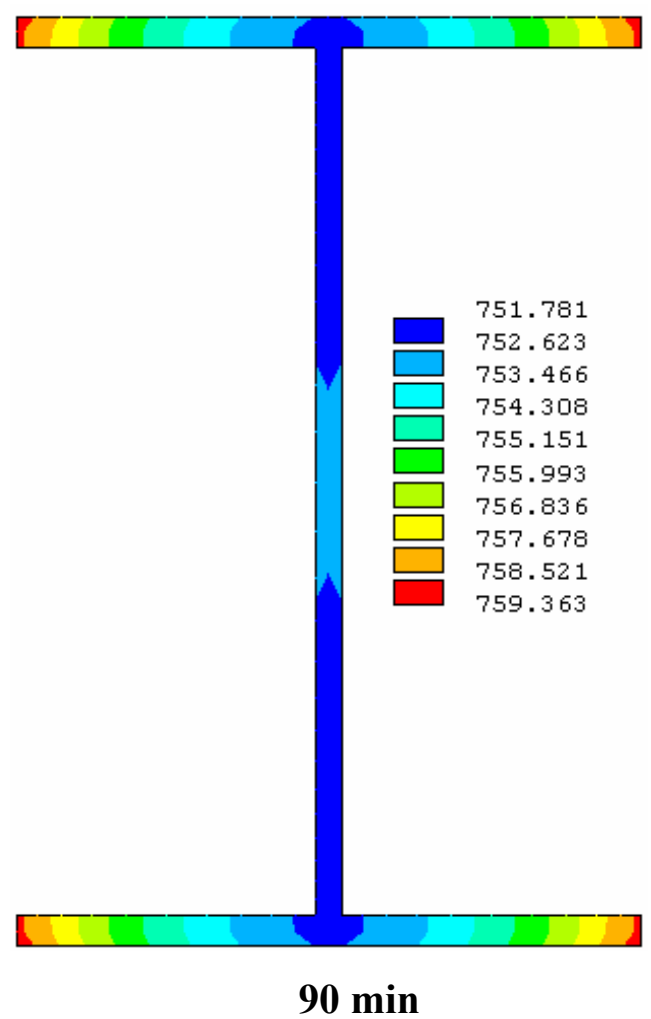

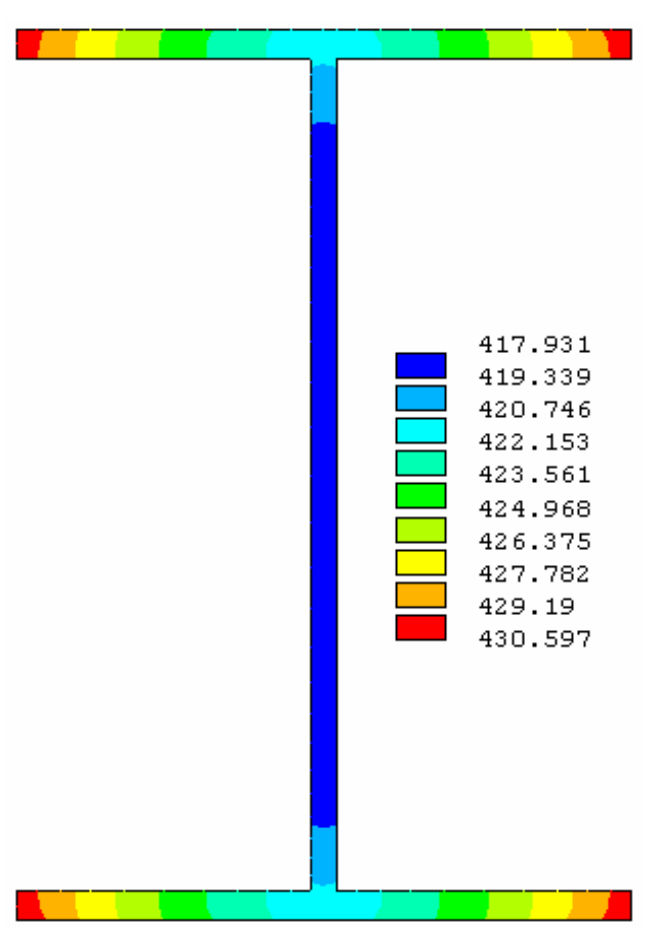

30 min

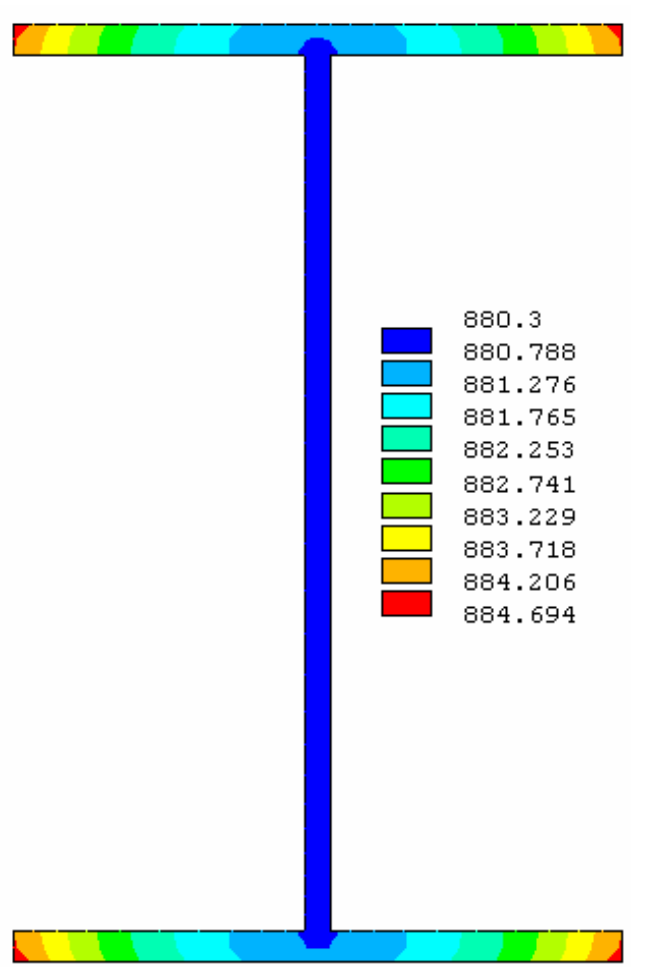

$120 \mathrm{~min}$ 
- Perfil W 250x25,3

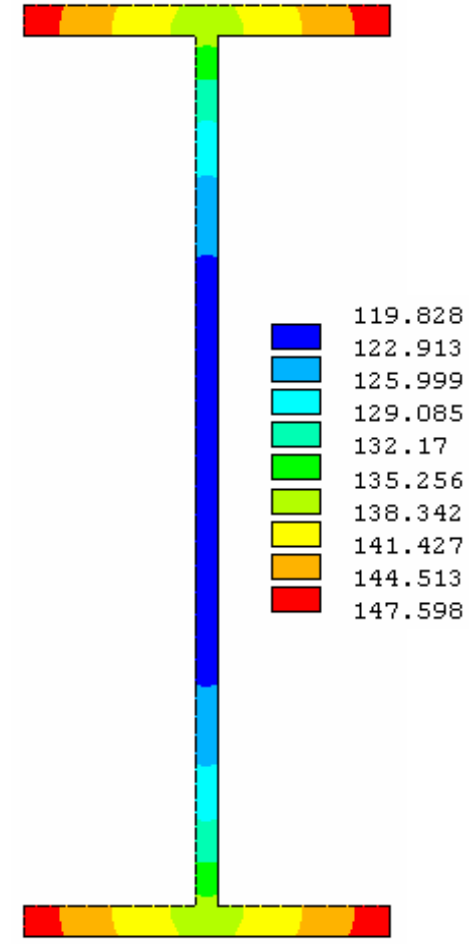

$15 \mathrm{~min}$

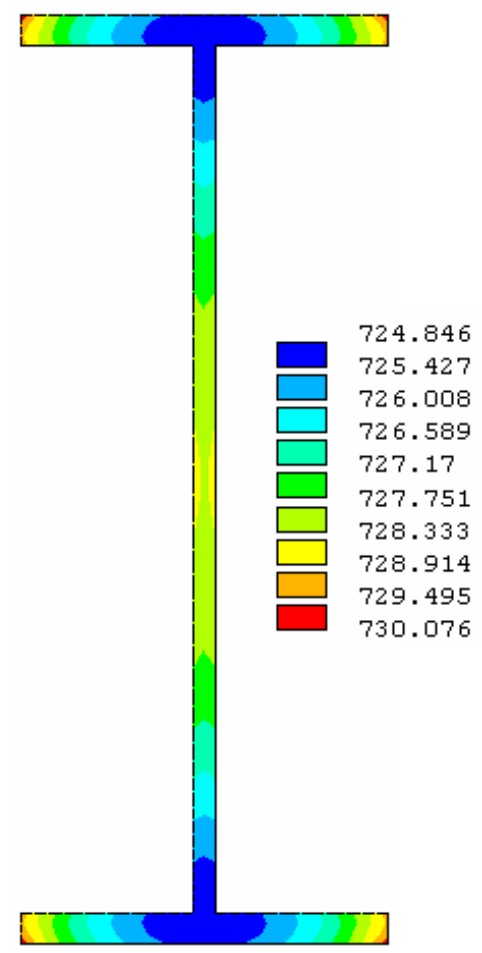

90 min

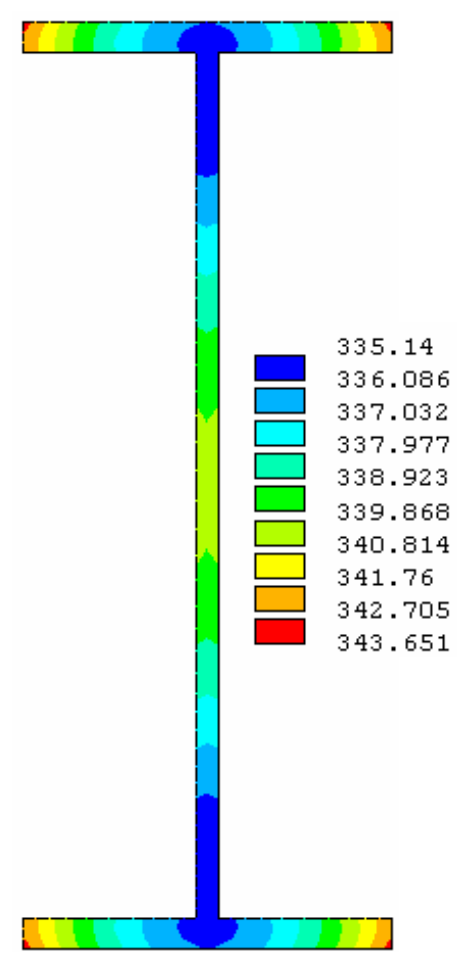

30 min

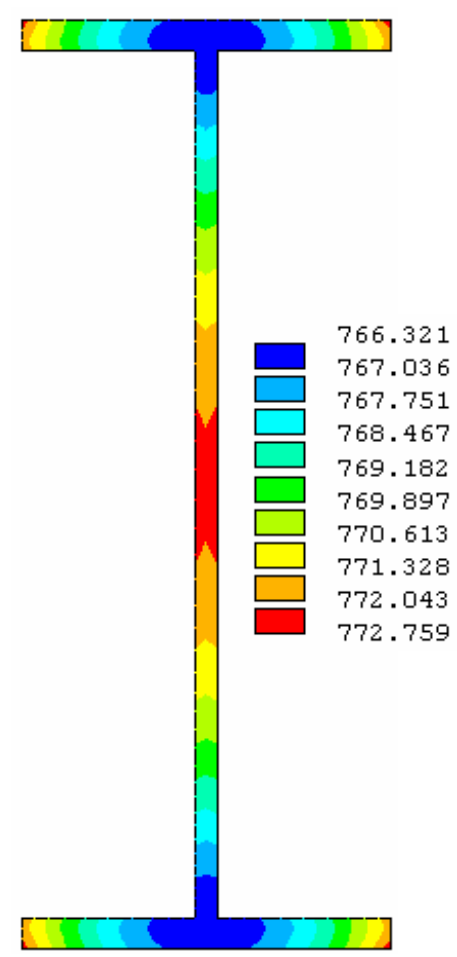

$120 \mathrm{~min}$ 
- Perfil VS 400x78

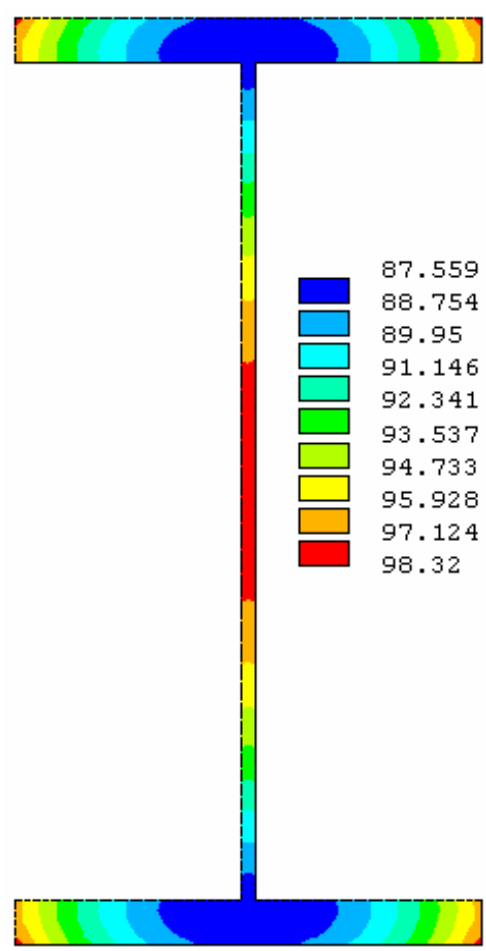

$15 \mathrm{~min}$

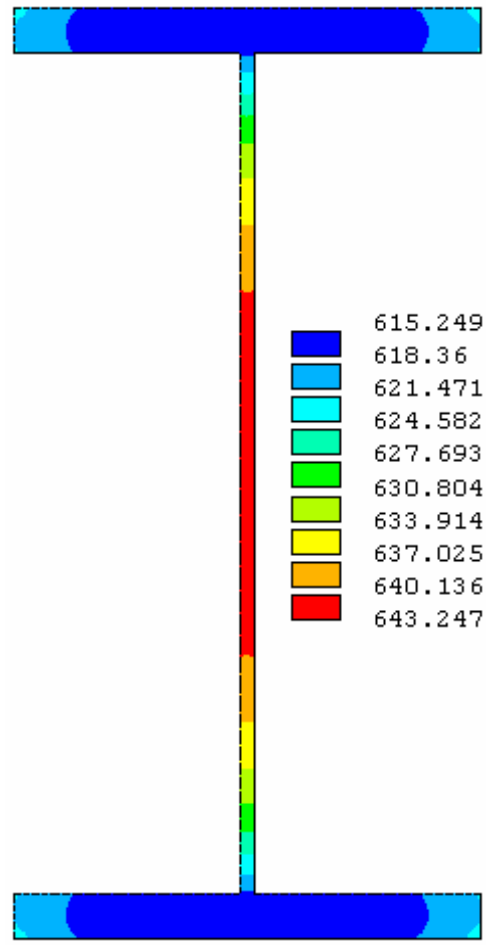

$90 \mathrm{~min}$

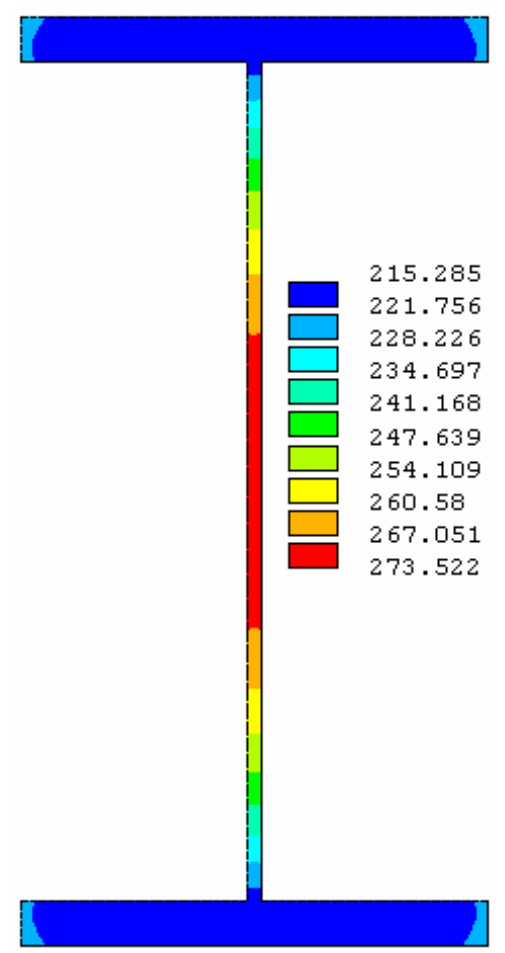

$30 \mathrm{~min}$

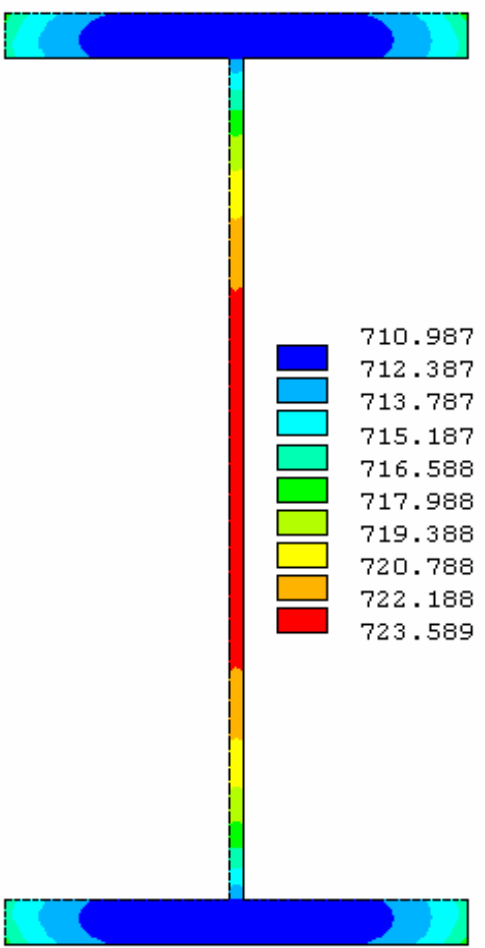

$120 \mathrm{~min}$ 


\section{- Perfil CS 550x502}

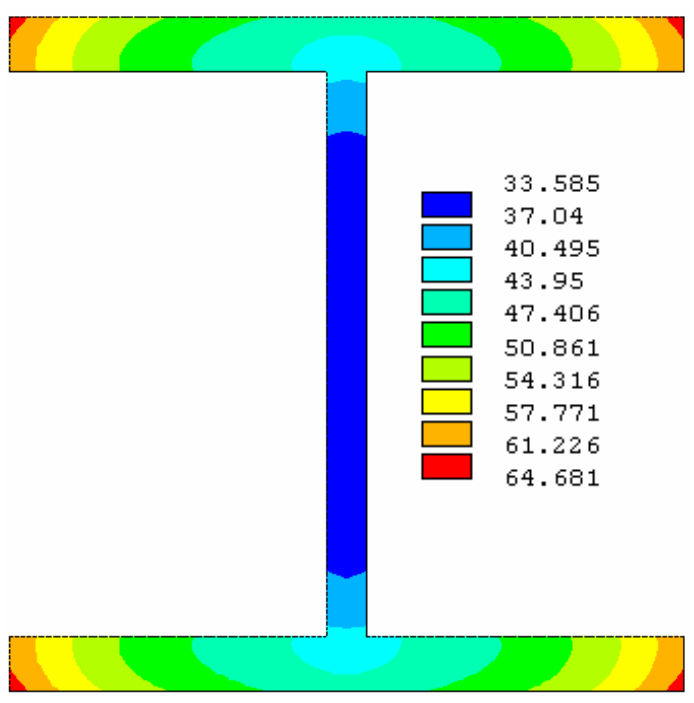

$15 \mathrm{~min}$

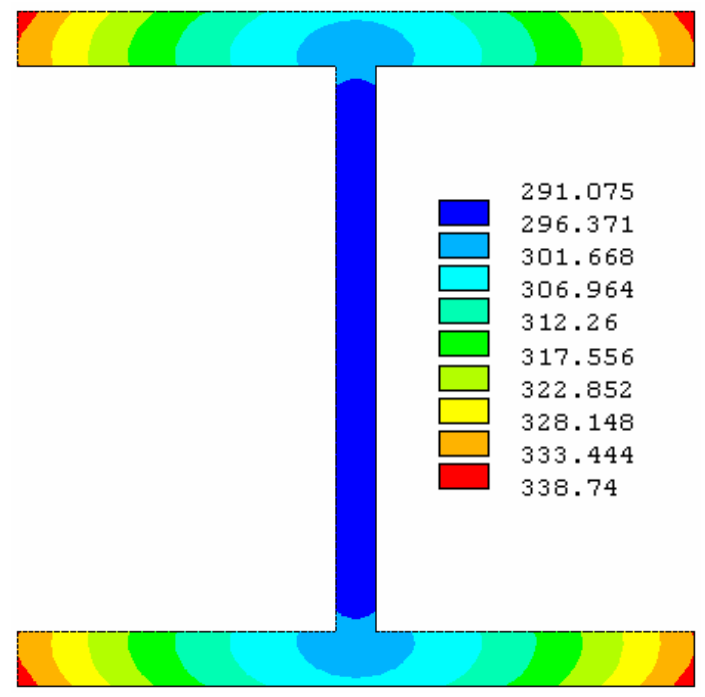

$90 \mathrm{~min}$

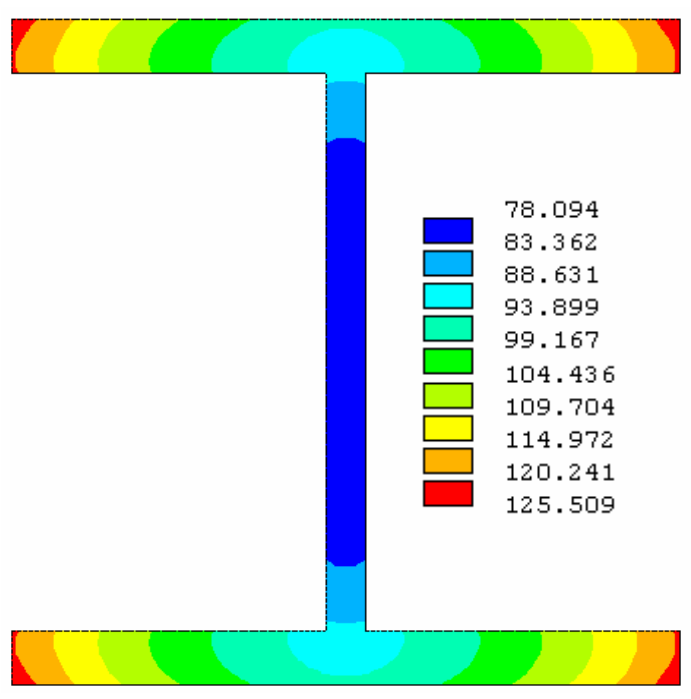

$30 \mathrm{~min}$

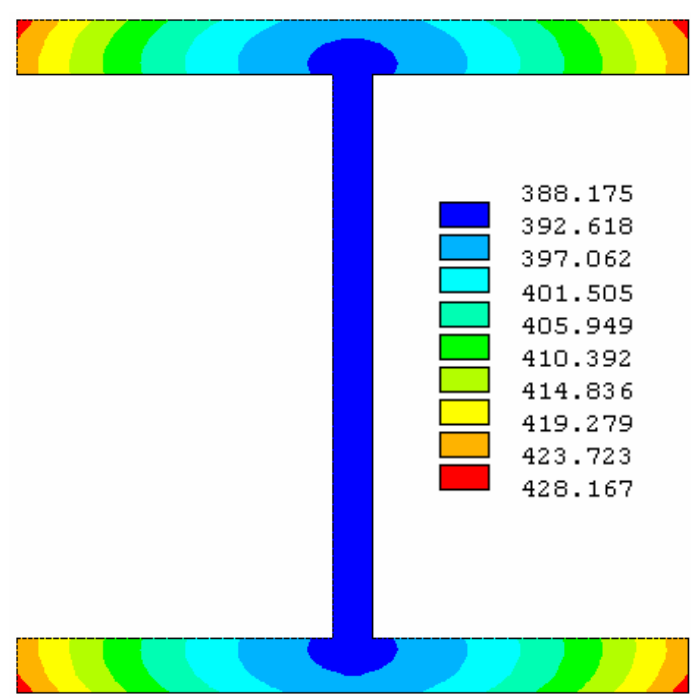

$30 \mathrm{~min}$ 
- Perfil W 250x25,3 + Gap 25 mm

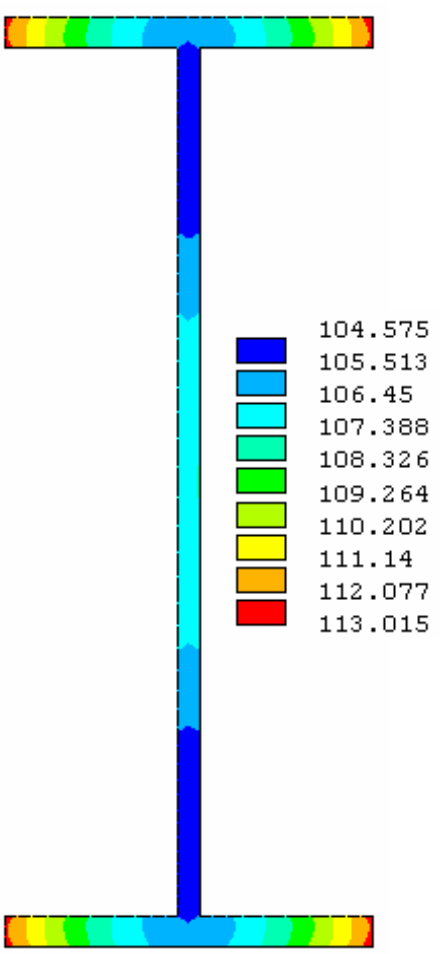

15 min

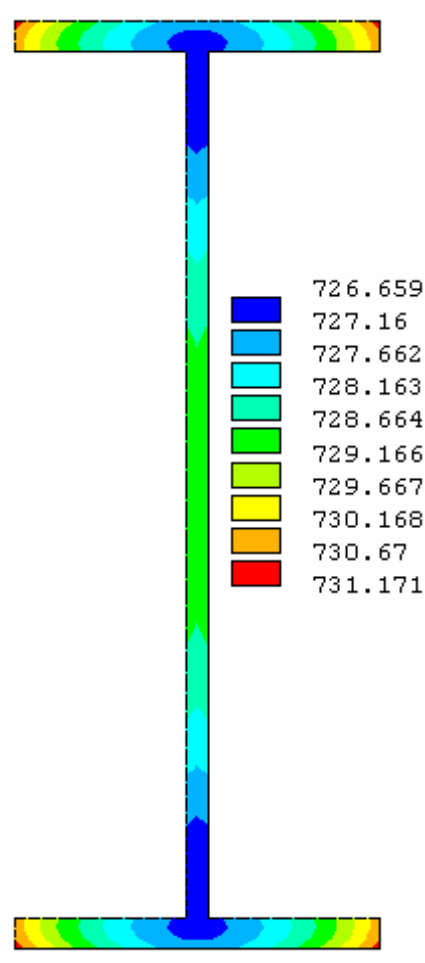

$90 \mathrm{~min}$

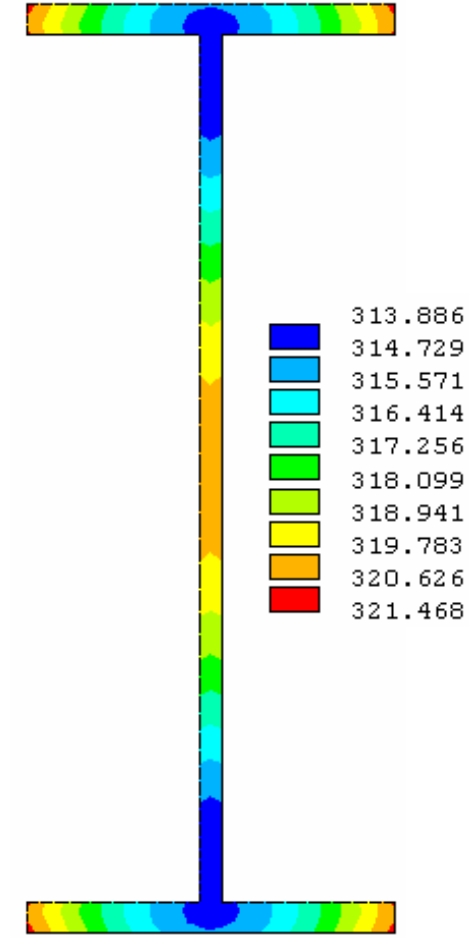

30 min

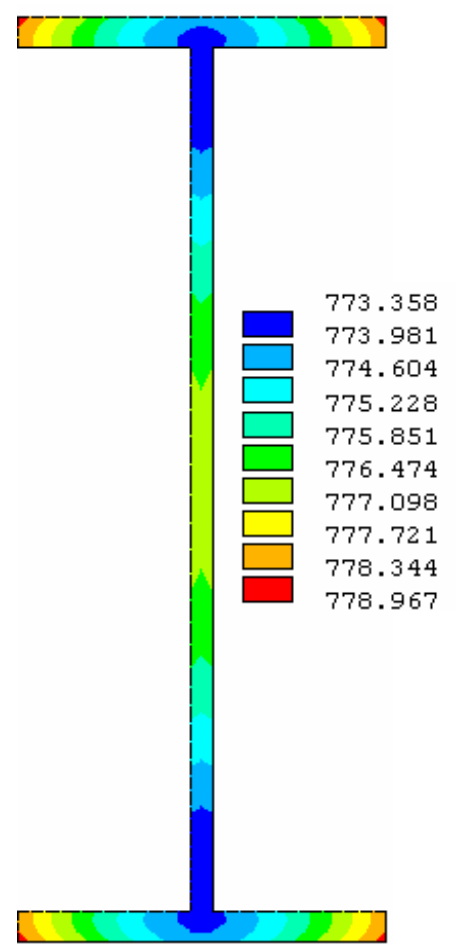

120 min 
C.6 CASO 6 - Seção I com proteção tipo caixa, de espessura uniforme exposta ao incêndio por três lados

- Perfil W 150x13
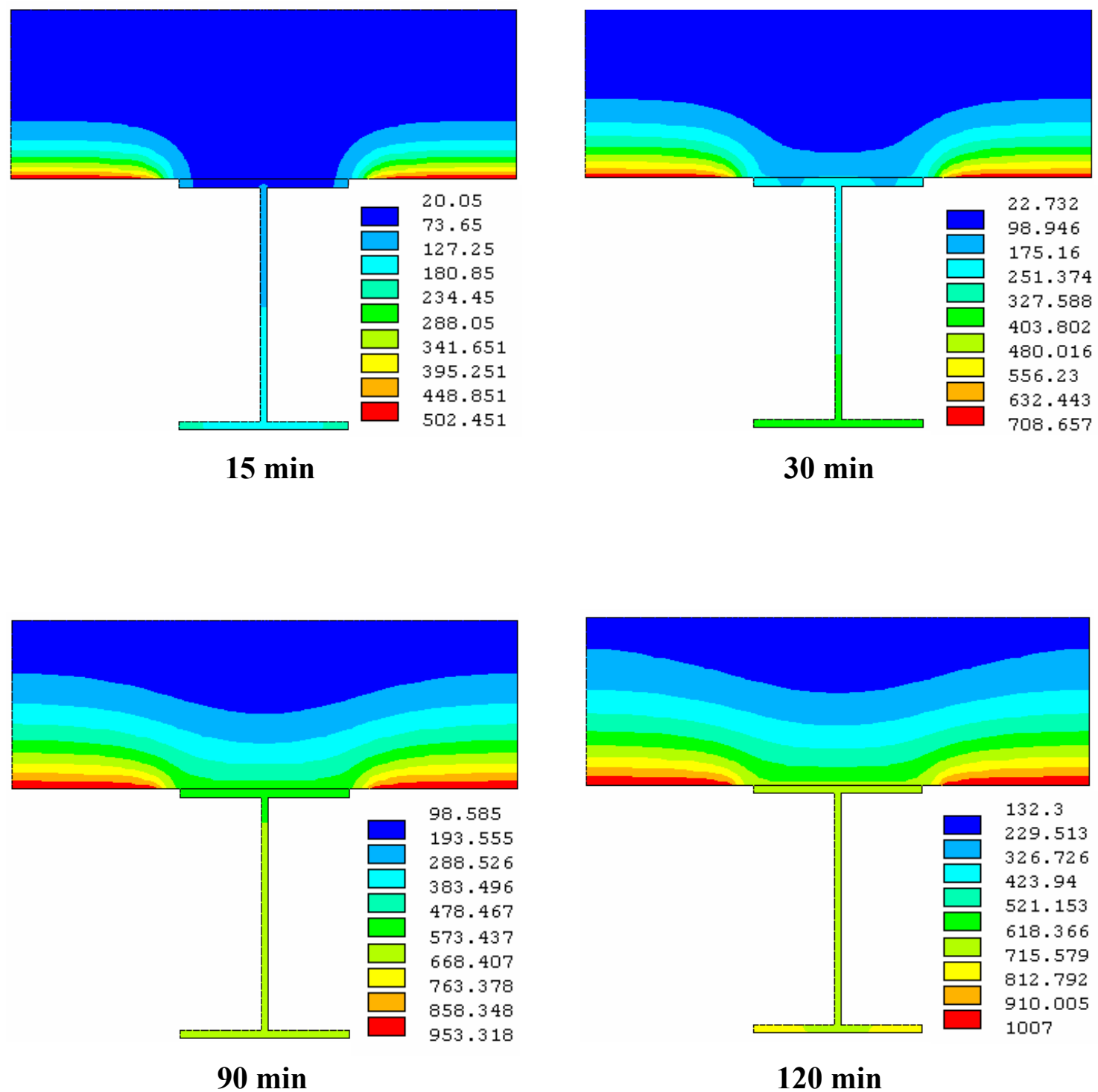

$120 \mathrm{~min}$ 
- Perfil W 250x25,3

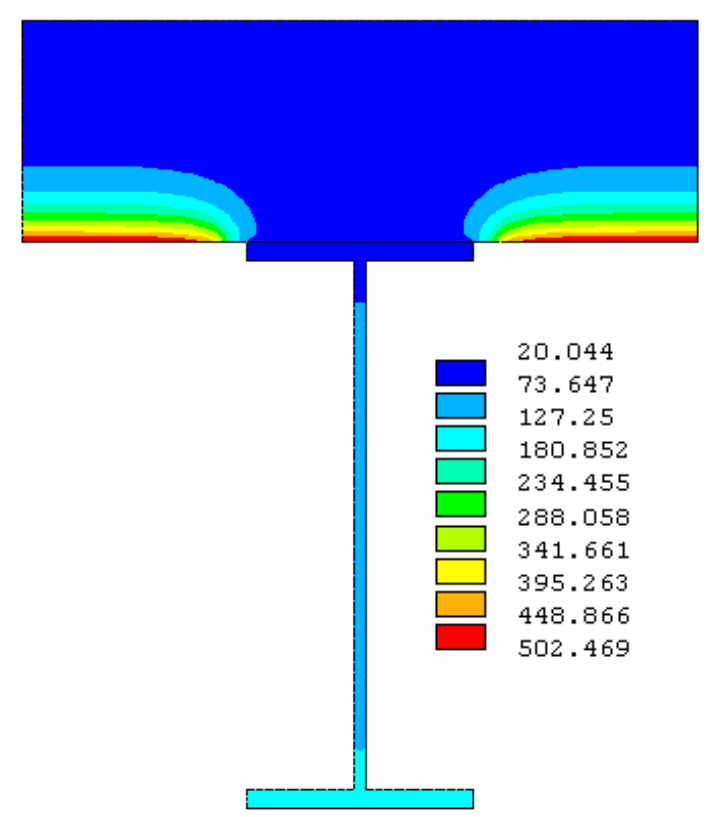

$15 \mathrm{~min}$
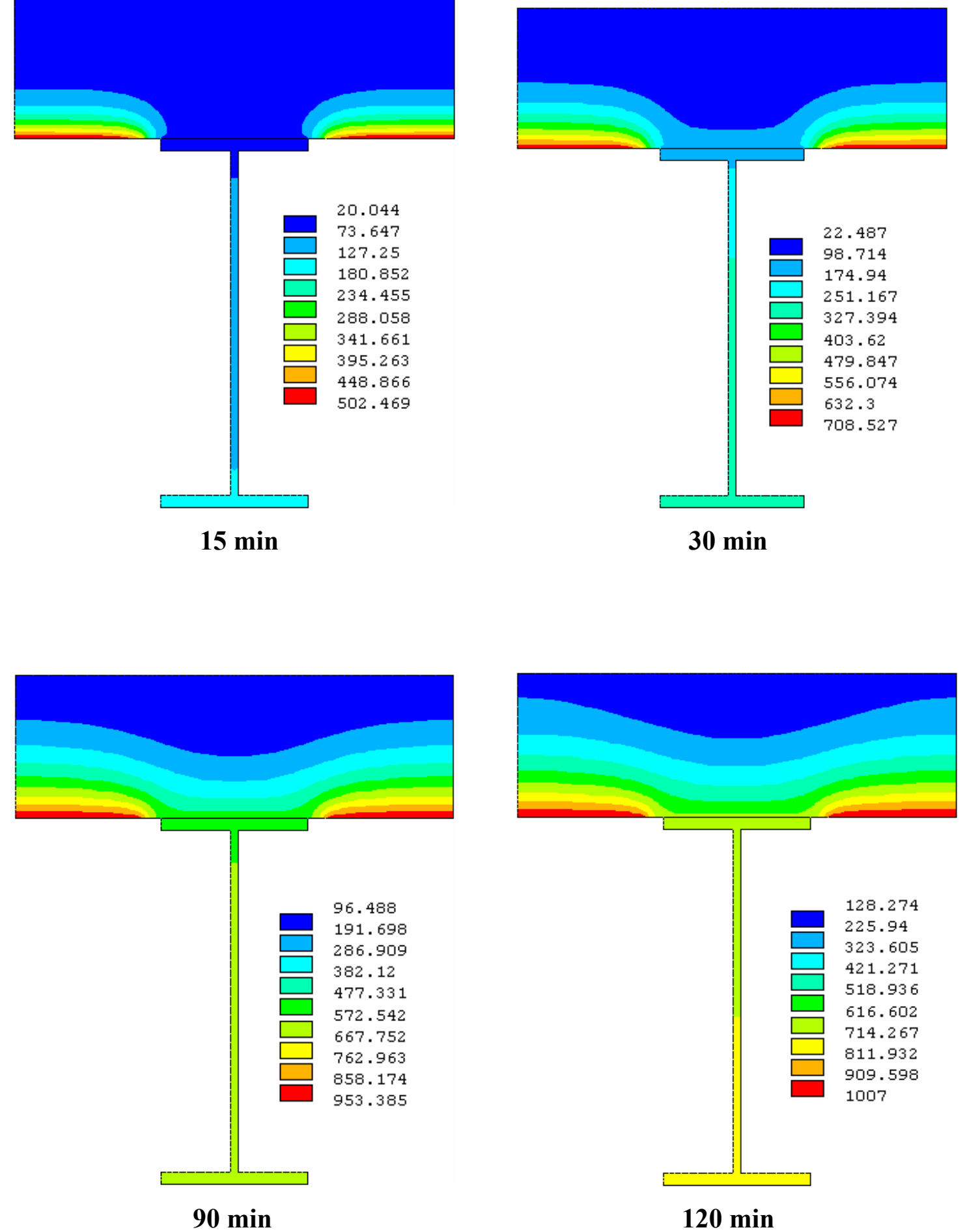

$120 \mathrm{~min}$ 


\section{- Perfil VS 400x78}

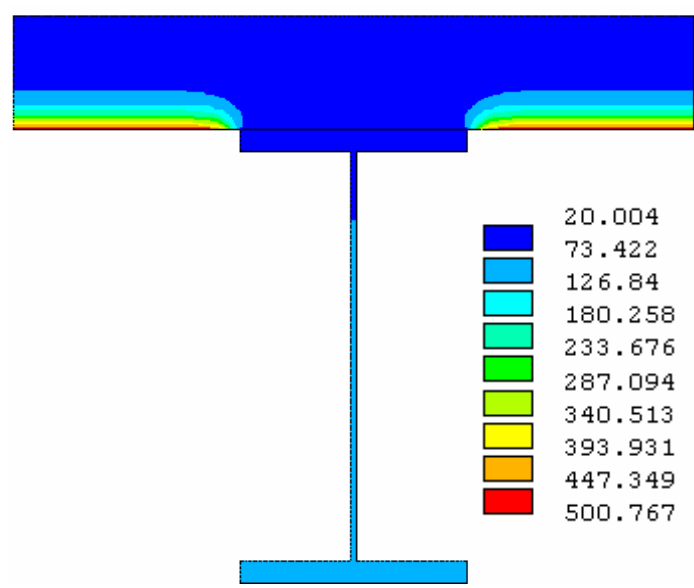

$15 \min$

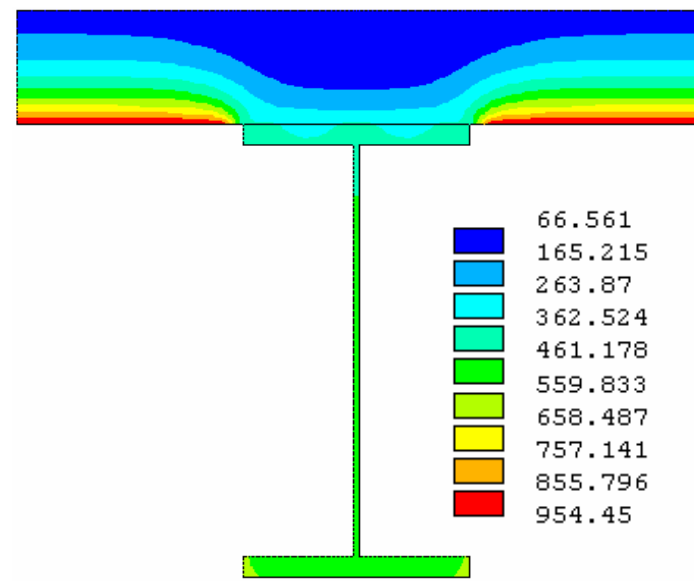

90 min

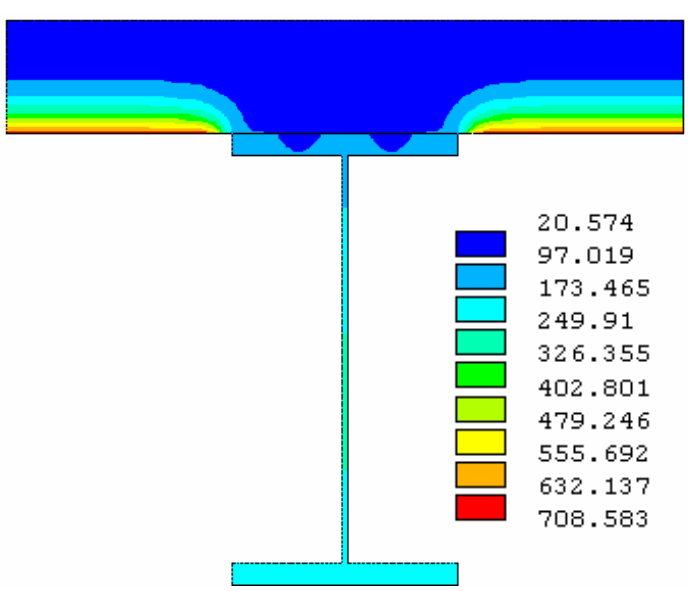

30 min

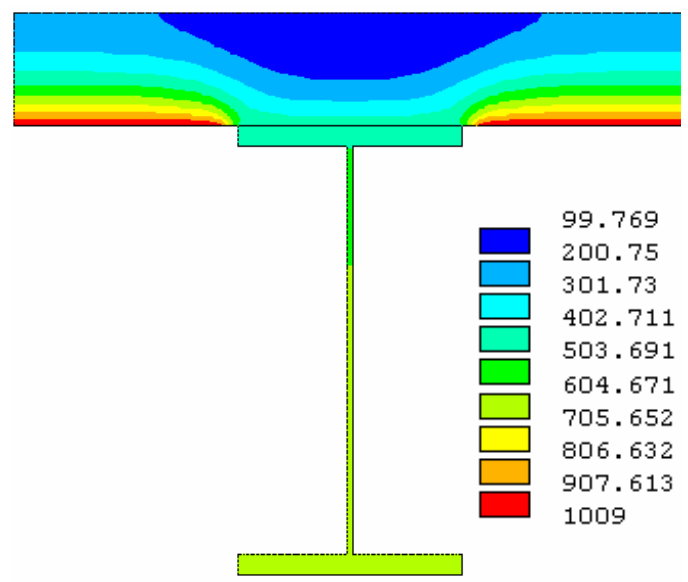

$120 \mathrm{~min}$

\section{- Perfil CS 550x502}

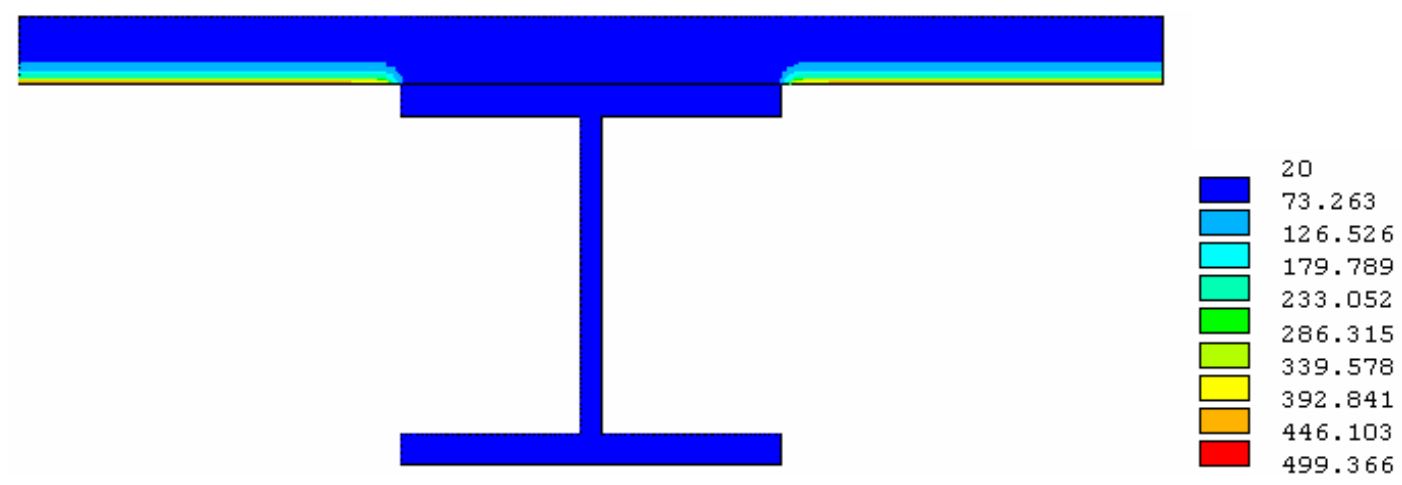

$15 \mathrm{~min}$ 


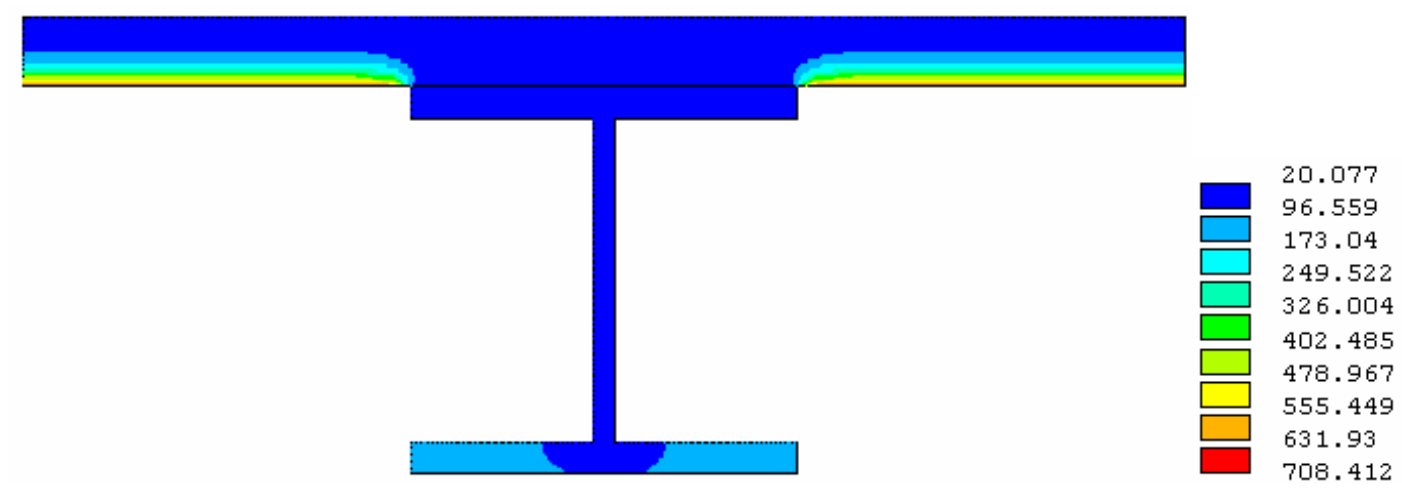

$30 \mathrm{~min}$

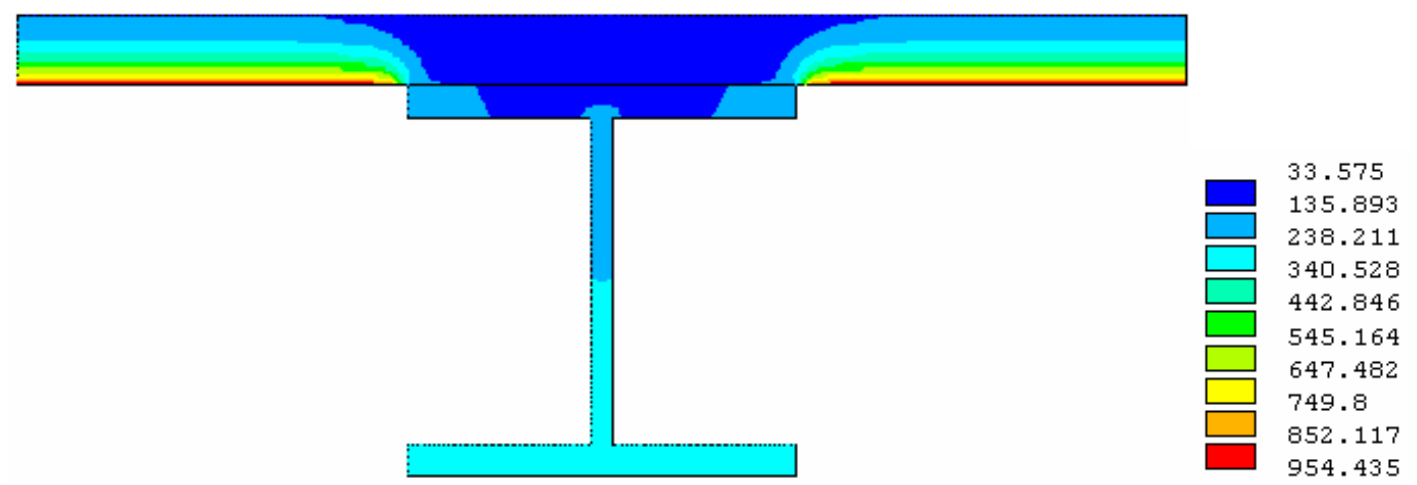

90 min

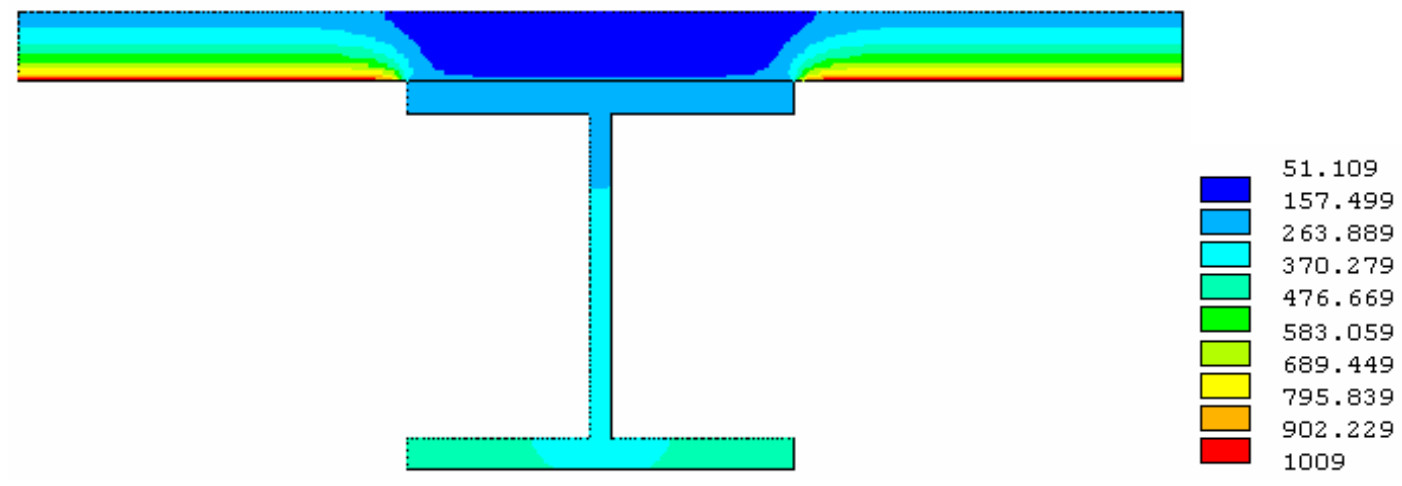

120 min 
C.7 CASO 7 - Viga I em contato com laje de concreto e alvenaria, exposta ao incêndio pelos dois lados da parede de alvenaria

- Perfil W 150x13
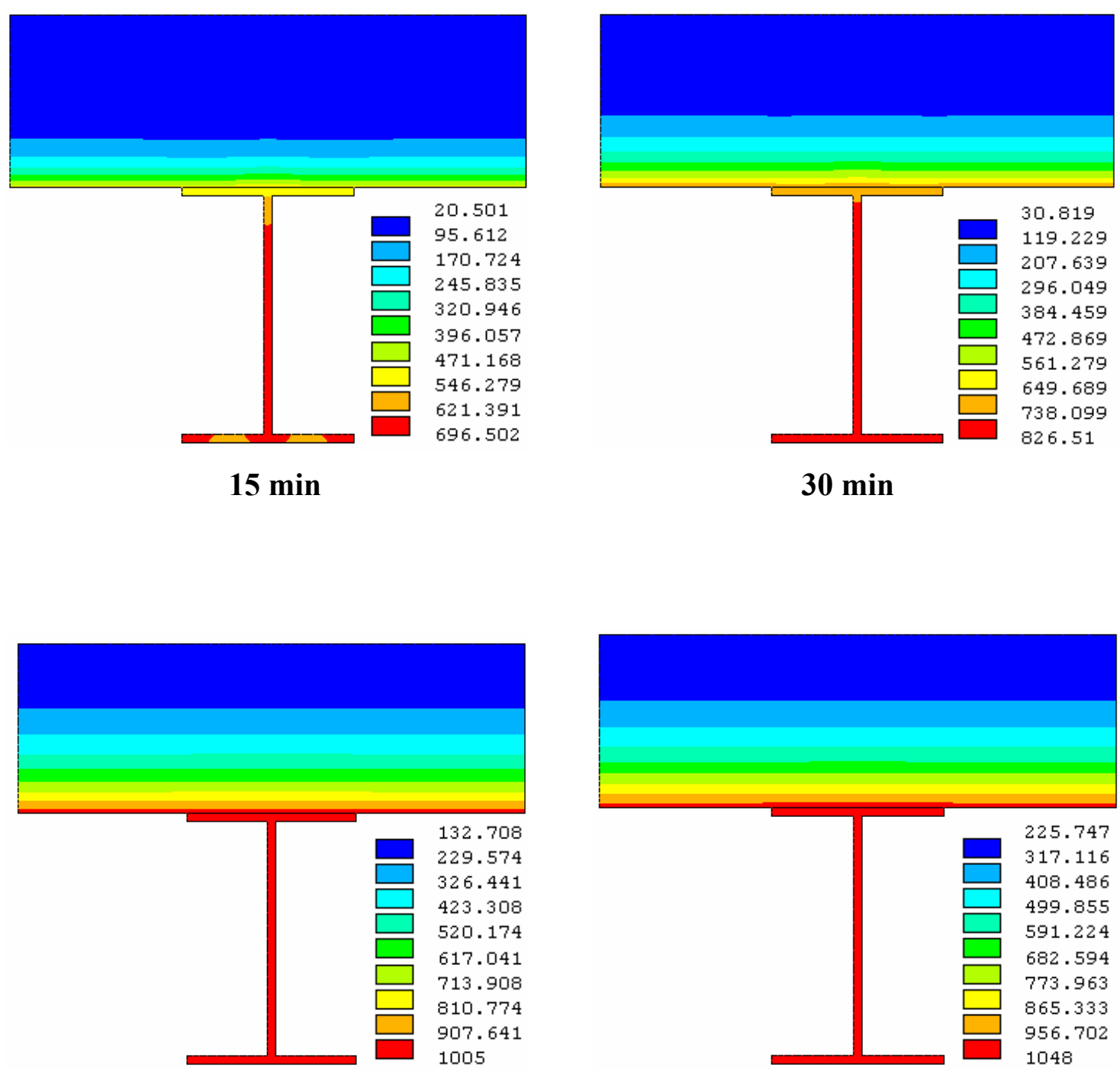

$90 \mathrm{~min}$

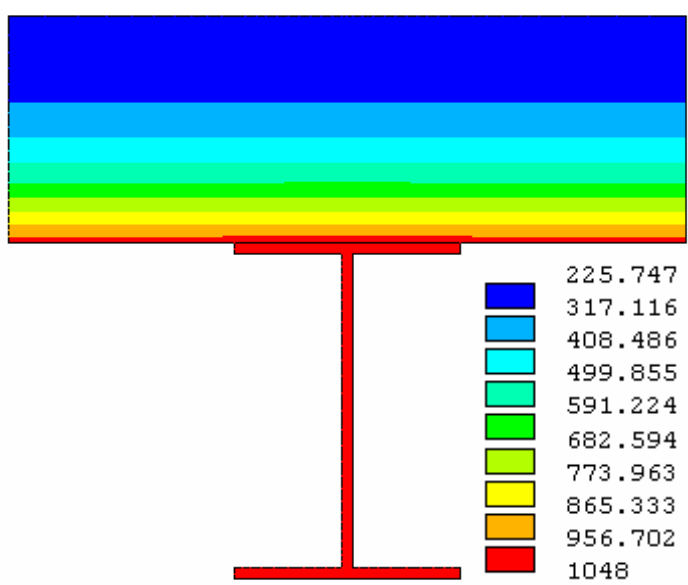

$120 \mathrm{~min}$ 
- Perfil W 250x25,3

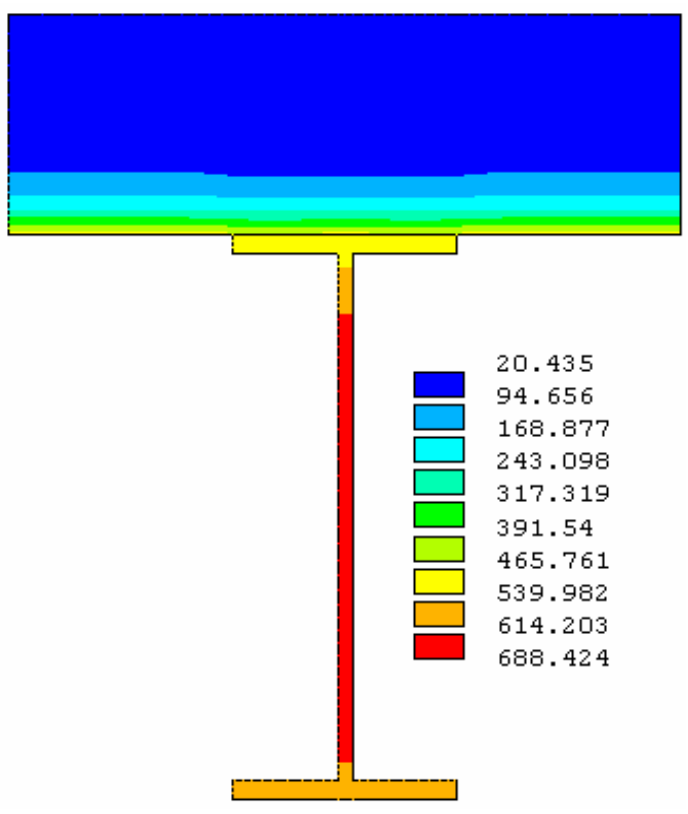

15 min

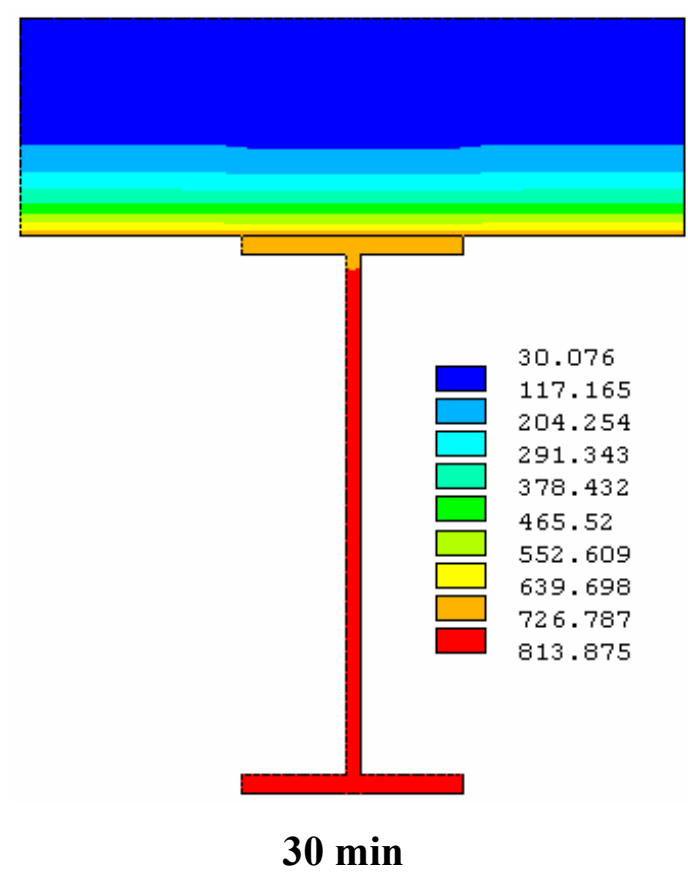

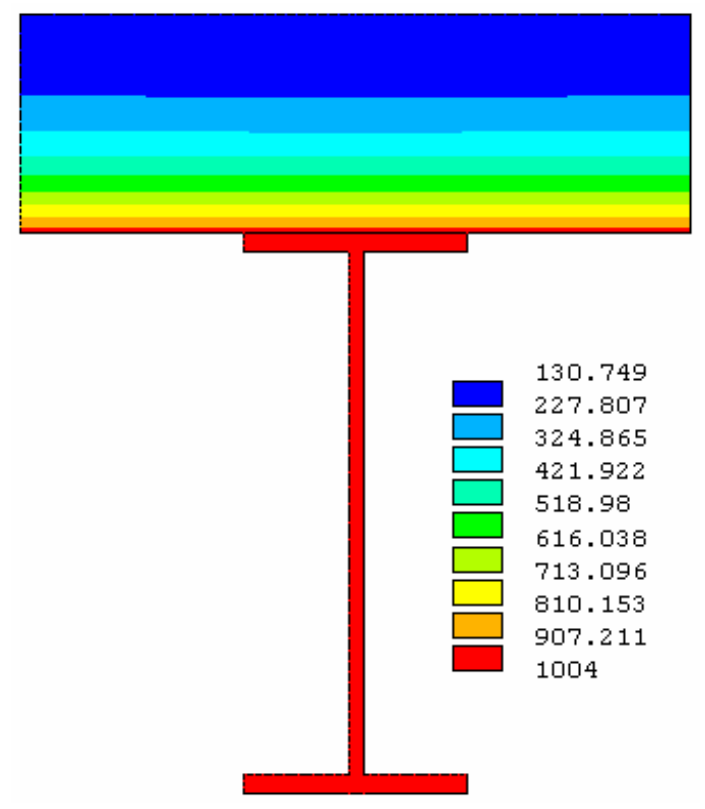

$90 \mathrm{~min}$

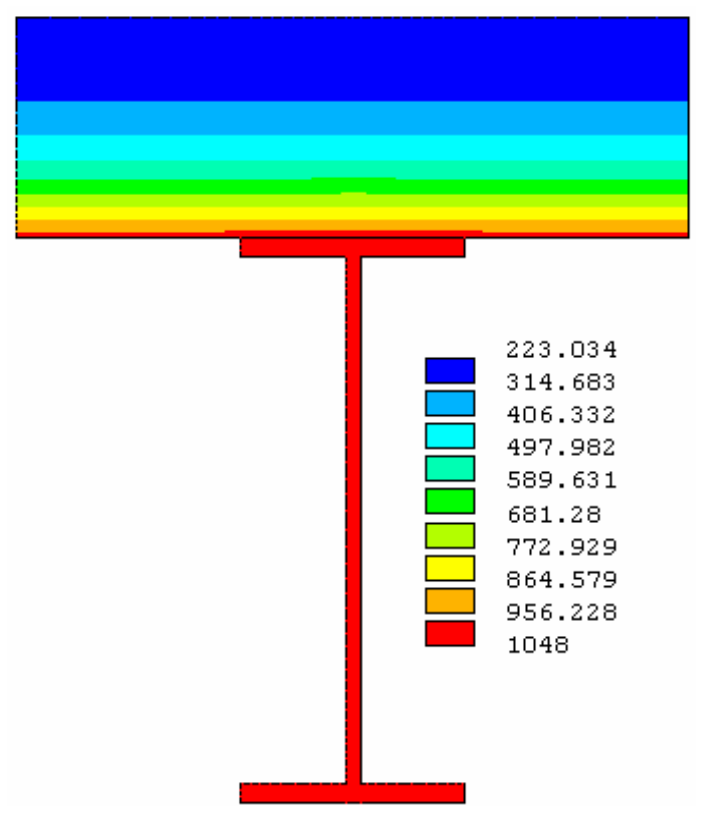

$120 \mathrm{~min}$ 


\section{- Perfil VS 400x78}

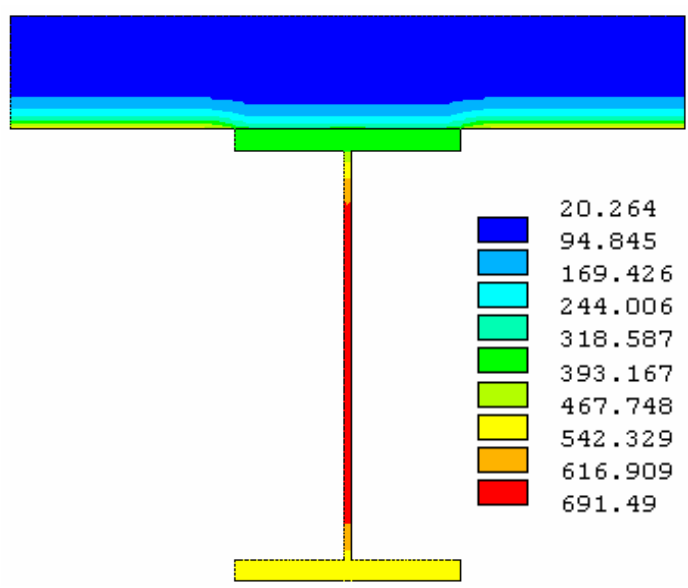

$15 \mathrm{~min}$

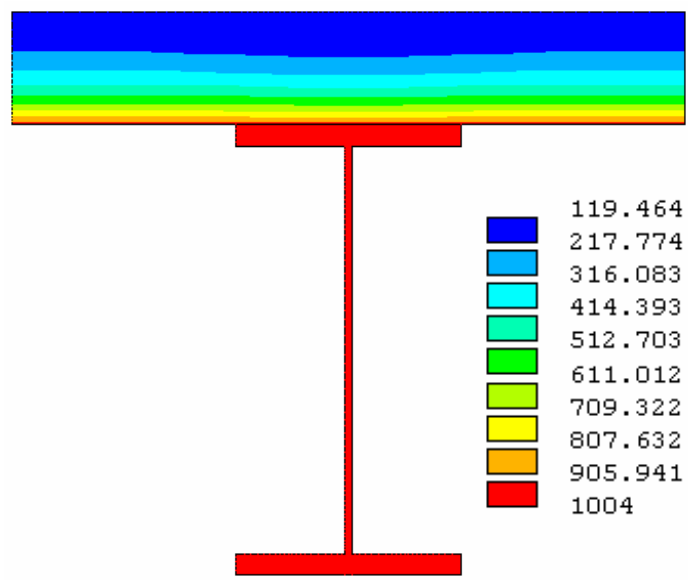

$90 \mathrm{~min}$

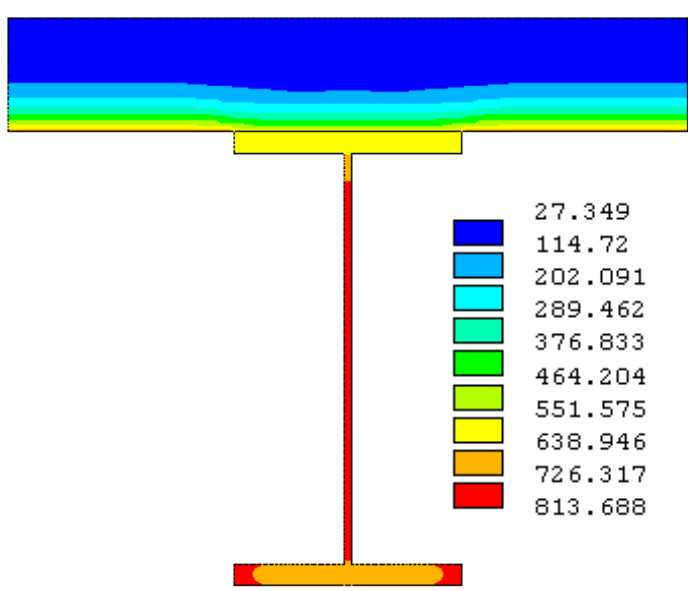

$30 \mathrm{~min}$

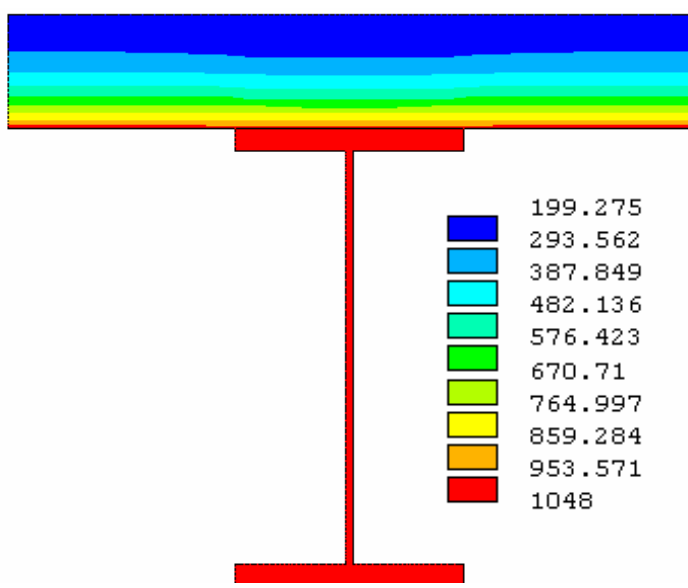

$120 \mathrm{~min}$

\section{- Perfil CS 550x502}

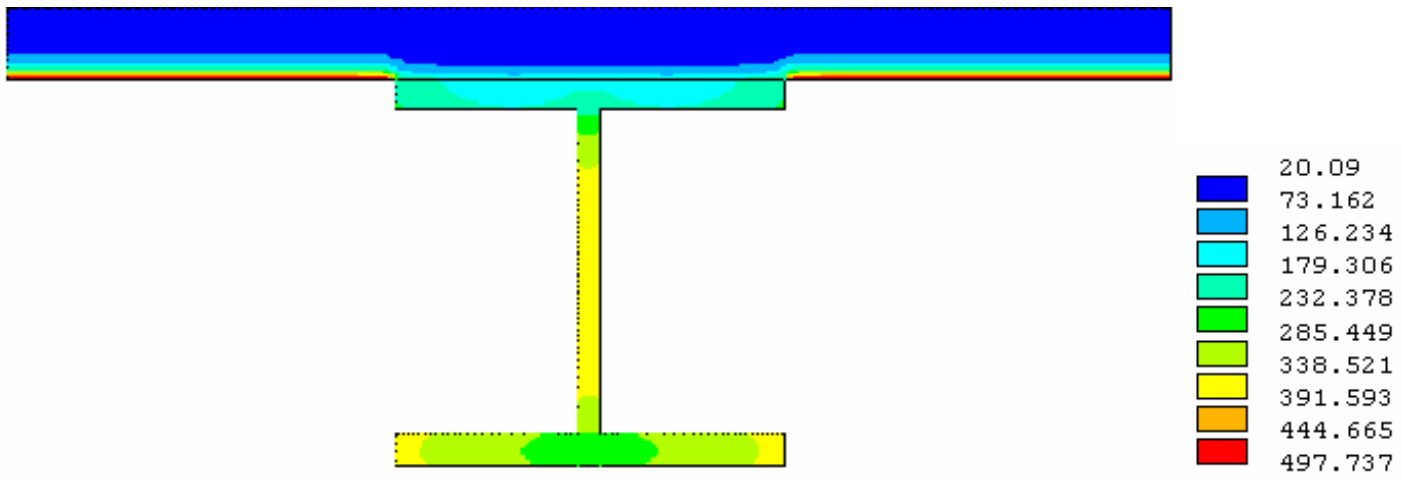

15 min 


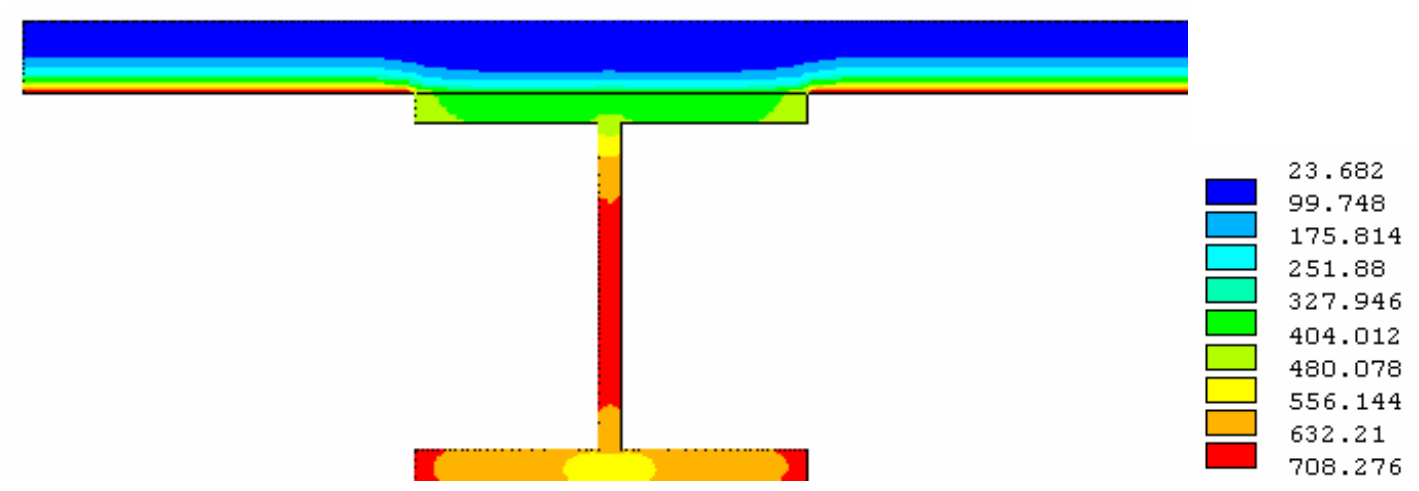

30 min

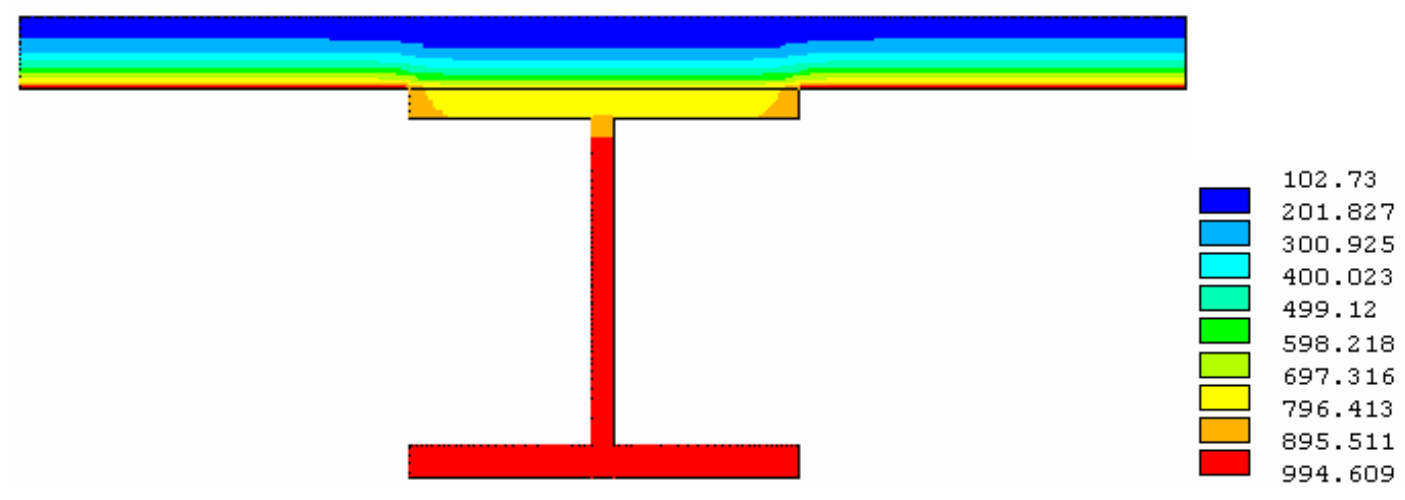

$90 \mathrm{~min}$

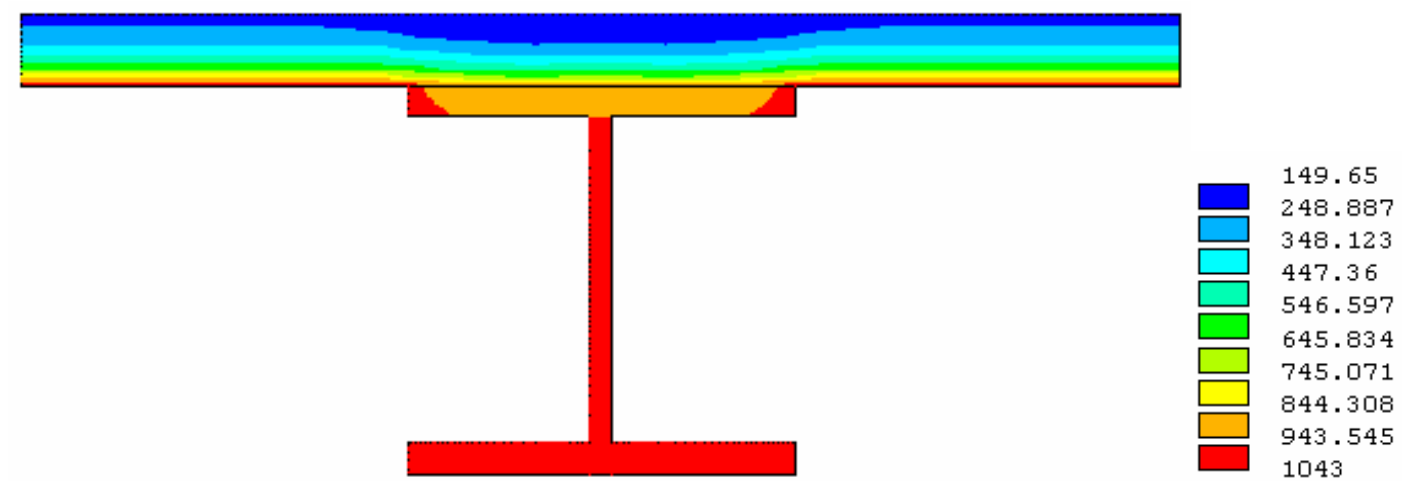

$120 \mathrm{~min}$ 
C.8 CASO 8 - Pilar com mesas em contato com paredes de alvenaria, exposta ao incêndio pelos dois lados da parede de alvenaria

- Perfil W 150x13

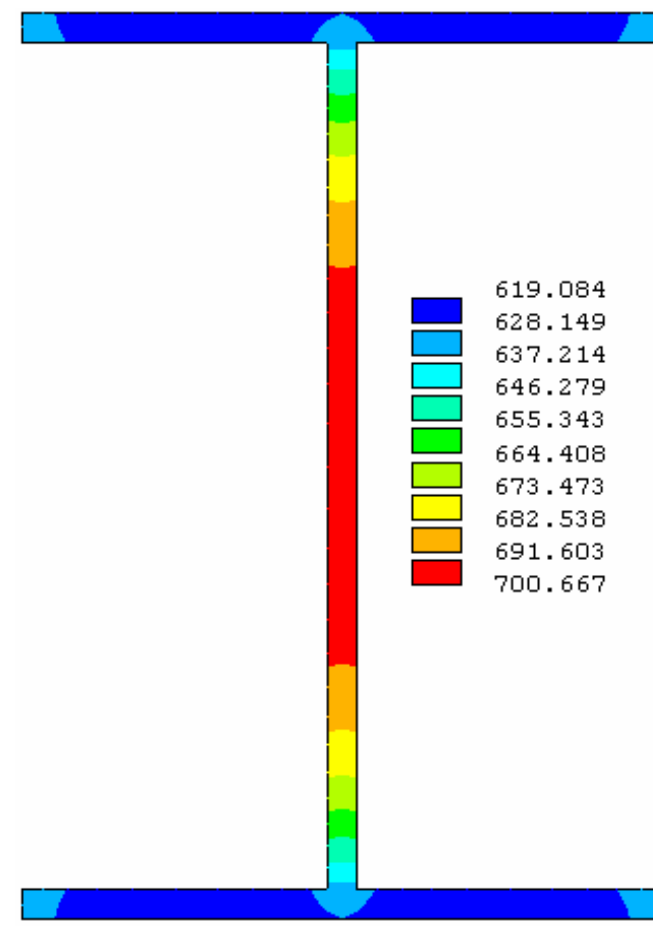

15 min

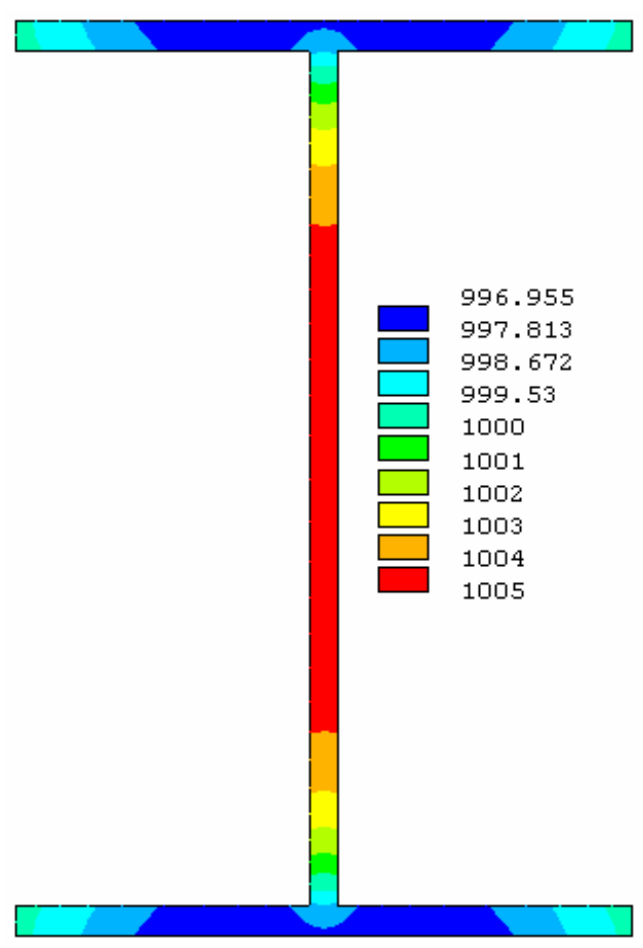

90 min

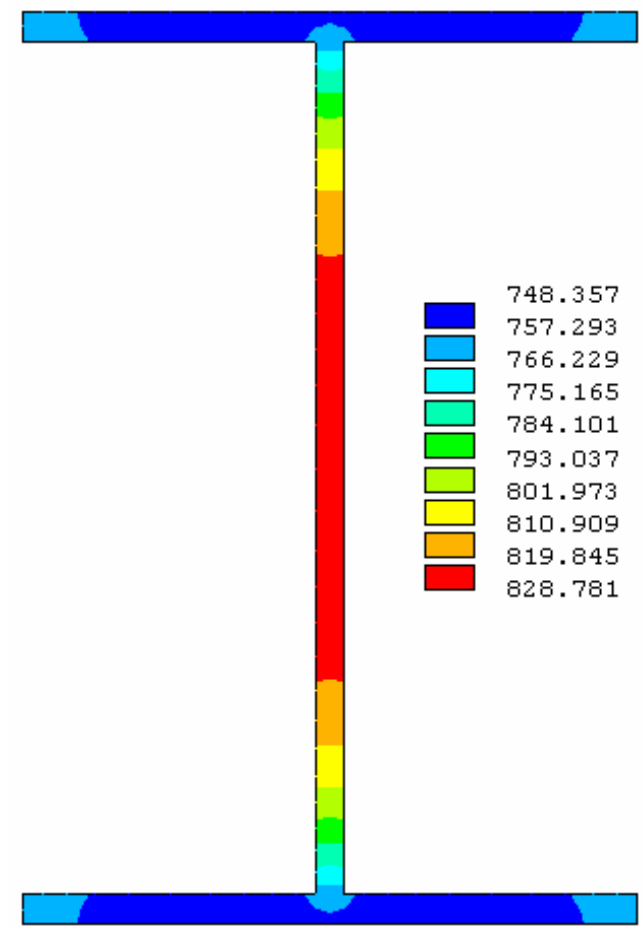

$30 \mathrm{~min}$

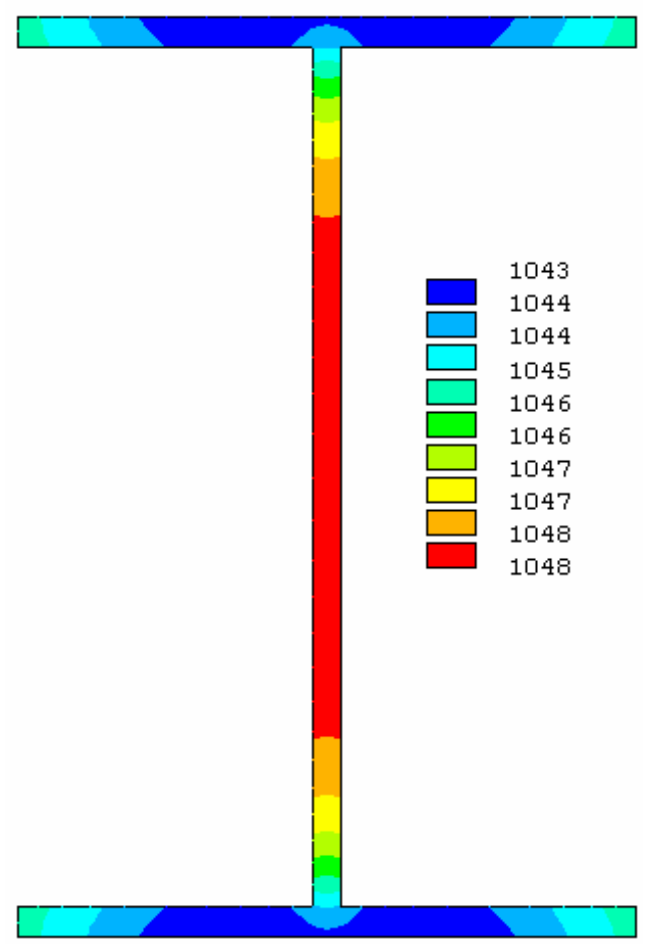

$120 \mathrm{~min}$ 
- Perfil W 250x25,3

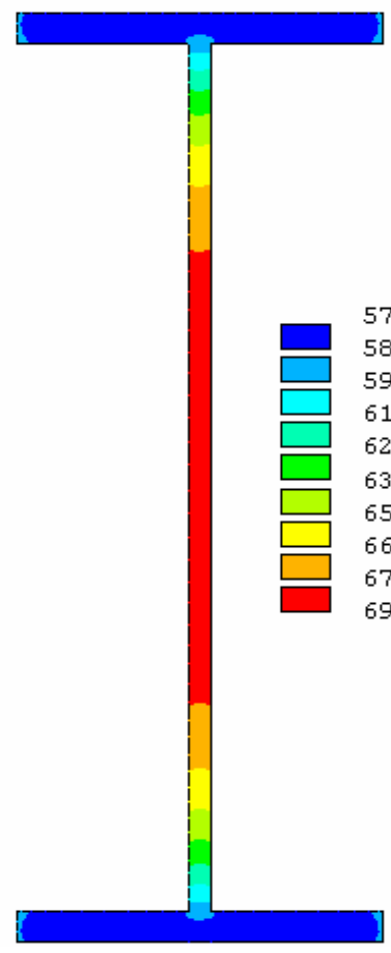

$15 \mathrm{~min}$

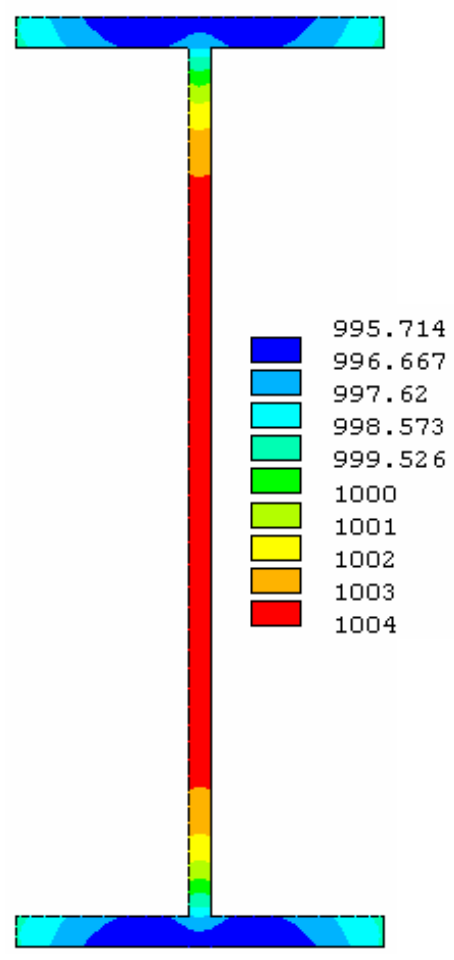

$90 \min$

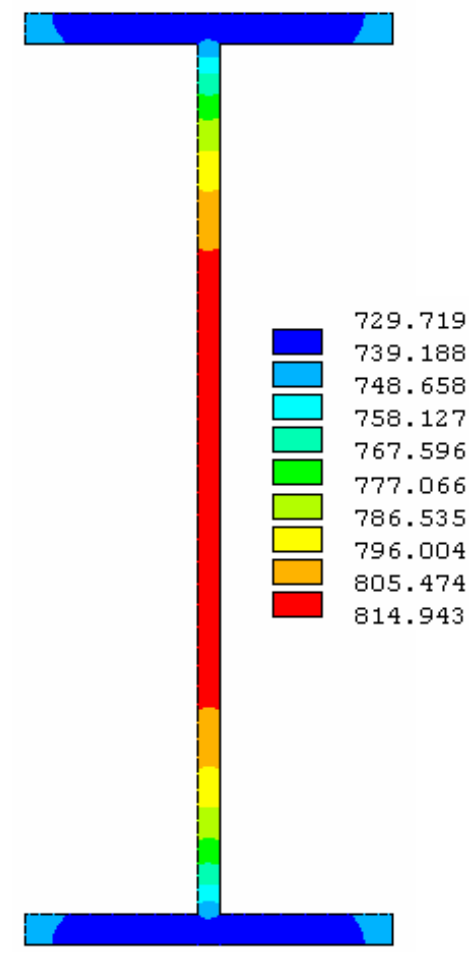

30 min

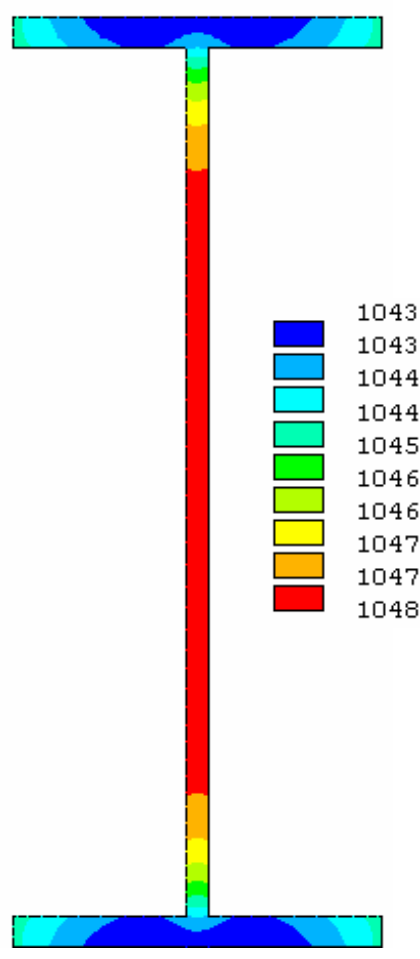

$120 \mathrm{~min}$ 
- Perfil VS 400x78

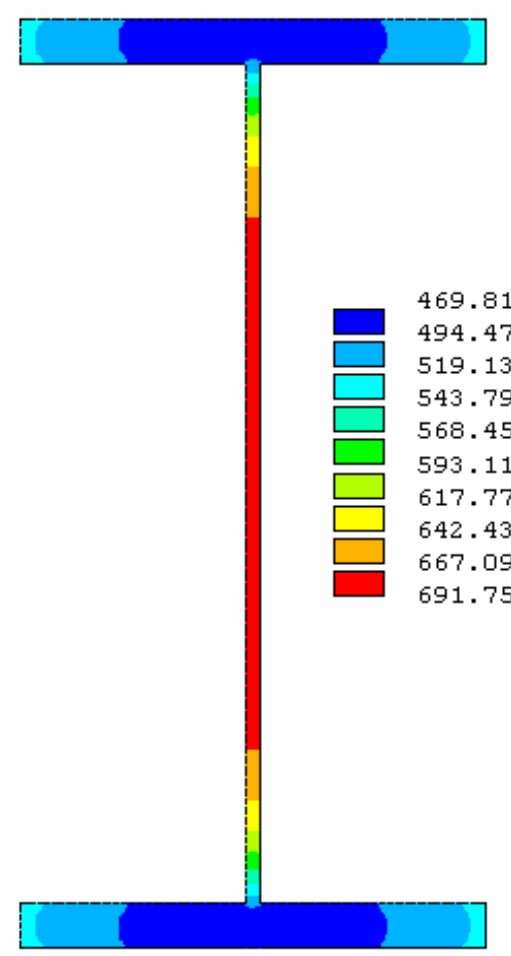

$15 \mathrm{~min}$

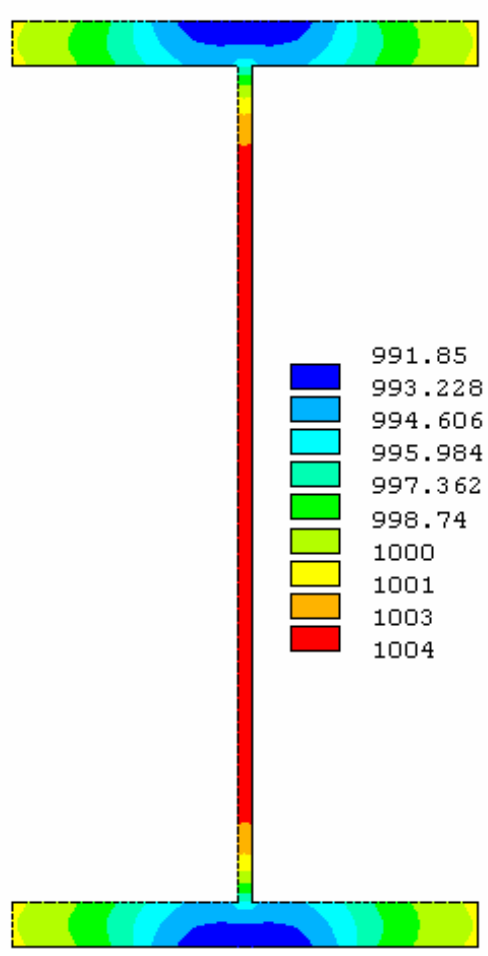

90 min

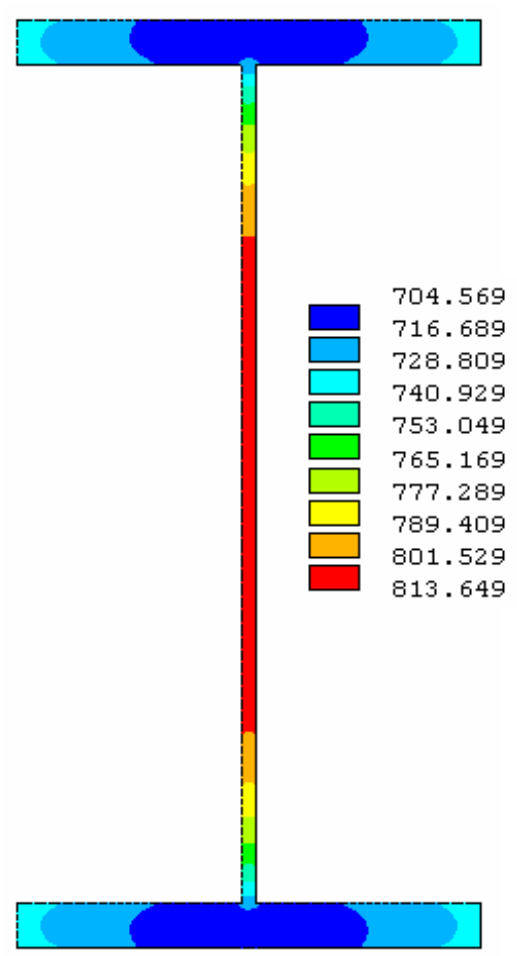

30 min

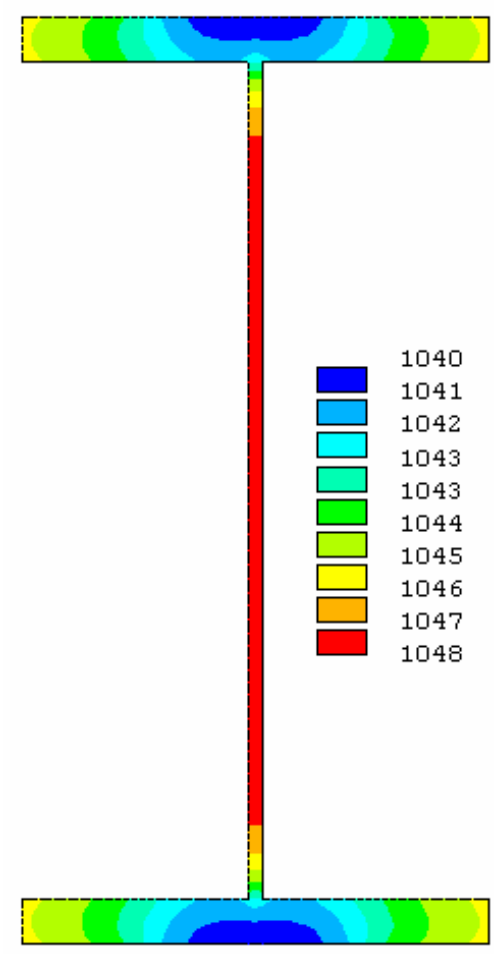

$120 \mathrm{~min}$ 
- Perfil CS 550x502

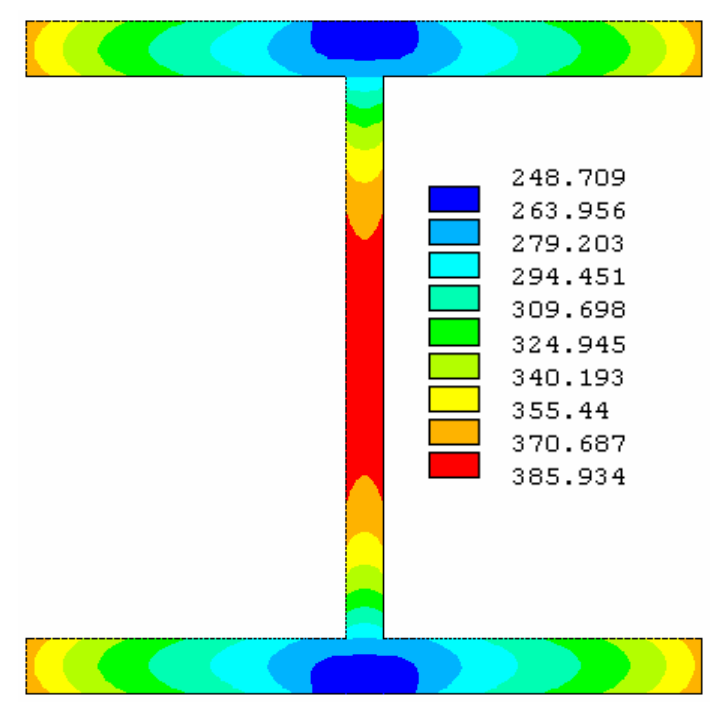

15 min

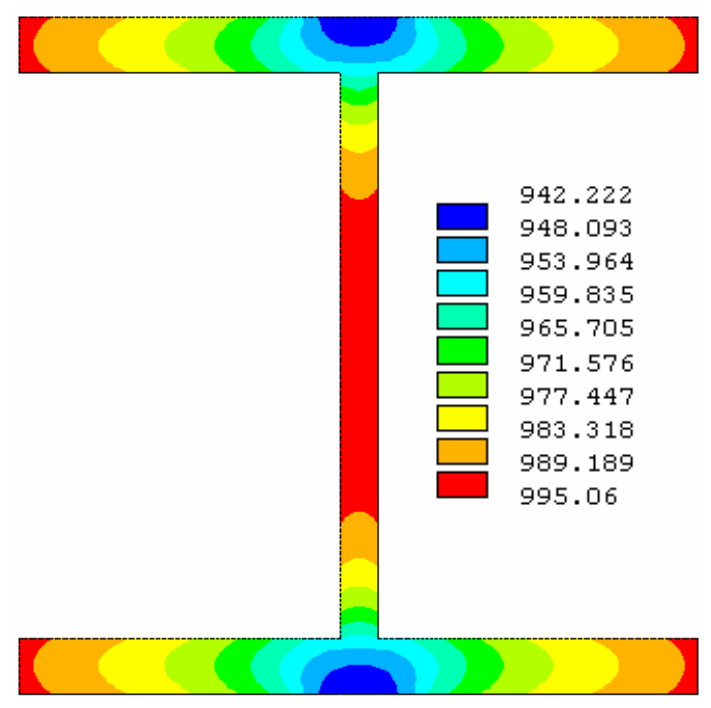

90 min

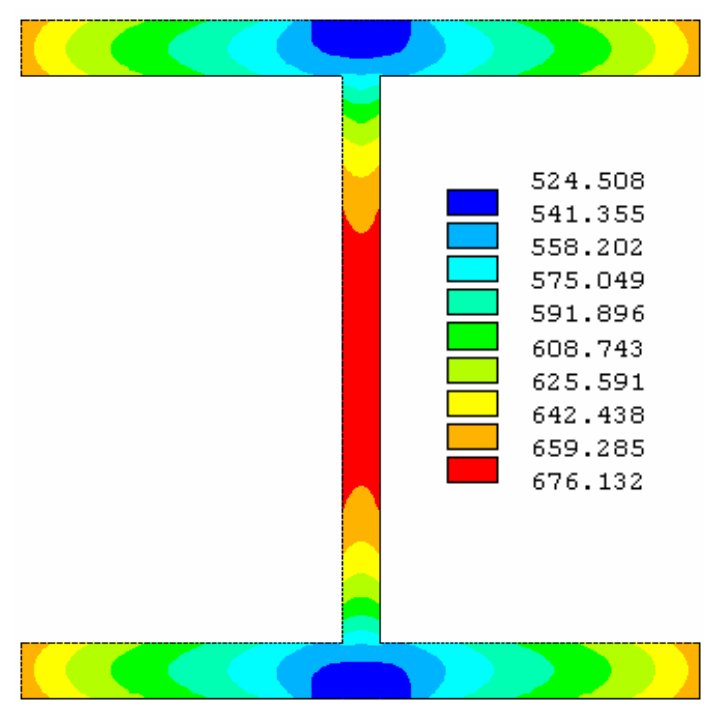

30 min

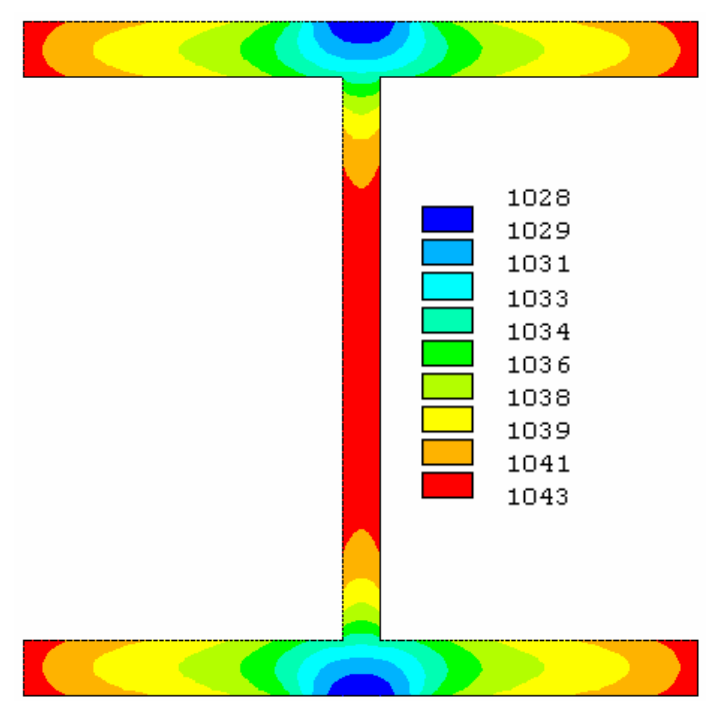

$120 \mathrm{~min}$ 
C.9 CASO 9 - Viga I em contato com laje de concreto e alvenaria, exposta ao incêndio em apenas um lado da parede de alvenaria

- Perfil W 150x13

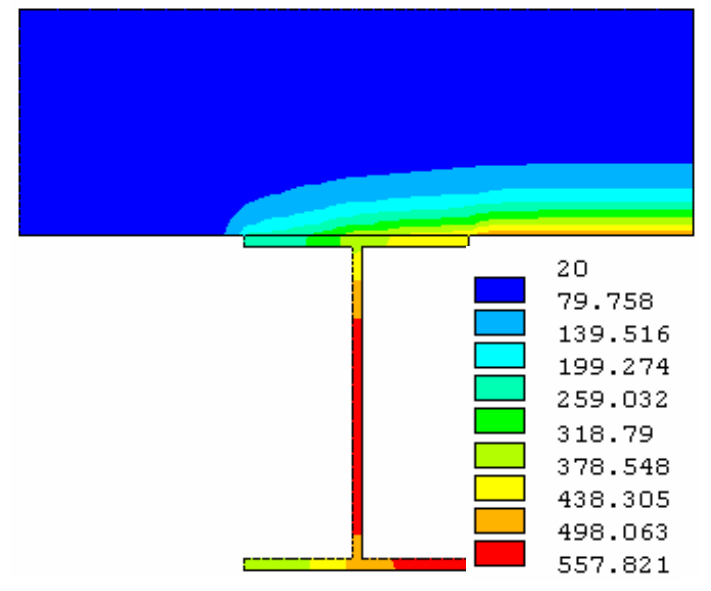

15 min

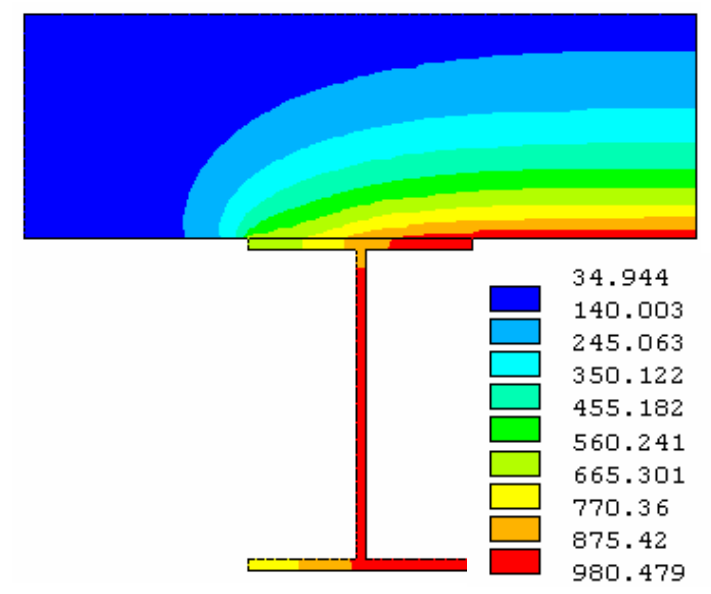

$90 \mathrm{~min}$

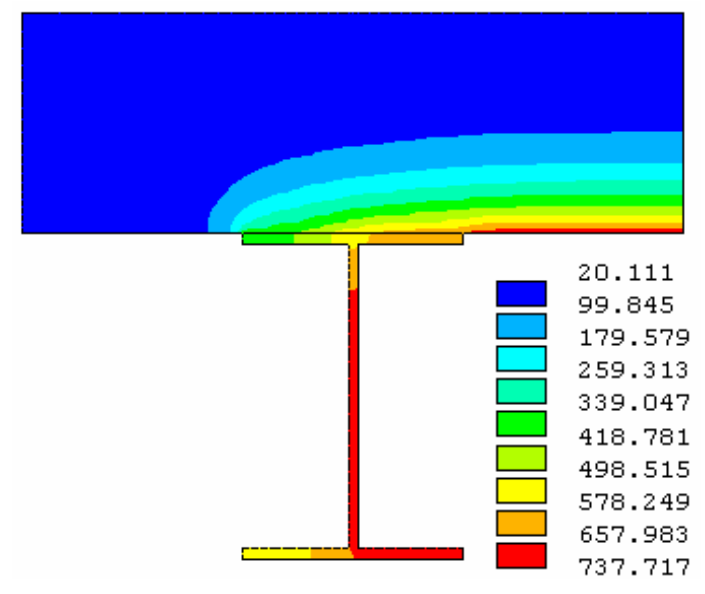

$30 \mathrm{~min}$

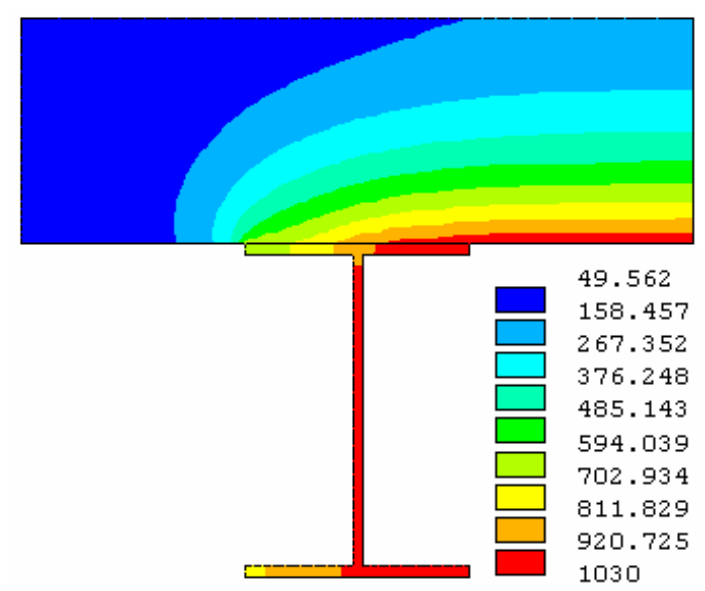

$120 \mathrm{~min}$ 
- Perfil W 250x25,3

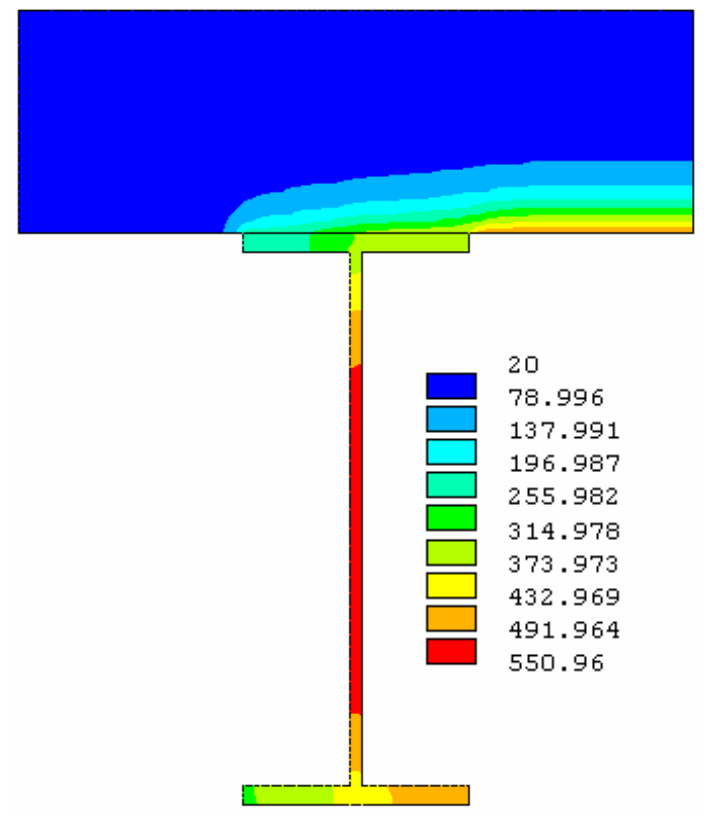

$15 \mathrm{~min}$

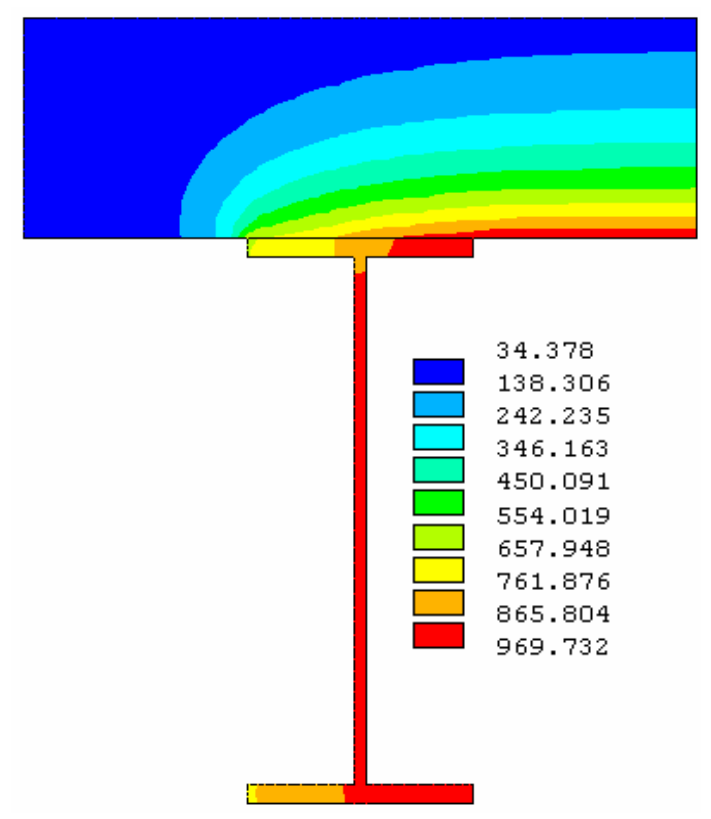

90 min
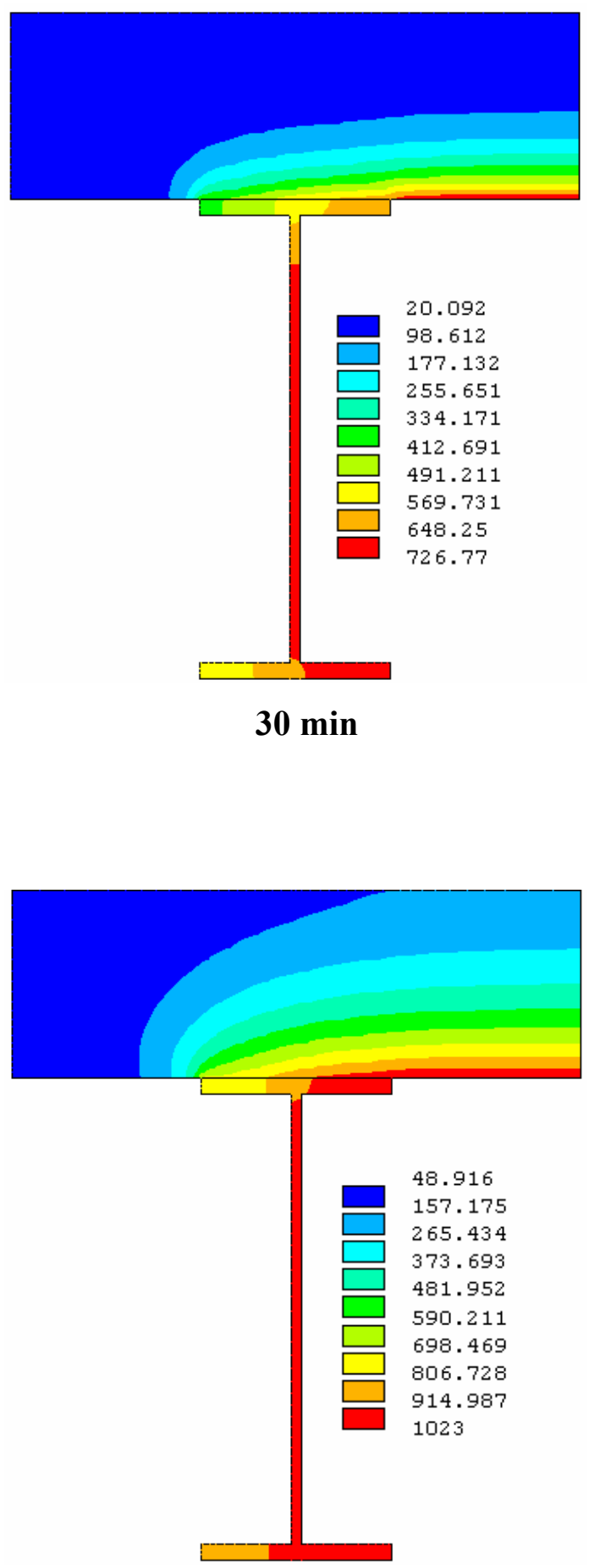

$120 \mathrm{~min}$ 


\section{- Perfil VS 400x78}

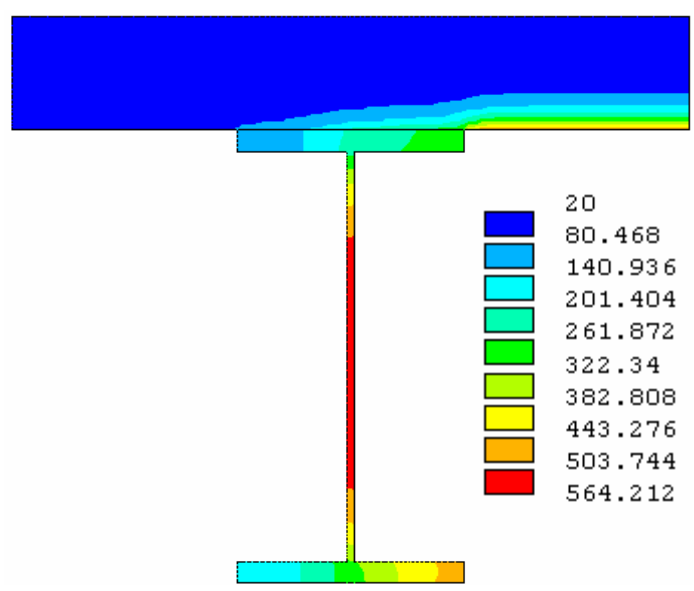

15 min

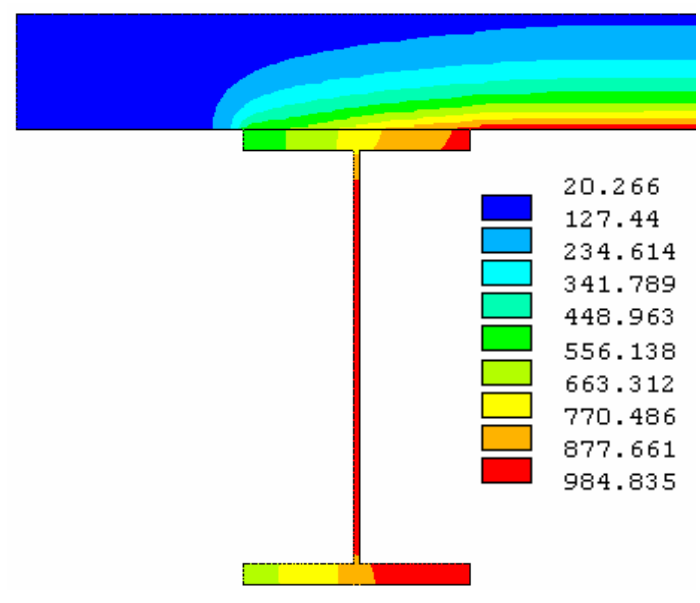

90 min

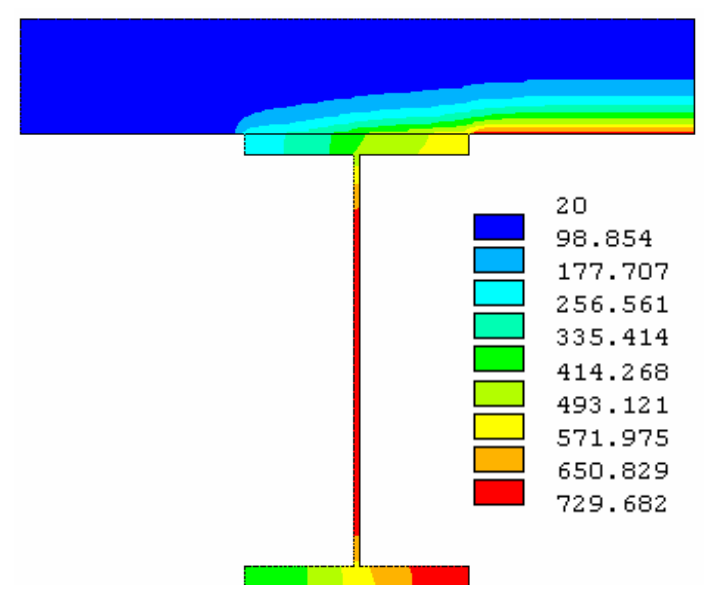

30 min

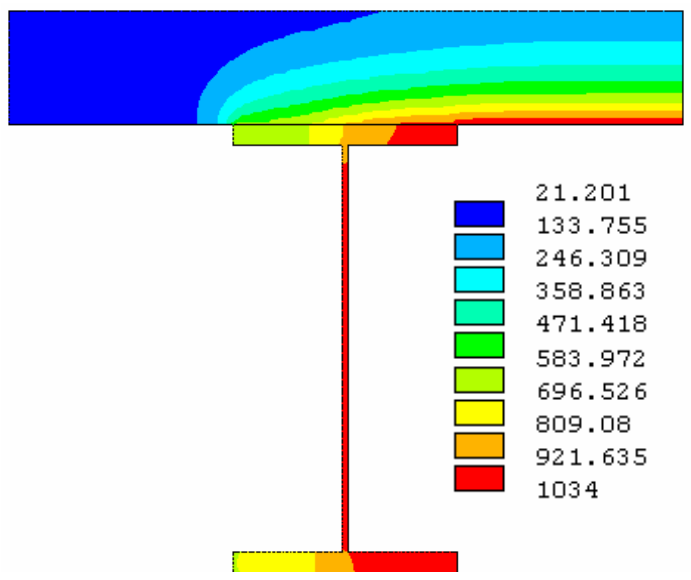

120 min

- Perfil CS 550x502

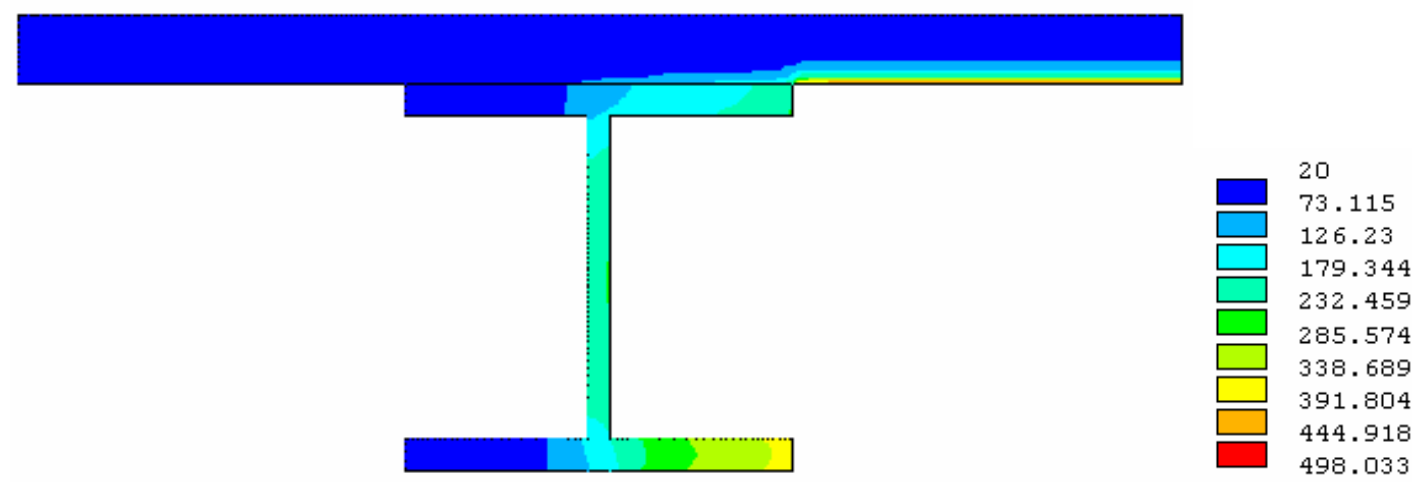

$15 \min$ 


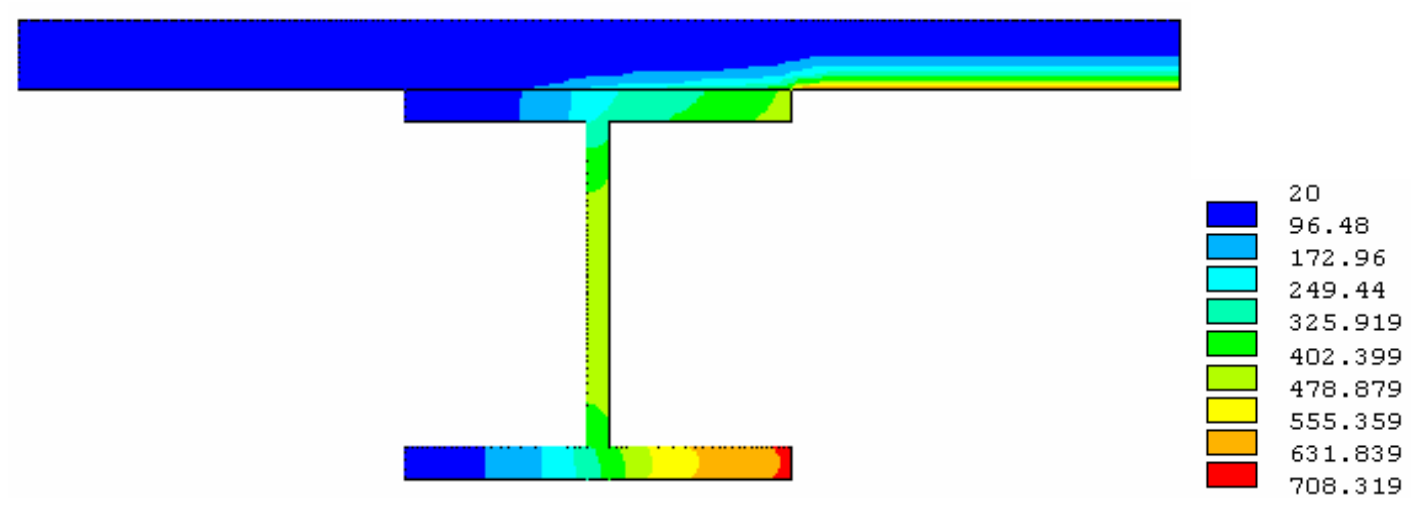

30 min

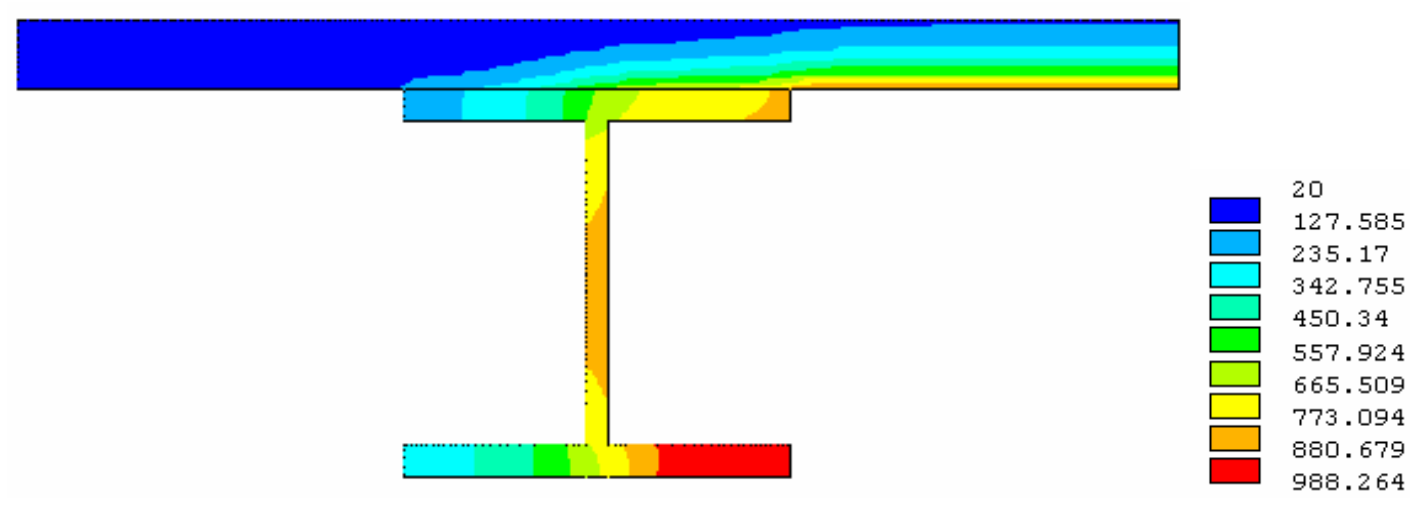

90 min

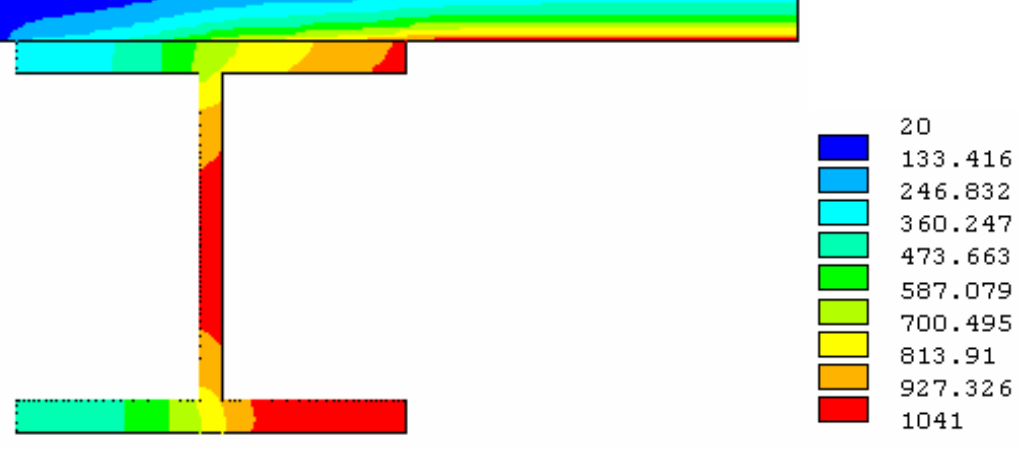

$120 \mathrm{~min}$ 
C.10 CASO 10 - Pilar com mesas em contato com paredes de alvenaria, exposta ao incêndio em apenas um lado da parede de alvenaria

- Perfil W 150x13

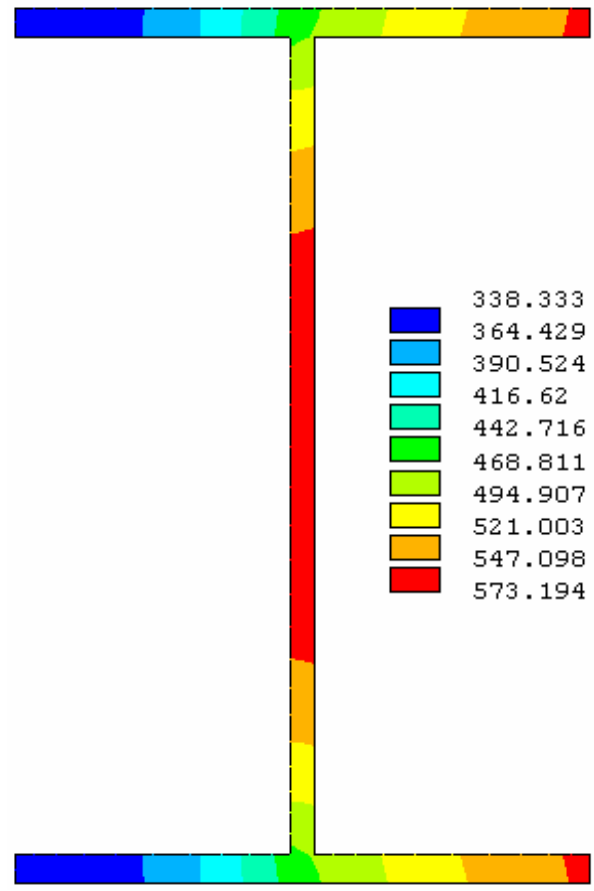

$15 \min$

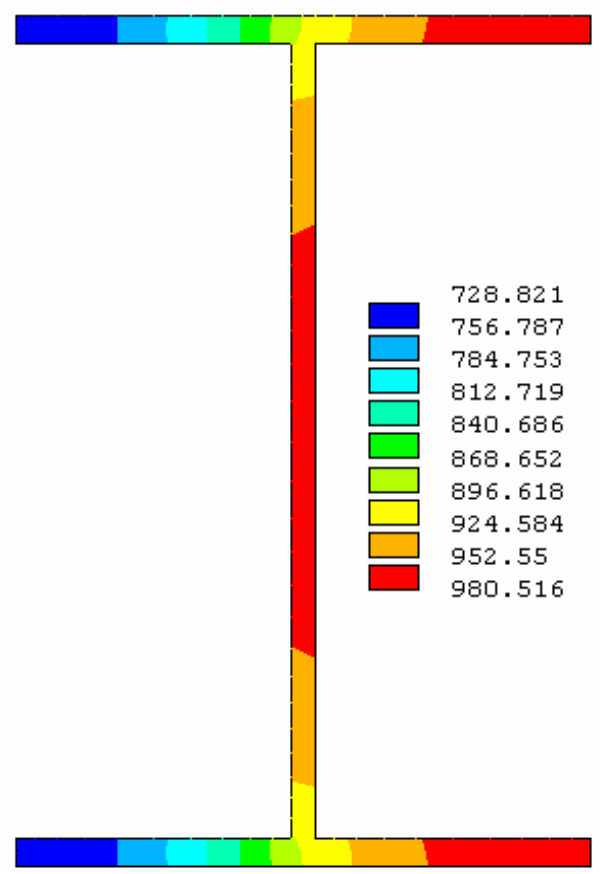

$90 \mathrm{~min}$

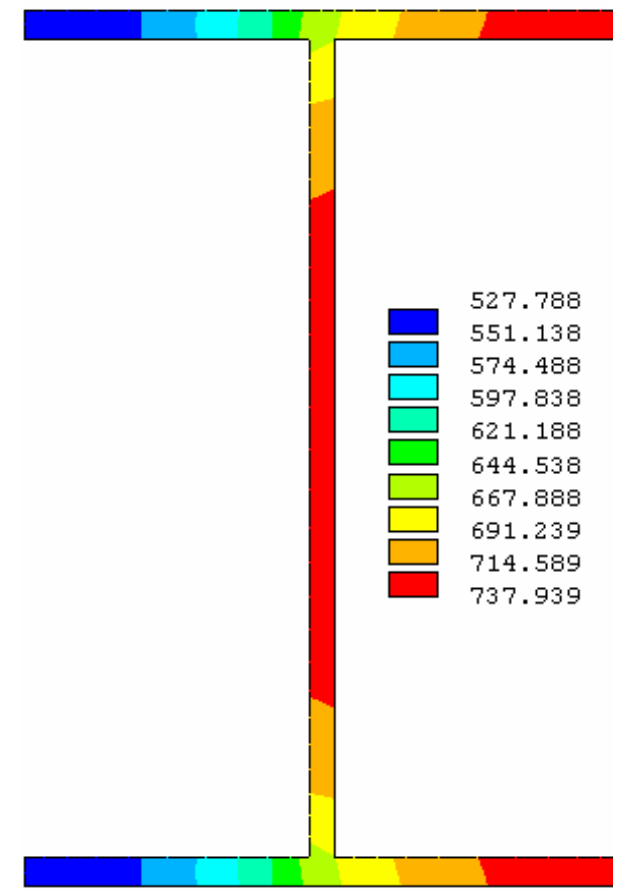

30 min

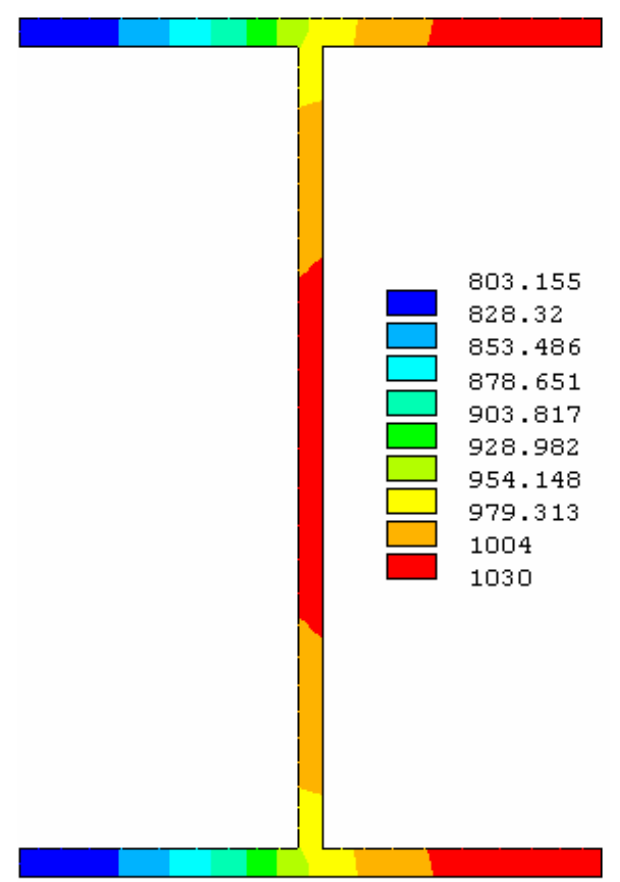

$120 \mathrm{~min}$ 
- Perfil W 250x25,3

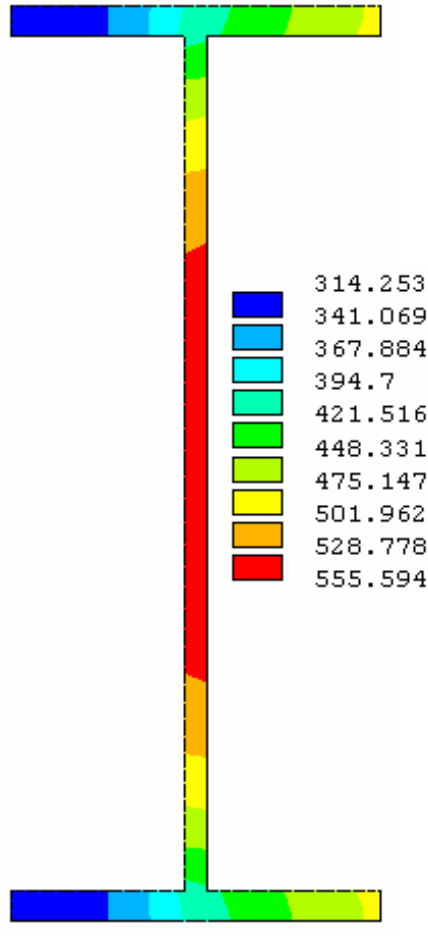

$15 \mathrm{~min}$

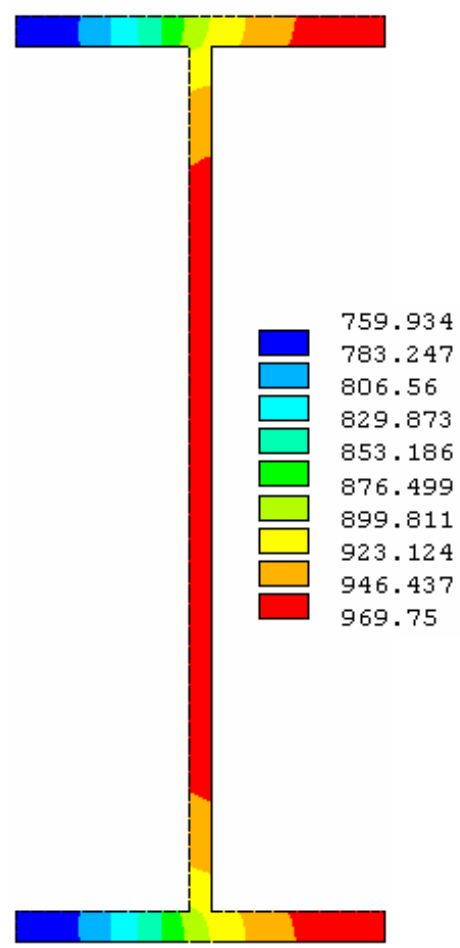

90 min

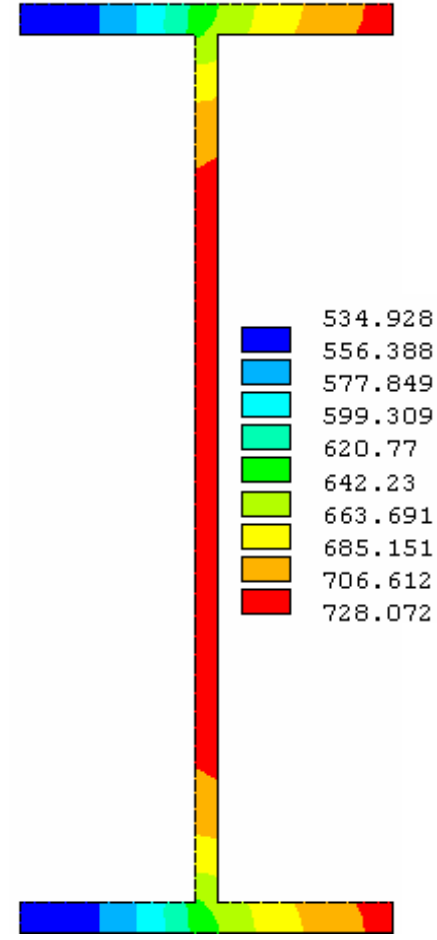

$30 \mathrm{~min}$

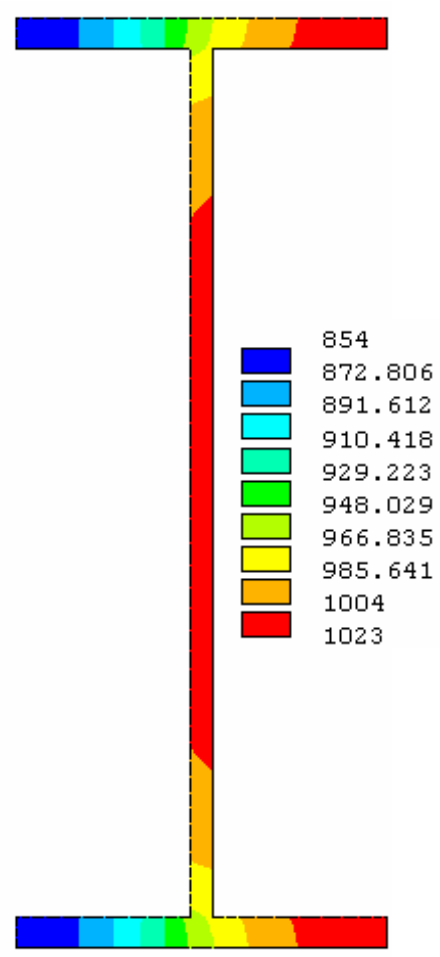

$120 \mathrm{~min}$ 
- Perfil VS 400x78

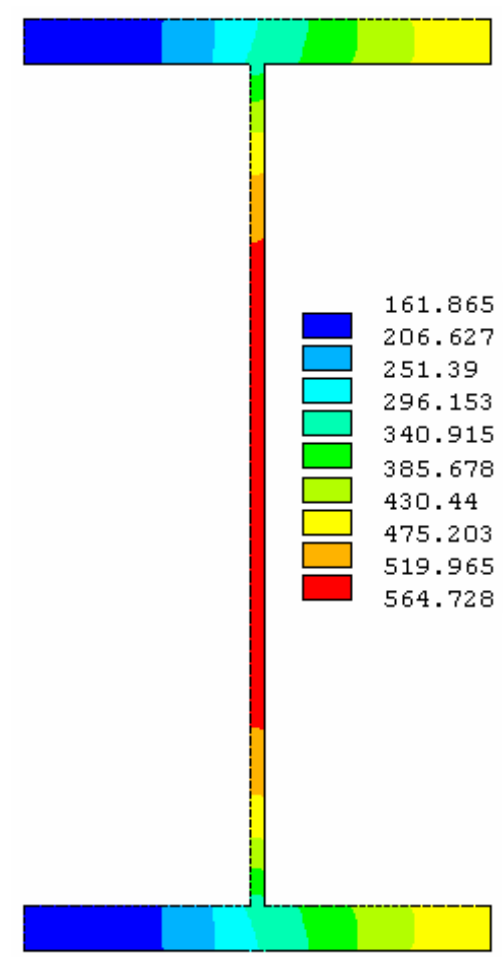

$15 \mathrm{~min}$

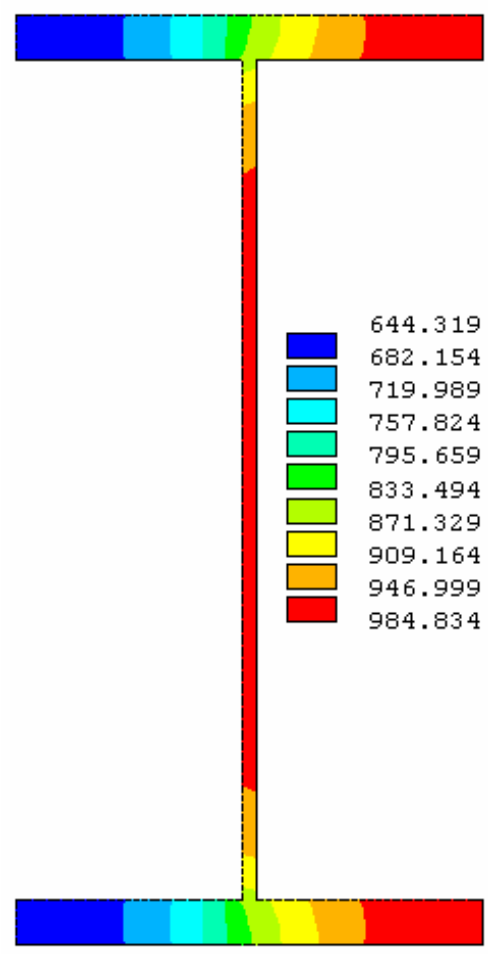

90 min

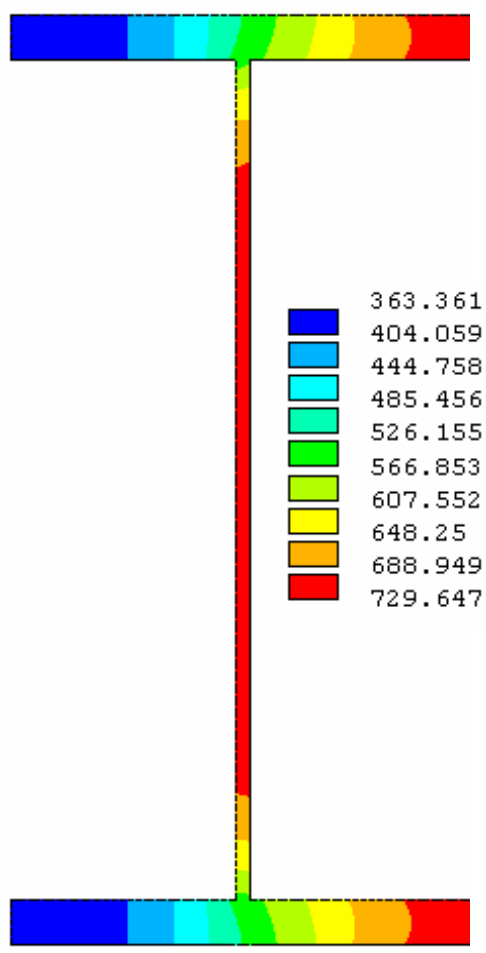

$30 \mathrm{~min}$

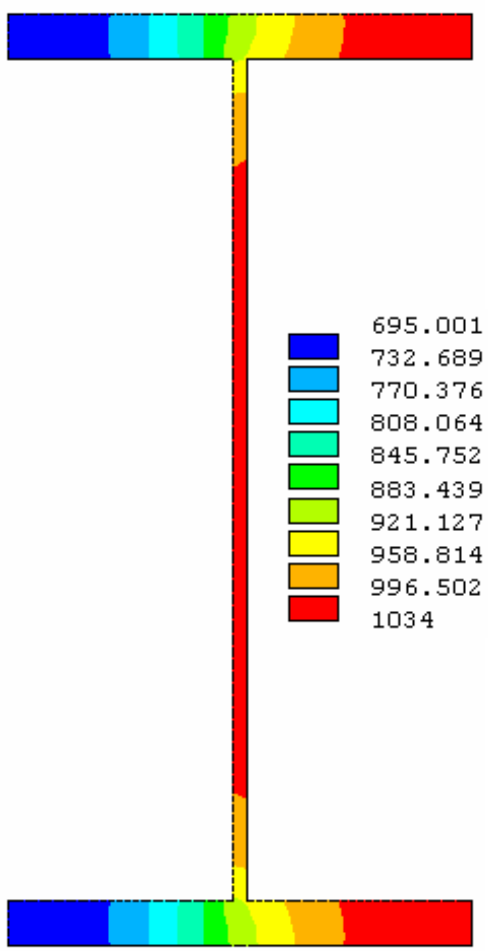

$120 \mathrm{~min}$ 
- Perfil CS 550x502

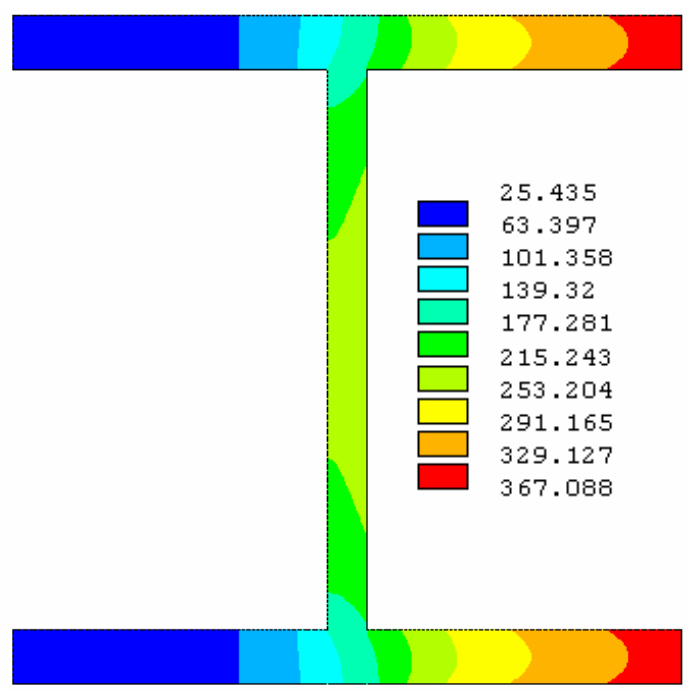

15 min

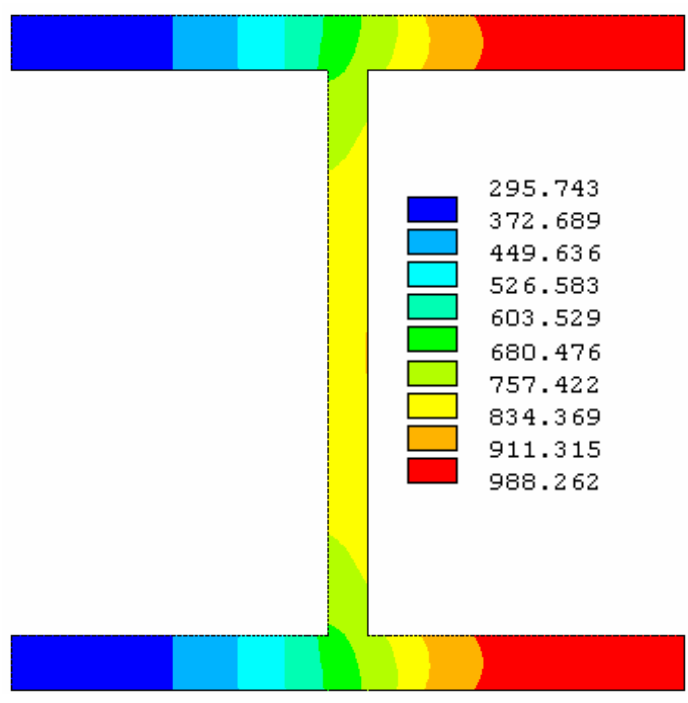

$90 \mathrm{~min}$

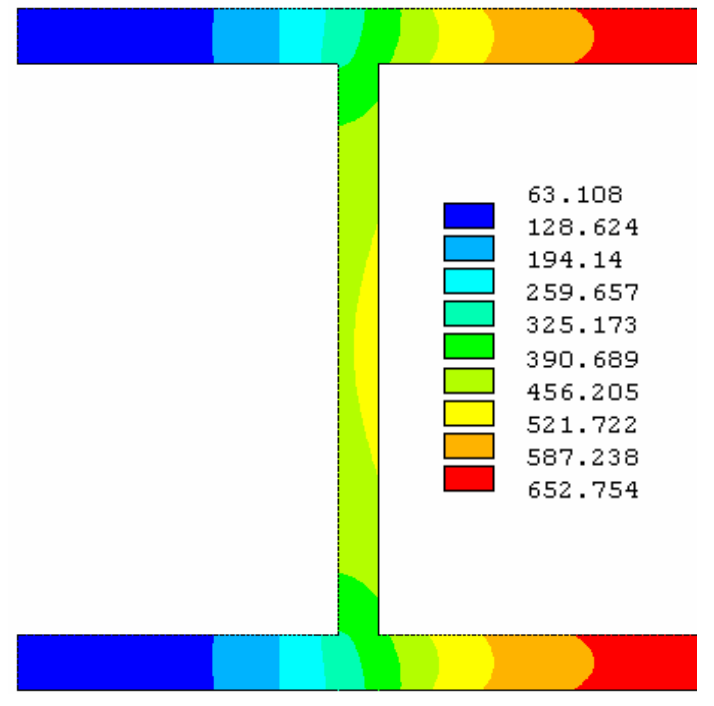

30 min

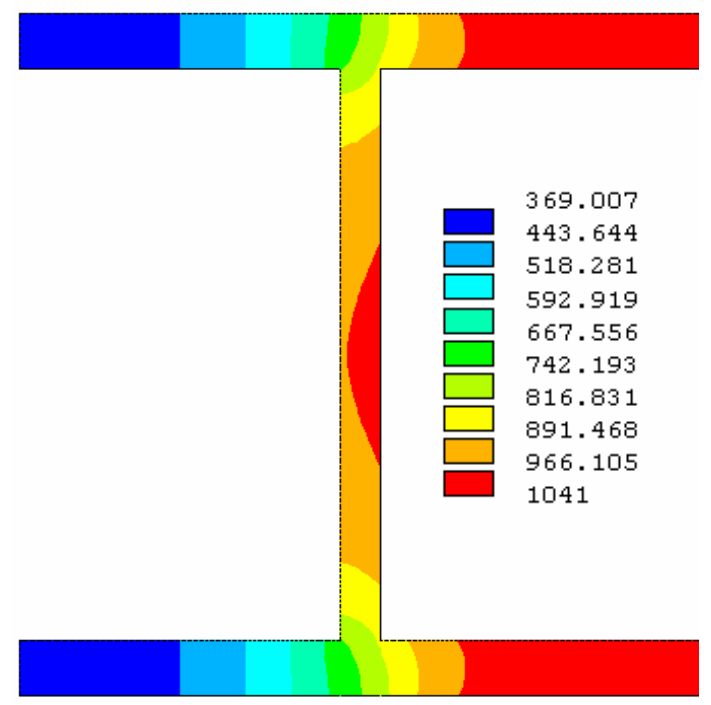

$120 \mathrm{~min}$ 
C.11 CASO 11 - Pilar com alma em contato com paredes de alvenaria, exposta ao incêndio em apenas um lado da parede de alvenaria

- Perfil W 150x13

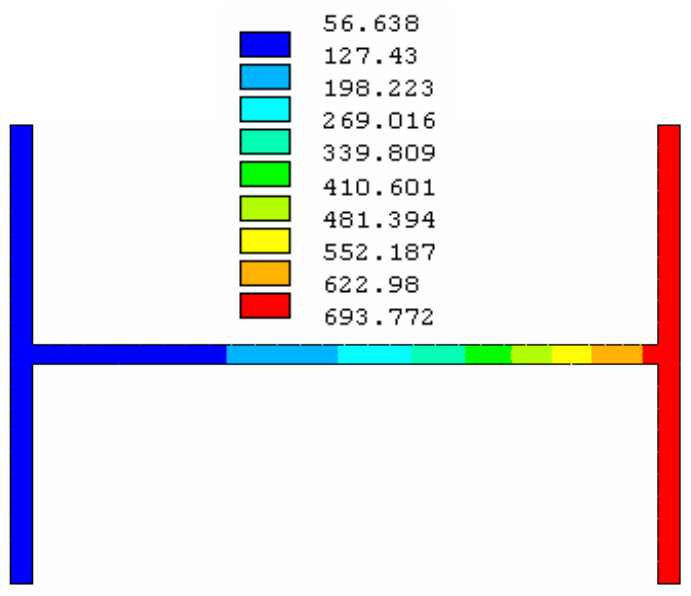

$15 \mathrm{~min}$

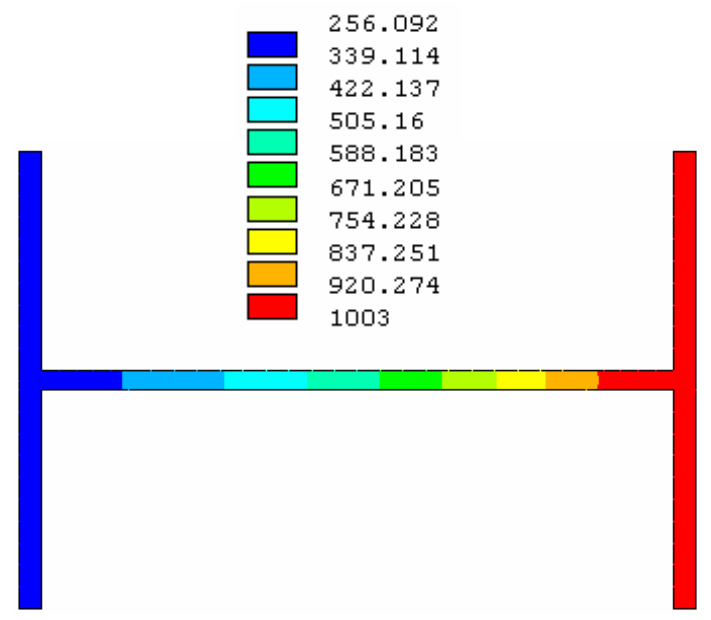

90 min

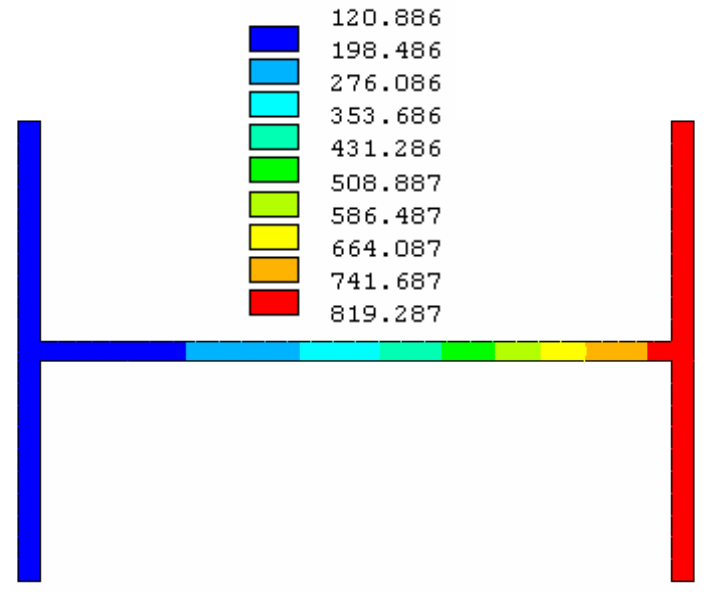

$30 \mathrm{~min}$

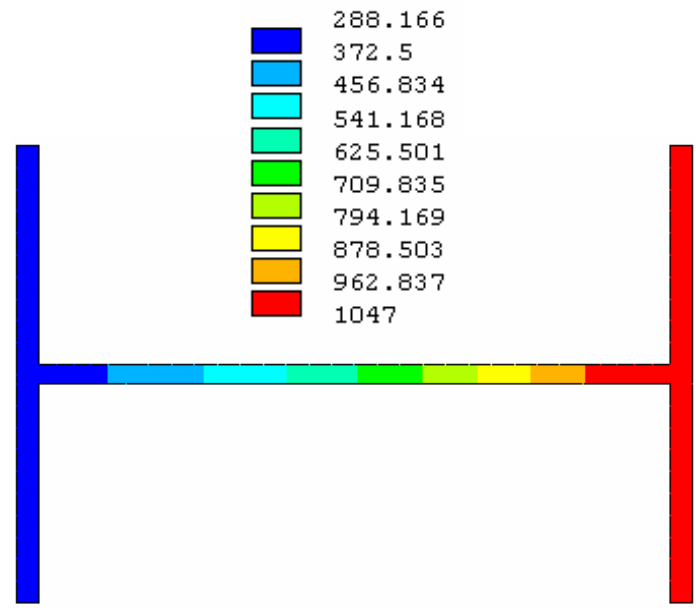

$120 \mathrm{~min}$ 
- Perfil W 250x25,3

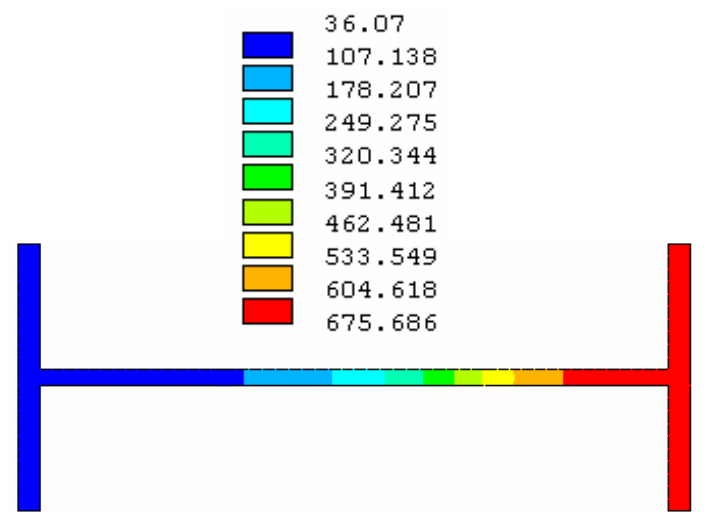

15 min

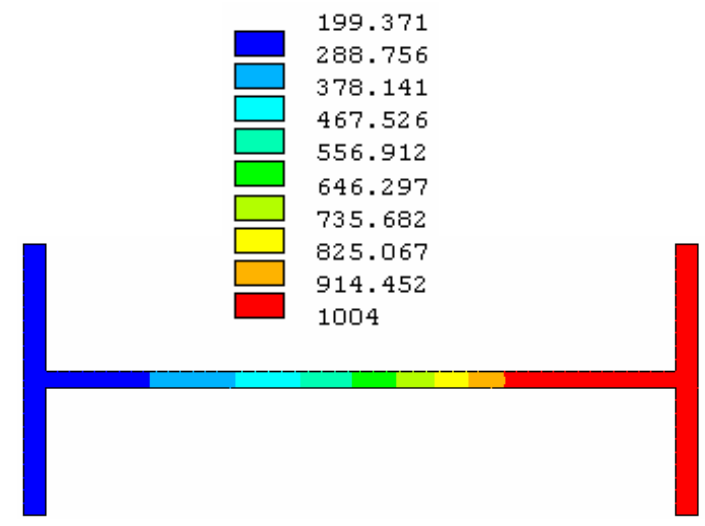

$90 \mathrm{~min}$

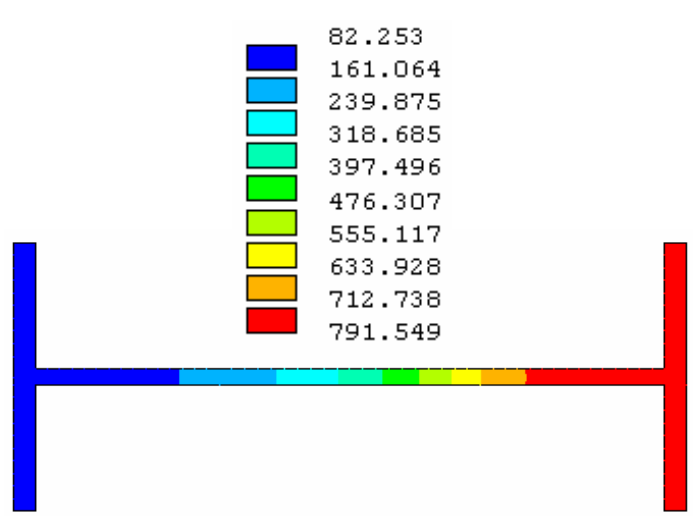

30 min

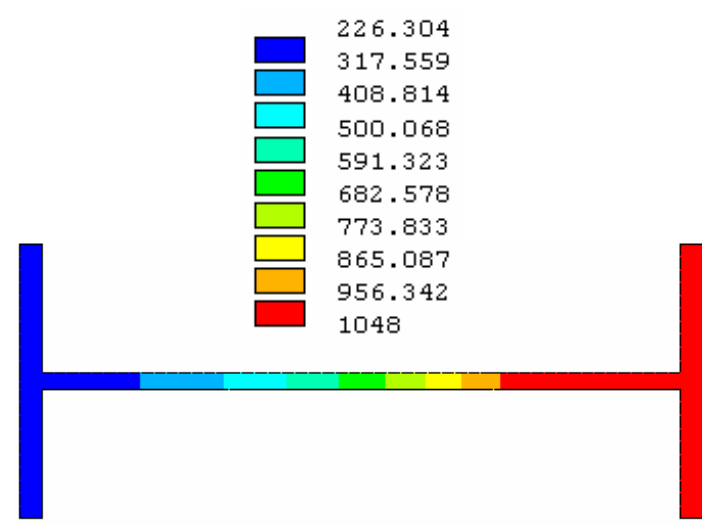

$120 \mathrm{~min}$

- Perfil VS 400x78

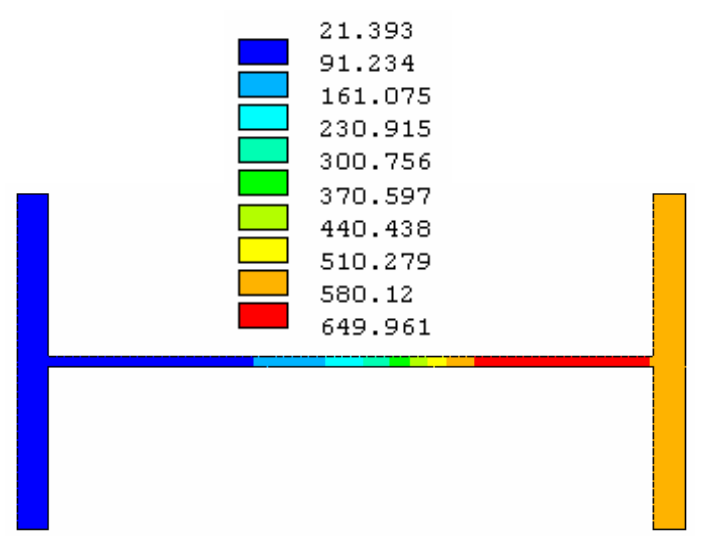

15 min

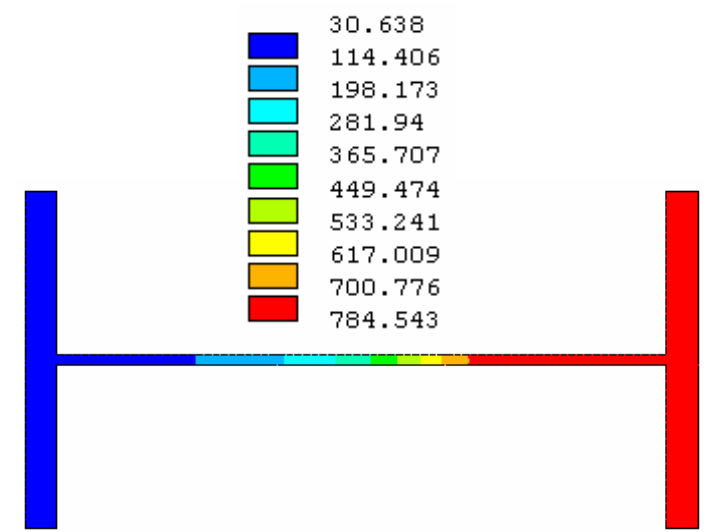

30 min 


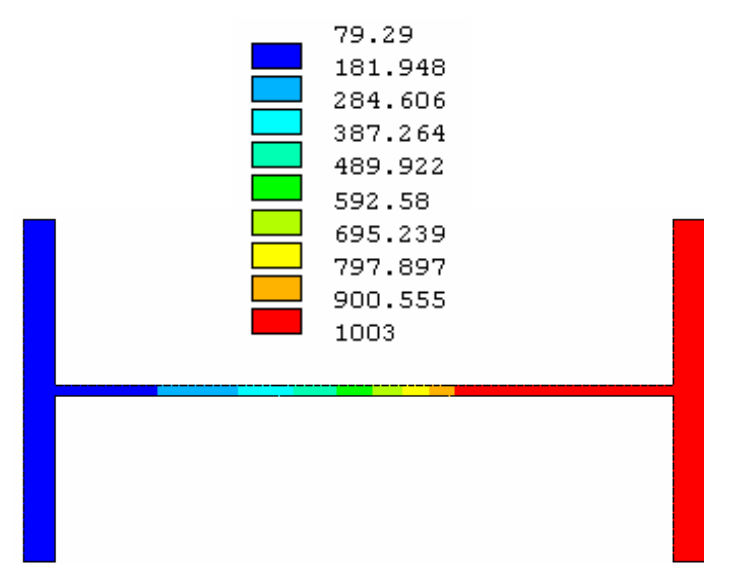

90 min

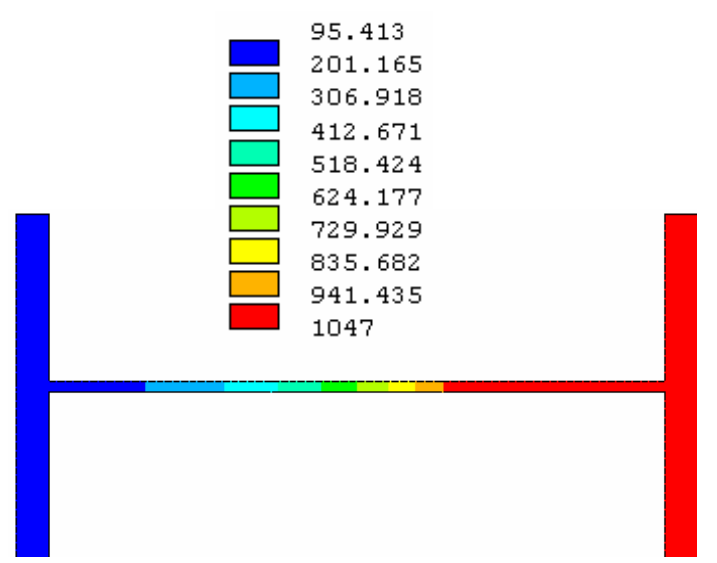

$120 \mathrm{~min}$

- Perfil CS 550x502

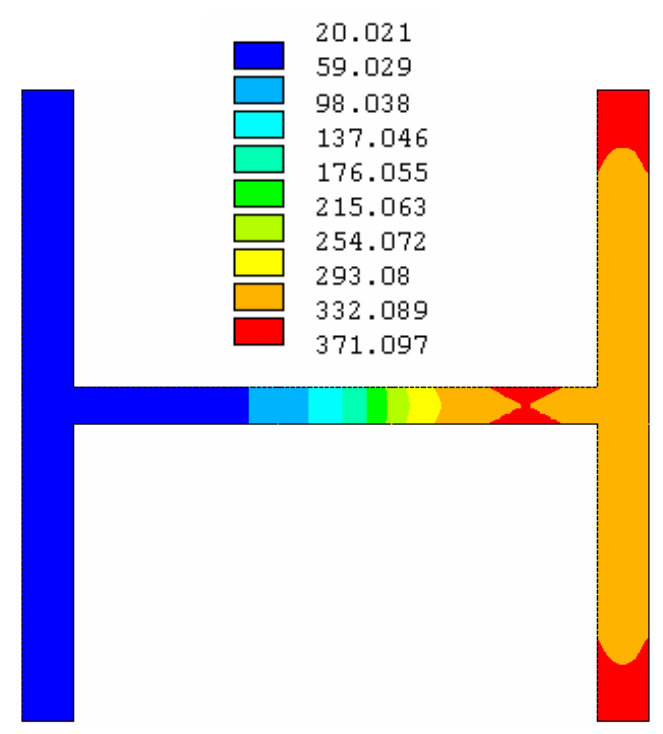

$15 \mathrm{~min}$

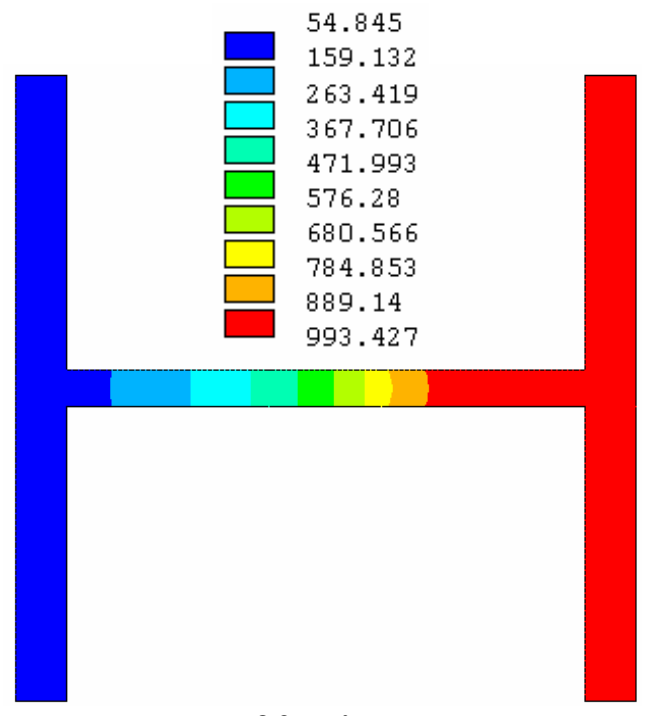

90 min

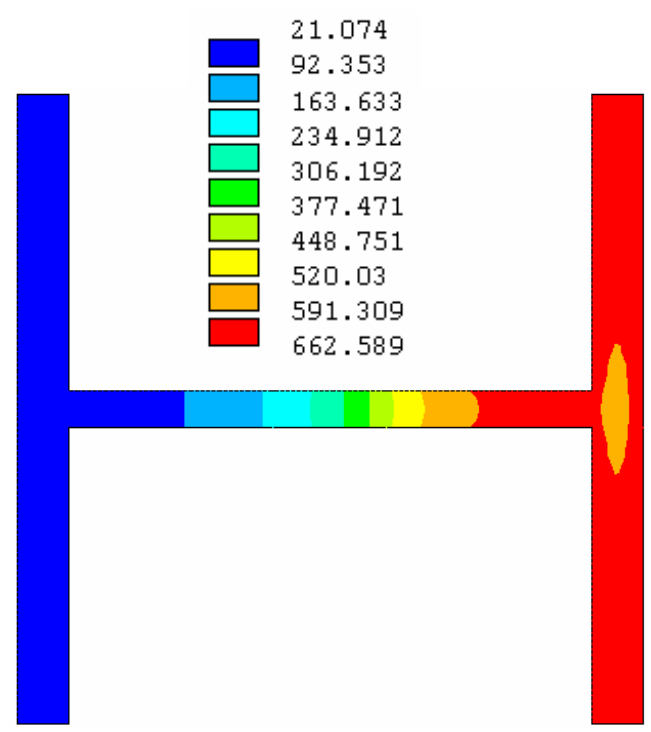

$30 \mathrm{~min}$

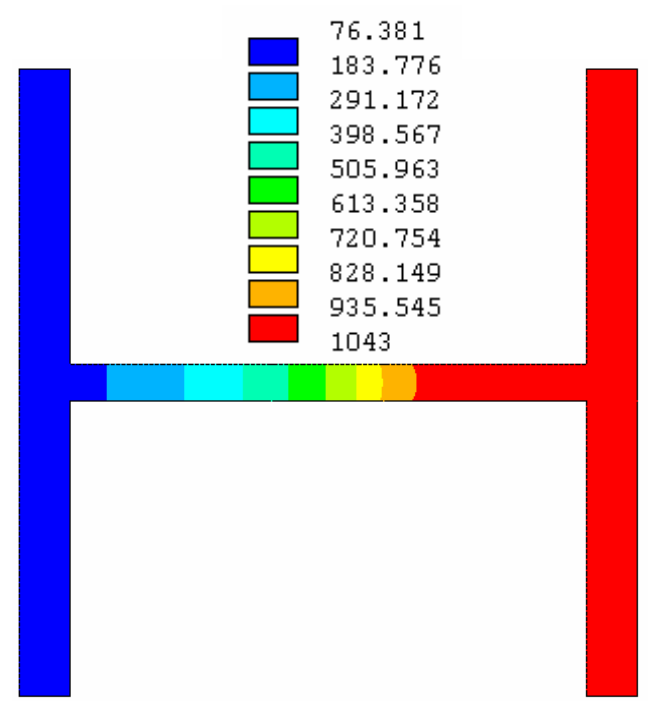

$120 \mathrm{~min}$ 